University of Michigan Law School

University of Michigan Law School Scholarship Repository

1968

\title{
Comparative Conflict Resolution Procedures in Taxation: An Analytic Comparative Study
}

\author{
L. Hart Wright \\ University of Michigan Law School \\ Jean Van Houtte \\ Pierre Kerlan \\ Helmut Debatin \\ James Arthur Johnstone
}

See next page for additional authors

Follow this and additional works at: https://repository.law.umich.edu/michigan_legal_studies

Part of the Administrative Law Commons, Comparative and Foreign Law Commons, European Law Commons, and the Tax Law Commons

\section{Recommended Citation}

Wright, L. Hart et al., Comparative Conflict Resolution Procedures in Taxation: An Analytic Comparative Study. Ann Arbor: The University of Michigan Law School, 1968.

This Book is brought to you for free and open access by the Law School History and Publications at University of Michigan Law School Scholarship Repository. It has been accepted for inclusion in Michigan Legal Studies Series by an authorized administrator of University of Michigan Law School Scholarship Repository. For more information, please contact mlaw.repository@umich.edu. 


\section{Authors}

L. Hart Wright, Jean Van Houtte, Pierre Kerlan, Helmut Debatin, James Arthur Johnstone, H. Schuttevaer, and Elizabeth G. Brown

This book is available at University of Michigan Law School Scholarship Repository: https://repository.law.umich.edu/ michigan_legal_studies/6 


\title{
MICHIGAN LEGAL STUDIES
}

\section{COMPARATIVE}

\section{CONFLICT RESOLUTION PROCEDURES}

\section{IN TAXATION}

\author{
An Analytic Comparative Study
}

Published under the auspices of The University of Michigan Law School (which, however, assumes no responsibility for the views expressed) with the aid of funds derived from gifts to The University of Michigan by William W. Cook and by the Ford Foundation. 


\title{
COMPARATIVE
}

\section{CONFLICT RESOLUTION PROCEDURES}

IN TAXATION

\author{
An Analytic Comparative Study
}

By

L. Hart Wright

Analytic Comparison; United States

Jean Van Houtte

Belgium

Pierre Kerlan

France

Helmut Debatin

Germany

James Arthur Johnstone

Great Britain

H. Schuttevaer

The Netherlands

Elizabeth Gaspar Brown

Research and Editorial Associate

Ann Arbor

The University of Michigan Law School

1968 
Copyright () by The University of Michigan, 1968 


\section{ACKNOWLEDGMENTS}

The five distinguished foreign tax experts who prepared, respectively, the analyses of the dispute-resolving process followed in the five European countries covered here have no responsibility whatsoever for the analytical or critical comparison which appears in PART ONE. Their individual country-by-country analyses-set forth in PARTS TWO through SIX* and geared to a common outline-were used by me in comparing analytically, in PART ONE, the merits of the structural arrangements, practices, and procedures of the five European countries, both inter se and with those of the United States. Indeed, because all but one of the European authors continue to hold high posts in their respective tax administrations, copies of PART ONE deliberately were not made available to them prior to publication. In consequence, I assume entire responsibility for any erroneous interpretations of their analyses which may appear in PART ONE.

Elizabeth G. Brown, Research Associate, The University of Michigan Law School, assisted in my work on PART ONE, suggested changes in the initial drafts prepared by each of the European authors, and translated PART THREE covering France.

Finally, I gratefully acknowledge the support provided by the Ford Foundation in facilitating the comparative aspects of this study, the help of the American Bar Foundation in pursuing my own study of relevant U.S. administrative practices and procedures, and the compassion of my understanding secretary, Mrs. Jean Hughes.

L. Hart Wright

Professor of Law

The University of Michigan

* Initial drafts of these parts were completed, some in 1964 and others in 1965. Revisions were last reviewed by the authors in April 1967, at which point the manuscripts were modified to accommodate the more important intervening procedural changes. 


\section{THE AUTHORS}

\section{Curriculum Vitae}

L. Hart Wright. Professor of Law, The University of Michigan, United States. Formerly: Professor of Law, Advanced Training Center, Internal Revenue Service (1954-1956); Consultant to the Commissioner of Internal Revenue (19561957, 1958-1959); Member, Advisory Group to Commissioner of Internal Revenue (1960). Author: Individual and Partnership Tax Affairs (Internal Revenue Service, 1957); Domestic Corporate Tax Affairs (Internal Revenue Service, 1962); International Tax Affairs (Internal Revenue Service, 1962); numerous tax articles. Coauthor: Chapter XI, "Taxation," American Enterprise in the European Common Market: A Legal Profile (1960); Federal Tax Liens (1961, 2d ed. 1967).

Jean Van Houtte. Senator, President de la Commission des Finances du Sénat, Belgium; Professor of Law, University of Gand; Editor-in-Chief, Tijdschrift voor Notarissen. Formerly: Minister of Finance (1950-1952, 1958-1961); Prime Minister of Belgium (1952-1954); Dean of the Law Faculty, University of Gand (1956-1958). Author: Traité des sociétés de personnes à responsabilité limitée (1935, 2d ed. 1950, 3d ed. 1962); De Herstelling van de oorlogsschade aan private goederen (1948); La Réparation des Dommages de Guerre aux Biens Privés (1948); De Personenvennootschap met beparkte aanprakelijkheid (1953); Beginselen van het Belgisch Belastingrecht (1956, 2d ed. 1965); Principes de Droit Fiscal Belge (1958). Also: numerous other treatises and over a hundred articles dealing with juridical and fiscal problems. Recipient of many honors and decorations from Belgium, other European countries, Cambodia, Chile, and Colombia.

Pierre Kerlan. Civil Chief, Tax Treaty Section, General Tax Division, Ministry of Finance and Economic Affairs, 
France. Coauthor: Taxation in France (Harvard University, World Tax Series, 1966). Author: articles. Contributor: Droit International Fiscal: Juris-Classeur.

Helmut Debatin. Ministerialrat, Bureau for International Tax Matters, Federal Ministry of Finance, West German Federal Republic. Author: Inländischer Wohnsitz, ausländischer Wohnsitz und Steuerpflicht (1966); Deutsche Besteuerung der Wertpapiererträge aus Deutschland unter Berïcksichtigung des neuen Kuponsteuergesetzes und der Doppelbesteuerungsabkommen (1965); numerous articles. Coauthor: Handbook on United States-German Tax Convention (1967); Taxation in Germany (1960). Contributor: Handbuch für Europäische Wirtschaft (Kommentar zum EWG-Vertrag).

James Arthur Johnstone. Member, Board of Inland Revenue, United Kingdom. Formerly: Member, Secretariat of the Inland Revenue Department (1936-1964); Secretary to the Radcliffe Commission on the Taxation of Profits and Income (1952-1955).

H. Schuttevaer. Vice President, Court of Appeal, The Hague, The Netherlands; Professor in Fiscal and Civil Law, State University of Utrecht. Formerly: Director of Taxes, Ministry of Finance; Lecturer, Rijksbelastingacademie (1942-1957); Counsellor, Court of Appeal, The Hague (1957-1958). Author: Netherlands Death Duties and Gift Taxation (1967); monographs pertaining to matters of civil and fiscal law; treatises in similar areas.

Elizabeth Gaspar Brown. Research Associate in Law, The University of Michigan, United States. Assisted Professor Wright in all of his tax writings. Author: Digest of Procedural Statutes and Court Rules (1954); Legal Education at Michigan, 1859-1959 (1959); British Statutes in American Law, 1776-1836 (1964); articles. 
CONTENTS

ACKNOWLEDGMENTS ................. v

THE AUTHORS: CURRICULUM VITAE .......... vi

PART ONE. THE UNITED STATES AND THE OTHER "FIVE": AN ANALYTICAL COMPARISON

CHAPTER I

AN OVERVIEW: REQUISITE ADMINISTRATIVE FRAMEWORKS

1.1 Introduction: Why the volume was written....... 3

1.2 Relationship of procedural goals to organization .... 4

1.3 Sequence of this volume...............4 4

1.4 First central theme: A centralized interpretative program.............5

1.5 Second central theme: Decentralization of the enfor cement function ............... 8

1.6 Third central theme: Centralization of final administrative hearings at an intermediate level... 10

\section{CHAPTER II}

CENTRALLY ADMINISTERED RULE-MAKING PROGRAMS 12

Section A. Evolution of U.S. Programs

2.1 Introduction ......................... 12

2.2 Evolution of U.S. regulations program ......... 15

2.3 Evolution of U.S. private and published rulings programs ....................... 19 
2.4 Weight normally accorded U.S. interpretative regulations and published rulings .........26

Section B. Analytic Comparison: The "Six's" Reactions to Vital Purposes Served by Centrally Administered Interpretative Programs

2.5 Introduction: Programs of the Six compared . . . . 34

2.6 Achieving timely uniformity, efficiently and fairly... 39

2.7 Choosing the wisest possible interpretative positions .................... 42

2.8 Neutralizing risks re prospective transactions .... 42

Section C. Implementing an Interpretative Regulations Program

2.9 Introduction: Inherent conflict among the goals . . . 44

2.10 The goal of proper quality . . . . . . . . . . . . 44

2.11 Processing regulations: Reconciling the goal of proper quality with competing goals of timeliness and efficiency .................. 48

Section D. Implementing Private and Published Rulings Programs

2.12 Introduction: Resolving inherent conflict between respective goals of private and published rulings programs ..................... 51

2.13 Confining private rulings to legal questions:

Requiring statements of fact and a brief ........ 54

2.14 Organization, conferences, review, and appeals re private rulings ............... 56

2.15 Priorities re advance rulings; and grounds for refusal to rule ................. 59

2.16 Completed transactions: Private rulings and in-service technical advice.............661

2.17 Publication of rulings and in-service technical advice. . 64 
CHAPTER III

ASSESSMENT AND ADMINISTRATIVE APPEAL PROCEDURES

Section A. Analytic Comparison of the "Six": Requirements of a Tax Administration's Own Conflict Resolution Procedures, Viewed in Aggregate

3.1 Introduction: Comparative profiles of the entire conflict resolution process .............. 70

3.2 Assuring impartiality of administrative conflict resolution machinery ................ 77

3.3 Assuring administrative machinery a reasonable chance to become fully acquainted with the taxpayer's side........................ 82

3.4 Assuring justice: Need for complete "settlement"

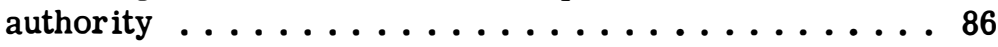

Section B. Analytic Comparison of Additional Requirements: Echelon by Echelon View of Assessment and Administrative Conflict Resolution Procedures

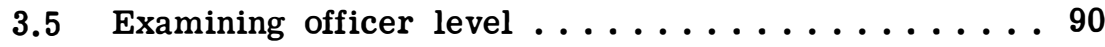

3.6 Mandatory internal review v. self-initiated requests for technical advice ............. 92

3.7 Jurisdictional screening function re administra-

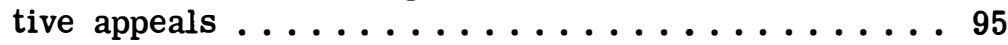

3.8 Requiring written protests .............. 99

CHAPTER IV

CONFLICT RESOLUTION BY INDEPENDENT TRIBUNALS

Section A. Analytic Comparison: Judicial Structures of the "Six"

4.1 Introduction: The goals ................ 102 
4.2 Trial tribunals: Impartiality and the relevance of a specialized bench's perspectives .......... 103

4.3 Trial tribunals: Other factors relevant to the goals . . . . . . . . . . . . . . . . . . 109

4.4 Appellate tribunals: The right and scope of review ......................... 120

4.5 Appellate tribunals: Quality of review......... 125

4.6 Appellate tribunals: Unifying interpretations . . . . 131

Section B. Analytic Comparison: Litigation Practices of the "Six"

4.7 Introduction . . . . . . . . . . . . . . . 138

4.8 Practices peculiarly important to the tax administration. ..................... 138

4.9 Practices peculiarly important to taxpayers ......151

4.10 Practices of common concern............157

PART TWO. BELGIUM

\section{CHAPTER V \\ ADMINISTRATIVE ORGANIZATIONAL AND PERSONNEL FRAMEWORKS}

Section A. Administrative Organizational Framework

1.1 Introduction . . . . . . . . . . . . . . . . 169

1.2 Organizational framework, national office level....171

1.3 Organizational framework, regional office level ...174

1.4 Organizational framework, local office level.....176

Section B. Personnel Framework (Governmental and Non-Governmental)

1.5 Governmental professional personnel ......... 177

1.6 Private tax practitioners ................. 179 


\section{CHAPTER VI}

Section A. Character of the Underlying Statute

2.1 Precision of the statute itself .............181

2.2 Legislative pre-enactment aids to interpretation ....186

2.3 Standards of construction followed by the judiciary in interpreting the statute ............. 188

Section B. The Regulations Program

2.4 Types and force of regulations . . . . . . . . . . 190

2.5 Precise purpose of "interpretative" regulations . . . 192

2.6 Manner of processing regulations ............ 195

Section C. The Rulings Program

2.7 Formal advance written rulings to taxpayers . . . . 196

2.8 Informal technical advice to taxpayers on proposed transactions ................ 197

2.9 Technical advice to field offices ............ 198

2.10 Publication of technical advice given taxpayers and local offices ..................... 199

\section{CHAPTER VII}

\section{ASSESSMENT, REFUND, AND ADMINISTRATIVE} APPEAL PROCEDURES

Section A. Assessment and Audit Procedures

3.1 Introductory note . . . . . . . . . . . . . . 201

3.2a Details of the typical assessment and audit procedure.......................201 
xiv

3.2b Details of assessment and audit procedure re cadastral income................. 207

3.2c Details of assessment and audit procedure re income arising from certain categories of professional activity ............... 208

$\begin{array}{ll}\text { Section B. Administrative Appeals } & 209\end{array}$

3.3 Introductory note. . . . . . . . . . . . . . 209

3.4 Details of administrative appeal procedure re assessments . . . . . . . . . . . . . 210

Section C. Extent Administrative Processing of Refund Claims Departs from Administrative Processing of Assessments

3.5 Introductory note.................. 213

3.6 Details regarding refund procedure in cases of "material error"................... 214

\section{CHAPTER VIII}

RESOLUTION OF INTERPRETATIVE INCOME TAX QUESTIONS BY INDEPENDENT TRIBUNALS

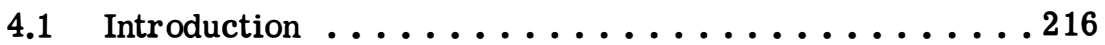

Section A. Organization and Procedures: Lower Courts

4.2 Organization of the lower courts...........216

4.3 Processing cases through the Court of Appeal ....217

Section B. Organization and Procedures: The Court of Cassation

4.4 Organization of the Court of Cassation ........220

4.5 Processing a case through the Court of Cassation . . . 221 


\section{CHAPTER IX \\ ADMINISTRATIVE ORGANIZATIONAL AND PERSONNEL FRAMEWORKS}

Section A. Administrative Organizational Framework

1.1 Introduction ................... 227

1.2 Organizational framework, national office level....227

1.3 Organizational framework, regional office level . . . 229

1.4 Organizational framework, local office level ......230

Section B. Personnel Framework (Governmental and Non-Governmental)

1.5 Governmental professional personnel ... . . . . . 232

1.6 Private tax practitioners ................. 236

\section{CHAPTER X}

Section A. Character of the Underlying Statute

2.1 Precision of the statute itself............. 238

2.2 Legislative pre-enactment aids to interpretation . . . 240

2.3 Standards of construction followed by the judiciary in interpreting the statute .............241

Section B. The "Regulations" Program

$2.4 \& 2.5$ Types, force, and purpose of "regulations"... 243 2.6 Manner of processing "regulations"..........246 
xvi

Section C. The Rulings Program

2.7 Formal advance written rulings to taxpayers . . . . 247

2.8 Informal technical advice to taxpayers on proposed transactions ................249

2.9 Technical advice to field offices . . . . . . . . 249

2.10 Publication of technical advice given taxpayers and local offices ................. 250

\section{CHAPTER XI}

ASSESSMENT, REFUND, AND ADMINISTRATIVE APPEAL PROCEDURES

Section A. Assessment and Audit Procedures

3.1 Introductory note . . . . . . . . . . . . . 251

3.2a Details of assessment and audit procedure re actual income ..................... 251

$3.2 \mathrm{~b}$ Details of assessment and audit procedure re

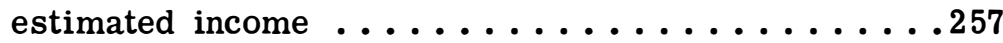

Section B. Administrative Appeals

3.3 Introductory note . . . . . . . . . . . . . . . . . . . 264

3.4a Details of administrative appeals to a departmental

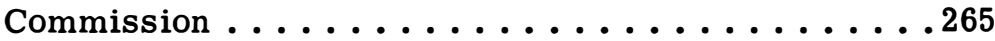

3.4b Administrative appeals to the departmental Director: Recours contentieux ............269

3.4c Administrative appeals to the departmental Director: Recours gracieux............271

Section C. Administrative Processing of Refund Claims 
CHAPTER XII

RESOLUTION OF TAX QUESTIONS BY

INDEPENDENT TRIBUNALS

4.1 Introduction ................... 273

Section A. Organization and Procedures:

Trial Level

4.2 Organization of the tribunals ............. 274

4.3 Processing cases through the trial tribunals . . . . 275

Section B. Organization and Procedures:

Appellate Tribunals

4.4 Organization of the appellate system ..........281

4.5 Processing a case through the appellate tribunal ...283

PART FOUR. GERMANY

CHAPTER XIII

ADMINISTRATIVE ORGANIZATIONAL AND

PERSONNEL FRAMEWORKS

Section A. Administrative Organizational

Framework

1.1 Introduction $\ldots \ldots \ldots \ldots \ldots \ldots \ldots \ldots \ldots \ldots \ldots$

1.2 Organizational framework, national office level.....292

A. Federal tax administration . . . . . . . . 292

B. State tax administration ............. 295

1.3 Organizational framework, regional office level ...295

1.4 Organizational framework, local office level......296 
xviii

Section B. Personnel Framework (Governmental and Non-Governmental)

1.5 Governmental professional personnel . . . . . . . . 299

1.6 Private tax practitioners ................. 304

CHAPTER XIV

ADMINISTRATIVE RULE-MAKING PROGRAMS

307

Section A. Character of the Underlying Statute

2.1 Precision of the statute itself .............. 307

2.2 Legislative pre-enactment aids to interpretation . . . .313

2.3 Standards of construction followed by the judiciary in interpreting the statute ...................

Section B. The Regulations Program 316

2.4 Types and force of regulations ................ . . . .

2.5 Precise purpose of interpretative regulations . . . . 318

2.6 Manner of processing regulations .............. 321

Section C. The Rulings Program

2.7 Formal advance written rulings to taxpayers . . . . . 322

2.8 Informal technical advice to taxpayers on proposed transactions ................. . 324

2.9 Technical advice to field offices ............ . 325

2.10 Publication of technical advice given taxpayers

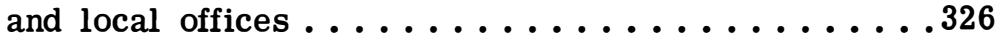


ASSESSMENT, REFUND, AND ADMINISTRATIVE APPEAL PROCEDURES

Section A. Assessment and Audit Procedures

3.1 Introductory note . . . . . . . . . . . . . 328

3.2a Details of assessment and audit procedures:

In general ......................... 330

3.2b Details of assessment and audit procedures where taxes withheld at source ................. 336

Section B. Administrative Appeals

3.3 Introductory note . . . . . . . . . . . . 337

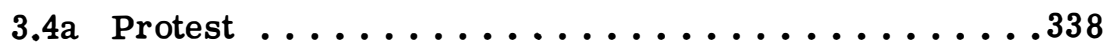

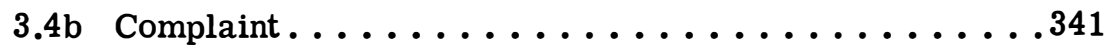

Section C. Extent Administrative Processing of Refund Claims Departs from Administrative Processing of Assessments

3.5 Introductory note. . . . . . . . . . . . . 342

3.6 Details regarding refund procedures ............342

CHAPTER XVI

RESOLUTION OF INTERPRETATIVE INCOME TAX QUESTIONS BY INDEPENDENT TRIBUNALS

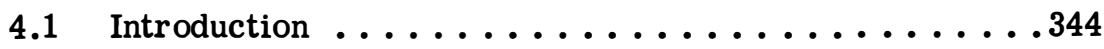

Section A. Organization and Procedures: Trial Level

4.2 Organization of the trial tribunals...........346

4.3 Processing cases through the trial tribunals .....348 
Section B. Organization and Procedures:

Appellate Tribunals

4.4 Organization of the appellate court system......353

4.5 Processing a case through the appellate tribunal . . 355

\section{CHAPTER XVII}

\section{ADMINISTRATIVE ORGANIZATIONAL AND} PERSONNEL FRAMEWORKS

Section A. Administrative Organizational Framework

1.1 Introduction $\ldots \ldots \ldots . \ldots \ldots 3$

1.2 Organizational framework, national office level.....365

1.3 Organizational framework, regional office level . . . 367

1.4 Organizational framework, local office level......368

Section B. Personnel Framework (Governmental and Non-Governmental)

1.5 Governmental professional personnel . . . . . . . . 369

1.6 Private tax practitioners .................. 372

\section{CHAPTER XVIII}

Section A. Character of the Underlying Statute

2.1 Precision of the statute itself............. . 375

2.2 Legislative pre-enactment aids to interpretation . . . 383 
2.3 Standards of construction followed by the judiciary in interpreting the statute .....................

Section B. The Regulations Program

2.4 Types and force of regulations . . . . . . . . . . 385

2.5 Precise purpose of statutory regulations . . . . . 388

2.6 Manner of processing regulations ............. 389

Section C. The Rulings Program

2.7 Formal advance written rulings to taxpayers . . . . 390

2.8 Informal technical advice to taxpayers on proposed transactions ................. 392

2.9 Technical advice to field offices .............. 393

2.10 Publication of technical advice given taxpayers and local offices ...................... 396

\section{CHAPTER XIX}

ASSESSMENT, REFUND, AND ADMINISTRATIVE APPEAL PROCEDURES

Section A. Assessment and Audit Procedures

3.1 Introductory note. . . . . . . . . . . . . . 399

3.2 Details of the assessment and audit procedures ...401

Section B. Administrative Appeals

3.3 Introductory note...................406

3.4 Details of procedures analogous to administrative appeals .....................4407

Section C. Extent Administrative Processing of Refund Claims Departs from Administrative Processing of Assessments

3.5 Introductory note..................410 
xxii

3.6 "Error or mistake" claims: Refund procedures prior to an administrative appeal . . . . . . . 4410

3.7 "Error or mistáke" claims: Procedure equivalent to administrative appeal. ..............412

CHAPTER XX

RESOLUTION OF INTERPRETATIVE INCOME TAX QUESTIONS BY INDEPENDENT TRIBUNALS

4.1 Introduction .....................413

Section A. Organization and Procedures: Trial Level

4.2a Organization of the General Commissioners . . . . . 4414

4.2b Organization of the Special Commissioners .....415

4.2c Organization of the Board of Referees.........416

$4.2 \mathrm{~d}$ Organization of the 1960 Act tribunal ........417

4.3a Processing appeals: The General Commissioners. . 418

4.3b Processing appeals: The Special Commissioners . . 421

4.3c Processing appeals: The Board of Referees .....422

4.3d Processing appeals: The 1960 Act tribunal .....423

Section B. Organization and Procedures: Appellate Tribunals

4.4 Organization of the appellate court system.......424

4.5 Processing cases through the courts .........425 


\section{CHAPTER XXI}

\section{ADMINISTRATIVE ORGANIZATIONAL AND PERSONNEL FRAMEWORKS}

Section A. Administrative Organizational Framework

1.1 Introduction . . . . . . . . . . . . . . . 431

1.2 Organizational framework, national office level....432

1.3 Organizational framework, regional office level . . .434

1.4 Organizational framework, local office level......436

Section B. Personnel Framework (Governmental and Non-Governmental)

1.5 Governmental professional personnel . . . . . . . .439

1.6 Private tax practitioners ............... 442

\section{CHAPTER XXII}

Section A. Character of the Underlying Statute

2.1 Precision of the statute itself . . . . . . . . . . .444

2.2 Legislative pre-enactment aids to interpretation . . . 449

2.3 Standards of construction followed by the judiciary in interpreting the statute ............451

Section B. The Regulations Program 453

2.4 Types and force of regulations ........... . 453

2.5 Precise purpose of interpretative regulations . . . . 453

2.6 Manner of processing regulations ...........454 
xxiv

Section C. The Rulings Program 454

2.7 Formal advance written rulings to taxpayers .....454

2.8 Informal technical advice to taxpayers on

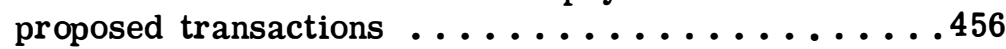

2.9 Technical advice to field offices ............457

2.10 Publication of technical advice given taxpayers

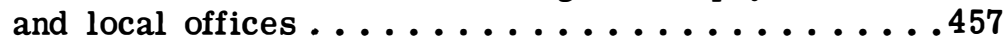

\section{CHAPTER XXIII}

\section{ASSESSMENT, REFUND, AND ADMINISTRATIVE} APPEAL PROCEDURES

Section A. Assessment and Audit Procedures

3.1 Introductory note . . . . . . . . . . . . . . . 459

3.2a Details of the assessment and audit procedures re individuals (income tax) . . . . . . . . . . 4459

3.2b Details of the assessment and audit procedures re corporations (corporations tax)..........4464

3.2c Details of the assessment and aduit procedures re individuals (wage tax) .............. . 465

Section B. Administrative Appeals 466

3.3 Introductory note. . . . . . . . . . . . . 466

3.4a Details of the administrative appeal procedure re assessments in income tax (natural persons) ....466

3.4b Details of the administrative appeal procedure re corporation $\operatorname{tax}$ assessments . . . . . . . . . . 468

3.4c Details of the administrative appeal procedure re assessments in wage tax (natural persons)......469 
Section C. Extent Administrative Processing of Refund Claims Departs from Administrative Processing of Assessments

3.5 Introductory note. . . . . . . . . . . . . . 469

3.6 Details regarding refund procedures prior to an administrative appeal..............470

3.7 Details of the administrative appeal procedure re refund claims ..................471

\section{CHAPTER XXIV}

RESOLUTION OF INTERPRETATIVE INCOME TAX QUESTIONS BY INDEPENDENT TRIBUNALS 473

4.1 Introduction $\ldots \ldots \ldots \ldots \ldots \ldots \ldots \ldots \ldots \ldots \ldots$

Section A. Organization and Procedures:

4.2 Organization of the trial tribunals ........... . 474

4.3 Processing cases through the trial tribunals .....476

Section B. Organization and Procedures:

Appellate Tribunals

4.4 Organization of the appellate court system.......481

4.5 Processing a case through the appellate tribunals. . 482 


\title{
PART ONE
}

\section{THE UNITED STATES AND THE OTHER "FIVE": AN ANALYTIC COMPARISON}

\author{
by
}

L. Hart Wright 


\section{AN OVERVIEW: REQUISITE ADMINISTRATIVE FRAMEWORKS}

\subsection{Introduction: Why the volume was written}

Tax administrators in well developed countries rarely have either occasion or opportunity to compare experiences or exchange opinions regarding procedures and practices utilized in administering complicated tax laws. Moreover, there is little comparative literature on the subject. Even the tax institutes which are internationally oriented usually focus on substantive tax principles, not procedures and practices. Hopefully, therefore, administrators in highly developed countries will find useful this analytic comparison of practices and procedures through which six of their number resolve disputable income tax questions-administratively and judicially.

Concern for tax administrators in well developed countries, however, was not the prime motivation for this study. The initial conception grew out of the belief that administrators in countries just now developing would find especially useful an analytic comparison of diverse functioning models which had evolved out of long experience. Since these now developing countries differ from one another on many counts, it was imperative that there be equally wide dissimilarity among the several experienced countries selected as models. Thus, the choice of Belgium, France, West Germany, Great Britain, the Netherlands, and the United States. These countries differ in their size and population, the complexity and precision of their tax statutes, the degree their legislative bodies provide additional guidance through pre-enactment materials, the assessment system used (self-versus non-self-assessment systems), the standards of construction to which their courts traditionally conform, the theoretical status assigned by each to the doctrine of precedent, and the types of persons available to handle tax disputes-both within and without the government. Consequently, it was possible to determine whether such basic differences were relevant or irrelevant when choosing, from among the alternative functioning models, the structural arrangement and practices most appropriate for each level involved in the conflict resolution process. Also, the analytic comparison contained 
in the first four chapters should enable any given country to determine the extent to which diverse parts of different wholes are adaptable to its situation.

The third purpose of this study is a byproduct of the first two. Practitioners engaged in international tax practice may gain a useful insight into the conflict resolution process followed in each of the six countries covered.

\subsection{Relationship of procedural goals to organization}

Enactment even of a semi-complex income tax statute is bound to generate substantial uncertainty and a host of disputes. Uncertainty and disputes alike need to be dealt with in a timely fashion, uniformly but efficiently and conveniently to taxpayers, through impartial determinations of high quality.

These objectives cannot be achieved through spontaneous self-generation. Nor can they be achieved in a vacuum. Achievement-if it does take place-must come through the acts or non-acts of people, operating in the first instance within some administrative framework. Since the aims themselves ultimately conflict with each other, the likelihood they can be achieved in proper balance is affected inevitably by the manner in which the relevant parts of the administration are organized. In other words, once an administrative organization comes into being, the die tends to be cast regarding the relative degree of emphasis each such goal actually will enjoy. Consequently, the administrator should consider first those diverse goals, not organizational structures. Only after balancing the goals so they fit together properly-due account being taken of the personnel available to implement them-is he in a position to consider the implementing structure. In short, the "mix" of balanced goals should fix the shape of the administrative structure, not vice versa.

\subsection{Sequence of this volume}

The wide range of considerations relevant to the accomplishment of that first step (reconciling the goals) and the impact the resulting mix should have on the details of administrative organization, procedures, and practices, are examined by Chapters II and III in the course of analytically comparing the experience of the six countries. A comparable but selfcontained analytical comparison of the judicial machinery these countries use in resolving income tax disputes then follows in the concluding Chapter IV of this PART. Succeeding PARTS TWO through SIX then describe, on a country-by-country basis, 
the five European models (Belgium, France, Germany, Great Britain, and the Netherlands). These PARTS provide the basis for the analytical comparison to U.S. experience contained in this PART. Because PART ONE weaves a description of U.S. practices and procedures into its comparative study of all six countries, only its general sequence, not its topic headings, conform to the common outline to which the five European authors were requested to adhere in the subsequent PARTS.

The ultimate choices which a country must make in establishing administrative machinery to deal with disputable tax questions are no more difficult than those involved in setting up judicial machinery. As between the two, however, there is far greater variation at the administrative level in the relevant functions to be performed. Thus this level, viewed en toto, tends to become substantially more complex than the other. Because of this peculiar complexity at the administrative level, this introductory chapter is designed (i) to put briefly in overall perspective the main outlines of the administrative structure, described in Chapters II and III, which were evolved from the previously mentioned goals, and (ii) to identify at least the primary problems of practice and procedure with which each of the major components of that structure, and those two chapters, must grapple. ${ }^{1}$ This overview is accomplished by focusing separately on the three central themes upon which the relevant parts of the administrative structure should be organized.

\subsection{First central theme: A centralized interpretative program}

Whatever the inherent conflict otherwise existing between the previously described goals, not one can be effectively implemented in the absence of the first organizational requirement: specifically, a tax administration's National Office should establish at that same top level an active interpretative program for the benefit of lower echelons. A few specialists concentrated there can produce interpretations of a high quality which otherwise thousands of less qualified field officials would need individually to work out for themselves with consequent prejudice both to uniformity and overall efficiency.

1 Readers interested in detailed treatment of any of the matters specifically referred to in this Chapter should consult the table of contents. 
The first problem is whether these interpretative directives should be made accessible to taxpayers through publication. True, such a policy would create many administrative problems. Illustrative-but only illustrative-are questions pertaining to reliability, the right to make retroactive changes or indeed prospective changes, to say nothing of inherent difficulties associated with the requisite painstaking draftsmanship. But on the affirmative side, publication will contribute to uniformity even in so-called non-self-assessment countries. Further, it will help assure proper application of these directives by the field forces. Only through publication can this process receive assistance from an adversary-a taxpayer. For only then will he have a firm basis on which to question the way in which a given local official applies a directive to his own situation. Finally, publication will minimize uncertainty. Because these interpretations are centrally evolved, at the least they should have the stature of reliable advance warnings regarding the contours of an administration's litigation policy.

Of course, all interpretative difficulties can never be anticipated as of that point in time immediately following enactment of a new statute. Consequently, for the National Office to sustain its control over interpretative policy to the previously cited ends, it must promulgate, in addition to an initial set of interpretative instructions or regulations, ad hoc rulings as new questions arise. Many of the difficulties this policy would create are similar to those associated with publication of any initial set of directives. Distinctive here, however, is the problem of providing the "ivory tower" at the National Office with an effective early warning system, capable of alerting it in a timely fashion to the really significant newly emerging practical issues. The most effective device of this type actually depends on catering directly to taxpayer self-interest. The National Office can guarantee receipt of such warning if it establishes the practice of ruling in advance on the proposed transactions of individual taxpayers. While this practice also produces many administrative headaches to which detailed procedures must be responsive, it simultaneously satisfies a further significant and worthwhile aim: dispelling uncertainties for which the tax system itself is otherwise responsible.

Not one of the European countries covered here fosters major programs involving every one of these different types of interpretative efforts. Britain does the least, ${ }^{2}$ though actually 
it has the most complex statute of the Five. Normally, on enactment of a new statute, it does not publish an initial set of interpretative regulations, thereafter does not rule on proposed transactions, and as new issues emerge typically does not publish rulings thereon. However, by foresaking goals which, when viewed in long-run perspective, seem basic to wise tax administration, Britain has avoided the raft of difficulties experienced by the United States, the country which does the most in this area, and which maintains every one of the foregoing types of interpretative programs. For purposes of this overall view, only the two prime difficulties the United States has encountered need be mentioned.

The first involves certain inherent conflicts. Previously it was said that, given the doubts and volume of disputes stemming from a complex tax statute, the consequent goals (to deal with these doubts in a uniform, timely, efficient, impartial, and sophisticated manner) actually united to support establishment of a centrally administered interpretative program. Within such a program, however, are certain inherent and difficult-to-resolve conflicts. For example, in trying to promulgate an initial set of interpretative instructions, it is not easy to strike the right balance between timeliness, completeness, technical accuracy, understandability, and efficiency (in the sense of avoiding undue expenditure of talented manpower). As is indicated in Chapter II infra, however, adoption of certain procedures and practices will tend at least to provide a reasonable degree of assurance that each competing aim will enjoy the stress appropriate to it.

Another inherent conflict exists between that part of a program designed to neutralize uncertainty in individual casesthrough a private ruling on a taxpayer's proposed transactionand that part designed to achieve uniformity through publication of rulings. As to the former, speed is essential, for consummation of any given taxpayer's proposed transaction cannot be long postponed. Equally indispensable in the case of published rulings, however, is the exact opposite-painstaking care or absolute technical accuracy-for published rulings fix the nationwide stance of the government, not just the tax consequences of an isolated taxpayer's proposed transaction. Here again the difficulty lies in devising procedures and practices which at least tend to assure that each goal (speed v. quality) will receive that degree of stress appropriate to the purpose to be served. 
The second major problem is to sustain on a continuing basis the requisite emphasis on each aspect of such a multisided interpretative program. Interpretative directives long delayed guarantee an interim marked by uncertainty, lack of uniformity, inefficient use of field forces, or all three. Maintaining an interpretative program at an adequate level, however, can be prejudiced all too easily by a competing pressure on administrators. For example, a national office official, responsible for manning the typically under-staffed assessment function's "firing line," is concerned with putting out today's brush fires. Moreover, he knows that this kind of productivity is measurable day by day and man by man. That official would be under tremendous pressure not to allocate on an adequate sustaining basis the talented manpower-i.e., the "think time"-required to develop interpretations which will be wholly useless until completed. Also prejudicial is the fact that even then their exact net utility, however large, can not be recorded in terms of a precise monetarily expressed plus on his productivity charts. One possible remedial step-which simultaneously will further the goal of impartiality-is to assign responsibility for the interpretative function to senior officials who work outside the enforcement function-as in France ${ }^{3}$ and the United States. Chapter II indicates other arrangements and procedures which likewise can contribute to the first of these two ends.

\subsection{Second central theme: Decentralization of the enforcement function}

A second structural requirement involves a high decentralization of the enforcement function itself, with local administrative offices resolving the bulk of all actual disputes. These two activities-enforcement and dispute-resolution-are certain to engage a large number of personnel, which decentralization will spread widely across the nation. In consequence, this arrangement would make unachievable the goal of uniformity if not complemented by the previously described centrally administered interpretative program.

Even then, the first and most serious problem is to maintain-among such a large and decentralized staff-a sufficiently high level of competence to do the work properly. ${ }^{4}$ However,

\footnotetext{
${ }^{3}$ See Chap. IX infra.
}

4 The character, and its relevance, of non-governmental tax practitioners is considered in Chap. IV, \$4.9 infra. 
the overriding imperatives of efficiency and taxpayer convenience lead to an inescapable conclusion. Decentralization is so essential that the administration itself simply must assume the added burden of providing, through in-service training, the requisite professional understanding to otherwise educated persons. Even among the six highly developed countries covered here, the educational systems do not produce the particular type of specialists needed. Moreover, persons most suited to the task all too often-though with variations from country to country-are not available for government employment at this level in anything like a sufficient number. In consequence, each of the Six, having decentralized its enforcement function among offices numbering from 100 in the Netherlands to 1700 in France, ${ }^{5}$ has instituted some type of in-service training program.

Of the Six, Belgium does the least. ${ }^{6}$ Most inspectors in its local offices came into the system at a lower level, on the basis of an examination taken after completing secondary education. Their subsequent professional development, insofar as government bears the cost, involves little more than a planned program of on-the-job training. They must carry out on their own time the contemplated study of tax law, regulations, etc.

The most extensive government sponsored training programs among the European countries are carried on by France ${ }^{7}$ and the Netherlands. ${ }^{8}$ After passing a general qualifying examination, applicants for the job of inspector or assessor are subsidized during the period required to complete work on a law degree. In France, the applicant previously must have started work on this degree. His two-year training program at the National School for Taxes is arranged so that he can complete the degree requirements. The Netherlands' subsidy covers all university work leading to a Master's Degree in tax law and theory. Both countries require that the subsidy be returned should the applicant fail to stay with the government for a certain number of years. Both also provide substantial in-service classroom courses for the employee-rank

5 See $\$ 1.4$ in Chaps. V, IX, XII, XVII, and XXI infra. The U.S., while maintaining only 58 district offices, subdivides them into approximately 800 posts of duty.

${ }^{6}$ See Chap. V, §1.5 infra. But cf. Great Britain, Chap. XVI, $\S 1.5$ infra.

7 See Chap. IX, § 1.5 infra.

${ }^{8}$ See Chap. XXI, \$1.5 infra. 
immediately below inspector or assessor. As to these, Germany does likewise, with the classroom course there extending over nine months. ${ }^{9}$ Its assessors, however, typically are employed only after they have graduated from a university, usually with a law degree. These men then have three months of specialized training at the Federal Finance College, interspersed with on-the-job training.

The United States differs from the three European countries just mentioned. Its chief reservoir for the revenue agent class is made up of college graduates who majored in accounting. 10 However, during their first two years of employment, in addition to carefully supervised on-the-job training, these recruits attend in-service regional schools for almost five months, ${ }^{11}$ and there the emphasis is on tax law.

The second major problem at the local office level involves the inherent conflict between its dispute-resolution functionrequiring as it does an image of impartiality-and the local office's competing revenue-producing responsibility. Once again adoption of compensating procedures peculiar to that level becomes essential, but from the foregoing conflict and other considerations emerges a third organizational theme.

\subsection{Third central theme: Centralization of final administrative}

hearings at an intermediate level

To reduce the magnitude of the last mentioned conflict, it is important to isolate from the local office the highest administrative official with whom a taxpayer may discuss a disputed proposed assessment. Taxpayer convenience, however, bars assignment of this function to the National Office. Thus, the need for an intermediate layer, which incidentally will permit the concentration of particularly able men to fulfill a most demanding task. Of the countries covered here, three (Belgium, France, and the United States) do put the apex of the administrative conflict resolution process in just such an office.

A yet further hard choice emerges in trying to assure administrative impartiality. The aim is avoidance of unnecessary

9 See Chap. XIII, §1.5 infra.

10 Estate and gift tax examiners, on the other hand, are law school graduates.

11 Additional classroom courses are provided those who spend a substantial part of their time examining special types of returns-such as those filed by insurance companies or exempt organizations. 
litigation, with simultaneous protection of the government's interest. But this leaves unresolved two perplexing questions: What litigation is unnecessary and, prior to litigation, what interest does the government have in a disputed question?

As to the first question, the tax system gains nothing, apart from protecting the government's interest in an individual dispute, from litigating cases which neither are essential to the central office's litigation policy nor are capable of clarifying the law to any really significant degree. The answer to the second question, however, ultimately means that, to obtain a bilateral agreement in many controversies, the intermediate office must be empowered to exercise true "settlement" or compromise authority, geared to a realistic appraisal of the litigation hazards each side faces. Not to be empowered to make mutual concessions in response to the litigation hazards deprives the intermediate office of the chance to be truly impartial and to obtain a bilateral agreement in disputes where the taxpayer has some reasonable chance to prevail in litigation. In short, the government's interest in a controversy not otherwise worth litigating is worth nothing more than the value of its relative chance to prevail should that dispute actually be litigated. Comparably, the taxpayer's competing chance represents his interest in that same controversy. And at the administrative level, i.e., absent actual litigation, justice cannot be impartial unless the total amount in issue is divided on the basis of those chances or interests. To permit such settlements, as is done in France, 12 the Netherlands, 13 and the United States, ${ }^{14}$ will generate certain major problems considered fully in Chapter III infra. Some are peculiar to this level; yet others pertain to the local office level. Both can be dealt with, however, by appropriate instructions and procedures. Conversely, not to empower an intermediate office to reach such settlements is bound to result in an excessive amount of time-consuming expensive litigation. 15

12 See Chap. XI, $\$ 3.2 \mathrm{a}$ and $3.4 \mathrm{~b}$ infra.

13 See Chap. XXIII, §§ $3.2 \mathrm{a}$ and $3.4 \mathrm{a}$ infra.

14 U.S. Treas. Reg. §601.106(f), Rule II.

15 see Chap. IV infra. 


\section{CHAPTER II}

\section{CENTRALLY ADMINISTERED RULE-MAKING PROGRAMS}

\section{Section A. Evolution of U.S. Programs}

\subsection{Introduction}

Among the six countries treated here, the U.S. tax administration maintains the most comprehensive set of centrally administered rule-making programs. A preliminary description of the evolution, magnitude, and effect of its programs will serve two purposes: first, to identify the consequent problems, answers to which will fix the major contours of such programs, and second, to facilitate a subsequent analytic comparison of the "Six's" diverse reactions to the vital purposes these programs serve.

Obviously, the appropriate legislative body, not the executive, ultimately is responsible for a nation's tax policy. Further, substantive policy considerations, responsive to the nation's socio-economic status and goals, alone should determine the general thrust of its income tax statute. But this is not so as to all details. Decisions regarding the latter, such as the number and types of substantive deviations to be incorporated and the manner in which the statute is to be drafted, should depend also upon the variable extent the alternatives would generate uncertainty and controversies between taxpayers and the tax administration. The significance the legislature actually attaches to any differences anticipated on this count should be affected, in turn, by the degree it is empowered and willing to share a clarifying rule-making function with administrators, independent tribunals, or both. Necessarily, its attitude toward this must be influenced by the anticipated relative capabilities of the other two. Also relevant, however, are its expectations regarding two other matters: first, the standards of construction to which administrators and/or independent tribunals would conform and second, its own willingness and power to employ pre-enactment materials (legislative committee reports, etc.) to reduce the uncertainties reflected in the statute itself and through this means control the range of rule making by the other two. Finally, in considering at the pre-enactment stage the extent to which the tax administration itself should be 
counted on to satisfy a clarifying function, the legislative body should take account of the degree it is willing to permit the administration to identify its interpretative position before transactions are consummated (through regulations and rulings), i.e., before controversies emerge rather than just after they arise in the setting of the administration's conflict resolution procedures.

Though the U.S. Congress should have examined the above questions before it chose from among competing statutory approaches, in fact the answers to many evolved after it already had gone beyond the point of no return in shaping a most complex substantive statutory pattern.

For example, as to the anticipated role of courts, the rule-making consequence of the fairly strong American doctrine of precedent undoubtedly was generally understood by those who enacted the first modern income tax statute in 1913. But neither the congressional debates nor the committee reports bearing on that act reflect any concern or expectations regarding either (i) the judiciary's standard of statutory construction (i.e., the degree courts should or would exercise an active or passive role in the interpretative process) or (ii) its capacity to share the rule-making function in a manner both timely and convenient to taxpayers. As events turned out, however, the congressional sponsors of that act would have been misled for the future by any findings as of that moment with respect to the first of these. Before, and just immediately after that act was passed, the Supreme Court insisted that the judiciary would follow a passive role in construing tax statutes:

In the interpretation of statutes levying taxes it is the established rule not to extend their provisions, by implication, beyond the clear import of the language used, or to enlarge their operations so as to embrace matters not specifically pointed out. In case of doubt they are construed most strongly against the Government, and in favor of the citizen. ${ }^{1}$

Within two decades, however, it was to abandon this standard of strict construction except perhaps-now to the taxpayer's

1 Gould v. Gould, 245 U.S. 151, 153 (1917). Accord, Benzinger v. U.S., 192 U.S. 38 (1904); American Net \& Twine Co. v. Worthington, 141 U.S. 468 (1891); U.S. v. Wigglesworth, 2 Story 369 (Cir. Ct. D. Mass. 1842). 
disadvantage -in the case of deductions. ${ }^{2}$ And even as to these the Court subsequently observed:

We are not impressed by the argument that, as the question here decided is doubtful, all doubts should be resolved in favor of the taxpayer. It is the function and duty of courts to resolve doubts. We know of no reason why that function should be abdicated in a tax case more than in any other where the rights of suitors turn on the construction of a statute and it is our duty to decide what that construction fairly should be. ... ${ }^{3}$

Shortly thereafter, the High Court took the final major step, by making abundantly clear that it expected the judiciary to play a more active role in combating avoidance, 4 though within the framework of a notion that courts should "seek the purposes of the applicable sections of the Code and adopt that construction which best gives effect to those purposes." 5 The judiciary, by this belated step, began to assist the legislative body in achieving one salutory effect, namely, greater "equality among taxpayers,"6 i.e., "uniform application"7 of the law by reference to the "substance" 8 of transactions rather than their mere "form."9 But these shifts also were responsible for generating additional uncertainty throughout the code and in consequence new controversies. In many affected areas, Congress then felt called upon to supply legislative refinements which made the basic law more complex ${ }^{10}$ and, because also new deviations were added, yet new uncertainties and controversies emerged.

While those who sponsored the first modern act could not have been expected to anticipate the above shifts in standards of judicial construction, they could have predicted that the then constituted federal judiciary provided a forum neither adequate

2 New Colonial Ice Co., Inc. v. Helvering, 292 U.S. 435 (1934).

3 White v. U.S., 305 U.S. 281, 292 (1938).

${ }^{4}$ E.g., Helvering v. Horst, 311 U.S. 112 (1940); Higgins v. Smith, 308 U.S. 473 (1940). But cf. Commissioner v. Tellier, 383 U.S. 687 (1966).

5 U.S. v. Benedict, 338 U.S. 692, 696 (1950).

6 Colgate-Palmolive-Peet Co. v. U.S., 320 U.S. 422, 425 (1943), reh. den. 320 U.S. 816 (1944).

7 Burnet v. Harmel, 287 U.S. 103, 110 (1932).

8 Commissioner v. Court Holding Co., 324 U.S. 331, 334 (1945).

9 Higgins v. Smith, 308 U.S. 473, 477 (1940).

10 E.g., I.R.C., $\$ \$ 671-678$. 
nor convenient in which to resolve all the uncertainties and controversies which that and succeeding acts were certain to generate. Within a decade the Congress was forced to create a specialized independent tribunal (Board of Tax Appeals, now called the Tax Court), both to provide a means of resolving a tremendous back-log of unresolved controversies and to permit this to be accomplished with more convenience to taxpayers, i.e., before they had to pay the contested portion of the tax. 11 But even with the addition of that tribunal, the conflict resolution burden was more than the judicial system could be expected to accommodate. Three years after that tribunal was created, top policy-making officials concluded it was necessary to adopt a compensating administrative procedure which, with certain limitations, prevails to this day. ${ }^{12}$ Administrative officials were directed to seek administrative "settlements" geared, if need be, to partial concessions by both sides, on the basis of their competing strengths and weaknesses, with nuisance values ignored by both. As the Under-Secretary of the Treasury described it:

... There are any number of legal questions for which there are no precedents, that are relatively unimportant, and where it pays the Government to make concessions to the taxpayer if, in return, the taxpayer will make concessions to the Government. In other words, we are applying, in the field of tax administration, the ordinary business methods of adjusting disputes, because we found that, both for the taxpayer and for the Government, litigation is unsatisfactory and expensive.

Settlement methods tend to keep tax questions where they belong: in the administration field, and tend to promote promptness and finality. . . 13

\subsection{Evolution of U.S. regulations program}

Though the Congress which passed the first modern act should have foreseen the ensuing substantial degree of uncertainty and controversy such statutes generate, there is little

11 Prior thereto, to litigate an issue, the taxpayer had to pay the entire contested amount and then sue for refund in either a federal district court or the United States Court of Claims. Flora v. U.S., 357 U.S. 63 (1958), reh. 362 U.S. 145 (1960). Refund suits in these two forums still survive as alternative remedies to the litigate-first-paylater remedy before the Tax Court. See Chap. IV infra. Indeed, outside the income, estate, and gift tax areas, they are the sole remedies.

12 See Chap. III, \$ 3.4 infra.

13 Mills, "Federal Administration of Tax Law," 52 N.Y. State Bar Assoc. Proc. 495, 503 (1929). 
to suggest it had any real intention of sharing in any significant degree its rule-making function with administrators. It probably believed that it was accommodating only otherwise unprovided for procedural requirements when, in three different instances, ${ }^{14}$ it required certain things to be accomplished under rules and regulations prescribed by the Commissioner with the approval of the Secretary of the Treasury. Three years later, however, on the substantive side, it did authorize the first of what might be described as narrowly focused legislative-type regulations. When establishing a "reasonable allowance for depletion" in 1916, it provided that "such reasonable allowance" would be determined "under rules and regulations to be prescribed by the Secretary of the Treasury."15 That this delegation of legislative authority was upheld came as no surprise; ${ }^{16}$ the Supreme Court previously, in non-tax areas, had said it was appropriate for Congress, after indicating its "will," to "give to those who were to act under such general provisions 'power to fill up the details'. . ."17

In the next year, 1917, similar legislative-type delegations were added to a few other isolated substantive provisions. ${ }^{18}$ And these were supplemented by the following catch-all provision which seemed broad enough to accommodate, as to the whole code, both interpretative-type regulations and procedural problems:

That the Commissioner of Internal Revenue, with the approval of the Secretary of the Treasury, is hereby authorized to make all needful rules and regulations for the enforcement of the provisions of this Act. ${ }^{19}$

In the years immediately following, only sporadic and limited concern was expressed in Congress regarding its increasing though still modest tendency to authorize issuance of legislative-type regulations covering specific isolated areas. ${ }^{20}$

14 Rev. Act of 1913, \$IIA, Subdiv. 2, IID, and IIE. But cf. an older provision in the general law. Rev. Stat. § 3447 (1875).

15 Rev. Act of 1916, §§5(a) Eighth, 6(a) Seventh, and 12(a) Second. Cf. $\$ 8(\mathrm{~g})$.

16 Burnet v. Thompson Oil \& Gas Co. 283 U.S. 301 (1931).

17 U.S. v. Grimaud, 220 U.S. 506, 517 (1911).

18 E.g., Rev. Act of Oct. 3, 1917, §§ 205 (a) and 210.

19 Id. §1005. Cf. Rev. Act of Mar. 3, 1917, § 207.

20 For a fairly current compilation of specific delegations, see Balter, "Relief from Abuse of Administrative Discretion," 46 Marq. L. Rev. 176, 182 n. 27 (1962). 
Even a leader of the minority side of the sponsoring congressional committee defended the practice, arguing that the language of the bill in these instances was "so obscure and almost nonunderstandable that somebody ought to have discretion in administering its provisions." 21

Far greater concern was expressed repeatedly, however, and on several counts, regarding administrative practices in implementing the catch-all provision dealing with interpretativetype regulations and rulings. From the responses to these concerns, emerged the main outlines of the present regulations program, the end product of which, as to the income tax, now could fill a volume of 3,000 pages at 400 words per page.

The first such concern, exposed to light in 1921, grew out of the administration's own belief that its interpretations did not attain automatically the force of law merely through the process of being incorporated in regulations issued under this general provision. It felt it was legally obligated not only to correct by amendment any previously issued regulation deemed by it to contain an erroneous interpretation, but in consequence to reopen all cases previously closed on the basis of the earlier "erroneous" interpretation. Frequently, from the vantage point of taxpayers, the earlier version, characterized belatedly by the administration as erroneous, proved to be the more favorable of the two. But the practice of reopening these cases on the basis of the later interpretation was defended by the administration before a congressional committee on the grounds that a mere administrative officer not only legally could not, but ordinarily as a matter of policy should not, be permitted "to waive a tax legally imposed" (i.e., imposed by the statute itself when properly interpreted). It added, however, that Congress itself might want to make room for a limited exception, by adopting a procedure enabling the administration to avoid any "great hardship" resulting from belated administrative revision of interpretative regulations or rulings. 22 Congress proceeded to adopt such an arrangement, 23 the modern statutory counterpart of which 24 permits the administration-within its discretion-to fix the extent to which any regulation is to be applied without retroactive effect. In currently implementing

21 Statement of Senator Walsh, 61 Cong. Rec. 6576 (1921).

22 Notes on the Revenue Act of 1918, submitted by the Secretary of the Treasury to the Committee on Ways and Means, 48-49 (1919).

23 Rev. Act of 1921 , § 1314 .

24 I.R.C., $\$ 7805$ (b). 
this discretion, the administration according to a top officialhas tried to conform to three sometimes-difficult-to-apply principles. Amendments which actually change the thrust of the regulations to the detriment of taxpayers are made prospective only. ${ }^{25}$ Where such a change is of benefit to taxpayers, it is applied retroactively to all open years. This is the practice also where the amendment deals with a matter not previously covered or clarifies an ambiguity in the previously issued regulation. 26

In 1924, just three years after the above statutory change was made, certain congressional quarters complained that the administration's interpretative regulations actually tended, on the whole, to stretch the statutory law to the disadvantage of taxpayers. 27 The House proposed to attack this problem by adding to the general authorization a limitation which provided that "such regulations shall not enlarge or modify any provisions of this act." 28 The Senate, however, rejected the proposed amendment 29 after being assured by the Chairman of the Senate Finance Committee that no administrative official could ever "make any rule or any regulation in violation of the law itself with any binding force." 30 Of course, literally neither this comment nor the proposed amendment were responsive to the only real and infinitely more subtle question: To what extent should the administration's own interpretative view regarding a statutory ambiguity gain additional weight because incorporated in its own regulations? In the end, while this question-the subject matter of 2.4 infra-was left to the courts, the Congress itself almost immediately began to step up its own effort to contain, by a flanking manuever, what otherwise would have been a larger potential range for administrative rule making. It began to supplement newly proposed statutory

25 Rogovin, "The Four R's: Regulations, Rulings, Reliance and Retroactivity," 43 Taxes 756, 762 (1965). This was not always adhered to at an earlier time. E.g., see Manhattan General Equipment Co. v. Commissioner, 297 U.S. 129 (1936). Further, if the earlier regulation itself was a reasonable interpretation, retroactive change may be beyond the Commissioner's power. Helvering v. R. J. Reynolds Tobacco Co., 306 U.S. 110 (1939).

26 E.g., see Helvering v. Reynolds, 313 U.S. 428 (1941).

27 See Statements of Representative Deal and Senator McKellar, 65 Cong. Rec. 3333 and 7140 (1924).

2865 Cong. Rec. 3334 (1924).

29 Id. at 7140.

${ }^{30} \mathrm{Id}$. at 7141 . Statement of Senator Smoot. 
provisions with more fully developed congressional committee reports which clarified and reflected more precisely the intention to be attributed to otherwise ambigious statutory terms. Both then ${ }^{31}$ and now, ${ }^{32}$ courts deemed statements in such reports, explicitly revealing the congressional intention, to be of controlling importance in interpreting the statute.

\subsection{Evolution of U.S. private and published rulings programs}

Almost coincident with the foregoing 1924 debate pertaining to administrative tendencies in drafting regulations appeared the first public expression of a frequently recurring congressional concern regarding private rulings which, at that time, could be obtained by individual taxpayers only from the National Office and then only as to completed transactions. ${ }^{33}$ At an earlier point, in 1919, the administration had begun to publish some of these, ${ }^{34}$ though with names and other identifying characteristics omitted. However, in 1924 a congressional subcommittee then investigating tax administration 35 observed that most private rulings remained secret. It contended that uniform treatment of all taxpayers could be assured only if all these rulings were published. 36 Apparently, it was in response to this charge and contention that the tax administration publicly committed itself to publish, after necessary revision, all rulings of general interest having precedent value. ${ }^{37}$ Two years later, however, the Senate indicated it was not content with this commitment. This was not just because the administration had failed to fulfill its own pledge. Interested Senators recognized that the nature of that commitment actually left the

31 McLean v. U.S., 226 U.S. 374 (1942).

32 Commissioner v. Bilder, 369 U.S. 499 (1962). The report issued by the Senate Finance Committee in connection with the major statutory revision in 1954 contained 614 pages. S. Rep. No. 1622, 83d Cong., 2d Sess. (1954).

33 Mim. 2880, Cumulative Bulletin [hereinafter cited as C.B.] I-1, 400 (1921).

34 C.B. 1-1 (1919).

35 Pursuant to S. Res. 168, 68th Cong., 1st Sess., Mar. 12, 1924. See 65 Cong. Rec. 4014-4023 (1924).

36 Hearings before the Senate Select Committee on Investigation of the Bureau of Internal Revenue, 68th Cong., 30-31, 56-57 (1924) and more generally discussed in 3630-3661 (1925). For a more complete statement justifying publication, see S. Rep. No. 27, 69th Cong., 1st Sess. 229-234 (1926).

37 see fly-leaf, C.B. III-1 (1924). 
administration free, in any given case, to turn the question of publication on the often all too subtle difference between what is a new precedent and what is merely a new application of a previously published precedent. ${ }^{38}$ In an attempt to force publication of both new precedents and new applications of earlier published precedents, the Senate passed an amendment to the general provision, requiring the Commissioner to "publish all rules, practices, principles, and formulas applied or followed in the interpretation and application of any revenue act. . . "39 A conference committee, composed of representatives of both chambers, drained this of much of its vitality by reducing it to two words 40 which, upon subsequent enactment, required the Commissioner "to prescribe and publish all needful rules and regulations for the enforcement of this act." 41 Nevertheless, the administration itself also continued, in the fly-leaf of each Cumulative Bulletin thereafter published, to repeat its own earlier self-assumed commitment. ${ }^{42}$ Years later, however, in 1953, the administration openly acknowledged to a second investigating subcommittee that it had not lived up to this commitment; proportionately, of the precedent-type rulings issued, "very few" had been published. 43 Senior administrative officials agreed, however, that this failure was not in the interest of wise tax administration, and promised immediate correction. 44 The number published annually then jumped from 115 in the preceding year, 1952, to a peak of 801 in 1955. Beginning in 1960, however, a sharp decline set in; only 388-well under 5 percent of the private substantive rulings issued-were published in 1964. ${ }^{45}$ By then, because many outside the government felt that federal agencies in general held back from

38 Hearings, Rev. Act of 1926, Senate Finance Committee, 69th Cong., 1st Sess. 93-96 and 136-145 (1926).

3967 Cong. Rec. 3879 (1925).

40 H. Rep. No. 356, 69th Cong., 1st Sess. 55 (1926).

41 Rev. Act of 1926, §1101. Italics added.

42 E.g., see fly-leaf, C.B. 1951-2 (1952).

43 Hearings on Administration of the Internal Revenue Laws Before a Subcommittee of the House Committee on Ways and Means, 82d Cong., 1st Sess. 1340 (1953).

44 Id. at 1564. Also, Hearings on Administration of the Internal Revenue Laws Before a Subcommittee of the House Committee on Ways and Means, 83d Cong., 2d Sess. 51 (1954).

45 of course, many of the private rulings had no precedent value. See note 50 infra. Nevertheless, to assure accuracy and integrity of the private rulings program, and to acquaint Congress with the manner in which the Commissioner exercised his interpretative function, a bill 
the public far more information than could be justified, a statutory remedy was being sought ${ }^{46}$-a so-called "Freedom of Information Act." For a variety of reasons, including the argument that the proposals would require publication of all private rulings, and thus cripple the latter program, 47 the tax administration opposed these efforts. 48 In 1966, however, one such proposal was enacted by Congress. 49 While the intent of the act was clear, to increase public knowledge and access to material not theretofore available, the language of the act was not. 50 In consequence, the tax administration now argues that, to determine congressional intention, recourse must be made to the relevant congressional committee reports. And to support the proposition that it need not publish all private letter rulings, 51 it relies on the following statement in the sponsoring committee's report:

... under $\$ 1160$, an agency may not be required to make available for public inspection and copying any advisory interpretation on a specific set of facts which is requested by and addressed to a particular person, provided that such interpretation is not cited or relied upon by any officer or employee of the agency as a precedent in the disposition of other cases. . . .52

\section{(footnote continued)}

introduced but not enacted in 1965 would have required the administration to publish within ten days all rulings involving potential tax liabilities exceeding $\$ 100,000$. S. 2047, 89th Cong., 1st Sess. (1965). See Statement of Senator Gore, 111 Cong. Rec. 11810, 11814 (1965).

46 See S. 1666, 88th Cong., 1st Sess. (1963).

47 See Statement of G. d'Andelot Belin, Hearings before the Subcommittee on Administrative Practice and Procedure of the Senate Committee on the Judiciary, 88th Cong., 1st Sess. 176 and 268 (1963) and $i d$. 88th Cong., 2d Sess. 168, 177E (1964).

$48 \mathrm{Ibid}$. Also see Statement of Edwin Rains in hearings before the same subcommittee, op. cit. supra note 47 , 89th Cong., 1st Sess. 30 (1965) and Treasury Department exhibit, $i d$. at 441.

49 Pub. Law $89-487,80$ Stat. 250 (1966).

50 See Panel Discussion on Freedom of Information Act, XX Bulletin, Taxation Section, A.B.A., No. 3, 43 (April 1967); Bennett, "The Freedom of Information Act, Is It a Clear Public Records Law?" 34 Brooklyn L. Rev. 72 (1967); Sexton, "New Law Changes Rules on What Information IRS Must Disclose; Confusion Likely," $26 \mathrm{~J}$. Taxation 120 (1967).

51 See Panel Discussion, op, cit. supra note 50, Statements of Messrs. Rogovin and Uretz. Also, Uretz, "Freedom of Information and the IRS," 20 Ark. L. Rev. 283 (1967).

52 H. Rep. No. 1497, 89th Cong., 2d Sess. 7 (1966). 
A second major problem in the rulings area concerned prospective transactions. In 1921, a Commissioner had explained that the administration was not equipped to do more than "advise taxpayers promptly of their present liabilities arising out of past transactions." 53 In 1938, however, to avoid delay or abandonment of legitimate transactions because of tax uncertainties, both the Treasury 54 and a congressional subcommittee 55 proposed to empower the Commissioner to issue binding advance rulings on prospective transactions where this appeared to be in the interest of wise tax administration. The Congress, however, substituted the more cumbersome bilateral closing agreement arrangement, with the signature of at least an Assistant Secretary of the Treasury being required in each case. 56 Sharp rate increases and the explosion of the economy accompanying the outbreak of World War II resulted in an enormous increase in requests for these closing agreements. To meet the demand, the administration-acting on its own initiative-substituted the less cumbersome unilateral advanceruling arrangement. By the $1960^{\circ} \mathrm{s}$, the number annually processed always exceeded 30,000 , of which about 10,000 involved substantive income tax questions.57 Generally speaking, none of these involved either factual questions or transactions

53 Mim. 2880, C.B. I-1 400 (1921). Italics added.

54 Statement of Under-Secretary of the Treasury, Hearings Before the House Committee on Ways and Means, 75th Cong., 3d Sess. 109 (1938).

55 Report of a Subcommittee of the Committee on Ways and Means, 75th Cong., 3d Sess. 55 and 79 (1938).

56 Rev. Act of 1938 , $\$ 802$. The statute itself no longer requires the signature of such a high official. I.R.C., \$7121.

57E.g., see Commissioner of Internal Revenue, Annual Report 1966, 6. A large proportion of the balance are requests for permission to change accounting methods or years for federal tax purposes. Further, of the 10,000 requests for substantive income tax rulings, not all spring from known doubts or real interpretative issues; in effect, some simply request what is tantamount to an "insurance policy" to protect the taxpayer-because of the large sums involved-from unanticipated or unrecognized doubts or uncertainties. For conflicting views regarding the propriety of this practice, see Rogovin, op. cit. supra note 25, at 765 n. 48. Finally, a majority of the 10,000 actually concerned exempt organizations. Quite apart from this, however, district offices issued 14,330 determination letters to organizations seeking exemptions, 15,515 determination letters affirming qualification of pension and profit sharing plans covering employees, and 7,231 determination letters covering pension plans for self-employed persons. 
lacking in business purpose; well publicized administrative practice renders both ineligible. 58

Finally, there is a difference between private and published rulings regarding the extent to which taxpayers may rely thereon. Implicit in the first public announcement that the National Office would issue private rulings on prospective transactions, 59 was a limitation-later expressly stated 60 -to the effect that a private ruling issued to a taxpayer on a particular transaction applied, generally speaking, only to that transaction and to that particular taxpayer. In other words, the government expressly sought to exclude the possibility that such a ruling could be relied upon either by the same taxpayer as to other similar transactions or by other taxpayers involved, say, in the same industry. ${ }^{61}$ It acknowledged, however, that the limitation would be appropriately adjusted where the ruling itself expressly either covered a series of identical transactions, as in the case of a taxpayer's excise tax, or covered all parties to a given transaction, such as a merger of two or more corporations. It is only because this limitation ordinarily has been respected by the courts 62 that the National Office has been willing to permit the great majority of these rulings to be issued by its own junior staff officials 63 -an absolute essential if it is to accommodate in an even reasonably timely manner the tremendous number of such requests. 64 In contrast to the limited range attributed to a

58 See $\$ \S 2.13$ and 2.15 infra.

59 Rev. Rul. 54-172, C.B. 1954-1, 394.

60 Rev. Proc. 62-28, C.B. 1962-2, 496, superseded by Rev. Proc. 67-1, Internal Revenue Bulletin [hereinafter cited as I.R.B.] 1967-1, 5 .

61 France, on the other hand, tends to issue rulings on prospective transactions only to industrial, trade, professional, or labor groups. See Chapter XIV, § 2.7 infra.

62 E.g., Goodstein v. Commissioner, 267 F.2d 127 (1st Cir. 1959). But $c f$. International Business Machines Corp. v. U.S., 343 F.2d 914 (Ct. Cl. 1965).

63 See Rogovin, op. cit. supra note 25. Within the National Office, more than $75 \%$ are issued at the Branch level; proportionately few go above the higher Division level, and not over $2 \%$ are reviewed by the legal staff in the Chief Counsel's Office. For a more detailed breakdown, see Caplin, "Taxpayer Rulings Policy of the Internal Revenue Service," N.Y.U. 20th Inst. on Fed. Tax. 1, 28 (1962).

64 Even so, of those issued in fiscal 1965, $58 \%$ took from two to six months, and of these almost one-third took more than six months. Rogovin, op. cit. supra note 25, at $767 \mathrm{n}$. 59. Not all of this delay is due, however, to excess inventory coupled with the actual time taken to resolve a given question; initial submissions by taxpayers often are 
private ruling, the above mentioned public announcement made it equally clear that the more carefully processed published rulings were addressed to all taxpayers. It added, in consequence, that a given taxpayer "need not request a specific ruling applying the principles of the published ruling to the facts of the taxpayer's particular case where otherwise applicable." 65

However, such a taxpayer does assume some risk, apart from that necessarily involved in determining whether the principle of a given published ruling applies to his own facts. Not all of the 14,776 substantive rulings published since 1919 continue to have vitality. Some expressly modified or reversed earlier ones. Others, however, have been affected by subsequent legislation, 66 regulations, or court decisions without any attempt by the Service to alert taxpayers to this fact. And, thus, the taxpayer assumes the risk. In other words, the practice governing the published rulings program 67 imposes on each taxpayer the burden of determining whether any such subsequent events affected an earlier published ruling on which he proposes to rely in consummating a transaction. 68 In theory, to overcome the particular hazard implicit in this practice, he need only research and carefully analyze relevant decisions, etc., post-dating that published ruling.

But no matter how carefully a taxpayer researched a question, he still could not protect himself if, having consummated a transaction in reliance on that ruling, the administration thereafter changed its interpretative position and applied the change retroactively to his case. In consequence, given the statutory limitations on its authority, the administration itself has stretched a long way in trying to minimize this risk. The type of protection it accords differs slightly, however, as between the two different types of rulings.

\section{(footnote continued)}

inadequate, and thus delay the ruling until adequately supplemented. See Rose, "The Rulings Program of the Internal Revenue Service," 35 Taxes 907 (1957).

65 Rev. Rul. 54-172, C.B. 1954-1, 394, 401.

66 E.g., of the 14,776 rulings issued between 1919 and 1965, 9,234 were issued before the revision of the code in 1954 .

67 See Rev. Rul. 54-172, C.B. 1954-2, 394, 401; Rev. Proc. 62-28, C.B. $1962-2,496,506$.

68 In 1967, the administration announced that it planned to re-examine all pre-1954 rulings, to the end of identifying publicly those it deems to be obsolete. 
Relevant to the sweep of the protection accorded in the case of private rulings is the fact that the tax administration, without congressional blessing, itself extended this program to prospective transactions at the beginning of World War $\Pi$. This action was taken in spite of the fact that the statute itself, enacted immediately prior thereto, literally authorized the administration to bind itself only by bilateral closing agreements. 69 However, at an earlier time when the National Office confined rulings to completed transactions, a previously mentioned statute, giving the Commissioner discretion to prescribe the extent a regulation would be applied without retroactive effect, 70 was amended so as literally to include also "any ruling."71 In the first public announcement extending the private rulings program to prospective transactions, the administration sought in two ways to reconcile the two foregoing statutory provisions: first, by asserting its right to revoke any ruling retroactively, and second, by declaring its "general policy" was not to do so (absent a retroactive change in the law itself) if the taxpayer had consummated a prospective transaction in good faith reliance on the ruling and retroactive revocation would be to his detriment. ${ }^{72}$ As applied to a situation of this type, the administration later sought to strengthen the image of its so-called "general policy," by noting that deviations would be limited to "rare and unusual circumstances." 73

As to modifications of earlier published rulings, the first public announcement mentioned above laid down what appeared to be an even more sweeping immunity, for no conditions were attached expressly to the asserted "general practice of the

69 That the administration has the power to revoke both published and private rulings retroactively is not open to serious question. Dixon v. U.S., 381 U.S. 68 (1965); Automobile Club of Michigan v. Commissioner, 353 U.S. 180 (1957); Helvering v. Reynolds, 313 U.S. 428 (1941). For one exception regarding excise taxes, see Rev. Act of 1926, §1108(b) and Treas. Reg. §601.201(1)(8). Also cf. International Business Machines v. U.S., 343 F.2d 914 (Ct. Cl. 1965).

70 Rev. Act of 1921 , $\$ 1314$, now I.R.C., $\$ 7805(b)$.

71 Rev. Act of 1934, §506, amending Rev. Act of 1926, §1108(a). Italics added.

72 Rev. Rul. 54-172, C.B. 1954-1, 394, 401. The limitation would not apply, of course, if the taxpayer had misrepresented the transaction.

73 Rev. Rul. 62-28, C.B. 1962-2, 496, 505. An administration hardly could go beyond this, given the fact that Congress expected each Commissioner to exercise discretion in each case. See Caplin, op. cit. supra note 63 , at 21 . 
Service to make such revocation or modification prospective only."74 Presumably, a taxpayer favored by an earlier published ruling would be protected whether or not he actually had relied on that ruling to his detriment, such as by reliance thereon before entering into a prospective transaction. There is nothing to suggest that the administration meant to change this policy when, in a later substitute announcement, it put the matter differently, saying that such rulings "ordinarily are not revoked or modified retroactively."75

That taxpayers place considerable reliance on the policy not to revoke retroactively either type of ruling is evident from the fact that, in fiscal 1964, only four asked for closing agreements, 76 in contrast to the thousands who secured private rulings or relied on published rulings.

\subsection{Weight normally accorded U.S. interpretative regulations} and published rulings

Related to the matter just considered is a broader question: just how much stature does an administrative interpretation gain from the mere fact, in a given case, it is housed in an interpretative regulation or ruling previously published by the National Office? Field personnel who examine returns would be bound, of course, by both-as a matter of hierarchical control.77 Taxpayers, however, on challenging either of these before the independent judiciary, find that it subscribes to a different view. To regulations, it attaches substantial but not binding significance, 78 and ordinarily even this is not extended to rulings as such.

74 Rev. Rul. 54-172, C.B. 1954-1, 394, 401.

75 Rev. Rul. 62-28, C.B. 1962-2, 496, 506 (1962). That a top official thought no such change was contemplated, see Rogovin, op. cit. supra note 25 , at 769.

76 Rogovin, op. cit. supra note 25 , at 770 .

$77 \mathrm{As}$ to the limited power of certain regional officials, on exercising their "settlement" function, to compromise private rulings, see Chap. III, § 3.4 infra.

78 For comprehensive early discussions regarding the effect of regulations, see Eisenstein, "The Clifford Regulations and the Heavenly City of Legislative Intention," 2 Tax L. Rev. 327 (1947); Griswold, "A Summary of the Regulations Problem," 54 Harv. L. Rev. 398 (1941); Surrey, "The Scope and Effect of Treasury Regulations Under the Income, Estate, and Gift Taxes," $88 \mathrm{U} . \mathrm{Pa} . \mathrm{L}$. Rev. 556 (1940). For a less comprehensive but more recent analysis, see Rogovin, op. cit. supra note 25 , at 759 . 
The Supreme Court's view is that an interpretative regulation, construing an otherwise ambiguous statute, ordinarily is entitled to "respectful consideration,"79 indeed, to "great weight,"80 and that an "assertion of its invalidity must be predicated either upon its being inconsistent with the statutes or its being in itself unreasonable or inappropriate." 81 Depending on the circumstances, the Court has relied upon one or more of three different rationales to justify this special significance.

The first involves the circumstances which surround the original promulgation of most but not all regulations. Currently, they are drafted shortly after a statute is enacted, by in-service personnel who also worked closely with the congressional committees through which the bill was processed (furnishing drafting assistance both as to it and the committees' explanatory reports). ${ }^{82}$ Given their intimate acquaintance with the specific congressional purposes, their "wide experience in tax matters, "83 and the administration's own general "'responsibility of setting ... [the] machinery in motion, of making the parts work efficiently and smoothly while they are yet untried and new," "84 their "contemporaneous construction" 85 of the statute undoubtedly warrants the respectful consideration it enjoys. Of course, a regulation though contemporaneous will not survive if deemed inconsistent with a statute not thought

79 Fawcus Machine Co. v. U.S., 282 U.S. 375, 378 (1931).

80 See Koshland v. Helvering, 298 U.S. 441, 445 (1936).

81 U.S. v. Morehead, 243 U.S. 607, 614 (1917). The Court has not always been careful to note a distinction between legislative and interpretative regulations; it even suggested in Koshland v. Helvering, 298 U.S. 441, 446 (1936) that they were governed by the "same principle." Elsewhere, however, it has indicated that the special delegation of power associated with legislative-type regulations provides "added reasons why ... regulations under it should not be overruled by Courts unless clearly contrary to the will of Congress." Commissioner v. South Texas Lumber Co., 333 U.S. 496, 503 (1948).

82 Indeed the division of the Service's legal staff housing draftsmen of income tax regulations is called the "Legislation and Regulations Division." Further, policy reviews are performed by lawyers in the Office of the Tax Legislative Counsel-a constituent of the Treasury Department.

83 Colgate-Palmolive-Peet Co. v. U.S., 320 U.S. 422, 426 (1943).

84 Norwegian Nitrogen Products Co. v. U.S., 288 U.S. 294, 315 (1933) quoted with approval in U.S. v. Leslie Salt Co., 350 U.S. 383, 396 (1956).

85 Fawcus Machine Co. v. U.S., 282 U.S. 375, 378 (1931). Italics added. 
to be ambiguous. ${ }^{86}$ Conversely, the fact a given regulatory interpretation was not promulgated contemporaneously with enactment of the statute is not in itself necessarily fatal to its claim for respectful consideration; 87 a second or third rationale may be invoked to justify attributing substantial weight to it.

The second possible justification is bottomed on the Supreme Court's long-standing conviction that uniform application of tax laws is one of the positive goals warranting encouragement. The implementation by the Court of this conviction began whenlong before the first modern income tax act was passed-it stated with respect to a tax regulation, in force for many years:

... But when there has been a long acquiescence in a regulation, and by it rights of parties for many years have been determined and adjusted, it is not to be disregarded without the most cogent and persuasive reasons. 88

According to this theory, in any given case, the extent to which the previous uninterrupted life span of a regulation will tip the judicial scales in favor of the regulatory interpretation necessarily is affected by the relative length of that life span. That the regulation will benefit substantially from this argument where the period is forty years 89 hardly means that it will benefit in like degree if only a relatively few years are involved. 90 But again, that a given regulation has been outstanding only a relatively short time when first challenged, does not mean it will have no special significance. Though challenged promptly, it may be entitled to special weight by reference to the first-mentioned rationale, i.e., because the regulation reflected the construction of experts contemporaneous with the enactment of the statutory provision. 91 Or it may derive special weight from a third rationale 92 which is of such a nature, however, that-as a practical matter-it is more likely to serve only as a complementary factor adding yet further

86 U.S. v. Calamaro, 354 U.S. 351 (1957); Koshland v. Helvering, 298 U.S. 441 (1935).

87 Lykes v. U.S., 343 U.S. 118 (1952).

88 Robertson v. Downing, 127 U.S. 607, 613 (1888).

89 Cammarano v. U.S., 358 U.S. 498 (1959)。

90 U.S.v. Calamaro, 354 U.S。 351 (1957).

91 Colgate-Palmolive-Peet Co. v. U.S., 320 U.S. 422 (1943). Cf. the fate of a belated amendment in U.S. v. Leslie Salt Co., 350 U.S. 383 (1956).

92 Lykes v. U.S., 343 U.S. 118 (1952). 
weight to regulations otherwise entitled to respectful consideration because of their fairly long life.

This third rationale emerged out of the High Court's conviction that taxation is essentially statutory in character; therefore it is not too much to expect Congress, having itself expressly authorized regulations, to exercise-perhaps "through its committees"93_some measure of legislative oversight, to which the judiciary could then attach significance. Even at a point before the first modern income tax statute was adopted, the foregoing premise had led the Supreme Court to the following conclusion:

... And we have decided that the re-enactment by Congress, without change, of a statute, which had previously received long continued executive construction, is an adoption by Congress of such construction. 94

This rationale proved to be of particular significance to the host of regulatory interpretations promulgated during the first twenty-five-year period (1913-1938) immediately following adoption of the first modern income tax act. In that period, each Congress-usually on a biennial basis-re-enacted the whole of the income tax law, making only such changes as it deemed appropriate. Thus, by reference to the above-quoted theory, any regulation promulgated during the early part of that period was certain to derive great vitality from the consequent repeated re-enactments of the underlying statutory provision. 95 The added possibility that, in the interval between re-enactments, a regulation actually was challenged by taxpayers but sustained by the lower courts, served only to reinforce the Supreme Court's conviction that Congress, upon re-enactment, should be deemed to have acquiesced in the earlier regulatory interpretation. 96

In 1939 the environmental setting changed drastically. Congress adopted a permanent tax code, the intention being that this law would survive ad infinitum. Each subsequent Congress, instead of making isolated revisions in the course of an otherwise wholesale re-enactment, was expected to do

93 See Haggar Co. v. Helvering, 308 U.S。389, 399 (1940).

94 U.S. v. Cerecedo Hermanos y Compania, 209 U.S. 337, 339 (1908). Italics added.

95 U.S. v. Leslie Salt Co., 350 U.S。 383 (1956); Commissioner v. Flowers, 326 U.S. 465 (1946).

96 Cammarano v. U.S., 358 U.S. 498 (1959). 
nothing more than amend the particular statutory provisions warranting change. Not until 1954 did Congress again re-enact the whole code in the course of a major revision.

The vitality which pre-1939 regulatory interpretations derived from the biennial re-enactments of the pre-1939 period survived, of course, the codifications in 1939 and 1954, provided the underlying statutory provision itself remained unchanged. However, the 1939 change in congressional procedure regarding tax legislation did pose the threat that newly promulgated post-1939 interpretations would have no chance to benefit from this third alternative rationale, and would have to justify their claim to substantial weight solely by reference to one or both of the two rationales first discussed. This threat did not materialize at once, however. For a time, a divided Supreme Court appeared willing to go a long way in reshaping its "re-enactment" theory to accommodate this environmental change. In one case, the Court attributed "substantial weight" to a post-1939 regulation though the underlying statutory provision had not been re-enacted even once. It observed that, after the regulation had been issued, Congress had amended many provisions of the code without amending the particular statutory provision interpreted by this regulation. ${ }^{97}$ From this congressional inaction, a majority of the Court apparently was prepared to presume congressional acquiescence to the regulatory interpretation. More recently, however, it appears that the Court has become more sensitive to reality and intends at least to back away from so sweeping a view regarding congressional acquiescence. Indeed, as to a post-1954 taxable year of one taxpayer, the Court refused to apply the re-enactment theory even to a regulation which had been promulgated three years before the 1954 code was substituted for the 1939 code. It reasoned as follows:

... The regulation had been in effect for only three years, and there is nothing to indicate that it was ever called to the attention of Congress. The re-enactment of $\S 3290$ in the 1954 Code was not accompanied by any congressional discussion which throws light on its intended scope. In such circumstances, we consider the 1954 re-enactment to be without significance. 98

97 Lykes v. U.S., 343 U.S. 118, 127 (1952). Also see Costanzo v. Tillinghast, 287 U.S. 341 (1932); McCaughn v. Hershey Chocolate Co., 283 U.S. 488 (1931).

98 U.S. v. Calamaro, 354 U.S. 351, 359 (1957). Cf. Commissioner v. Acker, 361 U.S. 87 (1959). 
This, of course, represented just a retrenchment, not an abandonment of the re-enactment theory. ${ }^{99}$ And it left completely unaffected the vitality of either of the first two previously discussed reasons which courts have invoked to justify special consideration for an interpretative regulation. Observe further that in fact both these reasons would support most currently existing interpretative regulations, and that the first of them alone would warrant respectful consideration of future regulations if promulgated more or less contemporaneously with new statutory amendments.

However, this latter justification (that the interpretation is contemporaneous, and is made by expert officials whose agency is responsible for enforcement and who worked closely with the legislative processing of the underlying provision) would seldom if ever warrant special consideration for the usual published ruling, as distinguished from the typical regulation. Most published rulings, as well as the private rulings from which they emerge, are issued long after, not more or less coincident with, adoption of the relevant statutory provision, and are drafted by personnel who did not work with the congressional committees at the earlier point when the statutory provision was being processed.100 Moreover, Treasury officials (as distinguished from those of the Internal Revenue Service), to whom Congress assigned final administrative authority in the case of interpretative regulations, ${ }^{101}$ ordinarily make no review of a private ruling and at best assume only a modest role regarding published versions. ${ }^{102}$ These differences undoubtedly contributed to the Service's initial position, expressed in its first volume of published rulings, that the latter were intended to reflect only "the trend and tendency of official opinion in the administration of the income and profits tax provisions of the Revenue Acts. The rulings have none of the force or effect of Treasury Decisions [i.e., regulations]

99 Fribourg Navigation Co., Inc. v. Commissioner, 383 U.S. 272 (1966).

100 While the published version ordinarily is reviewed by the Chief Counsel's Office, the review is carried out by the Interpretative Division, not by the Legislation and Regulations Division which drafted the regulations.

101 I.R.C., § 7805 .

102 The Treasury receives a syllabus of proposed published rulings, and even this just immediately prior to publication. Its attention is called specifically only to published rulings involving policy issues of a high order. See Rogovin, op. cit. supra note 25, at 766 n. 50 . 
and do not commit the Department [i.e., the Treasury] to any interpretation of law which has not been formally approved and promulgated by the Secretary of the Treasury."103 Implicit in this was the suggestion that the government itself ordinarily did not expect courts-by reference at least to the circumstances existing at the point a ruling was published-to give any greater weight to a published ruling than that accorded a brief submitted by the government at the point of litigation.

Later, however, the Commissioner did seek to induce the Supreme Court to extend the re-enactment theory to published rulings. The facts involved a ruling published between adoption of the 1921 and 1924 acts and applied by him in interpreting a provision in the latter which was common to both. The court refused, however, to apply the re-enactment theory to this situation, partly because of the government's own previously published disclaimer limiting the intended significance of published rulings. It stated:

The Commissioner's suggestion that, by retaining the same definition in the 1924 Act, Congress approved the construction for which he contends is without merit. The definition had not been construed in any Treasury Decision [i.e., in a regulation], by the Board of Tax Appeals or by any court prior to that enactment. . . . The rulings, I.T. 1379, 1660 and 1889, cited by the Commissioner were made before the passage of the 1924 Act but they "have none of the force or effect of Treasury Decisions and do not commit the Department to any interpretation of the law." See cautionary notice published in the bulletins containing these rulings. It does not appear that the attention of Congress had been called to any such construction. There is no ground on which to infer that by the 1924 Act Congress intended to approve it. 104

Later efforts to induce the High Court to reconsider the applicability of the re-enactment theory to published rulings always originated with taxpayers, not with the Commissioner. In each such instance, a taxpayer challenged an assessment which conflicted with a previously published ruling, claimed by him to have achieved irrevocable vitality through congressional acquiescence. With the parties thus reversed, twice the High Court seemed to find some attraction in the taxpayer's position, as distinguished from its own earlier view as quoted above. In both cases however, it first expressed its own

103 Fly-leaf, C.B. 1-1 (1919).

104 Helvering v. New York Trust Co., 292 U.S. 455, 468 (1934). 
conviction that the initial published rulings properly interpreted the act; then, by way of dictum, it merely added that Congress' repeated re-enactment of the underlying provision indicated its acquiescence also to that administrative interpretation. ${ }^{105}$

This dictum has not yet "blossomed into full fruition." However, a favorable environment for this was not provided by the cases subsequently arising before the High Court. In each such case except the most recent, the Court's own conviction, regarding the correctness of the ruling itself, was opposite to that reached in the two cases just described. In other words, in the subsequent situations, the initial published ruling each taxpayer sought to sustain was believed by the Court to reflect a clearly erroneous interpretation of the act. After expressing this conviction, the Court was to add that only in extreme circumstances could such rulings, of "less dignity" than regulations, be saved by the re-enactment theory. In one case, it put the matter as follows:

... Unless the administrative practice is long continued and substantially uniform in the Bureau and without challenge by the Government in the Board and courts, it should not be assumed, from rulings of this class, that Congressional reenactment of the language which they construed was an adoption of their interpretation. 106

Any practical assessment of this judicial position would require the addition of one further fact: once the more or less permanent codes replaced the earlier biennally adopted revenue acts, there was much less chance that Congress would ever re-enact any given statutory provision. Equally important because of this changed circumstance is the Court's recent refusal, in the case of published rulings deemed clearly erroneous, to equate congressional inaction with congressional acquiescence. In one such case, the Court again pointed to the "ample notice" contained in the rulings volume, that published rulings lack the

105 Helvering v. Bliss, 293 U.S. 144 (1934); McFeely v. Commissioner, 296 U.S. 102 (1935).

106 Higgins v. Commissioner, 312 U.S. 212, 216 (1941). Italics added. The Court also noted that the quoted comment in the two previously discussed cases was only dictum. Id. In circumstances similar to the Higgins case (earlier published ruling deemed clearly erroneous), the Supreme Court refused even to apply the re-enactment theory to "[ $t$ ] wo rulings [published] ... twenty-five years ago, [though] not repeated in the intervening quarter-century...." Manning v. Seeley Tube \& Box Co., 338 U.S. 561, 571 (1950). 
"force or effect of Treasury Decisions," and do not commit the Treasury. Its holding, that a revised or corrected interpretation could be applied retroactively even though a taxpayer may have relied to his detriment on the Commissioner's earlier mistake, then was explained as follows:

... This principle is no more than a reflection of the fact that Congress, not the Commissioner, prescribes the tax laws. The Commissioner's rulings have only such force as Congress chooses to give them, and Congress has not given them the force of law. Consequently it would appear that the Commissioner's acquiescence in an erroneous decision published as a ruling, cannot in and of itself bar the United States from collecting a tax otherwise lawfully due. 107

In conclusion, of the three different rationales used to justify the special weight accorded by the Supreme Court to most regulations, two (so-called "contemporaneous-construction" and "re-enactment" theories) currently fail to generate any special standing for rulings as such. However, as to the third, because of the High Court's interest in maintaining uniformity, there is reason to believe that a previously untested, long continued and consistent, administrative interpretation, of which published rulings may be evidence, will enjoy the judiciary's respectful consideration when interpreting an otherwise ambiguous statutory provision. ${ }^{108}$

\section{Section B. Analytic Comparison: The "Six's" Reactions to Vital Purposes Served by Centrally Administered Interpretative Programs}

\subsection{Introduction: Programs of the Six compared}

There is no uniformity in the extent to which the central administrative offices of the six countries covered by this study engage in substantive rule-making activity.

107 Dixon v. U.S., 381 U.S. 68, 73 (1965). However, where published rulings merely support the Court's own view regarding the clear import of an interpretative regulation, this reinforces the applicability of the re-enactment theory as applied to regulations. Fribourg Navigation Co., Inc. v. Commissioner, 383 U.S. 272 (1966).

108 See Estate of Sanford v. Commissioner, 308 U.S. 39 (1939). Cf. Fribourg Navigation Co., Inc. v. Commissioner, 383 U.S. 272 (1966); Higgins v. Commissioner, 312 U.S. 212 (1941). 
Under some limited circumstances, authority to engage in such activity has been extended specifically to all six offices. Each national legislature has encountered at least a few income tax problems which it believed could be resolved effectively only by a type of detailed rule making for which the otherwise burdened legislative process was deemed ill adapted. And in that situation, all six legislative bodies have chosen to complement statutory expression of a general objective with a specific delegation of legislative authority enabling the executive arm to fix the technical standards governing that isolated area. ${ }^{109}$ Since these gap-filling administrative promulgations do much more than merely interpret statutory language and, if not ultra vires, generally have the force of law, 110 they previously have been characterized as legislative-type regulations.

The frequency with which the six administrations exercise this particular type of rule making varies, of course. But there is a far more substantial range of variation in the magnitude and types of interpretative programs they centrally administer for the benefit of taxpayers as well as field personnel. No doubt national tradition and basic philosophical differences regarding the role appropriate to administrators are partially responsible for this. That this diversity in attitude (whether legislative, administrative, or both), regarding the need for full blown centralized interpretative programs, has survived in an area as complex as taxation may also be due to yet other differences peculiar to these individual tax systems. Most relevant to this are their differences in (i) assessment techniques, (ii) the types of income tax statutes being administered, and (iii) the standards of statutory construction to which their respective judiciaries adhere.

As to the relevance of the first of these, observe that the most comprehensive interpretative program is carried on by the one country (United States) which relies on the so-called self-assessment system.

In effect, in the first instance, each of its sixty-seven million taxpayers must assess himself, for returns prepared and filed personally constitute the sole basis for initial liability-fixing assessments. The other five countries employ the

109 See § 2.4 in Chaps. VI, X, XIV, XVII, and XXII infra. In France power to issue regulatory texts is also derived by the Prime Minister directly from the Constitution itself. See Chap. X, § 2.4 infra .

110 See $\S 2.4$ as in note 109 supra. 
so-called non-self-assessment system. ${ }^{111}$ In theory, the taxpayer himself is relieved of question-resolution burdens. The government assessor determines each assessment, theoretically on the basis of his examination.

As to the relevance of the second (type of statute), if every one of the sixty-seven million U.S. taxpayers was required to fix his individual liability unassisted by administratively fostered interpretations, in theory each would have to rely primarily on his own interpretation 112 of what clearly is the longest, most complex statute of the six. The U.S. code's substantive income tax provisions, if spread at the rate of 400 words per page, would cover an awesome 754 pages. ${ }^{113}$ Uncertainty persists, however, despite the meticulous care and supposedly finespun precision with which the provisions are drafted. Transactions in the United States vary from one another in every possible degree. To this, add the fact that most of the words used in that longest of all statutes are more likely than not to have multiple shades of meaning. These factors react cumulatively upon each other to produce countless interpretative difficulties, which are complicated further by a related factor, which in itself contributes further to the statute's length and complexity. The basic principles of this statute have been subjected to a multitude of deviations which have spawned their own subdeviations, and even deviations from sub-deviations, thereby creating additional interpretative difficulties with stress and pressure at many joints. Not just a few taxpayers are potentially affected by many of these. Indeed, of the total 754 pages, only 138 deal with tax patterns confined to peculiar types of enterprises such as cooperatives, insurance companies, exempt organizations, estates and trusts.

In contrast to the situation in the United States, the Parliaments of the Netherlands, Germany, Belgium, and France not only assign full responsibility for determining initial assessments to the government's own trained personnel, but also confine statutory provisions of a substantive character to abstract principles, which, if spread on the same basis as that indicated above, would cover, respectively, only 40, 114

111 see § 3.2, Chaps. VII, XI, XV, XIX, and XXIII, infra.

112 No doubt, they or their representatives actually would rely on interpretations appearing in texts written by experts but devoid of the harmonizing effect of interpretative regulations.

113 As of 1964 .

114 Section 2.1 Chap. XXII infra, refers to 57 pages, but of these $30 \%$ are devoted to administrative or procedural provisions. 
$50,{ }^{115} 100,{ }^{116}$ and $120^{117}$ pages. While the variation between the types of statutory techniques employed by these four countries, and those employed by the United States, may be one reason why the four have not embarked on a centralized interpretative program even approaching the magnitude of that in the United States, this underlying difference does not account at all for Britain. Its statute actually resembles that of the United States more than those of the other four European countries, being both complex and long-exceeding 350 pages. 118 Yet its administration does not publish interpretative regulations at the point a statutory provision is enacted;119 does not thereafter ordinarily issue advance private rulings on prospective transactions 120 nor publish rulings which explain to one and all the reasoning behind specific interpretative positions in-service field personnel will be expected to take in examining returns. 121 Nor does its Parliament attempt to clarify the statute by publishing carefully designed interpretative reports.122 In final analysis, of the five European countries covered here, it appears, surprisingly, that administrations in the four having the shortest and most abstract tax statutes (Belgium, France, Germany, and the Netherlands) actually carry on more comprehensive interpretative programs than does the fifth (Britain), which has a long and complex statute somewhat like that of the United States. The four, with Belgium traditionally at the head, 123 publish for one and all to see more of

115 Section 2.1 Chap. XIV infra, indicates that the corporate and individual taxes combined require 95 pages when spread at the different rate of 300 words per page, but of these about one-third are devoted to administrative or procedural provisions.

116 See § 2.1 , Chap. VI infra.

117 Section 2.1 Chap. X infra, refers to 80 pages, calculated, however, at the different rate of 600 words per page.

118 Section 2.1 Chap. XVIII infra, indicates that of the 511 pages, approximately 30 percent are devoted to administrative and procedural matters.

119 See Chap. XVII, § 2.4 infra. Interpretative instructions are distributed internally, however.

120 Id. $\S 2.7$.

121 Id. § 2.10 . While a series of pamphlets covering many different areas is published, these usually are devoid of the legal reasoning on which the indicated results were reached.

122 Id. § 2.2. The Belgian Parliament stands alone among the five European countries in making even modest use of this device. See Chap. VI, § 2.2 infra. Cf. the use of Parliamentary debates in France, Chap. X, § 2.2 infra.

123 However, official commentaries on the recent tax reform law of 1962 are much less complete than those on the earlier law. See Chap. 
their administratively engineered interpretative instructions, with at least the expectation that field personnel will be bound as a matter of hierarchical control. Further, Germany and the Netherlands also sporadically publish some rulings and-as to prospective transactions-give much advance advice, though usually through local offices, which, in practice, do respect the advice thus given. 124

There is a third difference among the six countries, however, which may partially account for the fact that Britain appears to feel the least pressure to develop a substantial published interpretative program. At least it is not surprising that the least comprehensive administrative program is carried on in the one country (Britain) whose judiciary apparently tends to interpret the tax statute most strictly. ${ }^{125}$ Given this circumstance, it could be argued that Britain has less room for, and thus less need for, a large scale, published, administrative interpretative program.

But this conclusion is relative in character. The fact is that differences in methods of assessment, in statutory approaches, and in the judiciary's standards of statutory construction, taken together, actually do not provide sufficient reason for the substantial differences existing in the Six's administrative interpretative programs. Other relevant characteristics, common to the Six, suggest that properly administered programs of this type would achieve purposes vital, whether or not equally so, to each country's tax system.

Each of the Six has millions of taxpayers, a highly decentralized administration bottomed on thousands of geographically dispersed field officials, a statute relatively inprecise and mysterious to everyone but the specialist and, finally, very high rates. These characteristics, taken together, should have led each of the six systems to include among its administrative goals three which are almost impossible to accomplish-given

\section{(footnote continued)}

VI, § 2.5 infra. Further, even the voluminous regulations interpreting the earlier law were, in substantial part, a compilation of results previously reached by courts. Finally, Belgian administers neither a formal private nor a published rulings program. Advance rulings ordinarily take the form only of informal advice or-as in France-of published answers to oral questions put to the Ministry on the floor of Parliament for the benefit of a taxpayer-constituent. See Chap. VI, $\S 2.7$ et seq., infra.

124 See Chaps. XIV and XXII, § 2.7 et seq, infra.

125 Cf. Chap. XVIII, \& 2.3 infra, with $\S 2.3$ in Chaps。 VI, X, XIV, and $\mathrm{XXI}$ infra, and-as to the United States-with $\$ 2.1$ supra. 
those same characteristics--without substantial centralized published interpretative programs, namely:

(i) Achieving timely nationwide uniformity in application of the law, efficiently and fairly;

(ii) Choosing the wisest possible interpretative positions;

(iii) Preventing uncertain tax effects from impeding, unnecessarily, consummation of legitimate prospective transactions.

Each of these three goals, and the general relationship of centralized rule making to each, is considered separately in the immediately succeeding sub-topics. Thereafter attention shifts to precise methods of implementation and difficulties to be circumvented.

\subsection{Achieving timely uniformity, efficiently and fairly}

Because all six of the statutes under consideration here involve national taxes and high rates, country-wide uniformity in applying the law is an absolute essential. This is difficult to achieve when income tax statutes are superimposed on, and hence must take account of the nice distinctions inherent in, sophisticated systems of private law and complex economies. In the application of each such tax statute a host-albeit a varying number-of interpretative difficulties will be generated whether that statute expresses abstract principles, as in Germany, or employs great detail, as in the United States. Nationwide uniformity in resolving these doubts can be achieved in adequate degree, efficiently, fairly, and in a timely manner, only if the central office administers an adequate interpretative program.

In both self- and non-self-assessment systems, many an interpretative difficulty, whether or not foreseen by the central office, actually becomes a "live" issue only at the point an examining official in the field faces the question of whether there is sufficient merit on the government's side to warrant pressing the matter as to a given taxpayer. Since that question necessarily includes the other side of the coin, i.e., whether to abandon the issue, nationwide uniformity will be achieved among similarly situated taxpayers only if all these lower echelon officials conform to a uniform interpretation. Left to their own devices, however, this goal will not be attained. These officials are seldom legally trained, 126 their number is large,

${ }^{126}$ See $\S 1.5$ in Chaps. V, IX, XII, XVII, and XXI infra. 
and they are scattered through many widely dispersed local offices-ranging from 100 in the Netherlands to 1700 in France. 127 Their individual analysis and research, however painstaking, in attempting to resolve interpretative problems of common concern to many, guarantees only duplication of effort, not uniformity in results reached. However, a centralized interpretative program, administered by officials more expert in analysis and research, not only efficiently avoids the duplication otherwise generated by this necessary decentralization, but also in itself assures a far greater degree of uniformity.

To attain the maximum possible degree of uniformity, and to accomplish this with efficiency and fairness, it is not enough to disseminate centrally-arrived-at interpretations only among the government's own field personnel.128 Public access to these interpretations, even in countries employing the non-selfassessment system, contributes efficiently to greater uniformity because knowledgeable voluntary compliance with the law is thereby encouraged. Even now, to assist assessors in those countries, taxpayers are required to file information returns. ${ }^{129}$ However, neither in those countries nor in a self-assessment country such as the United States, is it wise or even possible to design a form which requires taxpayers to reflect their affairs on a transaction-by-transaction basis. Details ordinarily are reflected only by subtotals, each covering transactions alleged to be of the same class. Obviously even under the non-self-assessment systems, assessors cannot possibly ascertain, with respect to each return, the true nature of each transaction affecting each subtotal. ${ }^{130}$ Thus, by trying to make the taxpaying public as knowledgeable as possible, albeit indirectly through published interpretations, the tax system efficiently furthers uniformity at least among the honest segment. The aim is to increase the likelihood that subtotals initially submitted by that segment will conform to what the tax administration believes to be the proper treatment of the underlying transactions, with exceptions anticipated where honest taxpayers believe the administration to be in error. Further, it is only fair to taxpayers, and responsive to the administration's

$127 \mathrm{Id}$. §1.4. While the U.S. is divided into 58 districts, these spread audit personnel across approximately 800 posts of duty.

128 All five of the European countries maintain at least this restricted type of program. See $\$ 2.4$ and 2.9, Chaps. VI, X, XIV, XVII, and XXII infra.

129 See § 3.2 , Chaps. VII, XI, XV, XIX, and XXIII infra.

130 Id. 
own interest in having its interpretations applied correctly, that these centrally-arrived-at interpretations be exposed to the public's view. This exposure enables a taxpayer to determine whether the examiner has correctly interpreted the central office's regulation or ruling when applying it to that taxpayer's situation.

The foregoing analysis cannot be shunted aside by the argument that statutory interpretative difficulties should be resolved, not by tax administrations, but by tribunals independent of them. Such argument itself necessarily assumes that, on proper occasions, someone somewhere in the tax administration must adopt interpretative positions antagonistic to given taxpayers; otherwise such matters would never reach the independent tribunal. Thus, mere adoption of a centralized interpretative program, without more, need neither subtract from, nor add to, the ultimate role of independent tribunals. Further, even where the independent tribunals are not expected to attach any special weight to administratively adopted published positions, a centrally administered program of that type is still vital to the maintenance of uniformity. Without such a program, interpretative anarchy will prevail until long after the interpretative difficulties are exposed to light, i.e., until that typically much later point in time when an independent appellate tribunal has had an opportunity to respond to the issue in an adversary proceeding initiated by some taxpayer. Of course, in theory, uniformity in an equally timely manner also could be secured by requiring the central administrative office, immediately upon discovering a significant interpretative difficulty, to seek binding advice from a so-called independent tribunal.131 But, disregarding other shortcomings of this arrangement, if the sole aim is to avoid the administrative character of the interpretation's sponsorship, the arrangement would be self-defeating. The so-called independent tribunal no longer would be independent of administration, for the tribunal itself would have become the administrator in fact, if not in name.

$131 C f$. the French practice wherein the government can seek advisory opinions from the separate Council of State. Chap. X, § 2.4 infra. In the United States, a declaratory judgment regarding the tax effect of a prospective transaction cannot be obtained in the regular federal courts. See Goodman, "The Availability and Reviewability of Rulings of the Internal Revenue Service," 113 U. Pa. L. Rev. 81, 97 (1964). It appears, however, that the Tax Court has the discretion to enter a declaratory order in such a situation. Id. at 109 . 


\subsection{Choosing the wisest possible interpretative positions}

Centralized interpretative programs are essential, not just to achieve uniformity in a timely and efficient manner, but also to facilitate wise selection of those interpretative positions as to which uniformity is to be sought. And this is true whether the controlling statutory datum is cast in quite broad terms or, as such things go, is fairly precise.

In the case of broad statutory language, frequently it would be equally reasonable, solely by reference to technical considerations, to draw the interpretative line at any one of two, three, or more competing places. In net effect, the ultimate choice must be based on non-technical or policy considerations. Ordinarily, however, the scattered local offices are staffed only with technicians. In addition to their difficulty in achieving uniformity if left without guidance, they obviously are ill-prepared to make the type of policy choice required here. Wiser selections can be expected from policy-oriented officials in the central office, using a centralized interpretative program as their medium.

Even in the setting also, relatively speaking, of fairly precise statutory language, diverse factual patterns can generate doubt-in every conceivable degree-regarding the correct technical answer. This is because, prior to litigation, the truly correct technical answer can be nothing more than a prediction. While the very nature of a prediction precludes certainty, often it is clear that technical arguments favoring the government's side are sufficiently persuasive to require a mere administrative official to adopt that position solely on the basis of technical considerations. On other occasions, however, the converse is true; it simply is not clear whether the technical arguments favoring that side are sufficiently persuasive to warrant forcing the matter to litigation if the taxpayer will not yield. In striking the balance here, account should be taken administratively of other variables, such as the degree to which a given answer could be effectively administered or the importance of the question to the tax system. Again, because of their broader administrative perspective, central office officials are better suited to this task, and uniform compliance with their decision can be achieved best through a comprehensive centralized interpretative program.

\subsection{Neutralizing risks re prospective transactions}

Tax systems have the capacity, though not always adequate authority, to neutralize legal uncertainties regarding the tax 
effects of prospective transactions. Such a program (i) satisfies a real need and (ii) enables the tax system to realize on a unique opportunity of benefit to itself. These two considerations provide distinct additional reasons for maintaining centralized interpretative programs.

As to the first, substantive tax uncertainties adversely affect the country as a whole, as well as individual taxpayers. Both suffer if, because of tax uncertainty, legitimate prospective business transactions are delayed or abandoned. Moreover, a tax system's own image also suffers. It will be held responsible not only for the consequent delay or abandonment of transactions but for complaints generated later if a taxpayer-having consummated the transaction-finds he must litigate the tax question to defend the personal interpretation on which he proceeded but which the tax system belatedly claims to have been erroneous. That it is the tax system, and not the individual taxpayer, which produces the tax uncertainty seems clear in the case of prospective transactions supported by legitimate business purposes. In consequence, where feasible, the system should bear the cost of neutralizing that uncertainty through some sort of advance ruling. And if the need really springs from uncertainty or doubt, this in itself is a reason for resolving it through a centrally administered interpretative program, rather than at the local office level. As previously explained, this centralization will provide greater uniformitymore efficiently and fairly-and simultaneously yield a wiser selection of those interpretative positions as to which uniformity is sought.

Second, requests from taxpayers regarding rulings on prospective transactions serve better than any other device to alert the central office immediately as new interpretative problems arise. They give that office the opportunity to develop and publish its position in a timely manner, for the benefit of field personnel as well as other taxpayers. In the United States, despite efforts to encourage field personnel to seek the central office's advice on difficult matters, the fact is that requests which originate with taxpayers are ten times as great. 132

132 E.g., Commissioner of Internal Revenue, op. cit. supra note 57, at 6 . 


\section{Section C. Implementing an Interpretative Regulations Program}

\subsection{Introduction: Inherent conflict among the goals}

A program, responsible for promulgating interpretative regulations of proper quality, in a timely manner, without undue expenditure of talented manpower, cannot hope to succeed unless these goals are considered in proper perspective. To this end, the first need is to analyze the specifics which make for proper quality, to maximize the likelihood that, in practice, the right balance will be reached between inherently conflicting constituents of that one goal. The essential second step is to take suitable account of yet another inherent conflict: the one between that goal-viewed as a whole-and the other two goals of timeliness and efficiency. The solution here is to so design the procedures (through which drafts will be processed) that they will avoid undue compromise of any one of the three goals.

\subsection{The goal of proper quality}

To say that interpretative regulations will be of proper quality if they are complete, technically correct, and understandable 133 is to say much but not enough. So simplistic a standard tends to obscure the complexity of each constituent and the inherent conflict among them.

If regulations alone discharged the entire interpretative function, then to be complete they would have to deal precisely with every significant ambiguity in the statute. Yet to seek absolute precision in an initial regulation issued more or less simultaneously with the enactment of the underlying statute involves great risk. With every precise line drawn at this embryo stage come increased risks of reaching unintended results in unanticipated situations and of committing technical error in the eyes of the judiciary. There is, of course, a competing risk. Overzealousness in trying to achieve absolute accuracy can produce regulations which are nothing more than purposeless sterile echoes of the statute itself and, thus, well below any meaningful level of completeness and understandability.

Technical accuracy, nevertheless, not perfect precision, does stand foremost among the constituents insuring proper

133 See Williams, "Preparation and Promulgation of Treasury Department Regulations Under Internal Revenue Code of 1954," So. Calif. 8th Tax Inst. 733 (1956). 
quality. If inaccurate, a regulation achieves the opposite of its sole purpose. Typically, after promulgation, several years will pass before the judiciary can make a final determination regarding a regulation. And if the courts belatedly disapprove the regulation, it alone bears responsibility for the injustice suffered by those who voluntarily complied and for the resulting nonuniformity between this group and those who successfully resisted. Further, recurring invalidation of regulatory interpretations, if by a judiciary which-in principle-customarily gives respectful consideration to regulatory interpretations, can tend only to shorten the life span of that customary practice. And too frequent invalidation even by a judiciary not so committed tends to lead taxpayers also to lose respect for the whole regulations program, and this will tend to produce wholesale nonconformity.

In attempting to achieve the right balance between two competing standards, technical accuracy and completeness in the sense of precise interpretations, three considerations should lead to a rather obvious conclusion. First, at the point when a statutory provision is enacted, those who must draft the interpretative regulation cannot possibly envisage the actual shape of every potentially affected transaction. In effect, from the vantage point of transactions not foreseen, any perfectly precise regulatory line would have been drawn by draftsmen who were "blindfolded." Second, to help alert the draftsman to factual situations not imagined, and also to test the logic behind his proposed interpretation and his choice of language in trying to reflect his intention, some type of public hearings, formal or informal, should be held after publication of a tentative draft 134 and before its formal adoption. ${ }^{135}$ Third, while this practice will help educate the draftsman, 136 neither public hearings at this early stage in the life of the statute nor the

134 Fairness to taxpayers also requires the government to take this type of meticulous care, given the fact that regulations, once formally adopted, bind employees at least as a matter of hierarchical control and can be tested, where adverse to a taxpayer, only by litigation.

135 of the countries covered by this study, only the United States holds formal hearings where any taxpayer may appear in person or submit statements in writing. However, most of the others do receive pre-adoption comments from interested professional, industrial, and labor groups. See §2.6, Chaps. VI, X, and XIV infra. While the U.S. practice, as it relates to interpretative as distinguished from legislative regulations, may not be required by statute, it is consistently followed. See Rogovin, op. cit. supra note 25, at 759 n. 6 .

136 See Williams, op. cit. supra note 133, at 753. 
draftsman's own study, can be expected to alert him to more than a fraction of all the diverse factual situations his attempt at a precise line would affect. 137 In consequence, the draftsman should be made to understand that a new regulation is not expected to discharge the whole interpretative function. A rulings program should assume part of the burden. After the regulation is issued, sporadic requests from taxpayers for rulings will further educate the central office regarding the factual patterns of the really marginal cases, thus removing additional bits of its blindfold and enabling it intelligently, through individual rulings, to "pinprick" its way toward a more precise line. 138

These considerations suggest that an interpretative regulation which clarifies a statutory ambiguity by the use of a general definition or principle-supplemented by illustrative concrete applications to the most frequently recurring but seemingly not marginal situations-is the only method which can balance properly completeness (in the sense of precision) and the paramount aim of technical accuracy. By hypothesis, such a regulation is more likely to survive judicial scrutiny than one which establishes a perfectly precise line. For absent a precise line, the courts remain free, when testing subsequent rulings in seemingly more marginal cases, to edge toward the exact location of the dividing line without prejudice to the regulation's general definition or to the large measure of uniformity achieved by its illustrative concrete responses to the more frequently recurring but seemingly less marginal cases.

Finally, to be of proper quality, a regulation must be understandable. Hence, draftsmen have the further burden of determining the intellectual level of the expected audience.

137 This is amply demonstrated by U.S. experience, where, though such hearings always are held, post-promulgation requests for rulings continue to expose problems in previously unanticipated situations.

138 This opportunity to pinprick toward a line is also the reason why, generally speaking, it is wise to use a series of narrowly tailored published rulings, rather than a general amendment to the regulations, to deal with situations not anticipated when the original regulations were drafted.

There is a yet further reason for conforming to this practice in countries such as the United States, where regulations, but not rulings, are given great weight by the judiciary. In good conscience, the government ought not try, through the amending process, to "bootstrap" what essentially are just belatedly arrived at litigation positions. 
This will differ, not just from country to country, but also from regulation to regulation. To illustrate, the U.S. program assumes that the regulations will not be used by the typical individual taxpayer who usually is completely unaware of their existence. The administration attempts to resolve the questions of such a taxpayer in 18 pages of instructions which accompany his return. As to other relatively small U.S. taxpayers for whom those instructions are inadequate (farmers, small business men, and employees with some outside interests), over two and a half million pay a few cents for a much detailed booklet distributed by the government. ${ }^{139}$ Millions more purchase an inexpensive commercial counterpart of those booklets. Yet other millions of taxpayers in the same bracket employ one of the many thousands of persons who, usually on a part-time basis and for only a few dollars, prepare these relatively simple returns. Further, these groups can consult field personnel associated with the taxpayers-assistance program which each local office maintains throughout the year (though the great bulk of its activity is concentrated in the filing season). During fiscal 1966, for example, this programmanned by the lowest grade technicians in the local office-responded to 16.6 million inquiries made by telephone and to questions raised by 9.1 million taxpayers who visited the local offices. ${ }^{140}$ Thus, those persons who use portions of the regulations affecting relatively simple returns include widely diverse groups. They range from tax professionals, who draft the instructions attached to returns and write the government's booklets or their commercial counterparts, to the far less well trained individuals who either man the local offices' taxpayersassistance program or, as part-time practitioners, prepare uncomplicated returns for small fees. And it is to these less less capable individuals that draftsmen of such regulations address their efforts.

At the other extreme, regulations affecting, say, depletion or consolidated returns, have an audience as sophisticated as

139 See Commissioner of Internal Revenue, op. cit. supra note 57, at 90. Of the large ones, the three most widely used are Your Federal Income Tax, Tax Guide for Small Business (the 1965 editions of which, in both cases, ran to 160 pages), and the Farmer's Tax Guide (164 pages). Approximately 60 other more narrowly focused pamphlets are distributed. Altogether, the total taxpayers' assistance program in fiscal 1965 required an expenditure of 1,298 man-years. See Commissioner of Internal Revenue, Annual Report 1965, 4.

140 See Commissioner of Internal Revenue, op. cit. supra note 57, at 4 . 
the business enterprises affected. Thus these regulations, in the interest both of technical accuracy and brevity, can use terms of art incomprehensible to those not intimately familiar with the affairs of such enterprises, and still conform to an acceptable level of understandability.

The understandability of a regulation is affected also by whether it is expected to respond to anything more than the anticipated ambiguities in a given statutory provision. Unquestionably, the interpretation accorded these, and its significance, will be both more readily understood and easier to draft if put in the context of a comprehensive regulation sufficiently self-contained to serve for most purposes as a substitute for the statutory provision itself. ${ }^{141}$ This approach, to which the United States conforms, also enables the draftsman to rephrase otherwise unambiguous parts of the statute to compensate, where necessary, for the formal legalistic mode of expression. ${ }^{142}$ But this is not without risk; to change language not otherwise ambiguous may change the meaning, however slightly.

\subsection{Processing regulations: Reconciling the goal of proper} quality with competing goals of timeliness and efficiency

To design a regulation of proper quality (striking the right balance as to technical accuracy, completeness, and understandability) takes both time and talented manpower. In consequence, stress inevitably emerges between that goal and the competing need for regulations to be issued in a timely manner, without undue expenditure of precious talented manpower.

A draftsman may invest substantial time just to identify the significant ambiguities in a new statutory provision and to learn something about the diverse types of transactions each such ambiguity affects. Then comes the painstaking effort to find language that is technically accurate, that is responsive both to the views of policy makers and to the administrative need of easy application, that is sufficiently precise to resolve

141 Persons who have some doubt about either the meaning of the regulation or its validity necessarily must have recourse to the statute itself, pre-enactment materials, and court decisions.

142 of the four European countries which issue interpretative regulations, apparently Germany is the only one which makes no attempt to rephrase the statute into the language of laymen, its premise apparently being that the regulations are intended to guide only in-service professionals. Cf. Chap. XIV, $\$ 2.5$ with $\S 2.5$ in Chaps. VI and XXI infra, and with §2.4, Chap. X infra. 
most recurring situations but not so precise as to create great risk of producing unintended results in unanticipated situations, and that clarifies the "legalese" in the unambiguous part of the statute without changing the meaning. Any public hearing, if scheduled to insure the public adequate time to react thoughtfully to a published tentative draft, will contribute to yet further delay, but also to an improved draft, as will any resulting revisions and necessary reviews by higher officials.

Nevertheless, if a regulation is to begin to fulfill its purposes in a timely manner, it should be promulgated, as in Belgium, 143 not later than the effective date of the new statutory provision. Delay beyond this, as is the case so frequently in the United States, is unfair to the type of frequently recurring prospective transactions to which the regulation itself should have been a dependable guide. In the event of such delay, on any comparative basis, it is grossly inefficient to try to accommodate these cases through individual private rulings. Prospective transactions more marginal or doubtful in character would be even more certain to suffer, for it would be both inefficient and often unwise to try to rule on these before finalizing the general principles of the regulation. Finally, if a regulation is not promulgated at least by the filing date of the first returns affected by the new statutory provision, then in both self- and non-self-assessment countries it will default pro tanto on all its remaining purposes.

While all tax administrations tend to suffer, whether more or less, from a perpetual shortage of talented drafting personnel, the magnitude of any given statutory revision itself will determine the actual difficulty generated by the inherent conflict between the goals of proper quality and timeliness. In any circumstance, however, measures which properly reconcile these competing goals will tend also to secure the right balance in the efficient use of talented manpower.

Countries covered by this study which do issue interpretative regulations lodge the drafting responsibility in offices which maintain close contact with the legislative processing of the new statutory provision. ${ }^{144}$ Given this essential contact, if historically diverse U.S. practices furnish a trustworthy guide, promulgation of a regulation will be expedited if three additional arrangements are built into the process.

143 See Chap. VI, § 2.6 infra.

144 See $\$ 2.6$ in Chaps. VI, X, XIV, XVII, and XXII infra. Also, note 82 supra. 
First, responsibility for the proposed draft should be lodged at the outset in the type of tax professional whose prior training is most likely to produce skilled, imaginative draftsmen. Second, they should be accorded timely access to policy-level personnel, as well as to technicians familiar with both administrative necessities and taxpayer concerns in the specific substantive area. Third, in proper circumstances, a regulation should be published piecemeal.

Unfortunately, at one time or another, practice in the United States has failed to employ one or more of these techniques. During the 1950's, most initial drafts were prepared and initially reviewed by technicians academically trained primarily as accountants. These drafts then were re-reviewed by both spadework and senior personnel academically trained as lawyers. Finally, the cumulative product was given a superreview by both spadework and senior personnel in the policymaking echelons. All too frequently, this arrangement resulted in superfluous duplication of effort on two counts, both of which contributed to substantial and unnecessary delay.

First, the reviewing lawyers tended to treat initial drafts prepared by those academically trained primarily as accountants much as they would have treated the proposed draft of a will submitted by a lay client. The lawyers tended to believe their technical review would be more effective if they started by preparing what was tantamount to an entirely new draft. In consequence, much of the original draftsman's efforts, and thus considerable time, was wasted. It took a change in procedure to remedy this. Initial drafting responsibility for income tax regulations was shifted to the lawyers who, with timely access to administrative technicians, could be alerted to administrative and taxpayer concerns as work on a regulation progressed.

Second, also in the 1950 's, because the policy-making echelon ordinarily was not involved until after a completed draft had been refined and polished, any redirection on policy grounds, coming belatedly and sometimes requiring a more or less complete overhaul, wasted the time spent previously but futilely on refinements and polishing. 145 This too can be prevented by affording more timely access to the policy-making

145 The comparatively small policy-making group contributed to yet additional delay because of its tendency to fly-speck each regulation, in terms of its completeness, technical accuracy, and understandability. See Williams, op. cit. supra note 133, at 751 . 
echelon. Initial contact with this level should occur not later than the point when the drafting office has isolated the major ambiguities in the statute, is alert to the more frequently recurring situations potentially affected by each, and has thought out the competing principles, if any, which would be technically defensible and administratively feasible to implement.

The purposes of the two foregoing arrangements also can be satisfied, and not infrequently are in the United States, by assigning a regulations project at the outset to a three-man team composed of a lawyer, a technician, and a policy-making representative. This completely avoids the time-consuming seriatum nature of their respective involvements as it existed during the fifties.

The third desired arrangement affects those instances where all of a regulation interpreting a given statutory provision is complete except for one isolatable and particularly difficult matter. If completion of that one aspect would unduly postpone the timeliness of the completed portion, the latter should be promulgated without further delay. The omitted paragraphs need only carry a notice that they will be published upon completion.

\section{Section D. Implementing Private and Published Rulings Programs}

\subsection{Introduction: Resolving inherent conflict between respec-} tive goals of private and published rulings programs

The first imperative in implementing separate programs covering private and published rulings is to insure that each takes proper account of the inherent conflict which exists between their respective goals. Otherwise neither goal can be adequately achieved.

As previously indicated, the principal goal of the private rulings program is to provide advance guidance to legitimate prospective transactions. To accomplish this objective, a private ruling must be timely, i.e., available before the deadline for consummation of the prospective transaction. Because in a fast moving economy, consummation of many prospective transactions cannot be long delayed, speed is an essential ingredient of the program. Published rulings, on the other hand, are intended as a supplement to the regulations program; their principal goal is nationwide uniformity, among both taxpayers 
and field personnel. And precisely because these rulings do fix the nationwide position of the government, rather than just the tax effect of a single transaction, absolute correctness is their most important characteristic. In consequence, the inherent conflict between the respective essential attributes of the two different programs can be summarized in terms of speed v. quality-i.e., absolute correctness. The potential consequences of this conflict can be awesomely serious.

On the one hand, in some instances, failure to publish immediately the result of the first private ruling in a given area, thus permitting time for further study prior to publication, may lead only to a loss of efficiency. Each local audit or assessing official will have to take the time, in the case of other taxpayers similarly situated, at least to think through a problem with which National Office rulings personnel already have dealt. But much more serious is the prospect that the widely scattered officials may reach nonuniform results, thereby depriving other similarly situated taxpayers of equal treatment under the law. On the other hand, immediate publication of the result speedily reached in a private ruling covering only a single case can extend across the entire nation a conclusion, possibly incorrect. The private ruling may have been incorrectly decided, not just because it had to be issued in a timely fashion, but because, rulings personnel in the National Office were not then aware of all the potential applications and implications of that ruling, i.e., of the diverse factual situations the ruling inevitably would affect. When subsequent analysis of later requests for private rulings on somewhat similar situations discloses error in the previously published ruling, the administration-to be logical-must either enlarge that error or reverse it. In the United States, there is a tendency to try to avoid this dilemma by postponing issuance of a private ruling until rulings personnel, working at the level at which the given type of ruling normally would be issued, conclude the result reached is one which safely could be published. 146 But because of this caution, too frequently the

146 Even so, private rulings sometimes are issued before the total implications are recognized. E.g., see Knetsch v. U.S., 348 F.2d 932 (Ct. Cl. 1965); "Warwick Fund Ruling Withdrawn; I.R.S. Policy Questioned," $19 \mathrm{~J}$. Taxation 197 (1963). Prior to issuance of a published version, the error is likely to be recognized, however. In substantial part, this is because published versions, as distinct from private rulings, always are reviewed at a high level, involving usually the Assistant Commissioner (Technical), the Director of the appropriate Division, 
private ruling covering a prospective transaction is not timely and consequently this program defaults pro tanto on its separate purpose. 147

Obviously the inherent conflict between the goals of the two programs needs resolution-and in a manner which ordinarily permits each effectively to accomplish its own separate mission. Personnel working on private rulings should understand (i) that the tax system itself-not the taxpayer-is responsible for any tax uncertainty suffered by a legitimate prospective transaction and (ii) that in consequence of the foregoing they are expected to reach the wisest decision possible, subject ordinarily, however, to an overriding responsibility: to respond within a fairly timely manner. Conversely, personnel working on the published version of a ruling should understand that absolute correctness is their most essential goal. 148 Publication, if need be, is to be postponed until there is sufficient acquaintance with the total factual terrain to insure correctness. With this overriding limitation, at least the subject matter (as distinguished from the exact result) of all precedent-type private rulings should become, in due course, the subject of a published ruling.

$\overline{\text { (footnote continued) }}$

and a senior official in the Chief Counsel's office. On major policy issues, the Commissioner himself and policy officials at Treasury's headquarters also become involved. See Rogovin, op. cit. supra note 25, at 766 n. 49, and Caplin, op. cit. supra note 63, at 27. Further, because often there is a substantial time lag between issuance of the first private ruling in an area and publication itself, several requests for rulings in that area will have been received and perhaps answered. In consequence, the senior officials who review proposed published rulings have the chance at least to become more fully acquainted with the total factual terrain than did the lower ranking official who issued the first private ruling. In further consequence, the actual result reached in the first published ruling may not coincide with the result actually reached in the first private ruling, in contrast to the supposed theory governing the relationship between the two programs as outlined in $\$ 2.3$ supra.

147 In fiscal $1965,37 \%$ of the rulings required more than 60 days but less than 6 months, and another $21 \%$ required more than 6 months. See Rogovin, op. cit. supra note 25, at 767 n. 59. An earlier Chief Counsel put blame for much of this delay on taxpayers themselves, citing their failure to present the facts fully, to pinpoint the issue, and to submit an adequate analysis of the authorities. Rose, "The Rulings Program of the Internal Revenue Service," 35 Taxes 907 (1957).

148 This is not intended to imply that different personnel should be used in carrying out the two different functions. As to the shortcomings of that arrangement, see § 2.17 supra. 
There is one exceptional type of case, however, where a private ruling should be withheld until personnel are certain they have reached that result they would be willing, by publication, to apply on a nationwide basis. This withholding should occur in any case where it is recognized that a subsequent change in position, if applied to that taxpayer's competitors, would substantially affect the business struggle between them. This limitation, however, probably applies more broadly to excise taxes with their direct effect on prices ${ }^{149}$ than to income taxes.

Observe, finally, that if each program otherwise is to focus on its own separate function as suggested here, publication will not serve to police the integrity of the private rulings program. 150 But that need can be satisfied by appropriate internal reviews.

\subsection{Confining private rulings to legal questions: Requiring statements of fact and a brief}

The central office would assume a burden for which it is ill-suited as well as make wasteful use of local office talents, should it ordinarily attempt to rule on prospective transactions

149 For a dramatic illustration, see International Business Machines Corp. v. U.S., 343 F.2d 914 (Ct. Cl. 1965). The abuse in that case was deemed to be so great that the court, in effect, extended an earlier favorable private ruling received by one taxpayer to a competing taxpayer who later had received an adverse ruling. For an argument that this should be the universal practice, even as to income tax questions, see Kragon, "The Private Ruling," 45 Taxes 331 (1967). For a contrary view, see Rogovin, op. cit. supra note 25, at 767 . That the general practice actually is to the contrary, see $\S 2.3$, supra notes $53-$ 55 , and Kragen, $i d$., at $334 \mathrm{n}$. 13. If the earlier erroneous ruling had continuing effect because concerned with an excise tax matter, it could be revoked prospectively, of course. This was done, though belatedly, in the above cited case.

150 In the United States, preservation of such clearly was one of the intended purposes of the publication program. See Hearings on Administration of the Internal Revenue Laws, Before a Subcommittee of the House Committee on Ways and Means, 83d Cong., 1st Sess. 1564 and 1570 (1953). In furtherance of that purpose, if S. 2047, 89th Cong., 1st Sess. (1965) had been enacted, the administration would have been required to publish within ten days any ruling involving a potential tax liability exceeding $\$ 100,000$. For reasons previously related, however, both the private and published rulings programs, and thus the tax system itself, would suffer from enactment of any proposal locking publication to the actual results reached in private rulings. See Rogovin, op. cit. supra note 25 , at 767 n. 60 . 
involving mere questions of fact. ${ }^{151}$. Such questions frequently require on-site inspections and the weight accorded much of the evidence often turns on the credibility of witnesses. Moreover, as a practical matter, the central office, precisely because it is central, would have to make its determination on the basis of a cold record. Thus, a local office would have to conduct an examination and certify that the record contained all the evidence and its own finding regarding credibility. Further, whether the central or local office actually issued the ruling, after the taxpayer had filed the return covering the affected transaction, the local office would have to conduct another examination to insure that neither the evidence nor facts had changed prior to the consummation itself.

This wasteful duplication of effort will be avoided, however, and the central office will be peculiarly well suited to the task if, as is generally true in the United States, it confines rulings to questions of law 152 and holds the taxpayer responsible for submission of a written statement reflecting all relevant facts-including a copy of all documents to be executed when the transaction is consummated.153 Then, laterafter the ruling has been issued, the transaction consummated, and the return filed-the local office, in its first and sole examination, need only ascertain whether the actual facts corresponded to those previously submitted by the taxpayer. 154 If they do correspond, the local office need not even make a legal analysis of the problem; that was done by the central office before issuing the ruling. In effect, labor has been divided between the two echelons, and all duplication avoided. On occasion, of course-particularly where unrepresented taxpayers submit self-prepared requests-rulings personnel may find an essential fact has been omitted and thus be unable to rule. Where feasible, the taxpayer should be alerted to the

151 Cf. Goodman, op. cit. supra note 131.

152 See Rev. Proc. 64-31, C.B. 1964-2, 947, amplified in Rev. Proc. 66-34, I.R.B. 1966-34, 22, which lists the no-rulings areas. Certain mixed questions are accommodated. Also, in a very few instances where the statute itself literally turns the tax on the presence of a tax avoidance purpose (e.g., I.R.C., $\$ 367$ and 1492), the administration will give advance rulings on this essentially factual question. E.g., see Treas. Reg. §367-1. In a somewhat similar statutory setting, England follows a similar practice. See Chapter XVIII, § 2.7 infra.

153 Rev. Proc. 67-1, Sec. 6.02, I.R.B. 1967-1, 9.

154 In the United States, the letter ruling itself will include a statement of all facts to which the result is addressed. 
difficulty, 155 but without prejudice to the overriding rule that, ultimately, he alone is responsible for exposing to light all relevant facts. If, upon later examination of his return, it appears that his request for the earlier ruling did omit a material fact or included material assertions at variance with the ultimate facts, the ruling will lack any force or effect.

In the interest of efficiency, taxpayers also should be required as in the United States, 156 or in fairness at least be encouraged, to accompany their request with a second statement which both identifies the precise statutory issue in doubt 157 and analyzes the legal data (authorities, etc.) supporting the taxpayer's particular contention. Exception should be made, of course, where the question in issue involves an amount so small that it would be against the taxpayer's economic selfinterest to employ a private practitioner. These cases aside, however, requirement of such a statement would contribute to efficiency by relieving the rulings specialist from one of the three demanding roles he otherwise must fulfill (advocate for the taxpayer, advocate for the government, and judge). Moreover, since the taxpayer's own representative typically is best suited to develop the arguments which support his side, this requirement would insure that the taxpayer's position would be presented fully. Thus, while contributing to efficiency, the greater interest of equity also would be fostered: the taxpayer's statement serving not only himself but also the government, which should have the single aim of reaching the truly correct result.

\subsection{Organization, conferences, review, and appeals re private rulings}

Comparably for the reason just indicated, it serves the interest of administration and taxpayer alike to grant an oral

155 This accords with U.S. practice. Rev. Proc. 67-1, Sec. 6.07, I.R.B. 1967-1, 11. On occasion, where this is not feasible, an information letter, describing but not applying the law, will be issued. Rev. Proc. 67-1, Sec. 5.01, op. cit., at 9.

156 Rev. Proc. 67-1, Sec. 6.03, I.R.B. 1967-1, 10.

157 The United States permits local District Directors to issue socalled determination letters as to non-doubtful situations clearly covered by statute, regulation, or previously published rulings. But because this practice generally is limited to completed transactions (Rev. Proc. 67-1, Sec. 4.01, I.R.B. 1967-1, 7), the national office itself receives many requests for rulings on prospective transactions which, while complex or involving large sums, are not believed by the taxpayer to involve any tax uncertainty. He simply wants an "insurance policy." 
conference upon request. But this is so only if the specialist responsible for the problem tentatively decides to rule adversely to the taxpayer's contention. A practitioner, preparing the earlier submitted written brief, hardly can be expected to anticipate every nuance of every court decision, etc., about which rulings specialists may develop some concern. Because both sides will benefit most if the conference focuses on the specific concerns which have emerged from the specialist's own considered study of the matter, taxpayers should be at least discouraged from seeking a conference at an earlier point, before the specialist has had a chance to study the matter and to determine the particular points he believes troubles ome. 158

Relevant to the choice of the government's representative at such conferences is the fact that, as requests for rulings increase, so too must rulings personnel. Illustratively, the U.S. program now absorbs the time of several hundred technicians. Moreover, if reasonable standards of efficiency are to be maintained, sizeable programs require a given division of labor. Most rulings personnel should specialize in a subjectmatter area with spadework on most rulings undertaken by the least experienced personnel, whose tentative conclusions will be reviewed by those more able and experienced to whom authority has been delegated to sign the ruling, yea or nay. When this division of labor has evolved, a reviewer in the latter actual decision-making category-if at all feasible-should attend any conference accorded a taxpayer, to explore at first hand, rather than hear second hand through an underling, the taxpayer's rebuttal to the actual decision-maker's concerns.

In responding to the need for efficient, fair, and informed discharge of the rulings function, rulings personnel in the United States have been spread among eight different specialized branches 159 and the branch chief himself, or a reviewer empowered to sign his name, ordinarily is required to attend any conference. 160 Such personnel at the branch level actually

158 This is the import of the U.S. procedure. Rev. Proc. 67-1, Secs. 6.08 and 7.02, I.R.B. 1967-1, 11 and 12 .

159 Six of these involve income taxation (corporation, corporate reorganizations, individual, depreciation, exempt organizations, and pension trusts). The other two deal, respectively, with excise and with estate and gift taxation. Yet other branches deal with actuarial and administrative matters. A given branch also may further subdivide its personnel into more narrow specialities.

160 Rev. Proc. 67-1, Sec. 7.02, I.R.B. 1967-1, 12. 
issue more than 75 percent of the rulings. ${ }^{161}$ Situations occur, however, where a broader-based expertise is needed. Illustratively, a particular factual situation falling within the competence of one specialized branch actually may raise an interpretative issue of common concern to two or more branches. And even where this is not so, the importance of some questions merits the attention, not just of specialists, but also of the most talented generalists. To accommodate these problems, the eight branches have been divided among three divisions, dealing respectively with income taxes, exempt organizations and pension trusts, and miscellaneous taxes. Each Division Director has a very small staff of reviewers (most of whom are generalists) and is responsible to the Assistant Commissioner (Technical).

This three-layer organizational arrangement (branch, division, Assistant Commissioner) causes some taxpayers, on receiving an adverse ruling at the branch level, to wish a further appeal were available-i.e., an appeal to the appropriate Division Director and, if need be, to the Assistant Commissioner. While no doubt such appeals would produce different results in at least a few cases, attempts at perfection must be tempered by recognition of the possible. The hard fact is that the Division Director and his staff could not possibly review in detail all adverse decisions issued by his branches. In consequence, instead of giving taxpayers a "right" to appeal to his office, the branches have been instructed to forward to it for further review, prior to issuance, any ruling the branch itself deems to be sufficiently doubtful or important to warrant such attention. Actually, well over three-fourths of all rulings are issued without such a review. And as to the remainder, it is physically possible to give affected taxpayers a "right" to a further oral conference in the Division Director's office only if that office tentatively decides either to reverse a ruling which the branch would have decided favorably to the taxpayer's contention, or to sustain an adverse ruling but on a new or different ground than that on which the branch relied. 162

161 See Rogovin, op. cit. supra note 25 , at 766 n. 49.

162 Rev. Proc. $67-1$, Sec. 7.02 , I.R.B. $1967-1,12$. Only a small percent of those reaching the division level are referred also to the Interpretative Division in the Chief Counsel's Office. 
2.15 Priorities re advance rulings; and grounds for refusal to rule

Any private rulings program, if responsive to prospective transactions, will encounter two different types of priority problems. One involves the order in which requests should be handled; the other, the areas which should be excluded from the scope of the program.

The first will become a problem even if, in the face of typically tight budgetary limitations, an adequate number of talented personnel can be assigned to the program. Requests for rulings do not come in throughout the year at a regular rate. Instead they tend in the opposite, with the United States, for example, showing a fairly consistent seasonal variation. Because this variation is an expected phenomenon, personnel working exclusively on rulings can use their time efficiently throughout the entire year only if there is at least a modest inventory or backlog to carry them through the slack periods. Inadequate staffing not infrequently causes that essential back$\log$ to increase beyond the essential level. Taken in conjunction with the work backlog, the varying amount of effort individual cases require typically will prevent taxpayers from receiving a ruling by return mail. Indeed, in the United States, not more than half the rulings usually can be issued within the first two months after the requests are received.163 In fairness, since most requests will involve prospective transactions, they normally should be disposed of, as they are in the United States, according to the order of their receipt. But situations will arise where a given taxpayer, without fault, clearly shows great need for extraordinary speed in resolving his problem. However, only if these requests for special priority are a very small fraction of the total should procedures be left sufficiently flexible to accommodate them.164 Otherwise, disposition of cases received earlier will be unduly postponed.

A second and more broadly ranging priority principle, of concern to management at the highest level, should contribute to a delimitation on the scope of the program. In deciding the extent to which talented personnel can be made available to this particular program, the administration must take proper account of other important but inevitably unmet needs typically spanning the entire spectrum of its responsibilities. Given

163 See note 147 supra for other reasons contributing to this delay. 164 This is the import of U.S. practice. Rev. Proc. 67-1, Sec.6.09, I.R.B. $1967-1,11$. 
these competing needs, any administration would be hard put to justify staffing this one program so adequately that its manpower will be available to extend the advance ruling program to cover types of transactions which at best can be covered only with gross inefficiency. The argument in 2.13, supra, for denying advance rulings to mere factual questions, was bottomed solely on this priority principle. ${ }^{165}$ The existence within the Service of various unmet needs also should be one reason for precluding this program, as is the case in the United States, from being so well staffed that it can take time to respond to prospective transactions deemed lacking in business purpose. 166 Indeed, in further support of this position, the only argument for launching an advance rulings program was that tax uncertainties should not be allowed to force delay or abandonment of transactions which would have been purposeful had no tax law existed. 167 The proscription regarding transactions lacking in business purpose will not be easy to administer, however. Only at the extremes is it easy to distinguish between proposed transactions which are motivated solely by tax considerations-and hence should fall in the no-rulings area-and others which would have a legitimate purpose in the absence of the tax law but are shaped to take advantage of the less costly of two or more different tax routes. Though the line between these two categories becomes less discernible as transactions move toward the center, an attempt to distinguish between them must be made, for ordinarily those falling in the second category should be granted advance rulings. Not to rule on transactions falling within the latter category would leave those responsible only for administration of a tax law open to a proper charge that, having established a rulings program, they now have transcended their administrative function. That is, by discriminating through refusal to rule, they presently hope, in terms of practical effect, either to regulate the

165 The prospect that effort might be wasted no doubt is also one reason why estate tax questions posed by living persons are beyond the ambit of the U.S. rulings program. See Rev. Proc. 67-1, Sec. 3.02, I.R.B. 1967-1, 7. The prospect of waste here relates to the substantial chance that the recipient's circumstances or the law may change during the possibly long period between the date of the ruling and the recipient's death.

166 Rev. Rul. 64-31, C.B. 1964-2, 947, amplified in Rev. Proc. 6634, I.R.B. 1966-34, 22, puts these in the no-rulings category. Germany does likewise. See Chapter XIV, § 2.7 infra.

167 Cf. Caplin, op. cit. supra note 63. 
shape of, or to deny a benefit accorded by the tax law to, transactions which would have been purposeful had the tax law not existed. Of course, the responsibility of a mere administrator to rule in this circumstance can be modified with perfect propriety expressly or implicitly by the legislature itself. For example, it may be implicit in a given statutory provision that the legislature specifically intended to use a loosely woven statutory standard (oftentimes subjective in character) as an en terrorem weapon to police the integrity, and hopefully in practice to fence in the range, of a given tax idea. An advance ruling in this circumstance obviously would frustrate the legislative intention. 168

\subsection{Completed transactions: Private rulings and in-service technical advice}

Again, employing a standard of priority, the absence of reliable tax guidance usually is less serious to a taxpayer whose transaction has been completed than to one facing a prospective transaction. Nevertheless, before filing a return covering a completed transaction, at least those taxpayers who live in self-assessment countries should be able-in a relatively routine manner-to obtain national office rulings on legal issues, to the end of enabling them to file proper returns and thereby self-assess the proper liability. And, generally speaking, this is U.S. practice. Indeed, if the question is not open to doubt and does not involve an industry-wide problem, even a local District Director can make the necessary binding commitment. 169

Once the return is filed, however, in both self- and nonself-assessment countries, the cumulative effect of three considerations furnishes a substantial reason why, from that point on, the taxpayer himself should be denied free access to the central rulings office. First, because both types of countries

168 On the other hand, in a yet different provision, the legislature may imply that the administration is expected to rule in advance regarding the motivation behind a given transaction, motivation being the crucial issue. E.g., see I.R.C., § 367 and Treas. Reg. §1.367-1. A similar example can be found in England. See Chapter XVII, § 2.7 infra.

169 His commitment is called a "determination letter" rather than a ruling. See Rev. Proc. 67-1, Sec. 4, I.R.B. 1967-1, 7, and supra notes 57 and 157. His authority ordinarily does not extend to prospective transactions, however. 
must undertake an enormous number of examinations, 170 effective administration is possible only if initial authority over filed returns is decentralized and lodged in local offices. 171 Second, because many, many issues will emerge from these examinations, a decentralized system of administrative appeal, geographically convenient to taxpayers-large and small-must be established. Third and finally, to preserve this indispensable decentralization and to prevent the system from being inverted and thus becoming top-heavy, every effort must be made to resolve at the lowest possible level as many issues as properly can be resolved there. To give taxpayers who had filed their returns complete freedom to deflect self-selected questions to the central rulings office, thereby enabling them to bypass the decentralized field procedures, would be totally inconsistent with this fundamental objective.

On the other hand, uniformity would be served and served efficiently if, at the earliest possible moment, legal issues of wide import and open to serious doubt (not having been resolved previously by court decisions or published rulings) could be identified, removed from the total mass of issues, and referred immediately to the central rulings office. Assuming that only the central rulings office can assure nationwide uniformity as to such properly selected issues, the greatest efficiency can be achieved if local offices can be trusted to exercise the screening function effectively; for then they also can be empowered to seek the requisite technical advice directly from the central rulings office, without involving intermediate or regional offices.172 Nevertheless, of the countries covered by this study which have placed intermediate regional offices

170 In theory, non-self-assessment countries examine each taxpayer. But even the United States, in policing the integrity of its self-assessment system, annually examines about three and a half million returns. See Commissioner of Internal Revenue, op. cit. supra note 57, at 23.

171 These range from 103 in the Netherlands to 1700 in France. While the U.S. is divided into only 58 districts, audit personnel are scattered among 800 posts of duty.

172 Under this arrangement, the latter offices need never be involved with any issue the central rulings office decides in favor of an affected taxpayer. Except in one instance, those offices also could be freed from the need to hear administrative appeals regarding items in a return controlled by an adverse private ruling previously issued to that taxpayer by the central office. The exception would apply in any country which, as an administrative settlement practice, wants to empower the intermediate office to split or trade the less significant of these debatable legal issues in order to avoid litigation. 
between the local and national echelons (England being the sole exception), ${ }^{173}$ only in the United States does a local (district) office normally bypass the intermediate office in seeking technical advice from the national office. 174 This country thereby avoids the inevitable and substantial duplication of effort which otherwise could follow if its intermediate regional offices sought to rescreen the 2,500 to 3,000 difficult questions local offices refer annually to the central rulings office.

In some of the other countries, the taxpayer himself may not even know that, in effect, the local office has yielded jurisdiction over an issue to a higher office. ${ }^{175}$ In contrast, through published formal procedures, the United States not only requires the local office to inform the taxpayer of the referral but also gives the taxpayer the "right" at that point to file with the central office a memorandum analyzing the law, and later to be orally heard 176 by the latter office before it can decide adversely to him. 177 On these counts, the procedure is the same as that previously described in connection with rulings on prospective transactions. 178 Further, before a local office can refer a question, the taxpayer is entitled to see the document in which that office presents its view of the facts, to the end that he can submit his own version if the two disagree. 179 Of course, no taxpayer can prevent a local office from referring a question to the central rulings office; nor in an earlier day could a taxpayer who requested such a referral appeal that mere procedural question if the local office chose not to refer the matter. 180 In short, at that time it had exclusive jurisdiction over the screening function, presumably in the interest both of efficiency and of preserving the integrity of the decentralized field procedures. The taxpayer then had only one method of recourse: to appeal the substantive issue

173 See Chap. XVI, §1.3 infra.

$174 C f$. \& 2.9 in Chaps. VI, X, XIV, and XXI infra. In England, of course, direct recourse is essential. See Chap. XVII, § 2.9 infra.

175 See \& 2.9 in Chaps. VI and X infra.

176 While typically such a conference is also available in Belgium, Chap. VI, §2.9 infra, it is otherwise in Germany and Great Britain. See $\$ 2.9$ in Chaps. XIV and XVIII infra.

177 Rev. Proc. 67-2, Secs. 4.08 and 4.09, I.R.B. 1967-1, 19.

178 See \& 2.14 supra.

179 Rev. Proc. 67-2, Sec. 4.06, I.R.B. 1967-1, 19.

180 Rev. Proc. 58-14, C.B. 1958-2, 1125. However, within the local office, he could appeal an adverse determination by lesser officials to the Chief of the local office's (district) Audit Division. 
to the intermediate regional settlement office and, if not satisfied with the result reached there, to litigate that substantive issue. Now, however, if the Chief of the local district's Audit Division rejects a taxpayer ${ }^{\text {'S }}$ request to refer an issue to the central rulings office, a written explanation of the reason must be given the taxpayer. If he disagrees and submits his reasons therefor in writing, these documents, together with all data bearing on the issue automatically are referred, not to the rulings office, but to the Director of the national office's Audit Division. In effect, the latter performs a rescreening function. He decides, not the substantive issue, but rather the procedural question of whether the issue is sufficiently important and doubtful to warrant referral to the rulings office.181

As is more fully explained in Chapter III, infra, even if the rulings office ultimately directs a local office to decide a substantive issue against the taxpayer, that taxpayer still is free to try to "settle" the dispute by entering an administrative appeal to the regional settlement office and then, if need be, to litigate.

\subsection{Publication of rulings and in-service technical advice}

If U.S. experience proves anything, 182 it is that the previously described prime purposes of a published rulings program $^{183}$ will be achieved year after year only if the program contains certain built-in arrangements which at least tend to assure its sustained compliance with two standards.

The first major need is to insure that the quality of each published ruling is responsive to the peculiar purposes of the program. While each, of course, must reach a technically proper result, this alone will not achieve uniform treatment for other similar transactions or provide reliable guidance for prospective transactions. To provide such uniformity and guidance, each ruling must be so structured that its scope will be understood readily both by taxpayers and field officials. A bare statement of the material facts and the resulit reached is not enough. If other interested individuals are to determine what actually was decided, the ruling itself must orient the legal issue. Further, since no two cases are exactly alike, if the ruling is to be applied properly to other cases-which is the sole reason for its publication-the legal reasoning on which

181 Rev. Proc. 67-2, Sec. 4.03, I.R.B. 1967-1, 18.

182 See $\$ 2.3$ supra.

183 See $\S 2.6$ through 2.8 supra. 
the result is based must be set forth. In short, a published ruling should take the form of an abbreviated judicial decision. The statement of the pivotal facts, legal orientation of the problem, the stated result and the legal reasons therefor all are essential if taxpayers and field officials are to determine with precision what was and what was not decided and be in a position, by analogy, to apply that ruling properly to other cases. 184

To insure also that each ruling reaches a technically proper result, and that the language chosen goes far enough but not too far in fixing that ruling's affirmative thrust, it is indispensable that the draftsman exchange ideas with others. The requisite exchange is accomplished best by having his draft reviewed from four distinctly different vantage points. The first review would come from an exceptionally able technical reviewer specializing in that particular area of income tax law. The second, from an exceptionally able technical generalist who understands thoroughly the whole body of income tax law and thus the way the pieces technically fit together. The third, from a policy-oriented generalist, for oftentimes-since the courts have not yet spoken-actually there is no one technically correct result but rather, at this stage of prediction, competing technically proper results, with the ultimate choice of position properly dependent upon administrative and policy considerations. And fourth, from outside the tax administration, from the market place, i.e., the taxpayers themselves. 185 The latter will serve two purposes. The public's very diversity equips it uniquely to focus the administration's attention on unanticipated situations affected, though unintentionally so, by the particular choice of words used in the ruling. Further, since the published ruling at the least will bind administrative echelons, it is only fair, before its formal and final adoption, that the public have a chance to be

184 This is essential, not just because of their need to determine the direct scope of the ruling but also because they will tend to use the ruling at the least as a clue pointing in one direction or the other in more remote situations, on the assumption that the rulings office itself will proceed thereafter in a logical legal manner. By way of contrast, a private ruling, if favorable to the taxpayer, need only state the facts and the result, for that will satisfy his concerm and it is not intended that this private ruling be applied to any other case. See $\S 2.3$, supra notes 60-62.

185 Only the first three types of review are utilized in the United States. See supra note 146. 
heard, if only in writing. Otherwise, affected taxpayers across the nation are deprived of a procedural safeguard which even a private rulings program (through a conference arrangement) should accord an individual taxpayer who has requested a ruling, and which administrative appeal systems in all countries covered by this study do accord an individual taxpayer who, at the point of examination, protests an asserted liability. The fact that a given taxpayer will have the belated right to be heard in this latter circumstance is not an adequate substitute for the proposal made here. The chance to be heard at the point of examination comes too late and will be meaningless if a previously published ruling-regarding which the taxpayer had no chance to be heard-covers the issue. That ruling binds the action of examining officials with whom he must confer.

From the foregoing, it should be obvious that time is a further factor in attaining a proper standard of quality for any given published ruling. And this is precisely the reason, as explained earlier, ${ }^{186}$ why an essential attribute of this program conflicts directly with one equally essential to the private rulings program (quality v. speed). As explained there, to assure each program a proper chance to fulfill its own separate purpose, rulings personnel themselves must understand that the result ultimately embodied in a published ruling need not follow blindly a result previously and more hurriedly reached in a private ruling.

The second major need, once a publication program is adopted, is to build in arrangements which at the least tend to prevent the central rulings office from defaulting pro tanto on the program's purpose by foregoing publication on some important precedent-type situations to which it has been alerted through requests received either for private rulings or inservice technical advice. Matters of integrity aside, U.S. experience of an earlier day serves to indicate that there are three circumstances most likely to contribute to such nonpublication.

One such circumstance will arise inadvertently: the failure of rulings personnel to appreciate the range of situations which, if covered by published rulings, would contribute significantly to the purposes of this program. While sophisticated lawyers might question the distinction which follows, not all rulings personnel are likely to be sophisticated lawyers. They must 
be made to understand that the purposes of this program are significantly served not only by publication of positions for all important precedent-type situations but also important new applications of earlier precedent-type rulings. 187

A second adverse circumstance will exist so long as the national office is permitted to send confidential communications to all field offices stating its views on substantive issues. Typically in a tax administration, only the head, and perhaps his deputy, bears an ultimate responsibility which extends both to the decentralized enforcement function carried out by field offices and to the centralized rulings function. 188 If his staff can use confidential communications to guide the field forces, he will have less interest in having his rulings office maintain a proper publication standard. ${ }^{189}$ To generate greater interest in him regarding the latter, a subcommittee of the U.S. Congress extracted from the U.S. Commissioner of Internal Revenue a promise that no confidential communications covering substantive issues would be circularized by the national office to field offices. 190 Thus the publication program became the exclusive vehicle through which the Commissioner could insure that field officials received their guidance. 191 The non-use of confidential communications had another salutory effect: no longer could a field official merely cite the reference number of a secret national office instruction in rejecting a taxpayer's contention. The self-interest which triggers a taxpayer into reading the relevant published communication enables him to discuss intelligently with the field

187 A U.S. congressional committee felt the second of these categories was ignored too often. See § 2.3 supra.

188 In the United States, the Assistant Commissioner (Compliance) is responsible for the first of these, the second being under the jurisdiction of the Assistant Commissioner (Technical). The Commissioner and Deputy Commissioner oversee both.

189 This no doubt is one reason why England's Board of Inland Revenue feels no great pressure to develop a full-scale rulings program. See Chap. XVIII, §§ 2.7 and 2.9 infra.

190 Statement of Commissioner Andrews, Hearings on Administration of the Intermal Revenue Laws, before a subcommittee of the House Committee on Ways and Means, 83d Cong., 2d Sess. 51 (1954).

191 In keeping with his promise to the congressional subcommittee, the semiannual volume containing all published rulings specifically provides that no unpublished ruling or technical advice may be relied upon by field officials in resolving other cases. E.g., see the fly-leaf in C.B. 1966-1. 
official the question of whether the latter was applying properly the national office's substantive instruction.

A third likely circumstance, adversely affecting administrative adherence to a proper publication standard, will be the failure of that lesser but senior official, alone responsible for the private and the published rulings programs, to attach a sufficiently high relative priority to the publication function. Typically, he lives with two facts: adequate staffing lags behind the workload of the two programs and outside pressure on him for work completion relates almost exclusively to private rulings which interested individual taxpayers want expedited because they involve prospective transactions. Left to his own devices, the official's understandable inclination will be to respond to this constant pressure, rather than to the abstract requirements of wise administration. He will spread disproportionately between the two programs the inadequate absolute amount of man-hours available to him, to the relative prejudice of the publication function. Without disparaging the vital function of private rulings, including the fact that the national office learns of new problems primarily from these requests, wise administration requires a fair balance of attention between the two programs. A private ruling, after all, solves but one case; a published ruling covering an important precedent-type situation not only resolves that problem uniformly and efficiently on a nationwide basis but simultaneously provides guidance regarding future transactions. The U.S. tax administration, at an earlier point in its history, divided its rulings personnel between the two functions, assigning them to separate subunits ${ }^{192}$-each being assigned its own review staff and subordinate director. It was hoped that this division would assure permanently both a more balanced application of manpower and proper application of the standard used in determining whether publication of a position was warranted. This device, however, proved to be both ineffective and inefficient in solving the first of these problems. At best, it assured only that some man-hours-not a fair proportion-would be devoted to development of published positions. The constant outside pressure to expedite private rulings tended to keep disproportionately large the inventory backlog of the subunit charged with the publication function when compared with that of the office handling private rulings. In other words, division

192 Then characterized respectively as the Tax Rulings Division and the Bulletin Branch. 
of the functions between two subunits did not guarantee that the official overseeing both would respond to their relative needs when allocating manpower between them. Further, the division was inefficient. Automatically it doubled the people who had to deal with any problem warranting a published position. Spadework personnel in the publication unit, and later its review staff, had to acquaint themselves with the total ramifications of a problem to which both spadework and review personnel in the private rulings office previously had directed considerable attention. Ultimately it was recognized that fewer total manhours would be needed if the latter, after issuing a private ruling, were given the time to develop properly a published version.

There is only one effective and effecient way to achieve a fair balance in the attention given to the two intimately related efforts. The head of the tax administration himself must provide inside pressure favoring a proper distribution of attention, to counteract outside pressure focusing exclusively on private rulings. As in other situations, he can use a survey team composed of personnel outside the rulings function periodically to determine, on a sample basis, whether attention is divided properly between these two efforts and whether rulings personnel are making a genuine effort to comply with the proper publication standard. 


\section{CHAPTER III}

\section{ASSESSMENT AND ADMINISTRATIVE APPEAL PROCEDURES ${ }^{1}$}

\section{Section A. Analytic Comparison of the "Six": Requirements of a Tax Administration's Own Conflict Resolution Procedures, Viewed in Aggregate}

\subsection{Introduction: Comparative profiles of the entive conflict resolution process \\ Because the character of the tax administration's own con- flict resolution process should depend upon the relative role it is expected to play in a country's entive tax dispute resolving process, certain of the latter's essential attributes and the relative roles each of the "Six" assigns to independent tribunals must first be mentioned. ${ }^{2}$}

Viewed as a whole, the dispute resolving process of a country should be designed to insure it has a reasonable chance to be both fair and efficient. For that process to be fair, at some point taxpayers must have a readily realizable right, as they do have in the six countries covered by this study, ${ }^{3}$ to lay their sides of disputes before a tribunal wholly independent of the tax administration. However, it is relatively inefficient to rely on such tribunals to resolve large numbers of tax controversies. Further, their use for such purpose either results in an expensive drain on talented and rare manpower or invites reliance on inexpert personnel. This is because increased reliance on this method of disposition brings an inevitable increase in the required degree of decentralization;

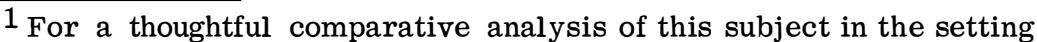
of developing countries, see Liker, "The Legal and Institutional Framework of Tax Administration in Developing Countires," 14 U.C.L.A.L. Rev. 240, 262-324 (1966). For an earlier study, see Surrey, "Tax Administration in Underdeveloped Countries," 12 U. Miami L: Rev. 158 (1958).

2 See Chap. IV infra regarding details of the conflict resolution process at the judicial level.

3 See Chaps. IV, VIII, XII, XVI, XX, and XXIV infra. 
otherwise, the inconvenience of the forum to taxpayers creates an unfair arrangement.

It is this requisite multiplication of such tribunals, if they are expertly staffed, that eats into a country's most talented and expensive manpower. When this consumption is balanced against a country's other needs, the probably resulting insufficient, albeit expert, staffing will create crowded dockets and delay as disputes await their turn. And those who represent the parties, though once intimately acquainted with all the niceties pertaining to a given dispute, must later-after the period of delay and just before the case comes to trial-take additional time to become reacquainted with those niceties and then devote yet further time, plus the time of the qualified judge, to educate that judge in all the ramifications.

At least less costly to such a country is the alternative device of staffing its host of decentralized, outside, independent tribunals-operating at the lowest level-with unremunerated and inexpert citizens. Great Britain has long followed the practice of deflecting directly to just such tribunals income tax disputes which a local assessment office is unable to resolve. ${ }^{4}$ Now 700 such tribunals (General Commissioners), with two part-time lay citizens constituting a quorum for each case, are spread geographically throughout that island. Only the clerk is paid and has legal training. 5 This arrangement, however convenient, invites three obvious risks if transplanted elsewhere. Except where appointment is deemed a distinct honor, unpaid lay members may not give adequate time and thought to their demanding function. Second, even if they do, problems of any complexity may still baffle them. Finally, given the large number of such tribunals, their lack of expertise, and the fact their decisions are not published, a high level of uniformity cannot be anticipated. 6 Apparently these were the risks the British Parliament sought to avoid ${ }^{7}$ when, as distinct from income tax questions, jurisdiction over surtax matters was lodged in a separate body of Special

${ }^{4}$ See Chap. XIX, §3.3 and Chap. XX, §4.1 infra.

5 See Chap. XX, §4.1 infra.

6 According to a new but yet unpublished study of Michigan tax procedures, all three consequences resulted from that state's use of approximately 1800 such tribunals to hear appeals of property tax assessments. Also see the earlier legislatively sponsored Michigan Tax Study Staff Papers 214 et seq. (1958).

7 See Chap. XX, §4.1 infra. 
Commissioners composed of eight full-time, paid professionals who ride circuit to the major metropolitan centers. 8 Further, by giving these two distinct types of tribunals concurrent jurisdiction over many but not all income tax questions, 9 some taxpayers were granted what is tantamount to an election between them. Nevertheless, the widely scattered, uncoordinated General Commissioners decide from 7,000 to 8,000 cases annually, compared with approximately 1,000 decided by the Special Commissioners.10 In either case, further appeal to the regular courts is available only with respect to questions of law. ${ }^{11}$

In contrast, because relatively few German taxpayers invoked a previously existing option to lay their cases before local lay committees, Germany recently abandoned that arrangement. 12 Now a taxpayer who is unable to resolve a dispute with local examining officials carries the case directly to one of the specialized fiscal courts staffed predominantly with professionals. ${ }^{13}$ These necessarily are decentralized to accommodate the yearly volume of 20,000 tax disputes, of which from 6,000 to 8,000 involve individual and corporate income tax matters. ${ }^{14}$ The Netherlands follows a similar practice, utilizing specialized chambers within their regularly decentralized court system 15 to accommodate an annually recurring 2,000 tax disputes which their local assessment offices are unable to resolve. Approximately seventy percent of these involve individual and corporate income tax matters. 16

Belgium and France, however, like Britain, make some use of decentralized independent tribunals staffed, predominantly but not exclusively, with outside laymen, to hear disputes between taxpayers and local assessment officials, though in these two countries these particular tribunals function solely in an

${ }^{8}$ Id. at $\S 4.2 \mathrm{~b}$ infra.

${ }^{9}$ Id. at $\$ 4.1$ infra.

10 Apart from so-called "delay" cases. Id. at $\$ 4.3 \mathrm{a}$ and $4.3 \mathrm{~b}$ infra.

$11_{\text {Id }}$. at §4.1 infra.

12 See Chap. XV, § $3.4 \mathrm{a}$ infra.

13 See Chap. XVI, §4.1 infra. However, before such action is taken, on filing a protest (in the case of substantive issues) with the local office, the individual taxpayer does obtain a hearing with the assessment official. See Chap. XV, §3.4a infra.

14 See Chap. XVI, §4.3 infra.

15 See Chap. XXIV, §4.1 infra.

16 Id. at $\S 4.3$ infra. 
advisory capacity. ${ }^{17}$ The lack of expertise on the part of the lay members presumably is responsible for denying to these advisory tribunals, in contrast to the British arrangement, any jurisdiction over questions of law. 18 And to assure some expertise regarding factual matters pertaining to a particular taxpayer's profession or business, each tribunal consists of a large panel, and the lay members for any given case are drawn from those having familiarity with the petitioning taxpayer's vocation. 19 A final contrast to British practice is most important. Taxpayers in Belgium and France may bypass these lay tribunals, ${ }^{20}$ carrying their disputes with local assessment offices directly to a higher in-service administrative appeal office (regional level), the jurisdiction of which must be exhausted in any event 21 before the taxpayer can lay his case before an outside professionally staffed independent tribunal. In one recent year, compared with the $135,312 \mathrm{Bel}-$ gians who carried their disputes with a local assessment office to one of the higher but decentralized offices handling administrative appeals, only 1107 required a final decision from a professionally staffed independent tribunal. 22 Corresponding numbers in France were, respectively, 365,000 and less than $5,000.23$

The in-service appeal arrangement in the United States is similar to that of Belgium and France in that the apex is also at a higher regional level, rather than at the local district level. However, to handle its administrative appeals, the United States actually maintains formally constituted appeal offices at both levels, each of which has decentralized suboffices. $^{24}$ When a dispute cannot be resolved by a local

17 See Chap. VII, $\$ 3.2 \mathrm{a}$ infra and Chap. XI, $\S 3.3$ and $3.4 \mathrm{a}$ infra . 18 Ibid.

19 Ibid.

20 Ibid. In Belgium, the assessor also can refuse to refer the case to the lay group if he believes the referral will not contribute to a proper determination of income. See Chap. VII, \& 3.2a infra .

21 See Chap. VII, §3.4, Chap. VIII, §4.1, and Chap. XI, §3.4b infra,

22 See Chap. VII, $\$ 3.4$ and Chap. VIII, § 4.3 infra.

23 See Chap. XI, \& $3.4 \mathrm{~b}$ and Chap. XII, § 4.3 infra.

24 Each of the 58 districts has a District Conference Office. Suboffices actually are maintained only in the larger districts. Each of the seven regions, among which the 58 districts are divided, maintains an office known as the Appellate Division and, together, the seven of these have about 40 geographically spread suboffices. 
examining official, 25 the taxpayer is encouraged by letter from the internal review staff to take the dispute to one or the other of the administrative appeal offices, the review staff's choice in a given case being determined by the character of the underlying issue and by the amount involved. 26

Typically, small cases and cases which can be resolved without special compromise authority (e.g., valuation questions) are encouraged to move to the lower of the two offices, i.e., to the appeal office operating at the district level. However, any taxpayer may avail himself of both offices on a seriatum basis before entering the litigation stage, or if encouraged to go to the district level appeal office, he may bypass it, going straightaway to the higher office, 27 or-contrary to the Belgian and French practices-he may, bypassing both, carry his case directly into the litigation stage.28 At this latter point, whether reached either after going through one or both of the

25Basically, these fall into two categories. Revenue agents are the more highly trained of the two (see \& 3.6 infra) and in each district are assigned to the Field Audit Branch of the local Audit Division. In fiscal 1966, these branches examined 767,000 returns of which 590,000 were income tax returns and of these 166,000 were filed by corporations, 411,000 by individuals and fiduciaries, and 13,000 by exempt organizations. Including supervisory personnel, this field force expended 12,473 man-years in fulfilling this mission. The second category, composed of tax technicians or office auditors, is situated in the Office Audit Branch of each local Audit Division. Together these consumed 3,093 man-years in examining $2,681,000$ of the less complicated individual returns. Much of this work was accomplished by correspondence. See Commissioner of Internal Revenue, Annual Report 1966, 23 and 68.

The 58 district Audit Divisions spread personnel among 800 different posts of duty.

26 Rev. Proc. 67-27, I.R.B. 1967-20, 45. See $\$ 3.7$ infra, The taxpayer simultaneously receives a written report, prepared by the examining officer but internally reviewed by a separate review staff, explaining the adjustments which the examining official proposed. In cases handled by examiners in the Field Audit Branch, these adjustments will have been orally discussed with the taxpayer at an earlier point when the examiner sought to get the taxpayer to accept the adjustments by executing Form 870. See U.S. Treas. Reg. §601.105(c)(2). In the smaller cases handled by the Office Audit Branch, at least half the cases are dealt with by correspondence, and the taxpayer's first chance to indicate his acceptance of an adjustment may be at that point when, by letter, he is invited to appeal to a given office and he does not accept the adjustment. See U.S. Treas. Reg. $\$ 601.105$ (c)(1).

27 U.S. Treas. Reg. $\$ 801.105$ and 601.106 .

28 See Chap. IV infra. 
administrative appeal levels or after bypassing both, U.S. practice differs on two principal counts from that of the other countries described above.

First, at the moment a case is docketed initially with an outside independent tribunal, the United States is the only country to shift substantial administrative control and the litigationrepresentation function to yet different government offices, composed entirely of lawyers. ${ }^{29}$ Since these separate offices (legal staffs) settle, 30 before trial, over eighty percent of all tax cases docketed with the independent tribunals, 31 they properly should be considered as a third level of administrative appeal. Second, the taxpayer at the litigation stage has three choices, two of which are substantially different. By paying the contested amount and suing for refund, the taxpayer may take his case into a nonspecialist federal district court of general jurisdiction. Only here-that is, subsequent to administrative appeals and in the course of trial before this one tribunal-are outside laymen used: in U.S. district court tax cases, either party may ask that a jury find the facts, though the judge will resolve all questions of law. As an alternative to the district court route, the taxpayer, before paying the contested amount, may docket his case with a specialized court (Tax Court of the United States) which rides circuit, with the judges finding the facts and deciding all questions of law. 32

29 In cases docketed with the Tax Court, the Chief Counsel of the Internal Revenue Service performs the litigation-representation function through his several Regional Counsels who maintain approximately 40 suboffices. Should the taxpayer, instead of taking the case to the Tax Court, pay the contested amount and sue for refund before either a federal district court or the Court of Claims, the litigationrepresentation function will be performed by the legal staff of the centralized Tax Division of the Justice Department.

30 In cases docketed with the Tax Court, settlement authority actually is shared jointly by the Regional Counsels: and Regional Appellate Division's suboffices. Exclusive settlement jurisdiction passes to the Regional Counsels' offices only when the court calls the calendar. Rev. Proc. 60-18, C.B. 1960-2, 988. In cases filed either with a federal district court or the Court of Claims, the centralized Tax Division of the Justice Department has settlement authority but it consults with the centralized Refund Litigation Division of the Service:s Chief Counsel's Office before settling important cases. See Chap. IV infra.

31 Commissioner of Internal Revenue, op. cit. supra note 25, Tables 17 and 20 at 134 and 135 .

32 The third alternative is to pay the contested amount and sue for refund in the Court of Claims. This court uses legally trained Commissioners to find the facts. 
In one recent year, approximately 60,000 cases were appealed to at least one of the three administrative appeal levels described above. Of this number, approximately 42,000 were routed by the district review staffs to the District Conference Offices. 33 Cases not agreed to there $(13,792)^{34}$ represented about half the 27,994 disputes which were appealed to the higher regional conference offices (Appellate Divisions). 35 The other half of that 27,994 went to those regional offices in the first instance, either on recommendation of the district review staffs or at the election of the taxpayer. Cases in which agreement was not reached at the regional level, together with the somewhat fewer than 5,000 which bypassed that same level, 36 made up the approximately 8,400 cases which were docketed with independent tribunals (courts). 37 These outside tribunals, however, actually decided fewer than 1,300 cases; 38 practically all the others 39 were settled, before trial, by the government's legal staffs, 40 which for that reason were characterized heretofore as the third administrative appeal level.

In summary, it is at least clear from the foregoing that income tax laws of small countries as well as large can generate a large number of disputes between taxpayers and local examining officials. Further, should a now developing country decide, for the first time, to resolve this entire mass of expected conflicts by forcing taxpayer reliance on a host of new outside or independent decentralized tribunals, that type of country in particular invites serious risks and problems whether it tries to staff those tribunals with professionals or inexpert laymen. Thus, there would be a distinct advantage in relying instead on properly designed internal administrative appeal procedures and, only where need be, on outside professionally staffed tribunals. However, even this arrangement will not be efficient unless the administrative machinery itself actually

33 Commissioner of Internal Revenue, op. cit. supra note 25 , at 25. 34 Ibid.

35 Id., Tables 15 and 16 at 133.

36 Id., Table 17 at 134 . These were based on final statutory notices of deficiency issued at the district level.

37 of these 6,874 were docketed with the Tax Court, 1,383 with federal district courts, and 125 with the Court of Claims. Id, Tables 17 and 20 , at 134 and 135 .

38 of these, the Tax Court decided 726, district courts 488 , and the Court of Claims 58. Ibid.

39 Ibid.

${ }^{40}$ See note 30 supra. 
has a reasonable chance to dispose, by bilateral agreement, of the great preponderance of these disputes. And it will have that reasonable chance only if it simultaneously possesses a reasonable chance both to be and appear to be fair. In those circumstances alone will taxpayers in sufficient numbers be willing, on a bilateral basis, to accept results achieved at that level. The administrative machinery itself also should have a reasonable chance to accomplish these dispositions efficiently; this, after all, is the primary aim in trying to reach agreement in as many disputes as possible without resort to an outside tribunal.

The administrative process, viewed in aggregate, will have a more reasonable chance both to be and appear to be fair, and also to be efficient in disposing of these disputes, if all parties know that at some point a specific office (i) is required to look at each dispute with a proper degree of impartiality, (ii) has a reasonable chance to become fully acquainted with the taxpayer's side of the story, and (iii) can assure "justice," which prior to litigation means that some such office is endowed with "complete settlement" authority. Each of these matters is separately discussed below.

\subsection{Assuring impartiality of administrative conflict resolution machinery}

If the administration's own conflict resolution machinery is to have a reasonable chance both to be and appear to be fair, it should be freed from the conflict of interest which almost inherently exists where the same person bears the twofold responsibility: to resolve tax disputes impartially and to produce revenue. One device alone will tend to eliminate, at least from the vantage point of ordinary taxpayers, both the appearance and actual existence of this conflict. However, sophisticated practitioners should acknowledge that a second device at the least will minimize the adverse effect of that conflict.

The first and preferred device is to separate, organizationally, personnel who hear at least the final administrative appeal from personnel immediately responsible for the original examination and assessment function. ${ }^{41}$ Obviously also, the

41 It would logically follow from this that appeal personnel-while trying to resolve an existing dispute-would not then be expected to look for new affirmative issues. To do so invites both the fact and appearance of the previously mentioned conflict, for raising issues is 
former should be free of the latter's control.42 Belgium, France, and the United States do divorce these two groups of personnel. While local district offices carry on the basic examination function, 43 the apex of the administrative-appeal function is at a higher regional office. 44 As previously noted, however, the United States, by a published procedure, also makes possible an administrative appeal within the local district

\section{(footnote continued)}

an examination or revenue producing function. So complete a bill of divorcement within the administration itself becomes less logical, however, if the administration otherwise extends the examination function right up to the courthouse steps, by raising new issues at that yet later point when a controversy regarding old issues is laid before a completely independent quasi-judicial or judicial body. In other words, if at the litigation stage the administration both can and does follow the practice of raising new issues, the argument for foregoing that practice at the earlier point when the case reached the apex of the administrative conflict resolution procedure is drained of much of its vitality.

In the United States, a deficiency asserted by the government is presumptively correct at that point when a taxpayer takes that issue to the Tax Court of the United States. While the government's answer to a petition filed by a taxpayer with that court can raise a new issue, the burden of proof regarding that new issue is borne by the government, not by the taxpayer. Rule 32, Tax Court of the United States. It is widely believed in the United States that this shift tends to dampen the likelihood that the legal staff (Regional Counsel) will raise new affirmative issues after the case has been docketed. This belief, coupled with the fact that the case still can be administratively "settled" before trial leads many taxpayers to bypass yet another regional settlement office (Appellate Division) until after the case is docketed. Relevant is the fact that if the taxpayer had gone to the Appellate Division first, but been unable to reach agreement there, the doctrine of presumptive correctness would have attached to any new issues that division raised and included in its statutory notice of deficiency.

42 Also at least the appearance of impartiality on the part of the administrative appeal official will be prejudiced if the original examining official attends the hearing and, indeed, sits at the same conference table. To avoid this prejudice as well as to save the time of the original examining official and to put pressure on him in the first instance to prepare an adequate written explanation of his adjustments (see note 26 supra), U.S. procedures properly provide that ordinarily the examiner himself will not attend the hearing. Rev. Proc. 67-27, I.R.B. 1967-20,45.

43 See $\S 3.2$ in Chaps. VII and XI infra, and U.S. Treas. Reg. $\S 601.105$.

44 See $\S \S 3.4$ in Chaps. VII and XI infra, and U.S. Treas. Reg. $\S 601.106$. 
itself (District Conference Office). 45 In the early 1950's, these appeals were heard by the immediate supervisor of the particular examining officer who had proposed the contested deficiency adjustment to the taxpayer's return. Most practitioners, however, pointedly objected to this arrangement. They believed the relationship and resulting daily contact between the supervisor and the examining officer prejudiced the likelihood the former would be impartial. For this reason, many practitioners elected to bypass this particular appeal, taking their disputes with examining officers directly to the higher regional level. ${ }^{46}$ The administration responded to this bypass pattern by a series of steps taken in the late 1950's and early 1960's. 47 Among other things, it divorced the district appeal function from the district examination function by shifting jurisdiction over appeals at the district level from the immediate supervisors of examining officers to a separate intradistrict office 48 created and staffed solely to carry on this function. 49

In contrast to the foregoing, the one administrative appeal allowed in Germany and the Netherlands is heard by the same office which originally proposed the assessment from which the dispute emerged.50 In most cases, a similar but not

45 See U.S. Treas. Reg. $\S 601.105$ (c) and Rev. Proc. 67-27, I.R.B. $1967-20,45$.

46 For another reason why so many practitioners bypassed the district office, see § 3.7 infra.

47 See Rev. Proc. 56-34, C.B. 1956-2, 1396; Rev. Proc. 60-16, C.B. 1960-2, 940; Rev. Proc. 60-24, C.B. 1960-2, 998; Rev. Proc. 62-8, C.B. 1962-1, 431; and Rev. Proc. 64-38, 1964-2, 965, superseded by Rev. Proc. 67-27, I.R.B. 1967-20, 45.

48 The head of this office (Chief, Conference Staff) is not under the control or supervision of the chiefs of the two separate branches which conduct field and office audits. While all three do report to the Chief of the district's Audit Division, in theory the latter does not become involved in the appeal process. In other words, the Chief of the Conference Staff reports to the Chief of the Audit Division only for administrative purposes. Appeal from a district Conference Staff's determination goes to the higher regional Appellate Division.

49 The United States also finally reversed its attitude toward the bypass problem. In 1964, it actively began to encourage taxpayers to bypass the District Conference Office in certain types of cases and to take them directly to the higher regional office. Rev. Proc. 64-38, C.B. 1964-2, 965, superseded by, but to the same effect, Rev. Proc. 67-27, I.R.B., 1967-20, 45. See \$3.7 infra for the reasons which led to this change and for a description of the types of cases to which the changed attitude was applied.

50 See $\S 3.3$ and 3.4 in Chaps. XV and XXIII infra. 
formally constituted practice prevails in Britain. 51 In these countries a taxpayer, who understandably might prefer not to discuss the issue again with the same person who actually proposed the original assessment, at best ordinarily can expect to discuss the issue only with an official in that same office who is senior to the examiner. 52

However, each of these three European countries, in further contrast to U.S. practice, does employ a second but less effective device which tends at least to reduce the adverse effect of the underlying conflict between the hearing-officer's appeal and revenue-producing responsibilities. The likelihood that the office will view appeals with a proper degree of impartiality is enhanced by the fact that it-that is, one of its inspectorsalso actually must fulfill the trial litigation-representation function for the government if agreement is not reached and if the taxpayer dockets the dispute with an outside independent trial tribunal. 53 Human nature being what it is, no local inspector wants to build up a record of losses in fulfilling his litigation function. This inevitable concern at the minimum puts some pressure on the local office, during the earlier administrative appeal, to conform to a proper degree of impartiality. Indeed, many practitioners in the United States believe that the absence of just this type of pressure on the two U.S. offices constituted solely to hear administrative appeals (District Conference Office and Regional Appellate Division) detracts from the prospect they will exercise an adequate degree of impartiality. 54 As previously noted, once a tax case in the

51 Because not formally provided for and because the reconsideration is by the examiner's own senior, the arrangement actually is deemed to be a mere extension of the examination, rather than an appeal. See Chap. XIX, \$\$3.3 and 3.4 infra. Also because the procedure is not formally provided for, some dissatisfied taxpayers write directly to the national office and it intervenes.

52 In support of an argument that this procedure does provide a fair re-examination in Germany, see Chap. XV, §3.4 infra. Also, as to an alternative possibility in Britain, see note 51 .

53 See $\S 4.3$ in Chaps. XVI and XXIV infra. In Britain, however, this is consistently so only as to income or profits taxes appealed to the independent General Commissioners. In the case of appeals to the Special Commissioners, a local inspector may and often does represent the government if the question involves income or profits taxes, but never if it involves the surtax. A separate Solicitors' ${ }^{\prime}$ Office represents the government in all surtax cases. See Chap. XX, $\$ 4.3 \mathrm{a}$ and $\mathrm{b}$ infra.

54 E.g., see Hobbet and Donaldson, "A Practitioner's Guide to Making a Good Settlement Within the IRS," 15 J. Taxation 230, 233 (1961). 
United States is docketed, say, with the Tax Court, the litigation-representation function is handled by a third office (Regional Counsel). Because this third office also shares the power to settle cases administratively once they are docketed with the Tax Court, 55 many practitioners believe it desirable to bypass the first two offices and seek an administrative settlement only after their cases have been docketed.56 One reason is that these particular practitioners believe the third office's litigation-representation responsibility leads it to be more "realistic" than the first two in considering possible administrative settlements. 57

Implicit in this is the suggestion that a tax administration, to enhance both the fact and appearance of impartiality on the part of its administrative appeal process, should implement both of the arrangements considered here. 58 In short, personnel who hear the final administrative appeal should be separated, organizationally, from those immediately responsible for the initial examination and assessment function, and should fulfill the litigation-representation function at the trial level if agreement is not reached. Certainly the second of these, standing alone, would contribute little to impartiality in any case where the relatively small amount in dispute leads the official to conclude that it would be against the given taxpayer's economic self-interest to assume the direct and indirect costs associated with litigation.59 Not one of the countries covered

\section{See note 30 supra.}

56 See Hobbet and Donaldson, op. cit. supra note 54. Also see U.S. Treasury Department, "Tax Practitioner Attitude Survey," 17 Bull. Tax. Section, A.B.A. 29 at 52, questions 17 and 18 (Oct. 1964). For another factor contributing to the bypass problem, see note 41 supra. In fiscal 1966, 4,489 cases were docketed by taxpayers before any effort was made to settle with the higher regional offices. However, in some of these cases, the taxpayer had no choice. For the district director himself, because the statute of limitations was about to run on the case, may have issued a final statutory notice of deficiency, thus forcing the taxpayer to docket his case with the Tax Court before trying to arrange an administrative settlement at the regional level.

57 Id. Where the first two offices had the opportunity but were unable to achieve agreement with the taxpayer and the case then is tried and lost, they at least unconsciously can take refuge in the possibility that the loss resulted, not from overreaching on their part, but rather from the failure of the third office to perform its representation function skillfully.

58 See \$3.4 infra for discussion of a third arrangement which will contribute substantially to this same end.

59 See note 74 infra for an arrangement designed at least to cushion this prospect. 
by this study employs both of the previously described devices. France, however, comes close. It maintains a regional office to which a taxpayer can appeal a local office's determination, and that higher office is responsible at least for final preparation of the government's memorandum of law if litigation ensues. However, in such event, it appoints an inspector from the particular local office where the outside tribunal sits, to appear for the government at the hearing. 60

\subsection{Assuring administrative machinery a reasonable chance to}

become fully acquainted with the taxpayer's side

An inherent conflict exists also between the need to give the administrative appeal procedure a reasonable chance to dispose of most disputes by bilateral agreement and the competing need to avoid laying undue formal burdens on taxpayers.

On the one hand, a typical taxpayer understandably wants to spend only the minimum time, effort, and money he considers necessary to convince the administration his position is correct. On the other hand, in theory, the chance of an administrative appeal office to be fair will be as good as that of an outside tribunal only if, before the former office hears an appeal, the taxpayer devotes as much time, effort, and money in developing his case (marshaling evidence regarding facts and arguments regarding legal issues) as he would if the matter were to be heard instead by the outside tribunal. At the administrative level, however, many taxpayers will not devote that amount of energy to developing their cases. There is an obvious reason: at this level, a taxpayer is not yet "up against the gun"; recourse to an outside tribunal remains available if need be, and only then will he suffer the felt pressure to "button up" his side of the case from top to bottom. In consequence, an administrative office just does not have as good a chance to reach the truly correct result as does an outside tribunal, and this reduces the former's ability to obtain taxpayer acceptance of its determinations.

Merely to require the taxpayer, as do certain European countries, 61 but not the United States, 62 to exhaust the

60 See Chap. XII, §4.3 infra.

61 For example, Belgium (see Chap. VII, $\$ 4.1$ infra) and France (see Chap. XI, § $3.4 \mathrm{~b}$ infra).

62 A U.S. taxpayer who disagrees with the adjustments an examiner proposes to make in the taxpayer's return can bypass the administrative appeal offices en route to litigation in either of two ways. 
administrative remedy before invoking the jurisdiction of an outside tribunal, will not assure the administrative office's exposure to a fully developed case on the taxpayer's side. "Hitand-run" tactics could satisfy this formal requirement. 63 Comprehensive development and indoctrination at the administrative level can be assured absolutely only by a requirement that puts each taxpayer "up against the gun" prior at least to completing his administrative hearing before the highest inservice office to which he can appeal. In effect, it would be necessary to provide that a taxpayer could introduce later as evidence-in litigation before an outside independent tribunalonly that evidence which he had submitted to the highest

\section{(footnote continued)}

First, the initial letter he receives explaining the adjustment (or, in small cases, a second letter, if the initial letter invited him to a district conference) will invite him, should he reject the adjustments, to enter an administrative appeal to the regional Appellate Division by filing a written protest. His default on this invitation will lead the district director to issue a statutorily required "notice of deficiency" (so-called 90-day letter). This informs the taxpayer that the deficiency will be assessed in 90 days should the taxpayer fail to file a petition during that period with the Tax Court of the United States. By filing such a petition within that time, the taxpayer postpones the assessment and the need to pay the asserted deficiency, though interest will run if the government ultimately prevails.

Second, taxpayers who plan to bypass the administrative appeal offices but prefer to litigate before a federal district court or the Court of Claims, may accomplish this by agreeing with the examiner's proposed adjustment (executing Form 870) and by paying the entive asserted deficiency. Flora v. U.S., 362 U.S. 145 (1960). The taxpayer then files a claim for refund. In theory, the administrative appeal procedures applicable to refund claims disallowed by an examiner ordinarily conform to those applied to disputed deficiencies, the prime exception being that an administrative refund exceeding $\$ 100,000$ must be reviewed by the congressional Joint Committee on Internal Revenue Taxation. See I.R.C. $\S 6405(a)$; U.S. Treas. Reg. $\$ \$ 601.105(e)(2)$ and 601.108; Woodworth, "The New Joint Committee Refund Procedure," 19 Bull. Tax. Section, A.B.A. 9 (Oct. 1965). However, the hypothetical taxpayer in this case does not intend to take advantage of the available administrative appeals and, upon final rejection of his claim, may sue for refund before either of the two previously mentioned courts.

63 To illustrate, before 1964, when all U.S. taxpayers were encouraged to take their disputes first to the lower of the two administrative appeal offices (District Conference Office), officials working at that level indicated they often encountered this "hit-and-run" tactic from taxpayers who invoked their jurisdiction but intended from the outset to take their cases to the higher regional appeal office the moment they determined that, to obtain a satisfactory disposition, they would have to develop their cases fully. Also see note 64 infra. 
in-service echelon. ${ }^{64}$ Logically, he further would be required to submit the same brief on the law. 65

Unquestionably, these formal requirements could be imposed in a manner that would achieve their aim without depriving taxpayers of a preliminary chance to reach agreement at a more informal hearing before that same high level inservice office. Proceedings there could be divided into two successive stages. The formal requirements would apply solely to the second stage. This itself would encourage taxpayers to develop their cases at least to a reasonable point prior to the first and more informal stage, for those who reached agreement there would be completely freed from the burdens and risks associated with the formal requirements. Only those unable to achieve agreement in that first stage would have to assume these burdens in preparation for the second stage. ${ }^{66}$

64 The United States does not impose any such requirement. See note 62 supra. In consequence, some administrative officials working in the regional Appellate Divisions have indicated that some taxpayers who did appeal to that office and, on failing to achieve agreement there, then did docket their cases with the Tax Court, fully developed their cases only at the latter point. In effect, it was said that the complexion of the taxpayer's case actually changed between the two different stages. This was said to be at least one reason why many disputes, though not resolved by bilateral agreement during the first administrative appeal to the Appellate Division, were administratively settled to the satisfaction of both sides after the case had been docketed with the court but before it was tried. Indeed, for this and other reasons, well over a majority of the docketed cases are administratively settled before trial. See Commissioner of Internal Revenue, op. cit. supra note 25, Table $17 \mathrm{~B}$ at 134.

For a detailed explanation regarding the proposal, see Traynor, "Administrative and Judicial Procedure for Federal Income, Estate, and Gift Tax Cases," 38 Colum. L. Rev. 1393 (1938); Surrey, "The Traynor Plan-What It Is," 17 Taxes 393 (1939). Mr. Traynor properly suggests that the independent tribunal itself would need some latitude in providing for exceptions to accommodate situations where the taxpayer actually was not at fault in failing, at the earlier administrative hearing, to submit certain evidence.

65 With provision for the same type of exception as that suggested in note 64 supra regarding evidence.

66 See Traynor, op. cit. supra note 64. Absent the two-stage division, the formal requirements would rob the entire procedure before that office of its informality. If there is but a single stage, with these formal requirements applying to it, many taxpayers would believe at the outset that they could afford to do no less than the perfect job and actually would expend more time, effort, and money than was necessary in arriving at a satisfactory disposition. 
Just as unquestionably, even with this division, many taxpayers-required to go through the second stage-would deem these formal requirements to be in their cases both onerous and superfluous. From the beginning, they had expected the administrative appeal office (local or regional) to react adversely in resolving the debatable questions in their cases if only because the national office itself had previously published its own adverse position. Thus, these taxpayers, if given a free choice and if guided by self-interest, might prefer to bypass completely the administrative appeal machinery, and place their cases before an outside tribunal as quickly as possible. Their situation also illustrates the principal yet distinctly different reason why these formal requirements, without more, would not achieve their ultimate purpose in the case of many other taxpayers whose need to resort to an outside tribunal would remain. An adverse administrative determination in any case really open to serious doubt will not convince any given taxpayer that an outside tribunal necessarily would reach the same adverse result even though exposed to the same evidence and the same brief. In all such truly debatable cases, a taxpayer's incentive to duplicate his effort by resorting to an outside tribunal would remain high.

But this incentive could be dramatically reduced in the type of truly debatable cases which a court necessarily would decide entively for one side or the other if a country adopts the policy of having the administrative office in question compromise such cases by reference to the litigation hazards, test cases aside. This practice alone, without the above formal requirements, would tend to induce these taxpayers, prior to such administrative hearings, to expend the time and effort essential to proper development of their cases if only because, at that point, they would be "up against the gun" with respect to this type of justice (compromise). Because-absent this practice-the previously discussed formal requirements would be onerous to so many, because the compromise practice alone will go a long way in achieving the aims of those formal requirements, and because this compromise practice is otherwise intrinsically justified for the reasons explained in the next subtopic, the formal requirements themselves should not be imposed by any country until it has determined from its own experience that they are indispensable in maintaining an orderly administrative process and in keeping outside tribunals from being inundated with tax disputes. 


\subsection{Assuring justice: Need for complete "settlement" authority}

The nature of the question appealed to an administrative office can affect adversely its ability to be fair and, thus, its opportunity to dispose of the issues by bilateral agreement. This is not a problem if the controversy involves, say, the valuation of property. In such a case, the office, in fairness, may find that the original examiner's proposed valuation actually was too high though the taxpayer's was too low. Officials hearing this type of appeal in any one of the six countries covered by this study possess adequate authority to reach an agreement with the taxpayer on the basis of what the officials believe to be an appropriate intermediate figure. This, after all, is the result a court might reach if the matter were litigated.

But these administrative officials also often encounter the type of issue which, if litigated, a court-to conform to the statute-necessarily must decide entively for one side or the other. ${ }^{67}$ At the prelitigation point of an administrative appeal, however, the right answer, albeit yes or no, actually may be open to serious doubt. This is because, at that point, the truly "correct" answer can be nothing more than a prediction of the likely decision by an outside independent tribunal if litigation actually ensued. If the official at the administrative hearing believes that, if litigation ensues, the odds regarding the

67 In determining the frequency with which these arise, vis-à-vis disputes regarding a mere amount, it must be remembered that a given subtotal on a return actually may cover many of the former. The fact that a court would find the taxpayer right as to some, but wrong as to others, and thus in effect require a change in the subtotal, does not mean that the dispute concerned a mere amount. To illustrate, consider a country which allows a current deduction for true "repair" expenses, but requires capitalization of expenditures for "improvements" in the nature of capital expenditures. The subtotal on a return reflecting so-called "repair expenses" actually may include a number of separate projects and, as to each of these, a court-viewing the projects separately-necessarily may have to decide the issue of deductibility entively for one side or the other. The fact that the taxpayer might win as to three projects, with the government winning on five, hardly means that there was but one issue involving merely an amount. There were eight issues. One or more of many separate items hidden in a subtotal may raise both types of questions. For example, there may be an issue as to whether a given trip was primarily a deductible business trip or primarily a nondeductible personal trip, and even if it is the former, there may be an additional issue regarding the amount actually expended for business purposes. 
government's chance of success are roughly fifty-fifty, presumably the real worth or value of the government's equity in the case is, as of that moment, only fifty percent of the previously proposed adjustment. However, in only three of the six countries (France, the Netherlands, and the United States) is it ever possible at the administrative level to compromise, by reference to these litigation hazards, this type of issue. 68

In the United States, appeal offices now situated at the regional level received initial authority to exercise this complete type of settlement authority 69 four decades ago, in the 1920 's. By then, policy-making officials had learned, the "hard way," the first of five reasons which cumulatively justify this practice. They had found it was fruitless to expect a wellrepresented taxpayer to make an outright concession if he believed he had, say, anything approaching a fifty percent chance to succeed in litigation. Indeed, by the time the administration decided to permit appeal offices now situated at the regional level to exercise complete settlement authority, the then fairly new Tax Court 70 already had become inundated with petitions from unsatisfied taxpayers and, in consequence, struggled with a tremendous backlog of unresolved tax disputes. 71

Second, U.S. policy-making officials believed it actually was unfair for an administrative office to expect the particular taxpayer described above voluntarily to pay one hundred percent and thereby forfeit his valuable possibility (say, fifty percent) to prevail in litigation. A compromise, based on

68 See Chap. XI, §§ 3.2a and $3.4 \mathrm{~b}$, and Chap. XXIII, §§ $3.2 \mathrm{a}$ and $3.4 \mathrm{a}$ infra. Also U.S. Treas. Reg. §601.106(f), Rule II. That such is not permitted in Belgium, see Chap. VII, § 3.4 infra; in Germany, see Chap. XV, §3.4a infra; or in Great Britain, see Chap. XIX, §§ 3.2 and 3.4 infra. It is widely recognized among U.S. practitioners that these compromises may be effected by splitting a single issue, by trading issues-sometimes subtly, sometimes otherwise, or by a package settlement. In the United States, the basic delegation is from the Commissioner directly to certain officials in the regional Appellate Division, not to the Regional Commissioner who otherwise exercises administrative jurisdiction over the latter officials. U.S. Treas. Reg. $\S 601.106(\mathrm{a})$.

69 For limitations on this authority, see U.S. Treas. Reg. §601.106(a) (2) (iii), (iv), and (v); and notes 73 and 74 infra. Regarding the extent this authority is shared with the legal staff once a case is docketed in court, see note 30 supra.

70 But at that time called the Board of Tax Appeals.

71 Its docket included 22,000 cases. See Mills, "Federal Administration of Tax Law," 52 N.Y. State Bar Assoc. Proc. 495 at 500 (1929). 
bilateral concessions suitably responsive to the competing weaknesses and strengths of the two opposing sides, was thought to achieve the most appropriate measure of "justice" if the parties agreed to forego litigation.

Third, it was recognized that, in many such disputes, actual litigation would not really help the tax system, i.e., would not contribute to needed clarification of the law. ${ }^{72}$ For example, some purely legal issues are unlikely to recur with any frequency, if at all. Again, other more frequently recurring issues, though of a type which a court necessarily would decide entirely for one side or the other, actually may involve mixed questions of law and fact and too many decisions by diverse decentralized trial tribunals may serve to confuse, not to clarify, the area. Finally, litigation of purely factual questions of this type would have little, if any, precedent value. On the other hand, the U.S. tax administration recently has made it exceedingly clear that a legal issue expected to recur frequently should not be compromised, for in this circumstance early litigation of a test case would.contribute to needed clarification of the law. ${ }^{73}$ Otherwise, however, a U.S. taxpayer enjoys what is tantamount to an election. On appealing to the regional level, he can seek to compromise a debatable issue by reference to the litigation hazards. If he does not agree with the official's supposedly impartial appraisal of those hazards, he can force the matter to litigation, in which eventin the type of case under discussion here-a court will decide entirely for one side or the other.

Fourth, to authorize an administrative appeal office to exercise complete settlement authority over issues a court

72 See Mills, op. cit. supra note 71 , at 497 and 501.

73 See Cohen, "Current Developments in the Chief Counsel's Office," 42 Taxes 663 (1964). These test cases will be chosen by the National Office through a more-or-less computerized information retrieval system which ultimately will cover all cases reaching the regional level. Also, implicit in the fact that the National Office previously has published a revenue ruling on a given issue is the supposition that this issue is sufficiently important to warrant being tested in court, though this hardly could mean that every case touching that issue would be a good test case. By way of contrast, not every private ruling involves a matter sufficiently important to the tax system to warrant litigation. Thus, some adverse private rulings, issued at a point when a transaction was prospective, should be subject to compromise by reference to the litigation hazards if the taxpayer actually consumates the transaction. 
would decide entirely for one side or the other tends also, as to those issues, to satisfy an important need of that office. The delegation increases that office's opportunity to become fully acquainted with the taxpayer's side. In many such cases, of course, the official still may conclude that the issue is not open to any real doubt and will refuse to compromise in the belief that the government almost certainly would win if litigation ensues. 74 But taxpayers will not necessarily know this in advance. Thus, at least those who initially believe they have a significant argument but prefer, if possible, to avoid expensive, time-consuming litigation which also exposes their financial affairs to public view, will be induced by the possible chance to compromise-available if at all only at the administrative level-to develop their cases fully before the hearing at that level. And this increases the likelihood administrative officials will be able to appraise all cases fairly and, consequently, to secure more bilateral agreements.

Fifth and finally, the compromises so achieved no doubt will produce more genuine uniformity among taxpayers concerned

74 In the United States, the authority of the regional Appellate Divisions to compromise by reference to the litigation hazards is subject to the limitation that "no settlement will be countenanced based upon nuisance value of the case to either party." U.S. Treas. Reg. $\S 601.106$ (f), Rule II. Italics added. A former senior official of the Appellate Division in New York has suggested that offers of 20 percent of the asserted deficiency, if truly responsive to the litigation hazards, should not be deemed a mere nuisance value, but that offers below that figure should be so treated. Rosenweig, "Pre-Trial Strategy in a Tax Case: Techniques and Limitations in Dealing with the Appellate Division," N.Y.U. 22d Inst. on Fed. Tax 109, 123 (1964). In other words, as to a doubtful issue which a court necessarily would decide entively for one side or the other, if the taxpayer holds what the government's settlement official believes to be less than a one out of five chance to prevail if the matter were litigated but refuses to concede, the government should force the matter to litigation rather than accept less than the full amount. And if the government is the party holding such a small chance, the general instructions to its settlement official should contemplate that he would concede the issue.

However, as to small doubtful cases of the type under consideration here, it is believed that the government's instructions to its settlement officials regarding its own concession policy should take into account the cost of litigation to the taxpayer. In short, it ought not expect any payment unless the settlement official believes it has a better than even chance to prevail should litigation ensue. To expect a 20 percent payment, for a one out of five chance, in a case where, solely because of the cost of litigation, it is against the taxpayer's economic self-interest to litigate, is tantamount to extortion. 
with the type of debatable issues under discussion here than would an attempt, by the substantial number of widely scattered administrative officials necessarily involved, to decide each such case entirely for one side or the other. Some would abandon an issue which others would force to litigation.

\section{Section B. Analytic Comparison of Additional}

\section{Requirements: Echelon by Echelon View \\ of Assessment and Administrative \\ Conflict Resolution Procedures}

\subsection{Examining officer level}

In both self-and non-self-assessment systems, practically all tax disputes are triggered at the examining officer level. It is imperative, therefore, that each administration identify the precise role of examining officials in the conflict resolution process.

This presents no problem at all for certain types of potential disputes, such as those involving a valuation question. Each country obviously should instruct its examiners to approach this type of inherently disputable question with the impartiality of a judge. Nor should there be any doubt about an examiner's function where he is at least fairly clear that the government is in the $r$ ight regarding the distinctly different type of question which, if litigated, a court necessarily would decide entively for one side or the other. But if, after objective and careful analysis, he concludes the correct answer to this type of question is open to serious doubt, delimitation of his function becomes somewhat more complex. His function should vary, depending on whether his country, as to these debatable cases, has adopted compromise as its ultimate standard of administrative justice, test cases aside.

While a country's adoption of this practice should affect the function of these lower level examiners, this is not to say that they themselves should be empowered to exercise compromise authority. Typically, they are far too numerous, too lacking in sophistication, too far removed from the litigation process itself and thus know too little about it, to be able to compromise wisely by reference to the litigation hazards. But where more experienced or higher officials have been so empowered, an examiner at the lowest level should be instructed, if in substantial doubt regarding the correct answer to this 
type of substantive question, to do simultaneously two things: to set up an assessment and to acknowledge his doubt to the taxpayer. ${ }^{75}$ This acknowledgment will make it clear that he actually is not trying to resolve definitively the difficult question in the impartial manner of a judge. Judge-like resolution of these apparently marginal questions would cause, all too often, one examiner to set up an assessment which, as to a similar dispute with a different taxpayer, another examiner would abandon. To avoid this, and further to facilitate a chance for both cases to be uniformly treated by reference to this country's hypothetical ultimate standard of administrative justice (compromise), assessments should be set up for the entire amount in both cases, 76 but only to set the stage for an administrative appeal by the taxpayer, eventually to an official possessing complete settlement authority. The latter, if convinced also that the correct answer is open to serious doubt, then either should compromise the issue by reference to his appraisal of litigation hazards or ask the national office for technical advice.77 Should he think it likely that the central office will wish to litigate a test case on this substantive issue, his choice should be for the technical advice route.

Where a country empowers no official to exercise compromise authority over the particular types of truly debatable issue under discussion here, a different procedural pattern should be employed. To be fair, each such official of such country, including those who examine returns, should be instructed to resolve all such debatable questions in the impartial manner of a judge. Since each of these questions, by

75 Unless specifically instructed to acknowledge openly his doubts, if any, the felt pressure to obtain a bilateral agreement is likely to lead many examiners to propose adjustments without indicating their own doubts, if any.

76Presumably this is the intention of U.S. procedures. On the negative side, examining officers themselves are denied the right, in doubtful situations, to attempt to resolve cases by reference to the litigation hazards, this being reserved exclusively to the administrative appeal offices. See §3.7 infra: U.S. Treas. Reg. $\S 601.106(\mathrm{f})$, Rule II; and Rev. Proc. 67-27, I.R.B. 1967-20, 45. On the affirmative side, examiners are instructed as follows: "Issues should only be raised by examining officers when they have merit, never arbitrarily or for trading purposes. At the same time, the examining officer should never hesitate to raise a meritorious issue." Rev. Proc. 64-22, C.B. $1964-1,689$.

77 For details regarding a centrally administered technical advice program, see Chap. II, § 2.16 supra. As to cases covered by previous central office rulings, see note 73 supra. 
definition, will have to be decided entively for one side or the other, the administration hardly can anticipate uniform decisions by the large host of examiners who work at the lowest level. But that is a price the country must pay for choosing to rely exclusively on a type of administrative justice comparable to the approach of the judiciary itself. Having exercised this preference, apart from administrative appeals initiated by dissatisfied taxpayers, there are only two further procedures whereby such countries can increase the prospect of uniformity at the examination level. A cornparison of these follows.

\subsection{Mandatory internal review $v$, self-initiated requests for technical advice}

Whether, in theory, a given country ought to provide for internal review of all determinations made by its large examining force should turn on the cumulative effect of several considerations. However, whether it realistically can afford to meet that talent-absorbing need, assuming that need exists, turns on a yet different factor.

Maintenance of integrity is a relevant but not the most important consideration in appraising the need for an allembracing review program. If this were the prime aim, a sampling procedure would suffice. Further, an internal review-relying as it does on the administrative file-will not necessarily indicate that the original examiner was or was not honest. Particularly in the case of business returns, such a review necessarily focuses primarily on the examiner's own written report. While this report should disclose all matters he thought at all questionable-whether ultimately resolved by him in favor of the taxpayer or the government-the file itself may leave no "tell-tale" tracks should he, in a given case, omit reference to those decided favorably to the taxpayer. This is why, in addition to its regular internal review program, the United States maintains a completely separate Inspection Service which typically probes behind and beyond the administrative file in attempting to expose in-service dishonesty. ${ }^{78}$ The very existence of internal reviews does tend, however, to put some pressure on examiners to be honest. And if this were the sole consideration, countries such as England and the Netherlands, given their civil services' long

78 See Trainor, "Functioning of the Inspection Service," N.Y.U. 17th Inst. on Fed. Tax 495 (1959). 
and widely recognized tradition of integrity, could justify easily their practice of not automatically reviewing internally the determinations made by their examining forces. 79

Nevertheless, the fact remains that, in measuring the need for internal review, the most important consideration involves the frequency with which the examining force is likely-in utter innocence-to commit technical errors. This likelihood inevitably is affected by the quality of personnel recruited for this force and of the in-service technical training program conducted for its benefit. On these counts, the United States compares favorably with both England and the Netherlands, as well as with the other European countries, 80 though it alone maintains a fairly broad-ranging, automatic, internal review program. Recruits to its revenue-agent classification (and they constitute approximately eighty percent of the entire examining force 81 ) must be college graduates with a substantial major in accounting. Further, practically all will have had at least one college-level course in federal tax law. Finally, at the point of recruitment, each also must attend on a full-time basis comprehensive in-service classroom courses covering not only federal tax law but other subjects as well. Given these standards, however, any comparison of error-incidence by this force with that of its European counterparts, must take account of the relative complexity of the different tax laws these various groups apply. Looking at this factor alone, the relative chance for error would be greatest in the United States. Its law, as noted earlier, is by all odds the most complex. 82 Moreover, the thousands of built-in deviations obviously are capable of spawning a multitude of interpretative difficulties. But a further factor tends at least to mitigate the apparent relative difficulty of the U.S. examiner's task.

The United States, in implementing the notion of justice it deems most appropriate at the administrative level, has delegated to high level regional officials complete "settlement" (or compromise) authority over all truly debatable issues, test cases aside. In consequence, whatever the difficulties of an

79 However, in both countries, inspectors who visit local offices may sample previously examined returns; but as in many other countries, this is to enable the higher official to appraise the overall quality of the work done, rather than to detect errors as such. See §3.2, Chaps. XIX and XXIII infra.

80 See $\S 1.5$, Chaps. V, IX, XIII, XVII, and XXI infra.

81 See note 25 supra.

82 See the comparison in Chap. II, § 2.5 supra, 
examiner at the lowest level, an escape-hatch exists. The examiner is not expected to make a refined judgment in the impartial manner of a judge if he concludes there is substantial doubt regarding the correct answer to an issue of the type which, if litigated, a court necessarily would decide entirely for one side or the other. In effect, it is enough for the examiner to recognize that the answer is open to serious doubt. That doubt in itself, at his level, is enough to trigger a tentative decision against the taxpayer 83 who, by an administrative appeal, can lay the case before a higher official possessing complete settlement authority. In contrast, performance of a more demanding task should be expected of examiners in a country such as Britain, which denies this type of compromise authority to all officials. The consequence of this denial should be the expectation that its examiners will make impartial decisions, i.e., refined predictions regarding the "correct" answer, with the consequent greater likelihood of error.

Nevertheless, a further overriding question exists: can any given administration afford to allocate sufficient personnel to permit internal review of all determinations made by its examining force? So sweeping an effort obviously would absorb a tremendous amount of talent. And on this score, the European countries, all of which utilize the non-self-assessment system, are in a situation quite different from that of the United States, which relies on the self-assessment system. These countries necessarily use vast amounts of talent in the examination function itself, though not one actually makes a complete examination of every return. 84 Their coverage, however, does extend far beyond that of the United States, which annually only examines about three and a half million returns out of the sixty-seven million annually filed. 85 This comparison suggests that the difference in basic assessment systems is the prime reason why, relatively speaking, the United States finds it easier to spare the talent required to review internally its examiners' determinations. In summary, the non-selfassessment countries tend to expend their technical personnel in achieving wide coverage at the examination level, whereas the United States tends to concentrate much more talent on each return included in the relatively small sample actually subjected to examination. That few administrations are likely

83 See note 76 supra.

84 See § 3.2 , Chaps. VII, XI, XV, XIX, and XXIII infra,

85 See note 25 supra. 
to be able to afford both is evidenced by the fact that even the United States is able to allocate to the automatic review function only enough personnel to review somewhat less than one million of the three and a half million returns annually examined, 86 despite an obvious chance for error in many of the other examined returns. The unreviewed category, consisting only of "agreed" adjustments to small returns, is examined by the administration's least talented technicians. Though the asserted deficiencies were agreed to by the affected taxpayers, 87 the fact they are even less knowledgeable obviously leaves room for mistakes, no doubt to the detriment of the affected taxpayers in many cases. Nevertheless, only a small sample of the adjustments to these returns are reviewed, and then only for quality-control purposes.

Far less costly in talented manpower than the automatic and fairly broad-ranging internal review program maintained in the United States is the non-automatic and selective type of arrangement used by most European countries. Examiners themselves are permitted to decide when they will request the technical advice of a higher, more able, and experienced official. 88 No doubt this practice does contribute to the prospect of uniform correctness at the examination level; however, the incidence of error is deterred in reality only if the examiner himself recognized the difficulty. Moreover, this arrangement can contribute little, if anything, to the maintenance of integrity.

\subsection{Jurisdictional screening function re administrative appeals}

For reasons previously noted, authority to compromise administratively a debatable issue of the type which, if litigated, a court would decide entirely for one side or the other, should be reserved to a relatively small but fairly decentralized cadre of able and experienced officials who understand and, therefore, can appraise properly the litigation hazards. 89

86 Typically, the number of reviewers on a district review staff will equal about 10 percent of the number of revenue agents (examiners) in the district's Field Audit Branch.

87 Small cases not agreed to at that level are reviewed.

$88 \mathrm{As}$ to legal issues deemed open to serious doubt, such countries would be well-advised to maintain a single centralized technical advice office at the national level, as described in Chapter II supra, and as is maintained in the United States. Reliance should be placed on local senior officials, however, if the examiner's doubt concerns a question of fact or mixed questions of law and fact of the type which must be decided entirely for one side or the other.

89 See \$3.5 supra, 
Moreover, where a dispute between an examiner and taxpayer involves to a significant degree an issue of this type, much time and effort will be saved by routing the whole case directly to a member of that cadre. 90

Their unique power and particular competence are not essential, however, to the proper resolution of many types of questions about which examiners and taxpayers will be in dispute. Illustrative are those issues involving a mere amount, such as the valuation of property. These fall within the competence of any fact finder. Again even as to a legal issue which a court would decide entirely for one side or the other, a given taxpayer may be unquestionably in the wrong though his particular examiner could not convince him of this. Nevertheless, there is nothing to compromise. In such cases as these, an official more experienced and able than the examiner, though lacking true compromise authority, frequently can persuade the taxpayer to accept a proper disposition of the matter. Because, proportionately, so many disputes will be of this type, they should be routed directly from the examiner to just such an official. Otherwise, either the more talented small cadre possessing complete compromise authority will become overloaded-though only because it receives cases not requiring special authority or competence-or that cadre must be expanded in size and, thus, include less experienced and talented officials. 91

The foregoing suggests that a country which contemplates empowering at least some officials with true compromise authority rnay well find, as did the United States, that its administrative appeal process can make effective use, whether a given appeai is formal or informal, of two different sets of

90 This is so whether the case raises either a single issue of this type or multiple issues of which only one or more of the significant ones are of this type. In the latter circumstance, since the one issue of this type cannot be accommodated properly by lower levels, both parties should reserve disposition of the other issues to facilitate a proper overall disposition.

91 In the United States, during fiscal year 1966, this cadre (regional Appellate Divisions, consisting of 717 technically trained conferees) obtained agreements in 27,428 cases. Tremendous expansion would have been required had not a lower administrative appeal office (District Conference Offices, staffed with about half as many technically trained conferees) reached an agreed result in another 25,231 cases which usually were less complex and did not require "settlement" authority. See Commissioner of Internal Revenue, op. cit. supra note 25, at 25, 68,133 , and 134 . 
officials, with only the higher ranking set, in contrast to the less restrictive practice in France and the Netherlands, 92 exercising true compromise authority.

While United States practice has long employed these two levels of officials, ${ }^{93}$ at one time all U.S. taxpayers who disagreed with their examiners were systematically encouraged, though not compelled, to take the dispute, first, to the lower ranking appeal office (District Conference Office) which lacked true compromise authority. ${ }^{94}$ However, where the case which went through this lower office involved at least one significant debatable issue of the type a court would have decided entirely for one side or the other, substantial duplication of administrative and taxpayer effort took place. True, in many of these cases the lower ranking appeal official did help sharpen the issues. But this gain did not offset the cost of an ensuing wasteful and predictable duplication. For it was inevitable, in view of the lower appeal office's lack of compromise authority, that a substantial proportion of its adverse decisions would be

92 There, in practice, the inspector who heads the local office, as well as officials at the regional level, may exercise such authority. See infra Chap. XI, §§ $3.2 \mathrm{a}$ and $3.4 \mathrm{~b}$, and Chap. XXIII, $\S 3.2 \mathrm{a}$ and 3.4a. However, in the Netherlands the inspector in charge of each local office does understand, and presumably can appraise properly, the litigation hazards, for he has at least the equivalent of a law degree and performs the representation function at the trial level if litigation ensues. In France the law degree possessed by each inspector and the two years of intensive training at the National School for Taxes likewise gives him a basis with which to appraise litigation hazards. All French inspectors, however, do not perform the representation function at the trial level. To represent the government in litigation before an administrative tribunal, an inspector must be located in one of the cities where an administrative tribunal sits. No inspectors from outside such a city are brought in for this purpose. See $\S 1.5$ of Chaps. IX and XXI, and $\S 4.3$ in Chaps. XII and XXIV, infra.

93 In a realistic sense, however, as before noted, the United States actually has three sets of administrative appeal offices, for the legal staff which performs the litigation-representation function also shares authority administratively to compromise cases. See §3.1 supra, note 30 . This function is performed by Regional Counsel part of the Chief Counsel's Office) in Tax Court cases and by the Tax Division of the Justice Department in refund cases before federal district courts or the Court of Claims.

94 See \$3.2 supra regarding a reorganization completed in the early 1960 's, hopefully to discourage the tendency of some practitioners to bypass that office. 
appealed to the yet higher office (Regional Appellate Division) possessing that special authority.

Recently, the United States reversed this earlier practice. It now seeks to avoid predictable seriatum use of two officials to hear successive administrative appeals of the same case. To this end, distinctly different officials, who internally review the administrative file in all cases not agreed to at the examiner's level, perform the necessary screening function. They determine the type of office 95 to which the taxpayer should be encouraged 96 to take the dispute in the first instance. ${ }^{97}$ If a given taxpayer is urged, because of the nature of his dispute, to take it first to the District Conference Office, he still is able, if agreement is not achieved there, to invoke the jurisdiction of the higher administrative appeal office. 98

Other countries which do not provide for internal review of cases unagreed at the examiner level, but do propose to use two sets of appeal officials in the manner described above, can assign the screening function to the examiners themselves, imposing on them the responsibility to choose the type of official to whom the taxpayer should be encouraged to appeal initially.

95 If their initial determination is to the effect that the taxpayer should be encouraged to bypass the lower administrative appeal office, the Chief of the latter office does review that determination before the invitation letter goes out. U.S. Treas. Reg. $\S 601.105$ (c) (2) (iv).

96 This encouragement is reflected in a letter which advises the taxpayer that he has 30 days in which to enter the appeal. Rev. Proc. 64-38, C.B. 1964-2, 965, superseded by Rev. Proc. 67-27, I.R.B. 1967-20, 45. For an argument that a taxpayer, in his own interest, always should process the case first through the district procedure, see Carey, "Choosing Tax Procedures for Tactical Advantage," 40 Notre Dame Law. 363 (1965).

97 Even so, in fiscal 1966, of the 39,023 cases dealt with by the lower administrative appeal office because encouraged to go there first, 13,792 ended in disagreement and most of these then were appealed to the higher office. See Commissioner of Internal Revenue, op. cit. supra note 25 , at 25 .

98 Ibid. U.S. Treas. Reg. \$601.106(b). Indeed, that taxpayer could have disregarded the advice of the screening office and taken the dispute to the higher office in the first instance. The important point, however, is that no taxpayer should be denied the right to take his dispute, at some point, to an official possessing true compromise authorityassuming that there is such an official. The taxpayer, rather than the screening office, may be right in believing the dispute properly is compromisable though, to repeat, this can be done only by an official having the special authority. 
The use of two sets of appeal officials, with only the higher set being given complete settlement authority, may generate a peculiar burden for small cases. Many such cases do involve a debatable issue of the type a court necessarily would decide entirely for one side or the other. And in fairness, these small taxpayers should be granted the same measure of justice as large taxpayers. This includes, if equally available to large taxpayers, a convenient opportunity-test cases aside-to compromise truly debatable questions by reference to an impartial appraisal of the litigation hazards. Because there are so many disputes of this type, it may be necessary to give the lower ranking appeal officials, to whom complete compromise authority otherwise is denied, authority to compromise small cases, a ceiling limitation being fixed by reference to a given amount of tax in dispute. Indeed, fairness may render this essential if the higher ranking appeal officials to whom that special authority otherwise is reserved, are assigned, as in the United States, to the regional level and hold conferences only in widely separated metropolitan centers.99 Otherwise, small taxpayers may find it is against their economic selfinterest to hold a conference with the one set of officials to whom the government has reserved total settlement authority. While the United States, in disputes not involving more than $\$ 2,500$ in tax for any one year, recently extended true compromise authority to its lower ranking and more conveniently located set of appeal officials, this authority is limited to "selected issues," where the higher regional office previously had worked out a compromise covering a "substantially identical issue." 100

\subsection{Requiring written protests}

For reasons previously noted, ordinarily a country ought not require a taxpayer to submit at the administrative-hearing stage all evidence and arguments he later formally would submit if the dispute is taken to court.101 On the other hand, two considerations will render the administrative procedure grossly inefficient unless a taxpayer is required to submit an appropriate written document prior to the oral conference held with the appeal official.

99 These regional offices maintain only about forty geographically spread posts of duty in the United States and ride circuit to approximately twenty other metropolitan centers.

100 See Rev. Proc. 67-27, I.R.B. 1967-20, 45.

101 See \& 3.3 supra. 
The first consideration relates to the conferee himself. If he is not forewarned regarding the grounds of the taxpayer's objections and the rationale upoin which the latter relies, he is deprived of a chance, in advance, to read all the relevant legal data (decisions, regulations, rulings, etc.), and to think through their implications and the questions he should ask regarding both the legal and the factual sides of the controversy. Lacking such preparation, in too many cases the first conference will be only exploratory, and an otherwise unnecessary and wasteful second conference will be required to enable the parties to discuss the refinements of the matter at issue. This need for a second conference leads also to a frequently unrecognized waste in that the conferee, at the first conference, must prepare a more detailed record of the points developed there than otherwise would be necessary. Further, because he inevitably will deal with many other cases during the interim between the two conferences, he must take yet further time, before that second conference, just to re-orient himself with respect to the earlier exploratory discussion.

The second consideration relates to the taxpayer. If not required to submit a written document before the conference, he will tend to handle his side of the dispute less efficiently and thereby contribute directly to the official's own inefficiency. This is particularly true where a taxpayer brings in a practitioner for the first time at the point of the first administrative appeal. Under such circumstances-if no advance document is required-there is the great risk that the practitioner actually will use the first conference as his starting point, i.e., to orient himself regarding the nature of the controversy and the type of showing required if the conferee is to sustain his client's position.

In spite of these considerations, throughout most of the 1950 's, no advance written document was required by the United States in the case of those taxpayers who elected to appeal first to-and hold an oral conference with-the District Conference Office.102 Such a document ("protest") was required, however, of taxpayers who elected to bypass that office and appeal directly to the higher Regional Appellate Division, or

102 See e.g., Rev. Proc. 56-34, C.B. 1956-2, 1396, ultimately superseded by Rev. Proc. 67-27, I.R.B. 1967-20, 45. The objective of that procedure was to surround that conference arrangement with as few formalities as possible in the belief this would facilitate resolution of issues at the earliest possible moment. 
who appealed to the latter office after failing to achieve agreement with the district's appeal office. ${ }^{103}$ In 1964, the administration extended this requirement, with an exception noted below, to all appeals lodged initially with the district office. 104 Presumably it believed this would tend to force taxpayers and their representatives to become more fully informed before that first district office conference and simultaneously enable the officials at that level to accommodate more efficiently the thousands of appeals they received.

Exempted from this general requirement were cases falling in the so-called small category-i.e., where the disputed amount for any one year did not exceed $\$ 1,000.105$ In early 1967 this ceiling was revised upward-to $\$ 2,500^{106}$ - a revision which probably would have exempted more than half of the 42,381 cases those district offices received in the preceding fiscal year. 107

Such an exemption is unnecessary where, as in Germany and the Netherlands, 108 the taxpayer's document need do nothing more than protest the examiner's determination. No arguments in support of the protest need be set out. That type of document, however, does not achieve the purposes heretofore described.109 Contrariwise, if a country actually intends to enforce a more demanding and informative type of requirement, such as that now imposed in the United States, as a practical matter some small-case category, however defined, must be exempted. Small taxpayers would find it against their economic self-interest to incur the expense necessary if the U.S. requirement were imposed on them; it calls for a written statement outlining "the facts, law, and arguments upon which the taxpayer relies." 110

103 Ibid.

104 Rev. Proc. 64-38, C.B. 1964-2, 965.

105 Under the 1964 procedure, the immunity also automatically extended to so-called office-audit cases which, collectively, made up about 40 percent of the appeals to the District Conference Offices and typically involved substantially less than $\$ 1,000$.

106 Rev. Proc. 67-27, I.R.B. 1967-20, 45. The new dividing line $(\$ 2,500)$ apparently applies alike to office audit and the typically larger field-audit cases.

107 See Commissioner of Internal Revenue, op. cit. supra note 25, at 25 .

108 See $\$ 3.4 \mathrm{a}$, Chaps. XV and XXIII infra.

109 At most it merely alerts the office to the fact of appeal.

110 Rev. Proc. 67-27, I.R.B. 1967-20, 45. 


\section{CHAPTER IV}

\section{CONFLICT RESOLUTION BY INDEPENDENT TRIBUNALS ${ }^{1}$}

\section{Section A. Analytic Comparison: Judicial Structures of the "Six"}

\subsection{Introduction: The goals}

An administrator who examines returns cannot avoid taking some position on a given issue even though he may believe the truly "correct" substantive answer is open to substantial doubt. In consequence, errors inevitably will be made even by administrators who strive to be objective-and not all will or can be. And some such erroneous results inevitably will be adverse to the affected taxpayers, whether due to the laws of chance or to an administrative belief that the government's interest in cases deemed marginal should not be conceded since separate tribunals exist to resolve just such cases. However, whether any given administrative determination actually is erroneous cannot be known at that stage. The administrator may hold one view and the taxpayer another, but in essence both views are mere predictions regarding the result an independent tribunal would reach if the matter were litigated.

The only feasible method of ascertaining precisely which of the many administrative determinations actually are erroneous is to assure all taxpayers who disagree with the administration, either as to the facts or the law, that they then can submit the case to a tribunal which is completely impartial. This is the essence of "living under law." Moreover, escape valves of this type are the only means of assuring an equally essential byproduct. The mere existence of that type of tribunal provides the best possible guarantee that the administration itself, during the earlier administrative stage, at least will try to be fair in resolving conflicts.

This right of taxpayers, to invoke the jurisdiction of impartial tribunals, will be meaningful in practice, however, only

$1_{\text {For a recent }}$ comparative treatment of this subject in the setting of countries now developing, see Liker, "The Legal and Institutional Framework of Tax Administration in Developing Countries," 14 U.C.L.A.L. Rev. 240, 325-45 (1966). 
if structural arrangements enable the latter to provide convenient forums. Also, in the interest of the whole tax system, those arrangements should facilitate decisions of high quality and interpretations having fairly lasting effect. Finally, they should permit efficient fulfillment of all these criteria-thereby avoiding undue drain on the totality of a nation's resources and talented manpower.

Unfortunately, no structural arrangement can assure, though it can foster, impartiality on the part of a tribunal. Further, neither this impartiality nor decisions of high and durable quality can be promoted in the fullest sense if efficiency becomes so much an end in itself that man-hours expended per case must be held to the bare minimum, or if the forum must provide convenient access in an absolute sense. These competing criteria are in inherent conflict, and arrangements which tend to stress one tend to slight another. Consequently any given structural arrangement can hope only to achieve some reasonable balance among these competing interests. Because this presents a problem of degree, it is not surprising that, among the six countries covered by this study, differences exist regarding the relative emphasis placed on each of these criteria. Reflections of these differences appear throughout the judicial structures: in the appointing procedures; in the types of persons who fulfill the decision-making function at the trial and appellate levels; in the extent decisions are made not by single persons but instead-as to the law, facts, or both-by a deliberative body; in the scope of review at the appellate level; in the arrangements which affect uniformity and certainty, including the role of precedent; and finally in the degree convenient access is accorded both small and large taxpayers.

\subsection{Trial tribunals: Impartiality and the relevance of a spe- cialized bench's perspectives}

Looking solely at the standard of impartiality, tradition in any one of these countries actually may compensate for particular excessive deficiencies in its structural arrangements. But these structural shortcomings should be shunned by other countries, for the structure, on transplant, will not be accompanied automatically by the compensating tradition. Further, a mere image of impartiality, whatever be the fact, in itself is important to taxpayer morale, and structural deficiencies 
can impair that image. ${ }^{2}$ For both these reasons, countries now evolving or reconsidering their structural arrangements should adopt plans which at a minimum tend to preclude the tax administration itself from having any control over the appointment, tenure, or future promotions of those named to such tribunals. Other methods of appointment, less likely to impinge on the tribunal's impartiality, are numerous, too obvious to recite, and have been invoked by four of the six countries covered here. ${ }^{3}$ And as to a fifth, though Britain's Treasury does make the appointments to one of that country's two primary trial level tax tribunals, 4 the Lord Chancellor (Minister of Justice) controls appointments to the other. 5 Only in Germany do finance officials appoint all of the technically trained trial judges who sit on tax cases. 6

Bias does not spring, however, solely from self-interest. The sum of a prospective appointee's past experiences inescapably affects the perspective he brings to such a tribunal and, consequently, his attitude toward the interpretative process. Thus, it could be argued, to the extent professionals are used, that individuals who have devoted their lives almost exclusively to the tax administration itself should be rendered ineligible for appointment to the separate trial tribunals. But this

2 Indeed, proponents of a bill to shift the otherwise independent U.S. Tax Court from the executive branch to the judicial branch rely upon the above argument as one reason justifying the change. See remarks of Senator Long, 113 Cong. Rec. S9035 (daily ed. June 28, 1967). Also, Gribbon, "Should the Judicial Character of the Tax Court Be Recognized?" 24 Geo. Wash. L. Rev. 619, 626 (1956).

3 In Belgium, where the courts of appeal sit as trial forums in tax cases, the King makes the appointment from two lists of nominees submitted respectively by the courts of appeal themselves and by the conseillers provinciaux. See Belgium Constitution, Art. 99. In France, most judges on its trial tribunals are drawn from the civil service. See Chap. XII, §4.2 infra. As to the Netherlands, see Chap. XXIV, $\S 4.2$ infra. The U.S. Declaration of Independence criticized King George III because he had "made Judges dependent on his will alone, for the tenure of their offices, and the amount and payment of their salaries." Not surprisingly, therefore, while the President appoints the judges on all U.S. trial forums, the nominations must be approved by the Senate. See U.S. Constitution Art. II, §2.

4 See Chap. XX, \$4.2b infra.

5 Except in Scotland, where a city or county council makes the appointment. See Chap. XX, §4.2a infra.

${ }^{6}$ See Chap. XVI, §4.2 infra. Finance officials there also exercise a veto over possible promotion of these same judges to the appellate fiscal court. Id. \$4.4 infra. 
argument, if valid, cuts two ways, for there are two parties to every tax controversy. Thus, a reasonable application of the same standard would render ineligible any professional who consistently had opposed the administration, always having represented taxpayers. And in practice, as to a given country, the two prohibitions together could preclude appointment of any professional possessed of tax expertise, thereby rendering the tribunals less efficient and in the view of some-given the complexities of tax law-less capable of handing down high quality decisions. Certain critics take issue on this latter count; indeed, believing that specialization makes it more difficult to maintain an "impartial" perspective and to reach decisions of "proper" quality, they also oppose granting exclusive jurisdiction over tax affairs to specialized tribunals. ${ }^{7}$ Otherwise, so one argument goes, the professionals appointed, whatever be their backgrounds, will become too far removed from the general law, will become overly devoted to the tax code itself and to its perfection, and-for judges-will become too zealous in trying, through the interpretative process, to give the whole code a somewhat more symmetrical impact by reference to the substance of transactions than the legislatively inspired language of the code's diverse parts deserve, usually to the advantage of the tax administration.

It is one thing to contend, as do these critics, that professionals on a specialized tribunal, if not otherwise restrained, ultimately would tend to go too far in this particular direction. It is quite another to acknowledge that these professionals would have the opportunity, in contrast to those on courts of general jurisdiction, to develop a more complete understanding and a deeper "concern" for the total implications of the tax code. In consequence, professionals on specialized tribunals, as a group but not necessarily so in any single instance,

7 See Sutherland, "New Roads to the Settlement of Tax Controversies: A Critical Comment," 7 Law \& Contemp. Prob. 359 (1940); Angell, "Procedural Reform in the Judicial Review of Controversies Under the Internal Revenue Statutes: An Answer to a Proposal, " 34 Ill. L. Rev. 151 (1939); Prettyman, "A Comment on the Traynor Plan for Revision of Federal Tax Procedures," 27 Geo. L.cJ. 1038 (1939). That the ultimate objective of the Hoover Commission Report was to prevent this, see Guy, "An Administrative Labor Court: Some Observations of the Hoover Commission Report," 24 Geo. Wash. L. Rev. 656, 666 (1956). Also in general, see Rifkind, "A Special Court for Patent Litigation: The Danger of a Specialized Judiciary," 37 A.B.A.J. 425 (1951). 
should be more inclined than judges on the other type of tribunal to interpret the diverse substantive provisions of the code to achieve results responsive-from a policy standpointto the multiple but often competing purposes of the whole code and, to that end, be more inclined to consider the substance of transactions, not just their mere legal form.

These modest projections do not indicate that professionals on specialized tribunals are likely to go too far, or conversely not far enough, in this direction. They indicate only a mere "probability," not otherwise measurable on any count, that as between the two types of tribunals, specialized types at least will tend to go somewhat further in that direction. As so defined, this "probability" should be viewed by a legislature as one of the positive factors supporting assignment of some significant tax role to a professionally staffed specialized trial tribunal.

Relevant to the positive quality of this one factor is the awesome function of a tax code. These codes, alone among all public laws, must respond, one way or another, to almost the whole factual terrain covered by the entire private law. Given this all encompassing quality and the inherent limitations of the legislative process, a legislature's own substantive efforts all too often will fall far short of achieving equity in a timely fashion if the interpretative machinery, because lacking in tax expertise, does not have the capacity, in individual cases, to take account of the multiple but often competing purposes of the whole tax code and, in consequence, gives scant attention to the substance of transactions. Avoidance of this latter consequence should be of real concern to the legislature itself, for taxation is peculiarly and essentially a legislative function. Unfortunately, however, apart from careful use of substantive language, there is only one practical way in which a legislature can attack that consequence, namely, by assigning some significant role to a professionally staffed special tribunal.

A further alternative does exist but only in theory. The legislature could try to complement its substantive language by indicating, as has been done in legislation much more limited in thrust, 8 its own expectations regarding the standards of judicial construction to be applied. But it would be extremely

8 E.g., New York, Alternative County Government Law, §700, and Private Housing Finance Law, $\$ 600$. 
unwise to undertake such a delineation of standards in the setting of a comprehensive tax code. ${ }^{9}$ Such a code contains countless competing substantive ideas. No one standard of construction could suffice. To help sharpen understanding regarding the relative vitalities of each single competing idea, the legislature would have to indicate the particular standard to be applied in each single instance. The resulting product would be appallingly cumbersome. Further, the legislature's human inability to anticipate the shape of countless factual situations means, to this extent, that however carefully it sought, by enacting standards of construction, to clarify the relative vitality of its competing tax ideas, it actually would be trying to respond to the unknown. Finally, since the weight which the legislature might want to attach to substance will vary depending upon the competing tax ideas in issue, the imprecision of the type of language associated with standards of construction suggests that appropriate substantive language actually could define the legislature ${ }^{\gamma} s$ intention more precisely, though not so precisely as to eliminate the need for technically competent, concerned, and efficient interpretative machinery.

Whether or not the countries covered by this study actually looked upon the above discussed "probability" as a positive factor, each one in fact has chosen, at least at the trial level, to make some use of the potentially greater competence, concern, and efficiency of a specialized or semi-specialized tribunal, composed entirely or predominantly of persons having some type of professional training or experience. Britain has its Special Commissioners, 10 Germany its fiscal courts, 11 and the United States its Tax Court.12 Belgium13 and the Netherlands ${ }^{14}$ differ only slightly; they use specialized chambers in their regular courts of appeal as trial forums. And France

9 As to the utility of canons of construction generally, $c f$. Frankfurter, "Some Reflections on the Reading of Statutes," 47 Colum. L. Rev. 527,544 (1947) with Jackson, "The Memory of Statutes: What Congress Says or What the Court Says," 34 A.B.A.J. 535 (1948).

10 See Chap. XX, §4.2b infra.

11 See Chap. XVI, $\$ 4.2$ infra.

12 I.R.C., \$\$7441-87. Of the three different types of trial forums used by the United States, a second-the Court of Claims-should be put in the semi-specialized category. About one-third of its docket concerns federal tax cases. See Kipps, "A Unique National Court: The United States Court of Claims," 53 A.B.A.J. 1025, 1026 (1967).

13 See Chap. VIII, §4.2 infra.

14 See Chap. XXIV, § 4.2 infra. 
assigns to special administrative tribunals three types of actions to which the government is a party; included are fiscal cases. 15

Relevant also to the perspectives of these tribunals are differences in the backgrounds of their more or less permanent personnel. In contrast to Belgium, Germany, and the United States, not all of Britain's eight Special Commissioners possess legal training. 16 The latter are drawn in roughly equal proportions from practising barristers and from non-legally trained but senior Inland Revenue officials who on appointment sever their connections with the administration.17 As to this matter of prior association with the tax administration, both the Netherlands and the United States tend to maintain a somewhat similar balance on their specialized tribunals. About half the sixteen legally trained persons on the U.S. Tax Court usually will have had some prior connection with the tax administration's legal staff, oftentimes in addition to outside experience as a practitioner. In the Netherlands, of the three judges who serve each of the specialized tax chambers, typically one previously served as a tax inspector, another first gained tax expertise on the outside, and the third served as a jurist on a yet lower nonspecialized tribunal.18 No such balance exists, however, in Germany or France. These two illustrate the competing extremes. All permanent German appointees, though legally trained, are drawn from the various state finance ministries from which they too sever their connection. 19 French administrative tribunals, on the other hand, include no counseillors who possessed tax expertise at the time of appointment. The great majority, however, will have received legal training. This follows because most appointments are made from graduates of the National School of Administration, and only a relatively small minority of these did not obtain a law degree before being admitted to that school. Moreover, while nongraduates of that school who are appointed to the administrative tribunals must have a law degree, in the interest of impartiality and independence these are drawn

15 See Chap. XII, §4.1 infra.

16 That the Netherlands' departure from this requirement is temporary, see Chap. XXIV, §4.2 infra.

17 See note 10 supra.

18 See note 14 supra.

19 See note 6 supra. 
from the Ministries of Interior or Justice, not from the tax administration. ${ }^{20}$

\subsection{Trial tribunals: Other factors relevant to the goals}

The potentially greater technical competence, concern, and efficiency of specialized tribunals are not the only considerations to which a nation properly might accord weight in deciding whether, how, or the degree to which it will utilize such tribunals.

Involved also is the matter of convenience and factors which compete with it. A practical dilemma may arise. If such a tribunal is available to the more complex and larger cases, where geographical convenience is a relatively minor problem, equitably speaking it should be equally available in fact to the host of smaller cases certain to arise, where geographical convenience is a major problem. However, such a wholesale requirement of convenience, with the consequent expense and drain on a nation's reservoir of able professionals, may present insurmountable difficulties to some countries, particularly those now developing. A professionally staffed specialized trial tribunal, nevertheless, is relevant to the needs of a small case-though admittedly the peculiar nature of such a tribunal's contribution in this circumstance does differ from that associated with complex cases. In the setting of a small case, the tribunal itself should assume the duty of assuring a fair deal for the taxpayer. In all cases, the government itself will be represented by a person expert in tax affairs. In a small case, however, the taxpayer simply cannot afford that type of representation. The consequent unreliability of the adversary system to promote justice in this circumstance requires that the tribunal be sufficiently expert to assist the taxpayer in presenting his case effectively and efficiently. ${ }^{21}$ For a government not to accommodate this need is peculiarly unbecoming in tax cases, for the government itself always is a party and, as before noted, typically is well represented. To grant small taxpayers access to such a tribunal will have little practical meaning, however, if they are required to travel a substantial distance to have their cases heard. In the absence

20 See Chap. XII, 44.2 n. 6 infra.

21 This consideration, while relevant here and actually responsible for introduction of a bill in the U.S. Senate to establish a Small Tax Division within the U.S. Tax Court, relates primarily to practices and procedures and is, therefore, dealt with more fully in \$4.9 infra. 
of geographical convenience, the small taxpayer, previously having taken time away from his job to process the case through the administrative stage, may find it is against his economic self-interest to spend additional time on the road.

The expense and drain in providing genuinely convenient access to a specialized tribunal will be multiplied further if, pursuant to the otherwise justified belief that a deliberative body provides the best means of reaching decisions of proper quality, a given country also prefers to use more than one judge in each case be it large or small.

Of concern also is the type of person who should be empowered to find the facts and the related question of whether the deliberative process should be extended to this function. Some believe, relevant to this, that there is an important difference between a full-time tax-case jurist and a judge who sits on a court of general jurisdiction where tax cases constitute only a small part of the docket. The full-time tax jurist, so the argument goes, is more likely, because he will more frequently encounter somewhat similar fact patterns, to develop preconceptions about these and, in consequence, more frequently will prejudge the facts of a particular case. 22 Some also argue that even judges on courts of general jurisdiction tend, on hearing case after case, year after year, to become somewhat bored and thus less attentive than persons who hear only a few cases and for whom each such case is an interesting new venture. These two suppositions argue for ad hoc infusion of ordinary laymen into the fact finding process. 23 This position gains further support if the comparison is between a panel of lay fact finders and a single judge who alone would decide questions both of fact and law. The panel arrangement itself creates the additional prospect, at least as to the fact finding process, that preconceptions of one man will tend to be neutralized through the interchange arising from the panel's deliberative process. 24 Further, a panel of laymen, if at all representative of the community, may be more sensitive than any judge or panel of judges to the community's sense of what is reasonable, 25 and factual controversies in tax casesas in other cases-often turn on just that. Further, from any

22 See Joiner, Civil Justice and the Jury 66 (1962).

23 An empirically based analysis of the American jury appears in Kalven \& Zeisel, The American Jury (1966).

24 See Joiner, op. cit. supra note 22 , at 66 .

25 See $i d$. at 65 . 
such division of power between judges and laymen emerges a system of checks and balances which alone may inspire taxpayer confidence in the fairness of the system. 26

Finally, a given legislature, though impressed by the potentially greater technical competence and concern of a specialized tribunal, may fear, as do the previously mentioned critics, that such a tribunal, absent some checkrein, might become too far removed from the general law and indulge "too much" in what some call judicial legislation. And this fear of the unknown may lead that legislature to cast about for suitable restraints, to be applied at either the trial or appellate levels or at both.

Each of the countries dealt with here, while making some use of a specialized or semi-specialized trial tribunal staffed entirely or predominantly with persons of professional training or experience, has responded also, though in diverse ways and degrees, to most of the additional considerations recited above.

Presumably to assure convenient access with a minimum of taxpayer travel, four of the Six (Belgium, France, Germany, and the Netherlands) have decentralized their specialized trial tribunals. 27 The Netherlands located these courts in five different cities, Belgium in three, France in twenty-four, and Germany in fifteen. ${ }^{28}$ Each court in the Netherlands, on the average, accommodates 2,570 square miles which, if the court were located in the center of that hypothetical square, would place it only twenty-six miles from taxpayers residing in the remote corners of the square. The comparable number of miles in Belgium would be forty-five, in Germany fifty-seven, and in France sixty-seven. In contrast to this decentralized approach, Special Commissioners in Great Britain 29 and judges who sit on the U.S. Tax Court are centrally located, but mitigate the taxpayer's travel burden by riding circuit. The U.S. court has the more serious problem, for the territory it must

26 See $i d$. at 64 and 67; Angell, op. cit. supra note 7, at 154. For conflicting views regarding the use of the jury system in tax cases, compare Walston, "The Use of Juries in Federal Civil Income Tax Cases," 39 Taxes 144 (1961) with Glaser, "Taxation-Is the Taxpayer Neglecting the Jury?" 28 U. Cinc. L. Rev. 352 (1959). In general, see Ferguson, "Jurisdictional Problems in Federal Tax Controversies," 48 Ia. L. Rev. 312 (1963).

27 For consideration of convenience as affected by procedural requirements and use of counsel, see $\$ \S 4.9$ and 4.10 infra.

28 See $\$ 4.2$, Chaps. XXIV, VIII, XII, and XVI infra.

29 See Chap. XX, §4.2b infra. 
cover is fifteen times as great as the entire territory of the largest of the Western European countries. Further, because it holds hearings in only fifty cities, 30 geographically speaking it is a substantially less convenient forum than any of its European counterparts. 31

The United States taxpayer, however, is not limited to the Tax Court. Two other alternative types of trial forum are provided, one of which is highly accessible. In fact, this country, compared to the other five, offers taxpayers the widest choice of forums from among the most varied types of trial tribunals. Their differences go beyond ordinary procedures 32 to include important structural differences which affect much more than mere convenience of access. These structural differences run the gamut, for they evidence extreme forms of both specialization and reliance on the deliberative process.

The Tax Court is the most specialized of these tribunals; there typically one judge alone decides questions both of fact and law. However, about one-third of the officially published decisions, because they involve peculiarly important or marginal questions of law, are subjected to the deliberative process through internal review by the whole court. But this practice is triggered internally, usually on order of the Chief Judge, 33 not upon request by the taxpayer.

A geographically more convenient hearing is available to the U.S. taxpayer if he elects to utilize a regular federal district court of general jurisdiction 34 where his case will be tried before a single nonspecialized legally trained judge. These courts are spread across the country and sit in over three hundred and eighty cities, seven times the number visited

30 See Appendix to Tax Court Rules, implementing the broad directive in I.R.C. $\$ 7446$.

31 The figure for this court, comparable to those cited above regarding other countries, is 192 miles.

32 As to these, see Ferguson, op. cit. supra note 26, and Brown \& Whitmire, "Forum Reform: Tax Litigation," 35 U. Cinc.L.Rev. 644 (1966). Also see $\S 4.10$ infra.

33 Pursuant to I.R.C. $\$ 7460(\mathrm{~b})$. Internal practices of this court are considered in articles by three of its judges. See Kern, "The Process of Decision in the United States Tax Court," 8 N.Y.U. Inst. on Fed. Tax. 1013 (1950); Murdock, "What Has the Tax Court of the United States Been Doing?" 31 A.B.A.J. 297 (1945); Raum, "Tax Court Litigation," 1957 So. Calif. Tax Inst. 631.

3428 U.S.C. $\$ 1346,1491$, and I.R.C. $\$ 7402(a)$. For a summary of all the features peculiar to these courts, see Brown \& Whitmire, op. cit. supra note 32; Ferguson, op. cit. supra note 26. 
by the Tax Court. 35 Peculiar to this election is the complementary right of either party to have the facts found by a deliberative body, a jury of laymen impanelled on an ad hoc basis for this purpose. To invoke the jurisdiction of a district court, however, the taxpayer suffers an encumbrance-oftentimes at very great inconvenience-not encountered in litigation before the Tax Court. 36 He must pay the asserted deficiency in advance, for a tax can be challenged in a district court only through a suit for refund. 37

By invoking a yet third alternative, which again is available only if payment is made in advance, a U.S. taxpayer can be sure that questions of law also will be decided by a deliberative body-the multijudge Court of Claims. ${ }^{38}$ This is a semi-specialized tribunal. Despite the sweep of its jurisdiction-covering any claim running against the United States except those founded on tort-it has developed considerable tax expertise if only because a significant part of its docket (34 percent in one recent year) concerns federal tax questions. 39 One of fifteen legally trained, circuit-riding commissioners 40 will make preliminary findings of fact and submit recommendations regarding the legal questions. The actual decision, however, will be rendered by legally trained judges of whom there are seven, concurrence by four being required in cases where the court sits en banc, though recent legislation permits it to sit in divisions composed of two or three judges. 41

35 Register, Department of Justice and the Courts of the United States 21-111 (1966).

36 The latter court acquires jurisdiction after a deficiency has been proposed, but prior to assessment, provided the taxpayer files a petition with the court within 90 days after receiving a formal notice of deficiency. I.R.C. $\$ \S 6212$ and 6213. In general, therefore, it has no jurisdiction over refund suits.

37 Flora v. U.S., 357 U.S. 63 (1958), aff'd on reh., 362 U.S. 145 (1960).

3828 U.S.C. §1491. For a survey of features peculiar to this court, see Kipps, op. cit. supra note 12; Miller, "Tax Litigation in the Court of Claims," 55 Geo. L.J. 454 (1966); Ferguson, op. cit. supra note 26; Pavenstedt, "The United States Court of Claims as a Forum for Tax Cases," 15 Tax L. Rev. 1201 (1959, 1960).

39 Kipps, op. cit. supra note 12 , at $\mathrm{n} .10$.

40 Even so, the bar in Washington, D.C., where the judges sit, tends to dominate litigation before this court. See Pavenstedt, op. cit. supra note 38 , at 12 .

4128 U.S.C. $\$ 175(\mathrm{~d})$ and (e). Many practitioners before that court are urging it to continue to sit en banc. Kipps, op. cit. supra note 12, at 1025 n. 5 . 
That the specialized Tax Court's jurisdiction is shared both with the semi-specialized multijudge Court of Claims, and with the regular nonspecialized single-judge district courts where a deliberative body of laymen may be invoked to find the facts, inevitably gives rise to forum shopping. This practice is further stimulated by other differences in their ordinary procedures 42 and also by the subsequently discussed absence, for all practical purposes, of a common or centralized court of appeal.43 And from this forum-shopping opportunity, certain unfortunate effects, examined later in $\$ 4.6$, admittedly do follow. As noted there, however, it is the absence of a common court of appeal, not the opportunity to choose from among different types of trial tribunals, that is the pivotal defect. No one trial judge or jury (or set of such) can hear every case. Therefore, except for the difficulty noted at the appellate level, spreading litigation through these different types of trial tribunals, instead of forcing resort to a common type, has great merit. By offering Americans a choice (subject to the unfortunate previously noted encumbrance regarding prior payment) from among all of what many deem to be really meaningful alternatives, this structure has the advantage of building confidence in the system. Further, this trial-level structure enables the tax system itself to benefit from the potentially greater technical competence, concern, and efficiency of a specialized tribunal, while incorporating also what some view to be the first of two worthwhile restraints 44 on that tribunal of specialists. At least the proponents of this view argue that the Tax Court's own awareness of the right of taxpayers to choose other forums tends to place a subtle and meaningful, though quite unmeasurable, restraint on that tribunal. 45 Whether this be an actual restraint or simply a

42 As to these, see Ferguson, op. cit. supra note 26, and Brown \& Whitmire, op. cit. supra note 32 . Also see $\$ 4.10$ infra.

43 See $\$ 4.6$ infra.

44 The second is at the appellate level and relates to the fact that the judges there are generalists. See $\$ 4.5$ infra.

45 See Sutherland, op. cit. supra note 7 , at 360 . For a conflicting view, to the effect that only specialized tribunals should be used at the trial level, the one restraint being that "judges of general outlook" should sit on appeal, see Miller, "Can Tax Appeals Be Centralized?" 23 Taxes 303, 306 (1945). To the effect that both should be specialized, see Traynor, "Administrative and Judicial Procedure for Federal Income, Estate, and Gift Taxes-A Criticism and a Proposal," 38 Colum.L.Rev. 1393 (1938). To the effect that the present choice of forum should be left intact at the trial level, with appeals from all 
belief of taxpayers, the fact is-given this structure with its alternative choices-a large proportion of litigants do choose the specialized tribunal. It decides over one and a half times as many substantive tax cases as all the other trial tribunals combined. ${ }^{46}$ This might suggest that taxpayers have a relatively high degree of confidence in that one tribunal. Their choice, of it, however, may be due in part to their opportunity, peculiar to that one court, to litigate before paying the amount in contest. And to this must be added the fact that taxpayers now know also, should they lose, that they can appeal as a matter of right to nonspecialized appellate courts. 47

Both of these latter considerations, however, are presently under attack. An important group of American practitioners believe it is unfair to confine the litigate-first-pay-later privilege to those taxpayers willing to submit their cases to this specialized body. This group favors extending the same privilege to those taxpayers who prefer to try their cases before generalists who sit on the federal district courts. ${ }^{48}$ Yet

\section{(footnote continued)}

three to go to a specialized Court of Tax Appeals, see Griswold, "The Need for a Court of Tax Appeals," 57 Harv. L. Rev. 1153 (1944). Each of these writers is aware that a decision as to whether the appellate function should be centralized in a specialized court, or left to judges with a "generalist's outlook," involves much more than the question of whether the latter is needed as a restraint on lower specialized trial tribunals. As observed in the discussion of appellate tribunals in $\$ 4.6$ infra, central to the issue is the problem of obtaining reliable interpretative guidelines having uniform significance across the nation. In general, see Ferguson, op. cit. supra note 26.

46 In fiscal 1966, for example, the Tax Court decided 726 cases on the merits, the district courts 448 , and the Court of Claims 58. See Commissioner of Internal Revenue, Annual Report 1966, 134 (Table 17B) and 135 (Table 20 n. 1).

47 In the same year in which the Tax Court decided 726 cases on the merits, of which the government won outright or in part a substantial majority, taxpayers alone filed appeals in 257 and were joined by the government in appealing another 34 cases, a total of 291 . The government alone initiated only 41 appeals. However, of all the tax cases originating with the Tax Court and finally decided on appeal in that year (total, 250), taxpayers prevailed entirely or in part in only 47, or in 18.8\%. See Commissioner of Internal Revenue, op. cit. supra note 46, at 44,134 (Table 17B), and 135 (Tables 19 and 21).

48 Proposal of the Committee on Court Procedure, Taxation Section, American Bar Association. See Program and Committee Reports, Twenty-Third Annual Meeting, Taxation Section, A.B.A., at 55 (1962). For competing views, see articles by Miller and by Traynor, op, cit. supra note 45. 
others have proposed that appellate jurisdiction be shifted from courts having general jurisdiction to a specialized court of tax appeals, 49 a matter dealt with more fully in $\$ \$ 4.5$ and 4.6 infra. Be that as it may, given the large number of American taxpayers, the aggregate number of substantive tax cases actually decided by all three types of trial tribunals is relatively-and in absolute terms is among-the smallest of the six countries. In no recent year has the total reached 1,300 cases. 50

Britain's volume of decided cases at the trial level is at the other extreme, on the high side-with the caseload being from 8,000 to 9,000 a year.51 It is, however, the only other country among the Six which provides even a limited choice of forum. Given the heavy caseload, not surprisingly most decided cases involve relatively small amounts and concern Britain's standard income tax, not its surtax. To provide convenient access for this large volume of small cases, Britain maintains 700 different geographically dispersed sets of General Commissioners.52 This far exceeds, of course, the number of tribunals maintained by any one of the other five countries. Necessarily it involves a substantial sacrifice in professional quality. Indeed, two unpaid laymen, domiciled in the local finance district in which the taxpayer lives, constitute a deliberative quorum for any given case, though frequently more than two sit and a paid clerk-often legally trained-is always there to assist.53 Given their background, they obviously are not well equipped to resolve questions of law, 54 as occasionally they must. However, the great preponderence of these small cases actually turn on questions of fact and to this extent the use of such personnel is as commendable, or at least can be as easily defended, as the American jury.

For the typically larger and more complex surtax cases, the British Parliament created the earlier mentioned circuit-

49 See articles by Traynor and Griswold, op. cit. supra note 26 .

50 For example, see text accompanying note 121 infra. $4.3 \mathrm{~b}$.

51 Excluding so-called "delay" cases. See Chap. XX, §§4.3a and

52 For a full description of these tribunals, see Chap. XX, $\S 4_{1} .1$, $4.2 \mathrm{a}-\mathrm{d}$, and $4.3 \mathrm{a}$.

53 See $i d ., \S 4.2 \mathrm{a}$.

54 The writer's belief that every practice has its exceptions was borne out here when he learned by mere happenstance that one of the world's great lawyers, Professor Otto Kahn-Freund, serves as a lay Commissioner for the district which includes Oxford University. 
riding, professionally trained or experienced Special Commissioners. 55 While these Special Commissioners alone exercise exclusive jurisdiction over surtax cases, 56 a quorum of two again being a minimum for each case, 57 this is not their sole responsibility. They share with the lay General Commissioners concurrent jurisdiction over a fairly wide range of income tax questions. ${ }^{58}$ In this respect, the British taxpayer enjoys a privilege similar to that of an American: he may elect between alternative types of trial tribunals. 59 This right in Britain to choose between generalists and specialists is not burdened, however, as it is in the United States, by any encumbrance: in neither case need the British taxpayer pay the disputed amount in advance of the tribunal's determination. 60 Also in contrast to U.S. practice, far more cases are taken to the generalists than to the specialists. Out of the total large volume of tax cases decided annually by British trial tribunals, 8,000 to 9,000 , the Special Commissioners decide less than $1,000.61$

Presumably, therefore, taxpayer willingness to resort to the General Commissioners has not been affected adversely by the fact that every such election alerts at least two ordinary locally domiciled citizens to that taxpayer's financial affairs. The community at large is not alerted, however; rules prohibiting administrative disclosure of a taxpayer's financial affairs extend both to the General and Special Commissioners. 62 It is otherwise in the United States: the findings of fact and decisions of all its trial tribunals are published.

Germany's experience with disclosure of private financial affairs, even to a small group of local private citizens, appears to differ from Britain's. Until recently, a German taxpayer had an election somewhat similar to that existing in Britain. As he now can, he could have his protest heard first by local assessing officials ${ }^{63}$ and, if dissatisfied, could appeal de novo

55 For a full description, see $i d$., $\$ \S 4.1,4.2 \mathrm{~b}$, and 4.3b.

56 See id., \$4.1 infra.

57 See id., $\$ 4.2 \mathrm{~b}$ infra.

58 See $i d ., \S 4.1$.

59 For a description of two other types of trial tribunals (Board of Referees and the 1960 Act Tribunal), the jurisdiction of which is very narrow, see id, $\$ \S 4.2 \mathrm{c}, 4.2 \mathrm{~d}, 4.3 \mathrm{c}$, and $4.3 \mathrm{~d}$ infra.

60 See $i d$., §§ $4.3 \mathrm{a}$ and $4.3 \mathrm{~b}$.

61 Excluding delay cases. See id., §4.3b infra.

62 See $i d ., \S \S 4.3 \mathrm{a}$ and $4.3 \mathrm{~b}$ infra.

63 See Chap. XV, § $3.4 \mathrm{a}$ infra. 
to one of the specialized fiscal courts. ${ }^{64}$ Alternatively, instead of having the protest heard by a local assessing official, he could have had the dispute referred to a tax committee composed predominantly of private citizens drawn from the local finance office's district. While the local assessor served as chairman, the presence of at least two private citizens was required to constitute a quorum, and all members voted on questions both of fact and law. ${ }^{65}$ Should the taxpayer have been dissatisfied with the result reached by the tax committee, he still could have appealed de novo to the appropriate fiscal court. 66

Proportionately, only about one percent of those German taxpayers who filed protests elected to have their disputes heard first by the appropriate lay committee;67 the remainder chose local assessing officials. Apparently it was not enough, in the eyes of German taxpayers, that the rule of secrecy at the administrative level extended, like the British rule, to these lay bodies. 68 And because jurisdiction of the latter was invoked by so few taxpayers, Germany recently ceased using these committees in the conflict resolution process. 69 Lay citizens nevertheless, do continue to play a role, albeit reduced, in resolving tax conflicts.

Laymen involved now, however, typically are less likely to reside close to the taxpayer. They are drawn from a previously selected panel to sit on the fifteen fiscal courts, although no one citizen will sit for more than twelve days in any given year. 70 In contrast to the U.S. jury, these laymen help decide questions of law as well as of fact, constituting two of a deliberative quorum of five, the other three being legally trained with specialized experience-having been appointed from the state's finance ministry from which they then severed connection. ${ }^{71}$ As before noted, these fiscal courts are spread geographically, being divided among and maintained by the individual German states. Because of different case-load levels,

64 See Chap. XVI, $\$ 4.2$ and 4.3 infra.

65 See Chap. XV, § $3.4 \mathrm{a}$ n. 23 infra.

66 See ibid.

67 See id., \$3.4a infra.

68 See $i b i d$.

69 See $i d ., \$ 3.4 \mathrm{a}$ n. 24.

70 For a full description of these courts, see Chap. XVI, $\$ 4.2$ and 4.3 infra.

71 Until recently, the ratio was reversed, with lay members making up a majority. See Chap. XVI, §4.2 n. 6 infra. 
the courts themselves range in size. Each has two to eight Senates, the respective jurisdictions of which are fixed by various criteria, including geography as well as types or subjects of tax. These courts decide a volume of income cases far exceeding their counterparts in the United States, the number being almost equal to the total decided in Britain. Their yearly work-load of 20,000 tax disputes of all types includes from 6,000 to 8,000 involving individual and corporate income tax matters. 72

Belgium, France, and the Netherlands are similar to Germany in one respect: in the litigation stage, the taxpayer is not given a choice between different types of tribunals. These three countries differ from Germany, however, and also from Britain and the United States, in that at this stage ordinary lay citizens have no participation whatsoever in the decisionmaking process. Each assigns exclusive trial jurisdiction to a specialized or semi-specialized tribunal composed of persons possessing some type of professional training or experience. While these judges ordinarily are generalists at the time of appointment, they develop tax expertise in the course of their work. In two of these three countries (Belgium and France), ordinary laymen may be allocated a limited responsibility during the earlier administrative stage. ${ }^{73}$ Midpoint in that stage, i.e., before a dispute is taken by the taxpayer to the tax administration's own regional echelon, the dispute could be referred to an outside body staffed primarily with laymen.74 But even here, those panels act in an advisory capacity alone, with the further limitation that, like the American jury and unlike Britain's General Commissioners, they decide only questions of fact and never questions of law. As before noted, once the litigation stage is reached, both Belgium and the Netherlands rely on specialized tax chambers in their regular courts of appeal to perform the trial function. ${ }^{75}$ Belgium has three such geographically dispersed courts, each having either one, two, or three tax chambers composed respectively of three legally trained judges who deliberate in each case. While they decide, in aggregate, far fewer income tax cases than do their counterparts in England or Germany, they do render almost

72 See $i d$, $\S 4.3$.

73 For a full description of their role, see Chap. VII, §3.2a infra and Chap. XII, $\S 83.3$ and $3.4 \mathrm{a}$ infra.

74 See Chap. VII, $\$ 3.2 \mathrm{a}$ infra, and Chap. XI, $\$ 3.3$ and $3.4 \mathrm{a}$ infra.

75 For a full description, see $\$ 4.2$ in Chaps. VIII and XXIV infra. 
as many income tax decisions (1107 in one recent year) ${ }^{76}$ as do all of the federal trial tribunals in the United States, the population of which is 18 times as large. In the Netherlands, aggregating income, profits and wage tax cases, a roughly comparable total number of trial decisions 77 is handed down by the special tax chambers included in each of its five geographically dispersed courts of appeal, two of which have two such chambers. In contrast to Belgium, however, the majority of all cases in the Netherlands are heard by a single judge, though ordinarily each chamber will honor a request that all three members sit on a given case. 78 France ${ }^{8}$ twenty-four geographically dispersed administrative tribunals, of which two have been sectionalized, bear a much heavier tax caseload. Each of these tribunals or sections is composed of five members, with three sitting as a deliberative body in each 'case. 79 In one recent year, they decided an overall total of 4,578 income tax cases. 80

\subsection{Appellate tribunals: The right and scope of review}

The multiplicity of trial tribunals in each of these countries requires some unifying means to correct their errors. The aim should be to provide an impartial 81 review body which will limit itself to those corrective efforts it can carry out effectively and efficiently, through high quality decisions likely to produce fairly durable interpretations. However, if these

76 See Chap. VIII, §4.3 infra.

77 Approximately $70 \%$ of the 1900 tax decisions in one recent year fell in these categories. See Chap. XXIV, § 4.3 infra.

78 see id., § 4.2 infra.

79 See Chap. XII, § 4.2 infra.

80 See $i d$., $\$ 4.3$ infra.

81 Impartiality in this area requires, just as it did in the case of trial tribunals, that the tax administration be denied a voice in the appointment or tenure of the judges. Given the existence of so many other alternative methods of selection, this criterion-as a formal matter-could be satisfied easily by any country. However, the continuing task of conforming actual practice to this standard no doubt is less difficult in countries where the appellate tribunals are courts of general jurisdiction, as in the United States, than in countries where the tribunal specializes solely in tax appeals, as in Germany. Indeed there, even as a formal matter, the judges are elected by a twenty-three member committee composed of the Federal Finance Minister, the eleven State Finance Ministers, and eleven persons named by the Bundestag. While the Federal Finance Minister has no vote, he does exercise a veto power. One redeeming feature is that judges thus elected are then appointed for life, by the President. See Chap. XVI, § 4.4 infra. 
latter purposes do not coincide perfectly with a given country's practice in non-tax cases, such fact will make their implementation in tax cases more difficult and well-nigh impossible if the country's regular appellate structure is used.

To give aggrieved parties an absolute right to appeal is the only effective, feasible, and efficient method of ferreting out errors at the trial level. Laying aside subsequently considered limitations relating to the scope of review, this right is accorded taxpayers with respect to decisions of all 82 but one of the previously discussed trial tribunals, specifically the U.S. Court of Claims. Its decisions are reviewable by the Supreme Court, but only upon the latter's seldom-granted leave. 83 And over the last twenty years, leave actually was obtained in less than twenty cases. 84 Indeed, during, the most recent five-and-one-half years of that period, it was allowed in only three of the approximately two hundred tax cases decided by the Court of Claims. 85

This one apparent exception to the otherwise prevailing practice of granting review as a matter of right is less real, however, than it appears. In part, this is because, when a U.S. taxpayer decides to invoke the jurisdiction of the Court of Claims, he elects, voluntarily, not to have his case tried by either of two other trial forums (the Tax Court or a regular federal district court) from which there would have been an absolute right to appeal. Of even more significance, the Court of Claims itself actually has the dual characteristics of both a trial and a review tribunal. 86 As previously noted, legally trained trial commissioners make preliminary findings of fact and submit recommendations regarding questions of law. Either party may file exceptions thereto, and these always are reviewed internally by a panel of the court's legally trained judges. ${ }^{87}$ In practice, this panel is larger, and in theory,

82 See §§ 4.4 and 4.5 of Chaps. VIII, XII, XVI, XX, and XXIV.

83 An official but general statement regarding appropriate grounds appears in Supreme Court Rule 19.

84 See Miller, op. cit. supra note 38 , at 458 .

85 Brown and Whitmire, op. cit. supra note 32 , at 652 .

86 See Kipps, op. cit. supra note 12.

87 Since the judges on the Court of Claims also review the determination of a commissioner even in cases where neither party filed an exception, in practice, reviews there are automatic. See Miller, op. cit, supra note 38 , at 461 . This contrasts sharply with the theoretically more efficient procedure applied to federal district courts where review by an appellate body is limited to appeals filed by a party 
never less, ${ }^{88}$ than regular appellate tribunal panels to which appeals would lie from the other two trial forums.89 And many practitioners choose the Court of Claims precisely because they can telescope the whole conflict into one proceeding and still be assured that the legal issue will be dealt with by a legally trained deliberative body, ${ }^{90}$ rather than by a single judge who typically would render the trial decision in cases filed with the Tax Court or a federal district court.

Both efficiency and quality of the total conflict-resolution effort will be enhanced if a reviewing body restricts its corrective efforts to those it can carry out effectively. Assuming that body is properly constituted, this limitation would permit it to substitute freely its judgment for that of the trial tribunal

\section{(footnote continued)}

who feels aggrieved. The difference in this instance, however, is largely theoretical; little real waste actually ensues from the automatic review by the judges of the Court of Claims. The fact is that exceptions to their trial commissioners' determinations are filed in the great preponderence of cases, the proportion in 1966 being $82.5 \%$ of the decided cases. Moreover the judges of that court undoubtedly devote much more energy per case to cases where an exception has been filed than to the others. In the latter, the court typically hands down a short per curiam decision adopting the Commissioner's determination, explaining that it does so because "it agrees with the trial commissioner's findings, opinion, and recommended conclusion of law, as hereinafter set forth." For example, see Dodge v. U.S., 362 F.2d 810 (Ct. Cl. 1966). No doubt also, taxpayers who invoke this court's jurisdiction realistically anticipate at the outset that the side adversely affected by a trial commissioner's determination probably will file exceptions thereto, if only because the average amount involved in cases which are filed with this court involves a far larger sum than the average in cases filed with the other two trial forums. See Kipps, op. cit. supra note 12, at 1026. As noted elsewhere, because the third trial forum (Tax Court) is a multijudge court but employs only a single judge to hear a case, it too has developed an internal review procedure. In contrast to the Court of Claims, however, not every case is subjected to an internal review. Prior to release of a decision, the Chief Judge is empowered to refer it to the whole court. And for thirty days after release, any judge on the Tax Court can request such a referral. See Kern, op. cit., Murdock, op. cit., and Raum, op. cit. supra note 33. Typically, about one-third of the decisions are reviewed.

88 That the court traditionally has sat en banc, all seven participating, see § 4.3 supra.

89 Typically a division of three sit, though a majority of a court's judges on regular active service can require the court to sit en banc, 28 U.S.C. \& 46 (c).

90 See Kipps, op. cit. supra note 12, at 1026; Miller, op. cit, supra note 38 , at 459 . 
with respect to all questions of law, though most certainly not as to all questions of fact.

Completely at odds with this latter limitation is the review arrangement within the U.S. Court of Claims. True, that court does treat its own commissioners' factual findings as "prima facie correct ... in the absence of exceptions thereto." 91 However, in case of an exception, that court believes "the law casts the ultimate burden of making findings on the judges of the court, and wherever we are convinced that the weight of the testimony is contrary to the finding of the [trial] commissioner, it is our duty to substitute for the commissioner's finding what we consider to be the correct finding." 92

This all embracing view has led the judges on that court, in the face of conflicting evidence, to reverse the finding of a trial commissioner even with respect to a subjective factual matter where the credibility of the taxpayer-witness was at issue and where no one but the trial commissioner had occasion to observe him. In that particular case, the question, involving only the taxpayer's initial intention, was whether he had "purchased land for the purpose of farming it."93 Perhaps less open to criticism was the judges' action in the case of a given officer-stockholder. There in the face of conflicting evidence, they reversed a commissioner's finding regarding the precise amount of salary deemed "reasonable" for deduction purposes. ${ }^{94}$ At least this action is defensible if limitations on the scope of review actually are imposed only because of the inherent difficulty of a review body confined to a written record. But even in this type of case, free substitution of judgment is a questionable practice if overall efficiency also is to be stressed, to the end of enabling the review body to focus primarily on significant and relatively durable interpretations.

Surveying all the trial tribunals covered by this study, there is wide variation in the scope of review severally available on appeal. The sweeping character of review applied within the Court of Claims is at one extreme, shared only by France. Though the latter's appellate tribunal is physically

91 See Miller v. U.S., 339 F.2d 661, 662 (Ct. Cl. 1964). Italics added. 92 Id. at 662 . Italics added.

93 Id. at 662. Cf. the dissent of Davis, J., at 664 and the cases cited therein. Italics added.

94 Bringwald, Inc. v. U.S., 334 F.2d 639 (Ct. Cl. 1964); Gordy Tire Co. v. U.S. 296 F.2d 476 (Ct. Cl. 1961). 
distinct from the trial echelon, questions of fact may be raised on appeal and even new evidence may be presented.95 In short, both bodies approach the case anew, though the nature of the question submitted originally to the trial tribunal cannot be changed on appeal. ${ }^{96}$

At mid-point between that position and the other extreme are the fairly restrictive standards applied to the regular U.S. courts of appeal on reviewing cases originating in the other two U.S. trial forums. If a jury of laymen, after being instructed correctly by the trial judge regarding questions of law, decides a federal district court case, an appellate tribunal cannot reverse if "reasonable men could reach differing conclusions on the issue." 97 And if a trial is conducted by a federal district court judge without a jury, or by a judge of the Tax Court which never uses a jury, the lower court's findings of fact must stand on appeal unless "clearly erroneous." 98 Unquestionably these standards, when compared to those applied within the U.S. Court of Claims, do gauge more accurately the limited capability of a review body confined to a written record. Hopefully, they also have some restraining effect on the number of appeals-thereby, enabling the regular U.S. appellate tribunals to spend more of their time on legal questions which are better suited to their peculiar competence. But even these restrictive standards can accomplish their aim only if the types of determinations to which they apply are clearly defined. In the United States, they obviously apply to pure questions of fact which are readily discernible. Also covered are "factual inferences from undisputed basic facts" 99

95 See Chap. XII, §4.5 infra.

96 Ibid.

97 Commissioner v. Duberstein, 363 U.S. 278, 291 (1960).

98 Ibid. Fed. Rules Civ. Proc. 52 (a); I.R.C. §7482(a). A "finding is 'clearly erroneous' when although there is evidence to support it, the reviewing court on the entire evidence is left with the definite and firm conviction that a mistake has been committed." U.S. V. United States Gypsum Co., 333 U.S. 364, 395 (1948), quoted with approval in the Duberstein case, $i d$. at 291. Italics added.

Appeals from Tax Court decisions are to be distinguished from the internal review that court may choose to give its own trial judge's decision. See note 87 supra. There are instances, for example, where the Tax Court reversed its own trial judge's findings of fact and was sustained on appeal because its findings were not deemed clearly erroneous. See Latchis Theatres of Keene, Inc. v. Commissioner, 214 F.2d 834 (1st Cir. 1954).

99 Id., note 97 supra. 
though, as before noted, not legal conclusions. Here difficulty does arise because, in a statutory tax setting, the line between the latter two categories is not always easily discernible. In consequence, courts of appeal occasionally disagree as to whether a given situation turns on a "factual inference from undisputed basic facts" (subject to the "clearly erroneous" limitation) or instead involves an indivisible mixed question of law and fact (where a court feels entirely free to substitute its judgment). 100

Finally, at the opposite pole from the sweeping review conducted within the U.S. Court of Claims and by the French Conseil d'État is the Belgian practice. There the Appellate Court may not consider anything other than a pure question of law; appeal of a so-called mixed question of law and fact would be dismissed.101 The same is true in Great Britain. There, however, the concept of a pure question of law is broad enough to permit an appellate tribunal to reverse if it appears that the trial tribunal could not have drawn from the evidence before it the inferences of fact upon which it relied in reaching its final decision. 102

\subsection{Appellate tribunals: Quality of review}

Obviously bearing on the quality of appellate decisions is the quality of the bench itself. In practice, neither of the only two countries (England and Germany) which make some use of ordinary lay citizens as judges at the trial level utilizes such persons on the appellate courts which hear tax cases. 103 Indeed, only in France and Germany is it even likely that professional persons without legal training might be appointed.104 In the rare circumstance where this occurs in France, the appointee would have been at least one of the top graduates of the National School of Administration. ${ }^{105}$ In Germany, the

100 For example, compare Mathews v. Commissioner, 315 F.2d 101 (6th Cir. 1963) and Rubino v. Commissioner, 186 F.2d 304 (9th Cir. 1951), cert. den. 342 U.S. 814 (1951) with Fahs v. Taylor, 239 F.2d 224 (5th Cir. 1956), cert. den. 353 U.S. 936 (1957), and Goldberg v. Commissioner, 223 F.2d 709 (5th Cir. 1955).

101 See Chap. VIII, §4.5 infra.

102 See Chap. XX, §4.5 infva and Ferguson, op. cit. supra note 26, at 364 n. 273. As to the Netherlands, see Chap. XXIV, §4.4 infra. 103 See $\S 4.3$ supra and $\S 4.4$ of Chaps. XVI and XX infra.

$104 \mathrm{As}$ to Belgium and the Netherlands, see $\S 4.4$ of Chaps. VIII and XXIV infra.

105 See Chap. XII, §4.4 infra. 
exceptional nonlegally trained appointee typically has had previous experience in tax affairs and has sat for a minimum of three years on one of the specialized trial tribunals.106

As a further quality control device, all six countries utilize the deliberative process. Typically, the number of appellate judges who sit on a given case equals or exceeds the number who sat on the trial tribunal.107 The two exceptions to this are Great Britain, though only for cases arising in England and Wales, and the United States, but only in the case of appeals from certain Tax Court decisions. With respect to the former, the exception is more shadow than substance: it pertains only to the first appeal, and England and Wales stand alone in allowing as a matter of right appeals to two different appellate levels. There, 108 decisions of both the General Commissioners (where two ordinary laymen constitute a quorum) and the Special Commissioners (where a minimum of two persons with professional training or experience is required), are appealed first to the High Court of Judicature, where one legally trained judge of the Chancery Division, sitting alone, will decide the case. Further appeal may then be taken to the Court of Appeals, where typically three legally trained jurists constitute a panel, though from two to five may sit. Also, by leave of that court or of the House of Lords, the trial tribunal's decision may be reviewed a third time, before a bench of up to five legally trained Lords of Appeal. The United States, as an exception, is such only in a very limited sense, since most appeals are heard by a larger bench than was involved at the trial level. This follows from the fact that the great preponderance of trial decisions are rendered by judges sitting alone, either on the Tax Court or a federal district court, 109 and appeals from both courts go to a court of appeal, where typically three judges hear the case.110 This latter number, however, is substantially exceeded by the number of

106 See Chap. XVI, §4.4 infra.

107 See text accompanying notes $128,130,132$, and 135 infra.

108 See Chap. XX, \$4.4 infra and Jackson, The Machinery of Justice in England 84 (4th ed. 1964).

109 See note 46 supra.

110 The eleven courts of appeal have a varying number of judges, depending on workload, and each does have the power, by order of a majority of a court in regular active service, to order that the court sit en banc on a particular case. 28 U.S.C. $\$ 46$ (c). It was anticipated, however, that this practice would be invoked only in rare cases. See H. Rep. No. 1246, 77 th Cong., 1st sess. 1 (1941). 
trial judges involved in those Tax Court cases where, prior to any appeal, the decisions of single Tax Court judges are reviewed internally by that sixteen member court ${ }^{111}$-as about one-third are. Following an appeal to a court of appeal, it also is possible in the United States to secure an additional hearing before the nine-member Supreme Court, but only by its leave which seldom is granted. ${ }^{112}$

Germany is the third and final country among the six to permit two appellate reviews of a trial tribunal's decision, with the second-like Great Britain and the United States-being to its High Court, but only in the case of constitutional issues.113 While France and the Netherlands, 114 and perhaps as a practical matter Belgium also, 115 permit only one such review, two of these three, further to promote high quality decisions, do make use of an additional procedural device unique among the Six. Belgium requires its Attorney General to submit to the appellate body 116 (as well as to the trial tribunal) 117 his own impartial view of the case, arrived at independently and presented separately from the view pressed on the court by the tax administration's representative. For the same purpose, France uses an official attached to its appellate body. 118

The perspectives of the appellate bench itself, and in this limited sense the character of its decisions, will be affected, of course, by the degree of its specialization in tax affairs-as was indicated more fully in the earlier discussion regarding trial tribunals. 119 There it also was suggested that, if a legislature fears-as do some critics-that a newly created specialized trial tribunal might lose touch with the general law or indulge too freely in what some characterize as judicial legislation, establishment of concurrent trial jurisdiction in

111See text accompanying note 33 supra.

112 See text accompanying note 123 infra.

113 See Chap. XVI, \$4.1 infra.

114 See $\$ 4.4$ of Chaps. XII and XXIV infra.

115 While Belgium, in tax cases, employs only two layers of courts, the fact that its appellate court (Court of Cassation), should it disagree with a trial tribunal, always remands the case to a yet different lower court for re-trial, does give rise to more than one appellate review. See note 143 infra. However, unless the Court of Cassation itself changes its mind on a yet second appeal to it, the view it took on the first appeal ultimately prevails.

116 Chap. VIII, §4.4.

$117 I d, \$ 4.2$.

118 Chap. XII, §4.4.

119 See $\$ 4.2$ supra. 
both a specialized tribunal and a general court might reduce this risk without forfeiting completely the benefit of the specialized tribunal's potentially greater competence, concern, and efficiency. This has been done, as before noted, by two of the countries covered here, the United States and, though to a lesser degree, Britain. Alternatively, or as an additional more direct restraint on the specialized trial tribunals, appeals therefrom can be lodged, as in Britain and the United States, in appellate courts of general jurisdiction. The latter, on reviewing cases, hardly would ignore completely the expertise of the lower specialized tribunal and, in any event, would benefit substantially from exposure to its views. Hence, the peculiar contribution this type of trial tribunal can make to a tax system would not be totally dissipated. 120

In deciding upon the type of appellate court to be used, however, legislators cannot cater just to their own peculiar preferences as between the perspective and competence which an appellate court would acquire from constant exercise of general jurisdiction and those which it would derive from specializing in tax cases. Relevant also to their choice are the interrelated factors of workload and the question of whether the requisite certainty and uniformity can be achieved if jurisdiction is lodged in other than a single court.

The significance of the relationship between these two factors is best illustrated by the contrasting circumstances in the United States and Britain. These two countries, it will be recalled, were at opposite ends of the six-country spectrum with respect to the actual number of trial decisions handed down each year with Britain on the high side. Their relative positions are just the reverse, however, with respect to the proportion of trial determinations appealed. For example, the various U.S. trial forums together resolved by decision only 1,232 substantive tax cases in fiscal 1966.121 During that same period, the eleven geographically spread U.S. appellate courts of general jurisdiction had to decide 373 civil tax

120 Even in reversing the U.S. Tax Court on a question of law, one American court of appeals said: "Indeed, the only thing which would give us pause is the unanimous decision of the Tax Court, whose expert view is always entitled to respectful consideration." Commissioner $\nabla$. Whitney, 169 F.2d 562, 565 (2d Cir. 1948), cert. den. 335 U.S. 892 (1948).

$121 \mathrm{See}$ Commissioner of Internal Revenue, op. cit. supra note 46, at 134 and 135 (Tables 17B and 20). 
cases. ${ }^{122}$ This was the highest proportion (approximately 30 percent) among the Six. Numerically, it was great enough, if all these cases were assigned to one appellate court, to restrict that court to the role of a specialized tribunal operating under the U.S. Supreme Court which, in that same year, decided only 10 tax cases ${ }^{123}$-all of which reached it with its individually-granted consent (writ of certiorari).

Britain is a complete contrast. Its General and Special Commissioners annually decide from 8,000 to 9,000 tax cases at the trial level. However, in 1965, the first appellate level for England and Wales (High Court of Judicature) issued decisions in only 14 such cases. 124 Also in that year, the second such level (Court of Appeal)-even if account is taken of decisions by the distinct but single levels to which appeal could be taken as a matter of right in Scotland (Court of Sessions) ${ }^{125}$ and Northern Ireland (Court of Appeal)-decided only 7.126 The House of Lords-on the basis of discretionary jurisdiction exercised over the whole of the United Kingdom-resolved 8.127 Appeals to the intermediate British courts represent by far the smallest proportion of trial determinations among the Six. Numerically, they obviously are not sufficient to keep one court occupied even if all such appeals were assigned to it. Since a large proportion of its docket would have to come from outside the income tax field, centralization, if otherwise justified, would not be accompanied, by either expectation or fear that the centralized court would develop the peculiar competence or perspective of a specialized tribunal.

122 Id. at 135 (Table 21). Little variance appears between the proportion of cases appealed from the district courts and from the Tax Court. In fiscal 1966, during which the district courts handed down 448 substantive tax decisions, the appellate courts decided 123 cases originating with district courts. Corresponding figures for the Tax Court were, respectively, 726 and 250. Ibid. As previously noted, however, none of the 57 cases resolved by the third trial forum (Court of Claims) could be appealed as a matter of right, though all decisions recommended by that court's trial commissioners were reviewed by the judges of that court. See note 87 supra.

123 of these, 4 originated with the Tax Court and 6 with the district courts. Op. cit. supra note 122 .

124 of these, 4 originated with the General Commissioners and 10 with the Special Commissioners.

$125 \mathrm{As}$ to this one court, it was necessary to use figures for 1964. 126 of these, 6 were decided by the Court of Appeal for England and Wales, 1 by the Court of Appeal for Northern Ireland, and none by the Court of Sessions in Scotland.

127 All figures based on the writer's count. $C f$. Chap. XX, §4.5 infra. 
In each of the other four countries, the proportion of appellate decisions to trial determinations falls far short of the U.S. 30 percent figure-always being nearer 10 percent. Yet the proportion is far larger than in Britain and numerically speaking would permit some degree of specialization if those countries were so minded. All four are. In three (Belgium, France, and the Netherlands), the appellate tribunal which hears tax cases also hears other types of cases. However, these tribunals are multi-chambered with one or more assuming prime responsibility for tax cases. In Belgium, one of the two chambers into which its highest court (Court of Cassation) is divided performs this function, with five Counseillers sitting on each case. 128 In 1965, 57 of its decisions involved impôts sur les revenus.129 The Netherlands Supreme Court has three chambers of five judges each. Here too one chamber is responsible for tax appeals. 130 Over a fairly recent two-year period, this chamber handed down 486 decisions involving various types of taxes and of these, 340 involved the wage tax and corporate and individual income taxes.131 The French government has entrusted to its Council of State a judicial as well as a consultative function. One of its five sections handles appeals from decisions in the various types of cases against the government originating in the 24 so-called administrative tribunals. This section $d u$ contenieux has nine subsections, 132 each having three Conseillers. Three of these subsections specialize in tax cases. 133 In one recent year, they decided 608 cases involving direct taxes, and of these 316 involved corporate and individual income taxes.134 Germany alone among the Six utilizes a physically distinct specialized court for tax appeals. In 1964, with five judges sitting on each case, seven different chambers (Senates) of its Federal Fiscal Court 135 dealt with a total of 2,000 tax cases of which 780

128 See Chap. VIII, §4.4 infra.

129 By the writer's count of cases published in the Pacicrisie Belge.

130 See Chap. XXIV, \& 4.4.

131 Id., $\$ 4.5$.

132 Décret 63-766, Art. 38 (July 30, 1963). Formerly there were 11. See Chap. XII, §4.4 infra.

133 While these sit separately, a reorganization decree (id., note 132 supra) apparently anticipates that at some future time they will begin to sit together in tax cases. See Drago, "Some Recent Reforms of the French Counseil D 'État," 13 Int. \& Comp. L.Q. 1282, 1296 (1964).

134 See Chap. XII, \&4.5 infra.

135 See Chap. XVI, $\$ 4.4$. 
concerned corporate and individual income taxes. However, out of the 2,000 tax cases of all types, final decisions were rendered in only $380 . .^{136}$ The largest proportion of the balance was dismissed, being deemed without merit.

\subsection{Appellate tribunals: Unifying interpretations}

The final consideration in shaping the appellate structure to be used in tax cases involves the need that it be capable of producing unifying and fairly durable interpretations. Such capability markedly affects the fairness and efficiency with which thousands of administrators can be expected to administer a tax system. Alsc, especially in self-assessment systems, it affects the extent to which taxpayers themselves can be expected to respond with an acceptable degree of uniformity. The ultimate question is whether interpretations of the requisite quality can be achieved adequately at the judicial level without vesting appellate jurisdiction in a single appellate court-or chamber, i.e., a division. Such a court would tend to become specialized should the anticipated appellate workload in a given country equal that in any one of five of these six countries.

Observe preliminarily that, whether the appellate tribunal be specialized or generalist, publication of its decisions (facts, conclusion, and supporting rationale) is an absolute prerequisite if taxpayers and administrations alike hope to possess guides for the future or any chance to question the applicability of past decisions in the context of other factual situations.137 This initial requirement is completely satisfied, however, in four of the six countries covered here (Belgium, France, Great Britain, 138 and the United States) through publication of all appellate decisions. And, in the other two (Germany and the Netherlands), at least those appellate decisions deemed important or of general interest 139 are published. 140

136 Id., §4.5.

137 Publication also helps preserve integrity and enhances the discipline with which the court approaches its work, for only by publication can a court be subject to the critical views of writers.

138 See $\$ 4.5$, Chaps. VIII, XII, and XX infra.

139 See $\$ 4.5$ of Chaps. XVI and XXIV infra.

140 Publication of trial decisions in these six countries ranges, however, from none in Britain to practically all such decisions in the United States. In between, a few are published in France and, in the three other continental countries, those deemed important are published. See $\S 4.3$ of Chaps. VIII, XII, XVI, XX and XXIV infra. 
Publication in itself, however, does not bring unification unless appellate court decisions bind lower courts for the future. Nor will the desired degree of certainty follow unless, in practice, appellate courts themselves tend to follow their own decisions. Since final decisions of appellate tribunals in the four continental countries covered here bind formally neither the lower courts nor the appellate tribunals themselves, theoretically their decisions have no precedent value. ${ }^{141}$ In theory, they bind neither the administration nor taxpayers with respect to future situations. Fortunately, however, practice and theory differ somewhat. 142 It is generally recognized that, in fact, these appellate tribunals ordinarily do follow their own prior decisions. And the lower tribunals, therefore, do tend to treat the appellate decisions as precedents-though a fairly complicated procedure is required in Belgium to accomplish this. ${ }^{143}$ A further practical consequence is that the tax administrations in these continental countries ordinarily do adhere to the principles decided at the appellate level and seldom force relitigation of an issue in a yet different case. 144

But this, no doubt, is due in substantial part to one particular structural feature of their appellate courts not shared by the United States and, in theory, not by Britain. And this difference is one of the prime causes for the not insubstantial degree of uncertainty which does exist in the United States. Whereas each of the four continental countries lodges ordinary tax appeals in one tribunal, 145 the United States employs eleven

141 See $\S 4.5$ of Chaps. VIII, XII, XVI, and XXIV, infra.

142 Ibid.

143 The Belgian difficulty actually relates to the doctrine of res judicata. In theory, its High Court (Court of Cassation) does not hand down a final decision on appeals to it. If the chamber which handles tax appeals concludes that the lower court erred in law, the latter's decision is quashed and the case is referred to another lower court for retrial on both the facts and law. That court is completely free to differ with the chamber of the High Court. But should it do so as to the legal question, on a second appeal by the aggrieved party, both chambers of the Court of Cassation sit in judgment. If the two chambers together agree with the single chamber which dealt with the earlier appeal, the case again is referred to another lower court which now, however, is bound to enter judgment in accordance with the views of the High Court. See Chapter VII, § 4.5.

$144 O p$. cit. supra note 141.

145 See $\$ 4.4$ of Chaps. VIII, XII, XVI, and XXIV infra. Constitutional issues in Germany, however, may be carried yet another step, i.e., to its Supreme Court. See Chap. XVI, \$\$ 4.4 and 4.5 infra. 
coordinate courts of appeal. Each has jurisdiction over a given geographical area, 146 with its decisions reviewable by a single High Court only with its leave. Because of the latter's heavy non-tax docket, over a recent ten-year period, it granted such leave and rendered a full opinion in only 78 cases (averaging 7.8 a year). 147 Moreover, far more typically than not, such leave was granted only after a conflict had emerged between two or more of the intermediate appellate courts. 148 Before such a conflict emerges, however, i.e., where only one intermediate court has passed on an issue, uncertainty continues. The possibility always exists that in some future case, on petition either of the commissioner or another taxpayer, a second appellate court might reach a contrary view which the Supreme Court might then adopt as it often has-proportionately speaking 149 -after granting certiorari. Because the geographically spread intermediate appellate courts are coordinate, the precedents of one do not bind the other, 150 though each does treat the decisions of the others with respect-apparently in lesser degree, however, than do Britain's three intermediate courts of appeal. 151

146 That, in effect, there is a twelfth which actually is coordinate on a nationwide basis, see text accompanying note 161 infra.

147 See Brown and Whitmire, op. cit. supra note 32 , at 658 . In fiscal 1966, the High Court approved only 4 of the government's 8 petitions for certiorari and only 8 of the 82 requested by taxpayers. See Attorney General of the U.S., Annual Report 1966, 335.

148 See Brown and Whitmire, op. cit. supra note 32 . That study indicates that over a ten-year period, in two-thirds (52) of the federal civil tax cases decided by a full opinion of the High Court, a conflict between courts of appeal was cited as a reason for hearing the case. In 6 of the remaining 26, such a conflict existed though it was not referred to by the High Court. Thus, on the average, only in 2 civil tax cases a year was the Court able, in view of the demands of other areas, to assume jurisdiction merely because an issue was important to the tax system.

149 A study, Brown and Whitmire, op. cit. supra note 32, at 659, indicated that in one-half of the High Court opinions involving conflicts between the lower appellate courts, the first appellate decision was found to be incorrect.

150 It is precisely because of this that the Supreme Court views, as one of its important functions, resolution of conflicts that arise among these appellate courts. As to the frequency with which this does serve as a ground for Supreme Court review, see Brown and Whitmire, op. cit. supra note 32.

$151 C f$. Chap. XX, §4.5 with the results of the U.S. study reflected in Brown and Whitmire, op. cit. supra note 32 . The chance that conflicts will emerge in the U.S. is relatively greater also because, compared to 
France and Germany, though employing only one appellate tribunal for ordinary tax litigation, 152 could have encountered the same difficulty as the United States, because their tax decisions are handed down by each of several coordinate divisions (three in France, seven in Germany) within their respective tribunals. 153 These two countries, however, faced up to the obvious problem generated by this structure; they established compensatory and somewhat similar internal referral arrangements. In Germany, 154 when one Senate (a division) of the Federal Fiscal Court encounters an appeal deemed to involve one or more important new issues of law, it may refer the case, in advance of a decision, to the Great Senate, a body composed of representatives from the separate Senates and presided over by the President of the Court. About five such referrals occur each year. ${ }^{155}$ Further, should a given Senate, in considering a case, tentatively decide against following an earlier decision of another Senate, it must refer that case to the Great Senate for decision. In France,156 though tax cases are dealt with by only three of the nine subsections which make up the judicial section of the Council of State, the Presidents of all nine subsections together with representatives of the consultative sections of the Council, sit as a plenary assembly, to which problems can be referred. So constituted, this plenary assembly considers important new tax questions as well as cases which may lead the Council to alter its position regarding an earlier enunciated tax principle.157

\section{(footnote continued)}

Britain, it has four times as many intermediate appellate courts and far more cases reach that level. See text accompanying notes 122 and 127 supra. U.S. district courts (trial tribunals) in the geographical circuit of a given intermediate appellate court are expected, however, to follow the decisions of the latter. But, that the other two trial forums do not feel bound by prior decisions of any particular court of appeals, see text accompanying notes 161 and 162 infra.

152 That constitutional issues in Germany may be further appealed, however, to its Supreme Court, see Chap. XVI, § 4.4 infra.

153 See $\$ 4.4$ of Chaps. XII and XVI infra.

154 See Chap. XVI, $§ 4.4$ and 4.5 infra.

155 A similar internal referral system is employed at the trial level by the U.S. Tax Court. See text accompanying note 33 supra. As noted there, however, the Tax Court internally reviews a much larger share of its cases, no doubt because of a tradition that the Chief Judge is expected to resolve "doubts in favor of court review." See Murdock, op. cit. supra note 33 , at 298.

156 See Chap. XII, §§ 4.4 and 4.5 infra, and note 132 supra.

157 For other devices used to secure uniformity in France, see Chapter XII, §4.4. Also, see note 123 supra. 
Obviously, such referral arrangements can neither eliminate uncertainty completely nor guarantee absolute uniformity among divisions. For example, not all important issues of first impression will be recognized as such and be referred in advance of a decision. Further, a given division may decide improperly that an earlier decision by another division is not in point and, quite logically though incorrectly, conclude referral to be unwarranted.

Far less perfect, however, is the device which links together the various intermediate U.S. courts of appeal. No arrangement exists enabling one such separate court to consult with the others before rendering a decision. Nor, as before noted, do the decisions of one bind the other. Further, it is unlikely the Supreme Court will involve itself, to the end of fixing a nationwide rule, until at least two circuits are in conflict. Consequently, the Commissioner of Internal Revenue, having nationwide responsibility for tax administration, feels that he must be free, on losing before one court of appeals, to test the issue before yet another.158 In the interval, which can run to several years, 159 uncertainty reigns. But the ultimate fault is not that of the Commissioner. It is inherent in the courts-of-appeals structure itself. The above mentioned second taxpayer also would have been free, had the theory of the court in the other circuit favored the Commissioner, to require his own court of appeals to address itself to the matter as one of first impression. 160 This particular consequence of the multi-courts-of-appeals arrangement takes on a yet different dimension when account is taken of one further feature of the appellate structure. One of the alternative trial forums having nationwide jurisdiction-the Court of Claims-has no allegiance to the decisions of any particular court of appeals. ${ }^{161}$

158 His decision not to conform to a given court of appeals decision is often reflected in a published Technical Information Release.

159 A study of Supreme Court decisions from 1955 to 1959 shows, as to these cases, that the median time involved in the development of conflicts between the circuits was 50 months. See Del Cotto, "The Need for a Court of Tax Appeals: An Argument and a Study," 12 Buffalo L. Rev. 5, 29-30 (1962). For a survey of other studies, see Brown and Whitmire, op. cit. supra note 32 , at 669 .

160 For a statistical analysis, based on one assumption and to the effect that history indicates the courts of appeal will not agree on $25 \%$ of the cases involving a difficult substantive issue, see Brown and Whitmire, op. cit. supra note 32 ,

161 The significant degree to which it has exhibited independence is analyzed in Pavenstedt, op. cit. supra note 38. See also note 166 infra. 
It considers itself coordinate to the regular courts of appeal because it too is reviewable only by leave of the Supreme Court. In consequence, a taxpayer who believes a previous decision of his own court of appeals is unfavorable to his cause, from the very beginning has the option, if the Court of Claims has not considered the issue, to invoke the latter's jurisdiction. And where the Court of Claims alone has spoken on an issue, no one-whether taxpayers or the Commissioneris bound as to future situations. After all, this tribunal is only one of twelve coordinate courts. It has nationwide jurisdiction but the entire nation is subdivided geographically among the other eleven coordinates.

In further aggravation, though not attributable to the appellate structure itself, is the fact that another trial forum, the Tax Court, essentially just because of its nationwide jurisdiction, also denies allegiance to any particular court of appeals. ${ }^{162}$ And this is so, though in contrast to the Court of Claims, Tax Court decisions are appealable, illustratively in the case of an individual, to the particular court of appeals having jurisdiction over the area where the particular taxpayer resides. Precisely because of this, neither the Commissioner nor other taxpayers, as to future situations, feel bound by Tax Court decisions. 163

In summary, neither the Commissioner, nor any of these tribunals, nor taxpayers themselves accord binding precedent to any decisions other than those of the Supreme Court. 164 Yet that Court seldom involves itself until one court of appeals differs from the previous decision of another. To some extent, however, the problem is mitigated by the Commissioner's usual practice of conceding an issue should he lose before two courts of appeal. For the uncertainty which prevails in the interim, however, the appellate structure bears the prime

162 Other reasons are also advanced in Lawrence v. Commissioner, 27 T.C. 713 (1957), rev'd 258 F.2d 562 (9th Cir. 1958). For an extended analysis, see Ferguson, op. cit. supra note 26, at 366 . As noted there, at 367 n. 285, a federal district court, on the other hand, is expected not only to follow decisions of the court of appeals for its circuit but, in the absence of any such controlling decision, tends also to attach great weight to appellate decisions of other circuits.

163 Typically, his reaction to adverse decisions is published, either as an acquiescence or non-acquiescence in the Internal Revenue Bulletin which is available to taxpayers.

164 That the one exception is a federal district court, see note 162 supra. 
blame, though the above mentioned Tax Court practice at the trial level is a significant aggravation. Together, these two circumstances lead (i) taxpayers to shop for the most "appropriate" forum 165 and (ii) the Commissioner to test an adverse result in yet another coordinate forum. Both the "shopping" and period of uncertainty are affected also by the prospect that a second coordinate court, perhaps because of slight factual variations, may be willing to distinguish the previous decision of another and thus avoid even the appearance of a conflict. If it does distinguish, and if the forums are alternatives, yet other taxpayers will be affected in their choice of a forum by what then are deemed to be differences in judicial attitude-if only in degree. 166

Certain individuals propose, through legislation, to handle the problem by requiring the Commissioner to follow the decisions of courts according to a given sequence. 167 Others would establish a centralized court of tax appeals, with some of these proponents content to leave the tribunal subordinate to the Supreme Court, 168 while some would make its decisions final. ${ }^{169}$ Other reformers would start at the bottom, at the trial level, by eliminating the existing right of taxpayers to choose between a specialized court and courts of general jurisdiction. They would put exclusive trial jurisdiction in specialized courts, 170 thereby also removing the right of jury trial, 171 with appeals from these courts going to a single specialized court.172 A completely opposite approach is taken by those who would eliminate at the trial level the encumbrance

165 Literally dozens of articles have been published to educate practitioners regarding the considerations they should take into account in choosing a forum. For collection of a large sample, see Brown and Whitmire, op. cit. supra note 32 , at 650 n. 52 .

166 Pavenstedt, in op. cit. supra note 38 , identified 17 areas where the Court of Claims was the more favorable forum and 7 where it was less favorable.

167 See H.R. 6914, 89th Cong., 2d sess. (1966).

168 See, e.g., Griswold, "The 'Need for a Court of Tax Appeals," 57 Harv. L. Rev. 1153 (1944).

169 Lowndes, "Federal Taxation and the Supreme Court," 1960 Sup. Ct. Rev. $222,257$.

170 For example, see Traynor, op. cit, supra note 45 , at 1425 . But $c f$. text following note 43 supra.

171 Id., at 1426. However, the architect of this proposal would preserve the deliberative process by having decisions of a single judge internally reviewed by the other judges on a court.

$172 I d$, , at 1426 . 
taxpayers now suffer should they prefer to try the case before a federal district court of general jurisdiction, perhaps with a jury, rather than before the specialized Tax Court. This group would establish true concurrent jurisdiction by enabling a taxpayer who prefers the former type of court to litigate there before paying the amount in dispute, as he now can do should he choose the Tax Court. 173

The ultimate controversy is between two groups. One places a high premium on efficiency, certainty, uniformity, and the peculiar competence and concern of specialized tribunals. The other values more highly both the perspective associated with courts of general jurisdiction (including juries) and the wholesome effect of permitting intermediate coordinate courts of this type to examine the same issue to the end, should they differ, of placing before the Supreme Court well reasoned but competing views of objectively oriented appellate court judges. The whole matter, as it relates to the United States, is now the subject of a comprehensive study by a colleague 174 of this writer.

\section{Section B. Analytic Comparison: Litigation Practices of the "Six"}

\subsection{Introduction}

In conducting trial litigation, each party has certain legitimate concerns peculiar to it. Practices particularly important to the tax administration, and those primarily of interest to taxpayers, are considered separately in the succeeding two subtopics. Thereafter the focus shifts to yet other practices-of common concern and basic to the entire conflict resolution process.

\subsection{Practices peculiarly important to the tax administration}

Each of the six tax administrations covered here must deal individually with thousands of suits initiated at many different locations across each nation. 175 In consequence,

173 See Committee on Court Procedure, Taxation Section, A.B.A., op. cit. supra note 48. Cf. Sutherland, op. cit. supra note 7 .

174 Professor Alan Polasky, under the auspices of the American Bar Foundation.

175 As to the number of suits actually tried, see $\S 4.3$ supra. However, in most of these countries many other docketed cases required 
their most important administrative problems emerge from an inherent conflict between two competing administrative needs: to handle this extremely burdensome effort efficiently, and to preserve for top policy makers the opportunity to formulate litigation policy. Whereas the latter necessitates at least some degree of centralization, maximum efficiency in handling the litigation function requires decentralization. The problem is to strike a proper balance between the two.

Considering only efficiency, the aims should be to avoid (i) duplicating, in the litigation stage, work that had to be done during the last administrative stage, and (ii) duplication of effort within the litigation process itself.

The first of these two ends obviously is best served by holding litigation to the necessary minimum, i.e., by closing out through reasonable settlements as many controversies as possible during the administrative stage itself. Practices most likely to achieve this were fully considered in Chapter III supra. As explained there, the foregoing objective cannot be reached merely by requiring taxpayers to exhaust their administrative remedies before invoking the jurisdiction of an independent tribunal. Far more important is the imperative of maintaining an image of impartiality at the administrative level. And, as further explained in an earlier chapter, this image of impartiality ultimately is enhanced inter alia by imposing on the person who hears the final administrative appeal the further responsibility of representing the government at the trial level should litigation ensue. ${ }^{176}$ This potential responsibility would remind him during the earlier administrative phase that it is he (in a representative capacity) who faces the risk of loss if the dispute is not settled administratively. Such a reminder should contribute to his sense of reasonableness and facilitate administrative settlement. And as to any cases not so settled, the proposed arrangement would

\section{(footnote continued)}

attention but were settled before trial. For example, of the 6,234 U.S. Tax Court cases disposed of in fiscal 1966, 5,195 were settled before trial, and only 726 actually were tried on the merits. The remaining 313 were withdrawn or dismissed. See Commissioner of Internal Revenue, op. cit. supra note 46, at 134 (Table 17B). Of the 1,504 refund suits filed that same year with the district courts and the Court of Claims (Attorney General, Annual Report 1966, 326 and 339 n. 20), previous experience would indicate that at least 1,000 will be settled before trial.

176 See Chap. III, $\$ 3.2$ supra. 
further the cause of efficiency. It avoids the expensive duplication of effort which otherwise follows when, at the point of litigation, one more professional employee must master complexities and nuances of a controversy. Implementation of this plan demands as a corollary that the official who hears the final administrative appeal possess the requisite skill to represent the government properly before the appropriate independent tribunal. This skill, however, is not irrelevant to the task he performed during the earlier administrative phase. His actions at that time should have been affected, in the interest of administrative fairness, by a careful appraisal of the anticipated litigation hazards. And assuming proper training, personal experience of such hazards provides the best possible preparation for making such appraisals.

The Netherlands actually utilizes the arrangement proposed here. The local inspector who dealt with the taxpayer in the last administrative stage ordinarily represents the government before the trial tribunal.177 His training, formerly in the administration's own academy but now entrusted on a subsidized basis to law faculties, is intended to equip him for this responsibility. 178 Likewise the British Inland Revenue, in those cases-typically small-tried before General Commissioners, is represented by the inspector who heads the local office or by his assistant. 179 For surtax cases tried before Special Commissioners, however, the responsibility for the representation ordinarily does not remain with the Surtax Office but shifts to the centralized Solicitor's Office. ${ }^{180}$ France uses yet another device to save, for the benefit of the litigation stage, much of the effort that went into the administrative stage. There the taxpayer's final administrative appeal is at the regional level (Departmental Director's Office), not the local level. If litigation ensues, the responsible official at that higher office typically prepares the memorandum of law which will be filed with the independent tribunal, though the administration actually is represented in court by an ordinary inspector residing in the city where the tribunal sits. ${ }^{181}$

177 See Chap. XXIV, §4.3 infra.

178 See Chap. XXI, §1.5 infra.

179 See Chap. XX, §4.3a infra.

180 Id., $\$ 4.3 \mathrm{~b}$ infra.

181 See Chap. XII, §4.3 infra. Its inspectors typically do have legal training. See Chap. IX, §1.5 infra. 
In contrast, Belgium and the United States, though in inverse order, probably suffer the greatest duplication of professional effort when a controversy shifts from the final administrative phase to the litigation phase. Belgium, alone among the Six, shifts trial responsibility outside the government, turning it over to a regular practicing member of the bar to whom the Minister of Finance has given a permanent part-time appointment to defend the government at this level. ${ }^{182}$ In the United States, the shift takes place within the government. Trial responsibility moves to the government's own full-time legal staffs. But the resulting duplication of effort is further compounded, irrespective of whether the taxpayer invokes the jurisdiction of the Tax Court or one of the other two trial forums.

When a case is docketed with the Tax Court, the administrative official (Appellate Division) who heard what in theory was the final administrative appeal continues, after docketing, to share jointly-with an attorney from the separate Chief Counsel's office-the responsibility to seek an administrative settlement of the case before the Court convenes for the session during which the case otherwise would be tried.183 Where settlement is not achieved, that same attorney will represent the government in the Tax Court. ${ }^{184}$ However, because almost

182 See Chap. VIII, §4.3 infra.

183 Rev. Rul. $60-18$, C.B. $1960-2,988$. Once the court convenes and the calendar is called, settlement authority then vests exclusively in the Chief Counsel's office. Typically, as in fiscal 1966, about $70 \%$ of all docketed cases actually bypass the last administrative stage. See Commissioner of Internal Revenue, op. cit. supra note 46, at 134 (Table 17A). However, as to these cases also, the two separate offices (Appellate Division and Chief Counsel) continue, as above, to share joint settlement responsibility.

184 Under present conditions it would not be feasible to avoid his duplication of the study and analysis previously put into the problem by the administrative official who heard the last administrative appeal.

Too frequently, the latter official is not in a position to handle the trial if one ensues. Many of these officials are not legally trained. Because of the procedures followed by the Tax Court, typically only persons with legal training appear before it. See $\$ 4.9$ infra.

Nor at the moment would it be feasible to avoid the consequent duplication by having the attorneys in the Chief Counsel's office take over the entire settlement function. A substantial proportion of those attorneys are recent law school graduates who stay with that office only during the four years for which they make a moral commitment. While there is no doubt about the quality of their work, not having the long experience enjoyed by the technically oriented administrative officials in 
85 percent of all docketed cases are settled during the pretrial period, ${ }^{185}$ this phase of the litigation process should be, and in practice is, viewed as yet another administrative appeal, though now with two quite separate government offices-each having its own internal review arrangement-sharing the responsibility for settlement.

When a refund case is filed, whether with a U.S. federal district court or the Court of Claims, responsibility shifts from the administrative officials, not to the office of the administration's own Chief Counsel, but to other lawyers in the even more separate Tax Division of the Justice Department. 186 Here too, of the cases filed, well over a majority will be settled before trial.187 But once again, as to a significant proportion of these, yet another office becomes involved. To help preserve a uniform litigation policy, many but not nearly all of the proposed settlements are cleared by the Justice Department with the tax administration's own Chief Counsel's Office. 188 Consequently, this latter office also must acquaint itself with the details of these cases.

Germany, among the Six, probably achieves the maximum degree of efficiency, by giving local finance offices the greatest possible autonomy. It even avoids duplicating in the appellate

\section{(footnote continued)}

the Appellate Division, they would not be nearly as efficient in settling the far greater number of cases which are and must be resolved administratively even before petitions are filed with a court. There were over 22,000 such dispositions at the Appellate Division level in fiscal 1966. See Commissioner of Internal Revenue, op. cit. supra note 46, at 133 (Tables 15B and 16B). In short, to consolidate the two functions in one office would require very different staffing arrangements than those now utilized by either office.

185 See Commissioner of Internal Revenue, op. cit. supra note 46, at 134 (Table 17B).

186 While this shift took place pursuant to an executive order issued under the Economy Act of 1932, the Justice Department itself defends it on substantive merit. See note 208 infra and Statement of Honorable Mitchell Rogovin, Assistant Attorney General, Tax Division, Department of Justice, on S. 2041. Before the Subcommittee on Improvements of the Senate Judiciary Committee, 90th Cong., 1st sess. (1967).

187 See note 175 supra.

188 And for this purpose, the Chief Counsel's office maintains a special division-the Refund Litigation Division. A "Settlement Option Procedure" instituted in 1964 permits the Justice Department to settle many of the less important cases without this referral. See Attorney General, Annual Report 1964, 320. By fiscal 1965, this covered $43 \%$ of the cases. See Attorney General, Annual Report 1965, 307. 
phase of the litigation stage the professional effort invested in the earlier or trial phase of that stage. If litigation does take place, the inspector who heads the local office or a senior subordinate who had dealt with the dispute typically continues to handle the case; he represents the government before both the trial and appellate tribunals. 189 Further, ordinarily he alone decides whether to appeal an adverse decision of the trial tribunal. Indeed, should either the state or Federal Finance Ministry or both decide to intervene in the appeal, whether voluntarily or at the invitation of the appellate tribunal, a Ministry-intervenor appears as a separate independent party to the action, using its own representatives and not interfering with the local office's presentation of its case. 190

If feasible, it is desirable, of course, to minimize duplication of effort by having the same professional appear before both tribunals. 191 It is quite another matter to stress efficiency or a local office's autonomy to a point that precludes National Office involvement and, thus, some duplication of effort regarding the question of whether to appeal a trial determination. Most countries covered here, however, actually experience duplication on both counts, i.e., the representation function does shift to a yet different professional at the point of appeal, and the National Office does involve itself in the question of whether to appeal.

As to the matter of representation, Belgium, for example, instead of having the trial attorney handle any subsequent appeal, employs a regular member of the Court of Cassation's own bar.192 In the United States, at the point of appeal the representation function shifts from the government's own trial attorney to appellate attorneys who work full time in the Justice Department's Appellate Section. 193

Much more easily defended is that duplication required of the National Office in trying to control litigation policies actually carried out at lower levels. In the last analysis, formulation of litigation policy is another form of administrative

189 See Chap. XVI, $§ 4.3$ and 4.5 infra. Ordinarily this senior class local official does have legal training. Ibid. Also see Chap. XIII, $\$ 1.5$ infra.

190See Chap. XVI, §4.5 infra.

191 The prime problem here is that some persons who make excellent trial advocates are less able in the appellate setting, and vice versa.

192 See Chap. VIII, §4.5 infra.

193 If the case goes to the Supreme Court, the representation function understandably shifts again to a high official-the Solicitor General. 
rule making. Where the latter is accomplished through more typical forms, such as rulings, Chapter II supra194 argued that the tax administration's own central office should assume final responsibility, primarily to achieve uniformity and to assure that the more important policy choices required by the interpretative process actually are made by senior officials having some policy orientation, not by technically oriented personnel who staff the lower echelons. The same rationale applies to litigation policy. Consequently, generally speaking, the central office itself should have at least the opportunity to decide whether or not a given trial determination should be appealed. Britain adheres to this practice, even though its central office otherwise does not carry on a major, published interpretative rule-making program. ${ }^{195}$ The Board of Inland Revenue itself decides whether a trial decision will be appealed, but only after its secretariat has consulted with administrative experts in the affected substantive area and, if need be, its Solicitor's Office. ${ }^{196}$ Roughly similar practices are followed in Belgium, France, and the Netherlands. 197

In sharp theoretical contrast, the U.S. tax administration's own central-office officials do not decide the question of whether to appeal. Ultimate authority rests with lawyers in the centralized but wholly separate Justice Department. 198 Any assessment of this arrangement must take into consideration the fact that U.S. appellate courts are courts of general jurisdiction. They must be able to accommodate all types of cases. A department with concerns extending far beyond the tax area is better able to take appropriate account of overcrowded appellate court dockets-if any. Moreover in practice, the Justice Department does try to be sensitive to policy concerns expressed by the office of the tax administration's own Chief Counsel. ${ }^{199}$ And the latter's subordinates normally are

194 See $\$ \$ 2.6$ and 2.7 .

195 See Chap. XVIII infra and, for comparative purposes, Chap. II, $\S 2.5$ supra .

196 See Chap. XX, \&4.5 infra.

197 See $\S 4.5$ in Chaps. VIII, XII, and XXIV infra.

198 This is a function of the Solicitor General. See Attorney General, Annual Report 1965, 300.

199 Typically, the file which reaches the Justice Department's Tax Division includes a memorandum from the Chief Counsel's office explaining why an adverse lower court decision should be appealed. Before forwarding the file to the Solicitor General for a final decision, a reviewer in the Tax Division's Appellate Section will add a memorandum reflecting 
expected to try to preserve the administration's own interpretative policies as reflected in its administrative regulations, rulings, and other official pronouncements. 200

In some of the countries covered here, central-office control over litigation policy begins not at the point of appeal but earlier, at the inception of the trial stage. In Belgium, for example, three centralized administrative branches are responsible for tax litigation. The appropriate one works closely with the appointed private practitioner who actually represents the government before the trial court. 201 In France, while both control and conduct of trial litigation ordinarily are decentralized, exceptions as to the former do exist. The regional Departmental Director whose office prepares the memorandum of law to be filed with the trial tribunal is expected, prior to the preparation thereof, to consult with the Director General of Direct Taxes at the national office in any one of four circumstances. And these circumstances include the situation where an issue is not covered either by case law or administrative instructions. 202

The United States, which likewise decentralizes the actual representation function in trial litigation before the Tax Court, goes beyond France in centralizing policy control at the inception of that stage. To this end, the administration's Chief Counsel maintains a mechanized two-way reporting system (Reports and Information Retrieval Activity) between his central office and his 40 field offices which handle those cases eventually to be tried before the circuit-riding Tax Court. This system, known as RIRA, provides his central office with an indexed inventory of issues involved in all pending Tax Court litigation complemented by an abstract of the facts in each case. RIRA performs two functions vital to central office control of litigation policy, and a third purpose important to efficient exercise of such control. 203

(footnote continued)

his own views. While officials in the Tax Division are expected to make an "independent review" of the litigation possibilities, they also are expected by the head of that Division to be as "fully responsive as possible to the policy direction of the Internal Revenue Service." See Attorney General, Annual Report 1965, 298, 300, and 307.

200 See Cohen, "Current Developments in the Chief Counsel's Office," 42 Taxes 663 (1964).

201 See Chap. VIII, §4.3 infra.

202 See Chap. XII, § 4.3 infra.

203 See note 200 supra, and Link, "RIRA-A Legal Information System in the Internal Revenue Service," 43 Taxes 231 (1965). 
The first two functions coincide with those of the above mentioned but less sweeping reporting requirements imposed by the French administration. RIRA enables the central office to assure that geographically spread trial counsel take consistent positions across the nation. Further, it assures that any position thus taken is sound from a policy standpoint.

Assurance that policywise-sound positions will be adopted even at this early trial stage has long-run significance not always recognized. The at least defensible technical position which technically oriented local offices can develop as to a disputable issue may in fact be indefensible in terms of tax policy. To urge such a position even at the trial stage can have unfortunate long-range consequences. A given trial judge may adopt that position and the taxpayer then may lodge an appeal. If it is not until this stage that the central office becomes involved, the likelihood is reduced that it will give the full policy implications of that technical position their just due. This is understandable. Once a trial court "has approved the Government's position in a case, the reconsideration of that position at the national office level is complicated by a natural reluctance to repudiate a view successfully urged upon a court." 204 Not irrelevant is the risk of affecting the future attitude of the trial bench toward the government's local trial representatives. Confidence the trial bench otherwise might have in future arguments advanced by those representatives may be shaken should a central office, making its first appraisal of a question at the belated point of appeal, confess error before the appellate court regarding a position the local trial representative had urged successfully upon that trial bench. Trial judges are human. Both the foregoing risks as they relate to U.S. Tax Court cases are avoided, in large part because RIRA permits the central office to trigger its policy consideration of a case prior to the trial. Further, to this same end, all briefs prepared by field offices are reviewed in the Chief Counsel's central office before submission to the Tax Court. And subordinates conducting that review are instructed, as before noted, to maintain positions consistent with the regulations, rulings, and other official pronouncements previously approved by the Service's senior administrative officials. 205

204 Attorney General, Annual Report 1965, 301. Italics added. 205 See note 200 supra. 
RIRA, by enabling the central office to identify at an early point important or frequently recurring issues, also contributes to efficient and effective implementation of litigation policy. From the cases raising such an issue, the central office can select the test case best suited to clarify the law. 206 The others can be settled or "put on ice" until the test case has been resolved.

Central office control over trial litigation pending in the wide-flung U.S. district courts and in the Court of Claims is accomplished through a yet different system. Almost all lawyers who represent the government in these cases are based at the office of the Justice Department in Washington. 207 To accommodate the geographically dispersed trials, they ride circuit. Thus it is easy for the Justice Department to raisewith the administration's Chief Counsel-questions pertaining to the desirability or undesirability of maintaining a given position. In theory, however, the former-rather than the tax administration or its Chief Counsel-makes the ultimate decision. 208

206 Ibid. RIRA also contributes in a yet different way to the efficiency of decentralized trial counsel. The latter are fed information regarding the status of similar cases pending in other offices. Thus, should a given local office find that a similar case, pending elsewhere, has reached a more advanced stage, it can minimize duplication of effort by soliciting the relevant memoranda, briefs, etc.

207 Of the 202 attorneys in the Justice Department's Tax Division at the close of fiscal 1966, only 6 were based elsewhere in a field office subject to central control. See Attorney General, Annual Report 1966, 367. 208 One who headed this activity for the Justice Department described the actual practice as follows: "Separation of responsibility has proved successful because it affords an opportunity for a fresh, intensive, and intelligent reexamination of the Government's position in each tax controversy at the point in time when that controversy emerges from the administrative level into full public view in Federal court. The Internal Revenue Service has a responsibility to examine tax returns with a view to developing arguments which maximize the Govermment's revenue in the specific cases at hand along with its responsibility to establish rules and policy without regard to their dollar impact in a particular case. While the Internal Revenue Service leadership has made great strides toward encouraging a balanced even-handed judgment by its agents, the administration of justice and the tax laws are well served by the independent review and direction given by the Tax Division to the tax cases going into Federal courts. The Tax Division of the Department of Justice is not free to direct revenue policy. But, when its examination convinces it that it would be a mistake to argue the position advanced by Internal Revenue, the matter is taken up with the Chief Counsel and through a process of conference and persuasion, a mutually acceptable position is 
A final problem confronting an administration relates to adverse trial determinations not appealed. Any number of reasons, in a given case, might cause an administration to decide against appeal. If formulation of litigation policy as to a given issue is another form of administrative rule making, for the reasons earlier set forth with respect to rulings themselves, 209 the government should state openly, at least as to the more important unappealed trial decisions that are published, whether it will conform to such published decisions. A similar statement of intent should be made, where a country utilizes an intermediate layer of appellate courts, with respect to their adverse decisions if published and allowed to become final without further appeal. In both instances, by publishing such statements, the central office (i) can contribute to uniformity-efficiently and fairly, (ii) can assure that administrative reactions to such decisions are fixed by senior policyoriented officials rather than by technically-oriented local officials, and (iii) can neutralize risks regarding prospective transactions. Accomplishment of these goals, however, requires two complementary practices.

The first such practice relates to the special care that must be taken to guard against the possibility that the administration's published reaction will be misleading. This presents a problem quite distinct from that encountered in publishing an ordinary ruling. In the latter circumstance, the administration itself can and should identify the facts it deems pivotal and supply its own rationale. 210 In short, by these means an administration controls the dimensions of the ruling. In the case of an adverse trial court decision, however, the administration may be willing to accept the result but not the totality of the court's rationale. Or a fact the administration deemed

\section{(footnote continued)}

sought. From its independent vantage point the Division is able to persuade Internal Revenue that, viewed from the standpoint of litigation, certain positions should not be pursued in court.

"If this prior examination were not carried out, the resulting responsibility placed on the Federal courts, of making an extensive investigation into the long-range implications of each Government position urged before them, would be too great. If the courts can be satisfied that only carefully considered positions are presented in court, they will have greater confidence in the Government's presentation." Attorney General, Annual Report 1965, 300.

209 See Chap. II, §§ 2.5 through 2.8 and $\S 2.17$ supra.

210 See Chap. II, § 2.17 supra. 
essential in accepting the result may not have been explicitly treated as such by the tribunal. In consequence, published administrative reactions to some adverse trial determinations either must state that the acquiescences or non-acquiescences relate only to the results themselves or must become what are at least abbreviated versions of complete published rulings.

The second practice relates to reliability. The announcement of administrative intent will not achieve all three of the previously enumerated purposes unless it is as reliable as published rulings should be.211 Absent this, it cannot be depended upon to neutralize risks regarding prospective transactions. However, if an administration is to assign to these announcements the high degree of reliability it should attach to ordinary published rulings, the two should be processed approximately in the same manner. 212

Among the six countries covered here, only the United States carries on an official publication program providing administrative reactions to adverse but unappealed trial decisions, though in the Netherlands something roughly equivalent to an unofficial program does exist. 213

As to the United States, in the case of unappealed adverse Tax Court decisions published by the court itself, the administration typically publishes in its own weekly bulletin a bare acquiescence or non-acquiescence,214 often with a footnote stating that the announcement relates only to the result reached. 215 However, while these acquiescences and nonacquiescences are intended to serve the first two of the three previously enumerated vital purposes, ${ }^{216}$ the administration

211 See Chap. II, $\S 2.3,2.4,2.8$, and 2.17 supra.

$212 I d$. $\$ \$ 2.12$ and 2.17 .

213 See Chap. XXIV, \& 4.3 infra.

214 For example, see C.B. 1967-1, 1. The Administration does not publish its reactions to the court's so-called memorandum decisions. This may be due to the fact that these decisions are not published by the court itself, but by private publishing houses, and until recently the Tax Court itself never cited its own prior memorandum decisions as precedents.

215 For example, see $i d$, at 3 n. 7 .

216 However, even those previously enumerated and vital purposes actually were not the original reasons why this program was instituted. Because of the long period the government once had (one year) in which to decide whether to appeal an adverse trial decision by what now is the Tax Court, an acquiescence was issued as a means of informing the taxpayer as to whether the government intended to appeal. See Rogovin, "The Four R's: Regulations, Rulings, Reliance and Retroactivity," 43 
presently is unwilling to assign to them the high degree of reliability it accords regular published rulings. As to a given decision, the administration not only reserves the right to change its published reaction by substituting, for example, a belated non-acquiescence for a previously published acquiescence. 217 It ordinarily actually does so, in contrast to the practice followed as to published rulings, without exercising the discretion it also has 218 to give the change prospective effect only. 219 In consequence, in contrast to an ordinary published ruling, an acquiescence in itself cannot be relied upon to neutralize the tax risk associated with an important prospective transaction. 220 The bare quality of these announcements, and the fact they are not processed in the same painstaking manner as published rulings, are at the root of the difficulty. And, as observed by a former Chief Counsel while still in office, to do that which is necessary to upgrade the degree of reliability would require such substantial manpower that, as a practical matter, only the more important adverse Tax Court decisions could be so processed. 221

Indeed, the tax administration has not even extended the present program in any comprehensive way to the other two trial forums (district courts and Court of Claims). However, on an ever-increasing scale it is tending to publish its reaction to adverse intermediate appellate court decisions (including Court of Claims decisions), using for this purpose

$\overline{\text { (footnote continued) }}$

Taxes 756, 771 (1965). However, the government's allowable "cogitation" period was reduced many years ago to three months. Rev. Act. of 1932 , 1101. Since then, it generally has been recognized that the program was maintained to serve the first two of the previously enumerated purposes. See Rogovin, supra, at 772 and 773.

217 Dixon v. U.S., 381 U.S. 68 (1965).

218 Under I.R.C. $\$ 7805$ (b).

219 See Rogovin, op. cit. supra note 216 , at 772 and 773 . It applied the change retroactively in one case though eleven years elapsed before the previously published acquiescence was withdrawn and a nonacquiescence substituted. See Acq. to Caulkins v. Commissioner in C.B. 1944,5 and the subsequent non-Acq. in C.B. 1955-1, 7. In another case involving an interim of twenty years, the change was given prospective effect only. However, this was characterized by the then Chief Counsel as an "unusual circumstance" because the substantive issue was of widespread importance and, during the interval, the Service had issued a number of private rulings relying on the earlier acquiescence. See Rogovin, supra, at 773.

220 See Rogovin, op, cit, supra note 216 , at 773 .

221 Ibid. 
Technical Information Releases (so-called TIR's) which typically do resemble exceedingly abbreviated published rulings. It even follows this practice for a very few district court cases.

\subsection{Practices peculiarly important to taxpayers}

Taxpayers in irreconcilable conflict with a tax administration also have peculiar concerns extending beyond the independent tribunals' structural arrangements. These pertain primarily to practices affecting the convenience of litigating a dispute.

Insofar as affected by geography, the convenience of taxpayer access to a trial tribunal was discussed earlier in connection with structural arrangements. Relevant also, however, to convenient access are other practices relating to (i) the point in time when the disputed amount must be paid and (ii) the matter of representation.

If it were true that a "king can do no wrong," 222 i.e., if the sovereign never forced to litigation issues other than those it was sure to win, there would be scant reason to object if payment of the amount in actual dispute were required before according access to a trial tribunal. Governments, however, like private citizens, often are adjudged wrong by trial tribunals. For example, of those U.S. Tax Court decisions which, in fiscal 1966, became final because not appealed, taxpayers were held to be wholly right in 18 percent and partially right in another 34 percent, for a total of 52 percent. 223 In similar circumstances involving suits between private parties, no government would dare have the temerity to enact a law which presumed an alleged debt was owing and which required payment before a trial court had spoken. Is it not then unbecoming for that same government to establish a different norm for cases where it is a party, solely for its benefit? There is, moreover, a second consideration: requirement of such prior payment can seriously inconvenience many taxpayers. Do not these reasons suggest that no prior payment should be required? Until an independent tribunal has spoken, it is enough that-as in the case of private litigation-(i) interest continue to run against the taxpayer should he lose and

222 See 3 Blackstone, Commentaries on the Laws of England 254 (1st ed. 1768).

223 This meant the government was wholly right in $48 \%$ and partially right in $34 \%$, for a total of $82 \%$. See Commissioner of Internal Revenue, op. cit. supra note 46 , at 44 . 
(ii) remedies be available to safeguard the government's chance to collect if there is reason to believe it otherwise would be in jeopardy.

The Belgians apparently think this is not enough. As a matter of law at least, there the duty to pay is not suspended pending resolution of the controversy by a trial tribunal. 224 The exact contrary is true in Britain: there payment is postponed when a dispute is carried to either the General or Special Commissioners. 225

The United States, as to substantive income tax disputes, has never decided which of the two competing practices is correct. Though it is entitled to interest on unpaid amounts owing 226 and does possess remedies to safeguard its chance to collect, 227 it follows the Belgian practice (prior payment) if the taxpayer prefers to litigate before either the appropriate district court or the Court of Claims. But it is content with the British practice (postponement) if a taxpayer tries his suit before the U.S. Tax Court.228 Germany 229 and France, 230 while less equivocal, adopted a yet different practice which falls between the Belgian and British usages. In Germany, for example, the local finance office itself generally has discretion in the matter. However, postponement must be authorized in either of two circumstances, both of which can be tested by summary judicial review even before an action on the substantive issue is filed. The two circumstances involve cases where either genuine doubt exists regarding the merits of the government's position or prior payment would have an unnecessarily harsh effect on the taxpayer.

Representation requirements also can affect adversely the convenience of taxpayer-access to a trial forum. In small

224 See Chap. VII, §3.4 and Chap. VIII, §4.3 infra.

225 See Chap. XX, $\$ 4.3 \mathrm{a}$ and $4.3 \mathrm{~b}$ infra .

226 See I.R.C. $\S 6601$.

227 Perhaps the most important is the jeopardy assessment. See I.R.C. $\S 6861$ et seq.

228 This is because by statute-absent a jeopardy assessment-the disputed amount cannot be assessed until the government serves notice of the taxpayer's right to appeal to the Tax Court and, assuming a timely appeal, until the decision of that court becomes final. I.R.C. $§ 6213$. However, should the taxpayer appeal the Tax Court's decision, payment will not be further postponed unless the taxpayer files an appropriate bond. I.R.C. \$7485. The Tax Court is an available forum, however, only as to income, estate, and gift taxes.

229 See Chap. XVI, §4.3 infra.

230 See Chap. XI, §3.4b, and Chap. XII, §4.1 infra. 
cases particularly, it actually may be against taxpayer economic self-interest to employ the particular type of representative required or, for that matter, any representative at all. However, given the adversary system, every such taxpayer has a conflicting concern, namely, that his case be presented effectively. Trial tribunals themselves have a stake in that concern. First, in the interest of their own efficiency, they would prefer not to waste any time on cases obviously and completely devoid of merit, but instituted because completely unknowledgeable taxpayers sought to represent themselves. Second, it is difficult for a tribunal to wear two hats, to try to serve as an advocate for the taxpayer and be also an objective judge.

In resolving these conflicting concerns, all six of the countries covered here permit a taxpayer to represent himself. ${ }^{231}$ However, in Germany, should the trial tribunal conclude that a given taxpayer is incapable of this, a new law permits the court to require him to secure counsel 232 though, as later observed, not necessarily a lawyer. In France, the difficulties which so-called pro-se cases pose for the tribunal are mitigated by a yet different practice, actually applicable to all cases. A subordinate of the tribunal itself is required to submit to it his own objective analysis of a case. 233 This analysis is in addition to and independent of those submitted by the two competing parties. In the United States, it has been proposed that a small claims division, with simplified procedures, be added to the Tax Court. In effect, an independent Commissioner would serve as judge, and often also as the advocate for taxpayers subjected to small (less than $\$ 2,500$ ) proposed deficiencies. 234

Closely related to the foregoing problem is the question of whether taxpayers who do desire representation should be barred from employing non-lawyers. In the case of general (non-tax) legal matters, tradition, society's interest, and affected tribunals are served where a country maintains, for the benefit of those who seek representation or mere legal advice,

231 See $\$ 4.3$, Chaps. VIII, XII, XVI, XX, and XXIV; and 28 U.S.C. $\S 1654$.

232 See Chap. XVI, §4.3 infra.

233 See Chap. XII, \$4.3 infra. Belgium, in "public interest" cases, follows a similar practice though the role is performed by a member of the Attorney General's staff. See Chap. VIII, §4.2 infra.

234 See S. 18, 90th Cong., 1st sess. (1967). Also see 113 Cong. Rec. (daily ed.), Jan. 11, 1967, S55. The commissioner's decision would be subject to internal review by a judge. 
a class of professionals (lawyers) whose prescribed training tends to assure a minimum level of competence. In a given country, however, circumstances may deprive the legal profession of any justifiable claim to a monopoly over certain matters that otherwise might be deemed to involve lawyer-like activity. For example, even in several of the highly developed European countries covered here, law schools have almost entirely ignored fiscal law. In consequence, given the complexity of the subject, lawyers as a class did not have the preparation necessary to pre-empt the advisory role in tax affairs. As legally trained individuals were unable to meet an obvious societal need, the resulting partial vacuum was filled by graduates of other disciplines (accountants or economists), by persons formerly employed and trained by the tax administration, or by self-educated and self-styled "experts." 235 These persons not only prepared returns but, as disputes arose, also represented taxpayers in their dealings with the tax administration itself.

All the European countries covered here except France responded to this extensive use of non-law trained counsel by permitting non-lawyers who work in this field to represent taxpayers fully before their respective trial tribunals. And France imposes only one limitation. 236 No doubt factors contributing to their decision included taxpayer convenience and the supposition that subject-matter knowledge-not just the skill qua skill of an advocate-counted for something.

According these considerations special weight and effect in the tax setting doubtless was facilitated in Germany, the Netherlands, and Great Britain by one further fact. Since these countries utilize separate specialized tribunals or chambers for the trial of tax cases, it was possible, without disrupting normal judicial procedures elsewhere, to develop informal procedures for these cases. The decidedly informal petitions and procedures utilized in Germany and the Netherlands 237 make it possible to carry on a conflict resolution process though German and Dutch lawyers rarely appear at this level.238 It also is very unusual for a British barrister to appear before England's General Commissioners. Taxpayers represented there typically employ accountants or solicitors; and the government itself is represented by a non-legally

235 See $\$ 1.5$ and 1.6 in Chap. V, IX, XIII, XVII, and XXI infra.

236 See text accompanying note 242 infra.

237 See $\S 4.3$ in Chaps. XVI and XXIV infra.

238Ibid. Also see $\S 1.6$, Chaps. XIV and XXI infra. 
trained inspector. 239 Not surprisingly, the procedures followed there are not as formal as those adhered to by the Special Commissioners before whom typically only solicitors and barristers appear for taxpayers, with the government usually being represented by its Solicitor's Office. 240 Comparably in Belgium, though non-lawyers are permitted in tax cases to perform the same function as lawyers, the fairly formal procedures followed taken in conjunction with the fact that the government itself is represented by a regular practicing member of the bar probably help explain why a lawyer customarily serves as the taxpayer's representative. 241

France, the only European country of the five to subject taxpayers to a formal detriment should they employ nonlawyers at the trial stage, does permit such a representative to prepare petition, brief, or any other essential document. The only restriction: he may not participate in oral argument before the tribunal.242 In actuality, however, French taxpayers most frequently are represented by persons who do hold a law degree and who, earlier in their careers, served as government inspectors. And their adversaries are of like quality, i.e., come from the legally trained inspectors presently employed by the government. 243

Practice at the trial level in the United States differs from every one of the foregoing usages, though it most nearly approximates that of Belgium. Prior to World War II, U.S. law schools-like so many of their present European counterparts-tended to ignore tax law. In consequence, at an early point in time accountants began to perform a substantial advisory role in tax affairs, prepared returns, and-as disputes arose-represented taxpayers in dealing with administrative officials. Even in that period, however, the heavy turnover suffered by the tax administration's legal staffs supplied the bar with a significant number of practitioners trained in tax matters. Since the war, this continuing reservoir has been complemented by graduates of law schools, practically all of which have instituted substantial course programs in taxation. In consequence of these two facts, though the bar never has monopolized either the giving of tax advice or taxpayer

239 See Chap. XX, § 4.3a infra.

$240 I d$., $44.3 \mathrm{~b}$. Also see Chap. XVII, § 1.6 infra.

241 See Chap. VIII, § 4.3 infra. Also see Chap. VI, § 1.6 infra.

242 See Chap. XII, § 4.3 infra. Also see Chap. IX, § 1.6 infra.

243 Ibid. 
representation at the administrative level, it has been able to maintain in fact, if not in law, a virtual monopoly in representing taxpayers before trial tribunals. Indeed, before two of the three alternative trial forums (district courts and Court of Claims), lawyers alone may appear in a representative capacity, 244 and each tribunal follows the formal procedural rules it otherwise applies to non-tax cases. ${ }^{245}$ Only before the Tax Court are non-lawyers permitted to appear in a representative capacity. 246 While its procedures, in practice, are not quite as well calculated as those of a district court to assist the parties in refining the issues and discovering evidence, 247 these same procedures mirror those of a judicial proceeding, not those of informal administrative hearing. Partly in consequence of this, appearance even there of a non-legally trained representative rarely occurs. Even taxpayers who were represented by large accounting firms during the administrative phase of the conflict resolution process typically employ a lawyer when moving into the litigation stage. In fact, were it otherwise, the accounting firms themselves would become entangled in the forum selection process and in what then becomes tantamount to a conflict of interest. Only a lawyer lacks self-interest when advising a taxpayer as to which of the three alternative trial forums would be most appropriate for his case. 248

At the appellate level, both Britain and the United States utilize courts of general jurisdiction to hear tax cases. 249 While Belgium utilizes a semi-specialized chamber in its Court of Cassation, 250 there, as in the United States, even those taxpayers who employ counsel at the trial level almost always hire attorneys. Hence, it is not surprising that all three countries permit only lawyers to serve in a representative capacity at the appellate level.251 France and the Netherlands, on the other hand, permit others to fulfill this

244 Federal Rules of Civil Procedure, Rule 11; Court of Claims Rules, Rule 2.

245 For a comparison of their respective rules, see Ferguson, op. cit. supra note 26 , at 339 and 348 , and $\$ 4.10$ infra .

246 Tax Court Rule 2.

247. See Ferguson, op. cit. supra note 26 , at 356 , and $\$ 4.10$ infra.

248 Only a lawyer may act in a representative capacity before all three alternative forums.

249 See § 4.5 supra and Chap. XX, §4.4 infra.

250 See $\$ 4.5$ supra and Chap. VIII, § 4.4 infra.

251See $\S 4.5$ in Chaps. VIII and XX infra. 
function-subject to the limitation that they may not make an oral argument. 252 Germany does not even impose this restriction. 253

\subsection{Practices of common concern}

Of the three parties associated with tax litigation at the trial level (taxpayer, administration, and tribunal), at least two have a common stake in three different goals. Each party shares an interest in fostering practices which efficiently and in a timely manner strip down the issues to the absolute essentials. Then, as to any issues remaining in dispute, practices which assure one party of the opportunity to obtain evidence under the control of the other become equally important, most often to the government but sometimes to the taxpayer. Finally, all three would appear to be benefited, should bilateral agreement then become possible, by permitting the two contesting parties themselves to terminate the proceedings. On balance, however, a practice of entering into agreements at this belated stage may be against the long-range procedural interests of the administration and of the tribunal, and of net benefit only to the particular taxpayer.

Timely refinement of issues is calculated to avoid both waste and surprise. The central need is to complete the process well before either party is "up against the gun." Most illustrative is the situation where a tribunal schedules oral hearings quite far in advance with consideration of evidence limited to that introduced at the hearing itself. Only if the issues are refined well before that hearing can the parties avoid the burdensome waste of collecting evidence affecting matters not actually in dispute, and prepare adequately to deal with all issues that actually will be put in conflict.

In France, 254 the need for advance warning is less serious than in most of the other countries. In the adversary sense, oral hearings in France, as in Belgium, 255 are of less significance. 256 Further, typically the evidence is in before the parties are put "up against the gun." Before the hearing is

252 See $\S 4.5$ in Chaps. XII and XXIV infra.

253 See Chap. XVI, §4.5 n. 25 infra.

254 See Chap. XII, §4.3 infra. Some parallel between French practice and that of the U.S. Court of Claims is noted in Ferguson, op. cit. supra note 26 , at 348 .

255 See Chap. VIII, §4.3 supra.

$256 C f$. $\$ 4.3$ in Chaps. XVI, XX, and XXIV supra. 
scheduled but after the petition and answer have been filed, the parties continue to sharpen the issues and arguments and to introduce evidence, by exchanging repeatedly through the tribunal further memoranda and supporting documents. They continue this process until one party fails to reply in a timely manner to the last memorandum submitted by the other. 257 The hearing which then follows consists of little more than oral argument. Ordinary witnesses do not appear.258 And should the tribunal itself inquire into a matter which leads a party to invoke a yet new ground, it must allow the other party time to prepare a responsive written memorandum and supporting documents.

The extent of responsibility a tribunal itself assumes necessarily affects all three of the previously mentioned common concerns. This is best illustrated by the contrasting experiences in Germany and the United States, two countries which do permit oral hearings with witnesses, etc.

The German fiscal courts reserve a more dominant role for themselves than do their U.S. counterparts. 259 Neither contestant bears the burden of proof. The fiscal court itself has the ultimate responsibility to unearth the truth and to decide the case in accordance with law. In consequence, the court does not accept formal agreed stipulations of fact. Further, if either party files a statement lacking sufficient specificity, the court-to satisfy its own need-may require submission of another, addressed more precisely to the issues in controversy. To that same end, it may require a party to submit evidence in response to matters introduced by the other. Finally, because it is the court's responsibility to decide the case in accordance with law, the parties themselves cannot terminate the proceedings on reaching a bilateral agreement. Only if the court deems the latter to accord with the tax law, will it be approved and the proceedings terminated. Thus, even if the parties were so-minded, the proceedings would not be dismissed should such an agreement attempt to

257 If these exchanges are continued unnecessarily, the tribunal can terminate this stage. See note 26 supra.

258 While the parties may agree upon a nonpartisan "expert" witness to determine a question of fact, or have the tribunal appoint such a person as head of a three-man panel, findings of fact by the expert also are submitted in writing. See note 26 supra.

259 See Chap. XVI, § 4.3 infra. 
split an issue which the tribunal itself necessarily would have had to decide entirely for one side or the other. 260

A trial in the United States, on the other hand, tends to be more adversary in character, as distinguished from the inquisitorial type of proceeding.

In litigation before the Tax Court, for example, one of the parties always has the burden of proof. Generally, it is the taxpayer. 261 At the least he bears the burden of proving that the deficiency asserted by the Commissioner was "arbitrary and excessive." 262 This, taken in conjunction with two facts, that the date of the session at which the trial will take place typically is set three months in advance 263 and that the court frowns on continuances, 264 emphasizes his need to have the issues sharpened well in advance.

Ideally, he should have been informed of the administration's precise position before he filed his petition. The final notice he received from the administration, 265 rejecting his contention as to a disputed item, should have indicated the specific ground for so doing. This is not always possible, however, and is not a requirement. One recurring reason why the administration cannot be specific at that point is attributable to the taxpayer himself, and grows out of the fact he need not exhaust his administrative remedies before filing a petition with the Tax Court. A taxpayer, who does not invoke the last administrative appeal (regional Appellate Division) available before a petition must be filed, in effect forces the administration to issue the notice before its most trusted field officials have had a reasonable chance to work out the specific grounds upon which it ultimately would want to rely. That these officials are bypassed at this point in approximately

260 That the German tax administration itself would not be so-minded, see Chap. XV, § 3.4 a infra.

261 With respect to matters belatedly raised (see text accompanying note 268 infra) and the issues of fraud and transferee liability, the government bears the burden. I.R.C. $\$ \$ 7454$ and 6902 (a).

262 Helvering v. Taylor, 293 U.S. 507, 513 (1934). However, once the taxpayer satisfies this burden, the Commissioner has the burden of establishing the correct but lesser deficiency owing. Ibid. It is otherwise in the case of a deduction. Mahler v. Commissioner, 119 F.2d 869 (2d Cir. 1941), cert。den. 314 U.S. 660 (1941).

263 Tax Court Rule 27 (c).

264 Tax Court Rule 27 (d).

265 This is a statutorily required notice of deficiency. I.R.C. $\$ \S 6212$ and 6213. 
two-thirds of all cases petitioned to the Tax Court 266 indicates the dimensions of the government's difficulty. $\mathrm{Be}$ that as it may, the final administrative notice is legally sufficient if it indicates the amount of the asserted deficiency and the years involved. 267 Indeed, there is a complementary principle which tends to deter specificity: should the notice set forth a specific ground, later adoption-in the government's answer to the taxpayer's petition-of a yet different inconsistent ground will shift the burden of proof as to that ground from the taxpayer to the administration. 268

While the petition the taxpayer subsequently files must contain "Clear and concise assignments of each and every error which the petitioner alleges to have been committed by the Commissioner," and "Clear and concise ... statements of the facts upon which the petitioner relies as sustaining the assignments of error," 269 it includes neither evidence nor legal arguments. Once filed, the petition of course can be amended. 270

266 Commissioner of Internal Revenue, op. cit. supra note 46, at 134 (Table 17A). The problem of reviewing statutory notices which then must be issued by lower echelons (District Director) is further complicated by the fact that approximately 200,000 taxpayers annually receive such final administrative notices only because they defaulted on all mail received from the tax administration.

267 Luke v. Commissioner, 23 TCM 1022 (1964); Holmes v. Commissioner, 22 T.C. 214 (1963).

268 Tax Court Rule 32. Tauber v. Commissioner, 24 T.C. 179 (1955). Also see Papineau v. Commissioner, 28 T.C. 54 (1959). Buf, if the notice merely cites the "Internal Revenue Code," without identifying a specific section, the burden will not shift though the government later places its reliance on a given section. Sorin v. Commissioner, 29 T.C. 959 (1958), aff'd 271 F.2d 741 (2d Cir. 1959). Cf. Luke v. Commissioner, 23 TCM 1022 (1964); Spangler v. Commissioner, 32 T.C. 782 (1959), aff'd 278 F.2d 665 (4th Cir. 1960), cert. den. 364 U.S. 825 (1960).

269 Tax Court Rule 7.

270 Tax Court Rule 17. Indeed, should the taxpayer, at the subsequent hearing, introduce testimony bearing on an ultimate fact not pleaded, he can make a motion to be permitted to conform the pleadings to the proof (Tax Court Rule 17 (d)), in which case, to avoid surprise, the government can request an extension of time within which to reply. Tax Court Rule 20. But in contrast to practice before the district courts, should the taxpayer introduce such testimony without amending his pleading, thereby creating the possibility of misleading the government, that testimony will not be considered by the court. Factor v. Commissioner, 17 TCM 459 (1958), aff'd 281 F.2d 100 (9th Cir. 1960), cert. den. 364 U.S. 933 (1961). 
Again to avoid surprise, the government's answer to the petition must indicate "fully ... the nature of the defense." Further, it must contain a "specific admission or denial of each material allegation of fact ... and a statement of any facts upon which the Commissioner relies for defense. . . "271 Finally, if the government desires to raise a new issue not covered by the previously mentioned final administrative notice, the facts pertaining thereto must be stated. 272 As to these, as before noted, it assumes the burden of proof.

Either party can test the degree of factual specificity actually necessary for either the petition or the answer by a motion that the other party be required to file "a further and better statement of the nature of his claim, of his defense, or of any matter stated in any pleading." 273 No doubt the court's attitude toward such a motion in any given case is and should be affected by two considerations: (i) the extent to which the non-moving party could be expected at this early point to know the facts in more specific detail, and (ii) the fact that, by the time the case is ready for trial, the court "expects," in contrast to German practice, that the parties will have stipulated formally "evidence to the fullest extent to which complete or qualified agreement can be reached including all material facts that are not or fairly should not be in dispute."274 To this latter end, the court expects the parties to commence to discuss stipulation possibilities not later than that point when they receive the typical three months' advance notice setting the date when the trial session will begin. 275 Until recently, however, this expectation was toothless. Not until the trial began was it necessary for a non-moving party to answer a motion to show cause why he should not stipulate facts and evidence contained in the moving party's proposed stipulation. 276

271 Tax Court Rule 14.

272 Ibid. Thus if a new ground is asserted for the first time in the legal brief which the government files after the hearing is over, it will not be considered by the court. Weisner v. Commissioner, 20 TCM 1150 (1961). Cf. Commissioner v. Licavoli, 252 F.2d 268 (6th Cir. 1958). But cf. Luke v. Commissioner, 23 TCM 1022 (1964) where surprise was not involved.

273 Tax Court Rule 17 (c).

274 Tax Court Rule 31(b)(1). Italics added. See Commissioner v. Licavoli, note 272 supra.

275 Tax Court Rule $37(\mathrm{~b})(2)$.

276 See Epstein, "The New Stipulation Procedures in the Tax Court: How They Are Working?"' 22 J. Taxation 180, 181 (1965). 
By amending its rules in two respects, however, the Tax Court put teeth into its expectation. The non-moving party now must answer the show-cause order not later than ten days before the session begins. 277 More importantly, the Tax Court has instituted a pretrial conference procedure 278 somewhat similar to that district courts have long followed.279 Upon request of either side, a judge will sit with the parties to facilitate the process of "narrowing issues, stipulating facts, simplifying the presentation of evidence, or otherwise assisting in the preparation for trial or possible disposition of the case in whole or in part without trial." 280

With respect to one matter, however, the Tax Court has not caught up with the district courts. The latters' procedures are considerably more helpful in discovering evidence, i.e., in assisting a given party, in advance of the trial, to obtain evidence which is under the control of the other party. District court and the Tax Court procedures alike enable a party to take pretrial depositions alone or on written interrogatories. 281 District court procedures also enable a party before trial to request admissions or inspection of documents controlled by the other party. 282

Because it is the taxpayer who usually controls most evidence pertaining to his case, comprehensive discovery procedures are of greatest benefit to the government. That it can be served in two respects, not just one, is best illustrated by the effect of a change made in the way the Justice Department deals with tax cases pending in district courts. Until 1961, when a taxpayer filed his complaint in court, the department tended "to await further moves by the plaintiff." 283 Since 1961, however, it has taken the offensive. Well before trial, it has used the comprehensive discovery procedures available in district courts not only to unearth the truth in

277 Ibid. Tax Court Rule 31(b) (5). Even so, because Tax Court judges ride circuit and do not arrive in a city until the day before a session is to commence, it is still inconvenient to obtain a hearing on the showcause order until the first day of the session.

278 Tax Court Rule 28. See Epstein, op. cit. supra note 276

279 Fed. Rules Civ. Proc., Rule 16.

280 Id., note 278 supra.

281 Fed. Rules Civ. Proc., Rules 26 through 33; Tax Court Rules 45 and 46. See Ferguson, op. cit. supra note 26, and Kamisky, "The Case for Discovery Procedures in the Tax Court," 36 Taxes 498 (1958). 282 Fed. Rules Civ. Proc., Rules 34 and 36. 283 Attorney General, Annual Report 1966, 366. 
preparing for trial should such ensue but also to stimulate more and better settlement offers 284 from taxpayer-adversaries who began to realize that discovered evidence increased their hazards of litigation.

This raises the question of whether the government, at this belated stage, should encourage bilateral settlements. That the United States does just this is apparent from the fact that the bulk of all docketed district court and Tax Court cases are settled before trial285 - as in the Netherlands 286 and in sharp contrast to France where few cases are settled after docketing. 287 Also, there is no doubt but that the effect in the United States benefits immediately both contestants. Avoidance of a given trial there, as would be true elsewhere, conserves the contestants' time and reduces their costs. Further, in contrast to the situation in France, 288 Britain, 289 and the Netherlands, 290 where even trials in tax cases are not open to the public, only if a bilateral agreement is reached can the U.S. taxpayer avoid exposing his financial affairs to public view. Finally and of imperative importance, the U.S. Tax Court itself is freed of a caseload it could not possibly decide on the merits. In fiscal 1966, of the 6,234 docketed cases closed out, it was able to decide on the merits only 726.291 Practically all the rest were settled. This fact-that the Tax Court otherwise could not accommodate the case load-is the precise reason why the U.S. tax administration now actually has no choice but to encourage bilateral settlements even at this belated stage. The same reason explains why the Tax Court, in contrast to the German courts, has no choice but to accept each such settlement whether or not it is in strict accordance with the tax law itself. 292 However, given the propriety of

284 Attorney General, Annual Report 1965, 308.

285 See note 175 supra, and Chap. III, §\$ 3.1 and 3.4 supra.

286 See Chap. XXIV, §4.3 infra.

287 See Chap. XII, §4.3 infra.

288 See Chap. XII, §4.3 infra.

289 See Chap. XX, §4.3a infra.

290See Chap. XXIV, §4.3 infra.

291Commissioner of Intermal Revenue, op. cit. supra note 46 . At year's end, 10,024 cases were still pending and, of course, most of these will be settled by agreement.

292 For all practical purposes, the settlements reached at this stage, including those which split a single issue, conform to the same policies as those which are reached during the earlier administrative stage. See Chap. III, § 3.4 supra. 
the aggressive settlement policy the $U_{0} S$. tax administration pursues during the earlier administrative phase, the pivotal question facing a country just now evolving its procedures is this: Over the long haul, would the U.S. tax system have worked more smoothly had its administrators-on first formulating its procedures years ago-treated the inception of the litigation stage as a cut-off point, after which cases would not be settled bilaterally?

As things now stand, the United States has neutralized the otherwise existing taxpayer incentive to make an all out attempt to settle a case before docketing it with a court.

Partly in consequence of this, only after a case has been docketed do many U.S. taxpayer-representatives (4,489 in fiscal 1966) ${ }^{293}$ make their first attempt at settlement. While certain advantages in so doing are peculiar to the United States, 294 an additional advantage would be equally operative elsewhere. By delaying discussions until just before the trial date,295 the taxpayer's representative can prepare simultaneously for settlement discussions and the trial-should one actually ensue.

For a variety of reasons, a second group of taxpayerrepresentatives will make two trys at settlement, one before a case is docketed and, if unsuccessful, one afterward. 296 But

293Commissioner of Internal Revenue, op. cit. supra note 46, at 134 (Table 17 A). Some actually had no other choice, for the District Director had issued a final statutory notice before giving the taxpayer a chance to enter settlement discussions at the regional level. This circumstance may arise, for example, where the statute of limitations was about to run on the proposed deficiency.

294 Most such advantages are discussed in Chap. III, §3.3 supra. Further, since the requisite statutory notice of deficiency will have been issued prior to sertlement discussions, these taxpayers-should a trial actually ensue-are freed of the burden of proof regarding any new affirmative issues raised by the government during the settlement discussions. See text accompanying note 268 supra. It would have been otherwise if the affirmative issue had been raised in settlement discussions which preceded issuance of the statutory notice. See text accompanying notes 261 and 262 supra.

295 While the U.S. tax administration has tried, as to docketed cases, to induce taxpayers to hold their settlement discussions before cases actually are scheduled on a trial calendar (Rev. Proc. 60-18, C.B. $1960-2,988)$, the fact is that a majority of all docketed settlements occur thereafter.

296 The great preponderance of those who follow this route actually achieve a settlement during the first of the two stages. In fiscal 1966, this was true for 21,475 . However, 4,251 failed to reach agreement at that point. See Commissioner of Internal Revenue, op. cit. supra note 46 , at 133 (Table 15B). 
because they know, at the point of the initial attempt, that a second opportunity is available, many do not make an all out attempt to prepare their cases for the first try. 297 In consequence of this, their first effort did not achieve the type of settlement which they were willing to accept. Hence, a second belated try.

Repetitious time drain on the administration 's personnel is the peculiar consequence of this second practice. 298 The practices of both groups, however, contribute to delay in settling old disputes and create, for the administration, an unbecoming image, akin to that of a private litigant "negotiating right up the courthouse steps."

A now developing country will have a chance to avoid the dilemma in which the U.S. tax administration finds itself only by deciding at the outset whether the foregoing consequences are sufficiently adverse to warrant terminating settlement activities at the point a petition is filed with a court. Once such a country extends its settlement activity beyond that point, retrenchment may become impossible. Taxpayers who otherwise might have settled prior to the litigation stage will begin to delay serious attempts at settlement until after the litigation stage is reached. In due time, this number will be so great that the practice cannot be ended without overwhelming the trial tribunals.

297 See Chap. III, note 64 supra.

298 Indeed, even a yet different office becomes involved. See $\S 4.8$ supra. 


\title{
PART TWO
}

\section{BELGIUM}

\author{
by
}

Jean Van Houtte 


\section{CHAPTER V}

\section{ADMINISTRATIVE ORGANIZATIONAL AND PERSONNEL FRAMEWORKS}

\section{Section A. Administrative Organizational Framework}

\subsection{Introduction}

The Belgian Ministry of Finance has three branches charged with the levying of taxes:

Administration of Customs and Excises, Administration des douanes et accises: collects customs and excise duties

Administration of Registration and National Property, Administration de l'enregistrement et des domaines: collects recording and stamp fees, inheritance taxes, transfer taxes, and similar levies

Administration of Direct Taxes, Administration des contributions directes: collects the direct taxes

So-called direct taxes fall into two main categories: the income taxes, properly so-called, and other taxes of somewhat less importance. ${ }^{1}$ The true income $\operatorname{taxes}^{2}$ include the following:

Individual income tax, Impôt des personnes physiques

Corporate income tax, Impôt des sociétés

Income tax on juridical persons, Impôt des personnes morales

Nonresident income tax, Impôt des non-residents

1 Other taxes under the jurisdiction of the Administration of Direct Taxes fall into the two following groups:

(a) Special taxes of which the most important is the tax on motor vehicles, taxe de circulation sur les vehicules à moteur.

(b) Additional taxes for the benefit of provinces and municipalities, additionnels provinciaux et communaux, on income from immovable property, and on the global income of corporations and individuals. Law of July 31, 1963.

2 Law of November 20, 1962, in force from fiscal year 1963 for corporations, sociétés par actions, and from fiscal year 1964 for individuals, partnerships, and private companies, sociétés de personnes. 
The bulk of these income taxes are prepaid through a system of withholding tax, précomptes:

Withholding on income from immovable property, précompte immobilier

Withholding on income from personal property such as securities, loans, royalties, bank deposits, précompte mobilier

Withholding on income from wages, salaries, etc., précompte professionel

At the head of the Administration of Direct Taxes is the Director General of Direct Taxes, Directeur Général, who is responsible to the Minister of Finance. Under the Director General are (a) the heads of the five divisions, and (b) the general inspectors, Inspecteurs Généraux. These latter, the general inspectors, have two functions: they maintain liaison with the offices of the regional directors and they supervise the Special Office of Direct Taxes to which interpretative questions posed by the regional directors are referred.

These regional directors, with whom the central administration maintain liaison through the general inspectors, are responsible for all revenue activity within their respective regions. This includes the resolution of interpretative questions referred to them by taxpayers in the course of administrative appeals.

There are fourteen regional directors for direct taxes, distributed as shown in the following table:

\section{Province}

Antwerp

Brabant

East Flanders

Hainaut

Liège

Limbourg

Luxembourg

Namur

West Flanders
Population

$1,455,644$

$2,011,842$

$1,276,803$

$1,249,536$

$1,007,516$

586,279

216,975

370,870

$1,075,949$
Number of

Divectors

The office of each regional director maintains liaison with the field offices through another group of inspectors, inspecteurs des contributions. There are two types of field offices: 
the controles and the receveurs des contributions. The controles are concerned primarily with the examination of tax returns, assessment, and audit. Some, however, have a particular area of specialization such as the taxation of corporations throughout an entire regional area. The offices of the collectors, receveurs des contributions, handle tax payments and prosecute delinquent taxpayers.

\subsection{Organizational framework, national office level}

Chart I (pages 172-73) reflects the organization of the Central Administration of Direct Taxes at the national level.

The head of the Central Administration of Direct Taxes, the Director General, has under him (a) the heads of the five divisions plus (b) the general inspectors, Inspecteurs Généreaux. Of the five divisions, the first four are organized along both functional and tax lines. The fifth division's prime responsibilities are administrative in character, covering the areas of statistics, accounting, personnel, housing, and equipment.

The first division has two subdivisions. The first deals with legislative matters (i.e., drafting of bills, assisting the Ministry of Finance in the course of the legislative process) and with the implementation of legislation by Royal Decree. The second subdivision deals primarily with the taxation of nonresidents and in consequence conducts tax treaty negotiations. The first of those two subdivisions is not concerned directly with the resolution of interpretative questions, but should a court resolve an interpretative issue adversely to the government, the Ministry of Finance frequently decides to introduce corrective legislation. In consequence, the first subdivision, through its legislative activities, necessarily becomes involved in matters of interpretation.

The second division deals primarily with the taxation of corporations, juridical persons, private companies, and partnerships, as well as with the prepayments of taxes on movable property, précompte mobilier.

The third division deals with individual income taxes.

The fourth division has five subdivisions. The first three have two main functions: representing the administration in tax litigation and in interpreting old tax legislation (i.e., laws in force prior to the effective dates of the major reform enacted November 20,1962). The fourth subdivision supervises the collection of taxes. The fifth has two areas of concern: prepayment of tax on income from immovable property, précompte immobilier, and various minor taxes, such as those on motor vehicles, taxe de circulation sur les vehicules $\dot{a}$ moteur. 


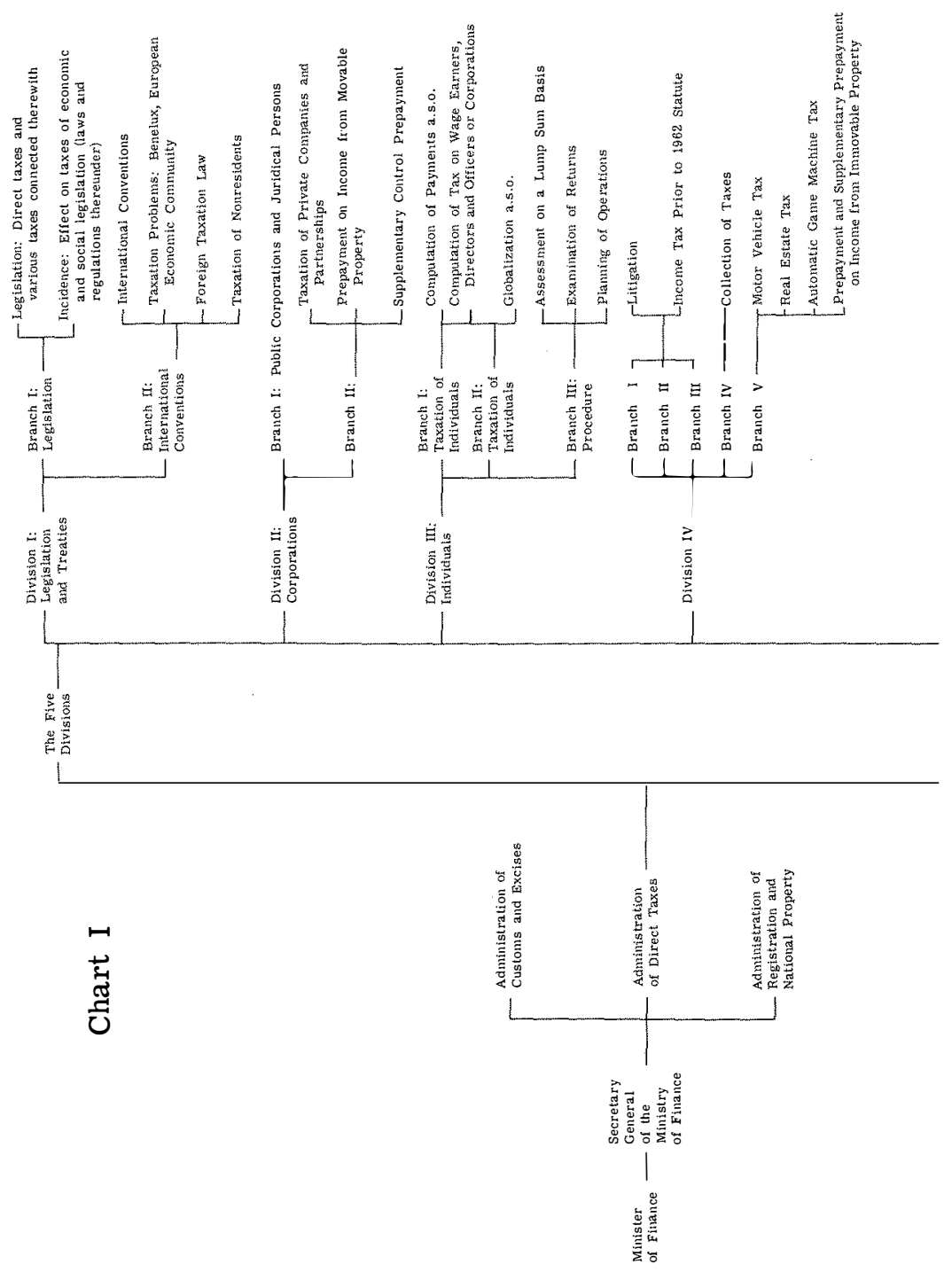




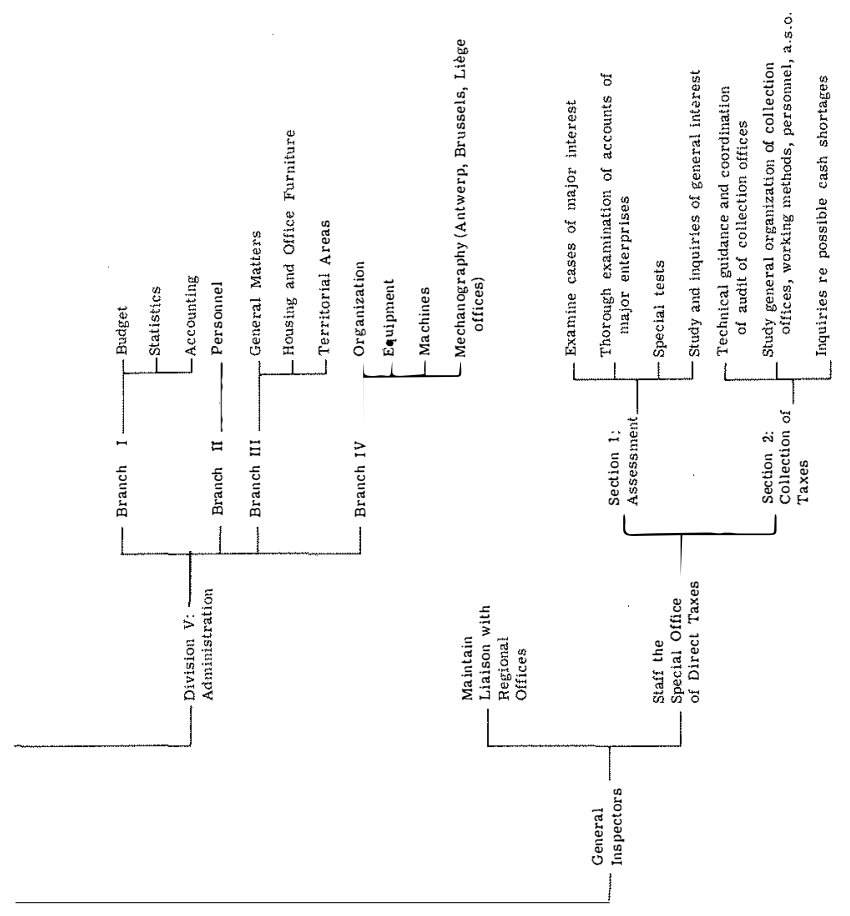


The divisions of the Central Administration of Direct Taxes deal only indirectly with interpretative problems, by reviewing regional inspectors' decisions on interpretative issues submitted by taxpayers in the course of administrative appeals. In contrast, the Special Office of Direct Taxes (staffed by general inspectors but responsible also to the General Director) deals directly with interpretative issues. Those interpretative questions which are laid before regional directors are sent to the Special Office of Direct Taxes which, lacking a superior office to which it may refer them, handles them itself.

\subsection{Organizational framework, regional office level}

Chart II (page 175) sets out the structural arrangement of both regional and local offices concerned with direct taxes.

As noted supra, liaison with the 14 regional directors of direct taxes, distributed through the 9 provinces, is maintained by the Director General of Direct Taxes (the head of the Central Administration of Direct Taxes) through the general inspectors. In turn the regional director, the chief administrator for his area, ${ }^{3}$ maintains liaison with the local offices through the inspecteurs de contributions. This group of inspectors is subdivided into three groups. The members of the first group, the accounting inspectors, handle the collection of taxes and supervise the local collection offices, headed by the receveurs des contributions. The two other groups, inspectors $\mathrm{A}$ and the inspectors for litigated matters, deal with assessment of taxes. Inspectors A supervise those local offices which deal with inquiries and with assessments, controles. This supervision includes a review of uncontested decisions made by the local assessing officials. In addition, inspectors $\mathrm{A}$ furnish advice to the local assessing officials in connection with interpretative issues encountered prior to making the actual assessment.

Inspectors for litigated matters, in contrast to inspectors A, do not supervise the work of lower officials. They assist the regional director in resolving administrative appeals lodged with the regional director by taxpayers following assessment by the local assessing offices.

Thus, through the two different sets of inspectors, the regional director is concerned with the resolution of substantive interpretative income tax questions at three points: first, when

3 As chief administrator, he is assisted by one or two assistant directors as to matters such as housing, equipment of offices, and personnel over all his territory. 


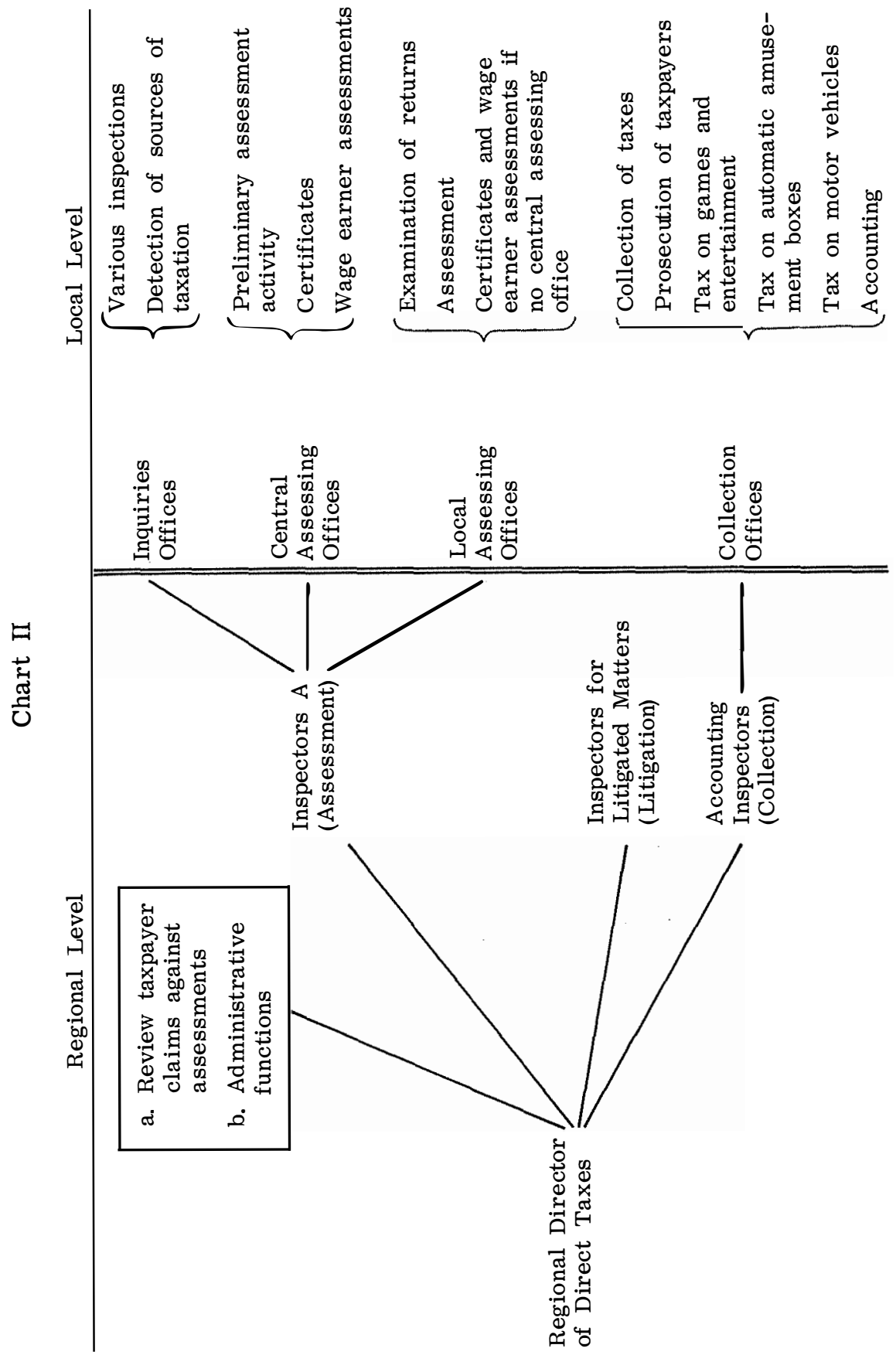


inspectors A are consulted by the local assessing officials prior to actual assessment; second, indirectly, as inspectors A review uncontested decisions made by the local assessing officials; and third, directly, when inspectors for litigated matters deal with administrative appeals lodged by taxpayers with respect to assessments made by the local assessing officials.

\subsection{Organizational framework, local office level}

In 1.3 supra, it was noted that inspectors $\mathrm{A}$, in addition to other specified duties, supervise the locally situated assessing offices, controles. Each inspector $\mathrm{A}$ is in charge of some particular part of the region to which he is assigned. Each such area has a number of local assessing offices.

These local assessment offices are of three kinds: (1) typical local assessment offices which deal with income tax returns of individuals within their respective areas, (2) central assessing offices which are located only in more populous areas and handle the less complex returns of individuals, leaving to the first mentioned local assessing offices within that same populous area the task of examining and assessing more complex individual returns, and (3) corporation assessing offices which are responsible solely for the income tax returns of corporations and private companies.

Irrespective of the type of return with which a particular assessing office is concerned, the basic pattern of its activity is similar to that of all other assessing offices. Each assessing office distributes, examines, and corrects returns. An attempt is made to iron out differences of opinion with taxpayers. If such differences cannot be resolved, the head of the local office, controleur, makes whatever decision he believes to be correct, including resolution of interpretative issues. On the basis of such decision, assessment is made. Administrative appeal from such an assessment is lodged with the controleur's superior, the regional director.

Belgium has about 325 local assessment offices to accommodate the returns of individuals. Where such an office is located in a city, it is responsible for between 15,000 and 20,000 people. Where located in the country, the number rises to about 30,000 . Since the territorial area fixed for a particular local assessment office is governed by population density, there is considerable variation. Illustratively, 20 or more small municipalities may be included within the area for which one rural assessment office is responsible, while Antwerp and Brussels, suburbs excluded, have respectively 15 and 16 local assessment offices. 
More populous cities of this type also have central assessment offices which are responsible for the more or less routine examination and assessment of wage-earners' returns (which present fewer interpretative questions than do other returns). Such central assessment offices also accomplish the preparatory work in collecting information about other taxpayers who fall under the jurisdiction of the various local assessment offices in that same area, and also the tax withholding. Thus local assessing offices within the area covered by the central assessing office are free to concentrate on a thorough examination of the more complex individual returns.

To increase efficiency in the examination of ordinary individual income tax returns, the larger local assessment offices classify such returns on the basis of the business or profession of the taxpayer. Each such occupational group then will be assigned to a particular official who specializes in that particular category. Because he becomes familiar with the tax problems likely to be encountered by such individuals, he can resolve more readily questions relating to expenses and deductions.

The duties of the third type of locally situated assessment offices (those which handle income tax returns of corporations and private companies) parallel the duties of the offices concerned with individual returns. They distribute and examine returns, resolve differences of opinion with taxpayers, and make assessments. While these offices concentrate on corporate returns, they necessarily work in close contact with the central assessment offices. Throughout Belgium there are about 80 corporation assessment offices. On the average, each examines the returns of about 600 corporations or private companies. There is no uniformity in size of the territory each covers, since it depends upon the number of corporations or companies within a given area. Illustratively, the entire province of Luxembourg has one corporation assessment office, while Brussels and its suburbs have twenty-five.

\section{Section B. Personnel Framework (Governmental and Non-Governmental)}

\subsection{Governmental professional personnel}

All employees of the Administration of Direct Taxes are subject to a statute covering all government officials or employees. For an individual to be employed at any level in the 
Administration of Direct Taxes, he must pass a competitive examination, administered by the central government recruiting office. Such an examination is held when requested by the Administration of Direct Taxes, usually once a year.

While there are four categories of government employees, tax administration employees charged with interpretative matters fall into the first two. The first category includes the heads of assessment offices, controleurs, chief collectors of taxes, receveurs principaux, inspectors, directors, and other higher ranking officials. The second category includes the technical clerks, redacteurs, as well as collectors and verifieraccountants.

Typically personnel dealing with income tax matters enter the Administration of Direct Taxes at the second category. Entrance at the first category, which requires a university degree, is very unusual.

Admission to the examination for the second category requires that the applicant be between 17 and 30 years of age 4 and have completed a secondary education-i.e., college, technical school, etc. The examination is designed to measure the applicant's general knowledge and includes questions on elementary mathematics, geography, and Belgian history. In addition, each candidate attends a lecture dealing with a topic of general interest. Without taking notes, he must summarize and comment thereon.

Successful candidates are admitted on probation. The probation period, for both the first and second categories, lasts two years, at the end of which comes a final examination dealing only with income tax laws. In case of failure, a second examination may be taken, but failure here entails dismissal from the service on three months' notice.

After at least four years' satisfactory service in the second category, officials are eligible for a competitive promotionexamination to qualify for appointment to the first category. This examination tests knowledge not only of areas included within the earlier entrance examination but also of tax laws and regulations, civil and commercial law, accounting, etc. However, once an individual reaches the first category of government employees, promotions no longer depend upon examinations.

4 Some members of the metropolitan or former African administration are excepted from the age limit. 
There is an extensive in-service training program, partly to prepare probationers for their final examination and partly for all levels of permanent employees, whether in preparation for promotion-examinations or in an effort to keep abreast of current developments in the statutes, decisional law, and administrative regulations. This training takes place almost entirely outside the regular hours of employment; "full-time" inservice training is completely unknown.

The government also pays the full expense of technical clerks who subscribe to a correspondence course dealing with commercial, industrial, and corporate accounting and with balance sheet analysis. Under exceptional circumstances-as in the case of the sweeping tax reform of November 20, 1962-additional lecture courses are given. Otherwise, in-service training is based primarily on private study of material published by the Central Administration of Direct Taxes. This material includes codifications of laws, the regulations, and official instructions (available to the public as well), and manuals such as the following: Organization of Public Administration, Relations with the Taxpayer, Public Finance, Elementary Concepts of Public and Private Law, Auditing Handbook.

\subsection{Private tax practitioners}

Two classes of private tax practitioners handle the tax affairs of individuals or corporations: tax lawyers and tax experts. The tax lawyer has a university background, with a degree either as docteur en droit or licencié en notariat. While he has passed an examination in tax law, this constitutes insufficient background for tax practice. Typically, a young law graduate planning to specialize in tax law spends many years in the office of one of the very few experienced tax lawyers, first as stagiaire and then as assistant. During that period, he gains practical experience and studies all types of tax materials.

The tax lawyer acts as a barrister in representing a taxpayer in the courts, and also furnishes advice when a taxpayer has a major difference of opinion with the tax administration as well as when an important transaction is under consideration.

The so-called tax expert, on the other hand, typically is not an attorney, although a few have graduated from a university with a degree in law or economics. The majority are accountants and have acquired their knowledge of taxation through experience. The government has not established any 
formal rules governing recognition of tax experts, ${ }^{5}$ although the major professional associations act as winnowing agents by accepting as members only those who have a good reputation and essential qualifications. If a tax expert is a member of an accounting firm, the firm usually will handle both the accounting and tax affairs of a client. However, some tax experts maintain an office as independent consultants or, at the other extreme, are employees of a large corporation. Such corporations expect the heads of their accounting departments to be knowledgeable and experienced in tax problems. In whatever capacity a tax expert works, he is likely to be engaged on a continuing basis in dealing with the current tax matters of one or more individuals or corporations. He is responsible not only for the annual preparation of income tax returns with their supporting documentation, but also represents his client or clients in resolving those differences of opinion with the tax administration which do not require a legal opinion.

5 Other than the negative provision of the law of November 20, 1962 , Art. 60, which enables the Minister of Finance to deny a tax expert the right to represent a taxpayer before the tax administration if he has not observed the ethical standards of his profession. 


\section{CHAPTER VI}

\section{ADMINISTRATIVE RULE-MAKING PROGRAMS}

\section{Section A. Character of the Underlying Statute}

\subsection{Precision of the statute itself}

The Code of Income $\operatorname{Tax}^{1}$ is divided into 437 sections covering about 100 pages with an average of 400 words a printed page. Most but not all substantive tax principles are set out in the Code. Those located outside the code include:

1. Such laws as temporary tax relief measures, ${ }^{2}$ or those granting provinces and municipalities a restricted power to tack surcharges on the national income $\operatorname{tax}^{3}$

2. Laws approving international tax treaties, ${ }^{4}$ and

3. Royal decrees which particularize on the Code's tax principles, pursuant to a specific delegation of legislative authority in a substantive section of the statute. ${ }^{5}$

The Code of Income Tax is divided into ten parts, each with a varying number of sections totaling 429 . Of these, sections 206 through 359 deal primarily with procedural matters.

1 The Royal Decree of February 26, 1964, known as the Code of Income Tax, coordinates the reform law of 1962, "the reform of direct taxation" and the "coordinated laws on income tax" put into effect in 1948.

2 E.g., enactment of July 15, 1959, providing for the partial or total exemption of capital gains to promote investments.

3 E.g., enactment of July 31,1963 , authorizing municipalities to levy a tax of $5 \%$ in addition to the regular corporate tax and/or individual income tax.

4 E.g., the statute of July 27, 1953, approving the income tax convention between Belgium and the United States, signed at Washington October 28, 1948, as modified and supplemented by the convention of September 9, 1952.

5 The "reform of direct taxes," November 20,1962, makes frequent use of this delegation of power. Decrees so issued must be distinguished from regulations bearing upon tax administration in a more precise sense of the term. Regulations of course, are the proper task of the executive power. Belgian Constitution, Section 67. 
Part

Number
Title of Part

I Definition of the income tax

II Individual income tax

III Corporate tax

IV Tax on juridical persons

V Nonresident tax

VI Provisions common to the four taxes such as prepayments, etc.

VII Assessment and collection of taxes

VIII Allocation to provinces and municipalities

IX Cadastral income of immovable property

$\mathrm{X}$ Transitory provisions
Section

Numbers

$1-2$

$3-93$

94-135

$136-138$

$139-152$

$153-205$

206-350

$351-359$

$360-429$

Despite its length, the statute itself is not expected to provide clear-cut answers to all problems. ${ }^{6}$ Every effort is made to be as precise as possible and to set out broad rules with a minimum of deviations. Nevertheless, administrative regulations are necessary to supplement the text of the statute itself and the judiciary also is called upon to settle many interpretative issues. ${ }^{7}$ Here, however, it is possible only to illustrate the statutory approach and the variation in the extent to which the statute anticipates with precise language the range of problems, which arise.

Consider first the methods by which it determines the taxable base from professional activity.

Article 43 of the Code provides as follows:

From the gross income of each professional activity are deducted the expenditures [dépenses ou charges] allocable to it. 8

The next section defines deductible professional expenditures:

Deductible professional expenditures are those the taxpayer proves have been made or supported during the taxable period in order to acquire or preserve the taxable income. ${ }^{9}$

6 The only problems susceptible of such ready solution would be questions such as those relating to the tax rate for a net income of a given number of francs, or to the final day for submitting a claim.

7 Every other consideration aside, the government, on introducing the bill or in discussing it before Parliament, cannot be expected to forecast all possible future developments in the area expected to be covered by a particular provision.

8 Art. $10,1^{\mathrm{o}}$, law of November $20,1962$.

9 Art. 11 , § 1 , law of November $20,1962$. 
It still must be determined whether an expenditure is made "in order to acquire or preserve the taxable income." While the statute goes on to enumerate certain deductible items-i.e., rent, heat, utilities for professional premises; wages and fringe benefit costs for employees; "normal" amortization of professional equipment-the list is not conclusive. ${ }^{10}$ The tax administration must also permit a deduction for any operational expense reasonably incurred in the course of the taxpayer's business activity. Illustratively, the cost of litigation concerning business would qualify, ${ }^{11}$ but not fines or punitive damages. 12

A second example of the statutory approach involves amortization, as to which the Code contains only two broad provisions. It authorizes "necessary amortization" of material and movable objects used in the business, to the extent such amortization corresponds to real depreciation occurring during the taxable period. ${ }^{13}$ Prior to 1963 straight line depreciation was the only authorized method. ${ }^{14}$ The officer in charge of the assessing office computed it by category of assets, in agreement with the taxpayer. Beginning in 1963, however, the Code authorized the tax administration, at the request of the taxpayer, to prepare a schedule of amortization charges computed on the declining balance method for assets purchased or constructed from 1963 onward. ${ }^{15}$ Clearly, these broad statements of policy do not cover with any precision all amortization problems. ${ }^{16}$ While it seems clear that amortization must be based

10 The items are listed in Art. 45 of the Code, originally enacted as Art. 26, $\$ \$ 2$ and 4, Coordinated Laws on Income Tax, Regent's Decree of January 28,1948 , which is referred to in Art. 11, $\S 1$, of the law of November 20, 1962.

11 Lucrum non intelligitur nisi omni damno deducto. Cass. July 4, 1865, Pasicrisie [hereinafter cited as "P."], 1865, I, 291. See Jean Van Houtte, Principes de droit fiscal belge, No. 254.

12 Art. $50,5^{\mathrm{O}}$ of the Code, Cass. October 26,1954, p. $1955,1,167$. That is the reason why some provisions in the Code make some expenditures related to the business activity not deductible, such as-in contrast to the statute in force prior to the law of November 20, 1962the individual income tax (Art. 50, 39) or the corporate tax (Art. 109).

13 Art. $45,4^{\mathrm{O}}$ of the Code (Art. 26, $\$ 2,4^{\mathrm{O}}$, Coordinated Laws).

14 Under straight line depreciation, the basis is deducted in equal annual installments over the estimated useful life or annual overall percentage.

15 Art. 49 of the Code (Art. 13, law of November 20, 1962).

16 In considering the scope of the amortization problem, it must be recalled that all objects used in any productive capacity are subject to deterioration or obsolescence. This includes not only machinery, industrial buildings, furniture, and office equipment, but also the purchase 
on the cost of an investment and not on the cost of replacement, a large area lies open for interpretative administrative regulations. Thus, one looks to royal degrees to find that the declining balance method may be used only in the case of movable assets having a useful life of not less than six and not more than nineteen years. ${ }^{17}$ Also, they provide that the allowable depreciation percentage is double that used for corresponding assets under the straight line method. Thus, the basis against which that percentage is applied in any given year is said to be the original cost less depreciation taken to date. Further, whichever method is used, the percentage mutually agreed upon can be changed whenever economic contingencies arising from operation so justify.

A third example of the statutory framework concerns valuation of corporate assets. Such valuation is necessary in drawing up a balance sheet and, in Belgium, is an integral step in computing both ordinary gross income and, under certain circumstances, capital gains. ${ }^{18}$ The Code does not specify a particular method of valuation to the exclusion of all others. ${ }^{19}$ Initially, it lies within the discretion of the tax administration to determine whether a given valuation is erroneous and serves to avoid tax. Its determination, however, is subject to judicial review. Indeed, such a case can reach the Supreme Court, Cour de Cassation, if a principle is in issue. Illustratively, in one case a corporate taxpayer had paid 3.840 francs per share for stock of another company. At the close of a later year, immediately before the taxable year in question, it entered these shares on its balance sheet at a value of 3.810 francs though the stock at that point was quoted on the market at 1.950. The corporate taxpayer sought to correct the error in the succeeding taxable year by showing a year-end valuation of 1.950 , the intention being to take advantage of the earlier year's loss in this later year. To preserve the integrity of the annual

(footnote continued)

value of a patent, the expenses and premiums paid for issues of stock and bonds, the preliminary expenses in forming a company, and all the other true expense items included in the asset valuations appearing on the balance sheet.

17 Art. 1, \& 3, Royal Decree of October 8, 1963.

18 Since the tax reform of November 20,1962 , in certain circumstances, capital gains are subject to a special tax of $15 \%$ instead of being subject to the corporate tax of $25 \%, 30 \%$, or $35 \%$. Code of Income Tax, Art. $93, \S 2,2^{\circ}$.

19 The valuation must be reasonable. If there is any overvaluation, the directors are responsible. Art. 62 of the Company Law. 
accounting concept, however, the High Court determined that, since no further decline had taken place in the current year, the shares had to be given the same value as that which had been used the close of the preceding year. ${ }^{20}$ A final example bearing on the degree of precision found in the statute involves dividends. Although Article 171 of the Code provides that a dividend is taxable when allocated or made payable by the company, it does not specify when a dividend will be deemed "allocated" or "made payable." Ultimately, the courts had to resolve this; logically and consistently they held that a dividend is not earned and the shareholder has no right to it until the general assembly (board of directors) reached a decision as to the company's profit distribution. ${ }^{21}$ Then, however, to prevent possible tax evasion, the legislature added a limited exception under which all sums allocated to working partners in private companies are taxable to them as of the last day of the company's fiscal year, whether or not the general assembly had decided to distribute a dividend. ${ }^{22}$

A minority of controversies between taxpayers and the tax administration involve interpretation of the statutory language. ${ }^{23}$ The great majority are purely factual, not developing out of any question as to the meaning of the statute, but rather requiring substantiation of amounts, such as gross income, or the exact amount of losses incurred, etc. As explained later, ${ }^{24}$ in either type of case, a taxpayer who does not agree with the "tax-paper" from the local assessor's office may file a petition with the regional director. If the petition is rejected, appeal lies to the competent Court of Appeal of which there are three. ${ }^{25}$ Decisions of that court can be appealed to the Supreme

20 Cass. September 10 (S. A. Overcor), P. 1964, I, 35.

21 Cass. December 11, 1962 (Suz. Van de Velde), P. 1963, I, 455; Cass. June 11, 1963 (Grimard), P. 1963, I, 1076; Cass. September 10, 1963 (Steinberg), P. 1964, I, 42.

22 Law of April 30,1958 , Art. 2.

23 Illustratively, the deductible trade or business expenses listed in the statute did not include litigation expenses developing out of the conduct of the business. A court decision established that litigation expenses constituted properly deductible expenses. Decision, Cour de Cassation, 4 July 1865, P. 1865, I, 1291.

24 See Chap. VII infra.

25 Court of Appeal for Ghent for decisions of regional directors in the provinces of East Flanders and West Flanders; Court of Appeal for Brussels for decisions of regional directors in the provinces of Antwerp, Brabant, and Hainaut; Court of Appeal for Liège for decisions of regional directors in the provinces of Liège, Limbourg, Namur, and Luxembourg. 
Court only with respect to questions of law. Thus the annual number of Supreme Court decisions involving direct taxes, as set forth in the following table, is some indication of the number of important interpretative issues raised each year:

SUPREME COURT DECISIONS INVOLVING DIRECT TAXES

\begin{tabular}{cccc} 
& \multicolumn{3}{c}{ Claims } \\
\cline { 2 - 4 } Judicial Year & Total & Dismissed & $\begin{array}{c}\text { Probably Involving } \\
\text { Interpretative Issues }\end{array}$ \\
$1957-1958$ & 223 & 27 & 196 \\
$1958-1959$ & 212 & 19 & 193 \\
$1959-1960$ & 196 & 1 & 195 \\
$1960-1961$ & 139 & - & 139 \\
$1961-1962$ & 138 & - & 138 \\
$1962-1963$ & 134 & - & 134
\end{tabular}

Despite the care exercised to draft precise statutes 26 with a minimum of deviations, it is considered likely that interpretative controversies will increase in the immediate future because of the new issues which will arise out of the tax reform law of November 20,1962, and the related decrees.

\subsection{Legislative pre-enactment aids to interpretation}

In interpreting the substantive statutory provisions, documents showing the progress of a statute through the legislative process can be of material assistance, particularly where the legislation is complex, as is true of the tax reform law of November 20, 1962. This does not mean that all stages of the legislative process are equally significant in providing helpful background material. Moreover, there will be great variation in the amount of material available..$^{27}$ For major tax legislation, such as the 1962 statute, hundreds of printed pages 28 are

26 Illustratively, in the discussions preceding the drafting of that section of the statute allowing deductions from gross income for contributions made to the four universities, the original version allowing such deductions for contributions to institutions of higher learning was rejected as imprecise and the specific names of the several institutions were inserted. Art. 54, §4, Code of Income Tax.

27 The fact that all Belgian parliamentary documents are printed folio-size in two columns, the Dutch text next to the French, doubles the amount of printed material.

28 The floor debates are printed in the Annales Parlementaires, with two series: Chamber of Representatives, Chambre des représentants, and Senate, Senat. These are edited by the Government as a supplement to the official gazette (Moniteur Belge, published at 40-42, rue de Louvain, Brussels 1. 
needed to set out the official documents and records of the draft of the bill, the introductory comments on the draft, the committee reports, and the floor debates. ${ }^{29}$ For minor tax legislation, it is unlikely that helpful floor debate will precede the vote, for the scope and technical niceties of the proposed amendment will have been explained sufficiently in the introductory comments and the committee reports.

The Minister of Finance may introduce a draft of a bill (projet de loi) in either the Chamber of Representatives or in the Senate. All drafts are printed and made available to the public. After introduction, the bill is turned over to the Committee on Finance of the house where the draft has been introduced. There the draft is discussed thoroughly, not only by the committee's regular members but also by members appointed by the respective houses, the Minister, members of his staff, and top-level officials of the central administration of direct taxes. While the committee does not hold formal public or private hearings, opportunity for comment and criticism is afforded to representatives of the various private interests concerned with the proposed legislation.

Amendments to the draft may be proposed by members of the committee and by the government's representatives. There must be an individual vote on each proposed amendment, each section, and the entire bill. A member of the committee-very

29 Illustrative of the bulk of such pre-enactment materials is the amount produced in connection with the legislative progress of the law of November 20,1962, the reform of direct taxes. The draft of the bill (89 articles) with the government's introductory comments covered 190 folio-size printed pages. Chamber of Representatives, Session 1961-1962, Doc. No. 264/1. About 400 amendments were introduced by the Minister of Finance and by members of the Chamber of Representatives' Committee on Finance. One hundred and ten were approved. The report of the Finance Committee itself covered 190 folio-size printed pages together with the three annexes, each about 100 pages, containing miscellaneous notes and documents. Chamber of Representatives, Session 1961-1962, Doc. No. 264/2. The floor debate is recorded in 294 folio-size pages of the "Annales Parlementaires." Meetings of June $6,7,12,13,14$, and 15, 1962. When the bill was under consideration by the Committee on Finance of the Senate, about 200 amendments were proposed. Sixty were adopted. The report comprises 418 folio-size pages. Senate, Session 1961-1962, Doc. No. 263. The floor debates cover 226 folio-size pages. Meetings of October 2, $3,4,10,11$, and 16, 1962. The bill as amended by the Senate was passed by the Chamber of Representatives on October 31, 1962, after a two-day debate which was reported in 66 pages of the "Annales Parlementaires." Meetings of October 30,31, 1962. It was finally promulgated on November 20, 1962. 
rarely two members-then prepares an explanatory report to accompany the bill. After approval by the committee, the report is turned over to the house of origin as an official record to be printed and made available to the public.

This explanatory report makes every effort to supplement deliberately the text of the statute and hence to resolve in advance possible interpretative questions. For example, when the deduction for child-care expenses was introduced, the report made it clear that the deduction was available only for a child for whom the taxpayer had a legal obligation. It was not available for a child casually sheltered.

The process of justification and explanation takes place in large measure within the committee. Nevertheless, the floor debates (contained verbatim in the official printed record) can be decisive in later resolving an interpretation dispute. ${ }^{30}$ For example, it is not uncommon during the debate for the Minister of Finance or the reporter for the committee to answer an interpretative question.

On approval by the house of origin, the bill goes to the other, where the foregoing process is repeated: deliberation in the Finance Committee, report, floor debate, and vote. If the second house amends the bill, as originally submitted, it must be resubmitted to the house of origin. Only after both houses have agreed on the same text of all provisions can the King promulgate and publish the enactment in the official gazette, whereupon it becomes a law.

As noted previously, the statutes are supplemented by the royal decrees. ${ }^{31}$ These do not pass through the same process as do the formal enactments. Absence of official pre-enactment aids has led, however, to the use of administrative commentaries to identify the objectives of the degrees and to clarify the meaning of a principle or of a word. But these have less stature than legislative pre-enactment materials explaining a formal statute.

\subsection{Standards of construction followed by the judiciary in in- terpreting the statute}

The Belgian constitution provides that only the body holding legislative power can enact taxes. ${ }^{32}$ Hence the first question

30 See note 28 supra.

31 See 2.1 supra.

32 This is explicit in the Constitution of February 7, 1831, Article 110. This is not a mere application of the fundamental rule that all powers are derived from the nation. Constitution, Article 25. Rather, 
raised in any substantive controversy pertains to the legality of the principle asserted by the administration, i.e., has it been formulated in a statute or in a decree pursuant to a specific delegation of power. ${ }^{33}$

Belgian courts cannot hold a statute unconstitutional. Even an unconstitutional law must be applied. The courts, however, are entitled to determine whether any decree of the executive power-whether royal or ministerial-is valid, should the question of such validity arise in any controversy, whether or not taxes are involved. Article 107 of the Constitution specifically provides that courts may not apply any provision of a decree demonstrated to be illegal.

In a tax controversy, unless the statutory language precludes any question as to its clear meaning, the judge first must determine the will of the legislature. The judiciary has no power to create requirements in addition to those prescribed in the literal language of the statute. While gaps in a statute must be filled in, this is the responsibility of the administrative authorities acting pursuant to a request from the government, not a task for the courts. ${ }^{34}$ When the language of a provision is ambiguous or obscure, the judge must try to ascertain the unquestioned common purpose of all who contributed to the making of the law: the government which introduced the bill and both houses of Parliament which discussed it. If, after using all interpretative methods compatible with the principle of legality, the judge is still in doubt as to whether the legislature intended to tax a person in the manner asserted by the administrative agency, the taxpayer must prevail.

(footnote continued)

it is a formal recognition in the written constitution of the principle, "no taxation without legislation," a principle found generally in the origin of all parliamentary democracies.

33 Fifty years ago, it was thought that only the legislature itself could formulate substantive tax provisions. This constitutional deterrent to the exercise of power by other than the legislature is no longer enforced so strictly. On several occasions, substantive tax provisions have been formulated by decrees under a specific delegation of power. While some constitutional law experts consider this delegation to be incompatible with the Constitution, Article 110, even an unconstitutional law must be applied by the courts. The Belgian judiciary cannot overturn the work of the legislature. Nevertheless, even in recent years, deviations from the constitutional rule are the exception.

34 The Court of Cassation, i.e., the Supreme Court, has so decided on several occasions. See Cass. February 12, 1940, p. 1940, 1, 48; Cass. June 10, 1952, P. 1952, I, 656. 
Explanation of the legislative history described above 35 often reveals the legislative intention. Nevertheless, contradiction is possible, illustratively between the clearly stated text of the statute and, for example, comments made in the course of the floor debate. In such a situation, the text prevails. ${ }^{36}$ From time to time, however, the preliminary materials will show that a given statutory term is used to convey a meaning quite distinct from the meaning conveyed by that word in common usage or in non-tax sections of the Belgian statutes. ${ }^{37}$

A judge, interpreting a provision of a new tax law, may refer to the pre-enactment reports concerning an earlier statute, now repealed, on the same subject, provided the text in the new statute-as debated in Parliament-and the text in the old one are identical. ${ }^{38}$

\section{Section B. The Regulations Program}

\subsection{Types and force of regulations}

The Belgian constitution empowers the King-i.e., the executive-to make necessary regulations and decrees for the enforcement of the laws, an overriding limitation being that the King may not suspend an act of the legislature or create an exemption from its application. 39

The tax administration's authority is not limited to issuing procedural instructions. It also issues substantive interpretative regulations without which all too often the law would mean little. However, it is not uncommon for procedural or administrative regulations and interpretative regulations to be commingled in one particular publication, whatever be the form in which it is issued-i.e., ministerial decree, in-service order, or published instruction.

The administration of direct taxes issues many interpretative regulations. Illustratively, the Income Tax Code provides:

35 See 2.2 supra.

36 Court of Appeal Ghent, June 5, 1951, Révue Juridique, Financière et Fiscale 321 (1951).

37 Concerning the sense of the words "suspension of the period of normal legislation," see Cass. February 23, 1955 (Aerts) P. 1955, I, 693.

38 Concerning the deduction of professional losses, see Cass. June 15,1956 (Jockin), P. 1956, I, 1133.

39 Constitution, Art. 67. 
Deductible professional expenses are those the taxpayer proves to have made or supported during the taxable period in order to acquire or preserve the taxable income. ${ }^{40}$

The statute itself furnishes a few examples to amplify this bare statement of the rule. To aid both taxpayers and assessing officers, the tax administration goes beyond these, using about 300 pages of 400 words each to comment on the foregoing statutory language and to list those expenses deemed "professional." This type of regulation, issued by the tax authorities without specific legislative delegation, ordinarily contains numerous examples, most of which are drawn from court decisions. When such regulations are challenged before the courts, the first question is to determine whether or not the regulation conforms to the standard of legality, i.e., constitutes a valid interpretation.

A second type of amplifying regulation rests on a specific legislative delegation to the tax administration to exercise legislative authority. Unless the delegated power deals solely with procedural matters, such delegation conflicts with the constitutional provision which restricts establishment of a tax to that body holding legislative power. However, as explained previously, the courts cannot overrule the legislature 41 and, therefore, do not have the power to rule on the validity of its delegation of legislative power. In consequence, courts have only the power to determine whether the government did or did not exceed the limits of the specific delegation granted by the law. For some time the legislature has turned over to administrative authorities much of its legislative power, including promulgation of substantive tax rules. The pretext is that the legislature is unable to deal in sufficient detail with those particular matters. While this may not be a completely satisfactory explanation, the fact is that the tax reform law of November 20, 1962, contains more such specific delegations than any previous statute. Two delegations drawn from this law will serve to illustrate the scope of such delegations.

As to the first, the general statutory rule is that all business associations, whether corporations or partnerships, are

40 Art. 44 , $\S 1$, of the Code of Income Tax, Art. 11, 1 , of the law of November 20,1962; Art. 26, $\S 1$, of the Coordinated Laws of Income Tax. Except insofar as the deduction of taxes is concerned, these provisions are largely identical.

41 See 2.3 supra. 
subject as entities to the corporate tax. ${ }^{42}$ However, under the new law, ${ }^{43}$ partnerships, sociétés en nom collectif, limited partnerships, sociétés en commandite simple, limited liability companies, sociétés de personnes à responsibilité limitée, and cooperatives, may elect-subject to formalities and conditions "to be determined by the King"-to be taxed under the individual income tax, on the basis of the individual members' respective shares in the profits. Under this delegation of power, a royal decree was promulgated ${ }^{44}$ prescribing as formalities and conditions the maximum permissible capital, maximum permissible number of members, and a requirement that all members agree to be so taxed.

The second illustration pertains to the statutory principle that all taxable income, irrespective of its source, is subject to a single global tax. ${ }^{45}$ In general this tax is prepaid through a series of withholding taxes known as précomptes, the specific amount of prepayment being dependent on the source from which the income is derived, i.e., whether derived from immovables, movables, or professional activity. However, the reform tax law provides that, as to income from certain sources "the King can renounce" entirely or partially the right to collect the prepayment (the précompte mobilier). ${ }^{46}$ In keeping with this delegation of power, royal decrees prescribed the conditions and limits under which income from movable property is exempt from the prepayment otherwise required. ${ }^{47}$

\subsection{Precise purpose of "interpretative" regulations}

The tax administration drafts its regulations with great care. While judicial decisions are incorporated, usually as specific illustrations of how the statute is applied in practice, the administration on its own initiative drafts regulations in a deliberate effort to supplement the statute and provide an interpretation in addition to the interpretation set out in the explanatory report. For example, recent legislation extended the

42 Art. 94 of the Code (Art. 24, § 1, law of November 20, 1962).

43 Art. 95 of the Code (Art. 24, § 2, law of November 20, 1962).

44 The royal decree was promulgated November 4, 1963.

45 This was one of the basic principles in the tax reform of 1962 as noted in 1.1 supra.

46 Art. 170 of the Code (Art. 43, §2, al. 1, law of November 20, 1962).

47 Royal decree of December 2, 1962, as amended by royal decrees of January 30, 1963, March 13, 1963, January 31, 1964, and December $7,1966$. 
scope of the existing tax on new building construction. The tax administration prepared a regulation to the effect that the tax would not apply to the home-owner who attached a garage to his house, even though the garage was entirely new.

As noted previously, interpretative and legislative regulations are often commingled in the same document. Moreover, sometimes it is difficult to determine what part of an administrative commentary on a given substantive tax provision interprets it and what part rests on a coordination of that provision with other statutory provisions dealing with the same subject.

In general, there is a great reluctance to rephrase substantive statutory language into lay terms. ${ }^{48}$ Even so, the statutory language is often supplemented by administrative explanation-with examples where feasible 49 -to provide marimum clarity for laymen as well as for experienced practitioners. Many interpretative difficulties will remain uncovered, however, because they are not likely to be foreseen except where preenactment materials focused attention on and provided solutions for the interpretative problems. ${ }^{50}$ Then, after the statute has been in force for a time, the unanticipated interpretative issues reach the judiciary. Not until a significant number of decisions have been handed down on a particular issue which tend to fix its dimensions, is it likely that the administrative regulations will incorporate the judicial decisions on that issue. Despite this reluctance to incorporate within the regulations the results of judicial decisions, experience shows that administrative commentaries on any particular piece of tax legislation tend to increase and become more detailed throughout the first fifteen or twenty years after enactment. Then follows a period of stability, assuming interim statutory amendments have been relatively few and insignificant.

Since the tax reform law of 1962 became effective for corporations during fiscal 1963 and for individuals during fiscal

$48 \mathrm{This}$ reluctance stems from the inevitable increase in disputes should a discrepancy appear between the official language of the statute and its rephrasing in an official commentary or instruction manual. The lack of precision in the statutory language itself causes some controversy but, in general, tax practitioners-whether representing the government or a taxpayer-possess adequate acquaintance with the technical terminology of the revenue administration.

49 Examples will be issued on occasion even in so-called "black and white" situations.

50 see 2.2 supra. 
1964, it is unlikely that there will be a court of appeals decision on an interpretative issue until early 1966 and yet another year probably will elapse before there is a Court of Cassation decision. In the interim, the official administrative commentaries on the tax reform law consist of a compilation of the text of the statute together with the following:

1. Extracts from the legislative history of the statute-i.e., introductory comment on the bill, reports of the Finance Committees of both houses, floor debate;

2. A paraphrase of the language of the statute, including examples; and

3. Answers given by the Minister of Finance in response to questions posed by members of Parliament with respect to the application of the statute. ${ }^{51}$

The comparative extent to which a regulation will elaborate on a new, as contrasted with an old, provision of the statute can be shown best by illustration. As previously noted, Article 44 of the Code-an old provision-defines "deductible professional expenses" in broad terms. The relevant commentary in official instructions covers about 300 pages of 400 words each. ${ }^{52}$ A new provision, Article 98 of the Code, ${ }^{53}$ subjects to the corporate tax the taxable net profits of a corporation, whether undistributed, distributed to shareholders, or paid to directors and auditors. ${ }^{54}$ Relevant official administrative regulations dealing with this include only seven pages of about 300 words each, with an annex of seven pages containing examples. The contrast reflected by that illustration is also apparent from a comparison of the overall magnitude of the regulations dealing with the old and new tax systems. Regulations covering the old, which is still partially in effect, ${ }^{55}$ fill seven looseleaf volumes. ${ }^{56}$ About 3,000 pages deal with the professional $\operatorname{tax}, 300$ with the tax on income from movable property, and 200 with the personal complementary tax. Regulations for the new tax system-i.e., the Law of November 20, 1962-as of

51 See 2.7 infra.

52 See 2.4 supra.

53 Art. 25, law of November 20, 1962.

54 Except for the special allowance to directors having special executive functions in the company.

55 See 2.1 note supra.

56 Loose-leaf volumes are used to facilitate replacement of pages superseded by amendments to the regulations. 
June 1, 1964, used only 351 pages to deal with the individual income tax, 150 with the corporate tax, and about 100 with other taxes and miscellaneous provisions. In 1965 the tax administration commenced to publish new, more detailed regulations for the new tax system. Issued in loose-leaf volumes, as of March 1967-and admittedly incomplete-it already covers approximately 4,500 pages of 400 words on each page.

\subsection{Manner of processing regulations}

Income tax regulations are drafted by the first branchlegislation-of the first division of the central administration of direct taxes. Typically, the officials of that branch will be familiar with the new statute's provisions. Usually they worked on the draft bill at the time of its submission to the legislature and attended the deliberations in both houses of Parliament. And if a commentary is to be prepared on a royal decree, these same officials also will have written that decree.

All persons who work on an income tax regulation belong to the first of the two categories of government officials. 57 However, regulations do pass through several levels. The initial draft customarily is prepared by a junior assistant, after which it is reviewed by a senior officer. Then it must be signed, on behalf of the Minister, by the Director General. In fact, the Minister entrusts to experienced top level officials of the revenue administration full responsibility for classification and coordination of regulations issued by the administration at different times, for cancellation of regulations relating to repealed enactments and decrees, and for preparing the text to be printed. Since there is a continuing amendment of administrative regulations, to take account of important decisions of the courts of appeal and of the Court of Cassation, drafting officials necessarily maintain close contact with officials in charge of the Treasury's litigation. Formal public hearings are not held prior to promulgation of the final version of a regulation. Nevertheless, representatives of industrial federations, chambers of commerce, trade unions, professional groups, etc., normally do communicate their views and observations to the revenue administration prior to the point a regulation is issued. Thus, the legitimate interests of affected groups can be taken into consideration to the extent the interpretation they foster is not incompatible with the legislature's intention.

57 See Chap. V, 1.5 supra. 
Typically about two months elapse from the date of enactment to the time an initial commentary is available to taxpayers and to revenue personnel. Under this time schedule, the commentary usually will appear a few weeks before a new law takes effect. The initial commentary, however, is brief, and must later be enlarged upon and amended as new interpretative problems arise. ${ }^{58}$

Where a royal decree-because of specific legislative delegation-contains one or more substantive tax provisions, an explanatory comment very often is published in the official gazette on the day of promulgation or within a very few days thereafter. 59

\section{Section C. The Rulings Program}

\subsection{Formal advance written rulings to taxpayers}

With respect to proposed transactions, the Belgian administration of direct taxes has no special program for issuing to taxpayers written advance rulings upon which taxpayers can rely. Since the basic criterion in interpreting the statute is legality, the administration could not legally commit itself in advance to apply the statute in a given way should that interpretation later appear to be erroneous. If a tax official, however highly placed, interprets the statute in a manner later shown to be contrary to the legislative intention-whether that interpretation takes place in oral conference, in a letter to a taxpayer, or in a printed instruction-the administration remains free to change its position. ${ }^{60}$ Since the courts have held that they are not bound by administrative interpretations, ${ }^{61}$ the

58 See 2.5 supra.

59 For example, both royal decrees on the prepayment of tax on income from movable property (Précompte mobilier, December 2, 1962) and the complementary prepayment of tax on income from movable property (Complément de précompte mobilier, December 3, 1962) were promulgated in the official Belgian gazette, Moniteur Belge, for December 29,1962 , and were accompanied on that date by an official commentary of about 14 pages, each approximately 500 words. The complementary prepayment has been abolished, effective January 1, 1967, law of July 15, 1966.

60 This is true even of the Director General or the Minister of Finance.

61 Cass. November 22 (Convents), P. 1950, I, 182. Recent decisions, unpublished, of the Courts of Appeal include the following: Liège, March 4, 1959 (Assurance Liègeoise); Brussels, March 15, 1962 (Frère); 
revenue administration is unwilling to run the risk of issuing written advance rulings with which the courts might disagree should litigation later arise.

Distinct from a formal rulings program are responses by the Minister of Finance to questions raised by members of both houses of Parliament, who are entitled to interrogate the government on all points of general interest, including the interpretation of a law administered by a particular Minister, such as the Minister of Finance. Question and answer alike are printed in an official periodical, and thus constitute a valuable source of documentation in interpreting the law. ${ }^{62}$ Later these answers are inserted in the administrative regulations. However, no Minister will answer a question concerning a particular case in which the taxpayer is mentioned by name. The major purpose of such questioning, especially in tax matters, is to elicit official interpretation of obscure provisions of the law. Further, it should be understood that the answer of a Minister to a parliamentary question is not binding. Like all administrative interpretations, theoretically it can be altered before or after publication if shown to be contrary to the legislature's will.

\subsection{Informal technical advice to taxpayers on proposed transac- tions \\ Although Belgium has no formal rulings program, officials} at all levels are free to give informal advice concerning the tax effects of proposed transactions.

However, a tax officer is not obliged to give such advice. He may conclude the circumstances are such that he should refuse. In such case, the taxpayer is told that no opinion will be issued until the transaction has been consummated, and that its tax effects will be determined when the yearly return is audited. Clearly any request should be refused if the officer believes that the facts have not been completely disclosed or that the prospective transaction involves fraud or tax avoidance. ${ }^{63}$

\section{(footnote continued)}

Liège, November 2, 1963 (Hamels \& Louis); Liège, January 20, 1964 (Baguette-Corman); Liège, February 17, 1964 (Transports routiers Veuve Julien Richard et fils).

62 Questions et réponses appear fortnightly in two parallel columns of French and Dutch text. There are two series: Sénat and Chambre des Représentants. Official printing office Moniteur Belge, 40-42, Rue de Louvain, Brussels I.

63 No data is available to show the extent to which the revenue administration is consulted informally as to the tax consequences of proposed transactions. 
While it must be emphasized that a taxpayer has no legal right to rely on any informal advice given him, even where it comes from the highest echelon, theory and practice are not precisely identical. Since the officer who answers a taxpayer's question concerning the tax consequences of a proposed transaction is also usually the officer who later will supervise examination of that taxpayer's return, in practice there is a substantial prospect that the advice will turn out to be reliable.

The level at which such informal advice may be given depends primarily on the importance of the prospective transaction and the difficulties it presents. Obviously, if the issue is presented clearly and succinctly, and if no dispute as to interpretation exists, the head of a local assessment office can decide whether such a transaction is subject to taxation. In more complex situations where the interpretation of the statute is less certain, or in situations where it is anticipated that a substantial tax will be involved, the taxpayer or his adviser is likely to deal with higher ranking officials, generally with an inspector general in the central administration or possibly with the Director General himself. Customarily, one or more oral conferences are held with the tax official, but the informal advice so given probably will not be reduced to writing inasmuch as the administration is not in a position to make a binding decision before the transaction has taken place. However, in practice the taxpayer knows that if he shapes the proposed transaction precisely as it was described to the official, he can rely on the advice given to him. The ability of taxpayers to secure these advance statements as to the tax consequences of proposed major transactions tends to decrease the number of interpretative issues which might otherwise arise with respect to completed transactions.

\subsection{Technical advice to field offices}

Lower officers are free to request the advice of higher echelons when faced with specific situations. The charts in Chapter $V,{ }^{64}$ showing the administrative framework at the national, regional, and local levels, indicate that the head of a particular local assessing office decides whether and to what extent an individual or corporation is subject to taxation. Since the activities of the local assessment offices are supervised at the regional level by the so-called inspectors $A$, officers in charge of the local offices are not only permitted but encouraged

64 See Chap. V, 1.2, 1.3, and 1.4 supra. 
to seek the inspector's advice regarding difficult situations, whether interpretative or factual. ${ }^{65}$ Generally, but not necessarily, the taxpayer is informed if such advice is to be sought. Since an oral conference with the higher echelon official is never refused, the taxpayer will have an opportunity to argue his point of view.

In addition to request for advice from the assessing offices to the higher echelons, frequently taxpayers or their advisers request intervention by a higher echelon (by the inspector general, Director General, or by a member of the Finance Minister's cabinet). ${ }^{66}$ Such intervention is requested to insure a supplementary and thorough examination of some problem prior to actual assessment.

There are no formal procedural requirements to be met in seeking intervention of a higher echelon, whether the request comes from a taxpayer or the head of a local assessing office. Typically the higher echelon is forwarded the file of the taxpayer, containing his return and all relevant documents. Rarely is the matter handled by telephone; at a minimum, the inspector whose intervention is requested expects to receive a memorandum analyzing the matter in dispute.

While the prime purpose of the foregoing practice is to insure certainty and uniformity in the application of the law, it serves also to decrease litigation. No publication sets forth all advice given by the higher administration echelons at the request of the lower ranking tax officers; however, where such advice is considered to be of general interest, it is inserted in the official printed instructions of the revenue administration which are more fully described below.

\subsection{Publication of technical advice given taxpayers and local offices}

The revenue administration issues a number of publications for the benefit of taxpayers as well as for the guidance of tax offices. Each appears in both a Dutch and French language edition. While they are distributed to all tax personnel, anyone outside the administration is free to subscribe to them.

The technical advice which is published is not limited to a bare statement of the rule to be applied. It includes not only the justification for the conclusions reached-that is, the

65 No statistical data are available concerning the number of questions laid before inspectors A by the local assessing offices.

66 No statistics are available to show the actual number of such interventions which take place. 
references to the statutes and to the regulations-but also the legal reasoning itself.

The publications fall into four groups. The first includes a text of the basic tax statute accompanied by all royal decrees promulgated either to fill out (in the case of specific legislative delegation) or to enforce the law. As of June 1, 1964, each language edition was set forth in two loose-leaf volumes totaling 600 pages with about 350 words a page.

The second is a loose-leaf coordinator containing important nonstatutory material, including administrative instructions concerning direct taxes. These instructions do include digests of the technical positions taken in response to informal requests for information by taxpayers or by local assessment officers, although the instructions in full are not officially published. 67 The coordinator also contains the legislative history of the statute, public answers made by the Finance Minister to parliamentary questions, and a summary of the decisions handed down by the courts of appeal and the Court of Cassation.

The third, a monthly bulletin, is the most popular publication of the Finance Ministry. It is designed to keep in-service personnel and practitioners up to date, and to that end contains recent laws and decrees, administrative regulations, court decisions, parliamentary questions, statistical surveys, and other data. Each language edition now runs to about 2,500 pages of 400 words a page.

The fourth is published at irregular intervals (usually bimonthly). It contains the full text of important decisions handed down by the courts of appeal and of the Court of Cassation on direct taxes. ${ }^{68}$ Each such publication runs to about 40 pages of 400 words each.

67 For the length of the instructions dealing with certain portions of the "old" and the "new" statutes, see 2.5 supra.

68 However; most other judicial decisions do not appear in Finance Ministry publications. All decisions of the Court of Cassation are printed, however, in the "Pasicrisie" Part I. See footnote 11 supra. 


\section{CHAPTER VII}

\section{ASSESSMENT, REFUND, AND ADMINISTRATIVE APPEAL PROCEDURES}

\section{Section A. Assessment and Audit Procedures}

\subsection{Introductory note}

The levying of taxes can be divided into three distinct and successive phases: (1) the assessment, i.e., the definition of the exact amount of income or profit subject to taxation under the statute, (2) the computation, i.e., the application of a progressive or proportional rate on the taxable amount, and (3) the collection, i.e., the procedure used to secure payment absent voluntary payment.

Essentially, Belgian assessment and audit procedures are the same for both individual and corporate taxpayers and with two prime exceptions for all types of income. The two special procedures relate to imputed income from immovable property situated in Belgium, the so-called "cadastral income," and to income arising from certain categories of professional activity.

\section{2a Details of the typical assessment and audit procedure}

All individuals (residents as well as nonresidents subject to the nonresident tax), ${ }^{1}$ corporations, juridical persons, and unincorporated communities must file an annual return showing taxable income. ${ }^{2}$ In essence, however, this is an information return, for the taxpayer himself does not compute the tax itself. The return, with the attached reports, is supposed to provide such complete information that the assessing official can rely on it to compute the correct tax.

The returns, in the form of questionnaires, are mailed by the Minister of Finance, during the year's first quarter, to all

1 Art. 212 of the Code of Income Tax (Art. 55, §1, Coordinated Laws and Art. 53, $1^{\circ}$, of the law of November 20,1962 ) requires the filing of a return by nonresidents, whether on their entire Belgian income or on remuneration earned in Belgium.

2 Art. 218 of the Code of Income $\operatorname{Tax}$ (Art. 54, 1 , of the Coordinated Laws as amended by Art. 9 of the law of July 13, 1959). 
persons subject to taxation. ${ }^{3}$ Different types of questionnaires are used: (1) for corporations, (2) for wage earners and those individuals whose income is derived from only two or three sources, and (3) for individuals whose income is derived from many sources. These returns are designed to supply the assessing officer with all possible data concerning the taxpayer, his family, his occupational activity, his real and personal property, and related expenditures. In the course of completing a return, a taxpayer or his representative may have to resolve one or more questions of law or mixed questions of law and fact. An officially prepared explanation of the law, covering 8 pages of about 1400 words each, is attached to each questionnaire for the benefit of the declarant who is otherwise legally presumed to know all of the provisions of the tax law.

The statute requires certain supplementary statements to be attached to specified types of returns. Corporation returns must be accompanied by copies of the balance sheet, profit and loss statement, and minutes of the corporation's general meeting where these financial reports were approved. ${ }^{4}$ Returns filed by partnerships must be accompanied by a statement of all amounts paid to the associates on the basis of the company's accounts. ${ }^{5}$ In certain cases individuals also must supply certain documents. Illustratively, when foreign income is declared, the taxpayer must identify its nature and the country of origin.

In addition to the statutorily required supplementary statements the administration is entitled to call for other information it anticipates using during the course of assessment and audit. For example, corporations filing the 1964 return were requested to add copies of about fifteen records or statements. These included (in addition to the documents noted previously) a list of directors, an account of sums paid to directors and to stockholders, a detailed depreciation schedule, and a valuation

3 This list is subject to annual revision on the basis of information communicated by the municipal authorities. However, the King is empowered to decide that individuals (not juridical persons) who, on the basis of the return previously filed, appear to earn an income below the taxable limit need not file a new return annually. This decision is subject to revision at any time. Art. 216, al. 1, Coordinated Laws, Art. $53,2^{\mathrm{O}}$, of the law of November 20,1962, Art. 144 of the Royal Decree of March 4, 1965.

4 Art. 218, al. 2, of the Code of Income Tax.

5 Art. 219 of the Code of Income Tax, Art. 54, §2, al. 1, of the Coordinated Laws, Art. 54 of the law of November 20, 1962. 
schedule of the stocks and bonds owned by the corporation. Included also in the assessing official's file for each taxpayer is other information drawn from returns filed by yet other taxpayers ${ }^{6}$ or received from other governmental authorities and agencies. $^{7}$

Typically, returns are examined by local assessing offices, though special offices at the local level handle all corporations except very large enterprises which are dealt with by the central administration's own special office for direct taxes.

The assessing office assumes a return to be correct until it determines otherwise. ${ }^{8}$ Its examination involves a verification both of the factual data on the return and attached documents and of the taxpayer's application of the statute in arriving at taxable net income. Any legal evidence, other than a sworn statement, can be utilized in the verification process. ${ }^{9}$

In practice, however, individuals who have returns showing a low income or income from an easily verified source will not have their returns audited except for such returns of this character as are selected for audit on a sampling basis. Individuals whose income is in the neighborhood of 500,000 Belgian francs $(\$ 10,000.00$ U.S. dollars) have their returns checked, however easily verifiable the sources. However, if such an individual has a stable income from approximately the same sources year after year, the local assessor tends not to check

6 The return of one taxpayer can be an extremely valuable source of information in verifying the return of another. For example, whenever a taxpayer includes within his deductible expenses the interest paid on borrowed money or the fee paid to a professional expert, he must show the name and address of the payee. When this information is placed before the appropriate assessing official, he can readily determine whether the payee has included such payment within his declared income.

7 When requested by the revenue administration, governmental, provincial, and municipal authorities (with the exception of the National Institute for Statistics, the Institute for the Study of Economic and Social Problems of the Middle Class, the credit institutions maintained by the government, and the Postal Checks and Clearing Service (Art. 235 , § 2 , of the Code of Income Tax)) must forward all records which an assessing or collecting official considers necessary for the assessment or collection of taxes. Art. 235, $\S 1$, of the Code of Income Tax (Art. 57, bis $\S 1$, of the Coordinated Laws, Art. 58 of the law of November 20,1962 ).

8 Art. 245 of the Code of Income Tax (Art. 55, § 1 , of the Coordinated Laws, Art. 56, $\S 1$, of the law of November 20,1962$)$.

9 Art. 245 of the Code of Income Tax (Art. 55, §2, of the Coordinated Laws, Art. 56, $\S 1$, of the law of November 20,1962$)$. 
his return after the first two or three years in the belief that this taxpayer's honesty can be relied upon.

During the examination, the assessor frequently finds himself in disagreement with the taxpayer, either as to the amount of the latter's income or the manner in which the taxpayer resolved a question of law or mixed question of law and fact. Typically, such a taxpayer is called into the office to be questioned in detail. During the course of such a discussion, the taxpayer may submit a statement, attesting to the accuracy of his figures and signed by an accountant belonging to an officially recognized group known as Institut des reviseurs d'entreprises. ${ }^{10}$ While great weight is attached to such a statement insofar as it relates to the mere accuracy of figures, the statement is not at all conclusive with respect to whether the tax law was properly applied in determining the tax treatment of each item.

The assessor is very likely to request informal advice from the appropriate inspector $A$ or even from the central administration whenever he confronts a new problem regarding proper application of the law to the situation before him, or other issues which emerge from the return of an important company or a return involving a substantial sum of money. It is entirely within his discretion whether he informs the taxpayer that he has requested this advice, but in practice the taxpayer is told. ${ }^{11}$ The taxpayer is free to request an oral conference. Comparably, and with equal informality, the taxpayer himself may try to resolve the problem in a conference with a higher ranking official and not infrequently he is successful. No statistics are available to show the number of taxpayers who seek such a conference at this level.

In practice, however, both assessor and taxpayer discuss exhaustively every aspect of the tax return. A complicating

10 There are no so-called chartered or certified public accountants in Belgium. Certain experienced accounting experts of good reputation have been selected by an official group, Institut des reviseurs d'entreprises, to act as auditors for corporations whose stocks and bonds are quoted on the stock exchange. In some circumstances, the members of this group have been appointed by the government or by a governmental agency to supervise the application of special regulations dealing with banking, insurance, etc. These appointments, however, do not authorize them to substantiate in any official sense the accuracy of the figures set out in a tax return.

11 There will, however, be relatively few situations where an interpretative question arises under the Belgian statute; its minimal number of deviations and broad statements of policy tend to curtail automatically the number of potential interpretative issues. 
factor is the requirement that the assessor complete his work within a given period in a particular year. This may effectively preclude a conference with an official at a higher echelon, for all assessments must be made by the end of the year. Nevertheless, the taxpayer is aware that if he is not fully satisfied with the results of whatever discussions have taken place, appeal to the regional director need cost no more than a postage stamp and is fully available. However, it not infrequently happens that the assessor and the taxpayer are able to reach an agreement as to matters of fact. At this local level, as to which there are no available statistics, there is a good deal of adjustment as to purely factual issues, such as those involving the value of an inventory at the end of the year or the amount of expenses incurred for some clearly business purpose. Illustratively, a taxpayer may claim 25,000 Belgian francs and have records showing expenditures of 15,000 Belgian francs. The assessor may say that from his station in life, it would be reasonable to assume expenditures of 20,000 Belgian francs and both agree as to this figure. The assessor, however, has no power to resolve interpretative issues and he cannot engage in settlement activities. He may only adjust fact questions where substantiation is the major problem.

The taxpayer is not allowed to bypass the detailed discussions with the assessor and go directly to the regional director. However, merely because the taxpayer cannot bypass the assessor prior to assessment, does not affect his right to file a petition with the regional director after assessment.

Certain taxpayers, in the course of the assessing official's interrogation, may assert that they are bound by professional secrecy and unable to communicate what they claim to be privileged information. ${ }^{12}$ Under such circumstances, the assessing officer consults a special advisory board, Comité d'avis, composed of the president and two members of the local professional or occupational group-lawyers, doctors, notaries-to which the taxpayer belongs. Within ten days after referral, the board must give its opinion as to the taxpayer's probable income.

12 Art. 458 of the Belgian Penal Code punishes physicians, surgeons, chemists, midwives "and all other persons who have a professional responsibility to keep secrets"-i.e., lawyers, solicitors, notaries, etc.should they reveal facts of which they have been informed in secrecy unless they must appear as witnesses in court or legally are obliged to reveal them. 
While such a board does not consider any question of law and has no power to make a final decision, in effect there is a presumption that its opinion accurately reflects the taxpayer's income. ${ }^{13}$

Should an assessing officer finally decide that a taxpayer has filed an incorrect return, informal interchange of views ends. But before the assessing officer can make a final adjustment to the income as reported, he must send the taxpayer a carefully prepared rectification, stating what he believes is the taxpayer's net taxable income. The rectification also requests that the form be returned within twenty days, together with the taxpayer's written objections, if any, to the proposed adjustment.

Until the twenty days have elapsed, no definitive assessment can be made. But if this period goes by without receipt of written objections from the taxpayer, the assessing official is free to act although, ${ }^{14}$ for reasonable cause, he may grant the taxpayer a twenty-day extension. Further, the mere fact that the taxpayer does file written objections will not necessarily postpone the assessment. The assessing officer is not required to reconsider arguments previously raised by the taxpayer if he believes the taxpayer's rationale to be in error. $\mathrm{He}$ may disregard them and proceed without delay to an assessment. However, on filing his written objections, the taxpayer has a rigint to request that the case be submitted to an advisory committee, Commission fiscale. ${ }^{15}$ This request is not automatically granted. It is approved only when the assessing official believes the referral will contribute to a proper determination of the taxpayer's income.

Such committees exist in each locality where there is an assessing office. The chairman is a tax inspector; the other members are private citizens, i.e., are representatives of trade, industrial, agricultural, professional, and wage-earners organizations. Designated by their officially recognized occupational organizations, they are appointed for three-year terms.

13 Arts. 254-255 of the Code of Income Tax (Art. 44, §13, of the Coordinated Laws, Art. 56, § 3, of the law of November 20, 1962).

14 Art. 251 of the Code of Income Tax (Art. 55, §12, of the Coordinated Laws, as completed by Art. 56, 2 , of the law of November 20 , 1962).

15 Art. 252 of the Code of Income Tax (Art. 55, § 14, al. 1 to 3, of the Coordinated Laws, as amended by Art. 56, $\$ 4$, of the law of November 20,1962$)$. 
Such committees never deal with interpretative issues. As before noted, an assessor can obtain informed advice regarding that type of question from the so-called inspectors A or from the central administration. The advisory committees are competent to deal only with questions of fact. They are expected to answer only one question: Did the taxpayer make realistic estimates of his gross income, professional expenses, etc.?

Once a question is submitted to the fiscal committee, the assessing officer and the taxpayer, or his tax advisor, are requested to forward all notes and documents. In addition, each side is given an opportunity to offer an oral explanation and argument.

In theory, the committee's decision does not bind the assessing official; its sole function is to advise. However, should the assessing officer assess a tax in excess of the amount considered proper by the committee and should the taxpayer subsequently appeal, a legal presumption arises, to the effect that the assessing officer erred and that the committee's finding represents the maximum possible amount of taxable income. ${ }^{16}$

Should a taxpayer fail to file a return or to turn over records or data upon request, the assessing officer estimates the tax due. Under such circumstances, the assessing officer need not prove the exact amount of net income he estimates the taxpayer to have received. ${ }^{17}$ The taxpayer, however, must prove that he did not earn that income. ${ }^{18}$

\section{2b Details of assessment and audit procedure re cadastral in- come}

As noted above, there is a separate assessment procedure for income from real property located in Belgium. The taxpayer himself neither calculates nor estimates the amount of his so-called cadastral income. This is not an amount actually received by the owner. Instead, taxable income of this type is a presumed income, i.e., cadastral income. The Land Register,

16 Art. 253 of the Code of Income Tax (Art. 55, §14, al. 4 and 5 , of the Coordinated Laws, Art. 56, 4 , of the law of November 20 , 1962).

17 Art. 248 , § 2 , of the Code of Income Tax.

18 Except where the taxpayer can give acceptable reasons why the filing of the return or the answer to questions of the assessing officer have been delayed. Art. 257 of the Code of Income Tax (Art. 56, al. 2, of the Coordinated Laws, as amended by Art. 57, § 2, of the law of November 20,1962). 
Administration du cadastre, determines the presumed income from each piece of such real property for a twenty-year period, by estimating the average normal income for one year, deducting a lump sum (one-fourth for buildings and one-tenth for land) for costs, maintenance, and repairs. Except where important changes are made to such property, the amount so determined remains, in principle, fixed for twenty years.

When this determination takes place, each owner is informed officially. Should he disagree with the conclusion of the Land Register, he has thirty days in which to send a letter to the official in that office, complementing his request for review of that estimate with his own proposal as to the net taxable income from the property. 19

If the Land Register officials and the taxpayer cannot agree, the taxpayer-owner may have the property appraised by an independent expert appointed by the Justice of the Peace for the locality where the property is situated. The appraisal procedure provided by statute is followed, ${ }^{20}$ and once made the expert's appraisal of the cadastral income binds both the taxpayer and the assessing official.

The cadastral income was revised last in $1956-1960 .^{21}$ The next revision occurs in 1975 . While the cadastral or presumed income from real property cannot be increased before that year, a supplemental income tax must be paid on the owner's actual net income therefrom to the extent it exceeds $200 \%$ of the cadastral income. ${ }^{22}$ Further, if there is no actual income or if the actual income has declined, an exemption or reduction of tax can be obtained. ${ }^{23}$

\section{2c Details of assessment and audit procedure re income aris-} ing from certain categories of professional activity

The legislature recognizes that it is not easy for some taxpayers to determine the precise amount of their occupational net income. In consequence, the tax administration, either at

19 Arts. $412-415$ of the Code of Income Tax (Art. 61, 1 , of the Coordinated Laws).

20 See Arts. 417-428 of the Code of Income Tax (Art. 61, §1, of the Coordinated Laws, as amended by Art. 10 of the law of July 14, 1955).

21 Law of July 14, 1955.

22 Only, however, when the rent paid to the owner can be deducted by the tenant as a professional expense. Art. $7, \S 1,1^{\circ} \mathrm{b}$, of the Code of Income Tax (Art. 4, §1, of the law of November 20,1962).

23 Art. $9, \S 1$, of the Code of Income Tax (Art. 4, $\$ 2,2^{\circ}$ and $3^{\circ}$, of the law of November 1962). 
the national or regional level, may reach agreement with occupational associations fixing an estimated base by which the taxable net income of their members will be determined for a period not to exceed three years. ${ }^{24}$

Some such agreements, as in the case of agriculture, are on a nationwide basis. Others, as in the case of bakers and butchers, are regional in scope, and in these cases the estimated base for occupational income differs from place to place.

Members of an occupational group subject to such an agreement are required, nevertheless, to file an annual return. But instead of listing both the gross income received and deductible expenses, they provide other factual information. Illustratively, in the case of farmers, they state for the given year the area of land cultivated, in the case of butchers or bakers the amount of wares sold. Using this factual data, the net income of such individuals is estimated, in accordance with the agreement reached between their occupational associations and the tax administration.

Foreigners running a business in Belgium also are subject to a system of estimated minimum taxable incomes. Since they remain subject to the regular assessment procedure, the estimation arrangement is intended only to assure that they will pay at least some personal or corporate income tax on a minimum base with reference to the number of employees, etc. $^{25}$

\section{Section B. Administrative Appeals}

\subsection{Introductory note}

To recapitulate briefly, the process of taxpayer assessment in Belgium places the responsibility for the actual assessment of the income tax on the assessing official, although only after opportunity for an informal exchange of views between the assessing official and the taxpayer and for referrals seeking nonbinding advisory opinions on factual matters from certain consultative boards.

Once the assessment has been made, the taxpayer may appeal the assessing official's decision to a higher level within the tax administration. Should the decision there be unfavorable, he may lay his case before the judiciary.

24 Art. $248, \S 1$, of the Code of Income Tax (Art. 28, §1, of the Coordinated Laws).

25 Art. 248 , $\$ 2$, of the Code of Income Tax. 


\subsection{Details of the administrative appeal procedure re assess- ments}

Two situations permit a taxpayer to secure a full administrative review of the facts and of the law relating to any disagreement with the assessor. The first is where tax payments exceed the amount the taxpayer believes to be correct, either because of an excessive withholding of taxes or because of excessive payments of estimated tax. The second is where the assessor, having completed his examination of a taxpayer's return as a prelude to making a regular assessment, does not agree with the taxpayer regarding the amount of tax due, all procedures available to resolve their differences having been utilized without success. The assessing officer then sends a formal notice of his conclusion (the so-called "tax paper") regarding the tax due and directs that payment be made within the legally prescribed period of two months. ${ }^{26}$

Should the taxpayer disagree with the tax paper-a likely situation since the parties failed to reach agreement earlieror should he believe that his previous payments exceeded the amount properly owing, he can file a petition with the regional director of direct taxes for his area. This enables him to secure a full administrative review of the case, not only as to questions of fact but interpretative questions of law.

As pointed out earlier, the twelve regional directors of direct taxes perform two functions in the overall tax administration. They constitute the authority to which an appeal is taken after formal assessment, and they supervise all local revenue offices within their respective regions, including the work done by assessing officials. ${ }^{27}$ In dealing with petitions for review, the directors are assisted by inspectors for litigation matters, whose assistance is necessary because of the large number of petitions filed annually. In many such cases, the taxpayer does not request an oral hearing because of the nature of the alleged error, for example, a claimed miscalculation. However, according to the following table of petitions filed during a recent six-year period, in approximately half the cases there is an oral hearing. But the bulk of the cases, even where there is a hearing and a detailed examination of the taxpayer's contentions, did not involve interpretative

26 Art. 304 of the Code of Income Tax (Art. 53, §1, al. 3 and 4, of the Coordinated Laws, Art. 63 of the law of November 20, 1962).

27 See Chap. I, 1.1 supra for discussion of the territorial competence of the twelve regional directors. 
issues. $^{28}$ Rather, they concerned questions of fact such as computation of gross income, the exact amount of business expenditures, losses, etc. Moreover, the petty cadastral property cases-which raise only issues of fact and which involve very small amounts of money-are included in this total. ${ }^{29}$

\section{PETITIONS FILLED WITH THE REGIONAL DIRECTORS OF DIRECT TAXES}

With

Preliminary

Year

1958

1959

1960

1961

1962

1963

\section{Examination}

61,142

61,625

58,448

53,754

58,494

69,199

\section{Without \\ Preliminary \\ Examination}

56,971

61,996

67,011

58,744

60,143

66,113
Total

118,113

123,621

125,459

112,498

118,637

135,312

The procedure governing this administrative appeal is both simple and common to all taxpayers-resident or nonresident, individual or corporate-and for all forms of income tax. To file a petition, the taxpayer need only mail a letter to the appropriate regional director, briefly explaining his objections to the tax as determined by the assessing official or as previously withheld or paid. The director or that inspector for litigation matters who actually subjects the taxpayer's return, together with the attached documents, to a new and thorough examination, possesses all the investigative powers of the original assessing official, 30 and in addition he may request any other potentially useful information from banks, other credit institutions, and the postal check and clearing service.

Since the regional director derives his review powers directly from the statute, not from the central tax administration, he is under no legal obligation to consult the central administration prior to making any decision on the taxpayer's petition. In the interest of uniformity, however, in practice the regional

28 The fact that a taxpayer can secure an unofficial informal opinion on the tax consequences of his prospective transaction means that if he completes the transaction precisely as he has described it, he will have no problems and hence no interpretative issues will arise.

29 The very minimal cost of a petition tends to make many taxpayers think it worth their while to appeal an assessment since they possibly may benefit themselves.

30 Art. 275 of the Code of Income Tax (Art. 64 of the law of November 20,1962$)$. 
director does seek the advice of the central administration on encountering an interpretative problem not previously treated in the official regulations or publications of the Finance Ministry.

When the regional director does consult the central administration, he is not required to, but in fact usually does, inform the taxpayer. Whenever the taxpayer knows that such consultation has occurred, he may and usually does request an oral conference with the central administration; such requests are always granted.

There is no opportunity at the regional director's level for settlement in the sense of compromise where interpretation or application of the statute is concerned. There is opportunity only to make corrections. Further, the only possible adjustments relative to issues of fact where proof is unavailable took place at the assessor's level.

The regional director informs the taxpayer of his decision by registered letter. ${ }^{31}$ If he rejected the taxpayer's arguments and dismissed the petition, or concluded that the original assessing official underestimated the taxpayer's income with the consequence that the taxpayer owes more than even the amount shown by the formal assessment, the taxpayer can turn only to the courts for further consideration. Should the regional director sustain the taxpayer, however, the tax administration is bound.

While no definite statistics are available, informed sources believe that about 40 percent of all petitioners at the regional director's level feel that they have secured whatever relief they sought. Of the remaining 60 percent, only a small percentage will carry their cases to the courts. A postage stamp is all that is needed for a petition to the regional director; an action in the Court of Appeal requires a lawyer and entails procedural costs. Thus a taxpayer does not commence a court action for a trivial reason. It must be worth his while. Further, it may happen that a number of petitions filed with regional directors in a given year raises a single issue, e.g., such as one relating to a particular type of professional or commercial activity. Under such circumstances, the trade or professional organization frequently selects the dispute of a single taxpayer to try as a test case and sometimes shoulders the entire financial expense, with everyone involved fully aware of what is happening.

31 Art. 276 of the Code of Income Tax (Art. 65, al. 1 of the Coordinated Laws). 
In the meantime, instructions from the national office will direct the regional directors to refrain-as they may do, not being under any limit as to time-from handing down a decision on all the other appeals raising the same legal question. Comparably, there is a close enough cross-communication between the regional directors to insure their awareness if a number of taxpayers throughout the country independently file petitions raising a similar legal issue. Under such circumstances, the national office usually selects one petition for litigation and holds back decisions on the others.

\section{Section C. Extent Administrative Processing of Refund Claims Departs from Administrative Processing of Assessments}

\subsection{Introductory note}

Except in the limited instance described in the next subtopic, the Belgian tax system has no separate procedure for refunds distinct from those which may be paid automatically in connection with the assessment procedure itself. In other words, generally speaking, a taxpayer must raise his objections, if any, in a timely manner during the course of the as sessment procedure, and the dispute will be handled in the same manner whether he had paid less or more than the assessment as finally determined. This stems from the fact that the tax return is essentially an information return, the tax on income (as originally stated or as corrected) is calculated and assessed by the administration. Once calculated, the taxpayer receives the so-called tax paper showing the total tax, which must be paid within two months. It is quite possible, however, that some or all of this tax was paid prior to that assessment, because of (1) withholding at the source or (2) voluntary payments of estimated tax which are made in certain cases to avoid supplementary exactions equal to 7.5 percent or 15 percent of the total tax. ${ }^{32}$ If the amounts paid through either

32 See 3.3 supra. No supplement is due if the advance payment is made before July 15 of the year during which the taxable professional income will be earned. A supplementary payment of $7.5 \%$ is paid on the corporate or personal income tax, as calculated at the normal rate on the professional part of the total income, if the advance payment is made fifteen days after the closing of the taxpayer's financial year. The supplementary payment is $15 \%$ if payment of the tax takes place at the usual time, i.e., at least two months after the tax-paper has 
method exceed the assessment fixed by the local office, a refund is in order, but this will be paid automatically. No special refund claim is required.

In other cases, should a taxpayer conclude that the assessment shown in the tax-paper is excessive and file a timely petition for review with the regional director, the full amount of the asserted tax need not be paid while the administrative appeal is pending. While the filing of the petition does not actually suspend the legal obligation to pay the entire assessment within the legally prescribed two-month period, in practice the tax administration will not commence a collection action if, within that two-month period, the taxpayer pays the undisputed portion of the tax.

Should the regional director, after examining the taxpayer's petition, decide in favor of the taxpayer, he will automatically refund overpayments, if any. However, should the taxpayer owe other taxes, the refund will serve instead as a credit against them.

Should the regional director decide against the taxpayer, the previously disputed portion of the assessment as to which payment may have been postponed must now be paid, with interest at six-tenths of one percent per month. However, to induce regional directors to avoid delay in processing administrative appeals, the legislature provided that such interest shall cease to run from a point six months after a petition has been filed to the point when the director's decision is forwarded to the taxpayer. 33

\subsection{Details regarding refund procedure in cases of "material error"}

A taxpayer who fails to contest an assessment by filing a timely petition for review with the regional director may not thereafter secure a re-examination of his return for the purpose of recapturing a claimed overpayment, except on a showing of material error. Such an error, whether discovered by the taxpayer or a revenue official leads automatically, without any formal requirement, to a refund if an overpayment is involved. This is subject, however, to two limitations. Refunds

(footnote continued)

been dispatched. Art. 89 of the Code of Income Tax (Art. 22, § 2, al. 1 to 3, law of November 20,1962, as amended by Art. 10, law of July 15,1966$)$.

33 Art. 306 of the Code of Income Tax (Art. 65, al. 2 of the Coordinated Laws, Art. 11, law of March 28, 1955). 
cannot be made following the lapse of three years from the beginning of the year to which the tax relates. Further, if the taxpayer had filed a timely petition for review of his original assessment to which the claimed overpayment relates, and a final decision on that petition has been handed down, that finally determined assessment cannot be reopened even upon later discovery of a material error.

Subject to those two limitations, the types of error accommodated under this procedure included mathematical mistakes which favored the government (whether made by the taxpayer himself or by a revenue official) or double computations of a taxable term. Also treated as tantamount to material error is the situation where the taxpayer, after the assessment is made, produces new records or facts which for completely valid reasons he was unable to submit prior to assessment. A new legal argument or a change in the administrative or judicial interpretation of the statute will never be considered a "new fact," however. 34

34 Art. 277 of the Code of Income Tax (Art. 61, §6 of the Coordinated Laws as amended by Art. 2, law of May 30, 1949, Art. 233, law of July 27, 1953, Art. 20, § 2, law of March 28, 1955, Art. 2, law of March 24, 1959, and Art. 63, §5, law of November 20, 1962). 


\section{CHAPTER VIII}

\section{RESOLUTION OF INTERPRETATIVE INCOME TAX QUESTIONS BY INDEPENDENT TRIBUNALS}

\subsection{Introduction}

As pointed out earlier, a taxpayer must exhaust the administrative processes before he may carry into court a dispute with the tax authorities. The government, however, faced with an adverse administrative appeal decision by the statutorily endowed regional director, does not have the right to carry its case to the courts. The taxpayer alone has this privilege.

The judiciary possess final authority to interpret the tax statute. The Belgian Constitution insures the absolute independence of the tribunal to which the taxpayer has an absolute right to appeal in the event of an adverse decision at the administrative level.

The courts with jurisdiction over tax matters are not specialized courts, limited either to tax litigation or to disputes between administrative agencies and individual citizens. They are courts of general jurisdiction-civil, commercial, criminal, etc.-fully competent also to resolve substantive income tax questions. However, these general courts do have specialized chambres for tax matters. To the extent necessary, they will re-examine the regional director's conclusions of fact and of law.

The Belgian judicial organization has no precise counterpart to trial and appellate tribunals. Nevertheless, two levels of competence exist. The Courts of Appeal make findings of fact de novo, to which they apply their view of the law. The Court of Cassation, the supreme court to which lies an appeal from the Courts of Appeal, is limited to questions of law.

\section{Section A. Organization and Procedures: Lower Courts}

\subsection{Organization of the lower courts}

Belgium has three Courts of Appeal each with a specified 
seat and territorial jurisdiction. ${ }^{1}$ A petition for revision of a director's decision must be brought before the Court of Appeal with territorial jurisdiction over the office of the regional director who handed down the decision.

Each Court of Appeal is divided into the number of sections, Chambres, reflected in following schedule, the number having been determined on the basis of average workloads:

$\begin{array}{ccccc}\begin{array}{c}\text { Court of } \\ \text { Appeal }\end{array} & \begin{array}{c}\text { Total } \\ \text { Chambres }\end{array} & \begin{array}{c}\text { Taxation } \\ \text { Chambres }\end{array} & \begin{array}{c}\text { Total Members } \\ \text { (Conseillers) }\end{array} & \begin{array}{c}\text { Taxation } \\ \text { (Conseillers) }\end{array} \\ \text { Ghent } & 8 & 1 & 26 & 3-4 \\ \text { Brussels } & 24 & 3 & 60 & 9-12 \\ \text { Liège } & 12 & 2 & 33 & 6-8\end{array}$

Every case coming before a section is heard at least by three members.

Irrespective of the section of the court of which they are members, all conseillers are doctors of law. Generally they have spent ten to twenty years as justices of a district tribunal or as members of a district office of the public prosecutor. As a rule, members of the tax section were not tax specialists prior to appointment, but they normally serve such long terms that they develop a high level of expertise. Whenever a matter of general interest is argued before a Court of Appeal, a member of the Attorney General's staff-usually a deputy attorney general-is present. He submits an advisory opinion in each case. ${ }^{2}$

Like the conseillers, the members of the Attorney General's staff are generalists upon appointment but after advising on hundreds of tax cases they acquire a thorough knowledge of tax law and experience in interpreting the statute.

\subsection{Processing cases through the Court of Appeal}

Should the taxpayer's administrative appeal be decided adversely in whole or in part, he will be so informed by a

1 The courts at Ghent, Brussels, and Liège exercise jurisdiction, respectively, over (1) West Flanders and East Flanders, (2) Brabent, Antwerp, and Hainaut, and (3) Liège, Limbourg, Namur, and Luxembourg.

2 This device of an advisory opinion is a requisite part of Belgian judicial procedure whenever the public interest, l'ordre public, is concerned. The office of the attorney general is not involved in the controversy between the parties. Hence, the representative of the attorney general's office, in tax cases the deputy attorney general, has the duty of delivering an impartial opinion which sometimes will favor the Minister of Finance and sometimes the taxpayer, depending upon his estimation of the merits of the case. 
registered letter from the regional director. The taxpayer then has forty days within which to file with the appropriate Court of Appeal a new petition, a copy of which is sent to the regional director. ${ }^{3}$

Neither administrative nor judicial appeal affects the taxpayer's obligation to pay his tax as assessed, nor is the running of interest suspended should the taxpayer delay paying that portion of the tax in dispute. 4

It is possible to settle cases after invoking the jurisdiction of the Court of Appeal. Where this occurs, the taxpayer officially waives the right to dispute further the regional director's decision. The Court, however, must decide whether it will approve the settlement. Should the Court conclude that the settlement is based on an incorrect interpretation of the statute, it can refuse to permit the petition to be withdrawn and hand down a decision as if no administrative settlement had been made. ${ }^{5}$ Should the Court be satisfied with the settlement, it will recognize withdrawal of the petition by a formal decision. No statistics are available to indicate the frequency with which such administrative settlements are reached.

Once a taxpayer files a petition with a Court of Appeal, the tax administration must defend the case. Communication of the taxpayer's petition to the regional director in effect summons the tax administration to appear before the court. At the hearing the government is represented by a lawyer, a regular practising member of the bar who also holds a permanent appointment from the Minister of Finance to defend the revenue administration in court. These lawyers maintain contact with the fourth division of the central Administration of Direct Taxes, three branches of which handle the work on tax cases, in litigation before the courts. ${ }^{6}$

Contrary to the customary procedure in the civil cases, taxpayers are not required to be represented before a Court of Appeal by a solicitor, avoué. Theoretically, any taxpayer may represent himself at such hearings, with or without the

3 Arts. $278-280$, Code of Income Tax (Arts. 66 and 67 of the Coordinated Laws).

${ }^{4}$ See Chap. VII, 3.5 supra.

5 See, for example, Court of Appeal of Brussels, June 27, 1956. (Chevalier pour Despatures), Recueil Special de Jurisprudence, XII, no. 649 .

6 The personnel of the office for litigated matters belong to the first category of government officials, whose educational background was discussed in Chap. V supra. 
assistance of a tax expert who may or may not be a member of the bar. In practice, however, the taxpayer is represented by a member of the bar, i.e., by legai counsel authorized to plead before any Belgian tribunal.

The proceedings are formal. ${ }^{7}$ Both facts and legal arguments must be stipulated in writing by taxpayer and tax administration alike. According to the general principle actori incumbit probatio, sed reus in exceptione fit actor, proof of facts and legal arguments must be borne by the party invoking them. 8

Upon receipt of a copy of the petition, the regional director must deposit all documents concerning the dispute, together with a certified copy of his decision, with the Court of Appeal, where the taxpayer is free to examine them. ${ }^{9}$ Should the taxpayer wish to rely on new documents or memoranda not introduced previously when the matter was before the regional director, he must file them at the same office of record where the director, in turn, may examine them. The director then has thirty days in which to respond, by submitting additional documents or memoranda in support of his position. ${ }^{10}$ With the court's permission, the taxpayer can reply by filling yet further records, documents, or memoranda.

In the end, both the tax administration and the taxpayer must have submitted formal documents, so-called conclusions, setting out their arguments. The view of the Attorney General is also submitted in writing.

There is, however, a typically exercised right to oral argument with respect both to the facts and applicable legal principles. But this is in addition to and not a substitute for the conclusions. Further, it is most unusual for the taxpayer himself to be interrogated, for other oral evidence to be introduced, or for witnesses to be used.

The court rarely hands down its decision on the day in which the hearing is completed. The time lag between the close of the hearing and the decision itself ranges from two weeks to two months, depending on the difficulty of the case.

7 Art. 287, Code of Income Tax (Art. 67, al. 1, of the Coordinated Laws).

8 Except where the advice of the "Fiscal Committee" was in favor of the taxpayer. See Chap. VII, 3.4

9 Art. 281, Code of Income Tax (Art. 67, al. 1, of the Coordinated Laws).

10 Art. 283, Code of Income Tax (Art. 67, al. 1, of the Coordinated Laws). 
The Belgian Constitution requires that the decisions of all tribunals be announced in public, but the litigants themselves need not be present. Since the Constitution also requires that decisions include more than the bare judgment, each decision sets out a detailed statement of facts as well as the legal reasoning which led the court to its conclusion.

The schedule which follows indicates the number of cases, involving direct taxes, decided by the Courts of Appeal in recent years:

\section{Judiciary \\ Year}

1959-60

1960-61

1961-62

1962-63
All Courts

of Appeal

1,727

1,537

1,283

1,107
Individual Courts of Appeal

$\begin{array}{ccc}\text { Brussels } & \text { Ghent } & \text { Liège } \\ 1,075 & 341 & 311 \\ 1,003 & 329 & 205 \\ 825 & 260 & 198 \\ 778 & 166 & 163\end{array}$

Tax periodicals, whether officially or privately printed, publish only those decisions of the Courts of Appeal which seem of particular importance, either to taxpayers or to revenue officials. ${ }^{11}$ Illustrative are decisions involving a new application of the statute or interpretations resolving a known disputed point of law.

In theory, except for decisions of the Court of Cassation under special circumstances, decisions of courts do not constitute precedents. In practice, however, it obviously is helpful in tax litigation to refer to comparable decisions by courts with like jurisdiction or, a fortiori, by the particular court itself.

\section{Section B. Organization and Procedures:}

\section{The Court|of Cassation}

\subsection{Organization of the Court of Cassation}

The Belgian constitution provides for one Court of Cassation for all Belgium and limits its jurisdiction to questions of

11 See Chap. VI, 2.10 supra for a discussion of the official publications issued by the central administration of direct taxes. The most important privately published tax periodicals are Journal Pratique de Droit Fiscal et Financier, Algemeen Fiscaal Tijdschrift, Revue Fiscale, Revue Pratique des Sociétés Civiles et Commerciales, Revue Pratique du Notariat, Tijdschrift voor Notarissen, Annales du Notariateet de l'Engistrement. 
law. ${ }^{12}$ This tribunal has its seat at Brussels, the national capital.

The Court is divided into two sections, Chambres. The first deals with civil and commercial cases, the second inter alia with tax cases. The total number of members is twentythree with eleven or twelve in each section. Five must sit on each case. In every case brought before the Cour de Cassation, either the Attorney General himself or his deputy must submit his views.

In general, the members of the Court of Cassation and the members of the office of the attorney general are selected from the members of the Courts of Appeal. The majority of members in that court's second section were not tax specialists prior to their appointment. Knowledge of and experience in the handling of tax problems typically are acquired while serving on the bench. ${ }^{13}$

\subsection{Processing a case through the Court of Cassation}

There are two important differences between the Court of Cassation and the Courts of Appeal.14

First, the Court of Cassation's jurisdiction is limited to issues of law. Thus an appeal must be based solely on an alleged misapplication of law, and should it appear that questions of fact or mixed questions of law and fact are involved, the claim is dismissed.

Second, while the taxpayer alone can invoke jurisdiction of a Court of Appeal, both the revenue administration and the taxpayer can invoke the jurisdiction of the Court of Cassation. Should a decision of a Court of Appeal be unfavorable to the government, the Director General of direct taxes, advised by members of the fourth division of the general direction of direct taxes (responsible for litigated matters), decides whether it will be appealed to the Court of Cassation.

An appeal to the Court of Cassation, as was true of an action brought before a Court of Appeal, does not suspend the taxpayer's obligation to pay the tax or the running of interest if the disputed part of the tax has not been paid.

12 Belgium Constitution, Art. 95.

13 Some members of the second section may have been appointed after lengthy service on the tax section of a Court of Appeal.

14 This is apart from the fact that all tribunals in Belgium are subordinate to the Court of Cassation in the sense that the Court supervises the manner in which the law (used in the broad sense of the 
A party who wishes to appeal a Court of Appeal's decision has ninety days after receiving official communication of the decision in which to file a petition and all relevant documents with the Court of Cassation. ${ }^{15}$ Within forty days after notification by the Court of Cassation's recorder that a petition has been filed, the defendant must file all documents and memoranda in support of his position. The petitioner is free to inspect these matters. 16

The taxpayer, whether petitioner or defendant, must be represented before the Court by a member of the bar of either the Court of Cassation or a Court of Appeal. Memoranda setting forth the taxpayer's arguments frequently are prepared by the lawyer, a tax specialist, who handled the case before the Court of Appeal.

The government, whether as petitioner or defendant, is not represented on appeal by a tax official or by the permanently appointed counsel who handled the case before the Court of Appeal. Instead the government's case is handled by a member of the bar of the Court of Cassation.

Procedure before the Court of Cassation is even more formal than before the Court of Appeal. There is no right to oral argument and all material must be submitted in writing.

Like all decisions of the Court of Cassation, tax decisions set out the legal reasoning which led the court to the result reached. The Bulletin des arrets de la Cour de Cassation ${ }^{17}$ publishes all of the court's decisions but decisions of major importance appear also in both official and private legal periodicals. 18

Should the Court of Cassation conclude that the law has been misapplied, it will quash the decision and, because it never finds facts, then send the case to another Court of Appeal. Within thirty days after notice of the decision, the petitioner must bring the case before the particular Court of Appeal specified in the decision. ${ }^{19}$

(footnote continued)

word to include implementation of royal and ministerial decrees) is interpreted and the rules of procedure observed.

15 Art. 289, Code of Income Tax (Art. 67, al. 1, of the Coordinated Laws).

16 Art. 290, Code of Income Tax (Art. 67, al. 1, of the Coordinated Laws).

17 The decisions appear in French and in Dutch versions.

18 of particular importance are the Bulletin des contributions and the Recueil Special de la Jurisprudence.

19 Art. 292, Code of Income Tax (Art. 67, al. 1, of the Coordinated Laws). 
This Court of Appeal decides both questions of law and fact. It is not bound by the action of the Court of Cassation, and may apply the statute as it sees fit, completely disregarding the Court of Cassation's decision. Should the second Court of Appeal reach the same conclusion as the first, the petitioner is free to file a second petition with the Court of Cassation using the same legal arguments as in the first.

The Court of Cassation then re-examines the case at a common session of both sections. If the Court of Cassation's second decision is based on the same legal reasoning as the first, the Court of Appeal to which the case is now sent must conform its decision to that handed down by the Court of Cassation.

Subsequently, the Attorney General will call the attention of the Minister of Justice to this situation so that the government can introduce an interpretative bill in Parliament, to prevent further interpretative difficulty with respect to the particular point of law which gave rise to the dispute. ${ }^{20}$

In general, the Minister of Finance does follow the principle of any case in which the Court of Cassation hands down a decision, but there have been a few exceptions. Also, since there is no opportunity for further appeal, the potential impact of an adverse decision has sometimes led the government to introduce in the Parliament a so-called interpretative bill to nullify or modify the holding of the Court of Cassation. ${ }^{21}$

20 In tax matters, recent interpretative laws which do not nullify or modify judicial decisions include the following: Acts of May 24, 1948; May 30, 1949; March 19, 1953; March 18, 1955; March 24, 1959; December 21, 1962; February 13, 1963; March 16, 1964.

21 Interpretative laws which nullify or modify judicial decisions include the following: Acts of July 13, 1930; April 7, 1936; May 30, 1939; October 28, 1950; June 26, 1957; July 8, 1957; July 13, 1959. 


\section{PART THREE}

\section{FRANCE}

by

Pierre Kerlan 


\section{CHAPTER IX}

\section{ADMINISTRATIVE ORGANIZATIONAL AND PERSONNEL FRAMEWORKS}

\section{Section A. Administrative Organizational Framework}

\subsection{Introduction}

French standards of assessment for each tax, whether imposed for national or local purposes, are uniform throughout the country. While rates imposed by local units are not uniform, the subject-matter of all assessments, i.e., the property or transactions against which taxes are imposed, are governed by standards fixed at the national level. Thus the General Director of Taxes, ${ }^{1}$ as head of the division charged with administration and collection of all direct taxes, must provide for uniformity in the subject-matter of assessment while simultaneously utilizing decentralized administrative organization to determine and collect local taxes in accordance with locallyset rates, as well as national taxes.

There are three levels in the French tax administration: the central or national office, departmental or regional offices, and local tax offices which, while covering geographical areas of varying sizes, are supposed to have approximately identical work loads.

\subsection{Organizational framework, national office level}

At the head of the central administration, L'Administration centrale de la Direction Génévale des Impôts, is the Director General. Serving under the authority of the Ministry of Finance and of Economic Affairs, he is concerned both with tax policy and administration of the French tax system at the national and local levels. His office has three important subordinate divisions, excluding those responsible for personnel matters or for supervision of departmental and local offices: the International Relations Service, Le Service des Relations Internationales, the

1 The Director General of the Customs occupies an equivalent position with respect to this class of tax. The administrative divisions headed by these two officials bear the prime responsibility for French taxes. 
Legislative Service, Le Service de la Législation, and the Legal Service, Le Service du Contentieux.

The International Relations Service handles the preparation, negotiation, and interpretation of tax conventions.

The Legislative Service has two subdivisions: one deals with income taxes on enterprises with particular attention to industrial and commercial activity, Sous-Direction des impôts sur les enterprises, and the other with taxes on individual incomes, Sous-Direction des impôts sur les personnes physiques.

By allocating to each subdivision of the Legislative Service responsibility for a particular type of tax, a coordinated approach to that tax becomes possible. The same office proposes reforms to the Ministry and, if the proposal is approved, goes on to draft the bill together with the accompanying explanation of its objectives and significance. When the draft bill reaches the Council of State, the office participates in the discussion. And when the bill reaches the legislature, the office assists the Ministry in preparing for the debates, by developing the Minis try's statements of explanation, interventions, and in advising the Ministry on the significance of any proposed amendment. Since the debates are published in the official journal, the Ministry's interventions are considered of major importance should it later be necessary, because of interpretative difficulties, to determine the legislative intent. Finally, upon enactment, the same office prepares a variety of implementing materials. These range from statements designed to explain to agents of the administrative division the interpretative position of the Director of Taxes ${ }^{2}$ to formulation of decrees which, in effect, are supplements to the legislation itself.

A French statute tends to do no more than state the basic principles of a tax, i.e., general rules. Subsequently, an appropriate administrative office drafts a decree which sets out the method of application. Illustratively, when use of the declining balance method of depreciation was authorized by statute, the determination of the consequent depreciation rates was left to the tax administration. Its draft of a decree setting out this rate pattern was then submitted for examination to the Council of State, with the appropriate office participating in the discussion. Should unforeseen interpretative difficulties arise thereafter, the same office prepares an explanation which, upon

2 These statements are published in an official bulletin distributed to all agents. Private publishers make this information available to the public. 
approval by appropriate superiors in the administrative hierarchy, then becomes the administration's official position.

\subsection{Organizational framework, regional office level}

A regional office has been placed in each of the ninety departments in France, except for the Seine, which, because of the heavy population concentrated in and around Paris, has two such offices. Since the departments vary in population density and economic activity, there are marked differences in workload among the ninety-one offices.

At most, a departmental office will have ten qualified technical personnel on its staff, though the average is five to an office (including the director). The offices will also have an average of four other less qualified agents who are, however, well acquainted with fiscal legislation. These offices perform two functions, overseeing local office activity and dealing with specific problems arising at the local office level.

A wide variety of controls are exercised by the departmental office over the local offices under its supervision. Principal inspectors, attached to the departmental office, each supervise two or more local offices and advise the departmental director of the state of affairs in each.

After a local office has assembled the figures relating to the income and deductions for taxpayers within its geographical jurisdiction, it sends this data to the departmental office, which then computes the tax for each taxpayer on the basis of the figures supplied. Only then are taxpayers informed of the tax due. ${ }^{3}$ Auditing programs for the local offices are also fixed at the departmental level. Further, it develops the formulae used in estimating the actual taxes to be paid by certain groups of French taxpayers-small tradesmen, skilled artisans, professional men including doctors, dentists, architects, and lawyers-who are subject to the régime du forfait, a form of estimated or presumptive taxation. 4 Similarly, farm income assessment bases are determined at the departmental level after consultation with farm organization representatives. ${ }^{5}$

Specific problems arising at the local level also are brought to the departmental office, some by the local office but most by taxpayers. A local office may encounter either a factual situation not dealt with at all by statute or regulation or an

${ }^{3}$ Local offices also forward the relevant information upon which the departmental office fixes penalties.

4 See Chap. XI, 3.2b infra.

5 Id. 
ordinary interpretative question it cannot resolve. Either may be laid before the departmental office. If the question cannot be resolved there, the matter is forwarded to the Director General. Some taxpayers encounter problems which fall within the peculiar competence of departmental offices. These problems spring from unexpected financial hardship, arising from circumstances beyond the taxpayer's control, such as the death of a husband or a catastrophe such as fire or flood which terminates productive activity. Under such conditions, the departmental office may remit the tax in whole or in part up to specified monetary limits. Should the amount exceed such limits, the taxpayer's petition goes to the Director General, accompanied by the taxpayer's file and a report prepared by an agent of the local office reflecting the petitioner's tax base and the agent's opinion regarding available resources and the accuracy of the facts alleged.

Other taxpayers may challenge the imposition of a tax on the basis of an interpretative issue. Here scrupulous adherence to the strict conditions of a form set out by statute is required: failure to comply results in automatic rejection of the claim. Such claims are submitted initially to the same departmental office which earlier made the final determination of his taxes. If the form is correct, the claim is then forwarded to the appropriate local office where the inspector who determined the income analyzes the facts and points of law and prepares a report reflecting his opinion on the merits. The report goes to the departmental office, which is empowered to waive the tax if the taxpayer's claim is considered valid. If it is not, the claim is rejected by letter. After such a rejection, a taxpayer must use the courts for any further challenge.

\subsection{Organizational framework, local office level}

Below the departmental directions and directly responsible for preparing the assessment rolls are the 1700 local offices distributed throughout France. Each office has approximately the same work-load, though the territory under each-termed a section-varies, depending as it does upon population density. Thus a section in a rural area may include several communes, while a so-called mixed section may include a town and one or more adjacent rural communes. Sections in urban areas may include all of a small city, or only a portion of a major one. ${ }^{6}$

6 Illustratively, an urban section might include a portion of Marseilles, a rural section might include St. Valery en Caux, located in Normandy, a mixed section might include a city of 9,000 such as Vitre with the neighboring communes. 
The following table illustrates the number of communes and of taxpayers likely to be found in each of the three major types of sections:

Type of Section

\begin{tabular}{crr}
\hline Urban & Rural & Mixed \\
\hline $\begin{array}{c}\text { Part of the city } \\
22,236\end{array}$ & 31,659 & 31,900 \\
15,068 & 9,440 & 7,500 \\
3,538 & 2,382 & 2,442
\end{tabular}

Each section is headed by an inspector, assisted by one or more tax examiners and several clerks. There are 2400 inspectors for the whole of France, for certain sections have two. Technically qualified agents assisting these inspectors total $1200 .^{7}$

Each section's prime responsibility is to determine the tax base. About one-third of its effort goes into preparation of assessment rolls for local taxes (the land tax upon real property, the tax on occupancy, and license and franchise taxes). Even more effort is involved in preparing assessment rolls for income taxes, based either upon taxpayer declarations of income (as in the case of income from salaries, sales of personalty, and from commercial and industrial activity), or upon estimates of income (as in the case of profits from agricultural activity, from small shops, or from the exercise of the liberal professions).

To assist the inspector to make the assessments for all these taxes each section maintains individual files for each taxpayer. A file includes not only the declarations or estimates of the taxpayer's income but also reports sent in from other sources. These reports may be from the local bank (covering the opening or closing of bank accounts, and income from securities collected by the bank for the taxpayer), or from the registry of automobiles reporting on a taxpayer's purchase or sale of an automobile, or from other sources indicating his purchases or sales of realty or other property.

7 The insufficient number of personnel is recognized but all French administrative agencies experience difficulty in securing sufficient personnel. 
An effort presently is being made to regroup the local offices in metropolitan centers, though without any fundamental change in functions or organizations. Even now, the offices of more than one section are sometimes housed in the same building and are called tax centers, some consolidation of minor administrative functions having also been accomplished, such as receipt and dispatch of mail. A principal inspector of taxes supervises the work of the inspectors of one or more of these tax centers, and reports directly to the departmental director.

\section{Section B. Personnel Framework (Governmental and Non-Governmental)}

\subsection{Governmental professional personnel}

Quite different methods of recruitment and standards of qualification are applied to the two principal groups of officials associated with the tax administration: the top echelon of the national office, and all other officials.

Prior to 1945 , officials in the top echelon of the national tax administration, and in all other comparable divisions of the government, had worked up through the lower levels of the particular agency, qualifying on the basis of seniority and rank for a rigorous competitive examination. While this system produced men with great technical competence, it did not contribute to their awareness of non-agency factors and problems relevant to the governing process.

To remedy this situation, the provisional government in 1944 established a school, under the Prime Minister, to recruit and train top level officials for all ministries, $L$ 'École Nationale d'Administration. Upon admission the students are considered as officials, and are paid by the state ${ }^{8}$ during the course of study which lasts for twenty-eight months. The competitive examination for admission may be taken by two groups. To qualify for the first, an individual must be less than 26 years of age, and either hold a degree of bachelor of laws or possess a diploma from the Institute of Political Studies, L'Institut d'Études Politiques, or from some other comparable institute. To qualify for the second, an individual must be a public official, less than 30 years of age, with a minimum of five years

8 Between 1946 and 1964, the School of National Administration graduated 1282 administrators. Of these 45 have been appointed to the tax administration, representing about half the effective force of that agency. 
of public service. Only about ten percent of the candidates survive the initial examination and the majority of these hold both the degree of bachelor of laws and a diploma from the Institute of Political Studies, courses which can be pursued simultaneously.

The written portion of the initial competitive examination has a broad economic, social, and political orientation, covering (1) the evolution of some ideas and political, social, or economic developments since the eighteenth century, (2) policy considerations bearing on a contemporary economic issue, (3) the current political institutions of some important nation, international organization, or constituent of French administration, and (4) a translation into French of a text in a foreign language chosen by the candidate. Candidates who survive that test then take a penetrating oral examination designed to test the candidates' ability to deal competently and exhaustively with some matter of political or economic philosophy, within the framework of a brief speech, prepared on short notice, followed by questioning from the board of examiners. ${ }^{9}$ Then follows a series consisting of four additional oral examinations dealing with the following areas: (1) the candidates' general knowledge, (2) some social question, (3) either administrative law or fiscal legislation, as chosen by the candidates themselves, and (4), again at the choice of the candidates, either international organizations or economic and human geography. This series of examinations is concluded by a test dealing with the candidates' physical qualifications.

The candidates receive points on the basis of their performance in each examination, and the totals are multiplied by individual coefficients. From these come the rankings which determine the comparative standing of each individual. ${ }^{10}$

9 "For the second examination, the corresponding interrogation consists of a conversation with the board of examiners, lasting about twenty minutes after a preparation of ten minutes, having as a point of departure a text which both interests the tax administration and enables the board to determine the experience acquired by the candidate.

"This interrogation is entirely conversational, born of the idea that practical experience of some years is as valuable as academic training and that equality between the candidates is better assured if each is considered in terms of the personal training which he is supposed to have acquired in service. But the examiners obviously cannot confine themselves to subjects too technical and do not limit themselves to administrative techniques." École Nationale d'Administration, Concours et scolarité 35 (1964).

$10 "$... at each examination, the members of the board of examiners are careful to test, as to these matters, the extent of the education 
Upon admission to the National School of Administration, the students are sent to some unfamiliar part of France or to a foreign country, where for eleven months they work with top level French or international officials to provide practical experience as well as an awareness of administrative realities. ${ }^{11}$

The second period of study, lasting some seventeen months, is spent attending lectures, administrative conferences, and in working in either private or public offices and on practical exercises.

At the conclusion of this second period, the students are ranked, and select their careers in the order of rank. ${ }^{12} \mathrm{Be}-$ fore commencing work, however, a student must sign a pledge to serve the state for at least ten years. If he refuses to sign, he must refund the salary he received during his period of study.

Only at this point do the young administrators or judges begin to familiarize themselves with the specific requirements of their assigned functions. Illustratively, at the Ministry of Finance, administrators attached to the office of the Director General of Taxes now begin to learn the details of the French tax law. Previously, they knew only the principles and major outlines of that law, but with the typical background in law and economics, adjustment is rapid.

(footnote continued)

of the candidates; this is equally true with respect to basic and elementary ideas which, as to practical subjects, one has the right to expect of a future student of l'École nationale d'administration.

"As another president wrote, 'The examination should permit the selection of students capable of benefiting from the full complement of the training given at $l^{\prime} E$ cole and of adaptation to the functions of toplevel administration; it is less important to probe the extent of the candidates' knowledge than their presence of mind, their skill in shifting from one subject to another, and, this done, to consider the new subject in its totality, their frankness in acknowledging ignorance or their skill in palliating this, and finally their possibility of growth within the service." École Nationale d'Administration, Concours et scolarité 34 (1964).

11 At the conclusion of this period, each student prepares a detailed memorandum on some aspect of political, economic financial, social, or administrative problems.

12 The posts to which the students may be appointed include the Council of State, le Conseil d'Etat, the Court of Accounts, le Cour des Comptes, the administrative tribunals, les tribunaux administratifs, the Office of the Inspector of Finances, l'Inspection des Finances, Administrator for the Ministries of Finance, Foreign Affairs, Work, National Education, and of the Interior, Ministères des Finances, des Affairs Étrangères, au Travail, de l'Éducation Nationale, de l'Intériéur. 
Other lesser officials enter the tax administration by taking either the examination for examiner or that for an inspector.

To qualify for the former, a candidate must be less than 26 years of age, and hold a diploma evidencing his completion of the secondary level of education. ${ }^{13}$ Success on the examination is followed by a one-year training period during which trainees are paid. The training period includes a three and a half month period of study at the National School for Taxes, L'École Nationale des Impôts, and an eight and a half month period of on-the-job training in the field. ${ }^{14}$ Then after five years service as an examiner, during which he assists an inspector, an individual may take the examination for inspector. One-fifth of the inspector vacancies are reserved for examiners. ${ }^{15}$

Otherwise, admission to the examination for inspector requires that the candidate be less than 28 years of age and have completed at least one year's study toward a bachelor's degree in law. Indeed, the written examination itself covers some of the matters studied in that first year, for it requires preparation of (1) memoranda on some phase of economic policy or fiscal legislation, and on some aspect of civil or commercial law, and (2) at the choice of the candidate, either the solution of certain mathematical problems or a memorandum on constitutional law and political institutions. ${ }^{16}$ The candidate is subject also to oral interrogatories.

Students who successfully complete the examinations are then paid while taking the two-year course of study for inspectors at the National School for Taxes, L'École Nationale des Impôts. This program includes two periods of practical experience in the field and two periods of study in Paris. ${ }^{17}$ The

13 The written portion of the examination requires the candidate to solve certain mathematical problems, to prepare an essay on a subject of general information and a memorandum on some aspect of France's governmental organization. Also the candidate must explain orally a text of general significance, and submit to interrogation on financial legislation.

14 Located since October 1966 in Clermont-Ferrand.

15 The examiners have the further advantage of being excused from the requirement of further academic study, i.e., they need not secure the degree of bachelor of laws.

16 While optional with each candidate, competence in foreign language and/or accounting may be demonstrated in addition to the required proofs of admissibility.

17 Since October 1966, located in Clermont-Ferrand. 
schedule deliberately is planned to permit the students to attend simultaneously the law school and thus secure their degrees in law. The first period of study emphasizes comparative tax systems, social and economic aspects of the French tax structure, principles of taxation embodied in French fiscal legislation, and principles of commercial accounting. Before the first year ends, the students choose between specialization in turnover taxes, taxes sur le chiffre d'affairs, or in registry and direct taxes, contributions directes et enregistrement. This choice largely controls the materials to be studied during the second year, though all students also continue to study accounting principles and procedures.

If the candidates for the rank of inspector did not possess a bachelor of laws degree upon entering the training program, they are required to obtain the degree before completing that program. Those candidates who are unable to obtain such a degree are classified as examiners. 18 Upon graduating from the National School for Taxes, students must agree to serve the state for at least eight years; sums previously advanced must be refunded if the agreement is broken.

New inspectors are assigned to either the national or departmental offices, or placed at the head of a local office. After ten years, they may take the competitive examination for the rank of principal inspector. 19

Principal inspectors may work under departmental directors, supervisory inspectors who either audit accounts or establish the assessment rolls. Alternatively, a principal inspector may be given specific duties of his own relative to either audit or assessment. Occasionally, principal inspectors also serve as technical associates in the national office or as departmental directors.

\subsection{Private tax practitioners}

There are three main groups of tax advisors: former inspectors of taxes, expert accountants, and specialized advocates.

18 Since the training program includes two periods of residence, initially in Paris, since October 1966 in Clermont-Ferrand, it is entirely feasible to acquire the required law degree.

19 While account is taken of the professional qualities and general abilities of the candidates, each candidate also must prepare an essay on an economic or financial problem and a very detailed memorandum on a specific tax question, his only reference being to the general tax code. Finally, oral examinations also are given to test his technical knowledge, his reasoning abilities, qualities of judgment, and his general aptitude in administrative and control techniques. 
Former inspectors of taxes comprise the largest single group of lawyers specializing in tax practice. These men have a bachelor's degree in law, ${ }^{20}$ have been trained at the National School for Taxes, and couple their practical experience with intimate knowledge of the inner workings of the tax system.

In consequence, this group typically represents taxpayers in contested cases, both at the administrative level and in the courts.

Because other lawyers who lack this in-service experience do counsel on business matters, some inevitably also give advice on tax problems. Their earlier formal education did not deal with the fine points of tax legislation. The subject was touched upon in only two of their courses: Public Finance, and Commercial and Tax Law of Business Transactions, which is required of students concentrating in private law but not of public law concentrates. In consequence, except for the very few who have devoted much time mastering the details of tax law, these advocates tend to be far less competent in tax matters than the previously described group of former inspectors.

Members of a final group of tax advisers were trained as accountants in accounting offices, though some have completed studies at the university level in either schools of commerce or law. The examinations for an accountant's diploma emphasize primarily accounting techniques and only secondarily touch upon legal matters. These accountants, after preparing the financial statements for a business enterprise, apply the tax law in extracting the data necessary to fill out declarations of income from taxable profits.

20 Except for former examiners who qualified for the rank of inspector and were excused from this requirement. 


\section{CHAPTER X}

\section{ADMINISTRATIVE RULE-MAKING PROGRAMS}

\section{Section A. Character of the Underlying Statute}

\subsection{The precision of the statute itself}

There are more than 2,000 articles in the General Code of Taxes which covers all taxes levied in France by the central government, departments, communes, and certain public institutions. Of these, only 248 articles deal with determination of the tax on income. These cover 80 pages, each of which includes about 600 words. An added 28 pages deal with collection, penalties, procedure, and litigation.

To the statutes enacted by Parliament ${ }^{1}$ must be added the regulations ${ }^{2}$ which are issued by administrative agencies and which may be tested, as to legality, before the judiciary. Tax regulations appear in an annex to the General Code for Taxes. Those relating to the income tax cover 77 pages, and thus, in bulk, almost equal that part of the code to which they relate.

A factor contributing to the importance of these regulations is the form of French tax statutes. Principles and fundamental concepts are not defined, although the terms-for example, income, profits, etc. -- are used constantly. Ultimately, independent tribunals hammer out the general meaning of such terms.

Special rules and exceptions, though relatively few in number, are set out in both the statute and in the regulations. And when these come before the independent tribunals, they are construed strictly. ${ }^{3}$ Illustrating the degree of specificity found in the exceptions is Article 157 of the Code, which enumerates the types of income which need not be taken into account in determining the total net income of an individual. Excludable income under this article includes (1) income from properties

${ }^{1}$ Article 34 of the French Constitution gives Parliament exclusive power, in the case of all taxes, to enact statutes relating to the tax base, the rates, and the methods of collection.

2 Parliament, in enacting a statute, can delegate expressly to the administrative agency the power to fix the method of applying the law which itself states only a general principle.

${ }^{3}$ See 2.4 infra. 
classed as historical monuments subject, however, to such conditions as may be imposed by the classifying decree, (2) interest on Treasury bonds with a maturity date of five years or less, (3) gratuities given to long-time workers to whom the Minister of Work has conferred a medal of honor, (4) arrearages on certain bonds issued in 1952 and 1958 .

As distinguished from the exceptions, however, the general rules leave room for much interpretation. To illustrate, Article 209 states that corporations are subject to the corporate income tax only to the extent that profit is derived from enterprises conducted in France. 4 The Code does not define the meaning of "conducted in France." An indication of the degree to which this created interpretative questions is implicit both from the following description of criteria which evolved out of case law and administrative regulations, and from the fact that, despite these criteria, difficulty in practical application persists. The criteria which evolved include: (1) operation of an establishment in France, (2) activity in France of an agent whose legal identity, in concluding contracts in the name of the enterprise, is not distinct from that of the enterprise itself, and (3) realization in France of profits from operations entirely carried on in France, e.g., purchases and sales of merchandise there.

Also illustrating the generality of France's statutory pattern is the area of depreciation deductions. The Code itself does nothing more than authorize deduction of "amortizations really effectuated by the enterprise, within the limit of those generally admitted according to the usages of each particular type of industry, of commerce or of operation." 5 Under this general provision, enterprises are free within the limits of the particular industry's customary usage, to determine their own depreciation deductions in the first instance. The tax administration is also free, however, to prove those deductions excessive. ${ }^{6}$ In this same connection, a recent statute which permits

4 The text of Article 209 follows in part: "... en tenant compte uniquement des bénéfices réalisés dans les enterprises exploitées en France."

5 Article 39-2 reads in part as follows: "... amortissements réellement effectués par l'entreprise, dans la limite de ceux généralement admis d'après les usages de chaque nature d'industrie, de commerce ou d'exploitation."

6 In actuality, the rate of depreciation is less of a problem in France than in other countries, such as the United States, where very precise and detailed rules have been set. There is little interest in 
the use of the declining balance method in calculating depreciation states only the principle; the method of application is left entirely to administrative regulation.

\subsection{Legislative pre-enactment aids to interpretation}

The initial characterization applied to proposed legislation depends upon its source. If presented by the government, it is termed a draft, if by a member of Parliament, a proposal. In either case, however, the initial presentation of the bill is accompanied by a written statement of the motives, exposé des motifs. This statement explains the purpose and scope of the proposed legislation. It also puts into lay language the technical terminology of the proposed bill which frequently will contain cross-references to existing statutes.

The proposed bill is examined by the Committee on Finances of the National Assembly. The Minister of Finance, accompanied by senior civil servants from the office of the Director General of Taxes, attempts a full explanation of the bill and answers inquiries. These hearings are not open to the public, nor are they published. The final report prepared by a reporter appointed by the Committee is published and distributed to the members of the Parliament. However, professional groups get in touch with individual members of Parliament and make known their opinions or objections. Further, the press usually carries a critical analysis of the bill as proposed.

In contrast to the non-publication of the Committee's hearings, the debates which follow in the National Assembly are fully published in the official journal. These parliamentary discussions are preceded by an explanation of the entire $d r a f t$ or proposal. Spokesmen for different groups state their general views on the proposed bill. Discussion of the bill then follows, article by article, with proposed amendments to any article being discussed before the article itself. ${ }^{7}$ Deputies state their positions, and the Minister of Finance, assisted by technical counselors (officials from the office of the Director General of Taxes), states his view of any proposed amendment,

\section{(footnote continued)}

France in instituting such a system. Under French law, all gains derived from the sale of active elements, assets, are taxed as ordinary income, and hence excessive depreciation cannot yield a preferentially treated capital gain on subsequent sales.

7 Any deputy is free to propose such amendments during the hearings before the Committee or before the debate opens. 
whether in criticism or assent. He also explains the government's interpretation of the proposed text. Finally a vote is taken on the article in question.

Because debates are published in full, the public has ready access to the Minister's stated opinions, explanations, and the answers he gave to the questions posed. These are extremely valuable in future attempts to interpret the statute, for in them may be found the intention of the legislature. Indeed, deputies frequently address interpretative questions to the Minister, in writing or orally, to force disclosure of the administrative interpretation of particular clauses. ${ }^{8}$ These questions usually are prepared by tax practitioners and provoke wide interest. ${ }^{9}$ In addition to publication in the official journals, the official tax administration bulletins and the tax law reviews reprint them with added commentaries.

\subsection{Standards of construction followed by the judiciary in in- terpreting the statute}

Administrative tribunals, with the Council of State at the apex, and not the ordinary judiciary, have jurisdiction both to determine the legal status of tax laws and regulatory acts (decrees and orders) and to interpret them. It is most unusual, however, for the tribunals to encounter a case wherein the taxpayer seeks to have even a regulatory act declared invalid for reasons of illegality, recours pour excès de pouvoir, on the ground the regulation exceeds the limits set by the law. But where such an action is successfully maintained, the act being declared ultra vires, it will suffer that impediment as to all taxpayers, present and future, erga omnes.

The prime function of administrative tribunals in tax cases is to apply the law and regulatory acts, and if their texts be silent, obscure, or inadequate, the tribunals must interpret them. This interpretative function has become an increasingly significant source of law because of the increasing complexity of legislation and the wide ranging diversity of transactions. Marginal and paradoxical situations heretofore unforeseen continually arise. Consequent imperfections in the regulatory texts

8 The oral questions are known as orales, Actually, they are written but are termed orales, because their text and the answer, also in writing, are read aloud.

9 These questions frequently relate to an anticipated interpretative difficulty which the recently enacted statute will create for some section of the tax codes, or to an apparent conflict between a taxpayer and some local tax official as to a particular situation. 
are inevitable, have become every day matters, and their firm resolution is the important task of the administrative tribunals. ${ }^{10}$ The manner in which these tribunals have approached their task has been marked by at least two tendencies.

The first has been facilitated by the generality of the French statute's basic principles. As distinguished from other areas of case law, the results actually reached by these tribunals reflect a greater concern for similarities in the net effect of transactions than for differences involving mere legal niceties. That facts and factual effects are stressed, ${ }^{11}$ rather than legal arguments based on the subtleties of the private law, warrants the conclusion that these tribunals tend to construe the basic provisions of the statutes broadly, not narrowly or pedantically. This rests on the supposition that France's publicly oriented income tax statute was intended, to a greater extent than the private law, to focus on the economic essence of transactions, and this necessarily renders formal legal distinctions less significant. Thus account may be taken of illegal situations or those lacking an equivalent in private law-e.g., illegal commercial practices, the existence of irregular corporations, or prohibited activities (drug traffic, white slave traffic, etc.). This is not to suggest, however, that the tax law is completely independent of the private law. Indeed, it appears primarily in instances where the broadly based general principle of a statute or regulatory act is coupled with a precise identification of those matters to be excepted.

A second tendency reflected in the results reached by the administrative tribunals shows their interest in guaranteeing certain basic rights to taxpayers, by imposing what might be called due process requirements. For example, it was the Council of State that first established the principle that a regulatory act could not have a retroactive effect if it established a tax covering the past. ${ }^{12}$ Again, the Council of State held that, to the end of preserving to a taxpayer the chance of making an adequate defense, a judge in a tax case could not take judicial notice of facts, submitted by the tax administration, if access to the source was denied to the taxpayer. While these guarantees may represent nothing more than an extension to the tax area of general legal principles, it is noteworthy that

$10 \mathrm{C}$. Lasry, The Council of State, Studies and Documents (1955).

11 See Conclusions Corneille, Order of January 21, 1921. Sirey 1921. 3.38.

12 Order, December 23, 1949, Lebon 567; Order March 16, 1956, Lebon 121. 
that the extension was accomplished in the first instance by courts. Only afterwards were they confirmed by the legislature. ${ }^{13}$

Where a court is faced with an interpretative question as such, it seeks to determine the intention of the legislature in order to clarify its own understanding of the text of the statute. It will give prime attention to the expose de motif, the explanation presented by the government at the time the bill embodying the presently considered statute was under consideration by the Parliament. In addition, the court will read carefully the debates to note the comments made prior to enactment, such comments frequently providing considerable assistance in the resolution of issues. In general, it may be said that the courts do not seek to limit the tax statute by strict construction but instead seek to effectuate what they conceive to be the basic purpose of the provision in question.

\section{Section B. The "Regulations" Program}

\section{4 and 2.5 Types, force, and purpose of "regulations"}

In France, the expression, regulations, has a quite different meaning than that accorded the term in United States tax administration. In France, the term covers both regulatory texts-that is, the decrees-which as a part of the law must be followed and thus possess true legal significance, and administrative instructions which do nothing more, on the substantive side, than reflect the administrative view.

The legal effect of the regulatory texts stems from the constitution, which vests regulatory power in the Prime Minister. ${ }^{14}$ These texts may be promulgated under the general regulatory power or pursuant to a particular statute which delegates to regulatory texts the establishment of details regarding a general principle and its application. The regulatory texts are published in the official journals and must be taken into account both by the tax administration and the tribunals.

In no case, however, may these regulatory texts be contrary to the statutes themselves. ${ }^{15}$ While the judiciary must recognize their force, it may inquire into their legality. Should the occasion arise, careful consideration will be given to the

$1 \overline{3}$ Acts of 1959 and 1963.

14 Art. 21, Constitution of 1958.

15 See 2.3 supra. 
question of whether a regulatory text creates a taxpayer obligation exceeding that prescribed in the law.

As noted earlier, taken together, these regulatory texts have considerable bulk as well as importance, ${ }^{16}$ in part because they both implement and supplement the statutes themselves. Thus not only do the regulatory texts complete the gaps left in the statute by the legislature but further they specify the manner in which the statute is to be applied in practice. All such texts, however, are not issued by the same governmental level and all are not of equal weight. The formal classification is significant, for the provisions of the text cannot be revoked or modified by a text of lesser weight. The revoking text must be at least of equal or greater weight. Thus a simple decree cannot cancel a decree issued by the Council of State, whereas a decree from the Council of State can revoke a simple decree or a ministerial order. A description of the different types of regulatory texts, ranked in descending order, follows.

Decrees which take the form of a regulation of the public administration spring from language of a specific statute which delegates the rule-making function regarding details and methods of application. They are issued by the Prime Minister after consultation with the general assembly of the Council of State. Drafts are prepared in the office of the Director General of Taxes and forwarded to the Ministry of Finance which submits them to the Council of State. There they are examined fully. Senior civil servants from the Director General's office are present for the purpose of explaining the regulation's general purpose and specific objectives, as well as to answer queries. The Council of State renders an opinion, favorable or unfavorable. It is free to propose changes both as to form and substance. Proposed changes of form are generally, but not always, accepted by the office of the Director General. Proposed substantive changes raise questions of public policy which the government itself ultimately must resolve, as such matters are not left to civil servants.

A second type, decrees of the Council of State, arise from the government's request that the Council of State render an opinion, which takes the form of a decree. It is not necessary to convoke the general assembly of the Council of State for this purpose; one of the administrative divisions acting alone is competent to act. As suggested earlier, such a decree carries

16 See 2.1 supra. 
less weight than a decree in the form of a regulation of the public administration. And should the Council of State render an unfavorable opinion, the government may disregard it. Moreover, opinions by the Council of State, falling in this second category, are never published.

Simple decrees issued by the Prime Minister constitute a third type. While he customarily consults the Council of State, this is not required.

Ministerial orders, a fourth type, are issued by the competent minister as he considers necessary or desirable.

Apart from these regulatory texts, circulars, instructions, and memoranda are prepared by the office of the Director General of Taxes for use by the tax administration. Unlike most regulatory texts, these publications are not submitted to the Council of State. Nor are there any public hearings, though in some cases officials will contact representatives of affected trade and professional groups ${ }^{17}$ or officials of other interested Ministries. These publications rephrase in lay language the statutes and the implementing decrees. ${ }^{18}$ They specify the procedures to be followed by the local tax officials who must abide by these instructions. Taxpayers are not bound by the interpretations set out in the instructions but they find them an excellent source of information regarding the governmental interpretation of the statute. They are free, however, to contest the application of such instructions to their personal cases before competent tribunals, citing in support of their position the statutes and regulatory texts. These administrative interpretations differ from the regulatory texts not only by reference to their respective official sources and in the weight accorded them, but also in the form they follow. Regulatory texts follow a legal form, similar to a statute. Administrative instructions are expository in that they seek to explain the law and the implementing decrees, using as an aid numerous examples. The examples cover not only the most frequently arising situations, but also some unusual ones. Often the administrative position they reflect is more liberal than strict construction of the statute would permit. These instructions are not considered unalterable; additional ones are published where

17 Typically, as soon as a statute is passed by Parliament, affected groups clamor to be heard that they may express their opinions on the implementation of the statute. Thus it is very easy for the office of the Director General of Taxes to learn their views and reactions.

18 In a typical instruction, the official text of the statute and the regulatory texts appear in an Annex. 
modification appears desirable, e.g., where new unforeseen interpretative difficulties arise. Unfortunately, however, the instructions do not cover all of the legislation enacted. Irregularly, the tax administration collects instructions which have been issued intermittently over a period, rearranges them in logical order and republishes them in a major circular. The prime shortcoming of the instructions is that they do not cover all of the legislation enacted.

\subsection{Manner of processing "regulations"19}

While regulatory texts and the administrative instructions have the important differences noted above, there is a strong unifying force. The same office prepares both. In fact the same officials will have drafted the original bill ${ }^{20}$ to which the regulatory text and instructions relate. ${ }^{21}$ This preserves continuity of thought beginning with the draft of a bill through its implementing regulatory text and complementary instructions. ${ }^{22}$

The time which elapses between the enactment of a statute and the appearance of the regulatory texts is not uniform. If the statute itself fixes a specific period of time, usually an attempt is made to comply. However, some regulatory texts have never been prepared for publication, despite statutory directives. This is most likely to occur where the statute was enacted as a result of parliamentary initiative, over government opposition stemming from a belief the statute itself is unworkable in practice. Illustratively, in 1959 a member of Parliament proposed-and Parliament enacted-a provision imposing a complementary tax of 15 percent on income derived by workers who took on additional jobs during their free time, that is, over the weekends and vacations. ${ }^{23}$ Complaints had arisen over

19 The diverse types of French regulations required that their purposes be dealt with in 2.4 and 2.5 supra.

20 Changes, of course, may have been made in the course of the parliamentary debate.

21 Where a circular treats the administrative matters outside the tax law area itself, it will be prepared by another group of officials who are charged with a different level of activity-i.e., administrative duties.

22 As pointed out in Chap. IX, the office of the Director of Taxes is divided into groups of officials by reference to particular types of taxes or activity. Thus the office responsible for taxes on industrial and commercial profits prepares, as to that subject, the drafts of any law, implementing or supplementing decress, and the administrative instructions.

${ }^{23}$ Law of December 22, 1959, Art. 22, paragraph 45 . 
this practice, travail noir, and the legislation was in response thereto. However, the tax administration considered that it was impossible to apply the measure, recognizing the clandestine nature of the activity and the difficulties in securing information. In consequence, it made no effort to take any actual steps to implement the legislation and hence addressed no instruction to the men in the field.

Administrative instructions tend to appear within one to four months after publication of the law and the implementing decree. The law of December 28, 1959, instituting the use of the declining balance method of depreciation, can be used to illustrate the typical time pattern. The regulatory text or decree was issued on May 9, 1960. The first administrative instruction was dated August 22, 1960, and since then a few decisions on particular points have been published by the administration.

\section{Section C. The Rulings Program}

\subsection{Formal advance rulings to taxpayers}

France makes no provision for advance rulings requested by individual taxpayers on prospective transactions. On occasion, however, collective rulings are issued in these circumstances, and even private rulings may be obtained in the case of completed transactions.

The so-called collective rulings are issued in response to requests received from the tax departments of trade or professional organizations, to resolve interpretative difficulties or unanticipated situations encountered by that trade or profession. Such tax departments constantly study new laws, implementing decrees, and instructions, to ascertain possible effects on the association's members. A commentary on the law, taking due account of administrative interpretations, is prepared and distributed to the members. Not infrequently, an organization's tax division contacts the appropriate officials in the office of the Director General to resolve a question or raise an objection bearing, e.g., on the rate of depreciation regarding new types of equipment or on the variations in the provisions regarding risks insured by insurance companies. If the matter lends itself to easy resolution, the competent official's oral opinion may suffice. If the matter does not lend itself to such informal treatment, detailed and thoughtful consideration being required, no oral answer is given. Instead, after the informal 
discussion, the organization's representatives submit the problem in writing to the office of the Director General of Taxes. This memorandum is turned over to the same group of officials who drafted the bill, decrees, and administrative instructions which provoked the inquiry. This group prepared the official response. The importance of the question posed by the trade or professional organization determines at what official level the response will be signed. ${ }^{24}$ Should a quite liberal interpretation be considered desirable, the Minister, who is responsible to Parliament, will make the actual decision, not the civil servants. In any event, any written response is always in the form of a memorandum which the administration is willing to have published. Once transmitted to the tax division of the particular association, the administration feels bound by the decision. The association itself will distribute this decision to its members, and the tax administration will send it to all officials.

Individual taxpayers may, though rarely do, request that the administration advise them of the effect of a statute, regulatory text, or administrative instruction on a given completed transaction. Such a request must be written, and should be as clear, complete, and precise as possible, explaining each detail of the completed transaction, so the administration's agents can obtain readily all of the requisite information and factual proof. Requests of this kind, addressed to the departmental Director of Taxes, are investigated by an inspector who makes a field audit. Should the departmental Director feel uncertain regarding the proper response, the taxpayer's request is forwarded on to the Director General of Taxes. The written response of this office is then forwarded to the taxpayer. A declaration of income prepared by a taxpayer in accordance with the official response will not be challenged if his own situation, and the relevant law and regulations, remain unchanged. However, the official response binds the administration only as to that taxpayer alone; it does not have general application.

While the above procedure is seldom used, another is employed fairly often. Trade associations or tax advisors will contact a deputy in the National Assembly and request that he pose an interpretative question to the Minister of Finance. The deputy will submit the question to the Minister in writing. The

24 In the order of increasing importance, the response will be signed by the head of the office, the under director charged with the tax on enterprises, the chief of the legislative service, or by the Director General himself. 
resulting answer from the Minister, contrary to a private ruling on a completed transaction, will apply to all taxpayers and as to both prospective and completed transactions, absent a statutory or regulatory change.

\subsection{Informal technical advice to taxpayers on proposed trans- actions}

It is most unusual for a French taxpayer to request informal advice from a tax agent on the tax consequences of a proposed transaction. Occasionally, legal advisors of large corporations do contact officials in the office of the Director General of Taxes to discuss orally some anticipated tax questions. Such officials do indicate their own opinions, and on occasion, at the request of the taxpayer, these are reduced to writing. 25

\subsection{Technical advice to field offices}

Should a local inspector be unable to resolve interpretative questions which arise during the course of an assessment, he will refer the question to the departmental Director. Should the Director, in turn, feel the need for advice from a yet higher echelon, the question is forwarded by him to the appropriate officials in the office of the Director General. The officials, to whom the matter is referred there, previously will have drafted the bill, implementing regulatory texts or decrees, and administrative instructions, and served also as the earlier described point of contact with trade associations. Thus consistency of interpretation is assured. These in-service requests for advice can be handled informally-i.e., by telephone or in a written communication not sent through the usual channels. More often than not, they are forwarded as official requests, and the formal answer of the superior relieves his subordinate of all responsibility. The taxpayer is not informed that such a request has been made, is not given a hearing by the higher echelon, and the response is confidential.

Most frequently, these requests for advice are settled at the departmental level. Those which reach the Director General's office usually raise questions having both broad theoretical and practical significance. Occasionally, conclusions reached

25 While this procedure is rarely requested by French taxpayers, American law offices located in France request advice with great frequency, without doubt to relieve them of responsibility or because of the well established American practice to invoke such a procedure. 
at the national level are published in the official weekly bulletin of the tax administration.

\subsection{Publication of technical advice given taxpayers and local offices}

The tax administration publishes a weekly bulletin which reprints statutes and decrees which appeared earlier in the official journal. Also included are the instructions, circulars, and interpretative memoranda sent out by the office of the Director General. Where deemed appropriate, the bulletin also sets forth the previously published answer to the written questions posed by deputies in the National Assembly, significant case law, accompanied by official comments, as well as other memoranda reflecting administrative positions. There is no systematic pattern as to the publication of such memoranda.

Those bulletins appear in looseleaf form with an index. They are distributed to the local inspectors, and taxpayers may subscribe to the edition which omits directives relating to internal procedures and policies. Unfortunately, the publication of the clarifying memoranda is seriously in arrears; the appropriate offices have not had time to complete the necessary synthesis and coordination. Further, in actual practice, outside publishers in contact with the tax administration and with government officials have taken over the prime responsibility of integrating such material as is made available, and prepare commentaries thereon. 


\section{CHAPTER XI}

\section{ASSESSMENT, REFUND, AND ADMINISTRATIVE APPEAL PROCEDURES}

\section{Section A. Assessment and Audit Procedures}

\subsection{Introductory note}

French income tax law relies on two procedures to make final assessments. The first begins with an annual declaration of actual income by all taxpayers not in receipt of certain types of income. The tax administration retains the right to verify and where necessary correct these declarations. The second, applicable only to small enterprises, the professions, and agricultural pursuits, is designed to minimize the burden both of record keeping by the taxpayer and of verification by the tax administration. It relies ultimately on estimates of income. Estimates may also be used where the external evidence of the taxpayer's wealth varies substantially from his declaration.

\section{2a Details of assessment and audit procedures re actual in- come}

Every taxpayer, whether individual or corporate, submits annually on appropriate forms furnished by the administration, a declaration of income. ${ }^{1}$ The head of the household includes any income received by his wife and dependent children. The declaration includes taxpayer identification data ${ }^{2}$ as well as information identifying each source of income. ${ }^{3}$ Where an individual, carrying on an industrial, commercial, or professional activity, must or chooses to be assessed on the basis of actual

1 Most taxpayers must submit their returns by February 28. However, taxpayers with income derived from industrial, commercial, or professional activities need not submit their returns until March 31 if such are based on actual profits.

2 Address, date and place of birth, nationality, social security identification number, as well as the names and dates of births of dependent children.

3 Where wages are listed as a source of income, the name and address of the employer must be shown. Where there is income from real property, the address of each piece of real estate must be given and the gross as well as the net rents. 
rather than estimated profits, ${ }^{4}$ the return must be accompanied by sufficient documentation to establish the net profit. This documentation includes profit and loss statement, a balance sheet, and a detailed abstract of the depreciation schedule and of inventories on hand. Individual taxpayers, who must or choose to be taxed on the basis of actual profits, calculate the total amount of taxable income but not the tax itself. ${ }^{5}$ The assessor will do the latter. Corporate taxpayers, however, not only calculate the total amount of taxable income but also the tax, forwarding with the return whatever tax may be due. ${ }^{6}$

Declarations, upon receipt by the appropriate local office, ${ }^{7}$ are classified on the basis of taxpayer files, arranged according to street addresses in the cities and by alphabetical order in little communes. These files, one for each taxpayer, ${ }^{8}$ contain all the information which has been built up over the years concerning his affairs, this being derived in part from his annual declarations and in part from outside sources. 9

4 See $3.2 \mathrm{~b}$ infra.

5 Thus there is a significant spread between the time the taxpayer files his return and the time he is notified of the amount owed. The administration must verify statements on his return, as well as check it for mathematical accuracy. Upon discovery of an error, the taxpayer will be notified, and further delay ensues, until he responds. Thus, commencement of the collection process, preceded by completion of the tax roll, does not begin until early autumn and the tax itself will not be paid before the end of the year. Because of this delay, individual taxpayers, whose tax is on an income for the preceding year exceeding 200 francs, must pay two installments during that year, each amounting to one-third of the preceding year's tax. When the final assessment is made for that year, only the balance will remain due.

6 In actuality, any corporation will have been making quarterly payments throughout a given year, covering the taxes for that year, the several installments each amounting to one-fifth of the total taxes paid in the preceding year. Adjustments in the event of decreased income may be made. However, should the tax owed prove to exceed the payments, a penalty for late payment is imposed.

7 Each is dated by the mail room (and an acknowledgment sent out) to avoid disputes over the application of the penalty for late filing.

8 Each local office, as pointed out in Chap. IX, is charged with a particular geographic section. If the taxpayer moves to another geographical area, the file is forwarded to the local office bearing responsibility for that area.

9 The local office uses other official sources to make sure its files include every taxpayer. For example, all inhabitants of each commune pay an annual local tax, and this requires an annual listing of all residents. In cities with populations in excess of 9,000 there is an annual census, each landowner being required to declare the names of his tenants. Identification of the landowners presents no problem because there is a cadastral survey. 
Once received and classified, the declarations are divided, those showing income in excess of 25,000 francs being placed in a separate category. This group is processed first. File sheets (constituting the original of the assessment role) are set up, with the taxpayers' names appearing horizontally at right angles to vertical columns showing dependents, type of income, etc. ${ }^{10}$ Once the declarations are checked for mathematical accuracy and the entries on the assessment roll are completed, the declarations themselves are placed in the taxpayers' files, to be fully examined for verification at a later date. The sheets are forwarded ${ }^{11}$ to the office of the departmental Director which calculates the $\operatorname{tax}^{12}$ and prepares the notices to be sent out to the collectors for each geographic district. ${ }^{13}$ The collector, the official personally responsible

10 The file of the taxpayer actually is made up of a permanent file and annual sub-files. The permanent file contains, inter alia, data bearing on his income from land (i.e., reports on the purchase and sale of real property, location of his real property, cadastral identification of real property and buildings thereon, if any), from industrial and commercial activity (including, if incorporated, articles of association and other relevant data), from choses in action, from stocks and bonds, and other reports showing the opening and closing of bank accounts (forwarded by the depository banks), purchase of automobiles (forwarded by the office handling registration of vehicles), contract of marriage, declaration of succession, and the declaration of capital in 1945 for the assessment of the national solidarity tax. The annual files are prepared on a yearly basis and include only documents relating to that year: the declaration of income with supplementary statements relating to income from land or to industrial and commercial profits, and also statements supplied by others, i.e., by payors regarding wages, fees for professional services, pension payments, and dividends.

11 Income is broken down according to its source, i.e., income from real property, wages, stocks and bonds.

12 The local offices are not able to prepare and forward all the assessment roll sheets simultaneously. Hence, the sheets concerning those taxpayers declaring income in excess of 25,000 francs are forwarded in order of their preparation to the office of the departmental Director by April 30. Later sets of sheets are dispatched to the departmental Director's office by May 20, June 20, and July 20.

13 Some effort is being made, on an experimental basis, to utilize a central computing system to handle tax calculation and notification. Under this proposed system, the local office would prepare a report for each taxpayer which would serve as the basis for preparation of perforated cards. However, the bulk of tax calculation is still carried on in the traditional manner. Under the generally prevailing method, when the assessment roll sheets arrive at the departmental Director's office, the portion of the sheet showing the names and addresses of the taxpayers is detached. The sheets, now devoid of any 
for the collection of taxes on the rolls sent to him, then addresses the notices to the taxpayers, and thereby fixes the future date when tax payments will be deemed overdue. ${ }^{14}$

At some point subsequent to the transmittal of the assessment roll sheets to the office of the departmental Director, the local office verifies or audits the taxpayers' declarations, either at the local tax office or at the taxpayer's place of business.

In the course of this verification or audit, the inspector has full authority to make such adjustments as he feels desirable, including the correction of errors of fact or law in the government's position. In addition, he may conclude, as to allyes-or-all-no questions of law, that it would be preferable to reach an accord with the taxpayer rather than pursue the matter through the higher administrative levels or even the courts. Accordingly, and to the end of attempting to reach an agreement, he may propose a settlement based on the relative merits of the positions of the two parties. Should the taxpayer agree, the settlement will be made and will bind both parties. Such a settlement can include either the trading or the splitting of issues. The inspector at this early stage-and at all subsequent stages-has the full power to reach a binding settlement. In complex or important situations, he may discuss the matter on an informal basis with his supervisor, but the authority and the responsibility are his alone.

Where the examination is confined to the local office, documents in the taxpayer's file furnish the prime, though not the only, informative source against which the declaration is tested. These will assist the inspector in verifying the dependents claimed, 15

(footnote continued)

identifying data, are sent out to individuals (not full-time employees of the tax administration but retired individuals or housewives who seek to supplement their incomes) who perform in their homes the work of tax calculation, on a piece-work basis. These taxers, working under the supervision of the tax administration, use tables which permit a ready calculation of the amount of tax with reference to the number of dependents, thus reducing the possibility of error. After the taxers have completed their calculations, the sheets are returned to the departmental Director's office where the names of the taxpayers are paired up with the sheets showing their income and their total tax.

14 Once the assessment roll sheets are signed by the departmental Director, they become enforceable. These rolls also are sent out to the collectors for each geographic district.

15 Since the local office has sent the first of these assessment roll sheets to the office of the departmental Director by April 30, theoretically a tax roll should be established by May 31, with the tax payable by June 30 . To take account, however, of the fact that delays in 
the income listed, ${ }^{16}$ and the deductions taken. 17 A quick check also is made to determine if the total income tends to correspond to the general manner of life led by the taxpayer, ${ }^{18}$ and to his capital investments, transfers, and debts incurred or repaid. ${ }^{19}$ Data on documents relating to his local taxes is scanned to see, for example, if the taxpayer is maintaining a secondary residence. 20

Should the inspector ascertain a discrepancy between the income declared and the results of his general audit, he either can request an explanation from the taxpayer or arrange for a field audit which would be undertaken by personnel at varying levels depending upon the nature and size of the business. The local inspector himself would handle it if the individual has

\section{(footnote continued)}

tax calculation do occur, a tax penalty of $10 \%$ becomes operative for communes with more than 3,000 inhabitants only after the fifteenth day of the third month following issuance of the notices, that is, at the earliest, after September 16-and for other communes the penalty is imposed at the earliest after October 31 .

16 The list of dependents claimed is compared with prior declarations. In the event of a discrepancy, the examining official may request an explanation from the taxpayer or check the local census.

17 Where income from real estate appears, the listing in the declaration for each piece of property will be compared with the filed documents described in note 10 supra. With respect to wages and salaries, the amounts shown by the taxpayer will be compared with the amount reported by his employer or employers, which report is due by January 31 of the year following receipt. Should the taxpayer's declaration include income from industrial and/or commercial profits or profits from professional activity, the detailed explanations which accompany the return itself will be examined but the profit reported also will be compared with official tables setting out typical profit levels for the several types of enterprise. Where income from stocks or bonds is listed, the sums will be compared with lists turned over by the banks which have acted as transfer agents in paying corporate dividends or interest.

18 For example, where the taxpayer lists deductions for items such as alimony, arrearages of rent, interest on indebtedness, the name and address of each beneficiary is set out on the return. Should the beneficiary live in another district, a report on the deduction will be sent to that district's local office, and if there is a discrepancy this will be reported back.

19 Particularly in a small community, the inspector will have personal knowledge of most taxpayers, and can determine readily if their general level of living corresponds to the income declared.

20 Taking due account of declarations made in previous years, and of reports filed by third parties relating to purchases of real estate, stock subscriptions, payment of high premiums for life insurance, etc. 
only a small industrial or commercial enterprise. Mediumsized enterprises are audited, however, by inspectors who are trained for this purpose, work under the authority of a principal inspector, and have responsibility for a territory covering several departments. Because of limited personnel resources, small and medium-sized enterprises are only audited when the declaration itself or reports derived from third parties suggest that income has been either inadequately documented or incorrectly reported. In contrast, large enterprises are audited on a more systematic basis. For this purpose, a director of verification supervises units, competent for all France, which specialize in the different major types of economic activity.

Should either the office or field audit indicate that the declaration was incorrect, the inspector will notify the taxpayer in writing of the proposed change and the underlying rationale. The taxpayer has thirty days in which to accept the proposal or express dissatisfaction, making a counter-proposal. Such differences are resolved by an informal, simplified procedure in the case of taxpayers whose turnover is below a certain minimum ${ }^{21}$ and whose good faith is not in question. ${ }^{22} \mathrm{~A}$ more rigid procedure is used, however, where the apparent discrepancy involves a larger enterprise which has been audited by a specialized verification unit.

In either case-that is, whether the simplified or more rigid procedure is employed-the inspector has full authority to attempt to reach a settlement with the taxpayer. As was the situation which existed during the original field or office audit, this power in the inspector includes that of splitting or trading issues of law on a basis responsive to the competing strengths and weaknesses of the two parties.

The verification unit inspectors prepare reports reflecting details revealed by the audit and the methods utilized to ascertain these details. To the proposed correction, which is explained in full, the unit's examiner adds his opinion regarding

21 Taxpayers who possess a residence are subject to a local tax, contribution mobilière. There is a strong incentive to avoid, if possible, reporting a second residence as this is subject to the same tax. However, should a taxpayer establish a second residence within a district other than the district where his domicile is located, the district of his domicile will be notified of the secondary residence.

22 The use of the simplified procedure is limited to taxpayers whose annual turnover is less than 600,000 francs where derived from a sales enterprise and 150,000 francs where derived from performance of services. 
the good faith of the taxpayer and the penalties that might be applicable. This report is reviewed by the head of the unit who may return it to the examiner with a recommendation for further investigation of insufficiently explored areas or that certain claims be abandoned.

Once the report is accepted by the unit's head, ${ }^{23}$ the taxpayer is sent a statement of the proposed changes. The taxpayer, who is entitled to be represented by two counselors of his own choice (lawyer, chartered accountant, tax advisor), has a right to request a conference to discuss the proposed changes with the head of the unit, ${ }^{24}$ and that conference may result in an accord. Again that accord may and usually does represent a settlement between the two parties or it may lead to the withdrawal of an issue by either party.

If agreement is reached, whether based on the tax administration's proposals, the taxpayer's proposals, or a compromise figure, the verification unit sends to the office of the departmental Director the information necessary for the tax roll to be completed.

Should no accord be reached, either the tax administration or the taxpayer can request that the dispute be submitted to the departmental Commission for its opinion-a procedure to be discussed later. ${ }^{25}$

\section{2b Details of assessment and audit procedure re estimated income}

Assessments on three types of income, and also in the case of one type of taxpayer, are based on estimates. These estimates, as to income from small industrial or commercial enterprises or from the liberal professions, are made individually for each recipient. Income from agriculture, on the other hand, is geared to averages based on collective data. However, in any of these cases, the taxpayer may request that assessment be based upon the income actually received, and the

23 To use this simplified procedure, certain conditions must be fulfilled: (1) The taxpayer's books must have been verified, (2) this verification must not have revealed any absence of good faith, (3) the taxpayer himself must have requested expressly the use of the simplified procedure, and (4) the taxpayer must agree to pay within 15 days the amount of whatever tax may be held due with the addition of interest, computed at the rate of $0.75 \%$ per month for the period of the delay.

24 This conference has no legal basis. However, it is used frequently to facilitate communication between the tax administration and taxpayers.

25 See 3.4 a infra. 
tax administration will honor the request. In practice such a request is made by those taxpayers who may have suffered a substantial loss or who have had markedly lower incomes than typical for taxpayers comparably situated. Otherwise, it tends to be to the advantage of eligible taxpayers to utilize the estimated income procedure. Finally, taxpayers whose standard of living suggests an income in excess of the amount declared are subject, individually, to an assessment based upon the exterior signs of wealth. The table on page shows that the overwhelming percentage of those taxpayers who are free to have their income assessed on the basis of an estimate chose to have such an estimated assessment.

The estimated assessment procedure does not extend to income derived from companies with capital stock or to partnerships. It is limited to individually-owned commercial and industrial enterprises whose annual turnover is 400,000 francs or less if derived from selling goods or furnishing lodging, or is 100,000 francs or less if from rendition of services. ${ }^{26}$

A qualifying taxpayer whose assessment will be based on an estimate, must submit before the close of the year a declaration setting forth certain information as to that year. The required information relates not only to business matters-i.e., amount of purchases, of sales, stock on hand, number of employees and wages paid, rent paid-but also to his standard of living including, for example, any purchases of automobiles.

The local inspector has access not only to the individual taxpayer's file (of substantial importance in facilitating an accurate appraisal of the taxpayer's standard of living), ${ }^{27}$ but also to certain data supplied by the Director General of Taxes: monographs dealing with a variety of occupations ${ }^{28}$ and indications of general economic activity. In addition, a given declaration is compared with those of other taxpayers engaged in similar activity. Using all available information, and taking particular account of the taxpayer's level of living, the inspector

26 Since January 1,1966 , the figures have been increased to 500,000 and 125,000 respectively.

27 Where the inspector is dealing with a rural of semi-rural area, his actual knowledge of the manner of life of its inhabitants will be extremely helpful.

${ }^{28}$ In addition, the offices of the departmental Directors, with the cooperation of agents charged with inquiry into certain occupations, have prepared surveys which indicate for certain retail establishments the norms of purchases from wholesale suppliers and the habitual profit margins of the retail establishments. 


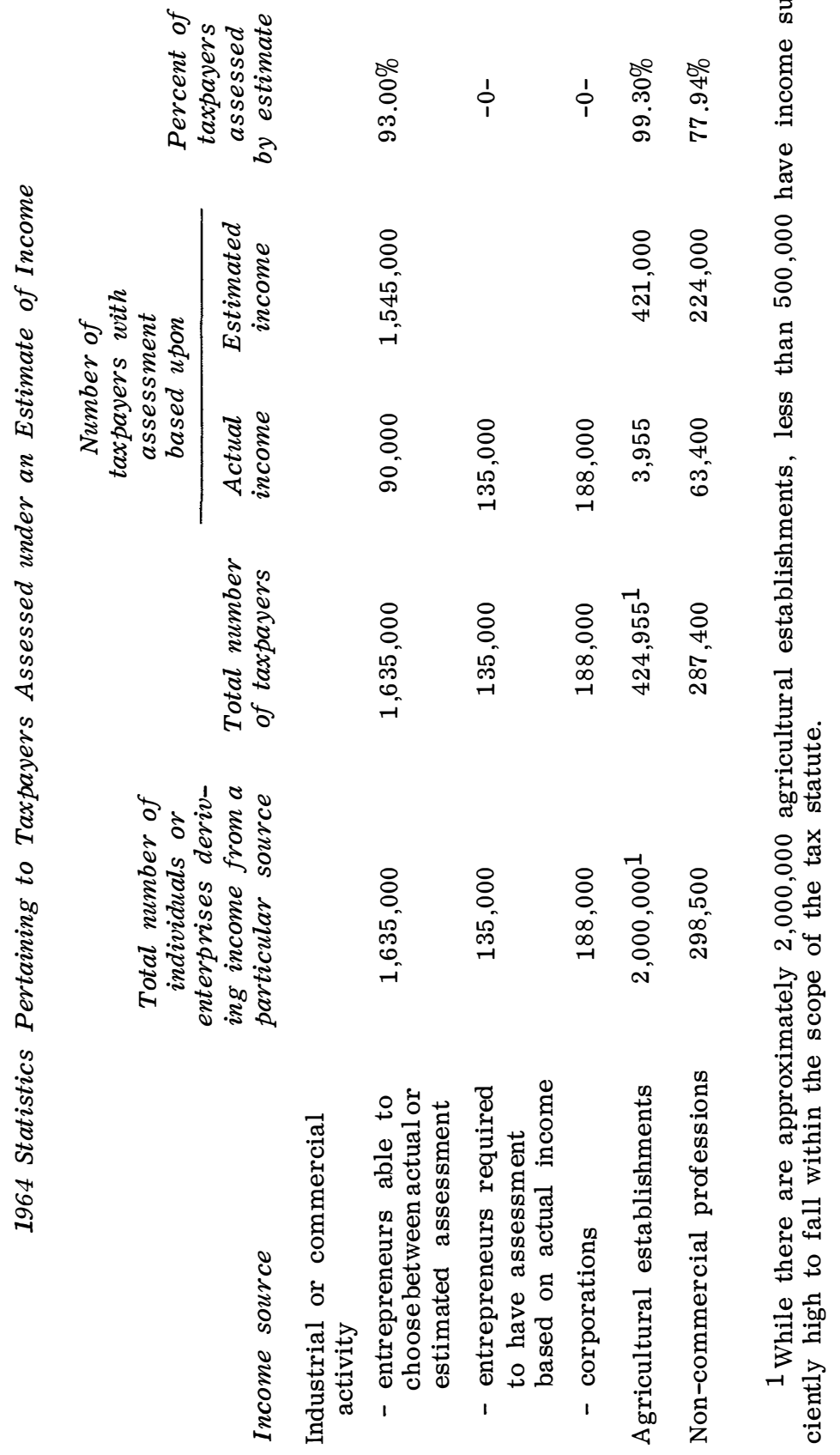


will propose an estimated figure, representing the profits that "enterprise can normally produce."

The taxpayer has twenty days to consider this proposed figure. If he accepts it, either directly or by not answering the inspector's letter, the estimate cannot be challenged by the tax administration for the next two years, ${ }^{29}$ unless it develops that the taxpayer furnished incorrect information.

The taxpayer, however, is free to protest the assessment. Should he protest, the dispute will be forwarded to the departmental Commission, which will fix the estimate. The figure so fixed becomes binding upon the tax administration, but the taxpayer is again free to protest, this time to the departmental Director of Taxes. ${ }^{30}$

While it is recognized that taxpayers who elect to use the estimate-based assessment are not bound to maintain full sets of regular books, any taxpayer who protests either the inspector's or the Commission's estimate should be prepared to furnish sufficient data to permit an estimate of the normal income his enterprise produces. ${ }^{31}$

The taxpayer using the estimated assessment procedure thus can meet his tax obligation with a minimum of recordkeeping. The tax administration also derives an advantage: It need not devote the man-hours otherwise necessary to make complete audits. Indeed, estimate-based assessments have proved to be higher than assessments based on statements of actual income. In the latter case, the administration has experienced real difficulty in proving profit concealment by petty tradesmen or small individually-operated service enterprises.

Whereas estimated assessments are used with respect to income derived from individually owned commercial and industrial enterprises only if annual turnover is below a certain level, 32 they are used in the case of individuals deriving income from a liberal profession-i.e., doctors, lawyers, chartered

'29 In practice, once the estimate is fixed, it will be renewed by tacit agreement for subsequent biennial periods as long as the turnover remains below the upper limit for this type of assessment and as long as neither the inspector nor the taxpayer gives notice of termination.

30 See 3.4 a infra.

31 Thus, at the least, such taxpayers should maintain a register of purchases supported by the invoices. Where the enterprise performs services, a book of original entries should be maintained, setting out the day-by-day receipts.

32 It should be repeated that use of the estimate-based assessment is optional. 
accountants, architects, etc., without reference to a monetary ceiling, though here there is an annual estimate.

While the procedures in the two cases are otherwise similar, ${ }^{33}$ there is a significant difference in the degree to which the estimates will approach true income. An inspector typically has a substantial number of small tradesmen and petty service enterprises within his area of responsibility; just as typically he has only a limited number of professional men. Thus it is more difficult to prepare estimates by comparing, say, a limited number of doctors. Moreover, decentralization of the tax administration places many young and inexperienced inspectors in local offices, and they often find it difficult to discuss an estimated assessment with an established professional man who is a long-time resident of the community. Further, the nature of professional activities vary and this leads to marked inequities in assessment. Illustratively, a relatively accurate estimate can be made in the case of an attorney who derives the bulk of his income from fees paid by industrial or commercial concerns, for the latter concerns will have reported the payments. By contrast, where an attorney's practice is primarily with individuals who pay him in cash, it is very difficult for the inspector to even approach an accurate figure. ${ }^{34}$ This contrast exists also in the case of doctors, though in a somewhat different form. Estimates will be fairly accurate in the case of physicians paid primarily from social security funds, whereas physicians in private practice, who receive their fees in cash, can be quite confident their income will be underestimated. This fact has caused many doctors to avoid the social-security type of practice, with the result that social security beneficiaries could not obtain adequate care. And in consequence, pressure was put on the tax administration to insure a less accurate estimate of the income derived by these physicians.

33 One difference is that in the case of the income from a liberal profession, the estimate must be filed by February 1, of each year. Also, it should be noted that if a dispute is forwarded to a departmental Commission, the Commission's membership will be geared to the particular professional activity of the individual taxpayer.

34 It is probable that in the situation where a lawyer has a mediumsized practice, the inspector can make a reasonably accurate estimate, aided by some appreciation of his general level of living. Where, however, an outstanding lawyer is able to command high fees from private persons, even an estimate based upon exterior signs of wealth is likely to lead to an underestimate of his actual income. 
The foregoing factors have led to marked differences in the accuracy of estimates and, in turn, this has created dissatisfaction among professionals who compare their respective estimates. Such inequities are tolerated both because of the legislature's unwillingness to require such professional people to keep an accurate and full set of books 35 and because of the tax administration's utter inability to audit the accounts of every professional man in France.

Unlike the other types of income subject to an estimated assessment, agricultural income is estimated, ${ }^{36}$ not on an individual basis, but rather by reference to averages geared to collective data, these averages then being applied to the units a given taxpayer has under cultivation. 37

These averages are calculated by the departmental Commission, on the basis of its knowledge of actual conditions and in light of certain information made available by the Director General of Taxes ${ }^{38}$ and the office of the departmental Director. ${ }^{39}$ The averages, however, are based on a mediumsized farm, theoretically typical of the region. Consequently,

35 Notaries are required to keep a full set of books. Chartered accountants, lawyers, architects, doctors, etc., are not.

36 While the use of the estimate-based assessment is optional for those deriving income from agricultural operations, in exceptional cases, the administration has the right to deny the use of the estimate and require the use of the actual income as the basis for assessment.

37 The units under cultivation may be calculated in terms of the land itself or in the terms of the use made of the land. Thus, where land is used for a specialized purpose-viticulture, orchards, apiculture, poultry-raising-assessment will be based on the amount of wine or the number of fruit trees, beehives, or laying hens. Where the land is used for more general agriculture, assessment will be based on the hectare, i.e., 2.47 acres.

38 The Office of the Director General of Taxes prepares a general study of the agricultural situation at the national level based on the different agricultural products. Taken into account are a number of factors including yield, prices in comparison with preceding years. This study is transmitted to the offices of the departmental directors.

39 The office of each departmental Director uses as a base the data forwarded by the office of the Director General of Taxes. See note 38 supra. Information peculiar to the region or to the agricultural portions of the department is assembled. This is forwarded to the departmental Commission, together with some proposals of a medium income which will serve to fix the assessable income of all the agricultural enterprises of the department. 
the more productive agricultural operations are underassessed. 40

Once the formulae for assessment-one for each type of agricultural activity-have been computed by the departmental Commission, 41 the list of agricultural enterprises, showing the acreage of each and the specific type or types of agricultural activity engaged in, is posted publicly for fifteen days. During that time, a taxpayer who disagrees with the classification of his property in terms of the activity carried on, can lodge a protest with the departmental Commission, ${ }^{42}$ not with the tax administration. 43

Finally, any taxpayer may be assessed on the basis of an estimate where the exterior signs of his wealth indicate a gross under-declaration. Before making such an assessment, the inspector requests the taxpayer to supply on a form certain facts relevant to his standard of living. The data relates, inter alia, to the rental value of his home or homes, the number of

40 Understandably, the owners of the more productive-because larger and efficiently managed-agricultural enterprises are staunch defenders of this system of collective assessment. Moreover, these same men tend to be the directors of the agricultural organizations which enables them to wield considerable influence. In 1959, the government proposed a bill which would have changed the method of assessment for agricultural operations, abolishing the existing system of the unitary profit per hectare and establishing an individual estimate for the largest farms, about 30,000 in number. The agricultural organizations were successful in persuading the Parliament to reject the government bill.

41 Where the agricultural land is utilized in some manner not provided for by the typical categories, thus rendering unusable the unitary profit per hectare computation, the income from the land will be assessed by reference to the cadastral income. This determination is made by the local inspector with the concurrence of the communal commission for direct taxes. This local group, in addition to its responsibility relative to this type of assessment, also assists the inspector in the assessment of local taxes (i.e., occupany tax, assessment of improved or unimproved real estate) and expresses its opinion on the lists of those in the commune liable to pay income tax.

42 see 3.4 a infra.

43 Should a particular farmer have sustained loss of anticipated harvest by reason of hail, ice, flood, etc., he can petition the tax administration-accompanied by an attestation from the mayor-to be allowed to deduct the amount of his loss from the estimated profits from his agricultural operations. This is the only situation in which the owner of an agricultural operation enters into direct communication with the tax administration. 
domestics employed, his cars, boats, etc., to each of which standard amounts of income are applied by the inspector. 44

These standard scales are then used, together with other available information, to calculate the assessment. The taxpayer has twenty days in which to protest. A taxpayer might counter, for example, with proof, that a portion of his apparent income actually represented capital gains-not includible within assessable income, or other tax-exempt income, such as interest on treasury bonds, pensions for war victims, etc.

In making estimated assessments on the basis of exterior signs of wealth, the inspector himself is subject to certain limitations. First, this method is not used when upon application of the standard scales the estimated income is 15,000 francs or less. Second, in practice, this method is used only when there is substantial discrepancy between the taxpayer's declared income and his general level of living. While not a rule of law, this method is used only where an estimate based on the level of living equals or exceeds 130 percent of declared income. Third, the administration deems the method inappropriate in cases where the taxpayer's income is composed in major part of sums paid by others-i.e., wages and salaries, fees for professional services, etc. In these cases, the administration focuses directly on the income itself. Also, the fact that such a taxpayer's income tax assessment is otherwise based on an estimate will not warrant a reduction by reference to a lower estimate geared to his external signs of wealth.

\section{Section B. Administrative Appeals}

\subsection{Introductory note}

As indicated in the preceding section, there are two types of income tax assessment in France: one utilizing a declaration of actual income by the taxpayer, the other an estimated assessment. In either case, i.e., should the taxpayer disagree with the result of a post-declaration audit by a tax agent or with an inspector's estimate of his income, he may carry the dispute first, to the departmental Commission, though this is not indispensable to a further appeal.

The form of the Commission's response will vary, depending on the type of income tax assessment. If the taxpayer had

44 The taxpayer cannot contest the figures set out in the scale though it is proper for him to show that one of the elements is not applicable to him, for example, that he has no domestic servants. 
filed a declaration of actual income, the Commission will render an opinion on the particular issue in dispute, provided it involves only a question of fact. The Commission has no power to rule on questions of law. If the taxpayer's original assessment had been based on an estimate of income derived from a sole proprietorship or from a liberal profession, the Commission will render a decision, fixing the total amount of estimated income. Whether a decision or an opinion has been rendered, however, a taxpayer is free to appeal further to the departmental Director.

For reasons later described, a taxpayer whose estimated income was derived from agricultural activity may not contest his assessment before the Commission. In effect, the previous ly described averages employed in making those estimates may be tested only by the tax administration or by an organization of farmers, but before a forum distinct from the Commission.

Finally, where the administration believes that a contract or other legal act conceals a legal deceit for which a heavy fine might be imposed, it may first refer the case to a yet different body, the Consultative Committee and if successful there, later avoid bearing the burden of proof should actual litigation ensue.

\section{4a Details of administrative appeals to a departmental Com- mission}

The departmental Commission for each department is presided over by the Counselor of the Administrative Tribunal, 45 that is, by a judge, not by an official of the tax administration. In addition, there are three tax administration ${ }^{46}$ and four taxpayer representatives, ${ }^{47}$ all appointed for renewable terms of

45 This judge is nominated by the Minister of the Interior, not by the tax authorities.

46 The secretaryship of the Commission is held by an inspector of taxes assigned to the office of the departmental Director.

47 The general pattern of these departmental commissions (four taxpayer representatives and four members of the tax administration) has remained constant for some time, though recent modifications have reduced the weight accorded the views of tax administration members.

Prior to 1954, the tax administration members were headed by the departmental Director of Taxes who held the chairmanship. While the views of a majority of the eight members theoretically determined the Commission's decisions, the Director or his delegate, in effect, cast an extra vote in case of a tie, a not infrequently occurring circumstance. Thus, much to the dissatisfaction of taxpayer organizations, the tax administration, in practice, always had the last word. 
one year. While the proceedings must be treated in confidence, there are few qualification requirements for membership on the commission. A member must be a French national, at least twenty-five years of age, possess civil rights, and must not have suffered a conviction for tax fraud. In general, a taxpayer whose case is to be heard is entitled to have four taxpayer representatives: in the case of professional men, these are drawn from their own professions; in the case of those engaged in trade (including manufacturing and the service occupations) representatives are appointed by the local business groups; in the case of handicraft-artisans by their special organizations. Agricultural groups likewise appoint their own representatives. To this end, each major occupational or professional group designates a number of such representatives to serve, as need be, on the departmental Commission. ${ }^{48}$

Some indication of the annual number of cases laid before the departmental Commission can be gained from the following figures pertaining to 1964 .

\begin{tabular}{|c|c|c|c|}
\hline Source of income & $\begin{array}{l}\text { Assessme } \\
\text { Real } \\
\text { income }\end{array}$ & $\begin{array}{l}\text { based on } \\
\text { Estimated } \\
\text { income }\end{array}$ & $\begin{array}{c}\text { Total } \\
\text { number } \\
\text { of } \\
\text { cases }\end{array}$ \\
\hline Industrial or commercial activity & 257 & 1,347 & 1,604 \\
\hline Agricultural establishments & 7 & $-0-$ & 7 \\
\hline $\begin{array}{l}\text { Liberal (non-commercial) professions } \\
\text { Total }\end{array}$ & 19 & 997 & $\frac{1,016}{2,627}$ \\
\hline
\end{tabular}

(footnote continued)

In 1954, these voting practices were altered. In the event of a tie vote, a deadlock ensued, requiring the matter to be referred to a departmental committee of arbitration. This committee was made up of five members. The chairman was a Counselor of the Administrative Tribunal (outside the tax administration), and of the other four members, two were members of the civil service and two represented taxpayers.

Another modification in 1959 abolished the committee of arbitration and instituted the present system.

48 The following four major occupational groups designate representatives to sit on departmental Commissions:

(1) Departmental chambers of commerce, for cases involving industrial or commercial profits;

(2) Guild chambers of trade, for cases involving artisans;

(3) Federations of the agricultural syndicates (half drawn from rural proprietors and half from farm operators), for cases involving agricultural enterprises; and 
Where the taxpayer has filed a declaration of actual income, but disagrees with the inspector's proposed increase, either side may request the Commission's opinion regarding questions of fact. In such event, the inspector forwards to the Commission the taxpayer's complete assessment file, together with a report summarizing all relevant information, including some indication of the amount the taxpayer previously was disposed to accept and, as to each point in dispute, the respective positions of the two parties. At least ten days before the hearing, the taxpayer is reminded that he may present his case orally or by written statement. Also, he is advised of the contents of any documents in his in-service file on which the inspector relies in sustaining his position and, as to documents and data the inspector submits relating to the income of comparable third parties, the taxpayer is informed of the names of the persons or corporations involved, but not their actual incomes. The intention is to enable the taxpayer to "assure himself that the points of comparison submitted by the administration completely take into account enterprises the activity of which is comparable to his own."

Though the taxpayer does not bear the burden of proof in the strict sense, he must provide the Commission with all items-accounts, etc.-essential to its proper resolution of the dispute. In presenting his case, he may be assisted by two persons, a lawyer and an accountant, or qualified agents.

Even though the Commission is presided over by a judge, the proceedings are very informal. If the taxpayer elects to make an oral presentation, it is for him to decide whether he will or will not present a written brief. After hearing both sides, the Commission issues an opinion which is communicated to the taxpayer. Neither he nor the inspector is bound, however, to accept the Commission's findings. The taxpayer may file a further appeal with the departmental Director. But should either the taxpayer or inspector pursue the matter into the actual litigation stage, by appealing to the administrative tribunal, the party which did not accept the Commission's findings will bear the burden of proof.

\section{(footnote continued)}

(4) Three professional organizations representing, respectively, physicians, dentist-surgeons, and lawyers. In the case of other liberal professions, if there is no taxpayer representative engaged in the profession of the taxpayer in question, he can demand that one Commission member be replaced by a representative of the professional organization to which he belongs. 
If a taxpayer who filed a declaration of actual income is accused by the administration of having entered into a contract or other transaction to conceal a legal deceit for which a heavy fine may be imposed, ${ }^{49}$ the administration has the alternative of referring the case in the first instance to a yet different body, the Consultative Committee, headed by a judge of the highest administrative court, the Conseil d'Etat, assisted by three additional members: the Director General of Taxes and two members designated by the Minister of Finance, one a judge of the highest civil court, Cour de Cassation, the other a professor of law, usually the Dean of the Faculty of Law of Paris. If the administration exercises this option and prevails before the Consultative Committee, its recourse to the Committee will have served the purpose of shifting the burden of proof to the taxpayer if he later appeals to the judiciary. ${ }^{50}$ But the administration is not bound by the Committee's findings; it too can appeal to the judiciary. But in such case, it bears the burden of proof to the extent its assessment exceeds that fixed by the Committee.

Consider now those taxpayers whose assessment was based originally on an estimate to which they have taken an exception. As to them, the regular departmental Commission's procedures will vary, depending on the source of the estimated income.

One set of procedures, applicable to income from small sole proprietorships and from the liberal professions, is similar to that described above. Here, however, the Commission will render a decision fixing the total estimated income. Also, typically the sole proprietor will attempt to show the amount his business normally can produce, whereas a taxpayer associated with a liberal profession will focus on the income actually received for the year in question. Finally, the taxpayer can appeal further to the departmental Director, but an inspector who takes exception to the Commission's findings must then enter the litigation stage, by taking the case to the administrative tribunal.

Where the original estimated assessment related to agricultural income, the Commission's role is quite different from that described above. This is the same Commission which earlier established the collective estimates which fixed the

49 Should a legal deceit be disclosed at any time, it will give rise to a fine equal to double the tax actually due.

50 Absent resort to this body, the administration would continue to carry the burden of proof. 
average profit for each particular type of agricultural activity. And that average was applied automatically by the inspector to each taxpayer engaged in agricultural activity, with deviations responsive only to the number of units a taxpayer had under cultivation. If the Commission's determination of the average was unsatisfactory to a particular taxpayer or to an inspector, neither can appeal directly. If appeal is taken, it must be by the departmental Director of Taxes or by the President of the Departmental Federation-an organization of farmers. The appeal goes to the Central Commission, a body with nationwide jurisdiction.

The Central Commission has three justices ${ }^{51}$ and four consultants (two senior civil servants from the office of the Director-General of Taxes, one senior civil servant from the Ministry of Agriculture, and two representatives designated by the National Federation-the previously mentioned organization of farmers). However, the justices alone hand down a binding decision determining the averages to be employed. Their decision can be appealed only to the Council of State and on only one very limited ground, that the action taken was ultra vires.

\section{4b Administrative appeals to the departmental Director: Re- cours contentieux}

Whether or not a taxpayer has appealed his case to a departmental Commission, he may not carry the dispute (tax penalty) to the judiciary (administrative tribunal) until he has laid it before the departmental Director unless the tax was assessed by a specialized office, in which case it is laid before the director of that office. Not until the taxpayer's claim has been rejected in whole or in part-or not acted upon within the six-months' time limit-may he turn to the judiciary.

Like the inspector, the departmental Director has full authority to reach a settlement on issues of law as well as, of course, the authority to correct errors of either fact or law in the government's position. This settlement may take place as a consequence of an oral conference with the departmental Director granted at the taxpayer's request, which permits a further exploration of all outstanding issues.

Such claims must be presented within a fixed time limit, which begins when the tax roll is placed in collection and ends

51 of the three justices, one is drawn from each of the following categories: a Counselor of State who is the chairman, a Counselor of the Court of Cassation, a Master Counselor of the State Audit Court, Cour des Comptes. 
on December 31 of the calendar year following such date. Certain other formal requirements are also imposed. 52 The contested tax must be identified; the assessment notice or copy thereof must be attached; the grounds upon which the taxpayer relies must be fully explained; and the claim must be signed by the taxpayer or by his duly authorized attorney or agent. ${ }^{53}$

Where the taxpayer's claim raises a question of law, the petition should cite the relevant legal provisions and set forth the interpretation on which the taxpayer rests his claim. In support of that interpretation, the petition may cite not only judicial decisions but also ministerial statements or even administrative instructions.

Where the claim relates to a question of fact, the petition should set forth all supporting circumstances and offer to provide proof of the facts alleged. All types of evidence, other than witnesses, can be used.

The petition may include also a request that actual payment of the contested tax be postponed, but unless future payment is sufficiently guaranteed, the request can be refused. This refusal can be contested, however, by means of the référé fiscal-an emergency procedure lodging summary jurisdiction over urgent tax matters in a single judge of the administrative tribunal, as designated by its president.

Claims received by the departmental Director, if free of defects in form, are sent back to the inspector who fixed the initial assessment. The inspector, after assuring himself that the formal requirements have been met, then examines the petition to determine if it correctly states the law and the facts. This includes a check of the statutes and regulations, and where time permits, the case law. At his discretion, he may contact the taxpayer for additional information, and the taxpayer himself may request the opportunity to explain his position.

The inspector then makes whatever adjustments he deems warranted, and send his conclusions, together with the taxpayer's file, back to the departmental Director.

The Director now examines the petition, file, and the inspector's report and may accord a hearing to the taxpayer. If

52 Where a defect is considered correctable (e.g., failure to attach the required notice of assessment or set out the taxpayer's conclusions and supporting arguments), the taxpayer will be notified and given 20 days in which to make necessary corrections. If not corrected within the time limit, the petition will be rejected.

53 For a corporation, any salaried employee who has received a commission from the board can sign such a claim. 
he finds the inspector's conclusions inadequately supported or believes an inadequate examination was made, he will return the file and require additional verification. He may not, however, require the inspector to alter his conclusions.

The departmental Director is expected to act within six months, but if additional time is necessary, the taxpayer will be so informed prior to the expiration of that period, and will be advised also regarding the probable additional time required. This cannot exceed three months.

Where a claim is rejected in whole or in part, the Director explains the reason for his conclusion, though his decision on the matter is not final. The dispute may be carried to the judiciary (administrative tribunal), the Director's action having been an indispensable prerequisite. About 365,000 such claims reach this office annually, though many involve very simple questions, such as dependency deductions for children.

\section{4c Administrative appeals to the departmental Director: Re- cours gracieux}

In addition to claims for tax reduction on legal grounds, taxpayers may petition the tax administration either to reduce tax penalties or to forgive or lower properly determined assessments which the petitioner cannot pay because of poverty or financial embarrassment.

The administration itself has complete jurisdiction over these recours gracieux petitions; the administrative proceedings are not a preliminary in any sense to a judicial stage. No time limit is imposed and the signature of the petitioning taxpayer is the prime formal requirement.

The taxpayer submits his petition to the office of the departmental Director who forwards it to the inspector who originally made the assessment. The inspector contacts the collection office to determine the likelihood of collecting the tax due, and then attempts to make a general estimate of the total situation, including an appraisal of the taxpayer's sincerity and honesty.

In the case of individuals, he will focus primarily on the taxpayer's actual resources and present financial condition. ${ }^{54}$ In the case of business enterprises, he also will be concerned

54 I.e., on the actual acuteness of the taxpayer's alleged financial stringency or poverty, taking due account of his age, profession, family situation, burdens, amount of income, exterior signs of wealth, etc. 
with its competitive status, the liquidity of its resources, and the attitude of its other creditors. 55 After all relevant information has been collected, the inspector will draft his report and submit his conclusions.

Decisional jurisdiction for recours gracieux petitions depends upon the amount of tax involved. Where 50,000 francs or less, it rests with the departmental Director of Taxes. Where more than 50,000 francs but less than 150,000 francs, jurisdiction lies with the Director General of Taxes subject to concurrence by the Council of Administration-a body made up of the heads of the several offices. In all other cases, decision rests with the Minister of Finance who normally follows the opinion of his Committee of Remission and Settlements.

Where jurisdiction rests in the first instance with the department Director, appeal can be made to the Director General. Should new facts develop, even after the Director General or the Minister of Finance has handed down a decision, a petition can be laid before the same authorities to obtain a better informed decision. However, no reason need be cited for any decision nor can a decision be challenged in the courts.

Approximately 120,000 recours gracieux petitions are filed annually with the departmental Directors. Only a relatively small percentage-in 1961, only 199 cases-is appealed from the departmental Director to the Director General.

\section{Section C. Administrative Processing of Refund Claims}

The French tax system does not have a special procedure for reimbursement of excessive tax payments. Where such payments have been made, the claim and reimbursement are handled in connection with the assessment procedures previously described. If the claim is justified, reimbursement is made without any additional formalities. Further, any administrative appeal regarding such a claim actually involves an appeal to contest the assessment itself. Such must be undertaken in a timely manner in accordance with previously described procedures.

55 Should the petition be for a reduction in a tax penalty, the inspector also takes account of the reason for the penalty: whether for late filing or late payment, failure to make a declaration, etc. 


\section{CHAPTER XII \\ RESOLUTION OF TAX QUESTIONS BY INDEPENDENT TRIBUNALS}

\subsection{Introduction}

Litigation in France is conducted in two distinct types of forums, the judicial and the administrative. The judicial forums have jurisdiction over disputes between private persons; the administrative over disputes between the government and private persons.

The original jurisdiction of the administrative tribunalsfrom which appeal lies to the Council of State-covers three types of actions, of which one is the contentieux fiscale, wherein a claimant asks that his tax obligation be determined. ${ }^{1}$ In addition to jurisdiction over actions of this type, the departmental Director may appeal to the administrative tribunal any taxpayer claim as to which he believes the tribunal should hand down a decision.

Procedures followed by the administrative tribunals are somewhat less formal than those followed by the regular judiciary. For example, the use of an attorney is optional.

A request, that the taxpayer be permitted to postpone payment of the tax until the administrative tribunal hands down its decision, cannot be made for the first time in a petition submitted to it. Such suspension, however, is automatic if the taxpayer, on invocation of an earlier administrative appeal to the departmental Director, secured his permission to postpone payment pending that appeal, the conditions imposed being the same in both cases. But this suspension will not carry over automatically during a yet further appeal to the Council of State. However, if such a taxpayer can show that payment prior to the Council's determination would result in serious

${ }^{1}$ A claimant also may bring a recours pour excès de pouvoir, and thereby challenge the legality of the administrative act-i.e., ministerial decree, decree of a prefecture or of a mayor, etc.-by alleging this act has violated a general and widespread rule of law. In effect, the tribunal is requested to nullify the administrative act. To protect citizens against arbitrary administrative actions, few formalities are involved in bringing a recours pour exces de pouvoir. A lawyer is not necessary. 
detriment, the Council has discretion, on special petition, to grant a yet further delay.

\section{Section A. Organization and Procedures: Trial Level}

\subsection{Organization of the tribunals}

There are 24 administrative tribunals for the 90 departments in metropolitan France. Thus their jurisdiction necessarily extends beyond departmental boundaries, with the exception of the Paris tribunal, which exercises jurisdiction only over the department of the Seine.

An appeal to the Council of State is not limited to questions of law. Questions of fact may be raised as well. Since the Council of State functions as an appellate tribunal, it can consider only those questions which previously were presented to an administrative tribunal. While the taxpayer is free to present new grounds of fact and of law, he cannot enlarge on the conclusions set out in his original claim addressed to the Director. Illustratively, a taxpayer who based his petition for the discharge of a tax on the ground that the sums taxed constituted capital assets may not allege upon appeal a procedural irregularity in the assessment itself; such a conclusion would constitute a new demand.

The typical administrative tribunal has a president and four members, of which one is vice-president and another is the Commissaive du Gouvernement. ${ }^{2}$ The Paris and Strasbourg tribunals, however, because of their work load, are larger, and are divided into sections-Paris has four-with a president for each section.

To hold court, a tribunal must have at least three members present, but it can request that a deputy serve when a quorum is absent. 3

The presidents of the tribunals are drawn from the tri-

2 The third type of action, a recours de pleine jurisdiction rests on assertion of an individual claim arising out of some action or nonaction on the part of the government. Illustratively, the claimant may allege a right derived from a government contract, with the government contesting the amount claimed, the method of payment, or even the very existence of the contract.

2 The commissaive is appointed from among the conseillers for a one-year term, with the prospect of reappointment.

3 The deputies can be drawn from the members of a neighboring administrative tribunal or from adyocates or solicitors. If the latter category is drawn upon, the oldest advocate available must be utilized. 
bunal members, the conseillers or justices, 4 whose qualifications are governed by statute to insure their competence and independence. Theoretically, all are supposed to have graduated from the National School of Administration. These graduates are not necessarily lawyers since they are not required to have their degrees in law. Their careers will have begun with a training period in that section of the Council of State which deals with judicial business. ${ }^{5}$ Other officials will be appointed also, but these men must have graduated in law before appointment. They will have been appointed to the tribunals directly from either the Ministry of Interior or the Ministry of Justice, never from the tax administration. 6

\subsection{Processing cases through the trial tribunals}

As explained earlier, ${ }^{7}$ a taxpayer cannot invoke the jurisdiction of an administrative tribunal until his claim has been laid before the departmental Director of Taxes and the Director either has rejected it or allowed six months to elapse from the time the claim was filed without communicating with the taxpayer. Upon receiving such a rejection, the taxpayer has two months, ${ }^{8}$ in which to file a petition with the clerk of the appropriate administrative tribunal.

Typically, the taxpayer lays his case before the administrative tribunal because he has been unable to work out a settlement or compromise earlier. $\mathrm{He}$ is aware that settlement, as such, henceforward is most unusual.

${ }^{4}$ Ranked in a descending order, the hierarchy of the judges of these administrative tribunals is as follows: president of the administrative tribunal of Paris, president of a provincial administrative tribunal or conseiller of the administrative tribunal of Paris, conseiller of a provincial administrative tribunal.

5 Thus they receive the same training as the auditeurs of the Council of State. See 4.4 infra. Both informal and formal contacts exist between the administrative tribunals and the Council of State. The tribunal members commenced their training with the Council of State. Also, tribunal members sometimes are appointed to the Council of State, and some members of the Council of State have been appointed to the Paris administrative tribunal. Finally, the Council of State inspects the tribunals through a three-member commission, not to check on case-by-case decisions of the tribunals but rather to appraise and bring some uniformity to their general operations.

6 This practice assures their independence as well as the independence of the tax administration.

7 See Chap. XI, 3.4b supra.

8 Upon receipt a petition is registered and marked with the date of arrival, to help police this limitation. 
Formal requirements pertaining to the petition itself are similar to those which applied earlier when the claim was submitted to the Director. A petition, however, must be on stamped paper ${ }^{9}$ and be accompanied by a copy of the Director's decision and a transcript on unstamped paper. As was true of the earlier claim, the petition should contain a summary of the facts, a statement of the arguments, the legal bases thereof, and the conclusions which set out the relief requested. The taxpayer cannot claim a reduction greater than that previously claimed but he is not precluded from asserting a different line of reasoning. Should he desire to use expert witnesses or present oral arguments, he may request such either in the petition or at a later date. But a request to the tribunal, seeking permission to postpone payment of the heretofore assessed tax, would be misdirected. This request must have been made earlier to the Director and, if granted, no additional request is necessary and the taxpayer may continue to postpone payment.

The administrative tribunal's clerk sends by registered mail to the Director a copy of the petition and any amplifying memoranda. After a cursory examination for form, the Director sends the petition to the inspector who made the original assessment and who examined the same taxpayer's earlier claim addressed to the Director. ${ }^{10}$

The inspector examines the petition for form, and tries to determine if any matter relevant to substance (factual or legal) was overlooked earlier. To this end, he re-examines the law (statutes, cases, and instructions) and may request further information from the taxpayer or even re-examine his books.

His investigation completed, the inspector prepares a report, analyzing the petition and the problem. After noting any defect of form in the claimant's petition, the report sets out the relief requested, the facts as found by the inspector, his analysis of each legal argument advanced by the taxpayer, and closes with a brief statement of his conclusion, indicating, if necessary, the amount of tax due or the reduction or reimbursement believed justified.

This report is due in the departmental Director's office

9 For each sheet of paper $21 \times 27 \mathrm{~cm}$, there is a charge of two and a half francs.

10 Where the disagreement arises from an assessment established by an agent who specializes in the examination of accounts, it is this agent who will examine the petition. 
within three months from the date the inspector receives the petition. In light of the report, the Director carefully reexamines the case and this may result in a request for supplementary information from the inspector. While this same claim was rejected earlier by the Director, the re-examination sometimes causes him to revise his decision and to declare justified the claim for reduction. Should this occur, the taxpayer is notified and a summary memorandum prepared, informing the administrative tribunal that the case no longer requires consideration.

More typically, however, the Director prepares a memorandum of law, submitting four copies to the administrative tribunal-in theory, within six months from his receipt of the petition, though an extension may be granted by the president of the tribunal. ${ }^{11}$ While this memorandum carefully considers the statute and case law, it does not cite instructions though their rationale may be used to justify his interpretation of the statutes and decisions.

Prior to the time the director prepares the memorandum, the taxpayer on occasion will request (a request which will be granted) an opportunity to confer with the departmental Director. Occasionally, the departmental Director at his discretion will ask the taxpayer to come into his office for an oral discussion of the matter. Typically, there is no settlement of issues at this point as any such adjustment will have taken place before invoking the court's jurisdiction. The one exception to the general rule that these pretrial negotiations only provide opportunities for the correction of errors-in addition, of course, to the clarification of issues-lies in the situation where a case was docketed to prevent the running of the statute of limitations. In such circumstances, discussions can lead to the settlement of issues.

In four circumstances, however, before submitting such a memorandum, indeed, before arriving at his own conclusion, the departmental Director will consult the office of the Director General. 12 This occurs, in the interest of uniformity,

11 The president of the tribunal first extends the time limit by another three months. Should this added three months be insufficient, the Director can request another extension, setting out the reasons therefor.

12 The taxpayer is not informed formally of such consultation by the departmental Director with the Director General. The departmental Director has no specific obligation to acquaint him with this fact. Unofficially, however, the taxpayer may be told but this is a matter entirely within the discretion of the departmental Director. 
where he believes the petition rested on a sound legal principle although such principle was not stated specifically in either case law or administrative instructions; where he is uncertain as to the interpretation of an international convention or of the constitution and bylaws of an international organization; and where the petition cites decisions which are contrary to administrative regulations but as yet are unpublished in either the compilations or the administration's official bulletin. Consultation also occurs for an obvious reason whenever he expects the decision would be against a pending petition presented in the name of the state by another administrative branch or by a division subject to the Minister of Finance's authority.

The administrative tribunal, upon receiving the Director's memorandum, forwards a copy to the taxpayer or his authorized agents, setting a time limit for reply. The taxpayer may file one or more memoranda in response to the Director's and the Director, in turn, may respond with yet another memorandum. Or, in the interim, the Director may have consulted with the inspector who made the original assessment and then modified his original conclusions. Otherwise, however, these memoranda are exchanged until one of the parties either does not reply at all to the memorandum of the other or does not reply within the time limit specified by the president of the tribunal. At that point the case is considered ripe for judgment although, in practice, memoranda can be deposited with the clerk of the administrative tribunal until the date set for hearing. The aim of this repeated exchange of memoranda is to enable the parties to refine the issues and their respective arguments. However, if these preliminary exchanges are continued unnecessarily, the president of the tribunal can terminate this stage of the proceeding by deliberately refusing to forward memoranda which merely reiterate the grounds or arguments presented earlier.

While memoranda deposited with the administrative tribunal otherwise are always forwarded to the opposing party, supporting documents submitted by the administration remain on file in the clerk's office, but are available to the taxpayer or his authorized agent. That file, for example, may include comparative data on third-party income or profits, and the taxpayer can check this material to determine whether the other situations or enterprises are truly comparable. 13

${ }^{13}$ To preserve secrecy regarding the affairs of others, third-party information accumulated by the administration should deal only with the averages, whether of business turnover or of income. 
In spite of this free exchange of memoranda and the opportunity for oral argument, the tribunal may find that additional facts are needed, and request supplementary information. But if the taxpayer, in response to this or on his own initiative, asserts at the hearing what in effect is a new ground, the tribunal must require him to develop this in a written memoranda, which then is forwarded to the tax administration to enable it to respond in writing. Also, if the tribunal believes, for verification purposes, that an inspection of the taxpayer's site is necessary, all, several, or only one of its members, may be directed to make the inspection. But in any case, an official written report of the inspection will be prepared and made available to the parties for their comments.

The tribunal may also call upon expert witnesses on its own initiative or by request of either party, 14 to determine doubtful or contested facts relevant to a final resolution of the case. ${ }^{15}$ Illustratively, such experts may be requested to determine the value of a corporation's inventory at a given date. ${ }^{16}$

Although the normal number of experts utilized is three, if the parties agree, one will fulfill all requirements. Where three are used, one is appointed by the tribunal and one by each party, though their cost will be borne by the losing party. While each must be placed under oath, there are no specific qualification requirements, except that appointments cannot be made from either of two groups: officials subordinate to the defending departmental Director of Taxes and authorized agents of the taxpayer. However, the departmental Director may appoint an inspector to accompany or observe the work of the experts where necessary. The taxpayer can do likewise, using either an authorized agent or an attorney. In either event, the experts will submit a full written report, individually or jointly. The official report, however, is drafted by the expert appointed by the tribunal; it describes the way in which they approached the problem, contents of documents examined by them, and their findings of fact.

14 The request may be made at any time during the proceedings. While the tribunal can refuse the request, the refusal should be accompanied by a full explanation.

15 Questions of law or theory do not fall within the competence of such experts.

16 The tribunal has no power to order an inquiry or an interrogation or consultation of persons. It cannot hear witnesses. But it can, for example, have experts determine the authenticity of documents if such is put in question. 
When the case is considered ripe for a hearing, that conseiller of the tribunal who has been appointed rapporteur for this case studies the complete file and prepares a report, setting out a resumé of the facts, and the legal arguments and conclusions reached by each party. The conseiller-rapporteur reads his report at the hearing, to point up the issues of fact or law to be resolved by the tribunal which consists of at least two other conseillers including the president. ${ }^{17}$

The public is barred from hearings relating to taxes on income. 18 The administration is represented not by an attorney, but by an inspector who is appointed by the departmental Director from among those residing in the city where the tribunal is sitting. ${ }^{19}$ While the taxpayer's agent may also attend and may present written memoranda during the hearing, he can participate in oral argument only if he is an attorney.

At the final hearing of the case, the commissaire of the government presents the factual and legal conclusions he has reached independently and, presumably, impartially. To these, the parties cannot reply; the tribunal takes them under advisement and usually will hand down its decision within the fortnight following. Its written decision should state the reasons, legal arguments, and supporting authorities for the conclusion reached as to each issue, to facilitate review in the event of an appeal.

The decision may, of course, reduce the amount of the assessment as originally established. But the tribunal may also increase the tax, as compensation for delay in payment, should it find that an earlier petition for postponement was entirely unwarranted.

Approximately 13,400 judgments a year are handed down by these tribunals. In $1960,4,578$ dealt with direct taxes-i.e., taxes on income and taxes levied for the state or the units of

17 The tribunal should be made up of an unequal number of conseillers at every hearing.

18 Indeed, if deemed desirable, the tribunal may request that it receive for private inspection in the court chambers, a full presentation of all evidence or documents concerning the income of other persons or enterprises to which the taxpayer's alleged income is being compared.

19 While the administration's representative can be heard and should answer questions posed by the tribunal, if the taxpayer's representative alleges new facts or new legal arguments, or deposits a written memorandum, the administration's agent is expected not to answer. Instead, he should request a continuance until he has had an opportunity to respond in writing. 
local government. Decisions in 3,580 or 78.2 percent upheld the decision of the tax administration and 998 or 21.8 percent were in favor of the taxpayer.

Unless such a judgment contains a new interpretation of the statute or administrative regulations, it will not be published. In part, this is because it would lack precedent value and in part because each such judgment is appealable and many feel that case law, as such, should be evolved only by the Council of State, not by an administrative tribunal.

\section{Section B. Organization and Procedures: Appellate Tribunals}

\subsection{Organization of the appellate system}

Decisions of administrative tribunals may be appealed by either the taxpayer or the Minister of Finance, to the Council of State, ${ }^{20}$ a body which fulfills a dual role. It furnishes the government its opinion on a variety of matters: drafts of proposed statutes, administrative regulations, ${ }^{21}$ points of law. ${ }^{22}$ It also is the supreme appellate tribunal for the administrative tribunals, and is the only body with jurisdiction over actions which challenge the legality of administrative acts and seek to set them aside-les recours pour excès de pouvoir. ${ }^{23}$

The Council of State is made up of the vice-president and the presidents of the five sections, 53 conseillers en service ordinaire, 69 maîtres des requêtes, and 44 auditeurs. ${ }^{24}$

The auditeurs are graduates of the National School of Administration who have chosen this branch of government service. ${ }^{25}$ From their ranks are drawn the maîtres des requêtes; and from the latter are drawn the conseillers. The one exception to this is that the government may appoint up to a third

20 Created by Napoleon I, the role of the Council of State has evolved in response to the current political climate.

21 The Council of State must be asked for its opinion with respect to regulations of the public administration; for all other types of regulations it may be asked for its opinion.

22 When the government requests the opinion of the Council of State upon a point of law, it is comparable to consulting a lawyer for a legal opinion.

23 Les recours pour excès de pouvoir may be utilized with respect to decrees or revenues stemming from administrative acts which have an area of application extending beyond the jurisdiction of a single administrative tribunal. See note 1 supra.

24 This diversity in seniority causes a wide age range among the members of the Council of State, typically 26 to 70 .

25 The graduates of the National School of Administration who select the Council of State usually ranked at the top of their class. 
of the conseillers and up to a quarter of the maitres des requêtes from outside the civil service hierarchy.

The auditeurs and the mâtres des requêtes prepare material for discussion. From these two groups are chosen the government commissaires who present to the Council of State their own independent and impartial view as to the legal conclusions which should be reached in contested cases. The questions will be heard and decided by the conseillers.

The administrative or consultative function of the Council of State has been more or less completely separated from its judicial function. Four of its five sections are charged with administrative matter $s^{26}$ the fifth handles the judicial function. The latter, the section du contentieux, is divided into eleven subsections, three of which specialize in tax litigation. Beyond this, the eleven presidents of these subsections (each of whom is a Conseiller $d^{\prime}$ Etat) ${ }^{27}$ together with four conseillers from the consultative sections, ${ }^{28}$ make up the plenary assembly of the section $d u$ contentieux, which is presided over by the vicepresident of the Council of State. The plenary assembly considers only matters posing new important questions which may lead the Council of State to alter its position or take a new position as to some legal principle.

A Conseiller d'Etat presides over each subsection of the section $d u$ contentieux. He is assisted by two associate Conseillers d'État, and about ten maîtres des requêtes and auditeurs who function as rapporteurs. Chosen from the maîtres des requetes is the previously mentioned commissaire who presents his own conclusions-presumably impartial-as to the facts, legal principles, and the decision he deems appropriate in each case. ${ }^{29}$ His report is of substantial importance to the judicial process and the most significant are published in the specialized legal periodicals.

26 The administrative sections-Finances, Public Works, Interior, Social-provide opinions in their respective areas of competence. In fulfilling its administrative functions, the Council of State will deliberate, sometimes in a single section, sometimes in two or more sections united for this purpose, and sometimes in a general assembly. In the latter situation, some conseillers from the judicial section will be present.

$27 \mathrm{~A}$ Conseiller d'État is so designated by a decree of the first Minister upon recommendation of the Ministry of Justice after his name has been presented by the vice-president of the Council of State.

28 These are elected by their colleagues.

29 The commissaive is designated in the same manner as a conseiller d'État. See note 26 supra. 
The fact that the section $d u$ contentieux has three subsections which deal with tax matters facilitates reasonably prompt decisions. But it does not facilitate uniformity of decisions. Nor is this difficulty completely mitigated by the close relation existing between the president of the section $d u$ contentieux and the members of the three subsections. However, three other devices, none entirely successful, tend at least to cushion the magnitude of the problem. The commissaire rotates among the subsections, and questions of prime importance or questions upon which the subsections disagree can be-but not too frequently are-examined by more than one subsection. ${ }^{30}$ Also, on very rare occasions, where an issue of legality is involved, the matter may be put to the entire section du contentieux. Finally, any interpretative conflict over the meaning of a statute or regulatory text, arising between a tax subsection and the earlier expressed opinion of the Council of State, must be laid before the plenary assembly. 31

\subsection{Processing a case through the appellate tribunal}

Taxpayer and tax administration alike have two months, ${ }^{32}$ from the date notice is received of the administrative tribunal's decision, within which to lodge an appeal to the Council of State.

Any decision by the tax administration to appeal must pass through a fairly complicated process. First, the departmental Director prepares a report on the administrative tribunal's decision, explaining-in the case of adverse decisions-why he believes the decision for the taxpayer was incorrect (i.e., whether it arose from an erroneous interpretation of applicable statutes or from an incorrect appraisal of the facts). Or, if he believes the adverse decision would be sustained on appeal, perhaps because of an intervening judicial decision, this is set forth.

This report, together with the complete file, is forwarded to the office of the Director General where it is carefully examined by senior civil servants, assisted by inspectors who

${ }^{30}$ This will occur on a very few occasions in the course of a single year.

31 The Council of State will have given its opinion as to the interpretation of the statute or regulatory text at an earlier point in time when its opinion was requested.

32 For the Minister of Finance the two-month time limit runs from the day the file is received at the office of the Director General of Taxes or from the day on which he is notified by the bailiff's writ of the administrative tribunal's judgment. 
come in from the field, to determine if an appeal should be lodged. ${ }^{33}$ These officials may decide not to appeal. If they favor an appeal, the report from the departmental Director may serve as the petition, ${ }^{34}$ or another will be prepared if a different line of argument or method of presentation seems appropriate. The petition is signed by the Director General of Taxes or a senior civil servant to whom this power has been delegated.

Petitions filed by taxpayers must comply with certain formal requirements which essentially are the same as those imposed by the administrative tribunals. Most are prepared by experienced lawyers, ${ }^{35}$ though the taxpayer may prepare his own. In fact, an attorney need not be used at all unless the taxpayer wishes to make an oral argument or comments during the hearing. ${ }^{36}$ In practice, twenty-six percent of all income tax petitions are prepared by a particular group-the avocats aux conseils. This group of lawyers, limited in number, are appointed by the state. They are permitted to handle private cases and have a monopoly on the right to make oral argument before the Council of State and the Court of Cassation.

The petition itself, and any supporting documents later supplied, can be filed, either with the secretariat of the section $d u$ contentieux or with the prefecture of the department where the taxpayer is domiciled, but in either case is forwarded to the office of the Director General of Taxes which, in turn, sends it to the appropriate departmental Director. There the petition is examined, both as to formal requirements and the merits, and a full report prepared for submission-together with a complete record of the administrative tribunal's proceedings-to the Director General of Taxes. ${ }^{37}$ The report will

33 The examination takes place in the office responsible for litigation before the Council of State, the service du contentieux.

34 If the office of the Director General does utilize the departmental Director's report, it is likely to make modifications or observations in the margin.

35 I.e., attorneys, tax counselors, members of the legal staffs of trust companies. Petitions which are prepared by taxpayers relate principally to local taxes and are limited almost entirely to uncomplicated matters, posing few technical difficulties.

36 The presentation of oral arguments or statements is an exception to the typical hearing.

37 By preparing the petition at two distinct levels, having both levels work on the petition, the best possible defense is assured. The departmental service is better situated to deal with issues of fact, and the 
carefully analyze the facts, legal arguments, and the conclusions which should be drawn. The inspector responsible for the original assessment normally will have been contacted only if the departmental Director determined either that the case has been inadequately examined prior to the administrative tribunal's decision or that the taxpayer is now relying on facts or legal arguments not heretofore raised.

Whether the taxpayer or the Director General entered the appeal, the parties exchange memoranda, just as they did in the tribunal below, until the case is considered ripe for judgment.

Occasionally the taxpayer's adviser will request the opportunity to elaborate orally on the pleadings, but this is the exception rather than the rule. When such oral elaboration does occur, it is limited to developing the contents of the written pleadings and, thus, can add little to properly prepared memoranda. The government never requests such an opportunity. ${ }^{38}$ Even more rarely, indeed in less than one percent of the cases, will expert witnesses be used at this appellate level. Presumably all facts have been established at the lower court level and, if necessary, additional documentation from witnesses will be submitted during the exchange of pleadings. Hence there is no particular need for their use at this level. Moreover, the lack of impartiality too often exhibited by the taxpayer's expert witnesses has diminished their value in the eyes of the Council of State.

When the case is considered ready for judgment, it is turned over to a rapporteur ${ }^{39}$ who analyzes it for the purpose of preparing two documents. The first is a memorandum which states the facts, analyzes the applicable statutes and case law, and concludes with a proposed decision. The second (visas of final judgment) summarizes the contention advanced by the respective parties, the principal documents, and the applicable law and sets forth a proposed final decree.

These documents, together with the entire file, are sent through the office of the president of the subsection to the commissaire of the government, who prepares his independent

(footnote continued)

office of the Director General is better prepared to handle the legal arguments. In addition, this arrangement reduces the work of the office of the Director General, for usually the report of the departmental Director contains all pivotal elements for the administration's defense.

38 The government takes the position that the submission and interchange of pleadings serves to clarify the issues and provide the judiciary with all necessary insights.

39 Drawn from the ranks of auditeurs or the maîtres des requêtes. 
and impartial conclusions. The commissaive views the case from a point which goes beyond that of the rapporteur. The latter considered only the particular case and file before him. The commissaire goes on to consider how this particular case fits into the totality of case law, the proposed decision's possible repercussions, in practice and on the law's future direction, and whether it would be wise to abandon the rationale of previous cases-however abrupt.

Submission of his written conclusions is followed by the hearing before the subsection, from which the public is barred. Typically, five members are present: the president, two Conseillers d'État, the rapporteur for this particular case, and a maître des requêtes. After the visas, as prepared by the rapporteur, are read, the attorneys, if they wish, are permitted to make an oral argument. The hearing concludes with the commissaive's presentation.

The deliberation which follows, from which the public and parties are barred, is participated in by the commissaire though he cannot vote. If either he or the president disagrees with the majority's view, however, either can demand that the case be submitted to the combined subsections.

The decree, which is prepared by the rapporteur and read at a public session, typically recites the names of the parties, their respective contentions, a summary of principal documents presented, and in concise form the legal reasoning which led to the decision. While such decrees of the Council of State are conclusive, in very limited circumstances involving formal defects, a decree can be vacated or modified. ${ }^{40}$ All of that body's decrees are published in a review; also tax journals reprint the more important tax decisions, sometimes together with the commissaire's conclusions and other comments. In addition, the administration's weekly bulletin prints those decrees which reflect important legal principles, typically with a commentary relating the decree to existing case law.

In general, a decision constitutes a precedent for similar situations arising in the future. Occasionally, however, the administration indicates that it will distinguish a particular decree from a given line of decisions for reasons not immediately apparent upon reading the decree.

In 1960-61, of the 4,883 judgments handed down by the lower administrative tribunals, 3,848 favored the administration. Nevertheless, the actual number of appeals from the ad-

40 Such formal defects include a judgment rendered by default in absentia, a defect in the procedure, correction of a material error. 
ministrative tribunals to the Council of State is spread almost equally between taxpayers and the government. This results from the fact that only about 10 percent of those taxpayers who initially suffered an adverse decision do appeal, whereas the government appeals between 30 percent and 40 percent of decisions unfavorable to it.

In 1960-61 the Council of State judged 815 tax cases, 724 of which were appeals from decisions of administrative tribunals. The tax administration submitted 94 cases.

Out of the 724 appeals, 608 dealt with direct taxes levied for the benefit of the state and of the communes, and of these, 316 dealt with taxes on income-with the majority (211) involving taxes on industrial and commercial profits. ${ }^{41}$

An analysis of decisions by the Council of State shows that in 1960-61 the government was completely sustained in 62 percent of all taxpayer appeals although almost a fourth of these resulted from defects in form. Of the administration's own appeals, 41 percent were decided completely adverse to it, another 41 percent confirmed the contested taxes, and 11.5 percent were abandoned by the administration.

While the administration was completely successful in only 41 percent of its own appeals, this is in sharp contrast to taxpayers who were completely successful in only 9 percent of their appeals. ${ }^{42}$ Several considerations contribute to this difference. On the one hand, taxpayers are not always knowledgeable, tend to view their own cases subjectively, can litigate at little cost (no attorney being required), and thus are willing to take a chance. On the other hand, the administration usually is more knowledgeable, attempts to be objective, employs successive levels to weed out errors made by lower echelons, tends to abandon the weaker issues in a case-submitting only the stronger ones to the tribunal-and, in general, exercises considerable restraint regarding the number of cases it will appeal.

41 This is understandable in light of the difficulty in determining such profits and the monetary interests involved.

42 An overall breakdown of Council of State decisions on tax appeals for 1960-1961 shows the following:

Taxpayer in error to appeal ........................

A ppeal by taxpayer badly taken........... 14.0

Taxpayer became discouraged ............. 14.0

Taxpayer right in whole or in part ........ 11.5

Administration in error to appeal . . . . . . . 9.5

Intermediate position . . . . . . . . . . . 6.0

Return to administrative tribunal. . . . . . . . 5.3

Use of expert witnesses . . . . . . . . . . . 0.6 


\section{PART FOUR}

\section{GERMANY}

by

Helmut Debatin 


\section{CHAPTER XIII}

\section{ADMINISTRATIVE ORGANIZATIONAL AND PERSONNEL FRAMEWORKS}

\section{Section A. Administrative Organizational Framework}

\subsection{Introduction}

Under the Constitution, the Federal Republic of Germany is composed of states, Laender, each of which, independently of the federal government, exercises legislative, administrative, and judicial powers. While fiscal powers are exercised simultaneously by the two levels of government, the states and the federal government, the Constitution does allocate certain functions between them by reference to the distinctions between (a) the authority to enact laws, (b) the authority to exercise administrative jurisdiction, and (c) the authority to dispose of the revenue from a given tax.

Taxes as to which all three powers are vested in the Federation are called federal taxes. These include especially the turnover tax, the transport tax, and the excise taxes, with the exception of the beer tax, the revenue from which accrues to the States.

The Federation is also authorized, and exercises authority, to legislate on taxes which are administered by, and accrue to, the States. This is true of the capital tax, Vermoegensteuer, the inheritance and gift tax, Erbschaftsteuer and Schenkungsteuer, the motor vehicles tax, Kraftfahrzeugsteuer. And above all, this category includes the income and the corporation tax where, ${ }^{1}$ however, part of the revenue accrues to the Federation which, to the latter extent, also has the administrative authority. Also within this group is the trade tax, Gewerbesteuer, the revenue from which accrues to the municipalities.

Only as to very few taxes do the States have legislative power, the most important being the real property transfer tax, Grunderwerbsteuer.

${ }^{1}$ While the Federation exercises the legislative function, the states indirectly play a part through the Bundesrat, which represents the states in the federal legislative procedure. 
The federal tax structure is headed by the Federal Minister of Finance, with comparable state officials at the head of the tax structure of each state. These are distinct administrative offices; the Minister of Finance for a state is not the subordinate of the Federal Minister of Finance.

At the regional level, however, the chief administrative official (Chief Finance President, Oberfinanz-praesident) is simultaneously a federal and a state official. The sixteen Regional Finance Offices, Oberfinanzdirektionen, comprise both federal and state offices, some divisions therein being concerned with federal and others with state taxes, and their respective employees belong either to the state or to the federal government. ${ }^{2}$

This contrasts with the local level where separate federal and state offices do exist. However, the federal offices, Zollaemter, are responsible only for customs duties and excise taxes, whereas the state offices, Finanzaemter, are responsible for the individual and corporate income taxes and also for the turnover tax. The fact that all of the turnover tax revenue and a portion of that produced by the income tax is turned over to the federal government ${ }^{3}$ does not in practice, diminish the authority of the local state offices. They have full, actual responsibility for local administration of these taxes because, to the extent of the Federation's share of such revenue, these state offices in effect act as agents of the Federation. In consequence, duplication of local administration is avoided. 4

\subsection{Organizational framework, national office level}

\section{A. Federal tax administration}

As noted previously, the Federal Minister of Finance is the highest ranking officer in the federal tax administration. As such, he engages actively in policy determination. In addition,

2 The Federal Republic of Germany is made up of states, Laender. The smaller states and the city states, such as Bremen, Hamburg, and West Berlin, have only one regional office. The larger states may have two or three.

3 The revenue from the income tax is divided between the federal government and the states. The federal quota is variable and may be modified at two-year intervals. For the fiscal years 1964 and 1965, the federal government received $39 \%$ of the total income tax revenue.

${ }^{4}$ In theory, the responsibility of administering the Federation's turnover tax rests with the Regional Offices. But, as the law stands, the Regional Offices may request the assistance of the state finance offices. In practice, as a result of this set-up, the state finance offices actually administer the turnover tax. 
he is responsible for organizational and personnel matters and for matters pertaining to the application of federal tax laws. In practice, however, the State Secretary of the ministry handles the day-by-day business.

Reporting directly to the Minister of Finance is a bureau concerned with fiscal policy and economic matters. Apart from that, the Ministry houses the six divisions set out in Chart I, each headed by a Ministerial-Director. Only the Third and Fourth Divisions are concerned directly with taxes. The divisions are divided into subdivisions, headed by Ministerial Deputy Directors, each of which in turn is broken down into sections, headed by senior officials, usually with the rank of Ministerial Counselor. These officials act on their own responsibility in that they make the first decision on all matters within their competence.

The most important tax division (Division IV) has responsibilities with respect to both turnover and income taxes, but these responsibilities are not identical. For taxes collected solely for the benefit of the federal government, such as the turnover tax, this division drafts laws, issues regulations, and hands down decisions in appellate proceedings. For taxes collected only in part for the federal government, such as income taxes, the division exercises less sweeping authority. Its formal direct responsibility is limited to the drafting of legislation. It also contributes to uniformity in interpretation, however, by having the prime responsibility for the drafting of regulations. Further, it plays a major role in the coordination of, and cooperation in, administrative measures taken by state tax administration. Rulings are not issued by the federal government, but by state governments; however, prior to issuance, the federal government in fact prepares and approves them. This, again, insures uniformity. Also, meetings of senior state and federal tax officials are called by and presided over by the Federal Finance Ministry with the end of insuring maximum uniformity in the actual application of the tax laws. To that same end, and to safeguard its interest in the revenues thus produced, the Central Federal Auditing Office within the Federal Ministry of Finance exercises its right to participate in the auditing activity which theoretically is the concern of the various states. For like reasons, acquiescence of the federal tax administration is also required with respect to the forgiveness of individual and corporate income taxes which exceed a certain sum. 


\section{CHART I}

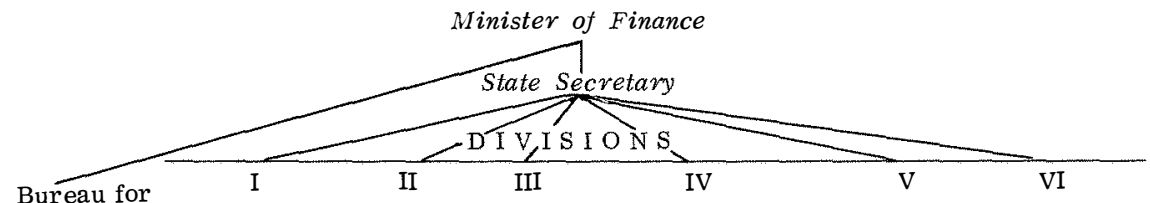

Bureau for

Fiscal Pol- Organization, Budget icy and Personnel

Economics

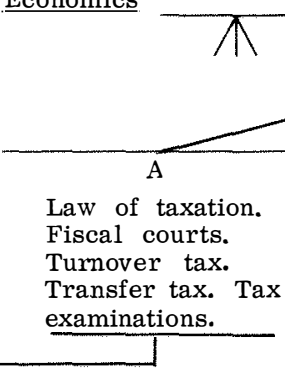

\section{-Section 1}

Double taxation. International integration of taxes. Foreign tax credits. Tax problems of international organizations.

- Section 2

Turnover tax (except as assigned to Section 3). Berlin Aid.

\section{- Section 3}

Turnover tax: International aspects, Saar territory, exports, additional turnover tax, agriculture, reform questions, extensions of time for payment, abatements of tax.

\section{- Section 4}

Transfer taxes and related taxes and charges.

\section{Section 5}

Training of fiscal personnel, Federal Finance College.
Taxes on income and profits. Tax simplification.

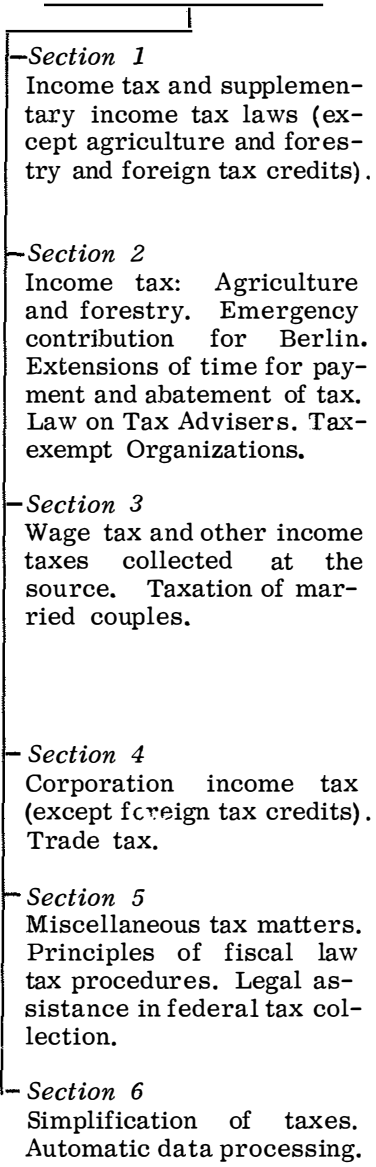

Taxes on net worth. Valuation. Contributions under the Equalization of Burdens Law.

\section{-Section 1}

Valuation: General rules and valuation of business property. Net worth tax. Inheritance tax.

\section{Section 2}

Valuation: Agricultural property and property devoted to forestry. Inventorization of arable land.

\section{-Section 3}

Valuation: Real property and business real property. Real property tax.

\section{-Section 4}

Contributions under the Equalization of Burdens Law.

\section{Secticn 5}

Tax examinations. 


\section{B. State tax administration}

As previously noted, none of the eleven State Ministries of Finance are subordinate to the Federal Ministry. The former are organized, however, along lines similar but not identical to those of the federal ministry, the difference being attributed to the fact that some functions are performed solely at the federal level. Nevertheless, each does have a tax division which is subdivided. The State ministry consists of several divisions subdivided into groups (which are the equivalent of the subdivisions of the Federal Ministry of Finance); each group comprises a number of sections-depending on the range and importance of the tasks assigned to it. As in the case of the Federal Ministry of Finance, these sections constitute the basic operational units of the ministry.

In the area of individual and corporate income taxes the Ministry of Finance for a particular state supervises implementation of the tax laws by lower-level authorities (regional finance offices and the local finance offices). In this process, instruction is given concerning assessment, auditing, tax forgiveness, etc. In some circumstances the state ministry hands down a decision in an individual situation.

However, all questions of common interest to tax administrations in the other states as well as questions relating to future legislation are referred to the federal tax administration by the state tax administrations. Moreover, no state ministry has any direct concern in the drafting of statutes dealing with individual or corporate income taxes.

\subsection{Organizational framework, regional office level}

As previously noted, the Regional Finance Offices serve as regional authority for both the state and federal tax administrations. The head, known as Chief Finance President, Oberfinanzpraesident, serves under joint nomination by the Federal and the appropriate state Ministers of Finance.

The heads of the several divisions, the Finance Presidents, Finanzpraesident, are subordinate to the Chief Finance President. However, the Customs and Excises Division is staffed with federal employees and its head is responsible to the Chief Finance President in the latter's capacity as a federal official, while the Division for Income, Profits, Net Worth, and Transfer Taxes is staffed with state employees and its head is responsible to the same regional Chief Finance President but in his capacity as a state official. Further, while the Group Unit for federal Turnover and Transport Taxes is attached to the Division 
for Taxes on Income, Profits, Net Worth, and for Transfer Taxes, the former unit actually is independent of the latter division's authority and reports directly to the Chief Finance President in his capacity as a federal official.

The tax division is concerned primarily with supervision of the local state tax offices, Finanzaemter, where the actual work of tax administration is carried on. Within limits set by the State Ministry of Finance, the Regional Finance Office instructs the local offices on all aspects of income tax and trade tax administration, with particular attention to assessment, auditing, and tax forgiveness procedures. It also usually works with the local offices in auditing the more important enterprises in the region. ${ }^{5}$ Further, under certain circumstances it hands down decisions covering particular fact situations which have been referred to it. In addition, the officials of this division of the Regional Finance Office conduct personal inspections to determine if the tax law is being enforced properly and if there is compliance with Regional Finance Office instructions. Finally, information forwarded by the local offices to the regional tax division is analyzed and matters of general interest called to the attention of the State Ministry of Finance.

\subsection{Organizational framework, local office level}

The actual administration of the tax laws falls upon the approximately 500 local offices which are severally responsible for geographical areas varying sharply in size and number of taxpayers. The number of local offices in a particular state depends upon geographic and economic considerations. In the City State of Bremen, only 5 local offices are needed, whereas 45 are established in the State of Hesse, 63 in Lower Saxony, 101 in North-Rhine Westphalia with its huge industrial centers, and 128 in Bavaria with its large rural districts. Also, the number of local offices serving under a particular Regional Finance Office varies according to the circumstances, and ranges from 5 (Bremen) to 69 (Munich).

The geographical areas assigned to the various local offices also vary in size. In a city with a great number of people and businesses concentrated in a relatively small area, the district of a local tax office is necessarily much more restricted

5 Among the other functions of the auditing section is the responsibility of fixing, on the basis of criteria and data collected by the local authorities, the standard rates for estimating the turnover and profits of enterprise. 
than in rural areas with widely dispersed settlements. The number of individual taxpayers-as distinct from residentswithin the jurisdiction of a local office also varies. In the federal territory approximately 3.2 million individuals are assessed for income tax. The number accommodated by a particular local office ranges from four thousand taxpayers to a high of twelve thousand or more, with an average in the neighborhood of seven thousand. 6 Throughout the Federal Republic of Germany there are approximately 60,000 corporate taxpayers. In some of the larger cities, responsibility for the assessment of the corporate income tax has been given to special offices for corporations ${ }^{7}$ but no data is available to indicate the average number of corporate taxpayers for which a typical office is responsible.

Each local finance office is divided into a number of branches which, in turn, are subdivided into working units, each of which is responsible for either a certain residential area or a certain category of taxpayers, such as corporations. The number of branches and of employees in a particular finance office depends upon the size of the area and the number of taxpayers. ${ }^{8}$ To some extent these same factors control the services performed by a given local office, as in the case of auditing. Certain small local offices do not have an auditing staff. Where this situation exists, assessment personnel perform office audits, but the more complex audits are turned over to the auditing staff of a nearby larger local office which customarily does have such a staff. Further, all auditing activity within a particular region is coordinated by the auditing section of the Regional Finance Office to insure uniformity.

The head of each local office is subordinate to the head of the Regional Finance Office, though his rank depends upon the size of the local office. He supervises the local administrative personnel, including the heads of the branches who, in

${ }^{6}$ Excluded from these figures are those taxpayers who are required to file tax returns but for some reason (i.e., income below minimum taxable) are not liable for any tax. Also excluded are those taxpayers who have had their taxes (i.e., wage tax, capital yields tax) withheld at the source.

7 In these same large cities, other local offices are charged with the centralized administration of certain other kinds of taxes, such as those on transactions, the inheritance tax, etc.

8 Offices in larger towns and industrial centers usually have staffs of considerable size, up to 450 , and more branches than smaller offices in rural areas. These latter average about 50 employees to an office. 
turn, supervise the work of the working units. In the larger local offices, one or two heads of branches are denominated coordinators for taxes of particular importance, such as individual and corporate income taxes, turnover taxes, or for a group of related taxes, such as capital transfer taxes. These coordinators perform consultative and coordinating activities with respect to the particular taxes falling within their respective competence.

Each taxpayer falls within the jurisdiction of some particular local office. If an individual, jurisdiction is determined by his domicile; if a corporation, by the seat of management; if a foreign enterprise, by the site of the permanent establishment.

In fulfilling its role as part of the state tax administration, each local office assesses, enforces, and collects individual and corporate income taxes from those falling within its jurisdiction. Although the revenues from the turnover tax accrue to the federal government, local administration is handled by the state's local office, acting as agent for the federal government. In fact, before preparing a taxpayer's income tax assessment, the state official in the local office first computes the turnover for establishing the turnover tax. After all, the turnover, measured by gross receipts, serves as a point of departure in computing the taxpayer's income. ${ }^{9}$ Moreover, in smaller and medium-sized tax offices, when the income tax assessment fora business is being prepared, the assessing official concurrently handles the work involved in computing the amount of the municipal trade tax, income being one of the multiple components which constitute the base of that tax.

Should the taxpayer wish to raise any questions relating to his tax, two administrative remedies are available. One, the protest, Einspruch, goes to the substance of tax liability; the other, the complaint, Beschwerde, involves discretionary matters which in practice raise procedural issues, e.g., forgiveness of taxes, or delay in filing returns because, illustratively, of force majeure or temporary absence from the country. Under both procedures, the protest and the complaint, the local office hands down a decision. Should the local office deny the taxpayer's protest, the taxpayer has no further level of administrative

9 If a taxpayer's business has establishments in two or more municipalities, the office apportions the trade tax receipts between the concerned municipalities. To facilitate the collection process, the larger municipalities have their own tax offices which administer not only the trade tax but other municipal taxes as well, including the real estate tax, levied in much the same manner. 
appeal but must bring his case before the appropriate fiscal court. In the case of a complaint, however, the taxpayer may have the denial submitted to the regional office. Should the regional office deny relief, the taxpayer then may proceed before the fiscal court.

To summarize the work of the local office with respect to the income tax, this office determines the basis of taxation and then assesses and collects the amounts due. The same office also handles all administrative appeals with respect to substance and the first of the two levels of administrative appeals with respect to procedure.

\section{Section B. Personnel Framework (Governmental and Non-Governmental)}

\subsection{Governmental professional personnel}

With very few exceptions the tax administrations ${ }^{10}$ of the Federal Republic and of the several states are staffed by civil servants. ${ }^{11}$ These fall into four classes-senior, administrative, clerical, and subclerical. Classification depends to a very substantial degree upon the individual's educational level at the time of entry. This educational level also determines the particular in-service training program into which an individual is channeled.

The lowest level of employment for the senior class is as head of a branch in one of the local tax offices. However, such a position may be one of the top levels for a member of the second or administrative class, although officials of this class are employed as assistants to the senior class officials

10 Fiscal administration is subdivided into three branches: taxes, customs, property and construction. This subdivision is particularly evident in the structure of the Regional Finance Offices. See 1.3 supra.

11 The term civil servant includes those persons whose status as such is governed by public law rather than by a private contract of employment. While theoretically practically all functions assigned to civil servants may be performed by salaried employees, the latter play only a minor part in tax administration. Where employed, salaried employees typically perform clerical work but sometimes, where there is a need and their qualifications are satisfactory, they will be utilized in administrative posts. Relatively often such employees with particular competence in tax matters and accounting practices will be employed in auditing sections. However, the majority of such posts are filled by civil servants. 
at all higher levels, and occasionally will be promoted into the senior class. Clerical and subclerical classes have no administrative responsibilities, being employed in subordinate capacities.

Since tax administration involves the application of relevant laws and-at the higher levels of the federal hierarchythe drafting of appropriate legislation, extensive legal knowledge is required of all officials who deal with other than purely administrative matters. In consequence, the senior posts within the tax administration are filled typically by lawyers, although in some instances these positions are filled by university graduates other than lawyers-i.e., from economics, etc.-or by officials promoted from the administrative class ${ }^{12}$ to the socalled senior class.

A lawyer applying for a senior class civil servant classification in the tax administration, like all other lawyers, has completed approximately seven years of training in a university and in post-university apprenticeships and has passed his First and Second Legal State Examinations, and thus qualifies for the title of Assessor. 13 If the appropriate State Ministry of Finance 14 accepts his application, the young Assessor is enrolled by a Regional Office as a Finance Assessor and undergoes a training period lasting from eighteen months to two years. The bulk of this period is utilized in practical training. He spends ten to sixteen months at a local office, where stress is placed on auditing, four months at the Regional Finance Office, and one month at a Finance Court. On the theoretical side, the Finance Assessor attends three training courses, each lasting about one month, at the Federal Finance College, supervised by the Federal Ministry of Finance. ${ }^{15}$

12 Officials in the top brackets of the administrative class frequently have duties comparable to those of senior officials. Therefore, they may move into the senior class without first qualifying through the examination process normally required.

13 This training is made up of two parts. First, there are at least seven half-year terms of legal training at a university, concluded by the First Legal State Examination, Referendar Examination. This is followed by at least three and a half years of apprenticeship training in courts, administrative authorities, and law offices, successful completion of which entitles the student to take the Second Legal State Examination, Assessor Examination.

14 The Federal Ministry of Finance handles the employment of attorneys to be used in the turnover and transactions tax areas.

15 In addition to the Federal Finance College, there are several finance training schools conducted by the several states. 
The courses at the Federal Finance College are designed to supplement the university legal training and give the Finance Assessor a broader and more detailed knowledge of the tax law as well as information in other areas (i.e., business administration with particular stress on industrial management) essential for tax administration. Special attention is given to accounting and the analysis of balance sheets. In addition, there is some discussion of certain aspects of economics, sociology, personnel management, industrial relations, and related subjects. Supplementing the formal course work are lectures of a general character, covering political, cultural, and scientific topics.

Upon successful completion of the training program, the Finance Assessor is appointed a Government Assessor, Regierungsassessor. Normally, his first assignment is as head of a branch at a small local office, but after two or three years he is promoted to Government Counselor, Regierungsrat, which is the lowest ordinary rank, according to Table A, of the seven ranks in the senior class.

TABLE A

Officials of the Senior Class: Promotion Sequence

Government Counselor . . . . . . Regierungsrat

Chief Government Counselor. . . . . . Oberregierungsvat

Government Director ........... Regierungsdivektor

$\left.\begin{array}{l}\text { Chief Government Director } \\ \text { Ministerial Counselor }\end{array}\right\}^{16} \cdots \cdots\left\{\begin{array}{l}\text { Leitender Regierungsdirektor } \\ \text { or Minsterialrat }\end{array}\right.$

Ministerial Deputy Director. ........ Ministerialdivigent

Ministerial Director. ...........Ministerialdivektor

This bottom rank heads branches in the larger local offices. In the largest local offices, however, the heads of the more important branches are Chief Government Counselors, Oberregierungsrat. The rank held by heads of local finance offices depends upon the size of the particular offices. Most offices are headed by experienced personnel who have progressed through two or three, sometimes in the case of larger offices even four, ranks. A few very small offices are headed by men of the lowest rank.

16 These two officials occupy an equal rank and enjoy an equal salary. The difference in title depends upon where the official in question works; the Leitender Regierungsdirektor works in the field, the Ministerialrat in either the state or federal Finance Ministry. 
In the Regional Offices, section chiefs are either Government Counselors, Regierungsrat, or Chief Government Counselors, Oberregierungsrat, while officials in charge of groups (made up of sections) are Government Directors, Regierungsdirektor.

Within the State Ministries, the rank of the head of the tax division depends upon the size of that division. Usually this division is headed by an official who holds the second highest rank in the senior class, i.e., a Ministerial Deputy Director, Ministerialairigent. Groups working on the level below that of the division are headed by Ministerial Counselors, Ministerialrat, or Government Directors, Regierungsdirektor, with the section chiefs holding the rank of Chief Government Counselor, Oberregierungsrat.

While the educational qualifications for tax officials of the second or so-called administrative class are not nearly as demanding as the standards applied to those who seek to enter the senior class, the wide variety and complexity of the tasks performed by the former does require them to have a sound basic educational background. Federal and state laws ${ }^{17}$ set out minimum requirements-i.e., completion of training at an intermediate-level school (e.g., commercial school) or qualification for the upper years at a high school ${ }^{18}$-but in practice the tax administration prefers candidates with somewhat greater qualifications-i.e., completion of training at a high school.

The candidate, upon acceptance of his application by the Regional Finance Office, commences his apprenticeship training at a local office, the training period lasting at least three years. The state-administered training programs are generally similar although they differ in detail. The bulk of the apprenticeship training, geared to familiarize the candidates with the work of the local offices, involves actual work in the different branches of these offices. In the course of the training, knowledge of administrative class functions is acquired through contact with experienced officials. Simultaneously, the candidate is introduced gradually to progressively more difficult cases.

17 The Federal Law on Civil Servants, which fixes the general requirements, is binding on the several states. In addition, each state has its own particular laws.

18 In the school system in effect throughout Germany, the subjects taught in the upper yearis at high school correspond at least in part to the subjects taught in the first two years in a college in the United States. 
In addition to this practical training, a minimum of nine months is spent in theoretical studies. To this end, six states maintain special training schools $;^{19}$ in the other states, Regional Finance Offices are responsible for administration of the training programs.

Typically, the first introductory course, usually lasting three but sometimes as long as ten months, begins after the candidate has had a short period of practical experience in a local office. This brief course, concluding by a preliminary examination, provides the theoretical knowledge necessary for successful continuation in the training program. A second course follows a substantial period of practical training and is concluded by written and oral examinations covering the important subjects a candidate will employ in his future work. These include: government and administration, accounting, balance-sheet analysis, auditing, individual income tax, corporate income tax, turnover tax, general tax law, capital tax, criminal law pertaining to fiscal offenses, enforcement measures, budgetary administration, etc.

Candidates successfully passing this second examination are classed as civil servants on probation and are hired as supernumerary Tax Inspectors. After satisfactory service during the probation period (normally two years), they are appointed to the lowest bracket of the administrative class, Tax Inspectors, and assigned a specific post within a local tax office.

Typically the working unit of a local office is headed by a Tax Inspector or Chief Tax Inspector. Such an official, with the aid of one or two assistants, handles the assessment work. Inspectors also bear the prime responsibility for field audits. The two highest ranks of the administrative class, Tax Superiors and Tax Counselors, are to be found for the most part as heads of branches in Regional Finance Offices. However, all four ranks of the administrative class also occupy posts at regional, state, and federal levels as assistants to senior class officials.

Normally, throughout the tax administration, the careers of all persons in the senior and administrative classes commence in a local tax office. From the staffs of these offices, appointments are made to the regional offices. The state ministries of finance draw their personnel both from the regional and the local offices. The Federal Ministry of Finance draws its staff

19 As of 1964 there were nine such training schools. 
from the tax administrations of all states, the several state governments consenting to the transfer.

When an official is transferred from a lower to a higher office, i.e., from the regional office to the state or the federal ministry, he will not be expected to secure further education or on-the-job training. Such an official is already a member of a particular class and he will continue, albeit on a higher level, to perform the duties of that class. Hence, such a promotion merely presumes superior qualifications, such as a high degree of specialized knowledge, administrative or executive capacities, creative imagination, and initiative. These are the essentials for appointment to the state and federal ministries; no consideration is given to proportional representation of lower level authorities or any particular class of personnel.

\subsection{Private tax practitioners}

With the heavy post-war tax burden, the services of tax advisors have become increasingly important. These advisors fall into two main groups-Tax Consultants, Steuerberater, and Agents in Tax Matters, Steuerbevollmachtigter-and presently number respectively 4,000 and 20,000 . To insure suitable educational background and necessary professional qualifications, the 1961 Law on Tax Advisors, applicable to all the states, set up certain requirements for admission to the respective professional examinations.

To sit for the Tax Consultant examination, an individual must have completed a full course of university study in law or economics and subsequently must have been employed for at least three years by an individual or company admitted to tax practice. There are somewhat less stringent requirements for the Agent in Tax Matters examination. Admission to this examination is granted on the basis of a high school or accredited school-of-commerce education followed by an apprenticeship with a tax or business advisor or a trader and four years practical experience in the giving of tax advice while employed by a Tax Consultant or Agent in Tax Matters.

In cooperation with the respective professional associations, the State Ministries of Finance conduct the examinations for Tax Consultants, the Regional Finance Offices for Agents in Tax Matters. Because of the high level of competence demanded, between 20 and 25 percent of the applicants fail to pass. Both types of examinations cover tax law, relevant criminal law and procedure, accounting with particular emphasis on balance sheet analysis, civil law, and professional law. The Tax 
Consultant examination, in addition to requiring a more extensive and sophisticated knowledge of these subjects, includes commercial and company law, public finance, and economics.

Candidates for the examinations may not attend the federal or state in-service training programs. Instead they attend private courses conducted by experienced teachers including Tax Consultants, Certified Public Accountants, and senior or administrative class tax officials. In addition textbooks and correspondence courses are available.

The typical candidate for the rank of Tax Consultant has completed his university training before taking the qualifying examination. However, the examination may be taken by two groups who lack university training: Agents in Tax Matters who have had ten years of full time service considered satisfactory by the head of the local finance office most familiar with their capabilities, and former tax administration officials (in practice members of the non-senior class) who in the ten years prior to their retirement had worked for five years as head of a branch. If such a former non-senior class tax administration official had headed a section or working unit under the same conditions, he may sit for the Agent for Tax Matters examination.

No qualifying examination for Tax Consultant is required of two groups: former judges of fiscal courts and senior class tax officials who for five of the ten years directly preceding retirement have headed a branch in a local office or occupied an equivalent position. Their technical knowledge is considered sufficient to warrant this special arrangement.

These two groups of tax advisors-Tax Consultants and Agents in Tax Matters-perform essentially the same functions, including closing taxpayers' books, establishing balance sheets, preparing tax returns, representing taxpayers in dealings with the tax administration or before the fiscal courts. However, Agents in Tax Matters handle primarily tax affairs of smalland medium-sized firms with less complex financial dealings, while Tax Consultants are retained by larger firms with more complicated tax problems. Only Tax Consultants may be the members of the boards of managers of the hundred-odd corporations or limited liability companies organized to engage in tax practice.

Both Tax Consultants and Agents in Tax Matters may represent taxpayers in administrative proceedings and in the tax courts. Two other groups of professional tax advisors have the same privilege: a very small and steadily decreasing group 
of Certified Auditors, vereidigter Buchpriifer; and the much more important group of Certified Public Accountants, numbering about 150, who have completed university training in economics and related fields, have had six years of professional accounting experience, and have passed a difficult qualifying examination.

Because a taxpayer can use members of any of these four groups as tax advisers and as representatives in tax litigation, it is not necessary to have a lawyer represent him. Yet representation in tax litigation is the only tax area where lawyers are at all active, for the giving of tax advice is almost entirely handled by members of other professional groups. 


\section{CHAPTER XIV}

\section{ADMINISTRATIVE RULE-MAKING PROGRAMS}

\section{Section A. Character of the Underlying Statute}

\subsection{The precision of the statute itself}

The basic principles of German income tax law are the same for individuals and for corporations. While there are two separate statutes-individuals are subject to the Income Tax Law and corporate bodies to the Corporation Income Tax Law-the corporation tax statute refers to and is based on the individual tax statute.

Both the Income Tax Law and the Corporation Income Tax Law are relatively short. The Income Tax Law fills 80 printed pages with approximately 300 words to the page. It has 73 sections. ${ }^{1}$ About two-thirds of these contain substantive provisions concerning the determination of income, tax rates, etc. The remaining one-third contains procedural rules, such as the authority to issue regulatory ordinances having the force of law. ${ }^{2}$ Most, but not all, of the individual sections of the law are relatively short. The most extensive sections are those which, in addition to a general principle, set forth rules granting special relief as to which the law seeks to be as precise as possible.

The Corporation Income Tax Law is shorter than the Income Tax Law, with 24 sections on 15 pages of approximately 300 words each. This brevity is possible because the Corporation Income Tax is essentially based on the Income Tax Law. Illustratively, it refers back to the Income Tax Law when dealing with income determination and tax assessment, restricting itself to special provisions governing the taxation of corporate bodies, i.e., intercompany holdings, tax rates, etc.

1 The numbered sections run only to 54 , but several sections marked with letters have been added, bringing the actual number of sections to 73.

2 During the post-World War II period of reconstruction, special economic considerations led to incorporation of a number of rules expected to have a short life. Their number is decreasing as the objectives of their enactment are being achieved. 
A factor contributing to the relative shortness of both statutes is the fact that there is a separate code of procedure covering all taxes, the Fiscal Code, Reichsabgabenordnung. This code deals with assessment, conditions permitting modification of assessment notices, collection of deficiencies, tax refunds, statutes of limitations, and penalties. Although extensive, comprising 488 sections, relatively few provisions directly affect the taxation of income. However, in addition to the two basic statutes, certain other comparatively brief laws do deal with isolated specialized sectors of individual and corporate income taxation, such as contributions to industrial pension funds, investment funds, and corporate reorganizations.

Another prime factor contributing to the brevity of the basic income tax statutes are the complementary regulatory ordinances, Rechtsverordnungen, discussed in 2.4 infra.

Most important, however, is the fact that the two laws are based on abstract concepts and state abstract rules. The statutory provisions do not enumerate concrete cases which may be encountered in practice. In solving any such problem, the abstraction is applied to the factual situation, with specific rules then being derived from the guiding principle.

This approach of the statute is based on the premise that, since the law must cover a wide range of factual situations, it must leave room for flexible interpretation. An enumeration of concrete cases might be helpful to the layman, but would tend to make the law rigid and inflexible, unable to adjust to changing conditions. ${ }^{3}$ Moreover, it is unlikely that inclusion of a large number of subordinate rules to govern diverse types of individual cases would reduce the volume of interpretative controversies, for no list could cover all possibilities. And in practice, it then would be difficult to classify factual situations under the competing rules however great their number. While Germany avoids this by using general provisions, and thus achieves far greater brevity than does the United States in its code, delimitations are not lacking; but they are confined to basic essentials and thus not nearly so numerous as those found in the United States code.

This greater reliance on abstract legal principles also insures greater uniformity in application of the law to economic

$3 \mathrm{~A}$ rigid statute, out of tune with current conditions, might grant unanticipated benefits or result in unforeseen hardships. Such inequity might lead to new demands by taxpayers, further detailed specifications in the statute with increased ramifications, and even an aggravation of existing rigidity. 
gain. Under the German law, income from trade or business comprises all income derived by a businessman from his business. It is immaterial whether the income arises from interest payments, capital gains, or profit from the sale of goods; income is treated as a single unit. The structure of the law itself tends to resist the insertion of complicated special rules according special or preferential treatment to isolated items.

Illustratively, the Income Tax Law, Section 2, paragraph 1, states that income tax is calculated on the basis of net income received in any one calendar year. Paragraph 2 provides, by way of deduction from the principle expressed in paragraph 1 , that net income is the total amount of income derived from each of the listed sources of income, less losses and expenses incurred in respect of those sources.

The sources of income listed in the statute are as follows:

(1) Income from agriculture and forestry;

(2) Income from trade or business;

(3) Income from independent personal services;

(4) Employment income;

(5) Income from the investment of capital;

(6) Rentals and royalties; and

(7) Other income defined and circumscribed likewise in abstract terms including

(a) Recurring payments such as pensions;

(b) Income from speculative transactions, i.e., sales of private property, if, in the case of real property, not more than two years, and in the case of other property not more than two months, have elapsed between the acquisition and the sale; and

(c) Income from any other payments or benefits received and not included in one of the sources of income listed as, for instance, income from the occasional leasing of movable property.

Under each of the sources of income are listed the types of income. Thus income from trade or business is said to comprise the profits derived by a partner from a partnership, including payment for his services to the partnership, payment for assets made available to the partnership, or interest on a loan granted by him. Employment income includes non-cash benefits and pensions, while income from the investment of capital includes dividends, interest, etc.

In the case of corporations, however, their entire income is deemed to be income from trade or business. 
The statute defines the terms surplus and profits. These concepts are of prime importance because for the first three sources of income listed above, income is understood to be the profit from the activity while for the other four it is the surplus of receipts over income-connected expenses.

Under the statute, profit is computed by comparing net worth at the end of one business year with that at the end of the preceding business year. This is an abstract approach, preceding from general terms to particular elements, starting with the balance sheet not the profit and loss account. Further, the balance sheet must be prepared to accord with commercial law principles, while at the same time taking into account special provisions in the tax law governing withdrawals and investments, valuation, physical depreciation, business expenses, etc. This reference to commercial law simplifies the tax law's structure, but in practice it requires the preparation of two balance sheets, one for commercial, the other for tax purposes.

Since income is determined by comparing two balance sheets, no capital loss deduction provision is needed: this becomes a matter of asset valuation in the balance sheet. Deductible expenses, however, are specified, with those not deductible regarded as withdrawals to be added to the profits.

By specifying certain types of receipts as subject to income tax, those not so identified are excluded, such as lottery gains; this stems from the structure of the law, that is, an item is excludable because it is not specifically included. Thus, while the statute does not list every kind of payment excludable from income tax, it does list approximately sixty items which, absent such identification, could be included under a source of income.

When determining an individual's net income, certain personal expenses are deductible. These include interest, life insurance premiums, church tax, etc. Further the taxpayer may deduct various allowances for dependent children or advanced age, and also certain extraordinary burdens such as unusual medical costs. Thus the net income figure is reached, a sum to which the income tax rate table is applied.

A statute stating abstract concepts inevitably creates interpretative problems in the course of applying the abstractions to individual cases. The following example relating to income from trade or business illustrates this process.

In determining whether items constitute receipts or expenditures, the statute establishes certain criteria. With respect 
to receipts, the only issue is whether the income was derived from the trade or business; the nature of the individual item is immaterial. With respect to expenditures, the statute provides: "Business expenses shall be understood to mean expenditures occasioned by the operation of a business." 4 Under this provision, expenditures for private purposes are not deductible. If the latter are shown as business expenses, an adjustment will be made, adding them back to profit. While the treatment of business expenditures is clear, disputes do arise as to the meaning of the standards, "occasioned by the operation of a business" or "incurred for private purposes." The statute attempts to clarify the abstract standards by providing that nondeductible expenses include expenditures to maintain a standard of living commensurate with the taxpayer's economic or social position, irrespective of whether such expenditure promotes the taxpayer's professional or business activities. ${ }^{5}$ However, because the terms used in these standards ("economic or social position" and "promoting the taxpayer's professional or business activities") do not readily provide a clear answer to each of the wide range of factual circumstances to which they must be applied, courts do encounter a large number of controversies in this area.

Where deductibility depends upon the expenditure's having been occasioned by the operation of the business, the principle of causality becomes the criterion. Should a businessman incur excessively large expenditures for customer entertainment, the abstract language of the statute, standing alone, might seem to warrant their deduction. To prevent this possible construction, the statute sets out concrete criteria and classifies as nondeductible the following expenditures:

1. Expenditures for presents made to persons who are not employees of the taxpayer and do not have continuous business relations with him under either a commercial agency contract or a contract for work and services, except presents with an aggregate value during the taxpayer's business year not exceeding DM 100 for each individual recipient;

2. Expenditures for guest houses maintained by the taxpayer outside the city or town where the business is located, to the extent these facilities are used for accommodating and entertaining persons other than employees; and

3. Expenditures connected with the acquisition or exercise of hunting or fishing privileges or the maintenance of yachts or similar facilities, and the entertainment of guests through use of such facilities.

${ }^{4}$ Income Tax Law, §4, para. 4.

5 Income Tax Law, § 12 . 
Finally, the following catchall provision provides a general safeguard against excessive expenses:

Expenditure affecting the standard of living of the taxpayer or another person shall not be taken into account when determining the profits, to the extent that such expenditure is deemed to be excessive by generally accepted standards. ${ }^{6}$

Since this less precise standard must be applied to each individual set of facts, here too courts encounter many controversies requiring construction of the phrase "deemed to be excessive by generally accepted standards." "Constructive dividends" is another phrase creating interpretative problems. The Corporation Income Tax Law does not define the phrase, simply stating:

The question as to which receipts are income and the method of computing such income shall be governed by the provisions of the Income Tax Law. In this connection, constructive dividends shall also be taken into account.

The relevant regulatory ordinance, Ordinance Regulating the Corporation Income Tax Law, ${ }^{7}$ gives ten examples but no definition. ${ }^{8}$ Consequently the courts must define and interpret the statutory expression.

The fact that the courts are available to resolve these interpretative disputes means, on the one hand, that the statute's reliance on abstract principles does not jeopardize the stability of the legal system. In borderline cases, on the other hand, the taxpayer cannot be certain in advance as to the tax consequence of his actions, for each decision covers only the case at issue.

Finally, it should also be observed that the German statute does include some provisions which contain precise definitions with scant room for interpretation, such as those dealing with the extraordinary depreciation allowances on private housing

${ }^{6}$ Income Tax Law, §4, para. 5 .

7 For details concerning the status of regulatory ordinances, see 2.4 infra.

8 Typically an ordinance does not contain illustrative examples. They are to be found in administrative regulations. The first two examples of constructive dividends set out in Ordinance Regulating the Corporation Income Tax Law, §19, read as follows:

"1. A shareholder is paid an excessive salary for his services as an officer of the company.

"2. A shareholder is paid, in addition to an adequate salary, extra compensation based on the turnover of the business." 
(including owner-occupied dwellings) and with charitable contributions. Thus German tax law employs deliberately a variety of drafting techniques, the overriding motive being to keep the law as flexible as possible. ${ }^{9}$

The annual number of income tax controversies which involve interpretative issues is not known. While some are resolved at the judicial level, administrative procedures handle far more. It is not even known how many reach, or how many are resolved by, either the lower echelon fiscal courts or the Federal Fiscal Court. ${ }^{10}$ Only the latter tribunal publishes decisions. And while, in 1963 for example, it published 164 income tax and 17 corporation tax decisions, the total number handed down was substantially higher, for even that court does not publish all its decisions.

\subsection{Legislative pre-enactment aids to interpretation}

Legislative pre-enactment aids to income tax law interpretation include:

(1) Minutes of the Budestag or Bundesrat Fiscal Committee or of any other technical committees dealing with income tax matters; 11

(2) Reports submitted to the Bundestag or Bundesrat by the Fiscal Committee concerning the results of its discussion; and

(3) Minutes of the plenary session debates of the Bundestag or Bundesrat.

Of these three, the Bundestag Fiscal Committee's minutes contain the greatest amount of information regarding the sense and purpose of a provision. The Fiscal Committee may and typically does invite the Federal Minister of Finance, senior officials of the Finance Ministry, experts from industry, etc., to participate in these clarifying discussions. However, the hearings are closed and the minutes, summary rather than verbatim reports of the discussion, generally are not available to the public.

9 One advantage: Taxpayers, rather than attempt to exploit the marginal areas hoping to find loopholes in the law, may seek sound footings, not otherwise being sure of a court's reaction.

10 The Federal Fiscal Court, the supreme court for German tax matters, deals only with questions of law. See Chap. XVI, 4.4 infra.

11 The grass-roots work on a given provision-apart from the preparatory work done by the Federal Ministry of Finance-generally is left to the several committees. 
The public, however, does have access to the reports which the Committee submits to the legislature and to legislative minutes. The utility of the former is limited because they reflect only a summary of the committee's views. And typically, the legislative minutes furnish no details regarding the interpretation of a given provision. The processing of one new provision in 1964 (section 6(b) of the Income Tax Law) illustrates the relative informative quality of these three sources. The portion of that provision of interest here reads as follows:

Profit from the disposal of certain fixed assets

(1) Taxpayers who dispose of real property, fixtures attached to real property including the appurtenant lands ... or livestock of agricultural and forestry enterprises in connection with a plant reorganization, may, in the business year in which the assets are disposed of, deduct from the cost of acquiring or producing the [especially defined ... similar] assets purchased or produced in the said business year an amount not exceeding the profit derived from such disposal. ...

Two questions arise. What are "fixtures attached to real property" within the meaning of the provision? What is a "plant reorganization"?

The Fiscal Committee minutes, though not available to the public, provide some clarification. They state that the expression, "fixtures attached to real property," is more or less restricted to irrigation and drainage facilities used for agricultural or forestry purposes. "Plant reorganization"-a term hitherto unused by German tax law-is said to cover not only the fundamental reorganization of a business but also situations where, for instance, a cattle farm is converted into a duck farm. The minutes go on to state that the ultimate definition of "plant reorganization" must rest with the courts.

The Fiscal Committee's published report to the Bundestag does not refer at all to "fixtures attached to real property." "Plant reorganization" is explained only by an illustration, "e.g., when changing from bovine cattle farming to small cattle farming."

The Bundestag minutes of the debate on the 1964 Tax Amendment Law mentions neither of the previously quoted statutory phrases. The plenary session did not concern itself with these details; it explored only the economic, political, and fiscal effects of provisions granting tax reliefs. 


\subsection{Standards of construction followed by the judiciary in inter- preting the statute}

A German court, construing a statute, takes as a point of departure the premise that the language of a law determines its construction, for the language reflects the legislature's intention. Therefore, any construction must accord with the language used in the law, unless a literal application were to lead to an obviously unreasonable result.

The extent of judicial interpretation depends, of course, on the way a provision was drafted. When a statute is phrased in abstract form, there is much scope for judicial interpretation. When a statute is expressed in precise terms, there is little judicial interpretation. Since each provision reflects its own character, the courts try to ascertain from the statute itself the proper degree of interpretative freedom. For example, a sweeping term such as constructive dividends obviously gives wide latitude.

That interpretations will be realistic and responsive to new situations is insured by the fact that certain principles of construction, not set out in any statute, ride piggy-back on the text of the law itself. Among those to which the judiciary adheres, the most important is the so-called economic approach, wirschaftliche Betrachtungsweise. This approach stresses the economic aspects of a transaction, its substance rather than the niceties of its legalistic form. The interpretation accorded "concealed capital stock" illustrates the use of this overriding economic approach. Should an interest-bearing loan be granted to a limited liability company by a shareholder, the loan will be scrutinized in the light of all facts pertaining to the company to determine whether it constitutes additional capital rather than a liability. If it is determined to be additional capital, interest payments are deemed distributions rather than recognized deductible business expenses.

This realistic approach also enables the courts to keep the law in tune with current economic developments. For example, changes in agricultural practices with greater use of farm machinery, fertilizer, etc., led courts to recognize that partnership agreements between farm parents and children should no longer be regarded as tax avoidance devices reflecting mere family ties, but as genuine contractual relationships.

This approach to interpretation also has enabled the judiciary to assure that cases of like economic substance receive identical tax treatment even in the instance where a literal interpretation of the law would produce different results. 
Illustratively, the statute literally accords different treatment to businessmen and to individual investors in depreciating capital improvements to realty. Should a businessman shift from coke to oil heat, the rules concerning the determination of profits from trade or business would apply with the consequence that his depreciation would be geared to the useful life of the new system. The private investor, however, is governed by the provisions relating to rental income, and literally would be forced to gear his depreciation to the longer useful life of the building. This obviously discriminatory treatment caused the courts to rule that the private investor, at the point when the new oil furnace became unserviceable, could write off as income-connected expenses the then remaining undepreciated basis of the furnace.

Finally, where the courts are uncertain as to the legislative intent, consideration is given to the historical background of a provision, though this may not be used to justify an interpretation incompatible with the thrust of the provision itself. The background includes the pre-enactment documents mentioned previously ${ }^{12}$ though, in general, these do not rank high among the guides to interpretation.

\section{Section B. The Regulations Program}

\subsection{Types and force of regulations}

As noted in 2.1 supra, German tax statutes are supplemented by regulatory ordinances, Rechtsverordnunger. These are issued by the Federal Government with the consent of the Federal Council, Bundesrat, pursuant to authority contained in the individual laws which lay down the scope, limits, and purpose of the authority. These ordinances then serve only to implement the law, providing specifics in accordance with the general legislative intent reflected by the statute itself.

Regulatory ordinances cannot change or modify the law's provisions nor can they create new obligations and privileges. Unless they fail to conform to the language and purpose of the law, they are regarded as binding legislation susceptible to interpretation. Thus they are far more than mere administrative instructions. They bind both the administrative authorities and the courts except where the courts hold either that a regulatory provision exceeds the delegated authority, or that the

12 See 2.2 infra. 
delegation itself was invalid because insufficiently defined in the statute.

Despite these limitations, regulatory ordinances can be used effectively to supply details not incorporated in the law itself or to permit adaption to changing conditions without further resort to the more time-consuming legislative process. Illustratively, the statute authorizes the issuance of regulatory ordinances granting special depreciation allowances for such items as sewage plants, mining, air purification, and research equipment, and to provide special deductions for certain categories of goods, including imported goods the prices of which have declined sharply on the world's market and other goods of particular importance to the German economy. Other regulatory ordinances are authorized to permit increased accumulation of reserves when prices rise or to allow special depreciation allowances during a recession. Again, authority is delegated to issue ordinances according tax relief to inventions by employees, independent inventors, etc.

The Income Tax Law confers both specific and general authority to issue regulatory ordinances. Specific authority is conferred in certain selected areas, 13 such as those previously mentioned. In order to insure equality of all taxpayers before the law, to provide relief in hardship cases, or to simplify tax procedures, general authority is granted to facilitate implementation of the Income Tax Law with respect to the delimitation of tax liability, determination of income, assessments, application of tax rate provisions, and payment of taxes.

The most important ordinance issued under the Income Tax Law is the General Ordinance regulating the Income Tax Law. It contains 91 sections and comprises about 60 pages of approximately 300 words each, and thus is somewhat smaller in size than the Income Tax Law itself. Also relevant to this comparison of size is the fact that this ordinance-like all regulatory ordinances-for more complete understanding frequently repeats the text of the various parts of the law with which it deals. However, not every section of the statute is supplemented by a corresponding portion of the regulatory ordinance. Only portions are so complemented, selected usually because

13 The identification of these specified areas is primarily a matter of drafting technique. At the end of the Income Tax Law, the text reflects both the general authority to issue regulatory ordinances, as well as specific authority in selected areas to make certain that the Federal Government is authorized to issue the latter ordinances with the approval of the Bundesrat. 
the statute is not exhaustive enough on a given point. Subject to the overriding requirement that a regulatory ordinance conform to the law itself, the government in exercising its authority to issue regulatory ordinances has full administrative discretion in determining what it will include within a particular regulation. In addition to the General Ordinance, there are approximately ten major regulatory ordinances covering important special income tax areas. The most voluminous of these is the Wage Tax Ordinance, which comprises 58 selections dealing in large part with the technical aspects of the wage tax. Other ordinances bear on the withholding tax on income from capital, taxation of independent inventors, tax treatment of inventions by employees, and on the calculation of the rental value of owner-occupied homes. Together, these ordinances add slightly less than a hundred sections.

These regulatory ordinances fulfill the purpose of making precise whatever may have been left open or unclear in the statute. They do not interpret the statute. Rather they set out supplementary rules omitted by the legislature. Further, they do not include summaries of Supreme Court decisions.

The Ordinance regulating the Corporation Income Tax Law, issued under the authority contained in the statute itself, has only 38 sections, for it deals only with the special problems peculiar to corporate taxation.

Whereas the regulatory ordinances establish legally binding rules, the quite separate administrative regulations discussed below serve only to reflect the government's interpretative position.

\subsection{Precise purpose of interpretative regulations}

The introductions to the Income Tax Regulations, Corporation Income Tax Regulations, and Wage Tax Regulations state their purpose as follows:

The regulations deal with questions of doubt and interpretative questions of general importance with a view to insuring uniformity in the application of the income tax law [corporation income tax law, wage tax law] by the tax authorities. In addition, they give instructions to the local finance offices on how to proceed in certain cases in order to prevent undue hardship and to simplify administrative procedures. ${ }^{14}$

14 Under German tax law (Fiscal Code, §131), taxes may be forgiven or refunded in whole or in part where, in the circumstances of the individual case, taxation would result in undue hardship. It also is permissible to reduce the base of income on which the tax rates are applied. Although this provision refers to hardship in relation to 
These administrative regulations describe and interpret both the law and the regulatory ordinances. They do not supplement the law, i.e., fill gaps left open by the legislature. This is left to the regulatory ordinances.

The authority to issue these administrative regulations is derived by the Federal government from the Basic Law, ${ }^{15}$ not from specific delegations in the tax statutes. However, because of the power held by the several states in income tax matters, the administrative regulations covering this area can be issued only after receiving the approval of the Bundesrat (comprised of representatives of the states).

Administrative regulations, unlike statutes or regulatory ordinances, do not bind the courts. A regulation may be taken into account, however, either because it is deemed to represent a well thought out administrative view or because it is a source of information regarding methods which have been applied in practice. Even so, in the end a court renders its decision on the basis of its own interpretation of the law.

Nevertheless, the abstract language of the German statutes makes centralized administrative interpretation a prerequisite to uniform application of the law by all administrative officials, and is peculiarly important as to matters having wide application. Since the focus on interpretative problems is only to assure uniform application by fiscal authorities, rather than to guide the lay public, lay language is not used. Nor are examples provided where the law itself provides a clear answer. In general, the aim is to strive to interpret the law to conform with objective criteria, i.e., as the courts would be expected to interpret it.

Two illustrations will indicate the type of interpretative assistance these administrative regulations provide. The first relates to Sections 2 and 21 of the Income Tax Law which require inclusion of rental income from real property. Income means receipts less income-connected expenses. The latter are defined in Section 9 precisely, to mean those incurred in obtaining, conserving, and maintaining receipts. In practice, however, it is difficult to distinguish between expenditures constituting income-connected expenses and expenditures requiring capitalization. The administrative regulations seek to clarify the distinction, as follows:

\section{(footnote continued)}

the circumstances of individual cases, it expressly allows similar arrangements to be provided for certain groups of analogous cases.

15 Basic Law, art. 108, para. 6. 
There is no fixed borderline between maintenance-connected expenditure and capital expenditure. Maintenance-connected expenditure invariably includes expenditure

1. Which does not change the nature of the real property and

2. Which is incurred with a view to maintaining the property in proper operating condition and

3. Which recurs regularly in about the same amounts. Even if not all of these conditions are fulfilled, expenses incurred may, under certain conditions, constitute maintenanceconnected expenditure (cf. Federal Fiscal Court Decisions, July 9, 1953 and March 1, 1960-BStBl (Bundessteuerblatt) III, 245 and BStBl III, 198). In particular, maintenance-connected expenditure includes expenditure on current maintenance and on repair (backlog of maintenance work). . 16

This effort to be as precise as circumstances permit is illustrated by the regulation dealing with Section 9a of the Income Tax Law. The latter allows, in lieu of a deduction for actual income-connected expenses, a standard deduction in the following amounts:

(1) DM 564 deductible from employment income;

(2) DM 150 deductible from the income from capital assets.

From this emerge several questions. Is a taxpayer with more than one employer allowed to claim more than one standard deduction? If a taxpayer receives both employment income and income from capital, can he claim both standard deductions? If he ceases to be liable for tax during part of a given year, must the standard amounts be reduced proportionately?

The Income Tax Regulations respond as follows:

The standard deduction for income-connected expenses shall be allowed only once in respect from the same source[17] of income ( $c f$. Federal Fiscal Court Decision, April 3, 1959BStBl III, 220). In the case of income from two or more sources, the standard deduction shall be allowed in respect of each source of income up to the amount of the income involved. The standard amounts shall not be reduced if the taxpayer's liability to tax during a given year failed to extend over the full year.

Observe that both of the above examples from the regulations cite decisions of the Federal Fiscal Court, the highest

16 Income Tax Regulations, para. 157.

17 E.g., employment income irrespective of the number of employers. 
German court in tax matters. Thus the regulations not only clarify but serve also to indicate the issues which the tax administration regards as now settled but which at some point were doubtful enough to have reached the highest judicial tribunal.

Finally, it should be noted that administrative regulations do not try to cover exhaustively all interpretative questions. Coverage depends on foreseeable or actual needs. Consequently, initial regulations must be supplemented with amendments and, in practice, almost every year amended versions of the Income Tax and Wage Tax Regulations are issued. ${ }^{18}$ The bulk of the provisions remain unchanged, but for identification purposes the particular year is added to the title, i.e., Income Tax Regulations for the Calendar Year 1963.

Administrative regulations are subdivided into paragraphs, unlike the laws and the regulatory ordinances which are subdivided into sections. The Income Tax Regulations contain 224 paragraphs covering 215 pages with approximately 300 words to each page. While procedural rules are of secondary importance in the case of the Income Tax Regulations, they are more important for the Wage Tax Regulations. Wage Tax Regulations spread 94 paragraphs across 120 pages, and the Corporation Income Tax Regulations include 69 paragraphs which run about 100 pages.

\subsection{Manner of processing regulations}

A division of the Federal Ministry of Finance, responsible for taxes on income, capital, and transactions, prepares all statutes, regulatory ordinances, and administrative regulations relating to the taxation of income.

Section heads within this division, ${ }^{19}$ assisted by senior officials and officials of the administrative class, ${ }^{20}$ handle the actual preparatory work. The section heads and senior officials are lawyers. Their prime guidance comes from the debates on the statute. Consequently the basic thrust is fixed by the time of enactment. But actual drafting takes place later, after all interested parties-i.e., the State Finance Ministries,

18 The regulations constitute definite instructions for local finance offices for the calendar year of issuance. Consequently, amendments are introduced only once a year.

19 See Chap. XIII, 1.2 supra.

20 See Chap. XIII, 1.5 supra, for a discussion of officials of the administrative class. 
other Federal Ministries, ${ }^{21}$ and private organizations (particularly the leading professional and industrial groups)-have expressed their opinions and made recommendations. Public hearings are not held though regulations are normally prepared after discussing matters with all interested groups-who may in fact have made the initial suggestion for the proposed regulation.

Typically a few months elapse between the enactment of the statute and the issuance of the regulatory ordinances. The administrative regulations, on the other hand, are published annually. 22

\section{Section C. The Rulings Program}

\subsection{Formal advance private written rulings to taxpayers}

The German tax administration is not required to supply taxpayers with rulings concerning the tax consequences of proposed transactions. There is only one exception: it is possible to obtain a ruling on whether and to what extent wage tax provisions must be applied. This exception is justified because the employer is liable for the proper deduction of this tax, even in the absence of fault. Information as to this liability may be obtained without formality, even over the telephone. While the administration is not legally bound by its answer, should it prove to be erroneous, in practice the administration legally stands by the position taken if the applicant relied thereon in good faith.

Though not legally bound to do so, the administration often does issue advance written rulings to accommodate taxpayers who plan to conclude important contracts or to commence largescale transactions. But this is a discretionary matter. No rules define the questions which will or will not be answered. And in exercising discretion as to whether or not a ruling should be issued, the administration is guided by the principle that a taxpayer deserves the protection of a ruling only in cases involving doubtful questions of law which impose an undue burden on a taxpayer unable by himself to clarify the problem. Further, rulings are never issued in two types of situations.

21 Most important of these ministries is the Ministry of Economics. Others likely to be invited, depending upon the nature of the questions involved, are the ministries of Labor, Transport, Food and Agriculture.

22 See 2.5 supra. 
Requests involving an issue of fact are rejected; this type of problem can be resolved only during a tax audit. Also rejected are requests for rulings with respect to transactions possibly inspired by tax avoidance possibilities.

Since no office is formally designated as a rulings office, requests may be addressed to, and rulings issued by, the local finance offices, Regional Finance Offices, State Finance Ministries, or the Federal Ministry of Finance. Each level may answer a request submitted to it. But Regional Finance Offices and State Finance Ministries will usually decide to refer the matter to the local finance office which is responsible for the applicant's assessment and hence familiar with his circumstances. In consequence, the local finance offices issue the bulk of all income tax rulings. This means that most rulings are prepared by officials who did not participate in any of the preparatory work on the statute, the regulatory ordinances, or the administrative regulations. However, if the question is of fundamental importance or involves large sums, the final ruling will usually come from the Regional Finance Office or the State Finance Ministry. The Federal Ministry of Finance avoids becoming involved in ruling on specific cases, and tends to rule only on abstract questions usually involving matters of fairly wide significance. Should a State Finance Ministry receive a question of this caliber, it forwards it to the federal level, ${ }^{23}$ because the officials there have participated in the preliminary work on the statutes, regulatory ordinances, and administrative regulations.

In theory, an advance ruling is only an expert opinion of the tax authorities. In preparing them, the officials strive to formulate and adhere to the line of reasoning which would be valid for the final decision on an assessment.

In the abstract, an expert opinion does not legally bind the tax administration. However, when a taxpayer obtains a ruling on a particular set of facts, the ruling is treated as a decision taken in anticipation of a subsequent assessment upon which the taxpayer may rely. In other words, even if the administration later concludes, on balance, that a different legal conclusion should have been drawn, it will adhere to the position taken in its ruling, regarding it as the equivalent of a promise. This is based on the well-established principle of fair dealing, originally developed under that part of the civil law which governs

$23 \mathrm{This}$ is in consequence of the constitutional status of the federal states. See Chap. XIII, 1.1, 1.2 supra. 
taxpayer-government relations. However, if the ruling was clearly erroneous, the principle of fair dealing is not deemed to override the competing principle, that no tax claim can be subjected to arbitrary manipulation. Thus the administration does not consider itself bound by clearly erroneous rulings it had no power to issue.

The absence of legal provisions covering the status of rulings is causing increased dissatisfaction. Disputes between tax authorities and taxpayers arise continuously over the degree of reliance a taxpayer is entitled to place upon a ruling in a given case. There is a widespread belief that a matter of such great importance should be governed by statute, and the Federal Government is planning to amend the Fiscal Code by adding provisions to permit local finance offices to issue binding advance rulings. The ruling will provide the basis of subsequent assessment provided there has been no change in the facts as presented. To secure such a ruling, the taxpayer will have to file a written application, describe the contemplated transaction, and analyze the tax question. Oral conferences with the issuing officials would be permitted, but in these the taxpayer may not alter the facts as originally presented. Nor need the local finance office audit the facts, though in suitable cases it may invite the applicant to supplement his presentation of the facts. In any event, the ruling would be binding only if all relevant facts were exposed and the transaction is carried out as presented.

The ruling itself will include an analytical explanation. The taxpayer will be informed also that the ruling may be appealed to the appropriate fiscal court, from whence appeal lies to the Federal Fiscal Court.

It is not contemplated that the procedure under the proposed statute would supersede the present practice. Moreover, there is no plan to limit the areas in which binding rulings would be issued. Because of the continuance of the present practice and because it is proposed to charge for a ruling with the added requirement that the request analyze the tax questions presented, a flood of requests is not anticipated.

At present, since most rulings are issued at the local level, statistics are not available showing the number requested.

\subsection{Informal technical advice to taxpayers on proposed trans- actions}

Authorities at all echelons typically are willing to discuss informally any problem with a taxpayer. The importance of 
the question determines the level at which the discussions will take place, however. If the case is relatively unimportant, higher-echelon authorities will refer the taxpayer to his local finance office. Taxpayers, however, try to get their advice from the higher echelons because of their fear that the local office's view may not accord with that of the Regional Finance Office and State Finance Ministry whose hierarchical status entitles them to send instructions to the local offices. Moreover, local offices tend to be far more reluctant to render definitive, albeit oral informal opinions, than the higher-echelon authorities with more extensive powers.

\subsection{Technical advice to field offices}

The local finance offices have full autonomy to render decisions on their own responsibility. They receive, however, binding administrative instructions from the competent Regional Finance Office, ${ }^{24}$ which usually acts under directions given by the State Finance Ministry, not on its own initiative.

State Finance Ministries are the highest level entitled to give instructions to the local finance office. To insure uniformity through the Federal Republic, heads of divisions (i.e., income tax, wage tax, corporation income tax) of the several State Finance Ministries frequently meet in the Federal Ministry of Finance to discuss interpretative questions under the chairmanship of one of that Ministry's competent top officials. Conclusions reached at such discussions are set out in minutes which are not published, but are used by the State Finance Ministries as the basis for instructions issued to the lower level authorities on interpretative problems.

The more important instructions, however, are published as general rulings, Evlasse, in the Federal Tax Gazette, Bundessteuerblatt, the official publication of the Federal Ministry of Finance which is available to the public. While published in this manner, the instructions are not actually issued by the Federal Ministry. Rather each State Finance Ministry has exclusive power to issue its own instructions in its jurisdictional area. However, publication is usually discussed and decided upon in the meetings held under federal auspices and the texts of each state's instructions ordinarily are drafted by the federal officials and are more or less identical. Consequently

24 For practical reasons, the more important instructions are arranged in card files which are supplemented regularly and kept up to date. Thus officials of local finance offices can draw on a convenient collection of important instructions to guide them in their work. 
these general rules are termed Coordinated Laender Rulings, and appear as such in the Federal Tax Gazette.

It not infrequently happens that when the annual volume of administrative regulations is issued, an important interpretative question has not been clarified sufficiently. Rather than wait until the next annual set of regulations is published, a Coordinated Laender Ruling can be issued in the interim.

While senior officials at the local finance office normally have ultimate responsibility for any decision, upon encountering a complicated question of tax law, it is under instructions to refer the question to the Regional Finance Office which then assumes responsibility for the decision. The referral is accomplished by submission of a detailed statement of the facts and a legal analysis of the issues involved. The Regional Office either will decide the question itself or, if it is a matter of prime importance, refer it to the State Finance Ministry. Should the State Finance Ministry consider the issue to be of interest to the tax administrations of all the states or one which should be the subject of future legislation, it will forward the question to the Federal Ministry of Finance.

Since the typical case referred to the Regional Finance Office presents a difficult question of law which the local office has explored extensively with the taxpayer, the taxpayer customarily is informed that the matter has been sent to a higher-level authority. The taxpayer then is free to contact and discuss his problem with the appropriate higher office, whether it be the Regional Office, the State Finance Ministry, or the Federal Ministry of Finance.

No information is available as to the number of cases sent to the Regional Office by the local offices. In general, local offices usually try to solve their own problems and secure higher level decisions only in exceptional cases.

\subsection{Publication of technical advice given taxpayers and local offices}

The Federal Tax Gazette publishes as rulings the instructions State Finance Ministries send to all local finance offices, instructions which normally stem out of concrete cases decided by the same Ministries. When an instruction is derived from a concrete case, the taxpayer's name is omitted and the solution shaped in terms of general application. Such an instruction sets out only one or two specific points decided, together with a rough indication of the legal issues involved. 
The State Finance Ministries and the Federal Ministry of Finance also issue information circulars, the more significant of which are published in the Federal Tax Gazette.

Other information is made available to the public in various ways. For example, the tax administration annually publishes standard profit margins for the most important types of trade and commerce, as well as tables of normally recognized depreciation rates. Less sophisticated information on topical tax matters is provided through press conferences and newspaper articles. Television and radio also are used. Whatever the method of publication employed, effort is made to provide not only the decision or conclusion but also the underlying rationale. 


\section{CHAPTER XV}

\section{ASSESSMENT, REFUND, AND ADMINISTRATIVE APPEAL PROCEDURES}

\section{Section A. Assessment and Audit Procedures}

\subsection{Introductory note}

The assessment procedure begins with the filing of the tax return by the taxpayer, and concludes when the local office issues the formal notice of assessment which establishes the tax due. In computing the amount, credit is given for the quarterly installment payments made by taxpayers during the assessment year. In addition to stating the tax due, the assessment notice sets out the factors making up the tax base, such as profits from business, income from other sources, personal deductions, etc. The notice states where, when, and how the tax is to be paid. Further, it specifies the points where the assessment differs from the information return filed by the taxpayer.

Since the tax depends upon the tax base, a taxpayer cannot challenge one and not the other. ${ }^{1}$ Should a taxpayer dispute the assessed tax, he must protest the assessment notice as a whole.

1 There is one exception to the general rule, i.e., that the assessment notice constitutes the final determination of the tax on income and that any challenge to either the tax base or the amount of tax must be made to the entire assessment notice. This exception arises when two or more persons jointly, most usually in the setting of a partnership or jointly owned property, carry on a business or are engaged in any other income-producing activity. It is unlikely that such individuals will have identical income from other sources or identical personal deductions. Moreover, their shares of the jointly derived income may differ. Under such circumstances, a preliminary notice dealing with such jointly derived income is sent to each of the participants, setting out the amount of tax each one owes on this particular income. As the law requires, such tax base and such amount are established "separately and uniformly." This notice may be contested separately by each taxpayer. It must be contested if the taxpayer does not want the amounts set out in the notice to be incorporated into the subsequent assessment notice determining his total income tax base and total tax liability. Moreover, if not contested on the basis of the preliminary notice, it may not be contested when the final assessment notice is received. 
If a taxpayer does disagree with the assessment, he must make known his disagreement within a month. Failure to act within that month renders the assessment incontestable unless the taxpayer qualifies for a so-called correcting assessment because new facts or new evidence is discovered. ${ }^{2}$ Generally, even this type of correction is not possible after the period of limitations (normally five years) has elapsed. Prior to the expiration of the five-year period, if the Regional Office should discover on examination-which in practice may be stimulated by a request from the taxpayer himself-that the taxpayer received a higher assessment than was justified, the error will be corrected. However, if upon such an examination an error is discovered showing the taxpayer should have received a higher assessment, no correction can be made.

The same assessment procedure is used for individuals and juridical persons, such as corporations. ${ }^{3}$ However, where wages are withheld at the source, a simplified procedure is used. 4

Tax assessments are signed by the head of the appropriate branch at the local office, but the tax assessors within that office do all the assessment work. Since the head is kept fully informed, the final signature represents not mere acquiescence but participating responsibility.

To insure maximum uniformity in assessment and audit procedures, within a local district and through the several units

${ }^{2}$ Certain safeguards have been thrown up around the use of the correcting assessment device. Absent the discovery of new facts or new evidence, a correcting assessment exceeding the original one is unenforceable unless accepted by the taxpayer-most unlikely circumstance. Moreover, the local office cannot claim facts or evidence were newly discovered if they were in its own files but their relevance went unrecognized. Should new facts or evidence in favor of the government develop, the local office may reconsider the entire assessment but the tax may not be decreased below the original amount. Comparably, a decreased assessment is possible if new facts or evidence in favor of the taxpayer are discovered in the course of an audit or if mistakes are discovered in the course of a review by the local office's supervising authority. Thus, where an audit reveals facts or evidence, partly in favor of the taxpayer and partly in favor of the government-the situation which in point of fact is the most usual one-the legal aspects of the entire assessment are reconsidered, with the result that there is a redetermination of the tax base and the amount of the tax, irrespective of the previous assessment. However, should the matter have been appealed, decisions rendered in the course of such appeal procedures must be reckoned with.

3 See 3.2 a infra.

${ }^{4}$ See $3.2 b$ infra. 
of government, there is continuing supervision at several levels. Over and above the assessing officials is the head of the local office. In cases of particular complexity, he handles the assessment personally, thus insuring maximum uniformity within his jurisdiction. The entire assessment procedure is supervised by the head of the office, who himself participates in the discussion of complex questions with the taxpayer, and both instructs and coordinates the work of his subordinates. The Regional Finance Office, in the course of its supervision of local office activity, examines individual cases. State and Federal audit authorities, technically separate but actually working together with a high degree of cooperation, review the work of local offices.

\section{2a Details of assessment and audit procedures: In general}

The formal assessment procedure, sketched in the preceding paragraphs, makes no provision for taxpayer self-assessment. ${ }^{5}$ The taxpayer merely files an information return. The local office determines whether the taxpayer is liable for tax and, if liable, the amount of tax due. In making such a determination, assessing authorities investigate all relevant factual and legal aspects, taking account of all factors whether favorable to the government or to the taxpayer.

Return forms are sent by local offices to known taxpayers, and others are reminded through public notices of their obligation to file. ${ }^{6}$ Failure to file a return renders a taxpayer liable to a fine up to a maximum of $\mathrm{DM} \mathrm{5,000.}{ }^{7}$ Also, in the event

5 Consideration has been given to the introduction of self-assessment procedures in the Federal Republic of Germany. On an experimental basis, certain localities temporarily introduced the system. Reactions varied. Tax consultants, on the whole, were unenthusiastic. Local tax administration offices reported favorable comments, if only for the reason that self-assessment released qualified staff members from assessment work to auditing. However, there were more unfavorable than favorable comments. The complexity of the tax law argued against computation by taxpayers of their own tax liabilities. Moreover, it was pointed out that with the introduction of automatic data processing, self-assessment would be obsolete. If electronic computers could compute the majority of the liabilities for all taxpayers, there was no need for taxpayers to compute their own taxes.

6 The Ordinance Regulating the Income Tax Law lists all cases where income tax liability appears likely, and adds a requirement that returns be filed by all such individuals. This list, however, is not of major practical significance, as every individual requested to file a tax return by the tax administration must do so.

7 Theoretically, failure to file is subject also to a prison term. 
of a definite refusal to file, the appropriate local office is authorized to make an assessment based on an estimate.

The official form which a taxpayer must use, if properly completed, should contain sufficient information to enable the local office to determine the correct tax liability. ${ }^{8}$ That office is free, however, to seek additional data and, if it proposes to rely thereon, the taxpayer must be informed and given opportunity to present his arguments.

Where a taxpayer derives profit from a business or income from rental properties, a supplementary return is required, listing receipts, expenditures, deductions for depreciation, etc. ${ }^{9}$ Also a balance sheet, ${ }^{10}$ prepared from business records, must accompany the return where-as in the case of business, agricultural or forestry pursuits, or service enterprises-net worth comparisons are used to determine income. Where a commercial balance-sheet is submitted by the taxpayer, the figures shown on it, though acceptable from an accounting point of view and correct from the standpoint of commercial law, do not always conform to tax law requirements. Additional data and annotations must be supplied to adapt these figures for tax purposes. Alternatively-and in practice, customarilythe taxpayer may submit a separate balance sheet prepared in accordance with tax law requirements. In any event, if the records are based on double entry bookkeeping, a profit and loss account must accompany the balance sheet. Finally, if deemed necessary, the local office may require the taxpayer to submit a principal account statement, Hauptabschlu Bïbersicht-i.e., a horizontal breakdown of all accounts. ${ }^{11}$ In theory, any available business reports, including reports prepared by certified public accountants, must accompany the return though, in practice, only larger firms, particularly corporations, comply with the requirement-not waiting for a special request from the office.

8 Where the taxpayer submits only estimates, necessary supporting information must be supplied.

9 Taxpayers themselves often add clarifying data relative to certain balance sheet items: for example, depreciation tables for individual assets, detailed breakdown of transitory balance sheet items, lists of new receivables and net payables, calculations concerning the revaluation of assets and reserves, and explanatory notes.

${ }^{10}$ This balance sheet may not be abbreviated, that is, the individual items must be shown separately and may not be grouped together or set off against each other.

11 It shows for each account the initial balances, accruals, and withdrawals, as well as the effect of each account on the profit and loss account. 
Where a taxpayer used a licensed professional tax consultant to prepare the return or the attached information, the return must state the consultant's name and address. While the local office generally can rely on the accuracy of the figures reflected in such a return, and can assume the return conforms to clearly established legal principles, it also recognizes that sophisticated advisors will have resolved in favor of the client any interpretative tax questions the answer to which may not be wholly clear. Hence, returns prepared with professional assistance are examined as thoroughly and carefully as any other returns and inquiries are made whenever considered necessary.

In examining a filed return, ${ }^{12}$ a local office makes use not only of the required supplementary data but also of the permanent file it keeps on each taxpayer. These files are extremely important, for they contain his prior years' returns, ${ }^{13}$ the results of earlier audits, and the so-called cross-check memoranda, Kontrollmitteilunger. Some cross-check memoranda are obtained, on request, directly from firms which make extensive fee payments to other taxpayers, e.g., from broadcasting companies. The bulk of such memoranda, however, come from the government's own tax audit of enterprises which transacted business with such other taxpayer. Illustratively, the books of a business may show intermittent payments to a payee who could indulge in tax avoidance through failure to report. An auditor, on noting such intermittent payments, prepares cross-check memoranda to place in the files of the taxpayer-payees, thereby enabling the latters' local offices, as a matter of routine, to check to be sure such payments were included in income.

Should questions arise concerning the accuracy of statements made in the return, the local office, in seeking additional information from the taxpayer, ${ }^{14}$ usually requests an oral

12 Very rarely, the local office decides before the return is filed to take emergency measures designed to insure proper collection of the tax, i.e., it may order that the inventories be checked during the first few weeks of each year.

13 Thus the assessing official has before him the full tax history of this particular taxpayer.

14 Circumstances creating such requests for additional data can include situations where the basis for valuation of balance sheet items is not clear or where the profit rate varies from the typical rate for the particular trade or business. Such differences are apparent to the assessor upon referring to the tables of standard profit rates published 
conference rather than a written explanatory statement. The former is preferred, experience having shown that written replies are often so vague and incomplete as to be almost useless, and the oral conference enables tax officials to gain an understanding of the actual facts as well as some impression of the taxpayer's reliability.

However, the local office may not request information or records other than those the taxpayer can reasonably be expected to furnish. Further, where it is necessary to look into extensive business records and documents, this normally will be accomplished on the taxpayer's premises unless he himself desires otherwise.

Since the taxpayer must declare in his return that the information therein is correct and complete to the best of his knowledge and belief, assessing officials commence their own work on the assumption that the return itself and accompanying documents are correct. Though the assessment process itself involves at least some examination of the taxpayer's return, accompanying documents, and permanent file, and oral discussions with the taxpayer if necessary, the assessing official is confronted with the necessity of completing his share of the total assessments of a district within a given time. Hence, other than in exceptional cases, the assessing official himself does not have time to examine the books and accounts of those taxpayers who submitted what appeared to be proper returns and adequate supplementary statements. Nor in such cases would he request third persons to supply information. In consequence of these practices, however, much of the assessment work in the local office is supplemented by later audits, i.e., extensive examinations of books and records, conducted on the taxpayer's business premises, by other tax officials. Where such a later tax audit is customary because of the size of the business or where the assessing official deems such an audit to be necessary, ${ }^{15}$ the assessor-if certain questions remain open-will make a provisional assessment, postponing final decision until completion of the audit. Modification of such provisional assessments is not subject to the restrictions applicable to final assessments.

\section{(footnote continued)}

annually for a number of trades and occupations. These tables indicate the typical mark-up and the rates of gross and net profits computed on the basis of turnover.

15 In rare instances, he alternatively may ask the so-called tax committee, discussed in 3.3 infra, to handle the matter, rather than the regular audit officials. 
The larger local offices maintain special audit sections which audit both the large industrial enterprises in their districts and comparable enterprises situated in nearby districts if the local office there does not have similar specialized personnel. Other specialists in these same larger local offices audit agriculture and forestry operations.

Medium and small enterprises ${ }^{16}$ are audited by the regular audit section, Betriebsprufung, in the typical local office, and this staff audits similar enterprises in districts where the local office does not maintain an audit section. Such an audit section, subordinate to the head of the local office, is staffed with men of a rank equivalent to those performing assessment functions, the personnel of both sections being interchangeable. ${ }^{17}$

As a general matter, audits cover only taxpayers who by law are required to keep books and records (though such audits may extend to such taxpayer's employees-wage and salary earners-past or present, particularly if there is some question concerning proper withholding of the wage tax). ${ }^{18}$ In practice, this means that the audits are restricted to industrial or commercial enterprises, independent professional offices, and the larger agricultural and forestry establishments. In all other cases, examination of returns is considered completed after the investigation by the assessing official and his superior, the head of the branch who signs all assessments which exceed DM 500 .

Every large enterprise according to the law should be audited at three-year intervals. In practice, however, because of the shortage of personnel, these audits actually are conducted at about four-year intervals, but the fact that each such audit commences where the prior one ended, means that all transactions of each large enterprise are subjected to audit on a continuing basis. By way of contrast, audits of medium and s mall firms usually cover only the preceding three years, and are made only after considerably longer intervals, the law not

16 Classification of enterprises as "small," "medium-sized," and "large" is governed by specific criteria. Any business which falls short of the standards required of a "small" business is classed as a "very small" business.

17 Under an experimental program, designed to increase the scope of audit coverage, assessors in some districts not only made the assessment, but also audited small enterprises. The results were generally unsatisfactory, primarily because of the heavy burden of the assessment work itself.

18 In addition, the wage tax staff of the local office conducts wage tax field audits. 
specifying any particular period. Medium-sized firms, again taking the actual practice, are audited about every six and a half years and small firms about every seventeen years. Consequently, at least 50 percent of the returns filed by mediumsized businesses and at least 80 percent of those filed by small businesses are not audited. Note the following data for 1962:

$\begin{array}{lrcc}\text { Type of enterprise } & \begin{array}{c}\text { Total } \\ \text { number }\end{array} & \begin{array}{c}\text { Number } \\ \text { audited }\end{array} & \begin{array}{c}\text { Number audited as } a \\ \text { percent of total }\end{array} \\ \text { Large Enterprises } & 48,441 & 11,911 & 24.59 \% \\ \text { Medium-Sized } & & & \\ \quad \text { Enterprises } & 314,360 & 51,166 & 16.28 \% \\ \text { Small Enterprises } & 737,576 & 42,814 & 5.81 \%\end{array}$

Though tax audits normally follow a regular schedule, audits also are made out of turn, especially when the period of limitations is about to expire, though even here account will be taken of the probable amount of tax involved. Sometimes they take place where the assessor, on examining a particular return, questions a taxpayer's statements, with verification requiring thorough examinations of the books and records and, perhaps, inspection of the business premises.

The auditor's functions are strictly limited. He only investigates the taxpayer's books and records. It is the assessor who draws the final conclusions from such an investigation, by deciding all questions of law and fact in order to determine the proper tax liability. The very nature of the task-i.e., deciding whether or not certain facts are to be regarded as having been proved sufficiently or deciding between competing legal arguments as applied to a given set of facts-clearly makes it imperative that the assessor exercise his own judgment in fulfilling his responsibilities. Since the assessor has the ultimate responsibility for the assessment, he usually is present at the final discussion which concludes the audit, where the taxpayer (and, perhaps, his consultant) confers with the auditing official and his superior. If the case is an important one, the assessor is accompanied by his superior or even by the head of the local office. If a particularly difficult question is involved, the audit officials from the Regional Finance Office may participate.

This meeting is designed to explain to the taxpayer the result of the audit, not to work out a compromise. The assessor has absolutely no power to settle in the sense of splitting or trading of issues; the judgment of the assessor includes only the power to determine what is or is not taxable. It does not include the power to compromise. The assessor, however, 
may see fit to state his views during the meeting so that the taxpayer will know what changes the local office will make in his assessment (a correcting assessment) and the rationale in support of the change.

\section{2b Details of assessment and audit procedures where taxes withheld at source}

While taxes on several types of income are withheld at the source, wage and salary earners constitute the largest single group of individuals subject to such withholding. ${ }^{19}$ Their tax payments are deducted by their employers on the basis of wage tax cards issued by the municipal authorities. The cards carry all relevant personal data needed to compute the withholding tax, being amended where circumstances change. ${ }^{20}$ Each employer must forward the proper amount to the local office at proper intervals. ${ }^{21}$ While the wage or salary earner is the actual taxpayer, he can be held liable only if proper deductions were not made or if he is aware of his employer's failure to forward the correct amounts to the appropriate office.

Should the tax withheld exceed the amount due, 22 the excess is refunded to the wage or salary earner under a special

19 Other types of income subject to withholding include dividends and directors' fees. Also withholding is applied to royalties and interest paid nonresidents, the amount withheld being the final tax thereby rendering a formal assessment unnecessary. The same is true of wages earned and, by a recent amendment, interest received by a nonresident. Earnings of foreign entities or of noncitizens, are subject to unlimited tax liability if they are residents of Germany, and tax is withheld on their earnings. If the earnings are attributable to a permanent establishment situated in the Federal Republic, a tormal assessment will take account of the amounts withheld.

20 Where an individual expects his deductible expenses to exceed the standard deduction, he may apply for an amendment of his wage tax card reflecting the additional expenses. Should the circumstances causing these additional expenses change, the taxpayer must have the entries amended. Should he neglect to do this, any resulting underpayment subsequently discovered is claimed by way of a special notice. This notice, however, has no relationship to the assessment notice issued after a regular assessment.

21 To insure proper computation and retention, wage tax audits in the field are carried out at regular intervals. Under the withholding procedure the tax is computed and retained in respect to the actual pay period-month, week, day-with special wage tax tables having been drawn up on the basis of the income tax table.

22 This can occur for a number of reasons. For example, the wage or salary earner may become entitled to higher allowances in the course of the year because of changes in his family status. His wage or salary may not be constant for all pay periods throughout the year. 
wage tax adjustment procedure, Lohnsteuer-Jahresausgleich. If the wage tax cards supply all necessary information, the local office then credits the employers. Millions of refunds are handled in this way.

Where wage tax cards do not supply all the necessary data, wage and salary earners entitled to refunds must make applications for such to the appropriate local office. In 1963, of the 23.8 million wage earners subjected to this withholding tax, 10 million or 42 percent obtained some refund from their local offices on the basis of such applications.

The fact that tax is withheld from an individual's wage does not always neutralize the need to make a formal assessment. Sometimes this is required simply because the salary exceeds a certain amount, or because the taxpayer had more than a de minimus amount of income from other sources. Under other circumstances, taxpayers themselves may request assessment, e.g., where they have suffered net losses from other sources of income. Should assessment be made under either type of circumstance, the amount withheld is credited against the amount declared due in the formal assessment notice. In 1961, out of the 3.277 million persons assessed for income tax, 43 percent were wage or salary earners, having been subject to withholding at the source by their employers.

\section{Section B. Administrative Appeals}

\subsection{Introductory note}

German tax law provides two distinct types of administrative appeal for all income taxpayers, whether individual or corporate. The protest, Einspruch, is used for substantive issues, the complaint, Beschwerde, for discretionary matters which in practice raise procedural issues. The taxpayer does not choose between the remedies; the type of issue determines the appeal to be employed.

Once a taxpayer has exhausted the protest unsuccessfully at the local office level, he must turn to the courts for relief. Where he must utilize the complaint, however, should the local office deny relief, the taxpayer may have the whole matter referred to the Regional Finance Office for a decision. Should he be dissatisfied with that office's decision, he then must proceed through the courts. 


\section{4 a Protest}

The prime use of the protest is to challenge an assessment, that is, to question whether tax liability exists at all or to raise specific questions involving the tax base or the amount of the tax. Its timely use prevents an assessment notice from becoming final or, where there is jointly earned income as in the case of a partnership, prevents the preliminary determination notice from being incorporated in an unchallengeable assessment notice.

Wage tax questions also may be raised through the protest. For example, a taxpayer may conclude he is entitled to a refund exceeding that fixed by the local office, believing that office erred in refusing to enter certain deductible amounts on his wage tax card. Or he may feel that office was wrong in contending that a deduction was entered incorrectly on the wage tax card and consequently was wrong in asserting a tax deficiency.

Every effort has been made to simplify administrative procedures, keeping them as flexible and uncomplicated as possible, with formalities at a minimum. The one undeviating requirement is that the protest be filed within one month, but the filing may be effected in a variety of ways. Though it may not be telephoned, it may be written, in the form of a telegram, or lodged orally with a local office official.

The law requires only that the protest state that the taxpayer disagrees with the local office's assessment. As a practical matter, however, the taxpayer should state the facts and supporting evidence he proposes to use; otherwise the local office will not know the basis for his objection. In preparing this protest, the taxpayer may use a consultant, who may have assisted him earlier in the preparation of his return. However, very frequently a tax consultant is called in only after the taxpayer has decided to file a protest.

Once filed, the protests are handled at the local office. Prior to January 1, 1966, taxpayers could choose to have the protest laid before the tax committee, attached to the local finance office. ${ }^{23}$ However, only one percent utilized this

\section{(footnote continued)}

The taxpayer's deductible expenses in excess of his standard deduction may not have been fully entered on his wage tax card.

23 One or more of these tax committees is attached to each local office, with the head of the local office or his authorized agent acting as chairman. Otherwise, the membership consists of private citizens. Each of the communities located in the district of the finance office 
procedure, and this limited use caused the procedure itself to be abolished. ${ }^{24}$

While in some local offices it has been felt convenient to establish special staffs to handle administrative appeals, the great majority of protests are handled by the same officials who prepared the original assessments, with a detailed review by the same superior who bears the ultimate responsibility. It is true that this superior approved the original assessment, but his scrutiny of the assessor's report on the protest goes far beyond his somewhat routine check of the normal assessment work.

The obvious question is how the taxpayer can hope to benefit from a protest if the decision on that protest and the review are made by the same officials who reached the original

(footnote continued)

is represented by one member nominated for a six-year term by the elected governing body of his community. These members participate in deliberations and decisions of the committee with reference to taxpayers who have their residence or their business in the particular community. In addition, the committee comprises two to four members who must be familiar with the specific conditions of the region and experienced in business matters. They, too, are nominated for a term of six years by the elected body of the self-governing political subdivision representative of the communities located in the district of the local office concerned. The head of the local office also is entitled to name suitable persons after considering candidates proposed by industrial, commercial, professional, or vocational associations, trade unions, farmers' unions, and the like.

The composition of the tax committee was one of the prime deterrents to its use for the protest. Most taxpayers were reluctant to let the tax committee know the details of their personal and financial transactions because of the nonofficial character of its members.

To constitute, for the purpose of the protest, a quorum of the tax committee, at least two members in addition to the chairman must have been present. Decisions were taken by majority vote, with the chairman entitled to vote. In the event of a tie, he cast the deciding vote. Decisions were not subject to instructions by the local office, but higher authorities-i.e., the Regional Finance Office and the State Finance Ministry-were entitled to be informed of cases before the tax committee and to be heard in an advisory capacity. A taxpayer dissatisfied with the committee's decision could then appeal to the courts.

In arriving at its conclusions, the tax committee had the same authority and was subject to the same limitations as the local finance office dealing with a protest.

24 Although the tax committee has lost the power to decide on a protest, it remains in existence because of the remaining function-to give advice in some rare instances of minor importance where the local office should take advantage of the members' practical experience. 
decision now being protested. The explanation lies in part in the fact that the taxpayer knows that pressures of time and shortages of personnel may have caused assessments to be prepared on the basis of a relatively routine examination. Moreover, the original assessment notice gave only the briefest explanation of the local office's refusal to accept the taxpayer's statements. By protesting the conclusions of this notice, the taxpayer, when the matter comes up for discussion, can give the local office a detailed explanation of the facts, set out the supporting evidence, and explore legal considerations. Both parties are fully aware of how the original assessment is handled and the device of the protest provides an opportunity for a full discussion of every possible relevant matter. Further, when the local office renders its decision on the protest, it evaluates all the taxpayer's objections, whether relating to law or to fact. Thus the taxpayer obtains a very detailed explanation of the considerations which led the local office to reach its conclusions. Should he decide to contest the decision further-which only occurs in about four percent of the cases protested, he can anticipate the arguments which the government will advance in court.

Once the protest has been filed, the local office has full jurisdiction, irrespective of whether the taxpayer has raised 'a question of law, a question of fact, or a mixed question of law and fact. It is not required to clear its decision with the Regional Finance Office. Merely because the taxpayer protests one part of the assessment notice does not restrict the local office to a consideration of that point alone. The local office may raise other issues not previously considered, or revise its own former conclusions-giving the taxpayer more relief than he requested or, contrariwise, asserting a higher tax than that reflected in the original assessment.

The finance office is required to decide the case in conformity with the law. It is not authorized to render a decision which would depart from what it thinks is appropriate both from the factual and the legal points of view, merely because it is in doubt as to the outcome of litigation. Thus, as to the type of issue which a court necessarily would decide entirely for one side or the other, the local office may not split the issue on the basis of mutual concessions responsive to the litigation hazards. Furthermore, it must render its decision in conformity with its own convictions even if it fears that the courts may hold different views on the subject matter, thus unfavorably prejudicing later cases where the facts are perhaps 
more in the government's favor. But in practice there are many questions of fact which by their nature cannot be precisely answered, or where complete substantiation is unavailable, leaving room for the assessor to reach a decision which he believes most closely approximates the actual facts of the case and which at the same time will secure the consent of the taxpayer who himself recognizes that he is unable to give a more precise or more complete substantiation.

The annual number of all protests filed in the local offices of the Federal Republic total between 450,000 and 500,000 and about 40 percent of this total relate to individual and corporate tax matters, ${ }^{25}$ though the way in which the 40 percent breaks down as between those two types of taxpayers is not known.

\section{4b Complaint}

Taxpayers must utilize another remedy, the complaint as distinct from the protest, when the matter challenged involves procedural rather than substantive questions.

Typical of the situations giving rise to the filing of a complaint is the case where a local office imposed a penalty (which may be as high as ten percent of the tax) on the ground the tax return was not filed within the prescribed period, and the taxpayer argues the delay was excusable. Again, the complaint would be used to contest a penalty imposed for late payment of the tax (one percent for every month or fraction thereof); or where a taxpayer and the local office disagree as to the sufficiency of the installment payments an individual or corporation makes - the taxpayer's income estimate for the current year being somewhat less than the amount of income he received from such sources during the preceding year.

Like the protest, a complaint must be filed with the appropriate office within a one-month period. The absence of formality with regard to the method of filing, the uncomplicated and loose standards bearing on statements supporting the complaint, the freedom to use tax consultants, which characterize the use of the protest, also characterize the use of the complaint. Also, upon the filing of complaint, it again is the local office which sits as the reviewing agency. However, contrary to the situation regarding protests, the issues covered by the complaint procedure allow a certain discretion, for example, as to the matter of penalties-the area where the most important

25 The remaining $60 \%$ relate to such other taxes as the capital tax, trade tax, turnover tax, inheritance tax, real estate tax, etc. 
complaints originate. Should the local office deny the complaint, another distinctive feature is that the whole case-with the local office's comments thereon-is sent up to the Regional Finance Office for a decision. Should the Regional Finance Office deny the complaint in whole or in part, its formal decision may be appealed by the taxpayer to the Fiscal Court. The number of complaints filed annually, relating to income taxes, is not known.

\section{Section C. Extent Administrative Processing of Refund Claims Departs from Administrative Processing of Assessments}

\subsection{Introductory note}

In the United States, a taxpayer himself may initiate a reevaluation of a finally assessed tax of an earlier year, provided only he files a claim for refund within a three-year period. No such procedure exists in Germany. German income tax law is based exclusively on the assessment procedure. The amount of tax payable is formally stated in an assessment notice, after having been computed on the basis of the local finance office's investigations which took account of evidence and arguments both favorable and unfavorable to the taxpayer. Normally, once the assessment notice has become final (within one month, absent an administrative appeal), the tax is definitively fixed even if an actual error was committed. Only in three instances does Germany have a procedure which bears any resemblance to the much more sweeping refund procedures available in the United States. These are described below.

\subsection{Details regarding refund procedures}

The first exception to the rule that, once an assessment notice becomes final, corrections cannot be made, relates to mere mechanical errors. For example, errors attributable to typographical or arithmetical mistakes must be corrected by the authorities automatically upon detection. However, the government is subject to the five-year statute of limitations even if the arithmetical error is to the government's detriment.

Second, an assessment notice which has become final can be modified by a so-called correcting assessment. But this means only that a change favoring the taxpayer is made if a tax audit (initiated by the government) reveals new facts or evidence in that taxpayer's favor. ${ }^{26}$ Most audits are conducted

26 See note 2 supra. 
in accordance with the overall audit program of the tax administration or the local office. Occasionally, a taxpayer himself will request that an audit be made-a request which the tax administration or local office may or may not honor-but this does not mean that the taxpayer himself can initiate a reevaluation of the case by filing a refund claim.

The third situation involves the procedure, discussed in $3.2 \mathrm{~b}$ supra, relating to refunds owed wage and salary earners who have been subjected to withholding at the source. For example, a given taxpayer may not have requested that the deductions shown on his wage card be adjusted in accordance with the facts or he may have made such a request and the request been erroneously denied. Under either set of circumstances, at the end of the year, under this procedure, the taxpayer may file a claim requesting a refund. The local tax office is in no way bound by its earlier decision, which in fact only established the probable pattern of deductions and which both parties recognized was subject to subsequent change. Should the wage or salary earner be entitled to a refund, he receives one. Thus, in one sense, the annual wage tax refund permits a second independent review of decisions reached earlier-albeit by the same local office-with the possibility of a change in its conclusion.

Since the annual wage tax refund procedure involves only tax refunds and not collection of unpaid taxes, it might appear to resemble the sweeping refund procedure followed in the United States. However there is only a superficial similarity. The wage tax refund procedure is actually deemed to be just a part of a simplified method of collecting taxes from a restricted group-wage and salary earners. Whereas the standard assessment process results in the taxpayer's being informed of the amount he owes, this wage tax refund procedure simply informs him that he paid, through withholding, more than what is finally due. And, as pointed out earlier, once a taxpayer receives the assessment, he has only one month to request administrative reconsideration. Should he fail to file either a timely protest or a complaint either as an end in itself or as a prelude to court action, the amount of the tax-absent later correcting assessment-is considered fixed. No administrative appeal is possible simply by filing a claim for refund.

Finally, should a taxpayer secure a readjustment of his tax liability through timely invocation of the administrative or judicial process, no formal application for a refund is necessary; repayment of any sum owing is automatic. 


\section{CHAPTER XVI}

\section{RESOLUTION OF INTERPRETATIVE INCOME TAX QUESTIONS BY INDEPENDENT TRIBUNALS}

\subsection{Introduction}

Jurisdiction over tax cases is conferred only on special courts designed for that sole purpose: ${ }^{1}$ Fiscal Courts Finanzgerichte of the several states, Laenders, which deal with both questions of fact and law, and the Federal Fiscal Court, Bundesfinanznof, which deals only with questions of law.

An act of October 6, 1965, effective January 1, 1966, made substantial changes in the procedures employed in the Fiscal Courts, changes so dramatic that they have been said to institute a new era in tax litigation. The statute provided that every taxpayer may have any decision of the tax administration-including the ministries-reviewed by an independent tribunal. ${ }^{2}$ Judicial procedures in tax cases also were conformed to those utilized in other types of litigation. ${ }^{3}$ Further to emphasize the judicial character of its proceedings, the governing statutory provisions were removed from the Fiscal Code and placed in a separate statute. In consequence, no longer-as a mere incident to resolution of a dispute-may a Fiscal Court usurp the administrator's function on a de novo basis. More specifically, taxpayers who institute proceedings against either the local or regional Finance Office, through a remedy termed a revision, do not now run the risk that a judgment favoring the government might be entered for an amount exceeding that in dispute. ${ }^{4}$

The taxpayer is free to sue the tax authorities for any benefit to which he believes himself legally entitled, the only requirement being that he set out facts which at least suggest

1 Including refund cases.

2 The Basic Law (Constitution) provides that any person who believes that a public authority has infringed his rights can seek redress from an independent tribunal.

3 See note 4 infra.

4 Previously, the Fiscal Courts were not limited to the adjudicative function of an independent tribunal. In cases coming before them, they could operate as if they were finance offices. No earlier finding of a finance office was binding; a Fiscal Court could substitute its own judgment as to the proper total assessment, in the manner of an administrative agency. 
detrimental impairment of his rights by application of law. The suit is based upon the act or, very rarely, the refusal to act of the tax authorities. Typically the taxpayer directs his claim against the assessment as it stands after the decision on his protest, either seeking cancellation of the assessment as a whole or requesting a mere reduction in his assessment. Occasionally, a taxpayer institutes proceedings to obtain from the local finance office a decision which that office either refused or failed to render. A taxpayer also may seek a declaratory judgment that a certain act of the tax authorities is a nullity and void.

Except in small cases, with respect to which certain additional restrictions are imposed, either the taxpayer or the local finance office has one month in which to appeal the decision of the Fiscal Court. Appeal lies to the Federal Fiscal Court, normally by revision. However, complaint is the proper remedy to secure review of a Fiscal Court decision on procedural questions-such as the admission of parties to a proceeding, wherever such decisions can be contested separately.

Ordinary tax litigation cannot be carried beyond the Federal Fiscal Court. However, a constitutional complaint can be taken within one month to the Federal Constitutional Court. This remedy is available when a taxpayer believes that his basic rights, as laid down in the Constitution, have been impaired by statute, administrative act, or a decision of the Fiscal Courts (e.g., on the ground that there has been a violation of the principle of equality before the law). A procedural requirement is to the effect that a taxpayer must exhaust his remedies in both the Fiscal Court and the Federal Fiscal Courts before lodging a constitutional complaint with the Federal Constitutional Court; it is waived only where an established practice in the Fiscal Courts precludes any likelihood of a decision favorable to the taxpayer.

A decision by the Federal Constitutional Court, holding a statute, or decisions of the tax administration or of the Fiscal Courts, incompatible with the Basic Law, renders the offending statute or decision void. Within recent years, this Court has declared unconstitutional a number of tax provisions, some of a fundamental nature-such as one which treated husband and wife as a unit for income tax purposes. In consequence, its decisions have become of increasing significance to the daily work of the tax authorities. 


\section{Section A. Organization and Procedures: Trial Level}

\subsection{Organization of the trial tribunals}

The fifteen Fiscal Courts are completely independent state tribunals, empowered to decide questions both of fact and law, with appeal on questions of law alone lying to a federal tribunal, the Federal Fiscal Court.

Prior to the act of October 6, 1965, there was considerable variation from state to state in the organization of the Fiscal Courts. The new law, however, sets out uniform provisions, in force throughout the Federal Republic. It also upgraded the Fiscal Courts: they have been raised to the higher of the two echelons of state courts and are the equal of the Regional Appeal Courts which handle ordinary non-tax litigation.

Each Fiscal Court is divided into so-called Senates, from two to eight for each court, depending upon local requirements. ${ }^{5}$ The jurisdiction of each Senate may be fixed by reference to any one of several criteria: (1) geographical boundaries, (2) categories of taxable objects, such as real property or business enterprises, or (3) types of taxes, that is, the individual income tax, the corporate income tax, etc. In each Senate, five members form a quorum, three members of which must be professional judges. The other two are honorary associate lay judges. 6

Each Fiscal Court is headed by a professional judge-the President of that particular court, who is appointed for life by the state finance ministry. As President, he bears the administrative responsibility for the overall functioning of the court. In his capacity as a judge, he acts as presiding judge of one or more Senates. His deputy is that President of a Senate who has the highest seniority among the court members.

5 Prior to the upgrading of the Fiscal Courts, these several intracourt divisions were termed chambers.

${ }^{6}$ By increasing the professional judges from two to three, and reducing the lay judges from three to two, the preponderance of laymen sitting on the Fiscal Courts has been eliminated. The earlier requirement, that there be three lay judges, was designed to counterbalance the tendency of Fiscal Courts to side with the finance offices. The change was made to more closely conform these courts to comparable courts in other areas of law and in the belief that other structural changes would preclude finance offices from exercising undue influence. 
Senates not headed by the President of the Court are headed by professional judges with the rank of "President of Senate." They, like the associate judges of the several senates, are appointed for life ${ }^{7}$ by the state finance minister. The Senate associate judges possessing legal training ${ }^{8}$ and carrying the title of Fiscal Court Counselor, ${ }^{9}$ are drawn from the tax administration. However, once a senior tax official is appointed professional judge on a Fiscal Court, his connection with the tax administration is completely severed. His new role requires that he be completely independent of the tax administration. But neither this, nor the fact that judges of the Fiscal Court are drawn from the senior tax officials, means that service as a judge is considered superior to that of the senior officials. The two are deemed equal in importance and are under the same salary pattern.

As stated previously, the new statute requires that a Senate quorum be composed of three professional and two lay judges. Each Fiscal Court has a committee which elects the lay judges for four-year terms. This nine-member selection committee, whose chairman is the President of the Senate, includes one official from the state tax administration and seven citizens "of confidence" selected by the legislative body of that state.

The lay judges are chosen by the committee from a list of candidates proposed by the President of the Court after consultation with professional and trade organizations. The number

7 According to the federal statutes, a judge may be appointed "on probation."

8 Senior tax officials who are appointed to the lowest rank of the tax judiciary typically will have passed the government's senior level legal examination which made them eligible at least to serve in legal capacities or as senior civil servants. While individuals who have passed qualifying examinations in areas other than law-specifically, economics-are appointed to senior administrative posts, and theoretically become eligible for appointment to the judiciary, such appointments are very rare.

9 It is not yet clear what the Laender will do in supplementing the new federal statute. Until the revision of the federal law, the following state of affairs existed. Fiscal Court Counselor was the lowest rank in the judicial hierarchy. An associate judge might be promoted from that rank to that of Senior Fiscal Court Counselor without any change in duties. The next higher rank was that of a Fiscal Court Director with the highest rank that of Fiscal Court President. Typically, the senior posts were filled through promotion of judges, although in the early years of the Fiscal Court, senior tax officials were appointed directly to the higher ranks if they occupied comparable posts in the tax administration. 
of names on the proposed list is expected to be three times the number of persons to be appointed, and the number appointed is sufficiently large that no one will have to sit on the Fiscal Court more than twelve days in any one year.

\subsection{Processing cases through the trial tribunal}

Every attempt is made to dispose of disputes at the administrative level and it now resolves 96 percent of the total. In keeping with this principle, a taxpayer-to invoke the jurisdiction of a Fiscal Court-must show that he has exhausted the administrative remedy. The one exception permitting the administrative procedures 10 to be bypassed, requires agreement of the local finance office and this usually occurs only when both parties recognize that administrative re-examination of the case would be futile. Such a conclusion might be reached, for example, where pre-assessment examination of the facts was so thorough that it is unrealistic to expect new factual developments, leaving for resolution only questions of law as to which neither party is prepared to yield. Direct appeal to the Fiscal Court in such cases saves administrative time ${ }^{11}$ and also accelerates the point of time when a yet further appeal can be made, if desired, to the Federal Fiscal Court.

Once the administrative process has ended, the taxpayer has a month in which he may bring an action challenging the assessment as it stands after the decision rendered on his protest. But even where this is done, in theory the disputed tax must be paid on the due date stated in the assessment notice, for the latter retains its vitality until altered or set aside. However, under the new law the local finance office may postpone payment by suspending implementation of the assessment notice. Moreover, that office is required to grant the taxpayer's application for postponement whenever serious doubt exists as to the assessment's correctness or where payment would have an unnecessarily harsh effect on the taxpayer. The Fiscal Court, even before an action is brought, also may order a postponement under these circumstances.

While a case, once brought, will be defended by the local finance office unless convinced its own position is untenable,

10 The new law refers to the administrative procedure as a "precursory procedure," i.e., precursory to the court proceedings proper.

11 Since the head of the finance office has the power to refuse or to consent to such a direct appeal, he determines whether or not additional effort will be made to settle at the administrative level. 
invocation of the Fiscal Court's jurisdiction does not prevent either party or both from changing its position. ${ }^{12}$ However, this in no way alters the obligation of the tax administration to resolve the issue in that manner which under the law seems to be the right solution. Consequently, should the taxpayer offer to concede more than appears justified to the administration, such a concession could not be accepted. Obviously, then, the taxpayer cannot hope to secure as a concession from the tax administration any treatment to which, from the administration's point of view, he is not entitled under the law. Further, on the basis of its own re-examination, the finance office may modify or replace the old assessment notice. In such event, the taxpayer may proceed with his action in the Fiscal Court under the new notice without having to re-process the case through the administrative procedures. The taxpayer also may withdraw his action at any time before the Fiscal Court's decision becomes final but, once the oral hearing has been held, only if the finance office agrees.

The higher levels within the tax administration are not routinely informed of all cases moving from local finance offices to the Fiscal Courts. Only if a case has substantial significance are the higher echelons alerted. They also keep abreast of important Fiscal Court decisions; these are published by legal journals. Thus such officials are in a position to make general suggestions to finance offices regarding the way in which similar cases should be handled in the future.

In hearings before the Fiscal Courts, the tax administration is represented by the local finance office, customarily by its head or by his nominee who usually is a so-called senior class official with legal training.

The taxpayer usually is represented at the hearing though rarely by a lawyer. Typically, his representative is the tax consultant or agent in tax matters who either assisted the taxpayer in preparing his return or first represented him at the point discussions were held with the finance office. While taxpayers are entirely free to represent themselves before the Fiscal Court, should the court conclude a given taxpayer is incapable of protecting his own interests, the new law permits it to require him to secure counsel.

Proceedings are as informal and flexible as possible, to insure maximum expedition consistent with full protection of the party's rights. However, strict adherence is required with

12 Under the old law, once a case had been carried to the Fiscal Court, the Fiscal Court assumed control and direction of the case. 
respect to the one requirement that actions be brought within one month from receipt of the protest (or if the protest procedure is waived, the assessment notice) which must advise the taxpayer of (1) his right to bring an action, (2) the competent court, and (3) the time limit to be observed. ${ }^{13}$

As long as the one-month time limit is met, considerable latitude is allowed with respect to the written statement which the taxpayer must file with the Fiscal Court, regarding both its form and the agency with which it is filed. Illustratively, the requirement has been deemed fulfilled by (1) a telegram sent to the Fiscal Court, (2) a statement of claim filed with the local finance office, or (3) an oral statement made by a taxpayer to a competent official, either of the Fiscal Court or the local finance office, who will make a formal record of the taxpayer's statement and see that it is properly filed.

Whatever the initial form of the statement, it must include the names of the plaintiff and defendant, the administrative notice which he disputes, and the subject at issue. The taxpayer, though not required to do so at this earlier stage, will also expedite matters if he identifies the specific relief sought and sets forth the facts and evidence supporting his claim, to the end of making it obvious that his rights were in fact impaired. In turn, the local finance office has no option but to submit all available records, even those received after commencement of the suit. Failure to do so is ground for reversal of revision. In practice, the documents submitted by both the finance office and the taxpayer are equivalent to briefs.

Apart from the foregoing, the new law itself permits, but does not require, other pleadings or statements prior to the oral hearing which that law made an integral part of Fiscal Court proceedings, ${ }^{14}$ though such can be waived by agreement of the parties. It also is possible for the court to issue a preliminary determination before an oral hearing if it also informs the taxpayer that (a) he may request such a hearing, and (b) that if he fails to do so the decision set out in the preliminary

13 Should the taxpayer decide to sue the finance office for failure to issue such a notice, he must wait six months after he has filed a protest.

${ }^{14}$ Under the old law, the Fiscal Court had full discretion whether to grant a taxpayer's request for an oral hearing, although in practice the request was granted. Under the new law, to prevent oral hearings from becoming an undue burden on the parties and the tribunal, the latter seeks to dispose in advance of all preliminaries so that one hearing is sufficient. 
notice will become final. Should an oral hearing then be applied for within the prescribed time limit, the decision set out in the preliminary notice becomes inoperative. At the hearing, and prior to the final decision, the parties themselves are free to introduce-and the court must take into account-new facts or evidence now considered relevant though previously not brought out during the administrative process-whether from ignorance, accident, or a mistaken belief in their irrelevance. ${ }^{15}$ Witnesses may be used at the option of the parties or under the direction of the court. Neither party bears the burden of proof as the prime concern of the court is to ascertain the true situation.

Whether or not the parties introduce new facts or evidence, or waive an oral hearing, the court itself, in fulfilling its responsibility to examine all relevant factual and legal aspects of the case, must make its own inquiry, and in so doing is not limited to matters of record. Indeed, it is expected to conduct such an inquiry even if the parties agree as to the facts. In consequence, the parties are not allowed to file formal stipulations of fact. To illustrate the practice: if the taxpayer, on instituting the proceeding, filed only an abbreviated statement regarding his claim, the court, through the presiding judge, may request, for example, that he furnish additional explanation to clarify apparent vagueness or to supplement the insufficient factual data, to facilitate either determination of the facts or appreciation of their significance. The court also may ask either side to prepare a statement in response to matters stated by the other side.

The court may base its judgment only on facts or evidence presented in the course of the hearing. Thus, in those rare instances where, to avoid delay, evidence is taken by a member of the court prior to the hearing, such evidence must be laid before the court during the hearing itself.

The particular relief which the taxpayer requests limits the relief the Fiscal Court may grant. ${ }^{16}$ Thus, without further ado,

15 Facts or evidence not introduced by the time the court hands down its decision cannot later be relied upon to justify a correction in the assessment.

16 Under the old statute, the Fiscal Court and the finance office approached the case in the same manner: each reached its decision on its appraisal of the taxpayer's entire situation, ignoring his particular claim for relief. Thus before January 1, 1966, the Fiscal Court was authorized to hand down a decision granting more than he had requested or it could change the decision of the finance office and place the taxpayer in a worse position than he was before bringing his case to the Fiscal Court. 
it may not accord more favorable treatment than he requested. But if the court believes the taxpayer actually is entitled to additional relief, he must be so advised and at that point may modify his petition. On the other hand, the court may not increase the contested tax beyond the total amount originally set by the finance office. In other words, at worst his action will be dismissed and the assessment of the finance office upheld. Then if the finance office concludes it treated the taxpayer too liberally, it may issue a new assessment notice which the taxpayer then may contest. Finally, it is possible for the court to conclude that, as to the question at issue, there are sound reasons for reducing the tax as originally determined but that other circumstances involving this taxpayer do justify a larger amount. In such circumstances, the court confirms the original amount.

Every effort is made to minimize the time lag between the date of the oral hearing and the date of judgment. The bare decision itself may be read in court at the end of the hearing or delivered in writing to the parties at a later date, usually within a two-week period. In any event, within two weeks after that bare decision is rendered, a complete written judgment must be forwarded to the parties. This judgment, in addition to the decision, sets forth the facts as determined by the court, an analysis of the legal rationale on which the decision is based, and information regarding further remedies available to the parties. The statement regarding the facts includes also an explanation of the weight attached to the several matters put in evidence. The legal analysis also explains why the court rejected any given arguments advanced by the parties. In short, the parties receive an exhaustive analysis of the facts and relevant law. To minimize the burden on the court, however, a statement of facts need not be included in the judgment where the amount in controversy is less than DM 100. It need only identify the points as to which the court differs from the result reached in the administrative procedures.

Approximately 20,000 appeals are decided annually by the fifteen Fiscal Courts in the Federal Republic. Between six and eight thousand such appeals involve individual or corporate income tax cases.

Not all Fiscal Court decisions are published. The several courts themselves select for publication in the Collection of Fiscal Court Decisions the particular decisions they consider of prime importance. 
In theory, a Fiscal Court decision has no precedent value whatsoever, either as to the court which decided it or any other court. However, as a practical matter, attention is given to previous decisions, by both the court of decision and other courts. Indeed, the judgments of the Fiscal Courts increasingly tend to discover prior decisions in developing the rationale in support of the judgment.

Since the courts themselves independently select the decisions to be included in the Collection of Fiscal Court Decisions, the mere fact of inclusion indicates that the court of decision believes this particular case is likely to influence future interpretations of the law. Understandably, these decisions are widely studied, further facilitating their use as precedents.

The tax administration itself provides no published clue as to its reaction to an adverse decision. Though it may decide not to appeal a particular judgment, it does not publish any indication of whether, in the future, it will follow the thrust of that decision or continue to press for its original position.

Since a decision of a Fiscal Court, in theory at least, has no precedent value in subsequent judicial proceedings, the defending local finance office, on encountering a substantially similar case, is wholly free to ignore the Fiscal Court decision and proceed as if it were dealing with a case of first impression. In practice, however, the local finance office tends, when faced with a doubtful issue covered by an earlier decision, to follow the court's reasoning and adopt a similar position.

\section{Section B. Organization and Procedures:} Appellate Tribunals

\subsection{Organization of the appellate court system}

The highest court for tax matters is the Federal Fiscal Court, located in Munich. Normally, its decisions are final; they can be reversed only by the Federal Constitutional Court if a taxpayer establishes that his constitutionally guaranteed basic rights have been violated. The most usual case involves a claim by the taxpayers of an impingement on his right to equal treatment before the law.

The Federal Fiscal Court consists of a President, VicePresident, five presiding judges of the Senates, and about thirtyfive judges. Members of the court must be at least thirty-five 
years of age. In practice, almost every member is qualified to hold a judicial post. 17

Persons appointed are thoroughly familiar with tax law and business economics, having had substantial practical experience in tax matters. They will have served in the federal or state tax administrations, ${ }^{18}$ on lower Fiscal Courts, or as tax consultants or tax lawyers. Occasionally, however, judges from other branches of the judiciary are appointed to the Federal Fiscal Court, thus enriching it with their knowledge of other legal areas.

All Federal Fiscal Court judges are appointed for life by the Federal President after election by a special committee. The Federal Minister of Finance appoints the other officials of the court: clerks, registrars, and about ten junior legal officers. Appointments as President, Vice-President, or presiding judge of a Senate are made from judges previously appointed.

The committee which elects the judges of the Federal Fiscal Court consists of twenty-three members: the Federal Minister of Finance, the eleven State Finance Ministers, and eleven others appointed by the Bundestag, Parliament. These latter eleven are recommended by the political parties represented in the Bundestag. The Committee's election of judges takes place in secret and is presided over by the Federal Minister of Finance. Although he does not vote, he does exercise a veto power.

The Federal Fiscal Court, for operating purposes, is divided into Senates, the number at any one time depending upon current requirements as determined by the Federal Minister of Finance. At present there are seven Senates, in addition to the so-called Great Senate. Six members of the latter are chosen by the court's governing board which is made up of the President of the Court, the presiding judges of the several Senates, and the two judges with the highest seniority. Decisions are reached by majority vote, with the President casting the deciding vote in case of a tie.

17 The relatively rare judicial appointee who does not possess the requisite formal qualification will have the qualification necessary for a senior administrative post or will have been for at least three years a professional judge of a Fiscal Court.

18 Once appointed to the bench, a judge may not serve the tax administration in any capacity. In an earlier period, it was feared that judges with a tax administration background might be prejudiced against taxpayers. This fear has proved groundless. 
The court's governing board also designates the members and their deputies of the other several Senates, though on occasion one judge may be a member of several Senates. Further, a year in advance each Senate is assigned responsibility for a particular group of taxes-though this assignment tends to continue year after year-and the scope of the responsibility is not changed during the year except where necessary to equalize the work load among the several Senates or to accommodate a particular Senate, the work of which has been adversely affected by illness, etc., of one or more judges.

Before each year begins, the President of the Court selects the Senate over which he intends to preside. The President and the presiding judges determine by majority vote which judges will preside over which Senates. Within each Senate, the presiding judge allocates all business before the year begins. As in the case of the inter-Senate allocations, no change is permitted except where required by work pressures or personnel changes.

The statute requires that five judges sit in every case. ${ }^{19}$ Three judges decide on those questions which raise preliminary or peripheral questions, normally of a procedural nature.

The seven-member Great Senate, ${ }^{20}$ made up of the President of the Senate and the six judges elected by the court's governing board, must render the decision whenever one Senate does not wish to follow any decision of another Senate. ${ }^{21}$ Moreover, any Senate may refer to the Great Senate a case involving an important question of law, considered significant to the development of either a legal principle or consistency in judicial decisions. Where a Senate does refer a case to the Great Senate, which happens about five times a year, one of its own members sits with the latter, participates in the discussion, and votes on the disposition of that particular case. Should a tie develop, the President of the Court casts the deciding vote.

\subsection{Processing a case through the appellate tribunal}

An appeal-termed a revision-to the Federal Fiscal Court may be entered by either the taxpayer or the local finance

19 The law formerly in force required that a minimum of five judges sit in each case.

20 Under the old law, the number of members of the Great Senate depended upon the number of Senates. Now the number is fixed permanently.

21 The old law required only that the Great Senate decide all cases where a Senate did not wish to follow a published decision of another Senate. 
office, but only with respect to questions of law. The Federal Court must accept the facts as determined by the lower tribunal; new facts or new evidence cannot be introduced. The court is bound by the facts as found by the lower court unless the error of fact is so dreadful and enormous that in the finding of the facts, the law itself was violated. Thus, it is possible to support a revision on the ground that the trial tribunal did not comply with the law when it determined the facts of the case. Illustratively, a taxpayer may request a revision, alleging that the lower Fiscal Court violated the law in not investigating the facts for itself as required.

The Federal Fiscal Court is not restricted to those issues of law specifically pleaded by the taxpayer. It is free to consider, at its discretion, any issues of law it believes emerge from the facts. Procedural defects, however, must be specifically pleaded.

A taxpayer may bring an action of revision if the amount in controversy exceeds DM 1,000 or if the trial tribunal granted permission to apply for a revision. And that tribunal is to grant such permission if:

(1) The legal issue raised is of fundamental importance;

(2) The judgment does not follow a previous decision handed down by the Federal Fiscal Court, or

(3) It is alleged that the judgment was bottomed on a procedural defect. 22

If the trial tribunal concludes that a taxpayer's application for a revision, which in practice contains a careful analysis of the rationale underlying his claim, does not fall in any one of these three categories and denies his request, the taxpayer is entitled to have the Federal Fiscal Court review that procedural determination. The Federal Fiscal Court, in then deciding whether or not to grant the request for a revision, need. not explain its decision, even if adverse to the taxpayer, so long as (1) all participating judges agree and (2) the taxpayer had an opportunity to state his views as to why he should be permitted to file a revision.

22 The new statute reduced the discretion of the Fiscal Court. Previously, the Fiscal Court was supposed to grant permission to file an application if the matter was considered to be of fundamental importance. This single but relatively demanding standard was imposed in an effort to reduce the volume of work handled by the Federal Fiscal Court in the belief that minor cases lacking any legal significance were dealt with satisfactorily by the lower-level Fiscal Courts. 
The Federal Fiscal Court can decide a case brought before it on revision only if it concludes that all of the essential facts were determined by the court below. Should it conclude further fact finding is necessary, the case must be sent back to the lower Fiscal Court for a new trial and decision, ${ }^{23}$ for the Federal Fiscal Court may decide only questions of law. Also, should it disagree with the rationale on which a lower court rested but conclude that the decision itself was sound for other reasons, it must refer the matter back to the lower court. This requirement is designed to safeguard the taxpayer's interests, by assuring him of an opportunity to discuss before a trial court all aspects relevant ${ }^{24}$ to the different reasons which influenced the Federal Fiscal Court.

Except for the foregoing, the procedural rules which governed the lower Fiscal Courts apply also to the Federal Fiscal Court. For example, though taxpayers typically use lawyers expert in tax matters to represent them in revision proceedings, in theory every taxpayer is free to appear and represent himself. Here too, however, the court may order the taxpayer to employ a representative if it believes he is unable to defend properly his own interests. ${ }^{25}$

On the government's side, the question of whether to appeal an adverse lower court decision rests with the head of the local finance office which originally issued the contested assessment notice. Typically, the individual who makes such a decision is a senior class tax official with legal training. Occasionally, those who supervise a local finance office may instruct it to seek a revision, but this is unusual. Even less frequently will the state finance ministry or the Federal Finance Ministry join the proceedings on their own initiative. If they do join, they are in the same position as the local finance office and the taxpayer: they are separate parties to the proceedings. In some instances, the Federal Fiscal Court itself

23 Under the old law, the Federal Fiscal Court had the power in theory to conduct its own fact-finding investigation. In practice, however, this power was rarely utilized.

24 It is no longer possible, as it was in the past, to refer the case back to the finance office.

25 Prior to January 1,1966 , a taxpayer's freedom to appear pro se was unlimited. The modification incorporated into the new statute was a compromise following extensive debates in the Bundestag. Some argued that taxpayers should be required to have representatives before this tribunal, and that such representation be restricted to certain groups of experts. These arguments were rejected. 
may seek the views of either ministry by inviting either or both to join the proceedings. Such an invitation usually is extended when the court is faced with a question of far-reaching or fundamental importance to the development of the tax law. Rather frequently, the state finance ministers decline to join such proceedings. The Federal Finance Ministry is much more likely to accept the invitation, particularly if it appears that the final decision may affect future legislation or administrative regulations.

Should either ministry join the revision proceedings, the head of the appropriate section represents it. However, he will not interfere with the presentation of the case by the local finance office; but he will focus primarily on the ministry's estimate regarding the overall importance of the issues.

The local finance office usually is represented either by its head or by an official designated by him. Typically, this is the same person who handled the matter before the trial court and who continues to handle the case for the finance office until a final decision has been reached.

The parties have one month, from the date they received notice of the trial court's final judgment, within which to file a request for revision with the Federal Fiscal Court. They then have another month in which to file supporting statements. 26

The request for revision must identify the specific relief sought, the statutory provision or legal rule which the party believes to have been infringed, and procedural defects, if any, on which he relies. Noncompliance with these rules will cause the court to reject the revision.

Provisions regarding oral hearings before the lower Fiscal Courts apply also to the Federal Fiscal Court. Thus there must be such a hearing, unless the parties agree to waive it. But, like the lower court, the Federal Fiscal Court retains the power to issue a preliminary notice without an oral hearing, provided the taxpayer is given one month before the notice becomes final within which to request an oral hearing.

In 1964 the Federal Fiscal Court dealt with almost 2,000 legal complaints, of which 39 percent (780) dealt with individual and corporate income tax questions. Of the 2,000, approximately 8 percent (160) were quashed because the amount in controversy was too small, 50 percent $(1,000)$ were dismissed

26 Upon application, the presiding judge of the Senate may extend these time limits. 
for being unfounded, that is dismissed on the merits, 2725 percent (500) were referred back to the lower courts, and final decisions were rendered in 17 percent (340).

Theoretically, decisions handed down by one Senate do not constitute precedents even for future cases which may come before it. However, the court itself classifies certain decisions as having fundamental importance. This includes any Senate's decision believed to be important and so well founded that it may be considered as a guide in pending or future cases. In practice, other Senates must respect these precedents. One Senate cannot deviate from such a decision coming from another Senate unless consent is given by the deciding Senate. Should consent be refused, the Senate seeking to overrule the earlier decision must refer the question of law, together with its own legal opinions, to the Great Senate. The Great Senate decides the matter, and its decision binds all the Senates. The Federal Fiscal Court publishes two groups of decisions: (1) the previously mentioned decisions of fundamental importance, and (2) other decisions believed to be of general interest. However, it will postpone publication of a decision of fundamental importance if it expects in the near future (1) that other Senates will deal with comparable cases or (2) that authoritative discussions of the problem by legal writers will appear. Delay of publication in these circumstances makes it easier for the particular decision-making Senate later to change its position if such a change seems to be warranted.

Published decisions appear in a special section of the Fedeval Tax Gazette, Bundessteuerblatt. This is issued as the need arises-three or four times a month-and is available to the public. Decisions of fundamental importance are marked, and to facilitate reference, all published decisions appear under subject matter headings.

In practice, all lower courts, whatever their formal obligation to rely upon and follow their own legal opinions almost invariably are guided by the published decisions of the Federal Fiscal Court, absent circumstances which suggest that the

27 The question may be raised as to why taxpayers-when approximately $50 \%$ of all complaints brought to the Federal Fiscal Court were dismissed on the merits-take the trouble to process a complaint. Basically, taxpayers feel it is worth the chance. The court costs are low. The Federal Fiscal Court is accessible. Attorneys' costs on the whole are low and depend entirely on the complexity of the case. Moreover, taxpayers tend to feel that taxes should be contested wherever there is any reason for so doing. 
Federal Fiscal Court will overrule its earlier decision. Obviously, this will not be anticipated where an earlier position has been reaffirmed recently by the Federal Fiscal Court, particularly if such reaffirmation occurs when either the earlier decision or the trend of thought it reflects has been attacked by legal writers.

In theory, the tax authorities, like the courts, are free to ignore the decisions of the Federal Fiscal Court but in practice tend to follow them. Understandably, again like the courts, greater weight is accorded published decisions, especially those considered to be of fundamental importance.

Interpretations the tax administration sets out in administrative instructions and regulations pertaining to individual or corporate income taxes (or to the wage tax) are frequently followed by the phrase, "subject to contrary appellate opinion." This is intended only to remind tax officials that they are expected to take into account any subsequent contrary decision handed down by the Federal Fiscal Court. Indeed, the regulations themselves are based in large part on Federal Fiscal Court decisions. By incorporating the principles of selected decisions, the tax administration indirectly indicates which judicial pronouncements the tax administration believes should henceforth control points heretofore in dispute. Otherwise, however, the tax administration does not publish its view regarding any court decision. On occasion, however, the administration does decide to relitigate an adverse Federal Fiscal Court decision in a similar fact situation. In such event, local finance offices are told to act on the basis of administrative pronouncements, not on the basis of the contrary decision. 


\section{PART FIVE}

\section{GREAT BRITAIN}

by

James Arthur Johnstone 


\section{CHAPTER XVII}

\section{ADMINISTRATIVE ORGANIZATIONAL AND PERSONNEL FRAMEWORKS}

\section{Section A. Administrative Organizational Framework}

\subsection{Introduction}

In the United Kingdom the income tax is placed, by statute, under the care and management of the Board of Inland Revenue, that is, all the processes leading to the ascertainment and enforcement of taxpayers' liabilities are initiated and controlled by officials of the Inland Revenue Department over which the Board preside. The staff of the Department consists wholly of civil servants, recruited by the same general procedures as the officials of other departments of the central government. The members of the Board themselves are civil servants and not political appointees; and the political responsibility to Parliament for the work of the Department rests with the Chancellor of the Exchequer (the title given in the United Kingdom to the member of the Cabinet in charge of Treasury problems).

As will be seen in Chapter XX $\dot{m} f r a$, certain independent authorities play a part in determining the legal liability in particular cases where the taxpayer disputes the calculation of the amount of tax for which the Inland Revenue Department proposes to hold him responsible. But the intervention of those authorities must be regarded as the exercise of a judicial function, and to that extent those authorities stand apart from the Inland Revenue Department, considered as an executive agency. The organizational framework of those authorities, therefore, is outside the scope of the present Chapter. Further, in keeping with the dominant purpose of this volume only those organs of the Department are described which contribute in some way to the resolution of substantive interpretative tax questions.

This principle of selection requires that reference first be made to agencies in the field which undertake the bulk of the work of assessing income tax liabilities, namely, the local Tax Offices. The broad principle of organization followed is to assign responsibility to a Tax Office operating in the geographical area where the source of income in question is found. 
The business profits of a shopkeeper, for instance, are assessed by the Tax Office for the area where his shop is located, and so on.

However, when the total income of an individual taxpayer from all sources exceeds a specified limit, the locally assessed income tax is not the end of his liability. He is liable, in addition, to a further charge, arrived at by applying a graduated scale of complementary tax rates to his total income less authorized deductions. In the cases affected, this complementary charge-known as surtax-is in reality a deferred installment of income tax. The work of assessing this surtax has been assigned, not to the local Tax Offices, but to a distinct branch at headquarters, covering the whole country and called the Surtax Office. ${ }^{1}$

Because of the function just described, the Surtax Office must handle, in relation to surtax, substantive interpretative tax questions closely analogous to those arising for decision in local Tax Offices. Consequently its organizational framework does fall within the scope of the present Chapter. ${ }^{2}$

Surtax, being a graduated complementary tax only on individuals with a sufficiently large income, does not affect the liability of corporate bodies. ${ }^{3}$ But corporate bodies (and notably limited liability companies) which carry on a trade or business are liable to a profits tax on their income, in addition to the income tax they suffer in common with natural persons. 4

$1_{\text {It }}$ was called formerly the Office of the Special Commissioners because, before the recent legislation clarifying the division of assessing and appellate functions, the formal responsibility for final approval of the estimates of liability prepared by Inland Revenue officials employed there rested with the Special Commissioners, the appellate body described in Chap. XX, 4.2b infra.

2 A ccount will be taken also in Chaps. XVIII-XX of procedures involving the Surtax Office to the extent that they diverge in principle from the procedures affecting local Tax Offices.

3 See, however, Chap. XX, 4.2c infra, for a reference to legislation under which surtax assessed on shareholders in certain companies may be collected from the companies.

4 The system of taxing companies was altered considerably by the Finance Act of 1965 . The income of companies was made subject to a new corporation tax (instead of income tax and profits tax), but income tax-with surtax-remained the tax on the income of individuals. From April 1966 onward, companies were made accountable for income tax withheld on the payment of dividends. The Act of 1965 also introduced a capital gains tax. Despite these changes, the procedure described in the text as existing before the 1965 legislation remains generally applicable. 
This complementary tax on corporate bodies is not, however, handled by any separate office of the Inland Revenue Department for computation of such a body's liability to profits tax is in the hands of the same local Tax Office which bears responsibility for assessment of the income tax.

In summary, the organizational framework of the Inland Revenue Department, relevant as essential background to any study of the processes by which interpretative tax questions are resolved, would include the following: first, the network of local Tax Offices, together with the higher echelons by which the activities of those Offices are directed, supervised, and coordinated: secondly, the Surtax Office; and thirdly, the organization through which the Board discharge their responsibility of undertaking the care and management of the taxes involved.

\subsection{Organizational framework, national office level}

The whole organization of the Department centers round the Board. The head of the entire Department is the Chairman of the Board; he is assisted by two Deputy Chairmen and by four other Board members.

The Board exercise their function of management through their secretariat (known as the Secretaries' Office) at headquarters. Parts of this latter office are concerned with areas not relevant here, such as personnel management, but one division which is significant here is known as the Stamps and Taxes Division. It is to this Division that the Board look primarily for advice and recommendations regarding the general administrative management of the Department. This same Division also handles the day-to-day correspondence sent to the Board and deals with important questions raised by the public or by the various branches and offices of the Department.

On specifically legal questions the Board are advised by their Solicitors' Offices (one in London, and another in Edinburgh, required because of differences in the legal system of Scotland and that of the rest of the United Kingdom). The staff of the Solicitors' Offices are available to conduct litigation on behalf of the Department.

The higher direction of the work of the local Tax Offices is entrusted to the Office of the Chief Inspector of Taxes. The Chief Inspector is the official head of the service in the field, that is, the corps of Inspectors of Taxes and their supporting staffs who man the local Tax Offices; in his headquarters office in London he is assisted by two Deputy Chief Inspectors and by a number of other officials, drawn from the field service 
but posted to headquarters for various specialist functions. In the main, these specialists have the task of furnishing guidance about the application of tax legislation to particular situations or particular classes of taxpayers thought to deserve separate study, whether because of inherent complexity or for any other reason. Illustratively, one small section of the Office contains the expert adviser on the grant of double taxation relief by way of credit when income derived by a United Kingdom taxpayer from an overseas country has already suffered tax in that country under the local tax legislation. Another example of a class of taxpayers requiring such expertise are companies which engage in life assurance business. But apart from those readily understood cases of specialization, two sections of the Chief Inspector's Office deserve particular mention here:

(1) The Organization Group is concerned with all matters of general organization, including the control of work processes, in local Tax Offices, and contains the unit which prepares periodic amendments to the code of departmental instructions supplied to those Offices and mimeographed circulars supplying guidance on new problems, including those arising from new legislation or court decisions interpreting existing legislation.

(2) The Inspectors of Taxes serving in the Special Appeals Section are available to present the Department's case in certain appeal proceedings before the Special Commissioners when it seems useful to call them in. For example, the appeal may relate to the income tax liability of a taxpayer in a provincial town: had the appeal hearing taken place locally the District Inspector in charge of the taxpayer's local Tax Office might have been expected to present the Department's case, but if the taxpayer has asked for the hearing to take place in London (because, for example, he has engaged a lawyer practicing in London to present his own side of the case), it may be more convenient to entrust the representation of the Department to the London-based Special Appeals Section.

One group of specialists at headquarters has long been concerned with the part of the tax code relating to superannuation funds and other arrangements for the payment of retirement pensions. Until recently, these specialists operated as part of the Chief Inspector's Office, but for a variety of reasons 
it has now been thought more convenient to reorganize the group as a separate unit immediately responsible to the Board through their secretariat. This change in formal responsibility does not, however, imply any change in the work of the unit.

To conclude this survey of organization at national office level, it must be recalled that (as previously pointed out) the assessment of surtax is in the hands of a single central office for the whole country, the Surtax Office. That Office comprises a number of executive sections which examine the returns of income made by individual taxpayers. The work of officials in the executive sections is under the supervision of a hierarchy of officials of senior rank; and the office also includes the following:

(1) An Organization Section which advises on office procedures and the design of forms, and

(2) An Intelligence Division which keeps a record of important decisions of general application and assists the top management with advice on the technical content of the instructions to be issued to the staff of the executive sections.

\subsection{Organizational framework, regional office level}

A noteworthy characteristic of the organizational framework of the Inland Revenue Department, so far as the administration of income tax and profits tax is concerned, is the absence of any formally constituted regional offices standing between the national headquarters and the various local Tax Offices. The creation of any such regional offices would be contrary to the deliberate policy of delegating the maximum degree of responsibility to District Inspectors in charge of local Tax Offices. There is no room for any larger degree of delegation to an intermediate authority. The District Inspector is responsible to the Department for the efficient running of his Tax Office, and although he has to conform to the general instructions issued from headquarters, his independence is a real one.

It is, nevertheless, recognized that some aspects of the work of local Tax Offices make desirable a link between those offices and the Chief Inspector at headquarters. This is provided by the appointment of Inspecting Officers, each having the oversight of a particular group of local Tax Offices. Through the Inspecting Officers, the Chief Inspector can keep himself informed of the general progress of work in the local Tax 
Offices. To provide this information, the Inspecting Officer makes regular inspection visits to the Offices in his group and keeps in close touch with the District Inspectors. $\mathrm{He}$ also plays an important part in the machinery of promotion by means of reports on the staff in his area. But he does not displace the headquarters specialists as the source to which the District Inspector would normally look for technical guidance in resolving substantive interpretative tax questions (though he might well be brought into consultation if the resolution of such a question gave rise to problems in ensuring that a common policy was adopted on a matter affecting several Tax Offices in the same locality).

It has already been noted that the separate legal system in Scotland accounts for the existence of a separate Solicitor's Office in Edinburgh which handles any legal problems requiring familiarity with the laws of that country. Side by side with this separate Solicitor's Office there exists the Office of the Comptroller of Stamps and Taxes. This latter Office has a variety of duties (e.g.,. in connection with receiving and accounting for tax payments) which are outside the scope of this study, but for the purpose of the current discussion the feature to be noted is that the Office undertakes, in Scotland, much of the work that for the rest of the United Kingdom is undertaken by the Stamps and Taxes Division of the Secretaries' Office. It would, however, be misleading to categorize the Office of the Comptroller as corresponding in any sense to a regional office of the kind found in other government departments. The Comptroller reports directly to the Board, and his office can perhaps best be regarded as comprising a geographically detached part of the Board's central secretariat which, for convenience, is placed in close proximity both to the Solicitor's Office for Scotland and to the Edinburgh headquarters of the diverse organizations catering to Scottish needs.

\subsection{Organizational framework, local office level}

In round figures there are 700 local Tax Offices. This means that the average number of taxpayers whose affairs are handled by any one Tax Office is in the neighborhood of 30,000 . and that the average area covered by a Tax Office is about 130 square miles. But in a country like the United Kingdom where the population density varies from less than one inhabitant per square mile (in parts of Wales and Scotland) to well over 20,000 inhabitants per square mile (in the London area), these national averages can conceal a considerable range of variation. 
Each Tax Office is headed by a District Inspector, who is supported by one or more assisting Inspectors, together with an executive and clerical staff which usually numbers between 40 and 50.

The bulk of this staff will normally be concerned with the administration of the "Pay as you Earn" scheme under which income tax is deducted currently from the wages and salaries of persons in employment. Others will be engaged on work connected with the determination of liability in respect of rents derived from the letting of property or with repayment claims lodged by taxpayers who have paid more tax, by deduction at source from dividends or other investment income, than the amount of their final liability (having regard to the reliefs granted in respect of dependents and so on).

The management of those blocks of work will be planned by the supervisors after any appropriate consultation with members of the Inspectorate. But apart from such consultation about the general running of the Tax Office, the prime duty of an Inspector who has undergone full technical training is the examination of accounts of business concerns in order to compute the assessable profit and thus the amount of liability to income tax and profits tax.

\section{Section B. Personnel Framework (Governmental and Non-Governmental)}

\subsection{Governmental professional personnel}

To facilitate the reader's appraisal of the procedures discussed in Chapters XVIII-XX, it will be useful to supplement the previously described organizational framework of the Inland Revenue Department with a description of the prior education and in-service training of the Departmental officials who play a leading part in the determination of tax liabilities. For this purpose, a superficial survey of the education and training of the staff in all the various grades employed in the Department probably would be less helpful than an account dealing more specifically with those officials performing technical and professional functions, and attention will therefore be concentrated on the following groups:

(1) The professional staffs of the two Solicitors' Offices;

(2) The examination staff of the Surtax Office; and 
(3) The members of the Inspectorate employed in local Tax Offices and, at headquarters, in the Office of the Chief Inspector of Taxes.

Recruitment of professional staff for the Solicitors' Offices is on the same lines as the recruitment for legal posts in other government departments, that is, candidates must already possess a recognized legal qualification and have had some experience in the practice of their profession. In other words, at the point of recruitment, entrants to the Solicitors' Offices will have undergone the normal professional education of a member of one or other of the two branches of the legal profession (as described in 1.6 infra).

On entry into one of the Solicitors' Offices, a recruit acquires familiarity with the work of his Office by actually taking part in it, under the guidance of a more senior member of the professional staff. He is not regarded as a trainee; the responsibility allocated to him recognizes that he brings with him professional qualifications and experience acquired outside the service.

In contrast to the system of recruitment to legal posts, which takes place after acquisition of a professional qualification and some outside experience, the recruitment of the Inspectors of Taxes and of the executive staff employed on examination work in the Surtax Office takes place through competitions which do not require or assume any previous study of the technical matters which will be involved in the candidates' future work. The respective competitions are adapted to test the attainments and capabilities of candidates who have completed some particular step on the ladder provided by the country's educational system. Thus the competitions through which recruitment to the Surtax Office's examining staff takes place are framed for young people leaving school after a full secondary education. The competitions through which Inspectors of Taxes are recruited cater to rather older candidates who have undertaken higher studies (up to first degree standard) at a university or similar institution.

New entrants to the Surtax Office are trained in the work of surtax examination in a special training section attached to the Office. Training consists of lectures, discussions, and practical work with revision courses and exercises, and includes organized visits to a local Tax Office and to a meeting of Appeal Commissioners. The basic training course normally lasts six months and falls into two three-month periods. In 
the first period, lectures are interspersed with a certain amount of practical work, in the second period, the emphasis falls mainly on practical work, though some advanced lectures are also included. At the beginning of the second three-month period, the trainees move into a unit which is intended to form a bridge between the lecture room and the normal working sections of the Office. Here, still under the close supervision of the tutorial staff, they undertake the actual duties of surtax examination, though the volume of work allotted to two trainees will correspond to the allocation handled by a single fullyexperienced surtax examiner. The object of the scheme is to provide trainees with a regular, but limited, flow of case work in an atmosphere which is a close copy of that obtaining in the main part of the Office to which they shortly will be transferred. The transition itself takes place in the last month of the second three-month period; leaving the training section the new examiner moves into the main part of the Office where he completes his training under the guidance of experienced members of the staff of the unit to which he has been transferred.

New inspectors are attached immediately to a local Tax Office, but time for study is allowed. They in fact undertake a long and systematic training for their future duties, their progress being tested by two Departmental examinations in which problems of accountancy and tax law figure prominently. As a general introduction to the Department, they pay a special initial visit to one of the eight training centers throughout the country. Thereafter, along with some members of the executive staff of Tax Offices who have been selected for full technical training and promotion into the Inspectorate, the cadet Inspectors undergo a fifteen-month Preliminary Course during which they attend a training center for two full-time periods amounting to 10 days and for 40 half-day tutorials. The Preliminary Examination follows. Inspectors who are successful in this examination then undergo the Final Course which lasts 16 months and again involves attendance at a training center both for short full-time periods and for numerous half-day tutorials. The course is followed by the Final Examination.

An Inspector who is successful in the Final Examination has completed his basic training and may anticipate transfer to an Office where, instead of being a trainee, he will be expected to take an active part (under the guidance of the District Inspector) in controlling the work of the Office. He is still, of course, broadening his experience and will have some additional formal training. During the succeeding year he will attend two 
post-graduate courses, each of a week's duration, at a residential center. This further training is designed in part to assist him to fit himself for the management of a staff when he eventually takes over an independent command, but the course covers also some of the more involved technical problems encountered by members of the Inspectorate in their individual case work.

There is no separate channel of recruitment for the Inspectors on specialist work in the Chief Inspector's Office at headquarters. These officers are selected from the Inspectorate at large on the basis of apparent aptitude for the duties to be undertaken.

\subsection{Private tax practitioners}

A taxpayer who wishes to receive advice about the extent of his tax liability or the steps which he ought to take in order to establish a claim for a particular tax relief is free to obtain such advice from any source that offers it. Thus many of the companies carrying on branch banking have established departments which, for a fee, will assist the banks' customers in the preparation of their returns of income and will conduct correspondence on their behalf with the Inland Revenue Department. However, by far the greatest part of the work of advising taxpayers and representing them in their dealings with the Department falls to members of the legal and accounting professions. In fact the only professional representatives who have general statutory right to be heard on behalf of a client when the client's tax appeal comes before the General or Special Commissioners for adjudication are (1) lawyers and (2) members of one of the incorporated societies of accountants. To complement the foregoing description of the education and training of professional and technical staff in the Inland Revenue Department a brief account should therefore be given of education and training for the legal and accounting professions.

At the outset, however, it must be explained that in each of the component parts of the United Kingdom the legal profession is organized in two distinct branches.

(1) The first branch consists of those known as barristers (in Scotland, advocates), who have the exclusive right of representing litigants in the higher courts and otherwise confine themselves to giving specialized advice on legal questions laid before them, on behalf of clients, by members of the second branch. 
(2) The second branch consists of solicitors, to whom members of the public go for all kinds of legal advice. When litigation is necessary, a solicitor may represent his client in the lower courts. Where the presentation of a client's case in any court is to be entrusted to a barrister (or advocate), the solicitor will make the necessary arrangements for this and, in particular, will supply a brief analyzing the legal issues at stake.

Admission as a barrister or advocate is in the hands of the ancient Inns of Court in London or of the corresponding body in Edinburgh or Belfast. The regulations are not entirely uniform throughout the United Kingdom, but in general a candidate must show that he has reached a prescribed standard in his general education and must also pass one or more examinations in legal subjects. The prescribed examination subjects do not necessarily include tax law.

Before admission as a solicitor a form of apprenticeship with a practicing solicitor for a prescribed period is normally required under arrangements approved by the Law Society (for England and Wales) or the corresponding Society in Scotland or Northern Ireland. A candidate must show that he has reached a prescribed standard in his general education, must pursue a suitable course of study in legal subjects, and must obtain a pass in all the subjects required for the qualifying examination. Tax law will usually be one of the subjects studied.

Almost all solicitors in private practice undertake a certain amount of tax work (if only because the settlement of outstanding tax questions is an inevitable part of the business of administering the estates of decedents). Specialization in tax matters, however, is not common among solicitors. Among barristers, on the contrary, specialization is quite common, especially at the English Bar. Any barrister possessing reputation as a tax specialist undoubtedly will acquire so much business in that one area that he will have no need to go beyond it.

Without discussing those bodies concerned solely with particular fields-e.g., the financial affairs of municipal corporations-there are four professional groups whose members all are fully qualified accountants: i.e., the Institute of Chartered Accountants in England and Wales, the Institute of Chartered Accountants of Scotland, the Institute of Chartered Accountants in Ireland, and the Association of Certified and Corporate Accountants. Nevertheless, the membership requirements for 
these four groups are not entirely uniform. Normally, a candidate first must have served an apprenticeship with an actively practicing member of the body concerned, but in certain circumstances the Association of Certified and Corporate Accountants accepts "as an alternative ... practical experience in the finance or accounting department of a commercial or industrial company, in a nationalized industry or in local government. . . ."5 Candidates must also show that they have reached a certain standard in their general education and must pass a series of examinations in professional subjects. Taxation law and practice will always be one of the subjects in which candidates are tested.

The range of work undertaken by a firm of practicing accountants will vary to some extent with the size and connections of the firm. But an important part of the work of the majority of practicing accountants is the preparation and audit of the accounts of business concerns of all kinds. This work naturally leads on to the discussion with local Tax Offices of the clients' tax liabilities in respect of the profits shown by those accounts. Thus almost all practicing accountants undertake some tax work. Within a large firm there is a possibility that some of the partners and the supporting staff will specialize in tax questions, leaving their colleagues to handle other branches of the firm's business.

5 H.M.S.O., Choice of Careers: The Accountant 14 (3d ed. 1963). 


\section{CHAPTER XVIII}

\section{ADMINISTRATIVE RULE-MAKING PROGRAMS}

\section{Section A. Character of the Underlying Statute}

\subsection{The precision of the statute itself}

Controversies arising from time to time about the precise amount of the tax liability in particular cases, certainly are not due to any paucity of legislative provisions indicating the rules by which Parliament intended to govern the matter. There is, indeed, a massive volume of guidance available.

The whole statutory code of income tax provisions was consolidated last in 1952. The result was the longest single Act of Parliament ever put on the statute book. This act contained 532 separate sections, together with 25 schedules. In the legislative practice of the United Kingdom the term schedule normally is used to denote an appendix to an Act of Parliament, supplementing the sections in the main body of the act by setting out subordinate and ancillary provisions. The standard edition of the statutes issued by the Queen's Printer has 511 octavo pages with upwards of 400 words to a page.

Since the consolidating Act of 1952 embodied virtually the whole of the code of income tax legislation then in force, it necessarily contained some materials other than the statutory provisions directly defining the amount of a taxpayer's liability. Nearly 30 percent of its sections related to administration in the broadest sense, covering a wide range of matters such as the obligation to make returns of income, penalties for noncompliance or fraud, appeal procedures, and the enforcement of collection. Only the remaining 70 percent related to substantive questions of liability, specifying how taxable income should be measured or what relief from tax should be available and in what circumstances. The basic code of general application, after the 1952 consolidation, numbered about 250 different sections, comprising roughly about two-thirds of this part of the statute. The remaining one-third of this portion of substantive provisions dealt with departures from the normal tax pattern. These departures do not-with two exceptions-cut across wide groups of taxpayers. Instead they apply only to special classes of taxpayers, such as estates in the course of 
administration, banks, insurance companies, charitable bodies, or nonresidents. The two exceptions to the general principle of the English statute-that deviations of the type used in the United States requiring itemization of deductions shall be avoided in favor of round-sum allowances-are the deductions for interest, available to all taxpayers whether businesses or individuals, and for life insurance premiums, available to individuals under certain specific restrictions.

Since that consolidating act was passed, Parliament has continued to occupy itself with income tax matters. In all, by 1964, fifteen subsequent statutes had been enacted, containing over three hundred additional sections and schedules. In part, this activity represents a process of reform in which new legislation entirely displaces the corresponding provisions of the old, thus enabling the superseded provisions to be repealed. On balance, however, the result has been a considerable net increase in the size of the income tax code.

The corpus of legislation just described covers the surtax as well as the income tax. Moreover, many of the basic principles which it sets out are applicable also to the computation of a company's income for the purpose of determining its profits tax. There is, however, a considerable number of supplementary substantive and procedural enactments not included in the foregoing enumeration that do bear upon the ascertainment of liability for the profits tax.

Information reflecting the volume of the applicable statutory material does not, of course, afford any complete index of the degree to which interpretative difficulties may be expected to arise when the statute is applied to practical situations. This will be affected, as well, by the character of the language used by the legislature, and, in particular, by the extent to which it sought to draw fine distinctions between one case and another in a search for greater equity. On this aspect of the legislative process, it is worth quoting from the Final Report in 1955 of the Radcliffe Commission on the Taxation of Profits and Income:

1085. The social and industrial structure of the United Kingdom is intricate. It comprehends a great variety of forms. A master tax, such as income tax has come to be, which has to be applied with fairness to all the variety of forms, must reflect to a large extent the intricacy and complication of the underlying structure. Even if the social pattern is itself becoming less complicated-an assumption which we do not makethe general extension of the range of the tax to new circles of 
taxpayers involves a complementary increase of detailed provisions.

1086. Secondly, the high rate of tax brings certain consequences. On the one hand, there is pressure for allowances, alleviations and qualifications wherever a special case can be asserted or a distinction claimed. Indeed, with a high rate of tax, a distinction acquires a potential value which it would not possess in other circumstances. Moreover, the methods and process of Parliamentary legislation, particularly, perhaps, as applied to the annual Finance Act, themselves assist in the multiplication of special provisions. On the other hand, a tax which has so heavy a bearing on the lives and prospects of its citizens is sure to meet with avoidance on a large scale: and the statute book becomes encumbered with elaborate provisions against avoidance, some of which rank among the least intelligible portions of English prose. ...

1088. In considering whether we can make any useful recommendation for the improvement of the present situation we must distinguish between the two other major criticisms of the tax code. First, as to the complications of its conceptions and structure. These can never be simple, as we have said. Can they be simpler than they are today? Such answers as we can give to this are to be found in the other Chapters of our Reports. We were at one in starting our inquiry with an ardent desire to leave the structure and the conceptions of the tax simpler than we found them. If we have had only small success in the result, we have at least explained in most instances why we have failed, and what were the reasons that have led us on occasions to reject a seemingly attractive simplification. Perhaps the most formidable single obstacle is the fact that hitherto the tendency both of Parliament and of the Inland Revenue Department has been in the opposite direction. Scrupulous regard has been paid to even small differences in individual situation: and, while it is comparatively easy to advance from a simple system to a more refined one by introducing qualifications and differentials, it is very much more difficult to retire from a refined system to a simpler one and, by so doing, to ignore distinctions which hitherto have been recognized and allowed for.

Here, then, is expert testimony to a significant tendency in the country's tax legislation: for some time it has been customary to accord differential treatment on the basis of rather small distinctions between one case and another. This process seems likely to continue. It certainly must be conceded that the broad and sweeping language of the earliest acts relating to income tax gradually has become overlaid by refinements involving elaborate definitions quite foreign to the original conception of the code. 
It is almost inevitable that this modern elaboration should prove a fruitful source of interpretative controversy. In practice, while no statistics are available, the accounts submitted by almost every business enterprise give rise to one or more interpretative controversies. On the other hand, it is unlikely that such controversies will arise frequently in the returns of wage or salary earners.

At the same time, it must be acknowledged that evidence is lacking by which to judge whether the old style of drafting tax legislation would have been any more successful in avoiding such controversies had Parliament been constrained to continue its use. Here it is possible to quote contrasting examples of the old style and the new, leaving the reader to draw his own conclusion on the matter. But first it may be helpful to quote another comment from the Final Report of the Radcliffe Commission bearing on what, after all, is one of the central problems any legislature encounters on adopting an income tax law, namely, the problem of indicating the distinctions separating taxable from nontaxable receipts. The report calls attention to the strains that may well arise when a form of definition that served well enough in former times must be applied to more modern conditions:

28. The tax code contains no general definition of income. It is often said that it is impracticable or undesirable that it should. We do not feel it necessary to subscribe to either of those epithets. The codes of other countries have achieved the work of definition without any known ill-effects. What seems to us more important is that no real advantage could possibly result from the introduction of a general definition that had to cover so multifarious a subject as taxable income. If it were expressed in very general terms the work of deciding how to apply to particular instances would have to be done by deductions drawn from other parts of the code's framework or with the help of general principles imported from without. To a large extent the United Kingdom system itself has proceeded by this method of interpretation. On the other hand, the more particular the definition the more it tends to become a mere list of different classes of receipt, and the anxiety not to exclude some class by inadvertence or omission leads to the addition of a comprehensive "sweeping up" clause at the end which, in effect, raises over again the problem of interpreting the general phrase in the light of a particular instance. The United Kingdom code has in fact established the limits of what it will regard as taxable income by formulating a list of different classes of income, grouped under five Schedules: and the interpretation of the wording and significance of these lists has been the subject of copious decisions of the Courts 
of law during the course of some three generations. Their interpretation has been governed by the principle, in itself unexceptionable, that income tax is a tax on income...

30. Since the tax code identifies income by a process of classification, a receipt, to constitute taxable income, must be capable of being referred to one of those classes. The classification itself takes two forms: either it specifies a kind of receipt which is regarded as being inherently of an income nature, e.g., interest, annuity, public revenue dividends, or, more often, it specifies a kind of source which is regarded as being inherently productive of income, e.g., land, trade, profession, securities, employment, and charges the income from that source. The identification of a receipt of the first kind presents little difficulty, once the material facts are ascertained. But very great difficulty arises from time to time in deciding whether a particular receipt is or is not to be regarded as income of the second kind. For it has to be determined, first, whether the recipient owns one of the specific sources to which the receipt can be related, and, secondly, whether the relation of the receipt to that source is such that it can be said to grow out of it by way of annual increment. The difficulties are added to by the fact that in most cases the income to be taxed is not receipts themselves but profits representing the balance between receipts and deductible expenses.

31. We have here one of the basic conceptions of the tax coae, that referability to a defined source is essential to permit of a receipt being categorized as income, unless it falls within the limited class of receipts that are identified as income by their own nature. The source provides the capital substance from which income can emerge. Since the division of classifiable income into five Schedules dates back to the Income Tax Act of 1803, the adaptation of increasingly complex forms of income to the general structure of the tax code has not proceeded without strain. For instance, though offices and employments appeared in the original list of 1803 as a categorized source of income, it is not always easy to recognize that it is the office or employment itself that constitutes the source of income, not the services rendered or the contract that secures the payment. While the fundamental structure remains signally unaltered, additions and alterations have, of course, been made from time to time either by changing or enlarging the list of sources or by ad hoc provisions to the effect that a particular kind of receipt is to rank as taxable income.

The need asserted above, to discern a classifiable source, such as a trade, for the purpose of identifying particular receipts as taxable, emphasizes the importance of the statutory definition of trade. The manner in which the statute approaches that term serves as our first illustration of the older style 
of definition (dating back to the Income Tax Act of 1805) which in this instance survives almost intact today. The present definition reads: "'trade' includes every trade, manufacture, adventure or concern in the nature of trade." 1

While this is a sweeping description, the language still leaves room for differences of opinion over the question whether the purchase and profitable resale of property in any given case does or does not amount to the carrying on of a trade. Is the answer to be influenced, for example, by the precise character of the property involved? What is the significance of the period that elapses between purchase and resale, whether long or short? Can a single transaction of this sort amount to an "adventure ... . in the nature of trade" or is it a requisite that there be recurring transactions? Does it tend to negative the existence of a trade if the property is in no way altered before it is sold? Is there an opposite tendency if the property is improved only to make it more marketable? Does the definition postulate that the surrounding circumstances show that the person originally acquired the property for the purpose of making a profit, and would a case be excluded where some different motive led to the acquisition? All of these questions have had to be considered in litigation over many years, to fix the proper interpretation of the definition itself.

The meaning of residence provides another illustration of the older style of drafting. From the very earliest period, Parliament has acted on the principle that income from sources within the country should be taxed irrespective of the nationality or place of abode of the recipient and that, in addition, persons residing in the country should be taxed also in respect of income which they received from foreign sources. Thus the concept of a person's residence long has been of crucial importance in determining the basis of liability. Nevertheless, Parliament did not specify any general definition of residence. Instead, the word residing apparently was to be viewed according to its everyday popular meaning, with such additional assistance as might be derived from two particular rules (originally enacted in 1799 and 1803 respectively) directed to specific situations. In their current form those rules read:

368. British subjects, etc., temporarily abroad. Every British subject or citizen of the Republic of Ireland shall, if his ordinary residence has been in the United Kingdom, be assessed and charged to tax notwithstanding that at the time the

${ }^{1}$ Income Tax Act of 1952 , § 526 . 
assessment or charge is made he may have left the United Kingdom, if he has so left the United Kingdom for the purpose only of occasional residence abroad, and shall be charged as a person actually residing in the United Kingdom upon the whole amount of his profits or gains, whether they arise from property in the United Kingdom or elsewhere, or from any allowance, annuity or stipend (save as herein is excepted), or from any trade, profession, employment or vocation in the United Kingdom or elsewhere.

375. Position under Schedule D of temporary residents. A person shall not be charged to tax under Schedule D as a person residing in the United Kingdom, in respect of profits or gains received in respect of possessions or securities out of the United Kingdom, who is in the United Kingdom for some temporary purpose only and not with any view or intent of establishing his residence therein, and who has not actually resided in the United Kingdom at one time or several times for a period equal in the whole to six months in any year of assessment, but if any such person resides in the United Kingdom for the aforesaid period he shall be so chargeable for that year.

It will be observed that these two rules have one thing in common; each deals with a situation constituting something of an exception to a person's normal way of life. Since the general concept of residence is fairly well understood where an individual is concerned, it could be said that Parliament has given fairly clear guidance as to its intention to use the term residing in that ordinary sense for normal cases, while taking care to spell out a definite rule for the exceptional cases where doubt might otherwise arise. But the income tax must be applied to corporations as well as individuals. Since the relevant statutory provisions say nothing about a corporation's residence, the courts had to decide whether analogies could be developed which would give some coherent meaning to the concept in the case of a legal entity so materially different from a natural person.

The contrast between the older statutory approach to definitional problems as illustrated above, and the more modern approach can be observed in one example taken from the considerable volume of modern legislation directed against the avoidance of tax by the ostensible transfer of income from one person to another. In 1936, Parliament provided that a settlement by a parent who transferred income to a minor child would not be effective for tax purposes (subject to certain conditions) unless the settlement had been made before the new statutory amendment was first proposed and was then irrevocable. Parliament in the same act set forth an elaborate definition 
of the term "irrevocable," the current form of which as amended in 1952 follows:

399. For the purposes of this Chapter, a settlement shall not be deemed to be irrevocable if the terms thereof provide-

(a) for the payment to the settlor or, during the life of the settlor, to the wife or husband of the settlor for his or her benefit, or for the application for the benefit of the settlor or, during the life of the settlor, of the wife or husband of the settlor, of any income or assets in any circumstances whatsoever during the life of any child of the settlor to or for the benefit of whom any income, or assets representing it, is or are or may be payable or applicable by virtue or in consequence of the settlement; or

(b) for the determination of the settlement by the act or on the default of any person; or

(c) for the payment of any penalty by the settlor in the event of his failing to comply with the provisions of the settlement:

Provided that a settlement shall not be deemed to be revocable by reason only-

(i) that it contains a provision under which any income or assets will or may become payable to or applicable for the benefit of the settlor, or the wife or husband of the settlor, on the bankruptcy of any such child as is mentioned in paragraph (a) of this section or in the event of any assignment of or charge on that income or those assets being executed by such a child; or

(ii) that it provides for the determination of the settlement as aforesaid in such a manner that the determination will not, during the lifetime of any such child as aforesaid, benefit any person other than such a child, or the wife, husband, or issue of such a child;

(iii) in the case of a settlement to which section thirtythree of the Trustee Act, 1925, applies, that it directs income to be held for the benefit of such a child as aforesaid on protective trusts, unless the trust period is a period less than the life of the child or the settlement specifies some event on the happening of which the child would, if the income were payable during the trust period to him absolutely during that period, be deprived of the right to receive the income or part thereof.

At first glance, it might be supposed that a definition so comprehensive would leave no room for argument about its application. A determined inquirer, however, would find room for arguments as to whether particular cases are covered. In connection with paragraph (a), for example, can a settlement be 
justly said to "provide for" a payment to the settlor if a trust does permit such a payment to be made but only at the discretion of the trustees, there being no certainty that any such payment will be made? Again, does a settlement provide for payments to the settlor "during the life of" his child if the enabling words are such that the payments, if made would not necessarily continue during the whole life of the child? Or, turning to paragraph (b), is there provision for the "determination" of a settlement if it permits or requires the trust fund to be invested in shares of a company which the settlor so dominates (e.g., through his holding of shares with special voting and liquidation rights) that he could neutralize the settlement by winding up the company and thereby legally take possession for himself of the entire assets?

\subsection{Legislative pre-enactment aids to interpretation}

When an Inland Revenue official or a private tax practitioner encounters a problem of interpretation arising out of a statutory provision, he may well seek to enlarge his knowledge of its background by studying the relevant passages in the published reports of the different Royal Commissions and committees of enquiry which have from time to time reviewed the country's tax system. He knows that, as a matter of history, many amendments of the tax law owe their origin to the recommendations of such bodies. In addition, he may decide to check his tentative conclusions against statements made on behalf of the Government when the proposal to enact the amending section was debated in the House of Commons (though, as noted under 2.3 infra, arguments based on such a statement could never be decisive). To this end, he can turn to the bulky volumes of the Official Report of Parliamentary Debates for the year concerned. This is a substantially verbatim report, published since 1909 under the authority of the House itself. Not every provision of a finance bill attracts notice in the debates on the second and third readings of the bill; the tendency at that point is to concentrate on major issues of policy. But the bill is also considered clause by clause in Committee of the whole House; and at this stage, it is usually for the Chancellor of the Exchequer or another member of the government to explain the object of each provision of the bill as it comes up for discussion. There are further opportunities for debate on points of detail when the bill as amended in committee is reported back to the House. 
It will thus be to those two different stages of debate in the House of Commons that the inquirer will turn, for there is no debate on points of detail in the House of Lords (which is constitutionally precluded from amending a bill relating to taxation). Nor are there any committee hearings, such as occur under the legislative procedures of some countries, at which evidence bearing on the provisions of the bill would be given by officials or representatives of interested taxpayers.

Any interpretative guidance derived from a study of these legislative pre-enactment aids is a complete byproduct. An attorney examines them to facilitate his own understanding of the meaning of the statute; they have no de jure weight in court. The status of such aids is not peculiar to tax legislation; it is common to all United Kingdom legislation.

\subsection{Standards of construction followed by the judiciary in inter-} preting the statute

While the reports of Parliamentary debates may afford a valuable indication of the government's intentions at the time the statute was enacted, the courts have regularly refused to turn to Ministers' statements in either House of Parliament in order to explain its meaning. The courts proceed from a common premise, that the language of a statute must be regarded as the language of the whole legislature and, in consequence, that the meaning attached to it by an individual member of either House cannot govern the interpretation. Indeed, it has been stated that if there is a difference between the language of a statute and the declared intention of its framers, the proper inference is that this difference was not accidental but intentional.

In interpreting tax statutes, courts are accustomed to apply the recognized rules of construction applied to statute law generally. If, for example, a statute uses plain and unambiguous language, the court will give effect to it; the court's duty in such case is not to make the law reasonable but to apply it by reference to the usual sense of the words. Words will not be read into a statute by implication unless it is necessary to do so to give the language sense and meaning in its context. If, on the other hand, some apparent contradiction arises between two passages in the same statute or in two related statutes dealing with the same subject matter, the court will interpret the actual words of the section under review in a manner which best harmonizes with the subject and with the scheme of the statute or statutes taken as a whole. 
In addition, courts tend to hold that tax statutes should be construed strictly. This approach rests on the view that when the legislature imposes a monetary obligation which, in some sense, encroaches on the property of a citizen, it is reasonable to expect it to manifest its intention in clear words, rather than leave the matter to mere inference. This approach was reflected in one judgment as follows:

In a taxing Act one has to look merely at what is clearly said. There is no room for any intendment. There is no equity about a tax. There is no presumption as to a tax. Nothing is to be read in, nothing is to be implied. One can only look fairly at the language used. ${ }^{2}$

\section{Section B. The Regulations Program}

\subsection{Types and force of regulations}

The United Kingdom tax code contains no general enabling provision authorizing issuance of so-called interpretative regulations. Hence, a regulations program of the type administered by the United States Treasury Department under the general authority of section 7805 of the 1954 Internal Revenue Code, could not be and is not, carried out by the Board of Inland Revenue.

However, in the tax code, as in many other United Kingdom statutes, Parliament sometimes does delegate legislative power. That is, it does provide that some specified authority shall have power to prescribe rules, having the force of law, which amplify and otherwise carry into effect some particular provision or group of provisions in the parent statute. These rules take on different forms and go under various names (for example, the instrument by which, after Parliamentary approval, effect is given to a double taxation convention with another country is an Order-in-Council), but it is convenient to refer to them comprehensively as statutory regulations.

Some statutory regulations may be primarily or indeed wholly concerned with matters of machinery. For example, they might specify the form of notification to be given to the Inland Revenue Department by a taxpayer who wishes to claim the benefit of a relief provision in the parent statute, and they

${ }^{2}$ Cape Brandy Syndicate v. Inland Revenue Commissioners, 37 Times L.R. 33 (1920), [1921] 1 K.R. 64, 71, per Rowlatt, J., aff'd on different grounds, 37 Times L.R. 402, [1921] 2 K.B. 403 (Aff'd Cas.). 
might also go on to outline the procedure to be followed in resolving a dispute between the taxpayer and the Department concerning the applicability of such relief in a particular case. But regulations also may deal with questions of substantive liability. Such regulations sometimes define more specifically than the parent statute the qualifying conditions giving rise to a claim for relief, or prescribe the actual method of calculating a result intended by the parent statute.

In 1945, for example, Parliament enacted a new code providing a system of capital allowances for amortization of expenditures incurred after a given date on various types of depreciable assets. The application of this new code to some types of assets in existence at the initial date was fully worked out in the statute. In the case of construction works connected with mining operations, however, the statute merely set forth certain general principles for determining the extent to which any relevant expenditure incurred before the initial date would qualify for amortization after that date, and then authorized the Board of Inland Revenue to make regulations indicating how those general principles would be applied in actual cases. ${ }^{3}$

Again, in 1956 the system of investment allowances (an incentive device to encourage capital investment in certain business assets) temporarily was withdrawn. Parliament decided, however, to make an exception in favor of investments undertaken in connection with the conservation of fuel. Since a very wide range of industrial equipment was involved, the statute did not attempt to catalogue the fuel-saving devices which would continue to be eligible for an allowance. Instead the Treasury was authorized to make regulations prescribing the types of equipment which would qualify. After obtaining technical advice, the Treasury promulgated a list of qualifying equipment.

These two examples are typical of the degree to which statutory regulations are used to complement a substantive statutory tax provision. The general objective was stated clearly by Parliament; but, the subject matter being one of some complexity, it was deemed advisable to delegate authority to develop the subsidiary specifications regarding application of the basic principles. Another typical feature is that the power to make statutory regulations is granted on each occasion for some more or less specific purpose; in the tax area,

3 The regulations made by the Board of Inland Revenue are printed and issued by H.M. Stationery Office. They are available to the public. 
Parliament would be most unlikely to grant a regulation-making power which extended to a wide range of different matters.

Where a question of substantive liability turns on a provision contained in statutory regulations, a court before which that question arises will determine whether the body which promulgated the regulation. exceeded the limits of the authority delegated to it by Parliament in the parent statute. If, upon review of the scheme of the parent statute and the actual language by which the power to issue regulations was granted, the court should conclude that some part of the regulation goes beyond the presumed intention of Parliament, a decision would no doubt follow that, to this extent, the regulation was ultra vires and therefore invalid. This is not, of course, a feature peculiar to statutory regulations on tax matters; it reflects the control which the courts exercise over all forms of delegated legislation. For example, the "Pay as you Earn" system, under which employers withhold income tax when paying employees' wages and salaries, was put into force by virtue of regulations authorized by legislation reading in part as follows:

The Commissioners [i.e., Board] of Inland Revenue shall make regulations with respect to the assessment, charge, collection and recovery of income tax in respect of emoluments to which this Act applies ... and those regulations may, in particular, include provision-

(a) for requiring any person making any payment of, or account of, any such emoluments, when he makes the payment, to make a deduction or a repayment of tax calculated by reference to tax tables prepared by the Commissioners of Inland Revenue and for rendering persons who are required to make any such deduction or repayment accountable to, or, as the case may be, entitled to repayment from, those Commissioners;

$* * *$

and any such regulations shall have effect notwithstanding anything in the Income Tax Acts. . . . ${ }^{4}$

For many years, the Bankruptcy Acts had provided that, in the administration of a bankrupt's property, there should be paid in priority to his other debts certain preferential claims, including one year's taxes and outstanding wages due to his servants and workmen. An analogous provision appeared in legislation relating to insolvent companies. Accordingly, the statutory regulations for "Pay as you Earn" were drafted so as to apply the same rules to the tax which an insolvent employer

${ }^{4}$ Income Tax Act of 1952 , 157 . 
had deducted but not yet paid over. In relation to bankruptcy for example, the relevant regulation read:

There shall be included among the debts which under section 33 of the Bankruptcy Act, 1914, are to be paid in priority to all other debts in the distribution of the property of a bankrupt or person dying insolvent, so much as is unpaid of the employer's liability for the period of twelve months next before the date of the receiving order or of the death, as the case may be.

Later, in the course of a dispute, the Law Officers of the Crown indicated their opinion that this part of the regulation was ultra vires. While the language of the parent statute clearly indicated that the authorized statutory regulations would be deemed to override any inconsistent provision in the Income Tax Acts themselves, it did not indicate that the regulatory power could alter the separate bankruptcy legislation dealing with preferential claims in bankruptcy. After the Law Officers' opinion was handed down, the Board of Inland Revenue rescinded this part of the regulation. ${ }^{5}$

\subsection{Precise purpose of statutory regulations}

The Parliamentary practice of delegating legislative authority may indirectly contribute to greater clarity in the affected area. When the subject matter is especially technical and complex, statutory regulations issued under the specific authority of a parent statute are likely to deal with the application of a new measure in a more detailed fashion than Parliament would have been willing to undertake if the entire matrer had to be compressed within the narrower bounds of the statute itself. This consideration apart, however, statutory regulations do not afford a means of resolving the interpretative problems which emerge from all tax legislation. For, as has just been seen, the ultra vires test means that, in the United Kingdom, these regulations are subordinate to, and controlled by, the parent statute. Since the power to make regulations is granted only for a specific and limited purpose, study of their language will not throw much light on wider questions arising even out of the parent statute itself.

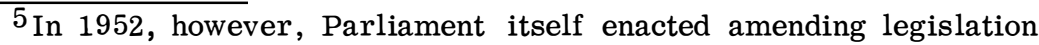
which directed that the priority rules in the Bankruptcy Act and other analogous legislation should extend thenceforward to "Pay as you Earn" tax not accounted for by an employer at the date of the receiving order or other relevant date. 
As these regulations are not designed to interpret doubts generated by the statutory language-recall that their purpose is to complete the gaps left deliberately by Parliament-there is no part in them designed to interpret the parent statute. However, as the Inland Revenue fills in the gaps, the statutory regulations indirectly come to serve an interpretative function for they are more detailed than Parliament itself would have provided in a statute. Although the process is a legislative one, the completion of details, it must be emphasized again that the regulations must not go beyond or vary the clear meaning of the statute.

From time to time, even without a new Parliamentary enactment, statutory regulations will be amended by whatever agency to which Parliament originally delegated the legislative authority. ${ }^{6}$ Illustratively, an incentive allowance encourages the installation of fuel economy devices. There is no general language which permits such an allowance for any and all devices insuring an economical use of fuel. Instead, the regulation lists specific devices with very precise engineering details. If a new device were to be invented, it would be added to the list, with great preciseness as to its engineering features.

\subsection{Manner of processing regulations}

In other countries where the primary tax legislation is supplemented by a comprehensive system of interpretative regulations, a regular procedure doubtless will be developed for drafting original regulations, as well as amendments should the primary legislation itself undergo amendment. But, as has been seen, statutory regulations, as used in the United Kingdom, have a much more limited scope. Each such regulation has something approaching an ad hoc character; in consequence, the process of bringing them into existence has not been formalized.

Generally speaking, however, the Board's secretariat takes the initiative in preparing any given set of regulations. To provide continuity, members of that office who are familiar with the underlying problem, having looked after the Department's interests when the enabling statute was originally proposed to Parliament, normally continue to handle the matter at the later point when the related regulations are to be prepared. The staff of the secretariat are administrators, not trained

6 See 2.4 supra. 
lawyers. However, they may seek the advice and assistance of the legally qualified staff of the Solicitor's Office. They also usually keep in touch with the relevant technical branch of the Department (e.g., with the specialist Inspectors in the Chief Inspector's Office) as the draft of the regulations takes shape.

Whether interests outside the Department will be consulted while the regulations are still in draft form and, if so, the arrangements to that end, will depend largely on the particular subject matter. The secretariat's timetable, within which regulations must be processed, is also variable and depends on the circumstances.

\section{Section C. The Rulings Program}

\subsection{Formal advance written rulings to taxpayers}

It is only in a few very special cases that the tax code gives the taxpayer the right to obtain a formal written ruling regarding the probable tax consequences of a transaction which he proposes to carry out in the future. Parliament has been extremely sparing in creating such a right. In each case where it has done so, it was enacting unusually sweeping provisions designed to counter avoidance of tax liability by artificial transactions; and there was some risk that its broad language would become a deterrent to normal business transactions unless the affected persons could obtain a clearance beforehand.

The first example dates from 1951. In that year there was a steep rise in profits tax rates, and antiavoidance legislation ras deemed necessary. It was designed to cover any transaction where the main purpose, or one of the main purposes, was avoidance of or reduction of liability to profits tax. In such cases, the Board of Inland Revenue was authorized to adjust the liability in a manner which counteracted the avoidance or reduction. Further, the legislation provided that avoidance or reduction would be presumed to have been the main or one of the main, purposes in certain types of transactions (e.g., on the transfer or acquisition of shares in a company) if the main benefit which might have been expected to accrue in the immediately succeeding years was avoidance or reduction of liability for the tax. It was provided, however, that a company could send to the Board full particulars of a projected transaction; and the Board, if satisfied that the transaction was being entered into "for bona fide commercial reasons" and ought not to be brought under the section, then must notify the company 
of its finding. In such event, the Board could not thereafter invoke the statutory provision in respect of the transaction described to them (though such a clearance does not prevent further action under the section if the particulars supplied did not amount to a full and accurate disclosure of the material facts).

Since this device of an advance clearance under these particular circumstances is considered as an exceptional departure, one to give swift comfort to a business man, an oral conference is not available. However, a refusal of advance clearance does not preclude recourse to the courts should the transaction be held by the Inland Revenue to fall within the thrust of the statute.

In 1960, provision for advance clearances was again inserted in antiavoidance legislation-this time in the income tax and surtax fields. For present purposes, it is enough to summarize the two groups of avoidance devices to which this legislation was directed:

(1) The first group is illustrated by cases where the disposal of a company's stock-in-trade (inventory) was effected indirectly by arranging for the intended purchaser to buy, not the stock-in-trade itself, but the whole share capital of the company holding it (so that the result was a capital gain for the former shareholders instead of a taxable profit for the company itself).

(2) The second group involved the manipulation of holdings of securities, so as to bring about a tax advantage analogous to that sought to be gained by the operations known as "bond-washing" and "dividend-stripping."

For the first group, the legislative remedy was, broadly, to make the vendors of the shares liable for income tax (and, if applicable, surtax) on an appropriate proportion of the taxable profit which would have been realized by the company had the disposition been carried out in a straightforward fashion. But it was also provided that prospective vendors and purchasers otherwise within the scope of the section might apply jointly to the Board of Inland Revenue for an advance clearance. To obtain such, they are required in effect to show that the company itself will eventually dispose of its stock-in-trade in a manner which produces a realized profit to the company. If the projected sale is carried out within six months of the clearance date, such a clearance again prevents the Inland Revenue from invoking the statutory provision. 
For the second group of avoidance devices, the remedy (as in the 1951 precedent) was to authorize the Board of Inland Revenue to require adjustments of liability sufficient to counteract the tax advantage sought to be obtained. The section did not apply, however, to transactions carried out "for bona fide commercial reasons," obtaining of tax advantages not being a main object. Here too, persons who intended to undertake one or more such transactions were authorized to seek binding advance clearances, by sending full particulars to the Board which then had the duty to respond one way or the other.

No formal procedure has been prescribed with respect to applications for a clearance under the three sections just described. A letter giving all relevant information is sufficient. Before the Board will rule, the application is examined by the secretariat in consultation, where appropriate, with the Office of the Chief Inspector or the Surtax Office. The Board's ruling takes the form of a simple notification, that a clearance is granted or, as the case may be, withheld. The sole purpose of the clearance system, as previously stated, is to prevent the legislation from acting as a deterrent to normal business transactions. Thus, if a clearance is withheld, there is no reason why the applicant should be permitted to make elaborate legal arguments regarding the precise technical application of the legislation. Such argument would be more appropriately held over to a later stage should the applicant, notwithstanding denial of advance clearance, carry out his proposal and should the Inland Revenue then take countervailing action under the statutory provision.

While statistics regarding the number who apply for clearances are not available, in the case of mergers or reorganizations involving issuance of shares to the public, it is not uncommon for the published prospectus to state that clearances have been obtained.

\subsection{Informal technical advice to taxpayers on proposed transac- tions}

The relatively restricted compass of the area within which the United Kingdom tax code has given taxpayers the right to obtain a formal advance ruling on the tax consequences of a proposed transaction is matched by the absence of any general custom of providing informal or oral technical advice on such transactions. However, as to one or two areas of tax law, the practice of the Inland Revenue Department does permit such advice to be given, and this practice might be looked upon as a partial rulings program. 
An outstanding example of this is afforded by the advice which the Department is willing to give when a business concern decides to establish a superannuation fund-or to institute some comparable scheme-for the payment of retirement pensions to its employees. The purpose is to give advice as to whether a given plan will qualify for tax purposes if carried out in accordance with the proposal submitted. The specialist unit at headquarters is able at a preliminary stage to call the employer's attention to any features of the proposal which make it difficult for the plan to achieve recognition for tax purposes and advises on the changes which would eliminate points of difficulty. The matter can be handled by correspondence, or by a combination of correspondence and oral discussion.

Since the advance informal advice is given by the echelon of the Department which renders technical advice to the Board's secretariat on recognition of pension arrangements when formally constituted, as a practical matter employers can place great confidence in the rulings they receive. It would be very unusual for an employer's representatives to omit the precaution of informal consultation before the proposed pension arrangements become legally binding on the employer.

It should be observed that this exception to the normal norulings practice of the department involves a circumstance in which the official who is consulted can obtain a complete picture of the proposed transaction. He can be supplied with complete copies of the proposed trust deeds and other legal documents which establish the funds and regulate the rights and obligations of employer and employees. The same is true in the other principal area in which informal technical advice is regularly given, namely, to charitable organizations. The tax code exempts from income tax, subject to conditions, "a body of persons or trust established for charitable purposes only." The Chief Inspector's specialists who give technical advice to the Board's secretariat on the recognition of charitable organizations customarily give informal advance rulings on the tax effect of a proposed constitution (corporate charter and bylaws), or change of constitution, in much the same way as the staff of the unit which handles questions about pension arrangements.

\subsection{Technical advice to field offices}

It is evident that the arrangements just described for giving formal advance rulings or informal technical advice on the tax aspects of proposed transactions cover only a small proportion 
of interpretative tax questions which arise. It follows that, in general, the key role in resolving such questions falls to the local Tax Offices which must apply the abstract language of the tax code to completed transactions in the course of making yearly assessments. Consequently, the very greatest importance attaches to the system adopted within the Inland Revenue Department for giving them technical guidance in the interests of uniformity and certainty.

The primary source of guidance upon which the local Tax Office relies in performing its task is that afforded by the departmental instruction manuals and by the circulars (mimeographed or printed) sent out from headquarters. These can be considered as a single medium because the instruction manuals represent a consolidated version of those previous circulars having permanent value, and also because the circulars use the instruction manuals as the point of departure in explaining new problems. Indeed, a circular may well take the form of a textual amendment of the pertinent passage in one of the manuals. It is convenient, therefore, to refer comprehensively to the circulars and manuals under the single name of instructions.

As a result of long experience, the conclusion has been reached that the local Tax Offices will be best served if editorial responsibility for instructions is placed on a single unit in the Office of the Chief Inspector. Inter alia, such consolidation helps to ensure use of uniform terminology and adequate cross-references to other instructions dealing with cognate problems. Because instructions often prescribe procedures as well as give substantive technical advice, the Instruction Section was made a part of the Organization Group in the Office of the Chief Inspector. ${ }^{7}$

Though editorial responsibility for a new instruction rests with the Instructions Section, that section necessarily consults with the specialist or specialists interested in its subject matter when preparing the text. To the extent the instruction attempts to resolve interpretative questions, the specialist provides necessary guidance regarding the departmentally accepted view of the law. In its final form, the instruction is sent out under the authority of the Chief Inspector; but where the instruction deals with a matter of substance (as distinct from a purely procedural matter), the text first will be submitted to the Board's secretariat to insure that the stated interpretation carried their approval.

7 See Chap. XVII, 1.2 supra. 
The circumstances which trigger new instructions vary from one occasion to another. In one case, for instance, Parliament may have amended the law, and the practice of the Department must be altered to conform to the amended legislation. Or a particular statutory provision may have been interpreted by a court decision. While local Tax Offices regularly receive the reports of tax litigation, a new instruction may be needed to point out the extent to which the new court decision appears to govern application of the code to situations analogous to, but not identical with, the actual situation subjected to litigation. Again, examination of some problem at headquarters (for whatever reason) may have clarified views hitherto held on a debatable question of interpretation, and it may be thought desirable to communicate the result to local Tax Offices. As a last example, headquarters may find that a question previously deemed to have only academic interest has begun to assume practical significance in a number of actual cases, and thus merits specific guidance in an instruction.

Instructions, however, are only part of the story. It previously has been stressed that (subject to compliance with departmental instructions) the District Inspector in charge of a local Tax Office has an independent command in a very real sense. Indeed, he has discretion to arrive at a reasonable settlement of controversies arising with taxpayers in his area. Nevertheless, from time to time he may want technical guidance on some specific point not adequately covered by the instructions. He is entitled to submit his problem to the relevant specialist at headquarters, though he will not do so lightly. In making such a submission, which normally is in writing, he is expected to provide, not only an adequate summary of the facts of the actual case giving rise to his request, but also citations to the statutory provisions and to any court decisions that appear relevant, together with an indication of his own view as to the correct solution. The object at this stage does not go beyond providing the District Inspector with an expert opinion on the interpretative question. In consequence it is not customary for the headquarter's specialist to meet with the taxpayer whose affairs are covered by the submission. Should the specialist think it desirable, before reaching a decision, to have a more complete understanding regarding the taxpayer's view of his own affairs, he probably will leave it to the District Inspector to make the necessary contact.

Although the Surtax Office is not a field office in the ordinary sense of the term, since it assesses surtax centrally for 
the whole of the United Kingdom, it nevertheless resembles the local Tax Offices in that it has direct contact (if only by correspondence) with the taxpayers whose liabilities it handles. When the amount of a taxpayer's income from a given source has been finally determined for ordinary income tax purposes, that amount is conclusive in calculating that particular source's contribution to the taxpayer's total income for the purpose of determining his surtax for that same year. This often means that interpretative questions affecting the assessable amount of an item of income, if not resolved between the taxpayer and his local Tax Office prior to the point the Surtax Office considers the surtax matter, continue to be the primary responsibility of the local Tax Office. Nevertheless, interpretative questions can arise for the first time in the context of the surtax computation for a case where no ordinary income tax assessment was required. A simple example might relate to the precise amount of an income item which was subject to deduction of tax at source and for which, accordingly, no income tax assessment was required. In this circumstance, the Surtax Office bears the responsibility of upholding the departmental construction of the tax code's provisions. Since the Surtax Office is a centralized branch of the headquarters organization, it is not as dependent on instruction manuals and circulars as the local offices, in trying to achieve uniform administration. Nevertheless, even at this higher level, the use of branch instructions has been found advantageous. The details of this separate system of branch instructions need not be discussed here, however; the procedures followed correspond generally to those associated with the Chief Inspector's instructions to local Tax Offices. For example, the Board's secretariat will be informed in advance regarding important newly proposed interpretations.

\subsection{Publication of technical advice given taxpayers and local offices}

The question of whether the Department should or should not publish what are sometimes termed Practice Notes in order to alert the public to interpretations officially placed on tax statutes was the subject of earlier debate. Some of the relevant arguments were indicated in the Final Report of the Radcliffe Commission:

982. The preparation of Notes of this sort is not free from pitfalls. In the first place the style and content of the Notes must be adapted to the needs and understanding of the prospective reader; and these must be supposed to differ from one case to 
another according to the branch of the tax code to which the Notes relate. Again, an official publication may well prove embarrassing if it does not state the whole law in complete detail. If minor qualifications of the main principles of the code are omitted in the interests of simplicity, there is a risk of misleading those taxpayers to whose affairs some such qualification is in fact relevant: on the other hand, if detailed treatment is resorted to, the Notes may be of little value except to the skilled lawyer and accountant-whose training already fits them to derive the same information at first hand from the code itself and the reports of decided cases. A further problem arises when the legal provisions to be dealt with have not been the subject of any Court decision. Unless the Notes are to give some account of the supposed construction of those provisions they may be seriously incomplete; but if they do enter upon the matter it can be objected that they lack authority. When in the past the Board have volunteered a public statement as to the basis of liability which they themselves suppose to be applicable in a given set of circumstances their action has sometimes been criticised as a usurpation of the proper functions of the appeal Commissioners and the Courts and they have on occasion been accused of an attempt to overawe taxpayers. We think that criticism of this sort is misconceived. The Inland Revenue Department must do what it can to secure that the law is uniformly administered; there must be therefore some view, officially received, as to the right interpretation of each enactment that bears upon the computation of liabilities. This view may have to be a provisional one in cases where the language of the statute has not been judicially construed, but that is no good reason for not letting interested taxpayers know what it is if it is regularly acted upon by the Department in its executive work of computing tax liability.

983. We ascertained from the Board that they were in favor of adding to the existing series of pamphlets and that a certain amount of preparatory work had already been undertaken for that purpose. In spite of the difficulties to which we have referred in the previous paragraph we think that the project ought to be encouraged, and we recommend that it should be persevered with. The kind of publication we have in mind is one which would describe, preferably with illustrative examples, the effect that a particular branch of the tax code is understood to have; the presentation in summary form of the facts of individual cases considered at headquarters and of the decisions arrived at was also suggested by some witnesses, but we do not think that a disconnected series of "rulings" of this sort would have any real value.

The pamphlets in existence at the time of that report consisted chiefly of a series explaining the postwar system of capital allowances for expenditures on different types of depreciable 
assets. Following the above recommendation, the Board have repeatedly added to their number. The subjects bear on such matters as the arrangements for double taxation relief, maintenance claims for relief in respect of expenses connected with the ownership of real property, and the tax consequences when company directors and executives receive benefits in kind or expense allowances from their companies.

In particular, the program has made a sustained effort to issue pamphlets which provide technical guidance on major legislative changes. For example, pamphlets have been issued explaining respectively (1) the 1957 tax reliefs for Overseas Trade Corporations, (2) the 1962 extension of the income tax to certain short-term gains, and (3) the 1963 comprehensive reform of provisions governing tax liability in respect of rents, etc., from real property.

A typical pamphlet conforms to the general specification suggested by the Radcliffe Commission, that is, as to some distinct branch of the tax code, it seeks to cover, in outline at least, the effect of the legal provisions on the whole range of normal situations to which those provisions are directed. When possible, definitions in general terms are illustrated by citing concrete instances which would (or would not) be covered; and simple numerical examples are added where this would help to illustrate the mathematical aspects of particular provisions. The emphasis throughout is upon final results deemed to follow from the terms of the statute, rather than upon the legal reasoning which could be advanced in support of the interpretation adopted.

It is through this publication program, and not through any system of published rulings on specific cases submitted for that sole purpose, that the Inland Revenue Department seeks to provide taxpayers with a starting point from which they may begin the study of interpretative questions arising in connection with their own tax affairs. 


\section{CHAPTER XIX}

\section{ASSESSMENT, REFUND, AND ADMINISTRATIVE APPEAL PROCEDURES}

\section{Section A. Assessment and Audit Procedures}

\subsection{Introductory note}

The assessment procedure adopted by the Inland Revenue Department follows a common pattern, whether the tax involved is income tax, surtax, or profits tax. The taxpayer is required by statute to furnish a return showing the sources of his income and the amount of income derived from each source. The local Tax Office or the Surtax Office then scrutinizes the information supplied, calls for any further information or explanation that appears necessary, and makes arrangements for a formal assessment in the amount that appears to be warranted by the facts.

This common pattern extends beyond cases in which the definitive action to be taken is an assessment. In a country such as the United Kingdom, which applies tax deduction at source-i.e., withholding-to a wide variety of income sources, cases in considerable numbers are bound to arise where the aggregate tax deducted exceeds the amount of the recipient's true liability.

For example, consider an individual whose income is derived primarily from investments, the income of which is subject to withholding at the source. This same individual may be entitled to various personal allowances and reliefs with respect to his dependents, or his business activities may have resulted in a net loss which he is entitled to set off against income from other sources. In such a case, this individual is entitled to a refund and will not receive an assessment. The procedural steps, however, are much the same as in the assessment situation. Such a taxpayer presents the necessary information on a return, and the initial examination is conducted in the same way and, generally speaking, by the same Tax Office which would have handled the matter if an assessment were required.

However, in the case where taxpayers derive their income from wages and salaries, both subject to withholding at the source, the making of a formal assessment on such salaries 
or wages is a prerequisite in the process of establishing whatever adjustment may be necessary, whether the amount of such an adjustment represents a refund or an assessment. ${ }^{1}$

In view of the foregoing, it seems proper to regard the making of assessments and the payment of refunds as alternative aspects of a single process. This conclusion is reinforced by the fact that the remedies open to the taxpayer when he disputes the amount of the refund offered to him are fundamentally similar to the remedies which a taxpayer can pursue when he disputes the amount of an assessment. In either type of case, he can make an oral argument before appeal Commissioners having jurisdiction in the matter, and can then appeal, if need be, to the courts on a point of law-as discussed in Chapter XX infra.

The tax administration of some countries use the so-called self-assessment system, that is, the field office automatically records as the assessment the tax liability calculated by the taxpayer himself on the return he files. This initial taxpayerdetermined assessment is then checked, but only in a selected proportion of the cases, by a subsequent examination-described as an audit-designed to verify the adequacy of the return. The United Kingdom does not use the self-assessment system; some degree of scrutiny is regularly applied to each return before final assessment. Therefore, the audit process is not distinct from the process of assessment.

Every taxpayer's return is processed to establish the correctness of the information stated thereon. For wage earners, who have no other source of income, this is a matter of determining whether or not, in comparison with past years, the taxpayer has reported his dependents correctly and whether the employer has withheld the proper amount under "Pay as you Earn." The same type of verification is applied where a return shows, in addition to earnings, income from another source, i.e., investments. An actual check of the mathematical accuracy to ascertain the totals (other than for incomes subject to surtax) is not necessary because the withholding system will have insured that a taxpayer will have been taxed correctly for each source of income.

1 The tax withheld by an employer is calculated on a basis which takes account of the employee's personal allowances and reliefs, to the end, hopefully, of collecting the correct final liability. The system in fact achieves this in the great bulk of cases; and when it does so, the law permits a formal assessment to be dispensed with unless the employee requests one. 
Even incomes subject to surtax are given the same processing at the local office. When the case reaches the Surtax Office for processing at that level, the Surtax Office then concerns itself with the exact amount of any income subject to withholding. 2

\subsection{Details of the assessment and audit procedures}

Ordinarily, the assessment procedure takes as a point of departure the taxpayer's own return of his income. A taxpayer's written claim for a refund (including where appropriate his statement of income) performs a similar role in the refund procedure. Even the "Pay as you Earn" system does not depart completely from this principle. Under that system, a return received from the employee in an earlier year, supplemented by any later information he may have supplied during the current year, is used by the Tax Office to determine the code number to be furnished the employer so the latter can determine from official tax tables how much tax should be deducted from any given wage payment. Thus even if the withholding process is deemed equivalent to a species of provisional assessment, it still is based upon a return by the employee. When the employer, after the end of the year, reports the total amount of tax deducted, the Tax Office's provisional assumptions about the employee's circumstances can be checked against the employee's return for that year. Normally only if the two differ (due, e.g., to a midyear change of circumstances not previously known to the Tax Office and not reflected therefore in the code number which governed the employer's action) will it be necessary to make an assessment. Although the taxpayer's return of income is tremendously important to the Department's procedures, a taxpayer is not allowed to defer his liability by neglecting to make a return. Where he fails to submit his return or submits one which is incomplete or unsatisfactory, the assessing authority is authorized by statute to make an assessment according to its best judgment.

Where surtax or profits tax is also involved, a separate return will not necessarily be obtained. When individuals have incomes sufficiently large to render them liable to surtax, there is a regular procedure by which photocopies of the income tax returns they have delivered to the local Tax Office are passed

2 It will be recalled that a determination by the local office setting out an assessment of tax on any income not subject to withholding is conclusive. See Chap. XVIII, 2.9 supra and 3.2 infra. 
on to the Surtax Office. Again, a company's profits tax liability is handled by the inspector who handles its income tax liability; the information supplied to him serves for both taxes.

The typical income tax return form provides space for the taxpayer to list all his different sources of income and the actual amount of income derived therefrom in a stated twelve months' period. Space is also provided to enter claims for the various personal allowances and reliefs. In other words, returns are designed to give the Inland Revenue Department as comprehensive a view as possible of a taxpayer's situation. Indeed, if the information requested was supplied with complete reliability year by year, the local Tax Office or the Surtax Office often could compute the proper tax solely by reference to the information in the series of annual returns. To make the computations for any given year may require examination of more than one return in the series. While each return would show the actual income of the tax year just completed, the assessment for certain types of income is measured by the amount received in a different year.

In making out his return, a taxpayer is not expected to resolve interpretative questions. Rather he is expected to present the raw materials which the Inspector will use in the decision-making process. Thus the taxpayer is to record the actual receipt of all kinds of gross income for a given period. Where expenses incurred or other amounts are claimed as a deduction from any one type of the several types of gross income from which the total gross income is derived, the taxpayer must show each class of deduction by a separate entry, to enable the assessing officer to determine whether in fact they are legally deductible. Similarly, in connection with the allowances and reliefs for dependents, etc., the return form asks that the facts be stated, so that the assessing officer can decide for himself whether those facts do confer a legal right to the allowance or the relief.

This approach, however, would hardly be practical with regard to business profits. Theoretically, only the net profit, which is the only chargeable income, needs to be shown in the taxpayer's return. As a practical matter, however, such a taxpayer almost invariably will supplement his return by supplying the local Tax Office with his accounts. In the case of a business of any magnitude, these will consist of a profit and loss statement and balance sheet, both vouched for by a professional accountant. Detailed depreciation schedules will also be included if the nature and scope of enterprise's equipment 
suggests this may be essential to a proper assessment. Such business accounts are freely supplied, although the Inspector handling the case has no express statutory power to demand them. One reason for such cooperation is that, if the Inspector believes the information given to him is inadequate, he does have the power to assess the profits on the basis of an estimate. Further, the taxpayer then would be obliged to contest the matter at an oral hearing before the appeal Commissioners. Where the Commissioners hear an appeal as to the chargeable amount of business profits, they do have statutory power to require, under penalty, submission of business accounts.

In examining taxpayers' returns (and any supporting accounts), Tax Offices make methodical use of information returns obtained from third parties. The degree to which an office audits a return naturally varies with the types of income it records. If, for example, a taxpayer earns interest from bank deposits, there can be little room for debate about its effect on his chargeable income. Again, if he is employed, there can be little question about the amount of gross income he derives from this source; correspondence may follow, however, regarding the merits of the taxpayer's claimed personal expenses against the gross remuneration. The type of income which generates most debatable questions is that arising from business profits. In consequence, the Department follows the practice of entrusting examination of business accounts to the senior members of the local Tax Office, i.e., to Inspectors who have completed the technical training program.

An Inspector engaged in the examination of business accounts takes due note of the professional standing of the persons responsible for their preparation. Should a trader submit home-made accounts in support of his return, the Inspector may invite him in for a conference, to obtain an oral explanation of the basis on which they were prepared. On the other hand, he would no doubt place much greater reliance on accounts verified by a qualified professional accountant. Nevertheless, business accounts, however satisfactory, do not resolve all tax questions. They reflect only a profit figure determined according to accepted conventions of commercial accounting. Rules for calculating profits for income tax purposes diverge on some counts from those commercially accepted conventions. For example, a sound but conservative commercial approach may justify deduction of a particular expenditure deemed to be of doubtful value to the business, though for tax purposes the 
expenditure may be properly classified as a nondeductible capital outlay. In examining accounts, therefore, an Inspector reviews the possible areas of divergence. With one or more of these in mind, he may ask the accountant to itemize particular entries in the accounts to assist in arriving at a profit figure adjusted to conform to tax rules. In some cases, responsibility for valuation of inventory rests with the proprietor of the business rather than with his accountant. In such cases, the Inspector often requests a certificate from the proprietor specifying the exact basis of valuation-i.e., cost or market-employed. Professional accountants, on the other hand, can anticipate the points likely to be of interest to an Inspector, and many try to shorten the question-and-answer process by submitting suitable supplementary statements beforehand, when the return is filed.

At any stage during an Inspector's examination of accounts the taxpayer or his accountant may indicate an unwillingness to accept the Inspector's view of the law, either as it relates to inclusion of particular receipts or deduction of an expenditure. The Inspector is most willing to outline the reasons supporting his contention and to take into consideration the taxpayer's counter-arguments. In other words, an examination involves more than elicitation of information. The Inspector seeks to arrive at a figure to which the taxpayer will agree if they can reach an accord as to the manner in which the tax code-in the light of the established view of the Inland Revenue-can be applied to any interpretative issue of law arising from the taxpayer's case. To avoid misunderstanding, it may be well to say that the Inspector's very full authority to reach a solution locally of interpretative problems does not extend to giving up or making a compromise settlement with regard to any issue on which he believes, after weighing the competing strengths of the two positions, that the law provides an answer in favor of the Inland Revenue.

The processes described above also are normally applied to income and supplementary statements supplied to a local Tax Office in support of refund claims. When the assessment or refund procedure reaches the point where a final figure is accepted by the taxpayer, the actual assessment or repayment is handled without further formality. There is no comprehensive system of review by officials superior in rank to the official who made the actual decisions on behalf of the Department. In dividing up the workload, the Department seeks to minimize the need for any such review by allocating the work initially to a 
senior or junior officer according to its presumed degree of difficulty. Settled cases are scrutinized on a sampling basis by the Inspecting Officer during his inspection visits to a local Tax Office. His purpose in such a case is to appraise both the efficiency with which a particular staff member performed his present duties and his prospective fitness for promotion. The scrutiny is not intended as a countercheck of current work. However, should there be a situation (whether arising from an error in mathematics or interpretation) which is considered to justify an assessment requiring the payment of an additional tax, as long as the six-year statute of limitations has not run, it is possible for such an assessment to be made. Under such circumstances, the Inspecting Officer would call the matter to the attention of the Inspector who then would make the additional assessment-just as he would if he himself had noticed the situation in question.

Much of what has just been said about the procedures adopted in local Tax Offices applies also to the Surtax Office's assessment and repayment procedures. As previously noted, the Surtax Office is supplied with photocopies of returns submitted to local Tax Offices though, if it seems desirable, the office is legally authorized to ask the taxpayer for further details. Attention has also been drawn ${ }^{3}$ to a rule which makes the final determination of an income tax assessment conclusive also for surtax purposes to the extent the taxpayer is subject to both taxes. This rule extends also to certain deductions from total income-for example, to the deduction allowed when a net loss from business is set off against income from other sources. Certain of the personal allowances and reliefs for income tax purposes also have counterparts in the surtax sphere-for example, the allowances for children and other dependents. In consequence, it is standard operating procedure for the local Tax Offices to notify the Surtax Office of all decisions made locally which are relevant in calculating surtax liabilities. With all such information as the starting point, examination of the returns for surtax purposes is conducted in a manner corresponding to that used by local Tax Offices in their assessment and repayment work. For example, if need be, the Surtax Office will discuss with the taxpayer or his advisers any problems of interpretation which arise in applying the tax code to the particular case, and every effort will be made to arrive at a legally and mutually acceptable result.

3 See Chap. XVIII, 2.9 supra. 


\section{Section B. Administrative Appeals}

\subsection{Introductory note}

For the efficient operation of any tax system, there must be some ready means by which a dispute between a taxpayer and an assessing officer can be resolved by a third party. Litigation in a country's regular courts, however, may not provide a sufficiently convenient method in the first instance, particularly with respect to the many small disputes which can arise where tax liability extends to a large fraction of the total community. In consequence, some countries have deemed it advisable to introduce an initial appeal, less formal in character than regular litigation, and typically before an agency within the tax administration itself, hence the characterization administrative appeal.

In the United Kingdom, however, the existence of the General Commissioners and the Special Commissioners ${ }^{4}$ has afforded, from the earliest days of the income tax, a convenient and relatively informal procedure for submitting disputes to independent tribunals. Given the existence of these facilities, a felt need for a system of administrative appeals has not evolved. The law which governs appeals to the Commissioners makes it clear that the taxpayer's decision to file a notice of appealsuch notice constituting the commencement of the appeal-does not mean that such an appeal must be carried forward to an actual hearing. It is quite possible for the taxpayer and the representative of the Inland Revenue to reach an agreed settlement after the taxpayer filed his notice and up until the time the matter comes to an actual hearing. The law provides that the same consequences shall follow as if the Commissioners had decided the appeal on the same basis as that reflected in the agreement. This clearly implies that there is still room for administrative negotiation even after the Inland Revenue has made a formal assessment, to which the taxpayer objected (or, in a refund case, after repayment has been offered of a lesser amount than the taxpayer considers to be due him). Accordingly, although the United Kingdom has no formal system of administrative appeals, and though the belated negotiations described above are carried out by the assessing office itself, the arrangement-as described in the succeeding subtopic-has some of the earmarks of the more formalized administrative appeal procedures in other countries.

${ }^{4}$ See Chap. XX infra. 


\subsection{Details of procedures analogous to administrative appeals}

At that point where a taxpayer gives formal notice of appeal from the assessing officer's decision regarding his assess ment or repayment claim, another official, senior in rank to the first, may be led to intervene in either of two ways.

First, the initial decision-making official may think it appropriate to consult higher authority before making arrangements for the hearing on appeal. For example, a member of the local Tax Office's staff may consult the District Inspector in charge in order to seek confirmation of the position he has hitherto taken. A staff member of the Surtax Office likewise can consult his own superiors. Also on occasion, the District Inspector in charge of a local Tax Office may seek advice at this stage from headquarters; and if an important point of interpretation is at stake, it is possible for the Surtax Office to consult the Board through their secretariat. In any of the foregoing cases, if the higher authority which was consulted advises the lower decision-making official that his position was too extreme, the latter is authorized to make a further attempt to settle the appeal, before a hearing, by direct negotiation with the taxpayer.

Action along the above lines perhaps should be regarded as an extension of the basic assessment procedure; it bears no very close resemblance to administrative appeals available to the taxpayer himself in other countries. There is, however, a rather clearer parallel when it is the taxpayer who takes the initiative after giving formal notice of appeal. Such a taxpayer may think it worth while to write to the headquarters of the Inland Revenue Department, setting out his arguments and enquiring whether in the face of those arguments, the position previously adopted by his District Inspector is supported by headquarters. In this quite informal manner, higher authority within the Department can be asked to express a view of an interpretative question about which the taxpayer and the local decision-making official have hitherto disagreed.

Again this does not mean that the higher authority ever urges the decision-making official to compromise an issue. However, should the senior official, drawing on his years of service and experience, consider that the lower-level official has taken such an extreme position that, considering the facts of the particular case, it is unlikely that the Inland Revenue would prevail in court, he will suggest to the younger man that it would be reasonable under these circumstances to yield to the taxpayer. 
Again, the taxpayer may send his letter to his representative in Parliament, asking the latter to approach the Chancellor of the Exchequer (or one of the other Treasury Ministers assisting him) in support of the taxpayer's view of the disputed interpretative question. Often, of course, correspondence addressed to this level goes beyond the mere matter of interpretation. The taxpayer's dominant purpose may be to urge that, if the meaning of the tax law is indeed the one for which local officials have been contending, the government ought to propose an amendment to the law. This wider aspect of such correspondence is obviously beyond the scope of the present study. But to the extent that the correspondent also indicates his disagreement with the departmental interpretation of existing law, the report submitted by the Board of Inland Revenue to the Treasury Minister, to enable him to reply to the member of Parliament, will incorporate any necessary defense of that interpretation. The Minister will not necessarily discuss the technical aspects of the matter in his own reply. He may prefer to take the line that neither he nor his officials have the last word on interpretative questions. By noting that taxpayers have a statutory right to a hearing before the appeal Commissioners and that the correspondent had invoked that right, he may excuse himself from consideration of the legal arguments. Nevertheless, the very fact that a responsible echelon within the tax administration's headquarters was put on notice that a departmental interpretation is disputed will lead appropriate officials to re-examine the question before reporting back to the Minister for the purpose of facilitating his reply. This total process may turn out in any given case to be the informal equivalent of an administrative appeal.

However, the analogy of this and the preceding illustration to administrative appeals in other countries should not be pressed too far. There is no identifiable group of appeals officers. The correspondence is handled simply as part of the general correspondence reaching headquarters on the particular topic concerned. Any disputed question is investigated on behalf of the headquarters office as such, and the departmental reply is likewise sent in the name of the office. Since this type of correspondence is not formally segregated from all other correspondence handled at headquarters, no statistical analysis of the process is possible. Moreover, there is no set procedure; it suffices that the taxpayer or his representative should raise the disputed question in correspondence. His analysis, no doubt, will cover the ground as extensively as he thinks 
advisable for the purpose of explaining his case. On occasion a memorandum prepared by the taxpayer's legal advisers may be included, but there is no obligation to do so. When the taxpayer writes to seek intervention by headquarters, he may ask for an oral conference there for the purpose of enlarging on his arguments. In such case, if the disputed interpretation is one which previously has been fully explored in the case of other taxpayers, the headquarters office may indicate to him, in his own interest, that it appears doubtful to the Department that such an interview would serve any useful purpose. If, however, he persists in his request, an interview normally would be accorded. It is left to the initiative of taxpayers to decide whether to bring their own expert advisers to assist in developing the cases they wish to present.

In essence, these correspondents ask headquarters to intervene, by overruling the initial interpretative position taken by the local decision-making official. In the nature of things, the headquarters of the Department does possess the necessary authority. But the staff members at headquarters, no less than the other officials of the Department, are bound by the tax codes. Consequently, they have no special power to compromise a case for the sake of avoiding litigation.

Every official handling a case is bound equally by the same tax code. Hence no power at any level exists to split or trade issues in an effort to reach a settlement.

The foregoing relates to disputed assessments and repayments claims generally. Mention should be made, however, of two classes of repayment claims which are subject to a procedural review which has some similarity to the administrative appeal procedures of other countries.

The two classes of claimants include (1) persons who are not resident in the United Kingdom or whose justification for relief depends in some way on the claimant's residence or domicile, and (2) entities or trusts claiming charitable exemption. Although their claims can be given final approval by the local decision-making officer, the final rejection of any such claim, by statute, must be made by the secretariat at headquarters acting on behalf of the Board. This latter requirement automatically ensures re-examination at headquarters of any claim initially rejected by the local decision-making officer. 
Section C. Extent Administrative Processing of Refund Claims Departs from Administrative Processing of Assessments

\subsection{Introductory note}

It previously has been indicated that normal repayment claims, where based on overpayments made during the taxable years-usually through withholding-are subject to the same procedure as that applied to assessments. Part One, relating to the United States, indicated that there the refund procedure can be used as an alternative method of contesting a controversial question which arises in the setting of a proposed assessment. In particular, it was noted that a taxpayer, after the close of the taxable year in question, may actually acquiesce in an assessment with which he disagrees and pay the tax so assessed thus laying the foundation for a refund claim which he can then litigate in a different judicial forum than that which he would have used in contesting the proposed assessment itself. An exact parallel to this does not exist in the United Kingdom. The treatment accorded one class of repayment claims, however, might be fairly compared to the situation which prevails in the United States, but only in the sense that the procedures governing this one class of refund claims are slightly, though only slightly, different from those applicable to normal claims.

This class consists of claims asserted on the ground, as the statute puts it, that "error or mistake" was made. The typical situation which the statute seeks to accommodate is one where, after an assessment has become final and it is no longer possible to invoke an ordinary appeal, the taxpayer discovers that, by inadvertence, he overstated the amount of assessable income in the return he submitted to the Inland Revenue Department, by failing, for example, to claim some expense which legitimately could have been deducted. Where he can show because of his own "error or mistake" an excessive assessment has been made, he is permitted to apply for an appropriate adjustment of his liability for the year concerned.

\section{6 "Error or mistake" claims: Refund procedures prior to an administrative appeal}

Subject to a right of appeal to the Special Commissioners (and, on certain questions of law, to the courts), final decision on an "error or mistake" claim lies with the Board, at headquarters. But to facilitate a preliminary examination, the taxpayer is required to submit his claim to the office which handled 
the assessment in the first instance-the local Tax Office if the claim relates to an income tax or profits tax assessment, and the Surtax Office if it relates to a surtax assessment.

The preliminary investigation is not ordinarily a burdensome one. The very existence of the claim implies that the original assessment was based on a return made by the taxpayer or some supporting statement. Attention, therefore, can be concentrated on the particular point on which the return or statement is now said to have been erroneous. The extent of the examination necessarily varies with the character of the alleged mistake. A simple arithmetical slip, on the one hand, may be more or less self-explanatory. On the other hand, a claim alleging that a deductible expense was overlooked in calculating the profits of a business can give rise to a question regarding the legality of any deduction for that expenditure-just as such a question might arise during the procedure which leads to an original assessment on such profits.

The official who considers the claim must concern himself, however, with certain additional matters which need not be considered when an original assessment is in question. In the first place, the legislation authorizing submission of "error or mistake" claims excludes cases where the return or statement, though now seen to have been erroneous, was in fact in conformity with the practice generally prevailing at the time when it was made. This limitation is designed to prevent the Department from having to undertake a wholesale reopening of closed assessments when, for example, a court decision belatedly holds that some type of receipt, hitherto accepted on all sides as taxable, is actually nontaxable. To illustrate a second restriction on "error or mistake" claims, assume that the taxpayer mistakenly reflected an item of income in his return for 1963 , but that the item should have been included in his return for the earlier year 1962. Assume further that the assessments for both years were made in conformity with the return as submitted. It would be inequitable to permit the taxpayer to profit from his mistake by allowing him to reopen the assessment for the later year 1963 if, because of the lapse of time, the assessment for the earlier year 1962 could not be reopened. To prevent that type of inequity, the "error or mistake" legislation permits the Inland Revenue to take due account of income tax liabilities for years other than the single year to which the claim relates.

If the official who undertakes the preliminary examination of an "error or mistake" claim is satisfied that it is well 
founded and outside the limitations described above, he is empowered to approve it and arrange for the consequent repayment.

3.7 "Error or mistake" claims: Procedure equivalent to administrative appeal

It may be, however, that the relief offered by the initial decision-making officer falls short of the amount claimed or that, for one reason or another, he rejected the entire claim. If the claimant desires to contest that decision, the claim is forwarded to the Board's secretariat for a formal determination by the Board. This decision will be transmitted to the claimant in writing. The Board must formally act on the matter before the claimant, if the Board's decision is adverse, can invoke a yet further appeal to the Special Commissioners. Since the secretariat re-examines these disputed claims before seeking the Board's authority to refuse or restrict the claimed refund, the procedure has some points of similarity to the system of administrative appeals found in other countries, for there is a reconsideration by a higher echelon of a dispute between the claimant and the decision-making official in the local Tax Office or the Surtax Office. This is not, of course, peculiar to "error or mistake" claims. As previously noted, certain other claim procedures likewise involve a formal determination by the Board, as the final step before a disputed case can be referred to the independent appeal tribunal. 


\section{CHAPTER XX}

\section{RESOLUTION OF INTERPRETATIVE INCOME TAX QUESTIONS BY INDEPENDENT TRIBUNALS}

\subsection{Introduction}

Prime responsibility for resolving disputes over income, surtax, and profits tax has been divided between a group called General Commissioners and another known as Special Commissioners.

The Special Commissioners are a central body of full-time tax specialists, with jurisdiction over the whole country. In contrast, the General Commissioners are locally oriented. Each of the nearly 700 divisions, the areas into which Great Britain is divided for purposes of tax appeals, ${ }^{1}$ has its own body of part-time General Commissioners. ${ }^{2}$

Responsibility is divided between the General and Special Commissioners as follows:

(1) The General Commissioners have jurisdiction over almost all income tax questions. On some matters-e.g., claims for personal allowances and reliefs for family circumstances-they have exclusive jurisdiction.

(2) The Special Commissioners have exclusive jurisdiction of a few income tax questions, notably relief claims by charitable bodies or by persons seeking exemption on the ground of nonresidence as well as claims for double taxation relief by way of credit for taxes paid overseas. (Presumably Parliament allocated these areas to the Special Commissioners because of the difficulty of the legal questions which emerge and the desirability of securing uniform interpretations.)

${ }^{1}$ In the main, these divisions correspond to the ancient areas of local administration.

2 There are no General Commissioners in Northern Ireland. The Special Commissioners have jurisdiction to hear any appeal arising there which, if it arose elsewhere, could be heard by the appropriate General Commissioners. However, a Northern Ireland taxpayer may elect to have any such appeal heard by the local county court instead of by the Special Commissioners. 
(3) The two bodies have concurrent jurisdiction over a wide range of income tax questions, with the taxpayer being free to choose between the two bodies. Illustratively, the right of choice exists with respect to appeals against assessments on wages, salaries, business profits, interest, and income from overseas.

(4) They also have concurrent jurisdiction with respect to appeals against assessments for the profits tax.

(5) The Special Commissioners have exclusive jurisdiction over appeals relating to surtax.

Because of the many areas over which the General and Special Commissioners have concurrent jurisdiction, it is convenient to describe them collectively as appeal Commissioners. However complicated the distribution of responsibilities may appear, the appeal Commissioners do, nevertheless, provide full coverage for all income, profits, and surtax disputes.

While the appeal Commissioners constitute the main device for resolving tax disputes, some questions arising out of antiavoidance legislation can go to two other tribunals: the Board of Referees (in existence for many years) and the special tribunal established for the purpose of the 1960 Act (see Chapter XVIII, 2.7 supra). Like the appeal Commissioners, neither of these specialized tribunals has any function outside the tax area.

The appeal Commissioners and the two specialized tribunals make their own independent findings of fact and draw conclusions as to the applicable legal principles. Their decisions on questions of law may be appealed to the ordinary superior courts of the country possessing a general jurisdiction.

\section{Section A. Organization and Procedures: Trial Level}

\section{2a Organization of the General Commissioners}

Each of the nearly 700 bodies of General Commissioners holds sessions in a convenient town located in or near its relatively small geographical division. In consequence, the taxpayer-appellant normally can expect the hearing to take place within easy traveling distance of his home or place of business. 
There is no formal limit on the number of Commissioners to be appointed for any division. ${ }^{3}$ Two Commissioners are a necessary quorum to hear an appeal, but typically more than the minimum attend the sessions.

In England and Wales the Commissioners are appointed by the Lord Chancellor, ${ }^{4}$ in Scotland by the appropriate city or county council. The Commissioners are unpaid, but the clerk they appoint to assist them is remunerated from public funds. This clerk often holds a legal qualification although the Commissioners themselves are not expected to be legally qualified or possess special expertise in tax matters. ${ }^{5}$ The Radcliffe Commission stated the principles which should govern their selection:

In our view the qualities to be looked for are, in essence, that he or she should be an honest and fair-minded person, able to display some understanding of figures and of legal distinctions, and ready to treat his work as an important form of public service. It is desirable too, that the Commissioners in a division should not all come from one section of the taxpaying community and that they should therefore include in their number persons with incomes mainly dependent on personal earnings as well as persons whose incomes are derived from property.

\section{2b Organization of the Special Commissioners}

The Special Commissioners, with their jurisdiction covering the entire United Kingdom, are based in London. Many hearings take place there, but to accommodate appellants they also operate a circuit system visiting a number of the chief towns in the country. 6

The eight Special Commissioners are appointed by the Treasury. They receive remuneration and give their full time to their duties. A quorum of two Commissioners is required to hear an appeal. The statute provides no particular qualifications for appointment, but in practice they are drawn in

3 Formerly, there was a limit of seven on the number of General Commissioners with provision for an increase if the work load required it.

4 Under the English legal system, the Lord Chancellor combines the functions of a Minister of Justice and the head of the judiciary.

5 The role of the General Commissioners in the tax area is comparable to that of lay justices of the peace in applying the general law of the land.

6 Since the Special Commissioners act in place of General Commissioners in Northern Ireland, their circuit coverage of those counties is particularly thorough. 
roughly equal proportions from barristers and senior members of the Inland Revenue staff. After appointment, members from Inland Revenue have no further connection with their former Department.

\section{2c Organization of the Board of Referees}

The Board of Referees was created to deal with certain questions arising out of the temporary excess profits tax imposed during World War I. In theory, under certain circumstances it can be asked to determine the depreciation rate for any class of machinery, but in practice it only hears appeals growing out of legislation relating to the surtax avoidance which results when closely held companies fail to distribute their profits.

This complicated legislation is applicable in cases where the controlled company has retained more of its profits than is required to meet the reasonable needs of its business. Since this unreasonable accumulation deprives the Exchequer of the surtax otherwise payable by individual stockholder on dividends, Parliament provided in such cases for the surtax to be assessed as though a dividend had been in fact declared in an amount equal to the total amount of the undistributed income, not just to the amount considered to constitute an excessive accumulation. Failing payments by the stockholders, the surtax so assessed may be recovered from the company. Accordingly, the company has the right to appeal the determination on the ground inter alia, that amount of the accumulation was not unreasonable.

Since such an appeal concerns surtax, it lies within the jurisdiction of the Special Commissioners. There are in addition two ways which enable the company to lay the case before the Board of Referees:

(1) When the Inland Revenue threatens such a determination, the company's directors may, in effect, challenge the action of the Inland Revenue on the ground that there is no prima facie case for action. The directors' written statement and a written counter-statement on behalf of the Inland Revenue are considered by the Board of Referees which can either uphold the directors' contention or rule that a prima facie case exists, in which latter event the company's ordinary right of appeal still remains open to it. 
(2) Where the Special Commissioners have heard and decided an appeal against a surtax direction concerning the undistributed income of a controlled company, either the Revenue or the company may require the appeal to be reheard de novo by the Board of Referees.

In any such proceedings, it may be a crucial question as to whether the company's actual distributions were reasonable, taking account of its business requirements, including those necessary or advisable for maintenance and development. The Board of Referees has the function of bringing to bear on problems of this character a wider practical knowledge of business conditions than the Special Commissioners possess.

For this reason there are eighty-odd members of the Board of Referees, appointed by the Treasury from persons experienced in industrial and commercial affairs. The Board, located in London, has jurisdiction over the entire United Kingdom. The members act without remuneration but there are three salaried positions: a part-time chairman, appointed by the Lord Chancellor from the ranks of senior barristers, a deputy chairman for Scotland, and a salaried registrar. Each case is considered by a small panel presided over by the chairman. The members of a given panel are selected by the chairman, account being taken of special expertise they may possess regarding the particular industry with which the given company is associated.

\section{2d Organization of the 1960 Act tribunal}

As discussed in Chapter XVIII, 2.7 supra, legislation passed in 1960 empowered the Board of Inland Revenue to counter certain avoidance devices designed, through manipulation of securities held, to secure a tax advantage analogous to that sought through bond-washing and dividend-stripping operations. There was, however, no intention to penalize a transaction where it could be shown that it was carried out "for bona fide commercial reasons," the obtaining of tax advantages not being a main object. Parliament tried to avoid impeding normal business transactions by setting up an arrangement which enabled taxpayers to seek prior clearance for prospective transactions, and by creating special rights of appeal to a new bodythe so-called 1960 Act tribunal.

The functions given this tribunal, with respect to avoidance through manipulation of securities, resemble closely those of the Board of Referees in the surtax area: 
(1) When a taxpayer is notified that the Inland Revenue is contemplating counter-action under the relevant section of the 1960 Act, he may submit to the tribunal a written statement seeking a summary ruling that there is no prima facie case for counter-action. If the tribunal so rules on the basis of both the taxpayer's statement and any written counter-statement by the Revenue, the Revenue cannot then proceed any further in the matter. If, however, the tribunal does not so rule, the taxpayer still retains his normal right of appeal against the counter-action proposed by the Revenue.

(2) The exercise of that right of appeal will result in a hearing by the Special Commissioners. When such an appeal has been decided by the Special Commissioners, however, either the Revenue or the taxpayer may require the appeal to be reheard de novo by the new tribunal.

The 1960 Act tribunal has a further function. As discussed in Chapter XVIII, 2.7 supra, an earlier act of 1951, designed to prevent profits tax avoidance, gave the Inland Revenue a right to counter-action. The same act gave the taxpayer a right to appeal such counter-action to the Special Commissioners. When the 1960 Act tribunal was created, the opportunity was taken to provide an additional right of appeal under the 1951 statute. On demand of either the Inland Revenue or the taxpayer, the new tribunal must undertake a rehearing de novo of any future appeals.

The 1960 Act tribunal is a single authority for the entire United Kingdom. Its ex officio chairman is the chairman of the Board of Referees: he is assisted by two or more members appointed by the Lord Chancellor on the basis of their "special knowledge of and experience in financial or commercial matters."

\section{3a Processing appeals: The General Commissioners}

In Chapter XIX, 3.3 supra, the point was made that the taxpayer's easy access to convenient appeal tribunals independent of the Inland Revenue Department had removed any need for a formal system of administrative appeals -within the Department itself. The access is very easy indeed. No special formalities precede an appeal to the General Commissioners. The taxpayer notifies the Inland Revenue that he intends to appeal and indicates, in a general way at least, the grounds of his appeal. 
Payment of the tax in dispute is not a precondition of the taxpayer's right to a hearing. Indeed, if an appeal against an assessment is pending, collection of the contested tax is suspended until after the appeal is determined. ${ }^{7}$

The Commissioners who hear an appeal against an assessment (income tax, profits tax, or surtax) have authority to increase or reduce it, depending on the evidence. In keeping with this principle, once an appellant invokes their jurisdiction, he cannot withdraw his appeal without the consent of the Inland Revenue. Because of this ability to withdraw-subject to consent from Inland Revenue-not every appeal of which notice has been given goes forward to an actual hearing. In addition, the law specifically provides that if the appellant and a representative of Inland Revenue can agree as to the proper resolution of the dispute between them, ${ }^{8}$ effect may be given to that agreement as if it were a formal determination by the appeal Commissioners. Statistics are not available to show precisely what proportion of all appeals are disposed of ultimately by agreement rather than by decision, but there can be no doubt that the great majority are resolved by such agreement. In fact this is the normal result in certain types of cases, such as those where an Inspector relied on an estimated assessment of trading profits because the business accounts were not available

7 Of course, the portion of the assessment not disputed must be paid.

8 The Income Tax Act, $\S 510$ (1), provides as follows: "Subject to the provision of this section, where a person gives notice of appeal to the General Commissioners, the Special Commissioners or the Board of Referees against an assessment, or a decision of any kind with respect to income tax other than surtax or surtax, and, before the appeal is determined by the Commissioners or Board, the surveyor or other proper officer of the Crown and the appellant come to an agreement, whether in writing or otherwise, that the assessment or decision should be treated as upheld without variation, or as varied in a particular manner or as discharged or cancelled, the like consequences shall ensue for all purposes as would have ensued if, at the time when the agreement was come to, the Commissioners or Board had determined the appeal and had upheld the assessment or decision, without variation, had varied it in that manner or had discharged or cancelled it, as the case may be." However, it must be stressed that the phrase "varied in a particular manner" does not carry the connotation of settlement in the sense of adjustment or compromise. It means, for example, that where both parties come to an agreement that the assessment or decision was in error-as determined by a closer scrutiny of the point or points in issue-in one or more aspects, an alteration will be made to take account of such an error. 
to him at the time when the assessment had to be made. Where there is undue delay in producing the accounts, the Inspector may ask the Commissioners to arrange an interlocutory hearing so the taxpayer can be questioned regarding the reason for delay and warned that the Commissioners, at a later hearing, may confirm the estimated assessment if the accounts are not produced within some reasonable time limit which they specify. Such a warning is often sufficient to get a delay case moving again.

In the small minority of cases where, following notice of appeal, issues of fact or law emerge which cannot be settled by negotiation, the District Inspector in charge of the local Tax Office has full authority to decide when to terminate the negotiations and allow the appeal to go forward for hearing. $\mathrm{He}$ has no obligation to notify headquarters of appeals that are going forward, though he might do so in a particular case, for example, where he previously had sought advice from a headquarters specialist.

In nearly all appeals heard by General Commissioners, the Inland Revenue's case is presented by the District Inspector or one of the other Inspectors assisting him in the local Tax Office. ${ }^{9}$ In appeals of special significance, however, a member of the London or Edinburgh Solicitor's Office may represent the Department. 10

Taxpayers are entitled to present their appeals in person and many do so. It is quite usual, however, for taxpayers to be represented by a professional adviser-an accountant or solicitor or, more rarely, a barrister.

There are no written rules of procedure governing the hearings, which tend to be informal, especially if the taxpayer is appearing without the assistance of a professional adviser. The degree of informality varies from one division to another, however, depending on the particular views of the local Commissioners. The parties are not required to file formal petitions or other documents, but it is not uncommon for the two sides to draw up an agreed statement of facts to reduce the ground to be covered in the oral evidence at the hearing.

In a typical appeal, the hearing is opened on behalf of the appellant, who may submit oral evidence himself and call

9 The representation of the Department of Inland Revenue at appeals hearings is one of the matters covered in the training course for members of the Inspectorate. See Chap. XVII, 1.5 supra.

10 Members of the Solicitors' Offices in both London and Edinburgh are trained lawyers. 
witnesses. To the extent appropriate, he and his witnesses are cross-examined by the representative of the Inland Revenue and then re-examined. The Inland Revenue's case follows: if any witnesses are called on behalf of the Inland Revenue, they too are subject to examination. The appellant's reply follows.

There is no simple answer to the question, which party must shoulder the burden of proof. With respect to construction of the statutory provision applicable to a particular case, as distinct from ascertainment of the actual facts to which the law must be applied, the general rule is that the Inland Revenue must show that the item it claims to be taxable does come within the scope of the words imposing liability. On the other hand, once it has been demonstrated that an item comes within a charging provision, a taxpayer who claims the benefit of a relief provision must show that the latter provision does embrace his case. As to questions of fact, normal rules associated with other litigation apply, absent special circumstances.

The Commissioners usually announce their decision immediately after the hearing, though not infrequently they take time for consideration and later communicate their decision to the parties in writing. The content of their decision, i.e., whether it includes the reasoning they employed in reaching the result or simply notes that the assessment is confirmed, discharged, or modified (or that the claim to relief is allowed or refused), depends on the discretion of the Commissioners and varies with the circumstances of the case.

Excluding the delay cases previously described, the 700 sets of General Commissioners decide about seven or eight thousand appeals each year. The hearings are private; also, the proceedings and decisions are not reported. Hence, these decisions have no precedent value. Further, in theory, the decision the Commissioners reach on an appeal for a given year is not res judicata should the same taxpayer appeal to the same set of Commissioners on a similar question as to a later year. As a practical matter, however, a local Tax Office no doubt will attribute some significance to a General Commissioners' decision when a later appeal on a similar point arises in the same division.

\section{3b Processing appeals: The Special Commissioners}

In hearing appeals falling within their jurisdiction, the Special Commissioners exercise virtually the same powers and functions as General Commissioners. The description just given regarding procedures before the General Commissioners 
is equally applicable to the processing of appeals before the Special Commissioners, with certain qualifications.

A surtax appeal may be settled by negotiation as readily as an appeal relating to income tax or the profits tax. While the taxpayer's adversary is the Surtax Office, not a local Inspector of Taxes, the prime difference lies in the matter of representation. The Surtax Office staff does not present the Inland Revenue's case at the oral hearing should one prove necessary. On a surtax appeal, the London or Edinburgh Solicitor's Office represents the Inland Revenue. But on income or profits tax appeals to the Special Commissioners, typically either an Inspector from the appropriate local Tax Office or a member of one of the Solicitors' Offices will represent the government-as was true in the case of appeals to the General Commissioners. There is, however, one further alternative here; sometimes the Special Appeals Section of the Chief Inspector's Office presents the Department's case.11 Further, taxpayers themselves are much more likely to be represented by professional advisers, including barristers, before the Special Commissioners than before the General Commissioners. For that reason the proceedings tend to be somewhat more formal. The number of cases in which the Special Commissioners reserve judgment at the close of a hearing and later give a reasoned determination in writing also is proportionately greater.

Excluding cases in Northern Ireland where Special Commissioners also take the place of General Commissioners, between two and three thousand appeals are dealt with annually by Special Commissioners. This figure, however, includes a considerable number of delay cases where the hearing is little more than a formality. The number of appeals in other than delay cases probably can be put at less than one thousand.

\section{3c Processing appeals: The Board of Referees}

Attention previously has been drawn to the privilege accorded a closely-held company threatened with action under the legislation dealing with unreasonable retention of profits. The company can ask the Board of Referees for a summary ruling that no prima facie case for such action exists. Oral hearings are not held. The company's directors simply submit a written statement setting forth the facts and circumstances on which they rely in requesting the ruling. The Inland Revenue has a

${ }^{11}$ See Chap. XVII, 1.2 supra. 
limited period to transmit this statement to the Board of Referees, together with a written counter-statement setting forth its competing view. The Board of Referees then circulates the documents among the chairman (in Scottish cases, the deputy chairman) and the panel of five members chosen because of their relevant experience in industry. The members send their respective written opinions to the chairman (or deputy chairman). Usually, on the basis of the written opinions, he is able, without a formal meeting of the members, to announce the Board's determination.

The Board of Referees has a second function under the same legislation: to rehear de novo certain surtax appeals arising when either party thereto is dissatisfied with the Special Commissioners' decision. The dissatisfied party must submit within a limited period a concise statement of the facts and the grounds on which this further appeal is based. The respondent party then submits a counter-statement. If any question of fact is in dispute the chairman, at a meeting with the parties, provides directions as to proof and procedure and fixes a time by which the copies of documents intended to be used at the rehearing must be in the hands of the Board's registrar. By statute, the Board of Referees has the same authority at the rehearing as the Special Commissioners had at the original hearing, though otherwise the tax code does not prescribe the procedures to be followed. In practice, the rehearing is heard by the chairman (in Scotland, the deputy chairman) and four members chosen from the panel. And the procedures generally are similar to those followed at the original hearing before the Special Commissioners. For example, as in other surtax appeals, a member of the London or Edinburgh Solicitor's Office presents the Inland Revenue case.

In recent years from ten to twenty cases are handled annually under the summary procedure described in the second preceding paragraph. Rehearings have been much more infrequent. Over one recent four-year period for which statistics are available, only one rehearing took place.

\section{3d Processing appeals: The 1960 Act tribunal}

Like the Board of Referees (with which it shares a chairman), the 1960 Act tribunal has a double role: it handles written applications for summary rulings where the Inland Revenue has threatened counter-action under the legislation dealing with securities' manipulation, and it rehears appeals originally determined by the Special Commissioners where the Inland Revenue 
has taken counter-action. During its first three years, no rehearings took place. The tribunal, however, had dealt with fifteen cases under the summary procedure, some involving applications by more than one taxpayer. Since that procedure is very similar mutatis mutandis to the corresponding procedure adopted under the surtax legislation, it will not be described further here.

\section{Section B. Organization and Procedures: Appellate Tribunals}

\subsection{Organization of the appellate court system}

The United Kingdom tax code provides that the decisions of any of the independent bodies described in the previous Section are subject to review, but only as to questions of law, before the regular superior courts of the country. Thus, either party has a right of appeal to a court from appeal decisions of the General or Special Commissioners and also from decisions rendered by the specialized tribunals after rehearing cases originally heard by Special Commissioners. ${ }^{12}$

It is otherwise, however, in the case of the summary procedure by which the Board of Referees and the 1960 Act tribunal can be asked in the first instance for a ruling to terminate Inland Revenue's threatened action under the relevant special legislation. This summary procedure was designed to enable companies (or other taxpayers affected) to test quickly and before an expert independent tribunal their asserted grounds for believing that the special legislation should not be applied. As already indicated, a summary ruling in the taxpayer's favor is conclusive against further action by the Inland Revenue. Indeed, in keeping with the limited purpose for which the procedure was designed, such rulings are not subject to any form of appeal.

The particular court which exercises appellate jurisdiction varies from one part of the United Kingdom to another:

(1) In England and Wales, jurisdiction rests with the Chancery Division of the High Court of Judicature, sitting in London. Proceedings take place before a single judge of that Division; his decision may be appeased,

12 This right of appeal to a higher court extends also to cases where a Northern Ireland taxpayer has elected to have his appeal heard by the local county court instead of by the Special Commissioners. 
however, to the Court of Appeal, in which event normally three judges sit.

(2) In Scottish cases, jurisdiction rests with the Court of Session, sitting in Edinburgh, and is exercised by one of the Divisions of the Inner House, usually with three or four judges hearing the case.

(3) In Northern Ireland, jurisdiction rests with the Court of Appeal of Northern Ireland, normally with three judges sitting together.

Throughout the United Kingdom, there is a final appeal (assuming leave is obtained, if necessary) to the House of Lords sitting in its judicial capacity as the supreme court of appeal in civil matters for the entire United Kingdom. Up to five members of the House commonly sit together on tax appeals. These regular courts treat tax litigation as one part of all the varied business which comes before them. Because they are courts of general jurisdiction, their judges do not specialize in tax matters. 13

\subsection{Processing cases through the courts}

The right of appeal to a court is limited by statute to questions of law, the decision of the trial tribunal being final as to questions of fact. In addition to questions of fact where the prime issue is one of substantiation, questions such as whether a given course of activity involved carrying on a trade or whether, given the periods and circumstances of an individual's presence in the United Kingdom, he became a resident, are deemed essentially to be questions of fact. On the other hand, it is a question of law whether the evidence before the trial body justified it in drawing the inferences of fact upon which it relied in reaching its final decision. If a court concludes there was insufficient evidence on which the tribunal reasonably could reach the conclusion it did, the reviewing court would feel free to reverse.

While the taxpayer's right of appeal to the courts is not conditioned formally on his prior payment of the tax outstanding, the tax code does provide that the tax is payable on the basis determined by the trial tribunal notwithstanding any appeal to a court. Therefore, the Inland Revenue can enforce

13 It is possible, of course, that a particular judge, did specialize in tax matters as a barrister, before his elevation to the bench. 
collection while an appeal is pending. Tax paid while an appeal is pending would be refunded, however, to the extent appropriate, should the court modify the trial tribunal's determination. The taxpayer may, and occasionally does, choose to appear in person to argue his own case; but if he is represented by an adviser, he must employ the type of lawyer who has the right to appear before the court in question-that is, a barrister in England, Wales, or Northern Ireland, and advocate in Scotland.

When General or Special Commissioners or one of the specialized bodies decides an appeal against the Inland Revenue, should the officer who represented the Department at the appeal hearing believe further appeal to a court is advisable, he could refer the matter to the Board's secretariat. To enable the Board to decide whether to authorize resort to the courts, the secretariat consults the Chief Inspector's Office in income tax and profits tax cases or the Surtax Office in surtax cases. The secretariat wants to learn whether these offices feel that the decision in question is completely unacceptable or whether they dislike the decision but do not consider it worth contesting, illustratively because of the unlikelihood that a similar fact situation will reoccur or whether they feel they can live with the decision. Sometimes, of course, these offices will urge that the decision be appealed, even though an adverse decision on appeal is anticipated, as the resulting clarification of the law will permit the introduction of remedial legislation. In short, the secretariat consults these offices to discover the administrative reaction. For purely legal questions, the secretariat has recourse to the Solicitors' Offices, though time pressures involved in the secretariat's decision whether or not to appeal may well prevent such consultation at this early stage.

Where appeal to a court is authorized, the Board and secretariat keep in touch with subsequent progress of the case. Inland Revenue's actual representative in court will be a barrister or advocate, but the secretariat represent the Department in a lay capacity, communicating with the barrister or advocate through the appropriate Solicitor's Office. The latter office, however, prepares the brief for the barrister or advocate who represents the Department in court. And if a particular member of the Solicitor's Office handled a given case before the trial tribunal, he typically handles the brief on appeal.

14 Advocates also may appear before the House of Lords on appeals from the Scottish Court of Session. 
But the key document in appealing to a court is the socalled stated Case prepared by the trial body itself. On giving due notice and paying the prescribed fee, either the taxpayer or the Inland Revenue can obtain from the trial tribunal this written statement setting out the facts of the case and the tribunal's decision thereon. Documents produced in evidence can be annexed to the stated Case as exhibits. The Case normally is drafted in the first instance by members of the trial tribunal (or, in the case of General Commissioners, by their clerk). It usually is sent in draft form to the parties for their comments and suggestions, but the trial tribunal which states the Case bears the ultimate responsibility.

The actual court proceedings center around the stated Case. During the oral argument-an integral part of all court proceedings in tax controversies-the appellant's representative advances oral arguments in opposition to the conclusions reached by the trial tribunal. The respondent's representative, also orally, supports it. The court commonly delivers an oral opinion. In simple cases heard by a single judge, the decision is delivered at the end of the trial. In more complicated cases, especially those heard by the full panel of three judges, there may be a delay of several days. In either case, a full transcript is made available. The judgment by the court sets out fully the legal reasoning in support of its decision.

The number of tax appeals-income, profits, or surtaxbrought before all United Kingdom courts varies from year to year, but twenty-five is an average annual figure. All the decisions, together with the stated Cases, are published officially.

The precedent effect of court decisions can be summarized as follows:

(1) The House of Lords is bound only by its own decisions. Its decision binds all lower courts.

(2) The Court of Appeal (England and Wales), the Court of Session, and the Court of Appeal of Northern Ireland are bound by their own respective decisions. Each of these three courts treats the decisions of one of the others with great respect. While not strictly bound to follow them, divergency comes with considerable reluctance.

(3) A judge of the Chancery Division is bound to follow a decision by the House of Lords or the Court of Appeal 
(England and Wales). He is not strictly bound by a decision of the Court of Session or the Court of Appeal of Northern Ireland, but in practice almost certainly would follow it, especially where the earlier decision was unanimous.

Any member of the accounting and legal professions concerned with tax matters will pay close attention to all court decisions. If a given appeal is decided adversely to the Inland Revenue in a court of first instance and no further appeal is taken to a higher court, this generally is taken to mean that, in the absence of a statutory amendment, the Department will follow the principle of the adverse decision. However, a single decision may not always establish the precise limits of that principle's applicability. Thus, a decision not to appeal does not exclude the possibility of further litigation involving a somewhat similar but not identical situation. The Inland Revenue, however, does not follow the practice of publishing statements as to the presumed range of court decisions. 


\title{
PART SIX
}

\section{THE NETHERLANDS}

\author{
by
}

\section{H. Schuttevaer}

Acknowledgments are due to $H$. Baron van Lawick, $H$. van Bijsterveld, J. F. de Jong, and $A$. ten Sande, and their colleagues, especially J. de Koning and P. de Haan. 


\section{CHAPTER XXI}

\section{ADMINISTRATIVE ORGANIZATIONAL AND PERSONNEL FRAMEWORKS}

\section{Section A. Administrative Organizational Framework}

\subsection{Introduction}

The Dutch administrative organization charged with the levying and collection of taxes has three levels: national, regional, and local.

Prime responsibility for the assessment of taxes lies in the local offices, i.e., with the 103 inspectorates, authorized by statute to make assessments and whose decisions cannot be overruled by superior officials. Administrative appeal by a taxpayer from assessments made by personnel working in those inspectorates is to that same local inspector. There is no appeal to a higher administrative level. Differences of opinion which cannot be settled locally must be taken to the courts.

Otherwise, however, the eight regional offices, headed by district directors, do operate as administrative superiors of the inspectors, inspecteur der belastingen. In turn, these regional offices are supervised by the National Office Directorate of Direct Taxes, one of the seven directors responsible to the Director-General of Taxes who, with his counterpart, the Director-General of Tax Affairs, reports directly to the Under Secretary of Finance, the actual head of the administrative structure. 1

The subdivision of the national office, called the Directorate of Direct Taxes, has five subdivisions. Two deal with the individual income tax, the corporation income tax, and the wage tax; three deal with collection and administration. The subdivisions dealing with income taxes handle requests for information from local offices relating to interpretative matters or to situations where an assessment was excessive but the time for administrative appeal within the local inspectorate has expired. This same division handles taxpayer requests for information on the tax consequences of proposed transactions.

${ }^{1}$ The Minister of Finance is the titular head. 


\subsection{Organizational framework, national office level}

Chart I, opposite, sets out the arrangement of the national office. The portion of the national office responsible for the levying and collection of all taxes is headed by the Under Secretary of Finance. Reporting directly to him are the two directors-general: the Director-General of Tax Affairs and the Director-General of Taxes. ${ }^{2}$

The staff of each of these two directorates is made up of inspectors or chief-inspectors of taxes (who have served varying lengths of time in local or district offices) supported by lower level personnel.

The Director-General of Tax Affairs handles tax policy, tax legislation, and international tax affairs. Reporting to him are four directors. None of these directors is directly responsible for the resolution of interpretative problems in individual cases, although the Director of Legislation for direct taxes is indirectly concerned with such matters. His office drafts proposed legislation and prepares legislative regulations and directives. Thus, whenever groups of affected taxpayers-i.e., insurance companies, banks, shipping-unions, chambers of commerce, trade-unions, agricultural societies-are dissatisfied with a statute or with its interpretation and desire a change in legislation, they contact this office.

Responsibility for the levying and collection of all taxes rests with the Director-General of Taxes who has seven directors reporting to him. Two deal with administrative matters, one with general and legal affairs, and the remaining four with the several kinds of taxes: direct, customs and excise, death, registration and stamp duties, cadastral, and mortgage. The Director of Direct Taxes is the one concerned with income and wage taxes, and as to these, his office performs varied functions. Occasionally it informs the local inspectorates of decisions reached in certain tax cases with which they should be familiar. It responds to requests from local offices for advice regarding litigation policy positions. It also determines future governmental policy regarding tax decisions reached by final judicial authority. Finally, it handles so-called hardship cases, ${ }^{3}$

2 Prior to 1950 the functions of the two present directors-general were performed by a single Director-General. The increasing importance of preparing tax legislation and the emergence of pressing international fiscal problems led to the division of the office.

3 In nearly every tax statute, authority is conferred on the Minister of Finance to grant relief in situations where applications of the statute, even with a flexible interpretation would constitute a case of 


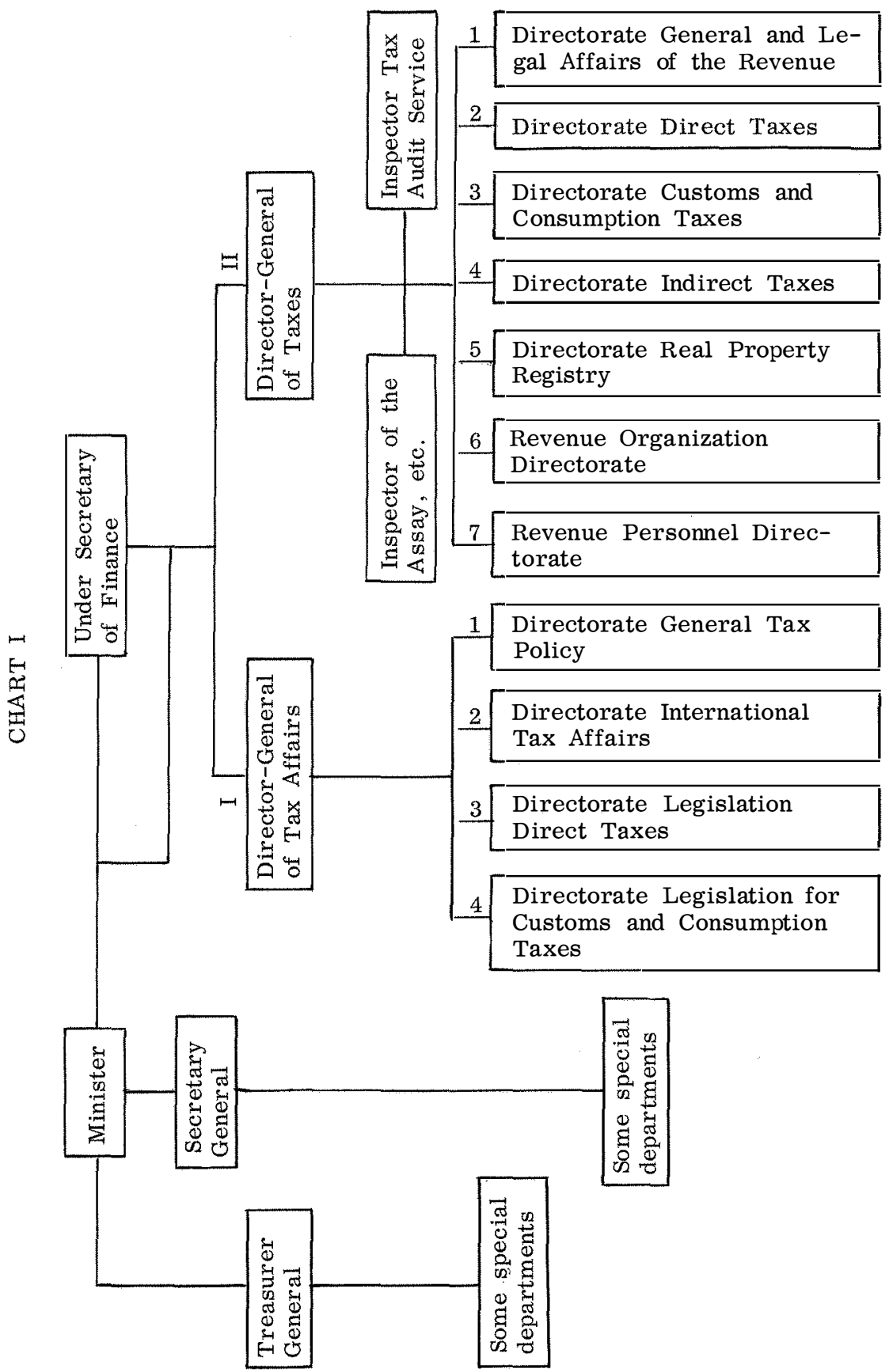


presented to it by inspectorates through the regional directors, although the Under Secretary of Finance actually announces the official decisions. ${ }^{4}$

\subsection{Organizational framework, regional office}

The eight regional directors' offices are concerned primarily with administrative matters. Each directorate contains a number of organizational units as set out in Chart II, opposite.

A regional director heads a staff ordinarily composed of four inspectors of academic level and of between thirty to fifty lower-level technical and administrative personnel.

The prime responsibility of a regional director is administrative supervision, to insure the smooth functioning of several local level offices. He personally does not perform any technical function with respect to the work of the local inspectorates which carry out audit, assessment, and collection functions and also handle their own administrative appeals.

In addition to his administrative responsibilities, the regional director has certain collateral functions. He remits tax payments in the case of insolvent taxpayers, and transmits socalled hardship cases to the national office, Directorate of Direct Taxes. Infrequently, a local inspector requests his advice in the handling of a particular case which poses interpretative difficulties or tactical questions. The regional director ordinarily responds to those exceptional situations, by forwarding the inspector's report, together with his own opinion, to the national office, Directorate of Direct Taxes. This same procedure is followed where a local inspectorate proposes to appeal a lower court decision to the Supreme Court, with ultimate approval regarding the appeal then resting with the national office.

On occasion a taxpayer may complain to the regional director with respect to an inspector's conduct while handling a

\section{(footnote continued)}

hardship, that is, a case where a tax, although in conformity with the statute, would be contrary to the intention of the statute. No statute can provide a concrete solution for every factual situation which may occur and interpretation will not always result in a reasonable conclusion. Thus in such cases the Ministry can provide relief through remission or reduction of the tax. Taxpayers, however, cannot claim such relief; it is wholly discretionary.

4 On some occasions, the national office, Directorate of Direct Taxes, delegates subsequent decisions in like situations to the regional or to the local offices. 


\section{CHART II}

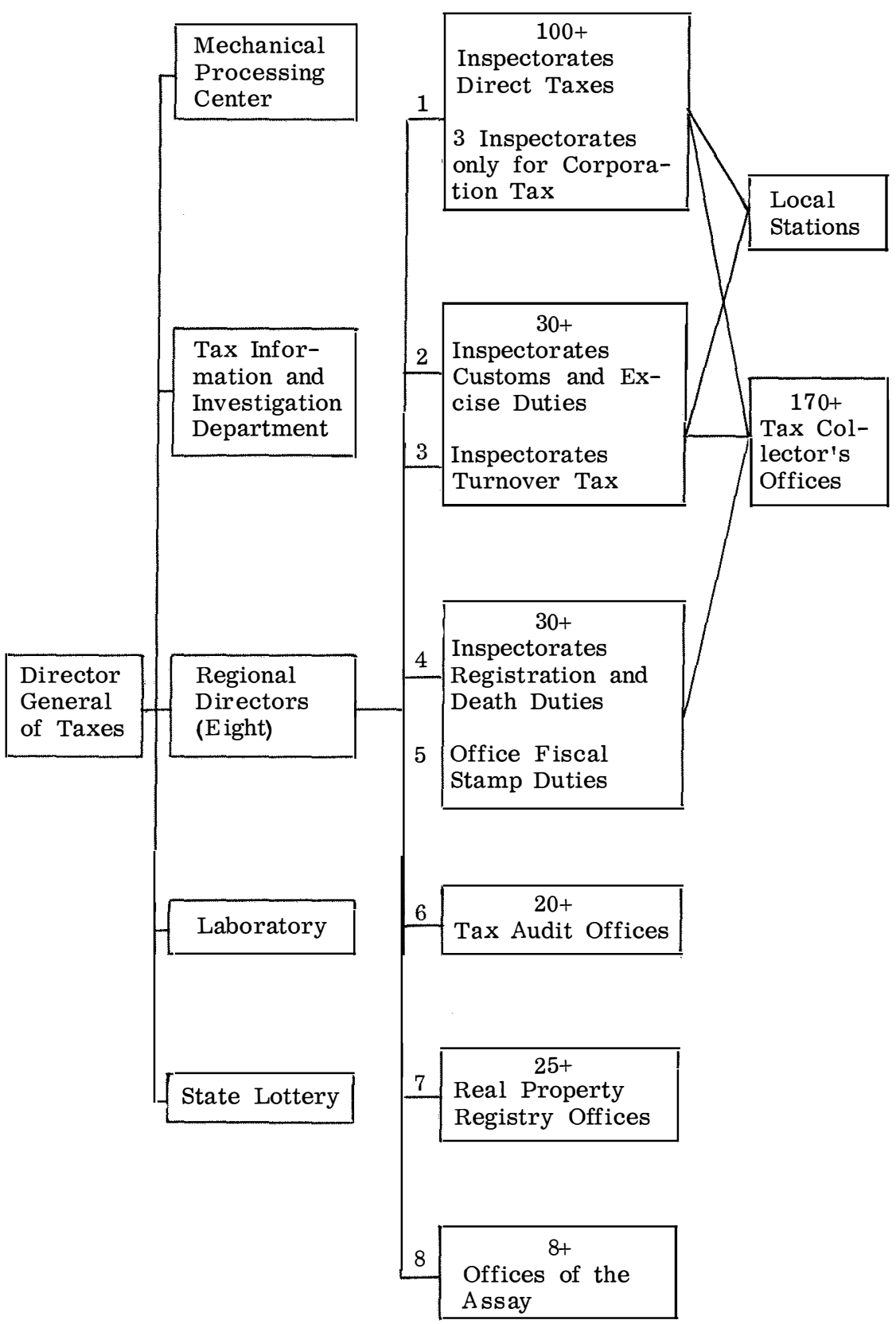


particular audit or assessment. Should the director conclude that the audit or assessment was incorrect, a theoretically possible but most improbable result, the director can recommend a change. The inspector, however, is free to disregard the recommendation; by statute he alone is empowered to change an assessment, though as a matter of prudence he may decide to shift his position. Should the inspector disregard the director's recommendation and the taxpayer decide to contest the assessment, the taxpayer can, of course, address the national office for hierarchic measures toward the disobedient inspector, though procedurally, he must lodge an administrative appeal with the same inspector. If the appeal is rejected, the taxpayer then can turn to the courts.

\subsection{Organizational framework, local office level}

As Chart II, supra, indicates, regional directors perform administrative functions with respect to eight different types of offices. Of these, however, only two deal with the income tax: the tax-audit or tax-accountant offices, and the inspectorates for direct taxes, inspecties der belastingen, who bear ultimate responsibility for all assessments.

There is wide variation in the size of the geographical area serviced by an inspectorate. Some cover as many as 800 square kilometers (480 square miles) some as few as $80^{5}$ (48 square miles). There are about one hundred inspectorates for direct taxes. Eighty deal only with individual income taxes and wage taxes. The remaining twenty deal with corporate income

5 The area of the Netherlands is about 32,500 square kilometers, with 1 square kilometer equalling two-fifth of 1 square miles. There is a population of 12 million inhabitants, with an average population density of 370 per square kilometer. The provinces of Noord- and Zuid-Holland, which make up the western part of the Netherlands, have an area of about 5,200 square kilometers. The population of that western part equals 5 million inhabitants with a population density of 960 per square kilometer. By way of comparison, note the following:

State of the

United States

Rhode Island

New Hampshire

Michigan

District of

Columbia

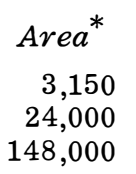

181
Population

0.9 million

0.6 million

7.0 million

0.9 million
Population Density**

280

25

47

500

**Square kilometers.

** Per square kilometers. 
taxes, as well as individual income and wage taxes. ${ }^{6}$ There are also approximately twenty tax audit offices. Their prime function is to audit the more complex income tax returns, usually those of corporations. Returns involving simpler, less complex issues are audited within the inspectorates by their own audit divisions. The twenty tax audit offices are staffed by chartered accountants who are considered equal to those of a university level, since they have passed several examinations in accounting, financial arithmetic, etc.

Inspectorates vary in size, from large, to medium, to small. The three large ones are located in Amsterdam, Rotterdam, and The Hague.

There are between forty and fifty inspectorates, respectively, in the medium and small categories.

Despite variations in size, all inspectorates have the same basic structural organization, headed by chiefs who have identical legal authority but whose titles and salaries vary depending on the importance of the inspectorate. Such persons are ultimately responsible, apart from supervision of subordinates, for assessments, hearing administrative appeals, and representing the inspectorate in litigation arising out of assessments it has made. To these ends, each inspectorate has either four or five divisions, the two most relevant here being the assessment and audit divisions. Except in small inspectorates, an assessment division will include several inspectors with a university background, and a number of less well educated controleurs and commiezen. In contrast, controleurs head up the staff of the audit divisions, and, in the case of small inspectorates, also the assessment divisions.

The assessment division performs the most important duties, concentrating on the income tax though also responsible for assessment of the tax on capital. Essentially, the other divisions are auxiliary to the assessment division; their function is to promote an optimal accomplishment of the entire assessment process (i.e., ordinary assessmento, deficiency assessment, handling of administrative appeals). For example, the audit division has no power to review an assessment made by the assessment division. It simply collects information outside

6 As of 1967 , there were about 100 inspectorates for direct taxes, dealing only with individual income taxes. Eight inspectorates deal with corporate income taxes. No inspectorates deal with both individual and corporate income taxes. 
the office and makes routine audits, both inside and outside the office, primarily of uncomplicated income tax cases. ${ }^{7}$

The following table shows that the number of assessments typically completed by an inspectorate varies depending on its size:

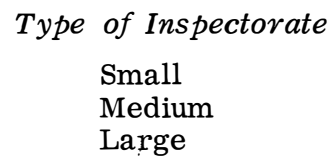

$$
\begin{gathered}
\text { Number of Assessments } \\
6,000-20,000 \\
20,000-50,000 \\
150,000-200,000
\end{gathered}
$$

While inspectors, with a university background, handle the more complex cases, the table below from one recent year in-

\begin{tabular}{|c|c|c|c|}
\hline & & umber of Asses & ments 8 \\
\hline $\begin{array}{l}\text { Levels of personnel } \\
\text { performing assessments }\end{array}$ & $\begin{array}{l}\quad \text { Income } \\
\text { Average } \\
\text { number } \\
\text { per man }\end{array}$ & $\begin{array}{r}\text { Tax } \\
\text { To }\end{array}$ & Corporation Tax \\
\hline $\begin{array}{l}\text { Inspectors (with educa- } \\
\text { tional background at the } \\
\text { university level) } \\
(\text { Hoofd) controleurs } \\
\text { Commiezen }\end{array}$ & $\begin{array}{l}1,000 \\
2,200 \\
3,700\end{array}$ & $\begin{array}{rr}200,000 & (8 \%) \\
600,000 & (24 \%) \\
1,700,000 & (68 \%)\end{array}$ & 36,000 \\
\hline
\end{tabular}
dicates that lower level personnel handle the greatest number:

Other data of that same year show within the inspectorates the annual number of administrative appeals.

$$
\text { Type of Tax }
$$

Corporation Income Tax Individual Income Tax Wage Tax

\author{
Annual Number of \\ Administrative Appeals
}

$$
\begin{array}{r}
3,000 \\
230,000 \\
120,000
\end{array}
$$

${ }^{7}$ A separate administrative division also performs a variety of supporting functions, such as maintaining up-to-date files for each taxpayer. On the basis of the income established by the audit division, the administrative division computes the tax or, more accurately as of the present, forwards the data to the national computer center. This division also oversees the payment of the wage tax withheld by employers. A yet separate external services division, sometimes known as the active service because of its non-sedentary activities, accumulates other data pertaining to the assessment process.

8 The entire income tax of a majority of taxpayers (in 1963, about $2,900,000)$ is withheld from their wage payments. In consequence, there is no assessment in the case of this majority. 


\section{Section B. Personnel Framework (Governmental and Non-Governmental)}

\subsection{Governmental professional personnel}

The Dutch Internal Revenue Service recruits its personnel from two distinct educational levels: those who have completed the course of study at a school of secondary instruction which prepares for admission to the university 9 and those who have completed or attended the later years of a school of extended primary education. ${ }^{10}$ From the first group are drawn the future inspectors and their superiors, from the second the personnel at lower levels.

Graduates of the schools of secondary instruction apply to the Ministry of Finance for admission to a competitive examination covering general ability and character. If they pass this, they enter the training program. Prior to 1964 this took place at the State Academy of Instruction and Education for the Internal Revenue Service, Rijksbelastingacademie, ${ }^{11}$ which was under the supervision of the Ministry of Finance. 12 The institution granted no degrees but a number of students secured master's degrees in law or economics from a university while enrolled in the Academy.

The Rijksbelastingacademie had a five-year course. The first half concentrated on public and private law and commercial economics; the second on taxation law and theory, with

${ }^{9}$ After attending a primary school for six or seven years, a child can enter one of the two main types of schools of secondary instruction: one with a five-year course stressing mathematics, modern languages, and/or economics and a six-year course which adds Latin and Greek.

10 After attending a primary school for six or seven years, a child can enter a school of extended primary education which gives four years of study in general courses, mathematics, and French, German, and English.

11 The Rijksbelastingacademie was created by the Ministry of Finance in 1939. It was designed to supersede the then-existing practice of preparing in private institutions for admission after examination to the higher echelons of the Internal Revenue Service. Either these admission examinations or similar screening devices had been in existence for a considerable number of years. The administration dealing with death duties had introduced them in 1822, the Internal Revenue Service in 1910.

12 Almost no inspectors between 1939 and 1964 entered the Internal Revenue Service other than through the Rijksbelastingacademie. The exceptions arose from a shortage in qualified personnel because of insufficient applicants. 
particular emphasis on the income tax, both individual and corporate. In addition a few months were spent at an inspectorate, concentrating either on income taxes or on turnover, customs, and excise taxes. Practically all students finished this course of study and all who completed it entered the Service. The esprit de corps, based on corps traditions dating from the early nineteenth century, was an enormously cohesive factor and one of the major elements which prior to 1945 held all but a very few Rijksbelastingacademie graduates in the service. The postwar period, however, saw a marked change, in part because of the more attractive salaries and opportunities available in nongovernmental service.

The difficulty in retaining trained personnel as well as in securing qualified applicants (partly because training did not take place within a university) led the Ministry of Finance to alter the training program for future inspectors. Since 1964 applicants who qualify for the training program have enrolled with the Law Faculty at one of the state universities. While the course of study is substantially similar to that provided by the Rijksbelastingacademie, on completion students now receive a master's degree in tax law and theory. This is followed by a short period of practical experience. A student enrolling in the program receives a government subsidy during his training period, but commits himself to remain with the Service for a certain number of years. Otherwise, the subsidy must be returned.

The corps of Dutch inspectors which is formed by the training program is not outstanding in terms of learning or intellectual qualities. Rather they are trustworthy and honest men, stolid and reliable in the performance of their duties.

In contrast to the extended academic preparation required of and provided for personnel who hope to become inspectors, most employees are hired at 17 or 18 years of age, directly after completion of all or part of the curriculum of a school of extended primary education and commence their duties immediately.

Such a young man enters a local office ${ }^{13}$ where he is taught how to do the simplest work in the administrative division. Later more difficult but still elementary work is assigned to him. Within two or three years, he is eligible to commence

13 Theoretically, there is no distinction in the recruitment pattern for this type of employee for whatever level of office; in practice, personnel in the district, and more particularly the national, office have served previously in one or more local offices. 
a three-to-four year in-service training program, primarily involving study at home of various texts, the tax statute, and regulations. During some of this time, he also has oral instruction for about three hours a month. No complex subjects, such as corporate accounting, are studied. Upon completion of the course and passing of the final examination-which frequently is not accomplished upon the first attempt-these persons are promoted to adjunct commies, some six to seven years after entering the local office. ${ }^{14}$

Two lines of promotion are available to an adjunct commies. He may prefer to remain in the administrative division or in the lower levels of the assessment or audit division of his local office. In such a case, after service in one of these divisions for some time, he is eligible for promotion, upon recommendation, ${ }^{15}$ to the rank of commies, later to be followed by promotion to hoofdcommies. Under no circumstances, however, will he perform important work comparable to that of a controleur. ${ }^{16}$

If an adjunct commies believes he is capable of performing more demanding work than that performed by a commies or hoofdcommies, after two to seven years of competent service as an adjunct commies and at about age thirty, he may apply for admission to the group of candidate controleurs. A selection commission tests these applicants on their general ability, education, intelligence, and character. If chosen-and the chances of selection depend primarily upon the estimated anticipated demand for controleurs in relation to the supply of applicants-the candidate controleur attends a two-year inservice training school conducted by inspectors and located in the town of Arnheim.

The course offers two tracks of instruction, enrollment depending in part upon the candidate's wishes and in part on the Service's needs. One combines direct taxes and death duties, the other direct taxes and the turnover tax. 17

While in attendance, each student weekly receives a day and $a$ half of oral instruction, spends two days in a local office

14 Within this time, such an individual will have fulfilled his military service.

15 Selection is made by a Commission, made up of inspectors under the head of a district director.

$16 \mathrm{~A}$ special in-service training program for the level of commies has been instituted since 1964. It has about 26 meetings a year.

17 In the second of the two tracks, varying proportions of the twoyear period are devoted to the subjects which follow: 
for practical training, and studies for the balance of his time. Upon completion of this course, the candidate controleur is eligible for promotion to the rank of controleur and subsequently to that of hoofdcontroleur. In most cases, he spends his life in the assessment or audit division of a local office, but in some cases he is transferred to a regional or to the national office. However, such an individual can never reach the rank of inspecteur, and hence can never head an inspectorate. He will be, rather, a right hand of the inspectors.

\subsection{Private tax practitioners}

There are no restrictions in the Netherlands upon the giving of tax advice. ${ }^{18}$ In consequence, the types of tax advisers range from a little bookkeeper to the tax expert, properly socalled, with a large number of individuals falling in the middle. Legally trained men are found only among the relatively few true tax experts. 19

An individual, seeking assistance in filling out a simple income tax return or calculating the profit of a small sole proprietorship, typically utilizes the little bookkeeper type of tax adviser. The more competent advisers in this group also handle less difficult controversies with local inspectorates but rarely, if ever, appear in the courts.

Somewhat above the little bookkeeper type of tax adviser is an ill-defined middle group, without specific academic

(footnote continued)

Subject

Bookkeeping and accounting

Civil law

General approach to tax law

Income tax

Wage tax, etc.

Corporation tax

Tax collection

Capital tax

Turnover tax

Real estate tax
Approximate

Percentage of Total

Time Allocated

$$
\begin{gathered}
23.0 \% \\
23.0 \\
4.0 \\
19.0 \\
9.0 \\
7.5 \\
1.5 \\
5.5 \\
4.0 \\
3.5
\end{gathered}
$$

18 Excluded from any consideration of tax practitioners are the notaries, notarissen, who handle practically all death and gift tax problems. There are jurists, with specialized knowledge of these taxes, appointed by the Queen.

19 While the middle range of tax consultants are known as belasting des kund, tax experts, their expertise is decidedly more limited than their name suggests. 
training. ${ }^{20}$ Its members deal not only with local offices but also frequently represent taxpayers in judicial proceedings though they are not lawyers. Indeed, the associations into which they have organized themselves ${ }^{21}$ require for membership only completion of an extended primary education. These associations have joined into a federation which has set up part-time training courses for the members. ${ }^{22}$ While the examinations are kept at a fairly high level, successful completion is no guarantee of professional expertise. At a minimum, a member of such an association, upon completing the course of study at a federation training school, would require several years of practice before attaining the level of knowledge and competence necessary to give reliable advice on relatively uncomplicated tax matters.

In truth, the Netherlands possesses very few true tax experts. Among these are former inspectors who will have graduated from the Rijksbelastingacademie. Others are lawyers who specialized in taxation. Frequently an office which concerns itself primarily with tax matters has a chartered accountant, a lawyer, and a tax expert, all working in close cooperation.

20 A 1958 report by a Commission, instituted by the Under Secretary of Finance, advised the government to create a state examination to insure more uniformity among this middle group of tax advisers. To date, the government has taken no concrete action.

21 Some of these organizations have joined with others of comparable status in an effort to insure some degree of uniformity. To increase a sense of professional status, the members may, after passing examinations, identify themselves as Members of the Institute of Tax Advisers or whatever is the name of the particular organization. A 1967 act makes it possible for a qualified individual to be registered as a Registered Accountant.

22 The courses offered by the federation provide some general instruction in law, economics, and bookkeeping, followed by a special program in tax law which stresses individual and corporate income tax law. Generally theory, public finance, and related subjects are given little if any attention. 


\section{CHAPTER XXII}

\section{ADMINISTRATIVE RULE-MAKING PROGRAMS}

\section{Section A. Character of the Underlying Statute}

\subsection{The precision of the statute itself}

The Netherlands does not have a tax code. Instead there are several tax statutes, each dealing with a specific tax. These statutes set out broad rules, generally applicable, with almost no deviations. The term income tax statute refers collectively to three major laws:

a. The Income Tax Law, inkomstenbelasting, covering the tax on the total net income of natural persons;

b. The Wage Tax Law, loonbelasting, covering the tax on wages; and

c. The Corporation Tax Law, vennootschapsbelasting, coving the tax on the profits of corporations. ${ }^{1}$

There is a fourth and less important statute dealing with the tax on dividends. ${ }^{2}$

A revision of Netherlands tax legislation, effective in 1966, is designed to clarify rather than alter provisions. ${ }^{3}$ Important to this clarification process is the use of a Basic Statute,

1 The corporation tax statute has a few paragraphs dealing with specific institutions-i.e., banks, insurance companies-but these constitute very minor deviations from the normal pattern.

2 The wage tax and the dividend tax both are withheld at the source and afterwards credited against the income tax. If income consists exclusively or almost exclusively of wages and does not exceed a certain annual amount (currently fixed at about f. 10,000), the wage tax covers all taxable income and precludes any additional assessment for income tax.

3 It was not felt there was a need for many substantive alterations in the legislation itself. However, it was felt that there was a lack of organization and clarity, a consequence of the patchwork alterations made during and after World War II. In 1964, three statutes were enacted: Wet op de inkomstenbelasting, income tax; Wet op de vermogensbelasting, capital tax; Wet op de loonbelasting, wage tax. No new corporation tax statute was enacted. While the examples in the text are drawn from the pre-1964 legislation, both they and the comments about the Netherlands' statutory practices remain valid today. 
Algemene wet, containing general principles relating to taxes levied by the Netherlands, Rijksbelastingen. ${ }^{4}$ Since this statute sets out general statements dealing with subjects relevant to all or to certain categories of taxes, comparable statements in each of the several tax statutes may be deleted, thereby increasing intelligibility and producing greater uniformity. The Basic Statute deals with such general subjects as domicile, ${ }^{5}$ returns, ${ }^{6}$ the levying of taxes by means of assessment ${ }^{7}$ and through withholding, ${ }^{8}$ administrative and judicial appeal, 9 repre sentation, secrecy, 10 and fines. 11

It is also important to remember that, in the Netherlands, only the central government imposes income, wage, and corporation taxes. ${ }^{12}$ Further, these statutes omit much detail, but do delegate legislative power to fill in the gaps. The delegation is accomplished by specific statutory provisions authorizing issuance of complementary rules and regulations. These regulations have the force of law when officially published in the Staatsblad or the Staatscourant. In consequence, hereafter the expression, substantive tax provisions, should be understood to include these published regulations but not other administrative directives without force of law. ${ }^{13}$

4 The Basic Statute was not changed in 1964. See note 2, supra.

5 Basic Statute, Chap. I.

6 Id. Chap. II.

7 Id. Chap. III.

8 Id. Chap. IV.

9 Id. Chap. V.

10 Id. Chap. VIII.

11 Id. Chap. IX.

12 In fact the lower administrative units (eleven provinces with some thousand odd communities) possess only a very limited power to levy taxes of any kind.

13 It should be noted that the limits on delegation of tax law-which limits are reflected in the particular statute to which the delegation relates-have been repeatedly the subject of substantial differences of opinion, both in Parliament and among authors. Paragraph 188 of the Dutch Constitution-"Taxation in behalf of the Kingdom can be effected only by virtue of a law"-would be infringed upon if such delegation were carried to excessive limits. To date, however, both the legislative and executive branches of the government have followed a reasonable middle-of-the-road course. 
The statutory enactments themselves, covering just substantive income tax, include only 153 paragraphs and cover only 57 pages of about 400 words each. ${ }^{14}$

A general description of how the net tax basis is established will illustrate the Dutch statutory approach. The income tax is levied on net income which, broadly speaking, includes only the total amount derived from several sources of income likely to have some degree of permanence-e.g., rental on a house, dividends from stocks, interest on bonds, wages and salaries from employment, and profits from commercial or industrial activities. Net proceeds from all sources of income are added together to constitute the aggregate gross income, from which are deducted items not directly related to any one component of gross income (i.e., interest on debts, premiums on life insurance). Operating losses resulting in a negative gross income in any of the six previous years also are deductible. ${ }^{15}$ After computing the net income, allowance is made for expenses from illness or other adversity ${ }^{16}$ and for a limited amount of charitable contributions.

A few relatively brief paragraphs set out the foregoing explanation of income, but many more paragraphs supply specific details. Illustratively, gross income is defined as the total of the net proceeds from three sources-(1) the taxpayer's activities in commerce, the liberal professions, or employment, (2) capital, and (3) certain life annuities. Each of these component parts of gross income is defined more specifically in subsequent paragraphs, totalling about thirty. ${ }^{17}$ In addition to

Basic departures from Number of Printed pages general tax pattern

\begin{tabular}{|c|c|c|c|}
\hline Tax Statute & $\begin{array}{l}\text { Number of } \\
\text { paragraphs }\end{array}$ & $\begin{array}{l}\text { Printed pages } \\
\text { of } 400 \text { words }\end{array}$ & $\begin{array}{l}\text { (rough estimate of } \\
\text { percentage of sections) }\end{array}$ \\
\hline Income & 68 & 28 & $10 \%$ \\
\hline Wage & 49 & 17 & 5 \\
\hline $\begin{array}{c}\text { Corporation } \\
\text { Total }\end{array}$ & $\frac{36}{153}$ & $\frac{12}{57}$ & 15 \\
\hline
\end{tabular}

15 Included in this provision is a deviation from the prevailing pattern, which permits the permanent carrying-forward of losses where such are incurred during the first six years of a newly founded trade or industry. family.

16 This is limited to those occurring in the taxpayer's immediate

17 Trade and liberal professions require about fourteen paragraphs, employment seven. Proceeds of capital are defined in terms of movable and immovable capital, requiring two and three paragraphs respectively. 
the statute, there are relevant paragraphs in the legislative regulations.

The Wage Tax Statute analyzes in detail the several aspects of the terms employment and wages. The Corporation Tax Statute, in defining the term profit, refers extensively to pertinent paragraphs of the Income Tax Statute (which defines profit resulting from a natural person's enterprise), and then takes account of variations required for holding companies, management trusts, insurance companies, etc.

On the whole, the statutory definitions of the net tax base are not overly detailed. It is difficult to determine whether this statutory approach tends to increase or reduce interpretative difficulties, when compared to other more detailed statutory descriptions which inevitably include more variations from a basic norm, with these additional variations creating the possibility of yet more interpretative difficulties. Be that as it may, for other reasons the legislature which accomplished the most recent statutory revision was probably wise in refraining from any attempt to supply all details in a possibly vain effort to reduce the number of interpretative difficulties. ${ }^{18}$ While general language in any law does create uncertainty, excessive detail makes the statute needlessly complex and impractical, as well as rigid and inflexible, and not easy to adapt to social and economic changes, including changes in business expectations. The meaning of general language, on the other hand, can be evolved, through judicial science, to meet those changing circumstances. Two illustrations will suffice to indicate the tendency of more recent legislatures to retrench from detailed prescriptions.

The first involves the provisions which, from 1941 through 1950 , set out quite detailed rules for computing profit, whether derived by an enterprise or from the exercise of a liberal profession. For example, it provided for the calculation of profits on stock, etc., by comparison of the capital at the end and at the beginning of the taxable year, as well as on the basis of the turnover, after deduction of expenses, and so on. In 1950 the legislature redefined profit and annual profit in the following general terms:

Profit is the aggregate of gains achieved, under whatever name or form, from enterprise or liberal profession.

18 Such detailed paragraphs might operate as case law, involving arguments a contrario when interpretation become necessary, to say nothing of the obvious lack of flexibility under changing social conditions. 
Annual profit is calculated in accordance with good merchant's usage, with observance of a consistent line of conduct (policy) irrespective of envisaged results, and which can be altered only when justified by special circumstances. 19

Observe that this definition does not address itself to details relating, e.g., to the evaluation of stocks and merchandise, to the effect on profit of an increase in the value of stocks arising from monetary depreciation or of an increase in reserves because of such depreciation, to the point of time at which profit is made (i.e., when the goods are delivered or services rendered, or when payment is received), or to the circumstances under which a merchant may change his method of computing annual profits. Many of these matters have been dealt with, however, by the Supreme Court of the Netherlands, Hoge Raad der Nederlanden, in decisions which supplement the written law, but which in hard cases need not lag behind changing circumstances. While judicial decisions fill in the gaps, the Dutch legal system accords no official precedent value to any judicial decision. 20

A second illustration involves the costs deductible from the proceeds of the several sources of income before totalling these proceeds. ${ }^{21}$ Whereas the old 1941 statute, after stating a general rule, went on to list examples falling in six different categories, the new bill repeated the general rule but omitted most of the earlier stated examples. The former approach had produced innumerable problems during the rapid post-World War II changes. For example, in the face of the long list of examples, what treatment should have been accorded commuting expenses? Should the crucial point be the business interests of the commuter, the housing shortage, or his personal preference for living in the country? Ultimately the Supreme Court

19 Besluit op de inkomstenbelasting (1941) शा 6 and 7 (superseded by Wet op de inkomstenbelasting (1964) आा 7,9). The few additional paragraphs (true also before 1950) defining depreciation and reserves which may be taken into account in calculating profits are not relevant here.

$20 \mathrm{~A}$ case may arise later involving the same issue and the Supreme Court is free to overrule its earlier opinion, though in practice this occurs almost never. See Chap. XXIV, 4.4 infra. Many times in subsequent decisions dealing with the same issue, the Court will refine or sharpen its position.

21 These costs are referred to in the statute as costs incurred for the acquisition, cashing, and retaining (verwerving, inning et behoud) of the proceeds, and the charges attributable to those proceeds. 
was able to develop standards from which emerged a workable overall concept of the system to be followed, despite the hindrance to logical interpretative development provided by so many statutory details.

It is impossible to determine the annual number of interpretative controversies, especially those regarding questions of law or mixed questions of law and fact. Many such problems are resolved by the tax inspector and the taxpayer. ${ }^{22}$ Also, often an issue originally thought to involve a mixed question of law and fact eventually proves to be entirely a question of fact, and thus loses entirely its interpretative character. Finally the decisions of the Chambers for Tax Procedures are published only when considered to be of real significance to taxpayers and tax experts. Hence the number of the published decisions bears no relation to the number of all decisions involving interpretative issues. Nevertheless, it is undoubtedly true that pure questions of law arise much less frequently than questions of fact or questions of a mixed character.

\subsection{Legislative pre-enactment aids to interpretation}

Once a government-sponsored bill has been drafted, ${ }^{23}$ the Queen requests advice from the Council of State. ${ }^{24}$ Assuming the Council approves, the Queen submits the bill to the Second Chamber of the States General, ${ }^{25}$ accompanied by an explanatory note signed by the appropriate Minister (in tax matters, the Under Secretary of Finance).

The Second Chamber refers the draft of the tax bill to its Committee on Finance, the members of which have expertise in tax matters. After thorough examination, the committee prepares a Preliminary Report which sets out the members' comments, criticisms, and suggestions, as well as questions. This

22 The number of such adjustments is unavailable.

23 Constitutionally, a bill may be presented by a member of the Second Chamber on his own initiative. This right, however, is almost never exercised.

The Second and First Chamber form the States General (StaatenGeneraal), a name which dates from 1464 although the institution itself has been changed over the centuries. The Second Chamber consists of 150 members, elected for four-year terms directly by the people in general elections. The First Chamber consists of $75 \mathrm{mem}-$ bers elected by the Provincial States, which are elected directly by the people.

24 The Council of State is a nonpolitical body of "wise men" whose deliberations are not published.

25 See note 21 , supra. 
report is referred back to the Under Secretary of Finance who reconsiders his draft bill and returns it with a written Note of Answer, signed by the Minister of Finance, typically accompanied by a Note of Alterations proposing modifications in line with the recommendations embodied in the Preliminary Report. At this point, an oral exchange of views frequently occurs between the Minister or Under Secretary and the Committee on Finance. ${ }^{26}$ This oral exchange is incorporated in a report, in most cases with a second Note of Alterations. Frequently the government prepares additional Notes of Alterations. Whatever their number, the totality of these written documents are published officially without delay. They constitute a full record of all proceedings prior to oral debate on the bill by the Second Chamber itself.

During that debate, the bill is subjected to criticism by representatives of the several political parties, the defense being led by the Under Secretary of Finance. Circumstances may lead the government to withdraw the bill. Or members of the Second Chamber may only urge alterations in the bill as presented, in some instances requesting that the government reconsider certain points, in others proposing their own amendments. Members proposing such amendments on their own initiative will have already secured informal technical assistance on the wording from the tax administration's Directorate (Legislation: Direct Taxes). If the Minister of Finance or Under Secretary approves the proposed amendments, the text as prepared by the tax administration will be incorporated in the government's own draft. ${ }^{27}$ Alternatively, the amendments may be placed before the Second Chamber for enactment or rejection.

26 It is possible that the Second Chamber will close the preliminary work on the draft without an oral exchange. Such omission, however, is unusual in the case of a new statute or an important change in existing law. It is usual where there is only a small change in an existing statute. Sometimes where the change is very minimal, the Minister makes only a Voorlopig Verslag and does not produce a Memorie van Antwoord.

27 It is possible that a proposed amendment would make such a structural or financial change in the original draft of the bill as to render it unacceptable to the Minister of Finance and the Under Secretary. Their conclusion, that a given amendment would make the bill unacceptable, may lead them to consider resignation should the Second Chamber pass the amendment. In instances of major importance, the entire Cabinet might consider resignation. However, it is more likely that their bare statement, that the amendment is unacceptable, would lead to its withdrawal. 
Not infrequently, a bill is altered substantially in the course of legislative discussion.

A bill which passes the Second Chamber has survived its prime challenge. The First Chamber cannot amend; it must accept or reject any bill in its entirety. Very rarely does the First Chamber fail to pass a bill enacted by the Second Chamber. However, the First Chamber subjects the bill to a process roughly equivalent to that of the Second Chamber.

After enactment by the First Chamber and royal assent, the new law is published in the Staatsblad, and typically takes effect within twenty days after publication unless the law itself specifies another period.

All documents referred to above are published, as is also a verbatim account of the treatment accorded the bill by both chambers in the States General. Taken together, this legislative history is most useful in interpreting the statute. This utility, however, especially where interpretative issues are concerned, is a byproduct; the States General do not have a policy here. On the other hand, traces in the sand frequently are left very deliberately. The Minister may give some examples to make clear his intentions about the law. If subsequent debates show definitely that the legislature approves his interpretation, the courts would be highly reluctant to disregard it.

The precise role of this legislative history is discussed in the next subsection, but that role, it should be observed, is not static. The law tends to establish a life of its own, for it must deal with circumstances unforeseen or ignored by the legislature. As time passes, both writers and the courts tend to place less emphasis on the intention of the lawmaker and more on the intention of the law, in the belief this is a more objective criteria. ${ }^{28}$

\subsection{Standards of construction followed by the judiciary in inter- preting the statute}

Theoretically, the standards of interpretation used with respect to tax statutes do not differ from those applied in the

28 This is a sound development. To look for the intention of the lawmaker seems next to impossible, in view of all that is written and (especially) said during the legislative processing by various people, not one of whom can be identified with the lawmaker, i.e., the government and the people's representatives, the States General. To consider as constant, the lawmaker's intention throughout the constantly changing life to which the law must be applied, is to misunderstand the function of a statute. Admittedly, wise interpretation of particular paragraphs of a statute may be assisted by examining what was written or said about the intention of the government, the Chambers, etc. 
case of other nonpenal statutes. In fact, however, until after World War I, the consensus of Netherlands opinion was that tax statutes should be construed strictly to establish, if not a literal interpretation, at least a barrier against loose interpretation and $a$ fortior $i$ application of the law by analogy. This conception now has been abandoned. ${ }^{29}$ Concurrently with this more recent trend in the direction of a more flexible interpretation, there is a growing tendency to consider tax law as autonomous in at least one limited sense. A particular construction followed by the civil law is not deemed conclusive in interpreting a word, expression, or concept also used in the tax statute (e.g., immovable property, alienation, sustenance, nullities in fiscalibus). Instead various other factors are taken into account to determine the tax meaning of the word, expression, or concept. ${ }^{30}$ It is now believed that this approach is not actually to be distinguished from the approach followed in construing the civil law itself. Indeed the Supreme Court has said that the tax law is to be approached "not in conformity with some special method of interpretation, but in the same way as in civil law," 31 and thus "no literal construction, but a construction on the basis, inter alia, of the ratio legis." 32 Thus, a reasonable application of the particular provision under consideration is the cornerstone of its interpretation and decision.

To this end, the courts now avail themselves of every possible device (historical, textual, teleological, etc.). The word rechtsvinding, finding the law, perhaps best indicates the objective of this open system of interpretation, to get at the purport of any given provision. Thus, no longer does it follow, $a$ priori, that questions bearing on the includability of an item in gross income should be approached in one manner while a different approach is used in deciding whether a given expense is deductible.

There is no official ranking of the weight the courts are to accord various sources. Consequently, the courts may accord

29 This concept perhaps was buttressed by what is now generally conceded to have been a misinterpretation of paragraph 188 of the Netherlands Constitution.

30 In this respect, the Dutch approach is less narrow and dogmatic than those employed in France or Belgium.

31 Decision of the Hoge Raad, February 27, 1935, B5801, WPNR 3417.

32 Decision of the Hoge Raad, June 15, 1921, N.J. 1921, 983, PW 11561. 
consideration to whatever factors they consider most important. Illustratively, at the beginning of a statute's life, the preenactment materials will receive greater attention than will later be true.

\section{Section B. The Regulations Program}

\subsection{Types and force of regulations}

As noted previously, the Netherlands delegates legislative authority in matters of minor importance. Under the authority so delegated, legislative regulations are issued either by the Crown or by the Minister of Finance and, when officially published, have the status of legislation. ${ }^{33}$

The tax administration also issues many kinds of other directives. In these, the tax administration reflects its interpretation of given statutory paragraphs. ${ }^{34}$ Since these interpretations were carefully considered by the Finance Minister and his staff, Tax Inspectors-as members of the hierarchyare bound, hievarchically not legally, to follow the directives. However, these do not bind taxpayers or judges, though the latter, knowing the directives were carefully considered by the administration, do not discount them completely. Not infrequently, however, the Supreme Court or a court of appeal will take a position contrary to the interpretation issued in a directive addressed to tax officials. Should this occur in a Supreme Court decision, the Minister of Finance usually alters the tax directive in question, and so informs personnel within the tax administration.

\subsection{Precise purpose of interpretative regulations}

Apart from legislative regulations which a given statute authorizes to fill in statutory gaps, so-called interpretative regulations, having the stature and coverage of those used in the United States, are not to be found in the Netherlands. The

33 Unlike the situation in the United States, neither the tax administration nor the Under Secretary of Finance has either general or specific authority to provide by regulation ordinary interpretations of the statute. The inspectors are bound hierarchically to interpret the statute in accordance with the instructions from the tax administration, but these instructions have no other binding force.

34 In preparing directives of this type-most usually when a new statute has been enacted or an old one amended-the tax administration uses every method of interpretation in trying to reach a proper interpretation. 
closest analogy is in the Dutch administrative directives program. These directives bind the tax inspector within the official hierarchy, without prejudice, however, to his right to attempt to have the directives amended. These directives strive primarily to reword obscure statutory language, give concrete examples of their application, or solve basic interpretative or controversial problems. The more wide ranging scope of this program, compared with the legislative regulations program, is evident in the following tabulation:

Number of Pages Covered-Average of 400 Words to a Page

Uitvoeringsregelen

Type of Tax

Income

Wage

Corporation

Total

\section{(Legislative Regulations)}

28

38

$\frac{16}{82}$
Leidrad̀en

(Administrative Directives)

141

35

$\frac{48}{224}$

\subsection{Manner of processing regulations}

Both legislative regulations which possess the force of law, and administrative directives which bind only personnel within the tax administration as a matter of hierarchical control, are prepared in the department of the Director-General of Tax Affairs by staff members with an educational background at the university level. However, legislative regulations are submitted for the approval of the Under Secretary and, following publication, became an official part of the law.

There is no formal provision or recognized practice for soliciting an expression of non-government opinion prior to formalization of the regulations and directives. However, the Minister on his own initiative may decide to consult with groups particularly interested.

\section{Section C. The Rulings Program}

\subsection{Formal advance private written rulings to taxpayers}

The Netherlands Internal Revenue Service does not issue unilateral, binding, private written rulings to taxpayers covering proposed transactions. Nor is it possible to enter into a legally binding closing agreement in such cases.

Repeatedly the Dutch Supreme Court has held that any agreement between the tax administration and a taxpayer lacks binding force and legally provides no certainty to either party. 
Indeed, even if an inspector and a taxpayer have agreed upon the depreciation to be allowed for a particular piece of industrial equipment in a given year, the taxpayer remains free to argue for the use of another method in a subsequent-or even the same-taxable year if he concludes that the agreed upon method of calculation is contrary to the statute.

The only agreements which the Supreme Court will uphold are those which establish a value at issue between the parties and do not require interpretation of a statute. For example, if the value of a parcel of realty in a given year is in question, the inspector and taxpayer may choose two experts, and agree that the average of the experts' estimates will bind both parties.

The various limitations described above reflect theory, however, not the actual practice. Daily, throughout the country, agreements are made between the local offices and the taxpayer or his practitioner, with a view to fix the exact amount of tax liability. Many controversies over issues of fact or of law are settled, i.e., compromised between inspector and taxpayer. This settlement has no legal status; but since it is a gentleman's agreement, the result is reliable and the system has seemed to work well in practice. Usually the compromise is developed between the taxpayer and the inspector, without the interference of a higher official. However, prospective situations involving more complex issues or greater amounts of money (e.g., a proposed merger or corporate reorganization) may lead a taxpayer to seek optimum certainty. After a written memorandum and all the relevant documents have been presented to the local inspector and have been discussed with him, the taxpayer may take the initiative in the mutual decision reached by the inspector and the taxpayer to raise the matter at the national office level. In that event, the national office, after consulting with the local office, will make a thorough analysis of its own and may hold extensive discussions with the taxpayer. In due course, the taxpayer will receive a letter from the Ministry, outlining the tax consequences of the proposed transaction if carried out as described by the taxpayer.

This practice grew out of the administration's belief that a taxpayer, who is interested in a complex and possibly controversial type of prospective transaction, ought not be forced to abandon the transaction because of tax uncertainties. However, since taxpayers have no legal right to such a decision from the Minister or, for that matter, even from an inspector, 
there are no formal rules of procedure governing the practice. Further the fact that there is such a practice does not mean that just any taxpayer can raise just any issue directly with the Minister. Indeed, an ordinary taxpayer who writes the Ministry, requesting a decision on a dispute between him and his inspector regarding an assessment normally will receive a prompt answer to the effect that, if the taxpayer considers the assessment incorrect, the matter is properly the concern of a Court of Appeal. Again, should a tax expert or a corporation inquire concerning the tax consequences of a contract seemingly inspired by the tax avoidance possibilities, the national office's response is not likely to prove helpful. In other words, the tax administration exercises complete discretion in deciding whether to rule in advance in any given case, and whether it will do so at the local or national levels.

The lack of statutory authorization for these rulings, settlement, and compromise activities has not made them less effective. Actions before the Court of Appeal rarely disclose evidence that a compromise agreement-which the court would be free to disregard-has been breached. This satisfactory, if extralegal, state of affairs is the prime reason the Under Secretary of Finance declared a few years ago that he saw no need for legislation authorizing and regulating formal closing agreements. That conclusion was clearly warranted, given the existing practices, certain recognized qualities of Dutch character and the high standards of the Internal Revenue Service inspectors, and the difficulty of designing a regulatory statute which would adequately respond to the many diverse aspects of which account must be taken if the practices are to be implemented wisely.

\subsection{Informal technical advice to taxpayers on proposed transac- tions}

It is not known how often taxpayers seek informal advice from the local inspectors on the consequences of proposed transactions. It is common practice, however, for both local and national levels to discuss freely with taxpayers the alternatives available in shaping a proposed business transaction, to the end of helping the taxpayer achieve the most favorable tax consequences. Should the inspector himself be in doubt about a question, he is likely, particularly in the case of a substantial financial matter, to request advice from the District Director, who in turn may refer the question to the Ministry. ${ }^{35}$ In

${ }^{35}$ In practice, only the important cases of large taxpayers are carried to the national level. 
the end, what began as an informal discussion may conclude with written advice. In either event, in actual practice, the inspector will feel bound despite the absence in law of official status for the advice. A gentleman's word has been given.

\subsection{Technical advice to field offices}

From the foregoing, it should be clear that local offices are permitted-though not encouraged-to request the higher echelon (i.e., the District Director) to indicate the appropriate stance with respect to a specific situation. Should the Director, in turn, request such advice from the national office, the response, commonly given in writing-not by telephone-is prepared by the staff of the Director-General of Taxes.

\subsection{Publication of technical advice given to taxpayers and local offices}

Interpretative positions taken by the Ministry in response to requests for advice in specific cases are not likely to be published except where the matter is one of general interest. 36 Illustratively, the Ministry would be likely to publish the answer to an inquiry by a life insurance company about the fiscal consequences of certain clauses in an insurance policy. The in-service publication will take the form of an administrative directive to lower echelon personnel. Outside publication will be accomplished by releasing the full text of the directive to tax periodicals. Usually, a published directive will set forth the underlying rationale.

Despite this practice of publishing the most important decisions, there is no formal publication program. Indeed there is no formal system of administrative rulings. Substantive technical rulings in the field of income, wage, and corporation taxes probably total less than a hundred a year, with about forty a year being published. This, of course, represents only a very small part of all the Ministry's decisions on matters sent up by the inspectors. Many such decisions, however, owing to the peculiar factual circumstances of the cases, have the limited character of jus in causa positum.

Despite the limited publication program, the inspectors very swiftly learn, albeit informally, the stance taken by the Ministry in particular situations. There is a high degree of cooperation and a continuing exchange of information as well as views and opinions.

36 Publication would be in the form of an incidental bulletin. 
In addition to the important administrative decisions of general interest, the national office intermittently informs inspectors and tax periodicals also of decisions taken in so-called hardship cases. The purpose is to alert taxpayers to the types of hardship cases where favorable decisions may be expected, either from the national office, or if power is delegated, from the local or district offices. 


\section{ASSESSMENT, REFUND, AND ADMINISTRATIVE APPEAL PROCEDURES}

\section{Section A. Assessment and Audit Procedures}

\subsection{Introductory note}

As noted earlier the Netherlands income tax statute actually consists of three separate though closely related laws (individual income tax, wage tax on employees, and corporation profits tax).

The discussion below of assessment and audit procedures focuses just on the income tax; then follows a summary of the differences peculiar to the two other related taxes.

\section{2a Details of the assessment and audit procedures re individ- uals (income tax) \\ Netherlands income tax legislation is not geared to the so-} called self-assessment system. However, it does rely on a taxpayer's so-called tentative return in making tentative assessments, and to this limited extent there is resemblance in fact if not in theory. The ultimate assessment though is made by an inspector in reliance, but only in part, on a yet different final return which, in essence, is a questionnaire showing the net income received during the preceding calendar year. But at least part of the tax due for that calendar year normally was paid in the course of that same year, on the basis of the tentative or estimated assessment which generally was made at some point between April and August. That tentative assessment was then payable in at least five monthly installments. Also, during that calendar year, tax was withheld at the source as to certain types of income, especially in respect to wages and dividends.

To illustrate, this overall reporting scheme is triggered in, say, 1966, when on or about February 1, the typical taxpayer receives a form containing his final return for 1965 and the tentative return covering income anticipated during 1966, both of which must be returned by April 1, unless for good cause the taxpayer is able to secure an extension. 
Should he fail to file by the due date without cause, a fine of five percent is imposed on the tax due. And on complete failure to file, the inspector is authorized to prepare assessments based on his estimate of the taxpayer's income. ${ }^{1}$ Further, for gross negligence in preparing the return or for deliberately filing a false return, a deficiency tax can be imposed, to a maximum of 100 percent. In addition, a deliberately false return is ground for a criminal indictment, which can lead to a heavy fine (or even a prison term), though this fine and the administrative tax increase mentioned above are not both imposed in the same case. ${ }^{2}$

The tax form contains four pages, and is accompanied by an explanatory booklet of approximately sixteen pages which answer the most frequently recurring questions about the tax law and the procedure to be followed in preparing the return. The form itself is in effect a questionnaire, seeking data regarding the taxpayer's personal affairs, i.e., marital status, number of children, sources and amounts of income, deductible items, and the amount withheld on wages, ${ }^{3}$ dividends, ${ }^{4}$ and certain other types of income. Taxpayers carrying on a trade or business must also attach signed copies of a balance sheet and profit and loss statement. Also, if the taxpayer's capital, however invested, exceeds a certain amount, 5 he is liable for a separate proportional capital tax, vermogensbelasting, and must fill in a form with two extra pages, covering both his income and capital tax, to which he attaches a list of his investments and the income therefrom.

To return to our illustration, the inspector upon receiving the tax form on or before April 1, 1966, typically does rely on it to make the tentative assessment for 1966, and thereby facilitates commencement of the installment payments. But the final return covering 1965 is examined before the final assessment for that year is made. ${ }^{6}$ The information there is verified,

${ }^{1}$ Since such an assessment is unlikely to err in the taxpayer's favor, such taxpayers usually lodge an administrative appeal.

2 Legally these are two distinct penalties that can be imposed for the same offense. The Under Secretary, however, has instructed the inspectors that they must refrain from assessing the deficiency tax in cases where there has been a criminal indictment.

3 The tax on wages is withheld at a progressive rate.

4 Withholding rate as of 1967 is a flat $25 \%$.

5 For a married taxpayer the free capital is f. 55,000, raised for each dependent child by f. 13,500. Thus, a married couple with three dependent children would have free capital of f. 95,500.

6 The term inspector includes not only inspectors of the academic level, but also any member of the inspectorate's personnel belonging 
first by reference to the files maintained in the inspectorate. ${ }^{7}$ However, even with the aid of these files, the inspector will not always know that a given taxpayer resolved a doubtful issue in his own favor even though, in consequence, a certain item was omitted in computing income, or a doubtful deduction was taken. $^{8}$ Also, if the issue was exposed to light, the explanation attached to the return may not be in sufficient detail to permit the inspector to resolve the issue. Thus, as explained below, the inspector's examination may be complemented by the audit division's verification of the taxpayer's accounts, and in either setting the taxpayer may be asked, by telephone or in writing, for additional information as to matters set out in the return or in an accompanying document. Should the taxpayer fail to comply with any such request, the statute provides that if he contests the assessment at a later date he will have the burden of proof.

It is recognized that an examination based just on the inspectorate's files will not expose all errors in all returns, but it is not feasible to undertake a more detailed examination of every return. These competing considerations are compromised; annually a proportion of the returns are examined with extreme care, primary attention being focused on those involving high incomes or those which tend to involve complex tax problems. Further, emphasis is placed on returns showing profits from a trade or business, as distinct from those reporting incomes from easily verified sources such as stocks, bonds, or annuity contracts. Returns of the former type typically are prepared by tax practitioners. While this fact is a reasonable guarantee that the figures in the return and supplementary records are accurate, it is no guarantee that the return includes no doubtful issues. While standards and instructions govern an inspectorate's selection process, the inspector has discretion to add any returns to those otherwise falling in the full-examination category. Once in this category, the books of the taxpayer will be examined by the Audit Division of the

\section{(footnote continued)}

to a group (hoofdcontroleur, commies) authorized by legislative regulation to perform tasks assigned by the statute itself to an inspector.

7 The inspectorate maintains for each taxpayer a legger containing the returns of previous years and a dossier which contains information of long-run value, such as reports from death duty inspectorates, copies of pertinent contracts, etc.

8 The inspector sometimes discovers that a taxpayer has erred in the government's favor and paid more in taxes than was owing. Under such circumstances, the inspector makes the correction. 
inspectorate. In particularly intricate cases, however, the Fiscal Audit Office takes over.

Either the Audit Division or the Fiscal Audit Office is free to and will draw its own conclusions as to what the audited records reveal. In the course of their audits, they will resolve interpretative issues and recommend a course of action to the inspector, giving their supporting reasons. It must be recognized, however, that their function is purely advisory. The inspector alone makes the final decision as to whether or not a deficiency assessment-or a refund-is in order.

Illustrating the foregoing is data pertaining to one recent year. Out of the approximately two and a half million income tax assessments, 440,000 taxpayers' books were examined. Of these, the Fiscal Audit Office checked about 72,000 and the inspectorates' own Audit Divisions--composed of hoofdcontroleurs and lower ranking staff members-the balance.

It should be emphasized, however, that the statute empowers the inspector alone to make or refrain from making an assessment. This power extends to the compromising of claims or issues, including the splitting and/or trading of issues in the course of reaching a settlement with the taxpayer over allyes-or-all-no questions of law. ${ }^{9}$

Higher echelons do not interfere with the inspectors' handling of their work and this noninterference extends to the inspectors' settlement activity. No careful check is made on the cases settled by the splitting or the trading of issues. In part, this is because the inspectors are trusted, bribery being nonexistent. In part, it is a realistic recognition that the taxpayer will litigate if he feels he is not receiving fair treatment, the inexpensiveness and accessibility of the courts making such litigation easy and available.

On the whole taxpayers (or their representatives) tend to accept the position taken by inspectors as being correct appraisals of the situations in question. Typically, if an inspector sees an item on a return with which he disagrees or which he questions, he telephones the taxpayer to come in to discuss the matter. At this initial point of contact, prior to any definite assessment, there can be and frequently is a settlement between

9 The Dutch term for this type of agreement is dading, the equivalent of the French term transaction. While the word is used in commercial dealings, in the tax area it means an act whereby the tax administration consents not to institute proceedings on the basis of an asserted deficiency in return for the payment of an amount of money mutually agreed upon. 
the parties of outstanding points in controversy, including the splitting or trading of issues. Moreover, at such a conference the inspector is free to and from time to time will make suggestions to the taxpayer for the taxpayer's benefit.

Only when the inspector himself concludes that he needs advice will he consult the head of the inspectorate or a higher echelon. Within the hierarchic setting, however, the Regional Office does maintain a running check on the inspectorates under its supervision. Incident to this, of course, the Regional office may sample the quality of an inspectorate's assessments, including its handling of administrative appeals. 10 Should it locate an error, whether in favor of the government or the taxpayer, it will force a correction.

Though examinations do delay the final assessment, this does not seriously prejudice the taxpayer, for most of his tax will have been paid earlier, either through withholding or installments. Further, there is a time limit within which the final assessments must be completed; for example, final assessments for 1966 must be made by July 1, 1968. The inspector's notice of final assessment, addressed to the taxpayer may indicate either that a refund 11 is in order or that some portion of tax remains unpaid. The latter situation may arise only because of a low tentative assessment, or because the inspector concluded that both the tentative and final returns were incorrect, the final assessment being based on a higher net income. In such case, the inspector must explain the difference ${ }^{12}$ in such detail that the taxpayer may decide whether to lodge an administrative appeal within the allowed grace period which commences to run from the date of the final assessment notice.

Although the inspector bases his notice of final assessment on an examination of the taxpayer's final return, even that assessment is not completely final. Under certain circumstances a deficiency assessment is possible. Ordinarily, of course, the preliminary contacts between the inspector and the taxpayer prior to issuance of the notice of final assessment will have resulted in satisfactory resolution of all difficulties and a

10 While this intermittent activity is useful, it does not insure uniformity among the inspectorates. Factors promoting, if not achieving uniformity, are the statutes, the decisions handed down by the several tribunals, the directives, the technical advice and other literature sent out from headquarters.

11 See note 7 supra.

12 Required by an administrative regulation. 
correct assessment. However, whether advertently or inadvertently, the taxpayer may have omitted one or more items which should have been included in total net income and the inspector may not have discovered the omission in the course of his examination for that year. In such cases, a deficiency assessment, navorderingsaanslag, is possible, if two conditions are satisfied. First, such deficiency must be assessed within a five-year period beginning with the close of the calendar year in question. Second, there must be a novum, i.e., such an assessment must be based on a newly discovered fact. A deficiency assessment cannot be made where the incorrect final assessment resulted from the inspector's own error or omission or because the inspector changed his opinion on a matter of statutory interpretation, for example because the Supreme Court shifted its position.

This limited use of deficiency assessments, authorized by statute and clarified by an extensive body of court decisions dealing with the existence or nonexistence of a novum, balances the taxpayer's need for certainty and the tax administration's responsibility for determining tax liability in accordance with the statute, not just in accordance with the taxpayer's return.

The overall assessment arrangement applies to millions of Dutch taxpayers, from men in high income brackets to those in low brackets, such as the greengrocer. However, taxpayers in the middle or lower income brackets who derive their income primarily or solely from wages need not file a return. Their income tax obligations are covered by the wage tax withheld by their employers.

\section{$3.2 \mathrm{~b}$ Details of the assessment and audit procedures relating to} corporations (corporations tax)

While assessment and audit procedures for corporations are very similar to those for individuals, four differences do exist.

The first and most important difference reflects the legislature's recognition that many controversial questions develop in the corporate setting. When the inspector decides that he will make an assessment which deviates from either the facts or figures in a corporation's return, the statute requires that he first give the corporation's board an opportunity to discuss with him the points at issue. As shown later, this requirement affects also the legal setting of any administrative appeal. Not infrequently, this discussion results in a splitting or a trading of all-yes-or-all-no issues of law. The inspector's power to 
enter into binding settlement agreements is as great in the corporate as in the individual setting.

Another difference: withholding of taxes at the source applies, in the corporate setting, only to dividends received by the corporation on stock of other corporations which it owns.

A third difference is in the basis used for a corporation's tentative assessment. While the assessment of an individual taxpayer is based on a current tentative return, the corporate tentative assessment is based on the final return covering the preceding year. This difference stems from the legislature's awareness that it is much more difficult to calculate future profits of a corporation than for a natural person.

A final difference is responsive both to the relatively high potential yield of each corporate return and to the intricacies involved in ascertaining the profit and loss of most corporations. In one recent year for example, just 36,000 corporations paid almost one and a third billion guilders, whereas two and a half million individual income taxpayers paid only two and a half billion guilders, with a like number of wage taxpayers paying another two billion. In consequence, the majority of corporation tax assessments are preceded by an audit of the corporate records. And as to these, the Fiscal Audit Office plays a more significant role than it does in the case of the individual income tax. In a recent year, out of approximately 36,000 corporate returns, 30,000 were audited, 13,000 by the Fiscal Audit Office, and 17,000 by the Audit Division of the inspectorates.

\section{$3.2 \mathrm{c}$ Details of the assessment and audit procedures re individ- uals (wage tax)}

Clues, suggesting that an employer has failed either to withhold the proper amount of wage tax or to forward an amount withheld, typically emerge as members of the inspectorate (most often from the Audit Division), carry on their regular investigations relating to other taxes (i.e., the turnover tax) or to the payment of state old age pension premiums.

Should an employer fail to withhold tax or fail to forward an amount withheld, the inspector can prepare an estimated assessment, as to which the taxpayer may enter an administrative appeal. Further, a deficiency assessment can be asserted where an employer failed to withhold an adequate amount of wage tax even though no novum is present, and in such case the tax can be raised by a maximum of 100 percent. 


\section{Section B. Administrative Appeals}

\subsection{Introductory note}

The Netherlands tax statute makes no provision for a taxpayer to argue his case, formally or informally, before an official of the tax administration other than the lowest grade decision-making official with whom the taxpayer first dealt and with whom he disagreed. Since the legislature itself has charged the local inspector of taxes with the task of making the assessments in his geographical area, in theory no other tax official, whether from the district or the national office, has any legal power whatever either to make an assessment himself or to annul an assessment made by the competent authority.

In fact, however, a review procedure in the nature of an administrative appeal does exist, though it is implemented in a manner which preserves the ultimate authority of the inspector. This procedure permits a taxpayer to secure a review only of questions pertaining to his original final assessment; the procedure is not available with respect to a deficiency assessment of any kind-income, corporation, or wage tax. If a taxpayer wishes to challenge a deficiency assessment, he must turn to the courts.

\section{4a Details of the administrative appeal procedure re assess-} ments in income tax (natural persons)

As noted previously, when an inspector's notice of final assessment differs from the taxpayer's final return, the inspector must include an explanatory note of any changes made. The change may actually be quite acceptable, for the taxpayer may have agreed to it earlier, during the informal exchange of views with the inspector. Illustratively, the taxpayer may have acknowledged he was in error or the change may represent an agreement to split or to trade all-yes-or-all-no issues. "It also is possible, however, that the taxpayer, though aware from the earlier discussion that the inspector planned to make the change, decided either that the assessment was too high or that he himself erred earlier in the government's favor by failing, for example, to take a deduction to which he believes he was entitled.

Should the taxpayer decide to protest the assessment, he has two months from the date of the notice of assessment to file a written but informal petition, bezwaarschrift, with the inspector. And even where a petition is not filed within the 
two-month period, in limited circumstances a taxpayer who has paid the assessment may secure a review by filing a claim for refund, a matter discussed more fully in 3.7, infra.

The statute does not require that the taxpayer's petition set forth the arguments on which his protest rests, though this obviously is desirable and usually is done in one degree or another. Further, if the taxpayer desires to be heard by the inspector before a decision is reached, a specific request to this effect must be included in the petition; otherwise the inspector is not bound to communicate with him.

Where a tax practitioner prepared the taxpayer's original final return, that same practitioner usually prepares the petition and handles the case in the inspector's office, though the taxpayer may accompany him. In any event, any correspondence or oral discussions are carried on quite informally.

The statute makes no specific provision regarding the entire burden of proof. However, the inspector may request the taxpayer to supply "such books and documents as can serve in support of the taxpayer's contentions." The statute also provides that, on failure to comply, the assessment will be upheld on the theory that there has been no proof the assessment was erroneous. In short, the statute assumes that the taxpayer who is asked to produce written documentation has these items in his possession, unless the contrary is shown clearly. Thus a taxpayer who withholds records or documents, claiming they would reveal confidential relationships or professional secrets, would bear the burden of proof even though the confidential relationship or professional secret could be established legally.

The filing of the petition sets in motion a series of discussions and investigations which explore every aspect of the case, with both sides exposing their evidence, rationale, and arguments. Typically, the process involves much more than a mere restatement of arguments presented earlier. It is entirely possible for the parties at this time to enter into a binding agreement to split or trade all-yes-or-all-no issues of law. Should this occur, the taxpayer withdraws his petition and the inspector notes the adjustments made in the original assessment. The care taken through this entire process, including that associated with the inspector's reconsideration of the rationale behind the original assessment, has led the government to compare the process-juridically a purely administrative one-with that of a trial tribunal, though admittedly more informal. While the inspector who initially made the assessment continues to represent the government, he is free to consult 
the head of the inspectorate before making a decision, but is not required to do so.

A period of time, varying from some weeks to many months, will elapse from the time a petition is filed to the point the inspector will hand down his written decision. Whether he accepts or rejects, either in whole or in part, the taxpayer's contentions, the rationale of the decision will be set forth, in part to assist the taxpayer in deciding whether to carry his case to the courts.

Not all petitions will be followed by a formal decision, however. In cases which raise a question of fact or a so-called mixed question of law and fact, racher than a clear-cut interpretative question of law, the inspector and the taxpayer, after exploring all points of view, may reach an informal agreement without actually resolving all of the potential legal arguments. Under such an agreement, the taxpayer may withdraw his petition, thus preventing an eventual recourse to the courts. On his part the inspector, recognizing that the taxpayer has some valid arguments, will have lowered the assessment. In short, something resembling a compromise has been reached.

The reason this procedure is not available in the case of deficiency assessments is attributable to the nature of the exceptional ground on which such an assessment must be based and to the consequent initial procedure followed in making this type of assessment. Such an assessment is permitted only if there is a novum (new fact). Further, the inspector must contact the taxpayer before making the assessment, and at that stage there always is a full exchange of views and arguments. In consequence, after that exchange, it would be superfluous to file an administrative appeal before the same official. Such a taxpayer can turn, however, to the courts.

About one hundred inspectorates deal with income tax matters, though the actual number of individual inspecteurs handling these administrative appeals is much larger. It has been estimated that the number of such appeals approximates 230,000 annually.

\section{4b Details of the administrative appeal procedure re corpora-} tion tax assessments

As earlier noted, a corporate tax assessment which varies from the return is preceded by a full discussion between the inspector and either the board of the corporation or its tax adviser. This exchange of views, which may well lead to a settlement of one or more outstanding issues, is comparable 
to those occurring during an administrative appeal from an individual income tax assessment. For this reason, the statute permits the corporation, with the written consent of the inspector, to bypass the administrative appeal procedure and appeal directly to the courts. In practice, however, very few corporations follow this route. Most prefer first to resort to an administrative appeal. In a recent year, 3,000 corporations filed administrative appeals, the average being 130 for each inspectorate dealing with the corporation tax.

3.4c Details of the administrative appeal procedure re assessments in wage tax (natural persons)

Theoretically, the employee who is subject to a withholding tax has as much right to lodge an administrative appeal as any other taxpayer. In practice, however, an employee is not likely to lodge such an appeal. The wage tax is basically just a method of payment, covering the tax due on employee wages, with the total income tax to be computed later. Hence the wage earner has no reason to use the administrative appeal procedure. Should he succeed in reducing the amount of tax withheld, the amount payable later, covering his total income, would increase proportionately.

When an employer fails to withhold tax or to pay over taxes withheld, he may receive an assessment or a deficiency assessment. Upon receiving an assessment, he may file a petition for an administrative appeal. However, should he receive a deficiency assessment, the administrative appeal procedure is denied him and he must move directly into the courts.

Section C. Extent Administrative Processing of Refund Claims Departs from Administrative Processing of Assessments

\subsection{Introductory note}

Except in the limited circumstance described in 3.7, infra, the processing of refunds is an integral part of, and not distinct from, the assessment procedure itself.

The tax statute, not the assessment, creates the source of the Dutch taxpayer's liability. Essentially, the assessment is a provisional consolidation ${ }^{13}$ of the legal obligation created by

13 In the Netherlands taxability exists as an obligato ex lege as soon as the circumstances set out in the tax statute have come into existence: i.e., a natural person has resided within the Netherlands 
law. Adjustment can be initiated either by the taxpayer's timely invocation of an administrative appeal (with ultimate recourse to the judiciary) or by the inspector's imposition of a deficiency assessment. Either of these actions, though involving only the assessment procedure, might disclose an erroneous assessment which could trigger an automatic refund of taxes previously paid.

\subsection{Details regarding refund procedures prior to an adminis- trative appeal}

Assume, for example, that the tax withheld from an employee's wages in 1966 exceeded the total liability subsequently set forth in his notice of assessment. No special refund procedure is required to accommodate this. According to the Netherlands' statute, the employee's 1966 tax obligation is fixed by the final assessment he normally will receive during 1967 or 1968. If the taxpayer has overpaid, the notice of final assessment will show a negative amount, i.e., that he is entitled to a refund. If he believes this negative amount should be larger, a petition timely filed will assure an administrative appeal, subject to the same rules as if he had received an assessment he believed to be too high.

A comparable situation arises where the taxpayer's tentative return showed a higher net income than his actual income proved to be. His final return will be followed by a final assessment setting forth a negative amount. Again the taxpayer can file a petition for review if he believes himself entitled to a greater refund.

There is one circumstance, however, where a taxpayer, prior to his receipt of a final assessment, may seek to obtain money previously paid in or withheld. Illustratively, a taxpayer may have filed a tentative return for 1966, received a tentative assessment based thereon, and discovered later that the estimate-and consequently the tentative assessment-was too high. An administrative appeal is not available, because no final assessment based on a final return has been made. Nevertheless, in cases where a delay in refunding would work

$\overline{\text { (footnote continued) }}$

and has enjoyed a certain net income, whatever the amount, during the past calendar year. Illustratively, should a taxpayer die on January 2 of a certain year, his estate would be legally burdened with a debt arising from the tax on his income of the previous year. It is immaterial that neither a final assessment or final return has been made for that year. 
a hardship on the taxpayer, administrative regulations issued by the Under Secretary of Finance authorize the inspector to handle such claims for refund as if they were administrative appeals. Accordingly, the inspector typically refunds an amount he considers reasonable. However, a refusal by the inspector cannot be carried to the courts. At most, if the inspector has acted unreasonably, the taxpayer might request the Under Secretary of State to exert his hierarchic power to change the inspector's mind.

\subsection{Details of the administrative appeal procedure re refund claims}

Normally, whether a final income tax assessment shows a negative amount (a right to some refund being recognized) or a positive sum, the taxpayer can contest the matter further at the administrative level only if, within a period of two months beginning with the date of the final assessment notice, he files a petition for review.

Not infrequently, however, a taxpayer discovers more than two months after the date of this notice that he did not deduct an item he believes to be deductible. In some such cases, special procedures are available to accommodate a refund. But these procedures are less clearly defined than are those which apply when the taxpayer has petitioned for review within the allotted two-month period. This is because the statute itself authorizes review only in the latter circumstances. The course of action to be followed by our taxpayer depends upon whether his failure to claim his deduction was due to his own negligence or was caused by circumstances beyond his control.

Where the taxpayer failed to claim a refund because of negligence or trivial inconveniences, he has no right to relief. Nevertheless, he may request the inspector to grant a refund and the latter may do so without consulting his superiors, provided less than five years have elapsed since the taxable year in question. If more than five years have elapsed, the national office, depending on the circumstances, might grant relief. It is possible, of course, that an inspector might deny a request in a situation where the equities were indubitably in the taxpayer's favor. The taxpayer would have but one recourse, i.e., request the Under Secretary of Finance to exert his hierarchic influence to the taxpayer's benefit.

Where, during the allotted two-month period following an assessment, a taxpayer failed, because of serious illness or other circumstances beyond his control, to invoke an administrative 
review of a claimed refund, he may seek a waiver of the twomonth rule by filing a written request with the President of the Chamber of Taxation at the Court of Appeal. This official may extend the two-month period otherwise prescribed by statute upon finding that the special circumstances did in fact prevent the timely filing of the petition. 


\section{CHAPTER XXIV}

\section{RESOLUTION OF INTERPRETATIVE INCOME TAX QUESTIONS BY INDEPENDENT TRIBUNALS}

\subsection{Introduction}

Recourse to the Netherlands tax tribunals, whether to the trial or appellate level, is inexpensive, and the procedures are as informal as possible. Under a 1956 statute, there is a single level of trial tribunals and one appellate tribunal. ${ }^{1}$

Under the 1956 statute, original jurisdiction over tax cases at the trial level was given to special taxation chambers in the regular appellate tribunals, the Gerechtshoven, not to the ordinary trial tribunals. ${ }^{2}$ The tax chambers so created-which replaced the Raden van Beroep staffed by nonprofessional

1 For years prior thereto, the need for reform had been acknowledged but there was considerable disagreement as to the shape it should take. Two proposals attracted particular attention. One advocated the institution of specialized courts for tax cases, with judges drawn from tax specialists (former tax practitioners of the academic level, former tax inspectors of the same level, lawyers with a high degree of competence in tax problems). The other advocated the use of ordinary courts of justice to handle all tax cases.

2 The use of special chambers within the regular appellate tribunals was dictated by the government's belief that tax cases should not be given to a specialized tribunal. It argued that many tax cases not only raised problems analogous to those arising in other areas of law but also involved contract and property issues. At the same time, the use of special chambers within a general court permitted the utilization of men with tax expertise. Jurisdiction was given to the general appellate rather than to the general trial tribunals for these three reasons. First, the government argued that the administrative appeal bore a strong resemblance to an action before a trial tribunal. Second, by the creation of special tax chambers in the five courts of appeal, Gerechtshoven, jurisdiction over tax cases would be confined to a limited number of tribunals, thereby facilitating specialization by the judges in tax matters and contributing to greater uniformity in decisions. Third, the fact that the judges of these taxation chambers would rank equally with judges of the appellate tribunals would more nearly insure first-rate applicants for the new positions. 

jurist ${ }^{3}$-are termed Belastingkamers, Chambers for Processing
Taxation cases.

Decisions of the Belastingkamers may be reversed by the Supreme Court, on appeal by either the taxpayer or the inspector. However, the jurisdiction of the Supreme Court is limited to questions of law.

\section{Section A. Organization and Procedures: Trial Level}

\subsection{Organization of the trial tribunals}

The five Courts of Appeal are located at Amsterdam, The Hague, and three provincial capitals. The Courts of Appeal located at The Hague and Amsterdam have two Taxation Chambers, the other three, one apiece. 5

Each chamber consists of three counselors, Raadsheren, and a clerk, griffier, who is a jurist. The counselors are appointed by the Queen and hold their positions until they reach age seventy. One has the rank of Vice President of the Court and acts as President of the Chamber.

3 The Raden van Beroep, established in the nineteenth century, were given a new legal status in 1914. This establishment terminated the use of general jurisdiction for tax cases which had been the practice since the Napoleonic period. There were 20 of these Raden van Beroep. The statute required that their decisions be written and include rationale. Appeal lay to the Supreme Court, Hoge Raad, but only in case of "either violation or misapplication of the statute" or "lack of motivation." The use of part-time nonprofessional jurists as judges brought mounting criticism to the Raden van Beroep. Since the judges were nominated to the post of honor from local and other jurists, or from economists, members of the Chamber of Commerce, municipal officials, lawyers, etc., there was no assurance they possessed any real expertise in tax matters-a matter of incrèasing concern as the tax statutes multiplied in number and complexity. Moreover, dockets became increasingly clogged because of the limited number of cases which could be heard by spare-time jurists.

4 Despite the fact that the institution of the Belastingkamers, with the shift from nonprofessional nonspecialist jurists, created a sharp break with the past, the procedures employed actually changed very little. In large measure, this is because the Supreme Court, since the creation of the Raden van Beroep, has borne the responsibility, through countless decisions, of developing procedural rules as well as interpreting the substantive provisions.

5 The greater population concentration in the western part of the country accounts for the additional Taxation Chamber at Amsterdam and The Hague. 
The intentions of the 1956 statute indicated, first, that the new tribunals were not to be isolated from the main stream of the Courts of Appeal but, second, that the three counselors were to be appointed from tax experts. Accordingly, every effort was made to appoint to each chamber (1) one applicant with previous judicial service, usually in a trial tribunal, (2) one applicant familiar with interpretative problems because of work as a lawyer or as a secretary to a former Raad van Beroep, and (3) one applicant with previous service as a chief inspector or director in the Internal Revenue Service. Thus counselors of the Taxation Chambers fall into two categories: tax experts who previously superimposed tax expertise on a general legal background, and judges with relatively little tax expertise upon appointment but who acquire this over their years of service.

Further to insure their expertise and to stabilize these Chambers, counselors appointed thereto are not entitled, contrary to the practice followed as to others, to have requests for a transfer to a non-tax chamber ${ }^{6}$ honored automatically.

An initial dearth of qualified applicants, however, resulted in one temporary modification in the 1956 statute, to permit appointment until $1967^{7}$ of suitable individuals without academic qualification. Specifically, instead of the required completion of law studies at a Dutch university-this being the customary requirement for judicial nomination-appointees need only have passed their examinations at the State Academy of Taxes or equivalent earlier examinations.

Many tax cases do not actually involve a legal problem. In consequence, the 1956 statute empowered the President of a Taxation Chamber to decide whether a case would be heard by the full chamber of three members or before a unus iudexa single counselor assisted by the clerk. While there is some variation in the practices of the individual courts, the Presidents have assigned a majority of the cases to unus iudex. Only in rare instances has a party to the proceeding requested to be heard by a full chamber, and typically those requests are honored. Indeed, that the competence of the Taxation Chamber judges has attracted far more confidence than did the

6 The practice among the Courts of Appeal, located at the three provincial capitals varies. Some use regularly, though on a limited basis, some only intermittently, counselors of the Taxation Chambers in sessions of their civil and/or penal chambers.

7 This cut-off date was extended in 1967 for five years, and probably will be extended for another five-year period. 
nonprofessionals who sat on the earlier Raden van Beroep is strikingly illustrated by the sharp rise in the number of cases heard by a unus iudex, ${ }^{8}$ and seems justified since also there has been a sharp decline in Supreme Court reversals of trial decisions. 9

Each Court of Appeal decides whether its Taxation Chamber, whether at full strength or in unus-structure, will go on circuit or hold sessions only in the city where the court is located.

\subsection{Processing cases through the trial tribunals}

Taxation Chambers have jurisdiction of all tax controversies except those involving turnover taxes, import and excise duties, registration fees and stamp duties. It is immaterial whether the taxpayer has or has not paid the tax.

An appeal to a Taxation Chamber is an inexpensive and a simple process. There are no court costs, witness fees are paid by the court, and the taxpayer need not be represented by counsel. The taxpayer must lodge his appeal within two months following receipt of either the inspector's decision on an administrative appeal or a deficiency assessment, or receipt of a corporation tax assessment. However, should the taxpayer fail to file the petition within the allotted time, and if he can show such failure resulted from a force majeure, he may request permission from the Taxation Chamber President to file later.

The petition of appeal, beroepschrift, prepared either by the taxpayer or his representative, ${ }^{10}$ should indicate both the particular relief requested and the rationale upon which he relies, attaching thereto any supporting documents. Taxpayers are permitted, however, to file abbreviated petitions within the statutory period, with the rationale being submitted at a later date. Normally, upon failure to submit a rationale, the chamber itself will request that such be forwarded in writing. Even so, it is not unusual for the President of the chamber, during the oral hearing, to permit the taxpayer to supply it orally.

Copies of the petition and of any supporting records are sent by the court to the inspector concerned. The inspector

${ }^{8} \mathrm{~A}$ unus iudex heard about $28 \%$ of the cases when the Raden van Beroep were the trial tribunals. Now a unus iudex hears about $58 \%$.

9 The Supreme Court reversed about $40 \%$ of the Raden van Beroep's decisions appealed to it. Presently, reversals occur in only about $17 \%$ of the appeals from the Taxation Chambers.

10 The representative may be a tax practitioner, an accountant, or a lawyer. 
has one month-which the court may extend-within which to file his written note of answer, verioogschrift, indicating both his underlying rationale and his objections to the taxpayer's conclusions or rationale. If, as usually is the case, there was an administrative appeal prior to this point, the inspector's written answer usually is based on the opinion set out in his earlier administrative decision. He is free, however, to add new arguments, new facts, and submit additional supplementary records. Also, he may alter his original opinion, reflecting a conclusion that the taxpayer originally was right in part, or even as to the whole, with new rationale being offered to justify the amount of taxable income as re-determined. Illustratively, the inspector may acknowledge that he himself erred in his treatment of one particular item in reaching his original decision. However, as will be noted later, the inspector may not wait until the oral hearing to introduce such a statement.

It is implicit in the foregoing that the inspector who receives the taxpayer's petition, prepares the note of answer, and represents the administration at the hearing, is the same inspector who made the original assessment and heard the taxpayer's administrative appeal. There is, however, one exception. An administrative regulation requires that, in a hearing before the Court of Appeal, an inspectorate must be represented by an inspector of academic level. If the official who earlier handled the taxpayer's assessment and/or administrative appeal did not hold this rank, he will be superseded by a properly qualified inspector.

The legislature attached great importance to the oral hearing. It anticipated that, in a typical case, submission of the taxpayer's petition and of the inspector's note of answer would complete the written phase of the trial. Upon request, however, the President of the Taxation Chamber, may permit a second round of memoranda to be filed by the parties. And this usually occurs in the more intricate cases. ${ }^{11}$

The interchange of memoranda sometimes leads the parties to renew their contact, orally or in writing. Each may have developed a greater appreciation of the other's position. Each may be inclined to believe certain aspects of the case make informal agreement preferable to court adjudication. Whatever the reasons, informal discussions, of which the court officially is unaware, may take place leading to a settlement. When such

11 There is, however, no direct exchange of documents between the parties; the court acts as intermediary. 
discussions are taking place, the court may receive notice from the parties, requesting an adjournment of the oral hearing until they have had an opportunity for further consultation. In these discussions, the inspector is free to exercise his own judgment regarding a settlement, though he may decide to consult the head of his inspectorate. If the informal discussions are successful, the court will receive a letter from the taxpayer, reflecting his wish to withdraw his petition.

Over a fairly recent three-year period, almost 70 percent of the taxpayer's petitions were withdrawn, though this figure is somewhat deceiving in present context, for it also includes what relatively is a much smaller number of cases withdrawn by taxpayers after the oral hearing.

Where a case is not resolved informally, the court fixes a day for the oral hearing, and notifies the parties by a simple registered letter. The taxpayer may be represented by counsel, although the court may require the taxpayer himself to be present. In any event, the taxpayer also is free to bring such experts-e.g., accountants-as he may wish. Before the court actually hands down its decree, it may request further written information from the parties themselves or from others. Such information must be turned over to the other party and should either party request another oral hearing, it must be provided within a reasonable time.

While the statute itself provides for an oral hearing, it does not otherwise set forth formal rules governing a Taxation Chamber's procedures. The draftsmen of the 1956 act concluded that the numerous Supreme Court decisions fixing procedural rules under the 1914 statute would remain applicable. In consequence, the decisions, arresten, of the Supreme Court are of enormous significance in dealing with matters such as the burden of proof, rules of evidence, rules of court, etc. Only the more important of these can be summarized here.

The court may not go beyond issues laid before it by the parties. Illustratively, if a point in controversy is whether a particular amount of depreciation is allowable as to a particular item, the court may not decide another issue on which the parties are agreed, for example, whether a certain expense is deductible or nondeductible. In other words, the court may not re-examine uncontested questions associated with the taxpayer's assessment.

By like token, even as to a contested item, the court may not make a finding which increases the taxpayer's income beyond that determined by the previous administrative appeal or, in other circumstances, by the assessment. 
There are no formal rules establishing the burden of proof. The court has full freedom to select and reject evidence as well as to determine the relative weight of the evidence offered. In practice, inter alia, this means the court need not accept the offer of a party to submit additional evidence in the form of documents or yield to a demand by one of the parties to use experts or hear witnesses. It also may decide whether evidence introduced by a given party is adequate, in keeping with the Supreme Court's general policy that a person must prove as much as may be expected reasonably from him under the circumstances of the case. For example, if normal experience in a given situation justifies the inspector's assumption as to a matter, the taxpayer will be expected to submit evidence if he makes a contention to the contrary. Not infrequently, a decision will include this type of comment "... that in [i.e., the particular circumstances] a reasonable distribution of the burdens of proofs requires that the taxpayer [or the inspector] should have proved that. ..."

As a corollary to the court's control over the acceptance or rejection of evidence, it has the same degree of control over the objection by a party to the introduction of evidence. Occasionally in the course of the oral hearing, a party may present an argument bottomed on facts not heretofore brought out in the exchange of documents preceding the hearing. Typically, the other party objects, on the ground the evidence comes as a surprise, and that he has not had adequate opportunity to defend against it. The court has power to reject or accept the objection. Should the objection be rejected, and the party allowed to place the evidence before the court, the case usually is adjourned to give the objecting party full opportunity to plan his defense to the newly presented material and the arguments based thereon.

If the hearing is before the full bank of the Taxation Chamber, the taxpayer usually is represented by a top-level tax practitioner and rarely is unrepresented. Exactly the reverse situation prevails where a unus iudex hears a case. This poses a problem for the unus iudex, for lack of representation tends to create uncertainty as to the reliability and accuracy of the information presented.

Only the parties and the taxpayer's representatives appear before the chamber members and the clerk. The public is excluded, to the end of preserving secrecy regarding the taxpayer's financial affairs. 
The president of the Taxation Chamber opens the hearing by requesting the taxpayer or his representative to state his case. This statement may be limited to a bare reference to the petition of appeal itself, or it may involve a detailed and complicated analysis. The inspector then makes his statement, responding to that of the taxpayer. This interchange may be followed by further discussion between the parties. The members of the Chamber also assume an important and positive role; they are free to raise questions, require further information as to certain aspects of the case, and may even take the initiative in establishing the facts. The whole process is intended to be informal, with both parties and the court participating fully, to the end of clarifying the points in dispute.

The president at his discretion closes the oral hearing. Typically, this occurs when the court believes it has sufficient information regarding the details to permit it to begin its own deliberations. Sometimes, however, by the close of a hearing the court does not have sufficient information and may request that it be supplied. Finally, a practice has developed which permits the judges to suggest an adjournment whenever they conclude the parties might benefit by resuming discussions between themselves. ${ }^{12}$ A judge may believe that the parties themselves may be getting a feeling that the truth lies somewhere between the two extremes. In such circumstances, the president-speaking informally-may inquire if the parties have any interest in further private discussions. If the parties indicate such an interest, the president adjourns the case and asks that the Taxation Chamber be informed of further developments. Sometimes an agreement is reached and, if so, the Taxation Chamber is notified that the case is withdrawn. Sometimes, while full agreement is not reached, the parties do agree upon certain facts. The Taxation Chamber is informed of this limited agreement and told that the parties desire a decision only on the remaining issues of fact and the issues of law.

The complexity of a case will determine whether the actual decision is handed down several weeks or several months after the hearing is officially closed. The statute requires that the decision be written and contain an explanation for the conclusions reached. In practice, the judgment states the findings of fact, explains the legal conclusions drawn from these facts, and

12 Though not based on a statute, this practice is considered as being with the ratio legis because of the prudence and restraint with which it is used. 
concludes by indicating whether it reverses or sustains, in whole or in part, the administrative appeal decision.

Not all decisions of Taxation Chambers are appealed to the Supreme Court. However, even unappealed decisions can have some effect on similar cases coming before both the deciding chamber and other chambers. The precise amount of effect, however, depends upon the strength of the underlying rationale of the decision as reflected in the explanation set forth in the opinion. Of course, some decisions have little precedent value if only because of the peculiar factual circumstances involved in the case.

Private tax publications print those decisions of the Taxation Chambers which develop principles of major interpretative significance and are likely, therefore, to have some future influence. Where such a decision favored the taxpayer, there usually is a footnote explaining why the Under Secretary of Finance did not appeal to the Supreme Court. However, all concerned realize that a decision by the Under Secretary not to appeal does not mean that he is prepared to adhere automatically to the principle of the case. About 15 percent of all Taxation Chambers decisions are published, with the remaining 85 percent falling into three categories: (1) those involving primarily questions of fact, (2) those which dismissed the petition because of formal defects, and (3) those raising such fundamental issues that appeal to the Supreme Court is anticipatedwith ultimate publication of the Supreme Court's decision.

But even the published 15 percent is a fairly large absolute number. For example, over a fairly recent three-year period, Schedule I in the Appendix to this PART indicates that the Taxation Chambers of the five Courts of Appeal decided in those respective years 2065, 1852, and 1897 cases. However, in addition to income, corporation, and wage tax cases, these figures include cases involving inheritance duties, capital tax, real estate tax, etc. Approximately 70 percent of the total fall in the income, corporation, and wage tax areas, with 80 percent of the 70 percent being true income tax cases.

\section{Section B. Organization and Procedures: Appellate Tribunals}

\subsection{Organization of the appellate court system}

There is only one appellate tribunal, for tax as well as other cases-the Supreme Court of the Netherlands (Hoge Raad 
der Nederlanden), which sits at The Hague. Each of the Court's three Chambers has five Counselors, highly qualified doctors of law appointed by the Queen, with tenure until age seventy.

The 1956 statute did not alter the Supreme Court's tax jurisdiction; one of its three chambers has continued, as its prime responsibility, to handle tax appeals. As is true of other civil and penal cases, however, appeals are confined to errors of law. However, as is not true of other civil and penal cases, appeals in tax cases may be based on a lack of motivationthat is, the decision handed down by the court could not be justified by the facts as found by the court.

In the case of the government, in theory it is the Under Secretary of Finance who decides whether an adverse lower court decision will be appealed. As a practical matter, however, the choice is made by the Director-General of Taxes at the national office, or by a senior member of his staff.

\subsection{Processing a case through the appellate tribunal}

Procedures associated with tax appeals to the Supreme Court are even simpler than those pertaining to a trial tribunal. Within one month after the lower court decision, the appellant files with the Supreme Court's record office a petition of appeal, beroepschrift in cassatie, simultaneously paying a small filing fee-f. 10.

This petition is usually, though not necessarily, prepared by a well qualified tax practitioner. In those cases, the petition itself, after identifying the legal issue, goes on to analyze the legal argument on which the taxpayer relies. A much more succinct, even defective, petition is legally sufficient, however, in accordance with the Supreme Court's belief that the processing of tax cases must not be impeded by formal requirements. ${ }^{13}$

A copy of the petition of appeal is forwarded to the appellee who, in turn, files a written answer, vertoogschrift. This exchange of documents is usually all that the parties do, although each has a right to request an oral argument, a right

13Illustratively, a peasant, on receipt of an adverse decision by a Raad van Beroep, sent a copy of the decision to the Supreme Court. He wrote on the copy "My shield and trust art thou, O Supreme Court," a variation on a line in the Netherlands national anthem, the "Wilhelmus," which reads "My shield and trust art thou, O God, my Lord," The Supreme Court accepted this appeal-couched in words both effectively eloquent and extremely vague-as one which fulfilled the statutory requirements. Obviously, this was an exceptional set of circumstances. 
rarely exercised by the Under Secretary of Finance. In a small minority of cases, taxpayers do request an oral argument, though it must be conducted by a lawyer whereas the petition itself may be prepared by the taxpayer.

In the majority of cases, some months elapse before the Supreme Court hands down its written decision. The decision includes a statement of the facts as found by the Taxation Chamber of the Court of Appeal, a summary of that lower court's rationale, a summary of the petition of appeal, and finally the Supreme Court's own conclusion. While the Court is responsive to the petition, it also is free to go beyond it, basing its decision solely on errors of law not raised by the appellant.

The great majority of Supreme Court decisions constitute precedents in fact, if not in law. This is particularly true where the Court itself elaborates on the meaning of a provision in the tax statute, as distinct from instances where heavy reliance is placed on the underlying rationale of the lower court. Today, many petitions and pleas in tax cases discuss and cite as authority Supreme Court decisions in analogous cases.

While a majority of Supreme Court decisions are truly significant, some are not. Illustratively, the appellant may have alleged a violation of the law because the court below did not supply a sufficient basis for its decision, that is, the facts established in the course of the trial could not possibly justify its decision. Under such circumstances the Supreme Court is likely to use language such as the following "... that the court, on the basis, of the facts as established, properly could render the decision reached," or "...that in the given situation the court did not act contrary to that which is reasonable when it imposed on the taxpayer [or, alternatively, the inspector] the burden of proof concerning. . .."14

More than 50 percent of all Supreme Court decisions are published, with publication being handled by private editors. The text of the decision often is accompanied by comments from tax specialists. Schedule II in the Appendix to this PART

14 And, of course, an important precedent is unlikely to emerge from a case in which the Supreme Court, without deciding the matter, remands it to the Taxation Chamber with a directive to re-open the case to make additional findings of fact, and hand down another decision "taking into consideration" the Supreme Court's generally stated views. 
indicates that, over a recent two-year period, the Court decided 486 tax cases, of which about 70 percent were income, corporation, and wage tax cases, with the great bulk involving the income tax. 


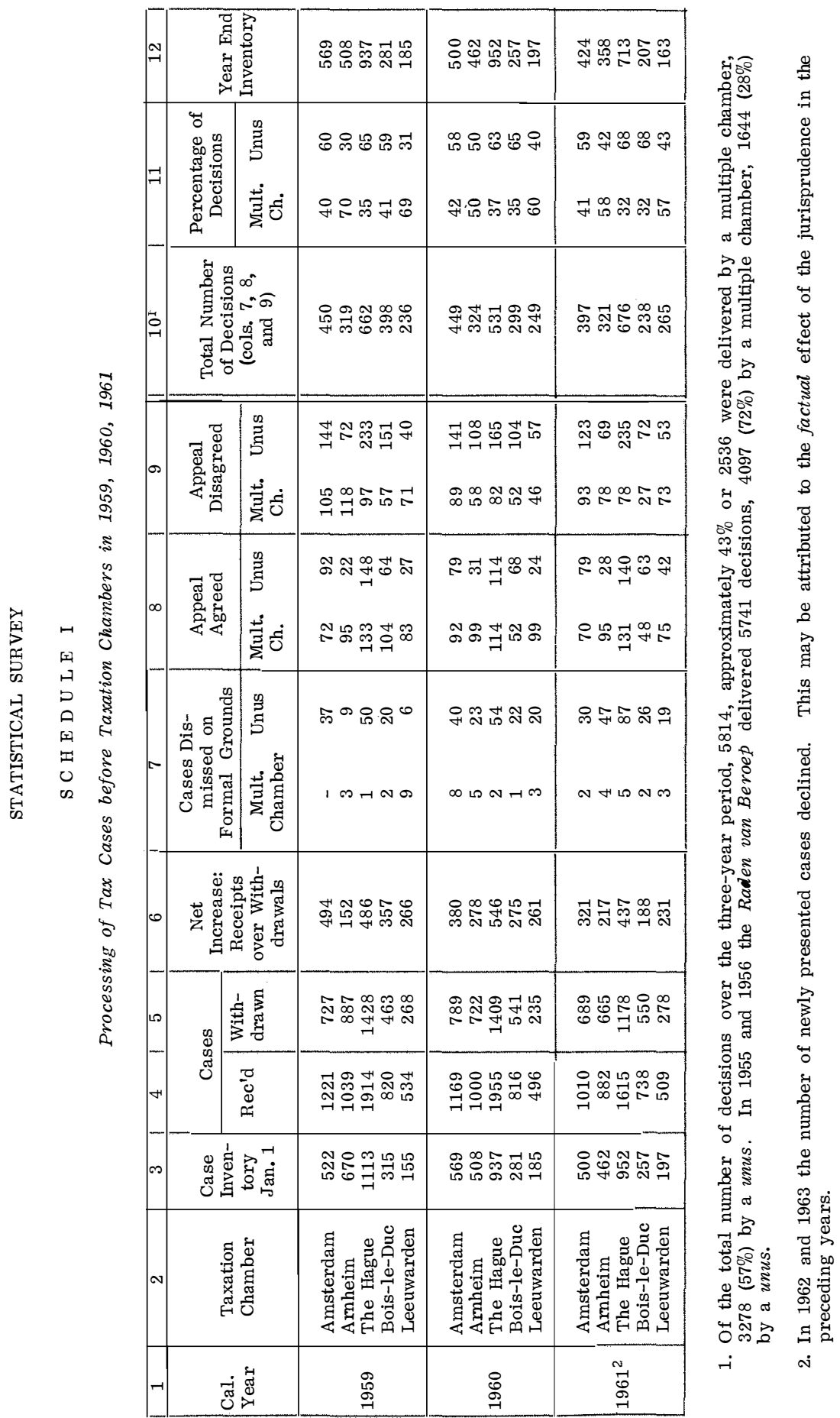




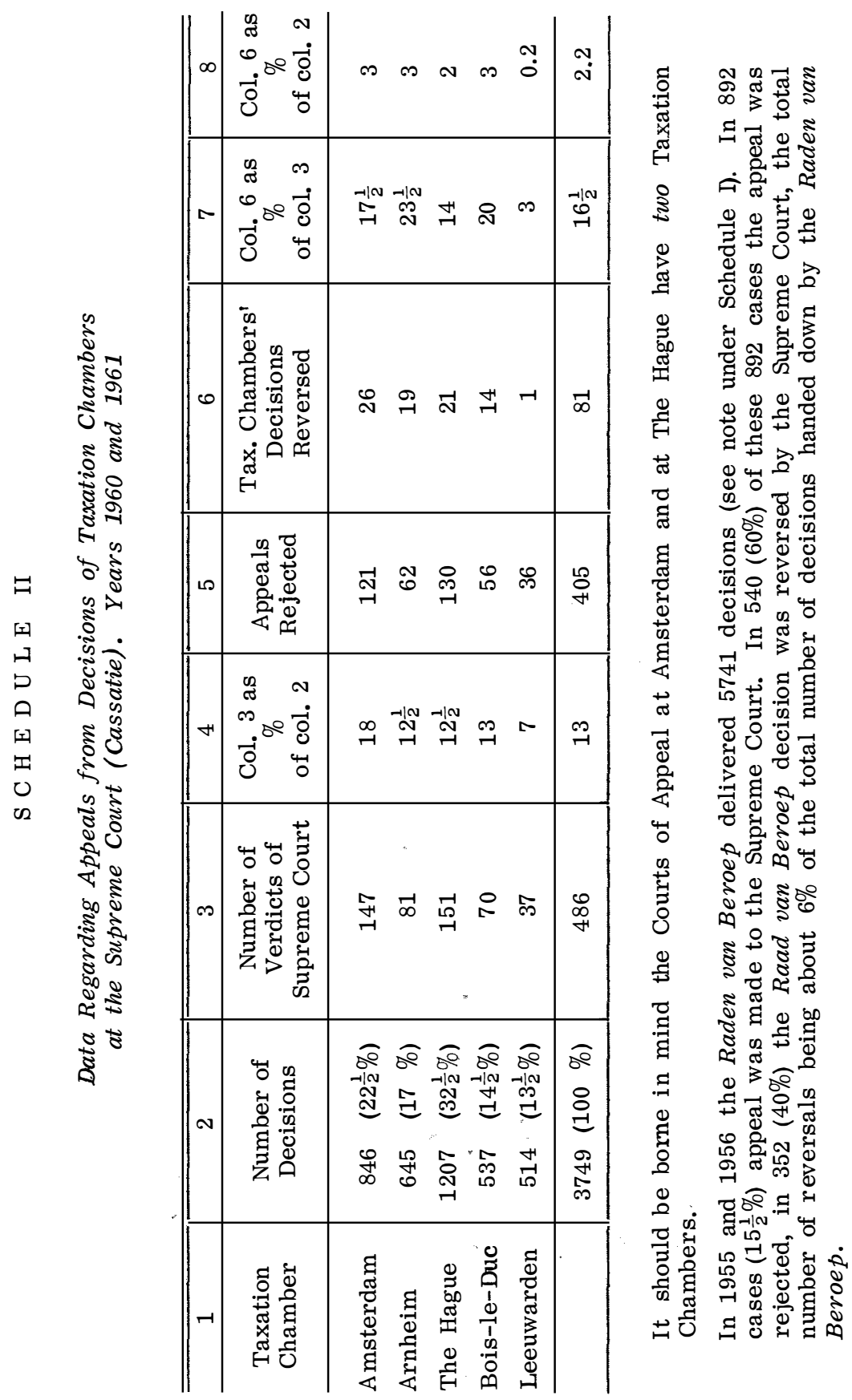

